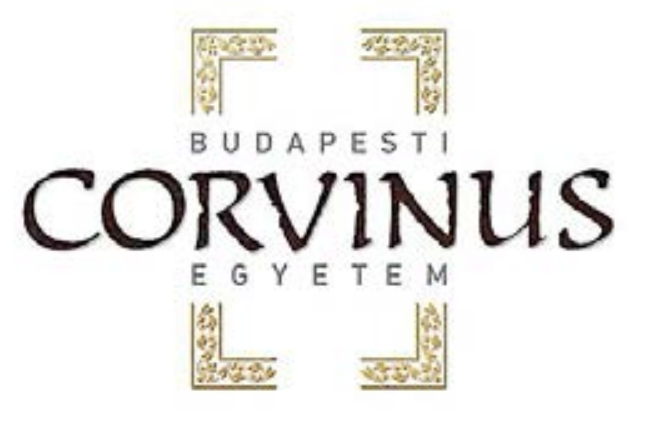

Doktori $(\mathrm{PhD})$ értekezés

\begin{abstract}
A Juhdöglő-völgy Erdőrezervátum lignikol bazídiumos nagygombáinak taxonómiája és természetvédelmi helyzete
\end{abstract}

\title{
PAPP VIKTOR
}

Témavezető: Dr. Rimóczi Imre, DSc professor emeritus

Budapest

2015 


\section{A doktori iskola}

megnevezése:

tudományága:

vezetője:
Kertészettudományi Doktori Iskola

4. Agrártudományok (4.1 Növénytermesztési és kertészeti tudományok)

Dr. Tóth Magdolna, DSc

egyetemi tanár

Budapesti Corvinus Egyetem, Kertészettudományi Kar, Gyümölcstermő Növények Tanszék

Dr. Rimóczi Imre, DSc

professor emeritus

Budapesti Corvinus Egyetem, Kertészettudományi Kar, Növénytani Tanszék és Soroksári Botanikus Kert

\section{A doktori iskola- és a témavezető jóváhagyó aláírása:}

A jelölt a Budapesti Corvinus Egyetem Doktori Szabályzatában elöírt valamennyi feltételnek eleget tett, az értekezés mühelyvitájában elhangzott észrevételeket és javaslatokat az értekezés átdolgozásakor figyelembe vette, ezért az értekezés védési eljárásra bocsátható.

Dr. Tóth Magdolna doktori iskola vezető
Dr. Rimóczi Imre témavezetö 
A Budapesti Corvinus Egyetem Élettudományi Területi Doktori Tanácsának 2015. december 8-i határozatában a nyilvános vita lefolytatására az alábbi bíráló Bizottságot jelölte ki:

\section{BÍRÁLÓ BIZOTTSÁG:}

EInöke:

Balázs Sándor, MHAS, BCE

Tagjai:

Terbe István, DSc, BCE

Lőkös László, PhD, MTM

Bartha Dénes, DSc, NyME

Opponensek:

Vetter János, DSc, SZIE

Lenti István, CSc, Nyíregyházi Főiskola

Titkár:

Balázs Gábor, $\mathrm{PhD}, \mathrm{BCE}$ 


\section{TARTALOMJEGYZÉK}

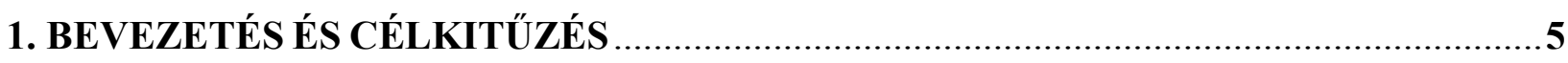

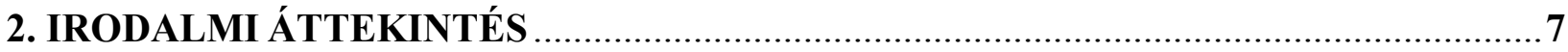

2.1. A LIGNIKOL BAZÍDIUMOS NAGYGOMBÁK JELLEMZÉSE.....................................................7

2.1.1. A lignikol bazídiumos nagygombák makromorfológiája .............................................8

2.1.2. A lignikol bazídiumos nagygombák mikromorfológiai bélyegei ................................12

2.1.3. A lignikol bazídiumos nagygombák szisztematikája ................................................15

2.2. LIGNIKOL BAZÍDIUMOS NAGYGOMBÁK TERMÉSZETVÉDELMI HELYZETE EURÓPÁBAN ..........20

2.2.1. Erdőrezervátumok és természetszerü erdők, mint refúgiumok a lignikol nagygombák

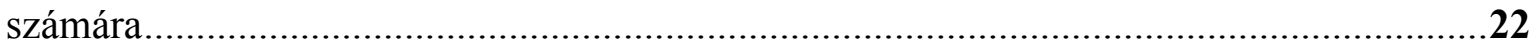

2.2.1.1. Magyarországi erdőrezervátumokban végzett mikológiai vizsgálatok ...............23

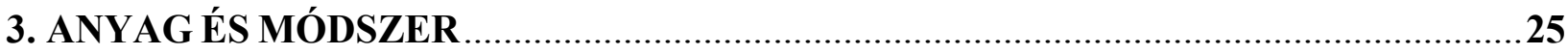

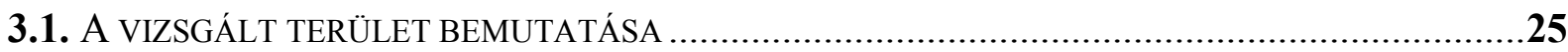

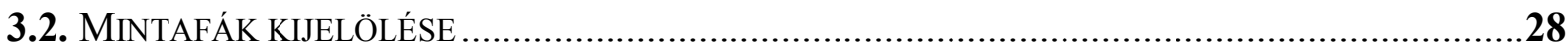

3.3. A MINTAVÉTELEK IDŐPONTJAI ÉS A GYÜJTÖTT ANYAG FELDOLGOZÁSÁNAK MÓDSZEREI.........

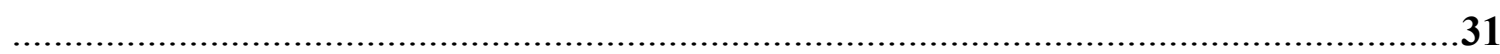

3.4. A LIGNIKOL BAZÍDIUMOS NAGYGOMBAFAJOK HATÁROZÁSÁHOZ HASZNÁLT ESZKÖZÖK

.

3.4.1. Határozókönyvek és -kulcsok ...................................................................................32

3.4.2. Mikroszkopikus vizsgálatokhoz használt eszközök .....................................................33

3.4.3. Molekuláris vizsgálatokhoz használt eszközök és módszerek ............................................33

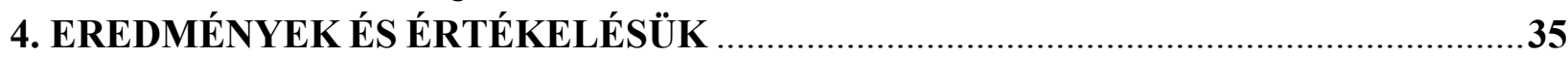

4.1. A JUHDÖGLÖ-VÖLGY ERDÖREZERVÁtUM TERÜLETÉRÖL DOKUMENTÁLT LIGNIKOL BAZÍDIUMOS NAGYGOMBÁK BEMUTATÁSA ÉS TAXONÓMIAI ÉRTÉKELÉSE ....................................35

4.1.1. A Pucciniomycotina osztályba tartozó lignikol nagygombák...............................................38

4.1.2. A Tremellomycetes alosztályba tartozó lignikol nagygombák ..........................................39

4.1.3. A Dacrymycetes alosztályba tartozó lignikol nagygombák...............................................39

4.1.4. Az Agaricomycetes alosztályba tartozó lignikol nagygombái ...........................................40

4.1.4.1. Agaricales Underw....................................................................................

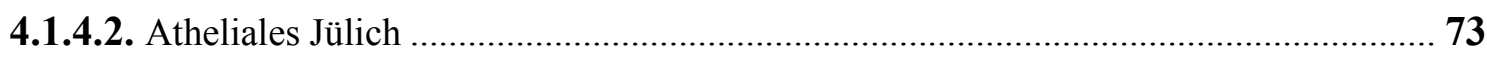

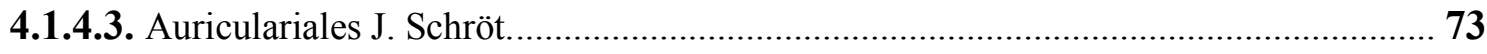

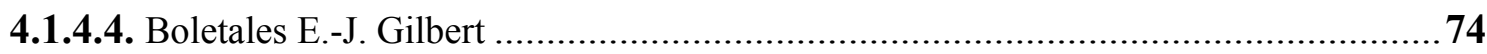

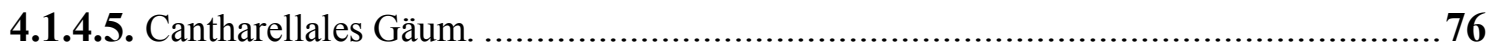

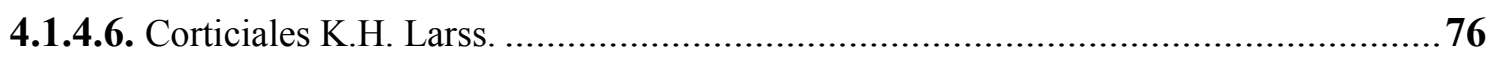

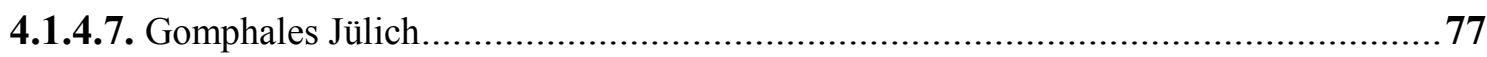

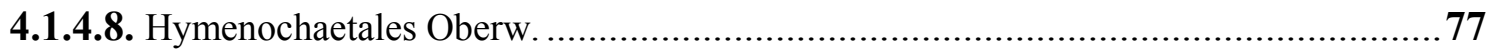

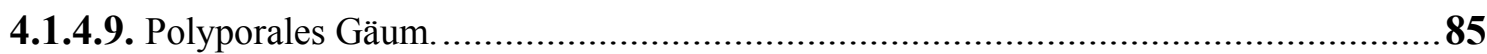

4.1.4.10. Russulales Kreisel ex P.M. Kirk, P.F. Cannon \& J.C. David ..................................114

4.2. TERMÉSZETVÉDELMI ÉRTÉKELÉS ...............................................................................119

4.2.1. A Juhdöglö-völgy Erdőrezervátum természetvédelmi jelentősége lignikol nagygombák szempontjából

4.2.2. Ritka, veszélyeztetett és védett lignikol nagygombák a Juhdöglö-völgy Erdörezervátumban 


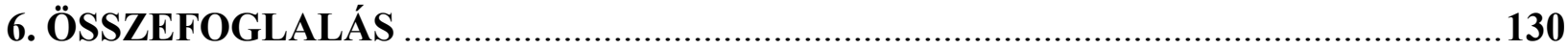

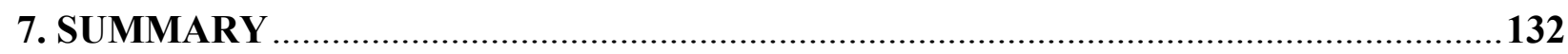

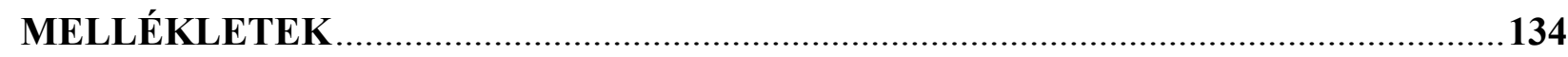

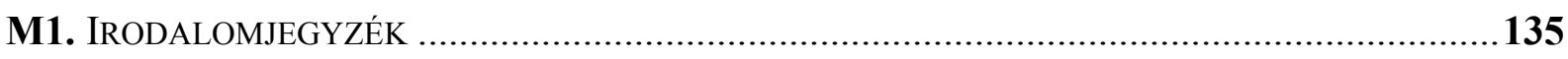

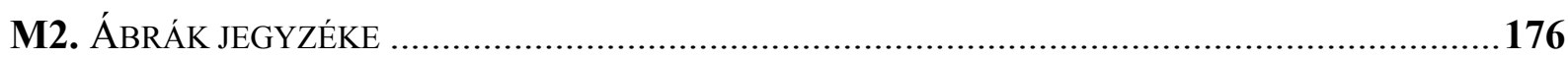

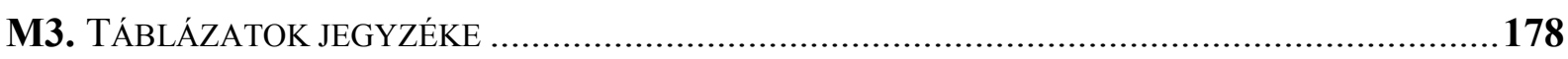

M4. A JUHDÖGLÖ-VÖLGY ERDÖREZERVÁTUM TERÜLETÉN GYÜJTÖTT LIGNIKOL NAGYGOMBÁK

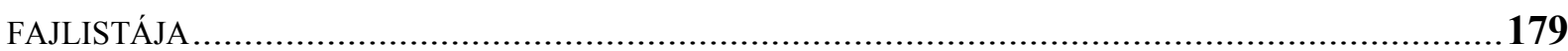

M4.1. A Juhdöglö-völgy Erdőrezervátum területén gyüjtött lignikol bazídiumos nagygombák fajlistája alfabetikus sorrendben.

M4.2. A Juhdöglö-völgy Erdőrezervátum területén gyüjtött lignikol aszkuszos nagygombák

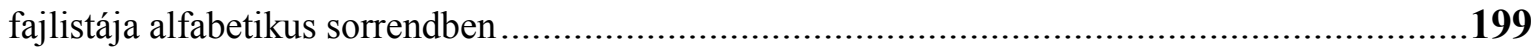

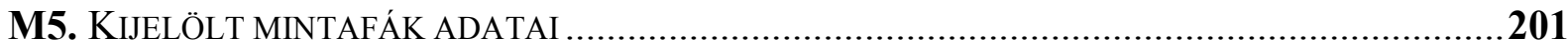

M6. FILOGENETIKAI VIZSGÁLATOKHOZ HASZNÁLT MINTÁK ADATAI.....................................204

M6.1. A Juhdöglö-völgy Erdőrezervátumban gyüjtött lignikol bazídiumos nagygombák jelen dolgozatban molekuláris módszerekkel vizsgált mintáinak ITS szekvenciái.

M6.2. A GenBank és Unite adatbázisokból letöltött és a jelen munkában ismertetett filogenetikai vizsgálathoz felhasznált ITS-szekvenciák lelőhelyi adatai, valamint herbáriumi és génbanki azonosítói 


\section{BEVEZETÉS ÉS CÉLKITŰZÉS}

Az emberi tevékenység hatására csökkenőben lévő, magas biodiverzitású erdei élőhelyek védelmében szükségessé vált a még természetszerü állapotukat őrző erdők megóvása. Ennek érdekében dolgozták ki az erdőrezervátum programot, amely során Európa szerte törvényi védelmet élvező erdőterületeket jelöltek ki. Az erdőrezervátumokban jellemzően a természetes ökológiai folyamatoknak köszönhetően jelentősen nagyobb mennyiségü és paramétereit tekintve (pl. átmérő, korhadási fázis, stb.) változatosabb holt faanyag halmozódik fel, mint az erdészetileg kezelt erdőkben. A holt faanyag számos olyan élőlénycsoportnak (pl. rovarok, mohák, gombák, stb.) szolgál szubsztrátumként, amelyek fontos szerepet töltenek be egy erdei ökoszisztémában. A holt fák ökológiájával foglalkozó tudományág („deadwoodology”) (Grove 2002) egyik jelentős területe a faanyag lebontásában kulcsszerepet játszó lignikol gombák előfordulásának és szerepének kutatása (LONSDALE és mtsai. 2008). A makroszkopikus méretủ termőtestet képző és a holtfa lebontására specializálódott nagygombák föként a dikariotikus [Dikarya Hibbett, T.Y. James \& Vilgalys] leszármazási vonalon alakultak ki, tehát az aszkuszos [Ascomycota Caval.Sm.] és bazídiumos [Basidiomycota Whittaker ex Moore] gombák törzsén belül is egyaránt megtalálhatóak. Fajszámukat és diverzitásukat tekintve a lignikol nagygombák döntő többsége viszont ez utóbbi törzsbe tartozik. A bazídiumos gombák esetében a lignikol életmód kialakulása konvergens evolúciós folyamat eredménye, tekintve, hogy szinte minden föbb rendszertani csoportban kialakultak élő vagy már elhalt faanyaghoz kötődő taxonok (ZMITROVICH és mtsai. 2015).

Magyarországon korábban a nagygombák felvételezésére irányuló fungisztikai kutatások főként egy adott terület változatos élőhelyeinek teljes nagygombavilágának feltárását célozták meg. Ezek között számos olyan munka található, amelyek a hazai középhegységi területek fungájának megismerésére irányultak: pl. BENEDEK (2002, 2011), EGRI (2009), FRANK (1997), KÁNYÁsi (1992), KoszKa (2011, 2014), LoCSMÁndi (1993), PÁl-FÁm (2001), PÁl-FÁm és LuKÁcs (2002), PAPP (2009), Rudolf és mtsai. (2008), Siller (2004), SZEMERE (1968), VASAS (1985), VASAS és LOCSMÁNDI (2009), VASS (1978). A Magyarországi hegységek közül a Vértes hazánk fungisztikai szempontból kevésbé vagy közepesen feltárt területei közé tartozik. A hegységből az első nagygombaadatokat tartalmazó publikációk egyike BoHUs (1939) munkája. Ezt követően sokáig nem végeztek szisztematikus fungisztikai felvételezéseket a Vértesben és többnyire csak szórványos adatokat publikáltak a hegységből. Az egyik ilyen jelentősebb munkát BABOS (1989) közölte, melynek során a Budapesti Természettudományi Múzeum Növénytárában elhelyezett agarikoid nagygombák, valamint néhány egyéb termőtestet képző gombacsoport (pl. Polyporus spp.) mintegy 1283 fajának adatait publikálta. A hegységből ismert 
szórványos adatok közül külön említést érdemel a hazánkból leírt, fürészporon vagy lombos fák faanyagán növő Pluteus variabilicolor Babos (BABOS 1981; LEZZI és mtsai. 2014), amelynek publikálása során BABOS (1978) a szárligeti gyüjtést jelölte ki típusnak (BP-FN 56936). RIMÓCZI (1994) az egész ország területéről származó 1340 gombafaj 5537 termőhelyi adatát ismertető munkájában szintén szerepelnek a Vértes térségéböl dokumentált (pl. Csákvár) adatok. KoszKA (2011, 2014) több mint egy évtizedes szisztematikus feltáró munkát végzett a hegységben, különösen a Vértes déli részén, amely során közel 550 terepnap alatt összesen 490 nagygombafajt mutatott ki. A hegységben található két erdőrezervátumban (Juhdöglö-völgy Erdőrezervátum és Meszes-völgy Erdőrezervátum) viszont ez ideig még nem végeztek szisztematikus fungisztiakai vizsgálatokat, ezért mind a Vértes, mind Magyarország fungájának minél teljesebb megismerése céljából célszerünek látszott a holt faanyagban gazdagabb Juhdöglö-völgy Erdőrezervátum nagygombáinak több éven át tartó felmérése.

Jelen munkában a nagygombák közül kifejezetten a faanyagon élő és szisztematikai szempontból a bazídiumos gombák közé tartozó taxonok feltárására koncentráltam. Munkám során az alábbi főbb célokat tüztem ki:

1. A Juhdöglő-völgy Erdőrezervátum lignikol bazídiumos nagygombavilágának feltárása, taxonómiai értékelése mikro- és makromorfológiai bélyegek alapján, kiegészítve filogenetikai módszerekkel is. Továbbá az élőhely teljes fajlistájának összeállítása.

2. A Juhdöglő-völgy Erdörezervátumból dokumentált gombafajok természetvédelmi helyzetének értékelése és a vizsgált terület valós természeti értékének meghatározása az új mikológiai adatok feldolgozása alapján.

3. A kutatás során felmerülő szisztematikai és nevezéktani kérdések tisztázása a Juhdöglővölgy Erdőrezervátum magterületén dokumentált lignikol bazídiumos nagygombák és a rokon fajok taxonómiai és nómenklatúrai vizsgálata alapján. 


\section{IRODALMI ÁTTEKINTÉS}

\subsection{A lignikol bazídiumos nagygombák jellemzése}

A faanyagon vagy azon belül élö gombákat lignikolnak nevezzük (KIRK és mtsai. 2008), függetlenül attól, hogy a számukra szükséges tápanyagot honnan veszik fel. A lignikol gombák döntő többsége xilofág, tehát a faanyagot felépítő strukturális elemeket (pl. cellulóz, lignin) fogyasztják. Ezeknek az elemeknek a lebontási módját tekintve a bazídiumos gombákat korábban vagy fehér- vagy barnakorhasztóként tárgyalták (BALDRIAN és VALASKOVA 2008). Fehérkorhasztásról akkor beszélünk, ha a gomba enzimei először a lignint bontják le, így a visszamaradt anyag a fehéres színü, homogén, puha és enyhén rostos struktúrájú cellulóz; ezzel szemben a barnakorhasztás során elsősorban a cellulóz bomlik le, így a visszamaradó anyag a tömbös szerkezetü lignin, amely vöröses, barnás színủ (SCHWARZE 2007; STOKLAND és mtsai. 2012). RILEY és munkatársai (2014) xilofág fajok genomjának és enzimkészletének vizsgálata alapján viszont arra a következtetésre jutottak, hogy ez a hagyományos felosztás nem alkalmazható minden gombafajra [pl. Botryobasidium botryosum (Bres.) J. Erikss., Jaapia argillacea Bres., Schizophyllum commune Fr.] és a faanyag korhasztási módjának kategorizálását újra kell gondolni. FLOUDAS és munkatársai (2015) vizsgálatuk során megállapították, hogy a Cylindrobasidium torrendii (Bres.) Hjortstam - a valódi fehérkorhasztó fajokhoz hasonlóan genomja karbohidrát-aktív enzimekben (CAZY) gazdag, ugyanakkor a barnakorhasztókhoz áll közelebb abban a tekintetben, hogy a legtöbb olyan gén hiányzik belöle, amelyek a lignin lebontására specializálódtak. Ennek a két recens munkának az eredményeképpen további kérdések merültek fel az egyes lignikol nagygomba taxonok faanyag lebontási módját illetően, amelyek tisztázásához további modellfajok genomvizsgálatai nagy segítséget jelenthetnek a jövőben.

A gombák termőtesteinek mérete alapján megkülönböztetjük a makro- (macromycetes) és mikrogombákat (micromycetes), amely utóbbi alatt a mikroszkopikus (szabad szemmel nem látható) sporokarpiumot képző taxonokat értjük (KIRK és mtsai. 2008). A két fogalom közti határ a szakirodalom alapján azonban nem mindig egyértelmü, mert sok esetben a mikológusok nem konkrét termőtest méret, hanem taxonómiai szempontok alapján különítik el a két csoportot (pl. KIRK és mtsai. 2008; MAGYAR és TÓTH 2003; TÓTH 1967). A lignikol bazídiumos nagygombák termőtestének méretében ugyanakkor jelentős különbségek lehetnek: nagyságuk a néhány milliméterestöl [pl. Phaeomyces E. Horak, Phleogena faginea (Fr. \& Palmquist) Link] a több méteresig [pl. Bridgeoporus nobilissimus (W.B. Cooke) T.J. Volk, et al., Phellinus ellipsoideus 
(B.K. Cui \& Y.C. Dai) B.K. Cui et al., Rigidoporus ulmarius (Sowerby) Imazeki] változhat (Burdsall és mtsai. 1996; CuI és DeCOCK 2013; DAI és CUI 2011; HorAK 2005; RedBerg és mtsai. 2003; SzCZEPKOWSKI és mtsai. 2008).

A bazídiumos nagygombákon belül az Agaricomycotina altörzsben a lignikol életmód számos filogenetikai szempontból távol álló leszármazási vonalon is kialakult, amelynek következtében ezen taxonok esetében a sporokarpiumok igen nagy anatómiai változatossága és makroszkopikus variabilitása figyelhető meg.

\subsubsection{A lignikol bazídiumos nagygombák makromorfológiája}

A tradicionálisan használt termőtest kategóriák (pl. gaszterotécium, holotécium, krusztotécium, pilotécium) (JAKUCS és VAJNA 2003) sok esetben nem kellően jellemeznek egyes sporokarpium-típusokat, ezért leggyakrabban egy jellegzetes taxon termőteste vagy trámája alapján csoportosítják a bazídiokarpiumok morfotípusait: agarikoid, athelioid, boletoid, ciphelloid, gaszteroid, hidnoid, kantharelloid, klavarioid, korticioid, poroid, telephoroid, stb. (BINDER és HibBetT 2006; Bodensteiner és mtsai. 2004; HibBeTt és THORN 2001; HibBETT és BINDER 2002; ZMITROVICH és mtsai. 2015).

A bazídiumos gombák törzsének [Basidiomycota Whittaker ex Moore] egy külön altörzsét alkotják a rozsdagombák [Pucciniomycotina R. Bauer et al.] (BAUER és mtsai. 2006), ahová nagyságrendileg 8000 leírt faj tartozik (KIRK és mtsai. 2008). Ezek közül viszont igen kevés azon taxonok száma, amelyek termőtestet képeznek (AIME és mtsai. 2006, 2014). Néhány nemzetségnél azonban előfordul reszupinátus [Septobasidium Pat.] (COUCH 1938; Li és GuO 2014) vagy stilboid típusú bazídiokarpium [Agaricostilbum Wright, Atractiella Sacc., Atractogloea Oberw. \& Bandoni, Chionosphaera D.E. Cox, Heterogastridium Oberw. \& R. Bauer, Pachnocybe Berk., Phleogena Link, Pycnopulvinus Toome \& Aime, Stilbum Tode] (BAUER és mtsai. 2006; COX 1976; HAUSNER és mtsai. 2008; OBERWINKLER és BANDONI 1982; OBERWINKLER és BAUER 1989; OBERWINKLER és mtsai. 1990; SZCZEPKOWSKI és mtsai. 2008; TOOME és AIME 2014), amelyek taxonómiai szempontból nem, de morfológiai értelemben nagygombának tekintendők.

A himéniumot hordozó tráma típusából ugyan nem lehet filogenetikai következtetéseket levonni (pl. HIBBETT 2007; KRÜGER és mtsai. 2001), de mint határozóbélyeg továbbra is igen nagy jelentőséggel bír az egyes morfológiai csoportok elkülönítésében (pl. BERNICCHIA és GORJÓN 2010; KNUDSEN és Vesterholt 2012; RyVARden és Melo 2014). A tráma kialakulásától függően a valódi bazídiumos gombák (Agaricomycotina) termőtestei két nagy csoportra oszthatók: nyitott (gimnokarp) és zárt (angiokarp) (KIRK és mtsai. 2008; WEBSTER és 
WEBER 2007). Az angiokarp, jellemzően gaszteroid típusú termőtestet képző bazídiumos gombák többnyire talajon jelennek meg (FRIEDRICH 2011; RIMÓCZI és mtsai. 2011) és viszonylag kevés a lignikol fajok száma [pl. Cyathus striatus (Huds.) Willd., Lycoperdon pyriforme Schaeff., Nidularia deformis (Willd.) Sw.].

A gimnokarp termőtestet képző gombákon belül korábban a tráma alapján elkülönítették a lemezes (agarikoid s. lato) és nem lemezes (aphyllophoroid) nagygombákat, amely utóbbi a PATOUILlaRD (1900) által „Aphyllophoracés”-ként elnevezett csoport után kapta a nevét. Korábban az Aphyllophorales rendbe (REA 1922) sorolt taxonok a termőtestek tekintetében igen nagy diverzitást mutatnak, amelyek alapján további morfotípusok különíthetők el (pl. korticioid, poroid, klavarioid, hidnoid, sztereoid). Tekintettel arra, hogy a „nem lemezes” nagygombák taxonómiai és morfológiai szempontból is nehezen körülhatárolhatóak, erre a csoportra az „aphyllophoroid” elnevezést számos újabb munkában még továbbra is használják (pl. GORJÓN és BERNICCHIA 2013; KUNTTU és mtsai. 2011; VolOBUEV 2013).

Az „agarikoid” gombák, az Agaricus L. génuszra jellemző termőtest makromorfológiai bélyegeivel rendelkeznek: tönk, kalap és lemezek (KIRK és mtsai. 2008). A tönknek (ált. rövid vagy hiányzik) a kalaphoz való excentrikus csatlakozása alapján az agarikoid gombákon belül elkülöníthetőek a lignikol életmódú ,pleurotoid s. lato” (crepidotoid, lentinoid, panelloid, pleurotoid s. str.) termőtestet képző taxonok: Crepidotus spp., Hohenbuehelia spp., Lentinellus spp., Pleurotus spp., stb. (Hrouda 2001; JaKOBSSON és NiEMElä 2004; KaLAmes 2007; ZMITROVICH és mtsai. 2004). Egyes szerzők az agarikoid csoporton belül, a pleurotoid mellett külön kategóriában tárgyalják az armillarioid, coprinoid, mycenoid és pluteoid típusokat is (ZMitrovich és mtsai. 2015). A pleurotoid termőtest típus azonban ezeknél a nemzetségeknél sem tekinthető szisztematikai bélyegnek; a Crepidotus (Fr.) Staude génusz leírásában ugyan többnyire nem szerepel (pl. CONSIGLIO és SETTI 2008; SENN-IRLET 2012), de a nemzetségből ismert több jól fejlett tönkkel rendelkező (agarikoid s. str.) taxon is: Crepidotus ibericus (G. Moreno \& Esteve-Rav.) Bandala, Esteve-Rav. \& Montoya, C. nyssicola (Murrill) Singer, C. subfulviceps Aime, Vila \& P.-A. Moreau, C. thermophilus (Singer) Aime, Baroni \& O.K. Mill. (AIME és mtsai. 2002, 2005, 2009; BANDALA és mtsai. 2008a). A lágyszárú növényekhez kötődő terrikol Pleurotus taxonok [P. eryngii fajkomplex] vagy egyes lignikol trópusi fajok [pl. P. rickii Bres.] esetében szintén megfigyelhető az agarikoid termőtest (LECHNER és mtsai. 2004; KAWAI és mtsai. 2008; MENOLLI és mtsai. 2014).

A ,poroid” termőtest (szűk értelemben vett taplófélék) alatt a pórusos trámát képző taxonokat értjük, amelyek „Polyporus” típusú bazídiokarpiumot képeznek (KIRK és mtsai. 2008). ZMitrovich és mtsai. (2006) viszont a „porioid” (Poria-típusú) kifejezést használják az egyéves, illetve évelő reszupinátus vagy orbikuláris, változatos konzisztenciájú, csöves 
termörétegtartót képző fajokra. Emellett megkülönböztetik a „tyromycetoid” típust is, amelybe az egyéves, húsos konzisztenciájú, csöves vagy ritkán fogas trámájú termőtesteket sorolják. IGMÁNDY (1991) a „taplók” definiálását szintén a tráma alapján közelítette meg: „a spórák a termötest sajátos módon kialakult (csöves, megnyúlt, labirintusosan üreges stb.) termörétegtartóján képzödnek. Nem tartoznak ide a vargányák (rend: Boletales)”. Azonban egyes Boletus s. lato fajokra emlékeztető terrikol termőtestet képző mikorrhizzás taxonokat (pl. Albatrellus Gray, Boletopsis Fayod) is a poroid gombák közé sorolnak (PoUZAR 1972; WATLING és MiLNE 2008). A tönkre és kalapra különülö termőtest jellemzően a talajon vagy talajban lévő faanyagon növő taplófajoknál alakul ki. Erre jó példa, hogy a tuskókon vagy rönkökön növő Postia Fr. fajok konzolos sporokarpiumot fejlesztenek, míg a talajon növő Postia stellifera T. Hatt. \& Sotome az Albatrellus s. lato taxonokhoz hasonló termőtestet fejleszt (HATTORI és mtsai. 2011). Szintén a poroid gombák között szokták említeni az ,irpicoid” [pl. Irpex lacteus (Fr.) Fr.] pórusos-fogas, a szabálytalanul megnyúlt pórusú „daedaleoid” [pl. Daedalea quercina (L.) Pers., Daedaleopsis confragosa (Bolton) J. Schröt.] és lemezes [pl. Daedaleopsis confragosa var. tricolor (Bull.) Bondartsev \& Singer, Trametes warnieri (Durieu \& Mont.) Zmitr., Wasser \& Ezhov] trámájú taxonokat is (BERNICCHIA 2005; KOUKOL és mtsai. 2014). A sporokarpiumok plaszticitása miatt egyes esetekben a különböző morfotípusok közti átmeneteket is megfigyelhetünk. Erre jó példa a Polyporaceae Corda családba tartozó Cryptoporus (Peck) Shear nemzetség taxonjainak sporokarpiuma, amely esetében a gaszteroid termőtestet képző fajokhoz hasonlóan a poroid trámát egy burok fedi, amely idővel felszakad (WU és ZANG 2000). Egyes taplógombákra jellemző, hogy az ivaros (teleomorf) termőtestek mellett, ivartalan (anamorf) áltermőtesteket is képeznek (STALPERS 2000), amelyek ugyan azon a szubsztrátumon [pl. Inonotus nidus-pici Pilát ex Pilát, I. rickii (Pat.) D.A. Reid, Phellinus pilatii Cerný, Postia ptychogaster (F. Ludw.) Vesterh.] (ČERNÝ 1968; MELO és mtsai. 2002; RYVARDEN 2005; VIZZINI és ZOTTI 2008), vagy akár különböző gazdanövényen jelennek meg [pl. Inonotus obliquus (Ach. ex Pers.) Pilát] (LEE és mtsai. 2008).

A tágabb értelemben vett korticioid gombák termőteste és trámája a sima (athelioid vagy korticioid s. str.) mellett különböző szerkezetű lehet. Az európai korticioid fajokat (Corticiaceae s. lato) tartalmazó monográfiákban (pl. BERNICCHIA és GORJÓN 2010; HJORTSTAM és mtsai. 1987) tárgyalják többek között egyes ciphelloid, hidnoid, reszupinátus poroid vagy éppen a sztereoid termőtest-típusokat is. A sztereoid (Stereum-típusú) termőtestet képző taxonok jellemzője a kalaposodó parageotropikus vagy reszupinátus, sima trámájú többnyire kemény állagú sporokarpium: pl. Amylostereum Boidin, Laxitextum Lentz, Stereum Hill ex Pers., stb. (JAHN 1971; ŢURA és mtsai. 2008; ZMITROVICH és mtsai. 2006). 
A ciphelloid termőtestek jellemzően csésze, henger vagy csöves alakúak és hosszuk, illetve átméröjük gyakran kevesebb, mint $2 \mathrm{~mm}$, de egyes taxonoké meghaladhatja az $1 \mathrm{~cm}-\mathrm{t}$ is; a himenofor jellemzően sima és a gyakran csüngő termőtest belső felületén található (BODENSTEINER és mtsai. 2004; DONK 1959, 1962a). A lignikol fajok közül jellegzetes ciphelloid termőtestet fejlesztenek többek között a Calyptella Quél., Cyphella Fr., Flagelloscypha Donk, Henningsomyces Kuntze, Lachnella Fr., Merismodes Earle, Phaeosolenia Speg., Rectipilus Agerer, Stigmatolemma Kalchbr., Stromatoscypha Donk vagy Woldmaria W.B. Cooke nemzetségek fajai (pl. AGERER 1973, 1978, 1979, 1980; BODENSTEINER és mtsai. 2004; COOKE 1961a; GORJóN és JESUs 2014; SIEPE és KASPAREK 2002).

Az Agaricales rendbe tartozó (MATHENY és mtsai. 2006) unikális termőtestet képző Fistulina hepatica (Schaeff.) With. fajt a legtöbb határozó a taplók (poroid) között tárgyalja (pl. BERNICCHIA 2005; IGMÁNDY 1991; RYVARDEN és GILBERTSON 1993), azonban a külön álló csövecskék alapján több szerző a ciphelloid gombák között említi (pl. KNUDSEN és VESTERHOLT 2012; SINGER 1986). Ennek oka, hogy a sporokarpiumot egy összetett termőtestnek is tekinthetjük (sztróma), ahol a különálló csövecskék önálló ciphelloid-típusú bazídiokarpiumok (policiphelloid) (ZMITROVICH és WASSER 2004). Hasonló, több különálló csövecskéből álló policiphelloid termőtest alakult ki a rendszertani szempontból taplófélék (Polyporaceae; központi polyporoid klád) közé tartozó Sparsitubus nelumbiformis L.W. Hsu \& J.D. Zhao fajnál is (BINDER és mtsai. 2013; DAI és mtsai. 2007). A Schizophyllum commune Fr. morfológiai szempontból teljesen különböző megjelenésü, de genetikailag közel áll a Fistulina hepatica fajhoz (/Schizophyllum-Fistulina klád) (BINDER és mtsai. 2008). A Schizophyllum commune termőtestének „lemezessége” ellenére a legtöbb szerző a bazídiokarpium formája és anatómiai struktúrája alapján nem az agarikoid, hanem a ciphelloid gombák között tárgyalja (ESSIG 1922; COOKE 1961b). Ez utóbbi mellett szól, hogy a S. commune trámája száraz időben összehajlik (LINDER 1933), amely tulajdonság a ciphelloid gombákra jellemző (AGERER 1986). A ciphelloid típusú termőtest lemezes vagy lemezek nélküli megjelenésére jó példa a Resupinatus Gray nemzetség, amelyben az európai taxonok közül a $R$. applicatus (Batsch) Gray és $R$. trichotis (Pers.) Singer fajoknak vannak lemezei, míg a R. poriaeformis (Pers.) Thorn, Moncalvo \& Redhead és R. griseopallidus (Weinm.) Knudsen \& Elborne sima, a R. porosus M.P. Martín, Lodge \& Thorn pedig poroid termőrétegtartót fejleszt (THORN és mtsai. 2005).

A „tüskeszerü” vagy „fogas” trámát képző gombák termőtesteit „hidnoid”-nak nevezzük a Hydnum L. génusz alapján. A tönkös hidnoid fajok jellemzően ektomikorrhiza képzők (pl. Hydnellum P. Karst., Hydnum L., Phellodon P. Karst., Sarcodon Quél. ex P. Karst.) (BAIRD és mtsai. 2013; VAN DER LINDE és mtsai. 2008), de a korábban szintén Hydnum-ként leírt taxonok között számos lignikol életmódú faj található: Climacodon septentrionalis (Fr.) P. Karst. (三 
Hydnum septentrionale Fr.), Dentipellis fragilis (Pers.) Donk (三 Hydnum fragile Pers.), Hericium cirrhatum (Pers.) Nikol. (三 Hydnum cirrhatum Pers.), H. coralloides (Scop.) Pers. (三 Hydnum coralloides Scop.), H. erinaceus (Bull.) Pers. (三 Hydnum erinaceus Bull.), Pseudohydnum gelatinosum (Scop.) P. Karst. (三 Hydnum gelatinosum Scop.), stb. (DoNK 1962c; KARSTEN 1868, 1881; PERSOON 1794). Hidnoid himénium reszupinátus növekedésű termőtesten számos genetikailag távol álló lignikol nagygomba nemzetségnél is egyaránt kialakult: Dentipellis Donk, Gloiodon P. Karst., Steccherinum Gray, stb. (DAI és mtsai. 2009; DeSJARDIN és RYVARDEN 2003; SPIRIN és mtsai. 2007). Abban az esetben, ha a tüskék hengeresek, kúposak vagy fogasak a himéniumot „odontioid”-nak nevezzük (BERNICCHIA és GORJÓN 2010; HJORTSTAM és mtsai. 1987).

Jellegzetes kocsonyás állagú, de sima trámájú termőtestet (tremelloid) képeznek a Tremella Pers. nemzetségbe tartozó fajok (WEISs és mtsai. 2014), amelyek többsége mikroszkopikus vagy egy cm-nél kisebb, valamint gyakran zuzmókon vagy nagygombák termőtestein fordul elő (Millanes és mtsai. 2014; PiPPOla \& KotiRAnTA 2008). A Tremella fajokhoz morfológiai szempontból hasonló termőtest típust találunk a Dacrymycetaceae család számos nemzetségében is: Dacrymyces Nees, Ditiola Fr., Guepiniopsis Pat., Femsjonia Fr. (OBERWINKLER 1993; SHIROUZU és mtsai. 2009).

Makroszkopikus képletet nem csak a sporokarpiumok között találunk, tekintve, hogy a hifák egyes taxonok esetében létrehozhatnak valamilyen ökológiai elönyt biztosító szabad szemmel is jól látható, jellegzetes morfológiájú struktúrát. A micélium vegetatív terjedésének segítése és védelme érdekében egyes lignikol nagygombák [pl. Armillaria spp., Ossicaulis lignatilis (Pers.)

Redhead \& Ginns] szabad szemmel is látható hifaköteget (rizomorfát) fejlesztenek (CLÉMENÇON 2005; GarRaWAY és mtsai. 1991; PERSOON 1801). Egy másik ökológiai előnyt biztosító hifamódosulat a Pseudochaete corrugata (Fr.) S.H. He \& Y.C. Dai légmicéliuma, amely a már átszőtt faághoz „odaragasztja” a hozzá közel levő ágat, így lehetővé téve a gomba számára a szubsztrátum kolonizálását, kompetíciós előnyt biztosítva a talajban lévő más szaprotróf gombákkal szemben (AINSWORTH és RAINER 1990, 2004). Egyes lignikol nagygombák [pl. Laccocephalum spp., Lentinus spp., Polyporus tuberaster (Jacq. ex Pers.) Fr., P. umbellatus (Pers.) Fr.] pedig terrikol életmódot is folytathatnak, annak köszönhetően, hogy a talajban kifejlődő, hifákból álló szkelróciumot („gombakő”) képeznek (PEGLER 1983).

\subsubsection{A lignikol bazídiumos nagygombák mikromorfológiai bélyegei}

A bazídiumos nagygombák fonalas felépítésủek és jellemzően több sejtes szerveződésủek (KIRK és mtsai. 2008). Az egymáshoz szorosan illeszkedő hifák létrehozhatnak egy kompakt, 
sürü szövedéket, amely morfológiai szempontból ugyan hasonlít a növények valódi szöveteire, de szerkezetileg álszövetes szerveződésünek tekintünk, mivel nem merisztéma eredetủek, valamint a gombasejtek között nincsenek plazmodezmák (DEACON 2006; JAKUCS és VAJNA 2003). A gomba álszöveteknek (plektenchima) két nagy csoportja ismert: a prosenhima, amely lazább szerveződésű, benne a gombafonalak mikroszkopikusan még elkülöníthetők, illetve a pszeudoparenchima, amely esetében a hifák szorosan illeszkednek, alakilag jelentősen módosulnak (MOORE 1994; KIRK és mtsai. 2008). A plektenchimák változatos szerkezete alapján YoshimURA és SHIMADA (1980) kilenc típust különítettek el, de ezeket leíró bélyegként jellemzően a lichenizált gombák (zuzmók) esetében alkalmazzák (pl. NAVARRO-RosiNÉS és mtsai. 2000).

A micéliumot felépítő gombafonalakat két nagy csoportra oszthatjuk: generatív- és vegetatív hifákra. Biológiai értelemben a vegetatív micélium a gombák legfontosabb részét képzik (GREGORY 1984), viszont mint morfológiai határozóbélyeg a lignikol nagygombák esetében kisebb a jelentőségük. Ennek egyik oka, hogy a lignikol fajok micéliumának faanyagból való kinyerése lényegesen nehezebb feladat, mint a terrikol gombák talajból történő kimutatása. Steril körülmények között viszont agaron előállított micéliumtenyészeteik taxonokként mutatnak eltérést biológiájuk, valamint mikro- és makroszkopikus bélyegeikben egyaránt (p1. NOBLES 2011).

A szintén gombafonalakból felépülő bazídiokarpiumokban mindig jelen vannak a generatív hifák, amelyek között azonban taxonómiai csoportokra jellemzően megjelenhetnek vegetatív hifák is: szkeletális-/váz-, illetve kötőhifák (CLÉMENÇON 1998; HJORTSTAM és mtsai. 1987; PEGLER 1996). A bazídiumos nagygombák hifáinak morfológiai változatosságára már több korai munkában is felfigyeltek (AMES 1913; FAYOD 1889; PATOUILLARD 1887, 1900), de Corner két taplófaj (poroid) termőtestein végzett részletes anatómiai vizsgálatai (CORNER 1932ab) voltak az első olyan munkák, amelyek a hifastruktúrát, mint taxonómiai bélyeget helyezték előtérbe. A taplók hifarendszerének szisztematikai szerepe, különösen a nemzetség szintű rendszerezésben való jelentősége az 1950-es évek elejétől került előtérbe (pl. CUNNINGHAM 1954; PINTO-LOPEZ 1952). Ugyanakkor meg kell jegyezni, hogy nem csak a taplók esetében fontos határozóbélyeg a hifák szerkezete, hanem más lignikol gombacsoportoknál is taxonspecifikus bélyeg lehet: pl. korticioidok (HJORTSTAM és mtsai. 1987), hidnoidok (MAAS GEESTERANUS 1962), vagy sztereoidok (JAHN 1971; REID 1965). A szeptált vagy csatos, illetve vékony vagy vastag falú generatív hifák mindig jelen vannak a termőtestben, és amennyiben csak ez az egy típus fordul elő a micéliumot monomitikusnak nevezzük. Abban az esetben, ha a generatív hifák mellett szkeletális hifák is előfordulnak a micélium dimitikus; mindhárom hifatípus együttes előfordulása esetén pedig trimitikus (CUNNINGHAM 1954). A hifarendszer típusát sok esetben 
nem könnyü megállapítani, tekintve hogy egyes, csak ritkásan szeptált vastagfalú generatív hifák (pszeudoszkeletális hifák) nagyon hasonlíthatnak a valódi szkeletális hifáka; ebben az esetben a hiferendszert pszeudodimitikusnak nevezzük (PARMASTO 1970; SPIRIN és ZMITROVICH 2007). Amennyiben a generatív és vázhifák mellett pszeudoszkeletális hifák is elöfordulnak, akkor a hifarendszer szubdimitikus; ha pedig kötőhifák is jelen vannak szubtrimitikus (ZMITROVICH és WASSER 2012). Ritkábban előfordulhat olyan struktúra is, amikor a generatív hifák mellett kötőhifák fordulnak csak elő, ilyenkor a hifarendszer amfimitikus (ZMITROVICH és mtsai. 2009; ZMITROVICH és WASSER 2012). A hifák típusain belül a szeptumok struktúrája is fontos taxonómiai marker a valódi bazídiumos gombákon [Agaricomycotina R. Bauer et al.] belül; fenotípusosan három morfotípust különítünk el: vezikuláris-tubuláris, perforált, imperforált (VAN DRIEL és mtsai. 2009).

A bazídiumos nagygombák termőtesteit felépítő hifák végein kialakulhatnak steril elemek (pl. cisztidia) vagy ivaros szaporítóképletek (pl. bazídia), amelyek együttesen alkotott rétegét nevezzük himéniumnak. Ezen belül megkülönböztetjük az euhiméniumot és a katahiménioumot (BERNICCHIA és GORJÓN 2010; DONK 1964). A himéniumban található módosult hifavégeket hifidiának nevezzük, amelyeket több alaptípusba lehet csoportosítani: dendrohifidia (szabálytalanul és sürün elágazodó), dichohifidia (dichotomikusan elágazodó) (PEGLER 1996). A cisztidiumok fontos határozóbélyegek, tekintve, hogy sok esetben alakjuk, méretük nemzetségre, vagy fajra jellemző (ROMAGNESI 1944). A cisztidiumokat csoportosíthatjuk eredetük (pl. himéniális-, szkeletális-, hifális-), pozíciójuk (pl. pileo-, cheilo-, pleuro-, kaulo-) és típusuk (pl. lepto-, lampro-, shizo-, gloeo-, chryso-) szerint is. A leptocisztidium vagy cisztidiol a bazídiumokkal együtt fejlődik és a monomitikus hifarendszerü taxonoknál a leggyakoribb típus (JUNG 1987 cit. in ŢURA és mtsai. 2011; PRICE 1973). A generatív hifa eredetű gyakran szeptált szeptocisztidia (CUNNINGHAM 1953) főként egyes korticioid gombákra jellemző [pl. Coniophora olivacea (Fr.) P. Karst., Hyphoderma spp., Hyphodontia spp., stb.] (BERNICCHIA és GORJÓN 2010; ȚURA és mtsai. 2011). Néhány lignikol nagygomba taxon [pl. Peniophora Cooke, Pluteus sect. Pluteus, Hohenbuehelia Schulzer] termőtesteiben előfordulnak metuloidok, amelyek valójában gyakorta kristályokkal berakódott, éretten vastag falú cisztidiumok (lamprocisztidia pro parte) (HJORTSTAM és mtsai. 1987; ŢURA és mtsai. 2011). Szintén a steril elemek közé tartoznak a Hymenochaetaceae családra jellemző szeták (pszeudocisztidia), amelyeknek jellegzetessége, hogy KOH-ra sötétednek és többnyire vastag falúak (KIRK és mtsai. 2008; ŢURA és mtsai. 2011). LENTZ (1954) megkülönböztette a „beágyazódott” (himéniális-) és a „csillag alakú” (astero-) szetákat is. A trámában kialakuló szeták (szetális hifa, makroszeta) hosszabbak, mint a himéniumban lévők. Egyes fajoknál (pl. Inonotus cuticularis) a kalapfelszínen alakultak ki elágazodó szetális hifák (RYVARDEN 2005; ŢURA és mtsai. 2011). 
A bazídiumok feladata az exogén módon kialakuló bazídiospórák képzése (INGOLD 1983), amelyek jellemzően négy szterigmán képződnek, de egyes taxonok esetében kialakulhat egy, kettő, három vagy négynél is több, akár nyolc is (TOMMERUP és mtsai. 1991; ȚURA és mtsai. 2011). A szterigmák száma viszont többnyire stabil egyes fajokra nézve, ezért taxonómiai bélyeg is lehet (HJORTSTAM és mtsai. 1987). A bazídiumok szeptáltsága alapján két nagy csoportot különítenek el: holobazídium és hetero-/fragmobazídium (WEBSTER és WEBER 2007). Mikroszkopikus vizsgálat során a himéniumban gyakran láthatók bazidiolumok, amelyek a leptocisztidiumokhoz (cisztidiolum) hasonló megjelenésü éretlen vagy steril bazídiumok. A bazídiumokon keletkező bazídiospórák alakja, mérete, színe és mintázottsága (ornamentációjuk) egyes fajra, nemzetségre vagy akár családra is jellemző mikroszkopikus bélyeg. A spórák morfológiai változatosságát az Agaricales rendben PEGLER és Young (1971) monografikus munkájukban tárgyalták; míg más szerzők a taplófajok szisztematikájában betöltött jelentőségükre hívták fel a figyelmet (PARMASTO és PARMASTO 1987).

Tekintettel arra, hogy a gombák leghatékonyabban spórák segítségével terjednek, KAUSERUD és munkatársai (2008) arra keresték a választ, hogy az európai taplófajok bazídiospóráinak morfológiai tulajdonságai mutatnak-e összefüggést különböző ökológiai tényezőkkel (pl. életmód, szubsztrátum). Elemzésük során pozitív korrelációt mutattak ki a termőtest és a bazídiospórák mérete között. Továbbá kimutatták, hogy a prazita életmódú, valamint lombos fafajokon előforduló fajok nagyobb spórákat képeznek, mint a szaprotrófok és a fenyőféléken növők. Érdekes összefüggést találtak a taplók korhasztási típusa és életmódja, valamint a spórák alakja között; eredményeik alapján a fehérkorhasztó paraziták spórái jellemzően gömbölyübbek, mint a barnakorhasztó szaprotrófoké. KAUSERUD és munkatársainak (2008) statisztikai módszerekkel végzett elemzései jól mutatják, hogy a különböző evolúciós vonalon kialakult és specializálódott gombafajok spóráinak struktúrája összefüggést mutat az ökológiai stratégiával. Ugyanakkor az egyes taxonok (faj, nemzetség) spóráinak alakja, mérete, ornamentációja, illetve reagensekkel mutatott reakciója, morfológiai stabilitásának köszönhetően továbbra is a legfontosabb határozóbélyegek közé tartozik.

\subsubsection{A lignikol bazídiumos nagygombák szisztematikája}

A növényekhez és az állatokhoz hasonlóan a gombák rendszerzésének alapegysége is a faj, amelynek megnevezésére a LINNÉ (1753) által bevezetett kettős nevezéktant (binomiális nómenklatúra) használjuk. A bazídiumos gombákat tekintve Elias Magnus Fries svéd mikológus müvei olyan meghatározóak voltak a későbbi mikológiai munkákra nézve, hogy a „Code” (International Code of Nomenclature for algae, fungi, and plants) alapján minden binom, amit a 
„Systema Mycologicum vol. 1-3.” (FrIES 1821, 1823, 1829), „Elechnus Fungorum vol. 1-2.” (FRIES 1828) és „Index” (FRIES 1832) köteteinek hasábjain szerepelnek szankcionáltak, tehát prioritást élveznek a korábban publikált nevekkel szemben (MCNEILL és mtsai. 2012, Art. 13.1.). A gombák nómenklatúrájának egy másik jellegzetessége, hogy az egy fajhoz tartozó teleomorf és anamorf alakoknak külön neveket adtak a mikológusok, amely sokáig megnehezítette a rokonsági fokon alapuló rendszerezést. A dupla nevezéktan eltörlésére („egy gomba egy név”) csak az Amsterdami Deklaráció (AD) elfogadása után került sor (HAWKSWORTH 2011, MCNEILL és Turland 2011, Norvell 2011b, TAYlor 2011). Az AD cikkelyeinek egyes elemei megosztották a mikológus társadalmat (GAMS és JAKLITSCH 2011), ezért vélhetően az egy névre való átállás még hosszabb időbe fog telni. A molekuláris módszerek terjedésével a tradicionális biológiai nómenklatúra szembe került a filogenetikai szemléleten alapuló nevezéktannal (MOORE 1998; REDHEAD 2000), amely elveti a hagyományos Linnéi rendszer magasabb kategóriáit (RIEPPEL 2006). A PhyloCode a fajt, mint a rendszerezés alapegységét kládokban tárgyalja, amelyek alatt monofiletikus csoportokat értünk (pl. DE QUEIROZ és DONOGHUE 2011; HIBBETT és mtsai. 2005).

A nagygombák szisztematikájának korai szakaszában a rendszerezés a termőtestek makroszkopikus jellemzői alapján történt (pl. PERSOON 1801; FRIES 1821), majd egyre nagyobb hangsúlyt kaptak a mikroszkopikus bélyegek (PATOUILlARD 1900; SACCARDO 1899). A nagygombák rendszerezésének ebben a szakaszában jellemzően a fenotípusosan megjelenő morfológiai hasonlóságok alapján állapították meg a rokonsági fokokat. Azonban a környezeti hatásra plasztikusan változó morfológiai bélyegeket előtérbe helyező rendszerezést alapjaiban forgatták fel az egyes DNS régiók hasonlóságán nyugvó molekuláris módszerekkel végzett munkák (pl. LARSSON és mtsai. 2004, HiBBETT 2006; HiBBET és mtsai. 2007).

A filogenetikai vizsgálatok eredményei azt mutatták, hogy számos gombacsoportnál a termőtest morfológiai sajátosságai evolúciós értelemben egymástól távol álló fajoknál is egyaránt kialakultak (1. táblázat).

Jelenleg a bazídiumos gombák törzsébe [Basidiomycota Whittaker ex Moore] közel 31 ezer leírt faj tartozik (KIRK és mtsai. 2008) és ezek közül a fajok több mint kétharmadát (3 osztály, 23 rend, 119 család és kb. 21000 faj) a valódi gombák [Agaricomycotina R. Bauer et al.] altörzsébe soroljuk (YANG 2011). Az Agaricomycotina altörzsön belül a lignikol életmódra specializálódott nagygombafajok szinte minden rendben megtalálhatók: Agaricales Underw., Amylocorticiales K.H. Larss. et al., Atheliales Jülich, Auriculariales J. Schröt., Boletales E.-J. Gilbert, Cantharellales Gäum., Corticiales K.H. Larss., Dacrymycetales Lindau, Geastrales K. Hosaka \& Castellano, Gloeophyllales Thorn, Gomphales Jülich, Hymenochaetales Oberw., Jaapiales Manfr. Binder et al., Polyporales Gäum., Russulales Kreisel ex P.M. Kirk et al., Sebacinales M. 
Weiss et al., Thelephorales Corner ex Oberw., Trechisporales K.H. Larss. és Tremellales Fr. (BINDER és mtsai. 2010; JAKUCs és Dima 2013; HibBETT és mtsai. 2007; Weiss és mtsai. 2004). Az egyes taxonok esetében azonban jelentős eltérések vannak a fajszám és a lignikol életmód dominanciáját illetően. ZMITROVICH és munkatársai (2015) szerint a bazídiumos gombákon belül az Agaricales, Hymenochaetales és Russulales mellett, a legjelentősebb lignikol rend a Polyporales, amelynek taxonjai szinte kizárólag xilofágok.

1. táblázat. A lignikol bazídiumos nagygombák kládok és termőrétegtartó (himenofor) alapján való megoszlása (HIBBETT és THORN 2001, valamint HIBBETT 2007 munkái alapján).

\begin{tabular}{|c|c|c|c|c|}
\hline Kládok/Himenofor & Sima & Fogazott & Pórusos & Lemezes \\
\hline $\begin{array}{l}\text { Agaricoid } \\
\text { (Agaricales) }\end{array}$ & $\begin{array}{c}\text { Brunneocorticium, } \\
\text { Chondrostereum }\end{array}$ & Deflexula & $\begin{array}{l}\text { Dictyopanus, } \\
\text { Favolaschia, } \\
\text { Poromycena }\end{array}$ & $\begin{array}{l}\text { Pleurotus, } \\
\text { Stropharia }\end{array}$ \\
\hline $\begin{array}{l}\text { Boletoid } \\
\text { (Boletales) }\end{array}$ & $\begin{array}{l}\text { Coniophora, } \\
\text { Serpula }\end{array}$ & Hydnomerulius & & Tapinella \\
\hline $\begin{array}{l}\text { Russuloid } \\
\text { (Russulales) }\end{array}$ & Stereum & $\begin{array}{l}\text { Auriscalpium, } \\
\text { Hericium }\end{array}$ & $\begin{array}{l}\text { Bondarzewia, } \\
\text { Heterobasidion }\end{array}$ & Lentinellus \\
\hline $\begin{array}{l}\text { Thelephoroid } \\
\text { (Thelephorales) }\end{array}$ & $\begin{array}{l}\text { Thelephora, } \\
\text { Tomentella }\end{array}$ & & & Lenzitopsis \\
\hline $\begin{array}{l}\text { Polyporoid } \\
\text { (Polyporales) }\end{array}$ & $\begin{array}{c}\text { Phlebia, } \\
\text { Pulcherricium }\end{array}$ & $\begin{array}{l}\text { Climacodon, } \\
\text { Irpex }\end{array}$ & $\begin{array}{c}\text { Fomitopsis, } \\
\text { Ganoderma, } \\
\text { Polyporus, stb. }\end{array}$ & $\begin{array}{l}\text { Lentinus, } \\
\text { Lenzites, } \\
\text { Panus }\end{array}$ \\
\hline $\begin{array}{l}\text { Hymenochaetoid } \\
\text { (Hymenochaetales) }\end{array}$ & $\begin{array}{l}\text { Hymenochaete, } \\
\text { Pseudochaete }\end{array}$ & Hydnochaete & $\begin{array}{l}\text { Inonotus s. l., } \\
\text { Phellinus s. l. }\end{array}$ & Rickennella \\
\hline $\begin{array}{l}\text { Cantharelloid } \\
\text { (Cantharellales) }\end{array}$ & $\begin{array}{l}\text { Botryobasidium, } \\
\text { Sistrotema, } \\
\text { Tulasnella }\end{array}$ & Sistotrema & & \\
\hline $\begin{array}{l}\text { Gomphoid/Phalloid } \\
\text { (Phallomycetidae) }\end{array}$ & Kavinia & $\begin{array}{l}\text { Beenakia, } \\
\text { Kavinia }\end{array}$ & & \\
\hline
\end{tabular}

A főként agarikoid termőtesteket képző nagygombákat tartalmazó Agaricales rendbe, több mint 13 ezer faj tartozik (KIRK és mtsai. 2008). A rend típusának számító fajgazdag Agaricaceae családba viszont jellemzően terrikol taxonok [pl. Agaricus L.; Amanita Dill. ex Boehm.; Lepiota (Pers.) Gray] tartoznak és csak egyes Lycoperdon s. lato fajok jelennek meg holt faanyagon; továbbá több taxonómus az Agaricaceae családba sorolja a gaszterotéciumot képző lignikol fajokat tartalmazó Crucibulum Tul. \& C. Tul., Cyathus Haller és Nidularia Fr. \& Nordholm nemzetségeket is. Egyes szerzők (pl. ZHAO és mtsai. 2007, 2008; CRUZ és mtsai. 2012) viszont a Cyathus nemzetséget a Nidulariaceae Dumort. családba sorolják, MATHENY és munkatársai (2006) által közölt filogenetikai vizsgálat alapján.

$\mathrm{Az}$ Agaricales renden belül a Cyphellaceae a termőtestek morfotípusait tekintve az egyik legdiverzebb család; a ciphelloid termőtestet képző típusnemzetség [Cyphella Fr.] mellett a családban megtalálhatóak pleurotoid [pl. Cheimonophyllum Singer], hidnoid [Sarcodontia Schulzer], korticioid [pl. Gloeocorticium Hjortstam \& Ryvarden, Granulobasidium Jülich; 
Thujacorticium Ginns] vagy sztereoid [Chondrostereum] lignikol génuszok is. A renden belül elkülönülö /Tricholomatoid klád négy családot tartalmaz: Entolomataceae, Mycenaceae, Lyophyllaceae és Tricholomataceae s. str. (MATHENY és mtsai. 2006). Az Entolomataceae családba föként terrikol fajok tartoznak, de több nemzetség [pl. Clitopilus, Entoloma s. lato] egyes fajai holt faanyaghoz kötődnek (KotLÁBA és PoUZAR 1972; NoORDEloos 1992; NoORDELOOS és mtsai. 2010). A lignikol taxonokat is tartalmazó, kozmopolita elterjedésü Entoloma s. lato génusz több mint 1500 ismert fajjal az Agaricales renden belül a második legfajgazdagabb nemzetség (KIRK és mtsai. 2008; MANIMOHAN és mtsai. 2006; NoORDELOOS 1988, 2004, 2008; NoOrdeloos és Morozova 2010; NoOrdeloos és Gates 2012). A Lyophyllaceae leválasztását a Tricholomataceae s. lato családtól JÜLICH (1981) javasolta a Lyophyllum P. Karst. típusnemzetség alapján. A család önállóságának létjogosultságát a morfológiai bélyegeken kívül molekuláris vizsgálatok is igazolták (HOFSTETTER és mtsai. 2002; MATHENY és mtsai. 2006). A Lyophyllum nemzetség típusfaja [L. leucophaeatum (P. Karst.) P. Karst.] ugyan terrikol szaprotróf életmódú, de a családba tartozó egyes taxonok [pl. Hypsizygus Singer, Ossicaulis Redhead \& Ginns] a faanyag lebontására specializálódtak.

A Strophariaceae Singer \& A.H. Sm. az Agaricales rend egyik legfajgazdagabb (több mint 1300 faj) családja (KIRK és mtsai. 2008), amelyen belül a Pholiota (Fr.) P. Kumm. génusz mintegy 150 faja főként lignikol életmódú (KIRK és mtsai. 2008; NoORDELOOS 2011).

$\mathrm{Az}$ Agaricales és Atheliales rendekhez szisztematikailag közel álló [Agaricomycetidae Parmasto] Boletales monofiletikus csoportot képez, ugyanakkor az ide tartozó taxonok nagy változatosságot mutatnak a termőtestek típusait, illetve életmódjukat tekintve (BINDER és HiBBETT 2006). A boletoid termőtestet képző fajok [Boletus s. lato] szinte kizárólag ektomikorrhiza képzők (WU és mtsai. 2014b), de egyes reszupinátus sporokarpiumú nemzetségek lignikol életmódúak: pl. Coniophora DC., Hydnomerulius Jarosch \& Besl, Leucogyrophana Pouzar és Serpula (Pers.) Gray (JAROSCH és BESL 2001; PoUZAR 1958).

Lignikol nagygombák szempontjából igen fontos leszármazási vonal a Polyporales rend, amelyben az ismert fajok száma (több mint 1800 faj) ugyan lényegesen alacsonyabb, mint az Agaricales rend esetében (KIRK és mtsai. 2008), de a faanyag lebontása szempontjából számos igen effektív és jelentős gombacsoportot (pl. taplógombák döntő többsége) tartalmaz (FLOUDAS és mtsai. 2012). BINDER és munkatársai (2013) munkájukban ismertetik a rend szisztematikai helyzetét, valamint 373 taxon hat génszakasza (nrLSU, 5.8S, nrSSU, rpb1, rpb2 és tef1) és 10 faj teljes genomvizsgálata alapján közlik a Polyporales rend aktuális filogenetikai törzsfáját. Eredményeik alapján a legtöbb elemzés támogatja a már korábban is elkülönített /antrodia, /központi polyporoid és /phlebioid kládok létjogosultságát, ugyanakkor a reziduális polyporoid 
csoporton belül számos taxon [pl. Gelatoporia Niemelä, Grifola Gray, Tyromyces P. Karst.] látszólag egyik főbb leszármazási vonalhoz sem tartozik.

A Hymenochaetales rendböl több mint 600 fajt ismerünk (KIRK és mtsai. 2008), amelyek döntő többsége jellemzően lignikol életmódú (LARSSON és mtsai. 2006). A rend legnagyobb fajszámú tradicionális nemzetségei [Hymenochaete Lév. s. lato, Inonotus P. Karst. s. lato és Phellinus Quél. s. lato] a Hymenochaetaceae Donk családba tartoznak. Ezeknek a filogenetikai szempontból polifiletikus génuszoknak jellemző morfológiai bélyegeik, hogy hifáik csat nélküliek, szetákat képeznek és KOH hatására xanthochroikus reakciót mutatnak (PARMASTO és PARMASTO 1979; WAGNeR és Fischer 2001, 2002). Korábban a rend Schizoporaceae Jülich családjában tárgyalt poroid termőtestet képző Oxyporus (Bourdot \& Galzin) Donk típusnemzetség alapján ZMITROVICH és MALYSHEVA (2014) leírta LSU szekvenciákon alapuló filogenetikai vizsgálat alapján az Oxyporaceae Zmitr. et V. Malysheva családot. Ezt az elkülönítést LARSSON és munkatársai (2006) korábbi molekuláris vizsgálata is alátámasztja.

A többnyire phalloid, gaszteroid vagy éppen ramarioid termőtestet képző taxonokat tartalmazó Phallomycetidae K. Hosaka, Castellano \& Spatafora alosztályban viszonylag alacsony a lignikol fajok száma (HOSAKA és mtsai. 2006). A /gomphoid-phalloid kládon belül a Gomphales rendbe tartozó gombafajok igen változatosak morfológiájukat és ökológiai igényeiket tekintve, de filogenetikai szempontból egy jól támogatott különálló kládot alkotnak (GiACHINI és mtsai. 2010; PINE és mtsai. 1999; VILLEGAS és mtsai. 1999). Lignikol nagygombák közül a rend Lentariaceae Jülich családjából említést érdemelnek a Kavinia Pilát [= Hydnocristella R.H. Petersen], valamint a Beenakiaceae Jülich családba tartozó Beenakia D.A. Reid nemzetségek (HiBBETT és mtsai. 2014).

A korábban szisztematikailag elkülönítve tárgyalt osztott bazídiumú nagygombataxonok [Heterobasidiomycetes R.T. Moore] az aktuálisan elfogadott filogenetikai rendszer alapján a valódi bazídiumos gombák mindhárom osztályában [Agaricomycetes Doweld, Dacrymycetes Doweld; Tremellomycetes Doweld] megtalálhatók. Ezek között számos olyan faj található, amely életmódját tekintve faanyaghoz kötődik. Az Agaricomycetes leszármazási vonalon belül például az Auriculariales rendben több lignikol nemzetség is elöfordul: Auricularia Bull. ex Juss., Eichleriella Bres., Exidia Fr., Exidiopsis (Bref.) A. Møller és Heterochaete Pat (WEISs és OBERWINKLER 2001). A rend poroid termőtestet képző génuszainak [Aporpium Bondartsev \& Singer ex Singer, Protodaedalea Imazeki és Elmerina Bres.] taxonómiai helyzetét több munkában is vizsgálták (pl. MiETTINEN és mtsai. 2012; SotOME és mtsai. 2014; ZHOU és DAI 2013a). A szintén jellegzetes morfológiájú heterobazídiumokat képző Dacrymycetes osztály fajai morfológia és taxonómiai szempontból egy jól körülhatárolt csoportot alkotnak (OBERWINKLER 2014). A Dacrymycetes osztályba mindösszesen két rendet sorolnak: Dacrymycetales Lindau és 
Unilacrymales Shirouzu, Tokum. \& Oberw. (SHIROUZU és mtsai. 2013). Mindkét rend taxonjai lignikol szaprotrófok, amelyek többnyire a cellulóz lebontására specializálódott barnakorhasztók (OBERWINKLER 2014; SEIFERT 1983). A Tremellales a Tremellomycetes osztály legfajgazdagabb rendje; a rend taxonjai viszont igen nagy változatosságot mutatnak, mind életmódjukban, mind morfológiai szempontból (MILLANES és mtsai. 2011; WEISS és mtsai. 2014).

\subsection{Lignikol bazídiumos nagygombák természetvédelmi helyzete Európában}

Egyre több azoknak a tanulmányoknak és tudományos publikációknak a száma, amelyek a gombák veszélyeztetettségével és védelmének lehetőségeivel foglalkoznak, ám ennek ellenére a természetvédelemben betöltött szerepük még mindig eltörpül a növény- és állatvilághoz képest. Az IUCN globális vörös listáján szereplő 17.291 élölény között például csak egyetlenegy nagygombafaj található, a Szicília északi részen endemikus (Madonie-hegység) - mindösszesen $100 \mathrm{~km}^{2}$ kiterjedésü területen élö - Pleurotus nebrodensis (Inzenga) Quél. (SENN-IRLET és mtsai. 2007; VeNTURELla 2000, 2002, 2006). Európában viszont számos nagygomba vörös listát állítottak össze (BŐSZE és FODOR 2005; SENN-IRLET és mtsai. 2007), amelyek közül a legtöbb követi az IUCN által meghatározott kategóriákat és kritériumrendszert (DAHLBERG és MUELLER 2011). Európában a hivatalos, illetve a szakemberek által elözetes javaslatként megfogalmazott (nem hivatalos) nagygomba vörös listák jellemzően a fajok (nemzetségek) országos (pl. BRANDRUd és mtsai. 2010; DAHLberg és mtsai. 2010; DencheV és Gyosheva 2010; Diamandis 2000, 2010; Evans és mtsai. 2006; Fraiture 2010; GyosheVA és mtsai. 2006; HAYOVA 2010; HOLEC és BERAN 2006; IRŠĖNAITĖ 2010; KARADELEV 2000; KOTIRANTA 2006; Krisai-Greilhuber 2005; Lizon 2001; Minter 2014; Perić és Perić 2006; Rassi és mtsai. 2010; Rimóczi és mtsai. 1999; Schembri és Sultana 1989; Stoltze és Pihl 1998; Tanase 2006; TKALČEC és mtsai. 2008; VEERMAN 2004; WOJEWODA és ŁAWRYNOWICZ 2006) vagy azon belül regionális (pl. Aron és mtsai. 2005; HaRdTKE és OtTo 1999; KARASCH és HahN 2010; LANGer 2000; SCHMitT 2012; SiePe és WÖlfEl 2009; WALleYn és VerbeKen 2000; ZeHFUß és mtsai. 2000) veszélyeztetettségét mutatja. Az egész kontinensre vonatkozó egységes nagygomba vörös lista a mai napig nem született meg. Az 1985-ben alakult, a gombák megőrzéséért tevékenykedő mikológusokat tömörítő szervezet, az ECCF (European Council for the Conservation of Fungi) 2003-ra viszont elkészítetett egy európai léptékü, 33 nagygombafajt tartalmazó javaslatot, amelynek elsődleges célja volt, hogy a tanulmányban szereplö nagygombafajok bekerüljenek a Berni Egyezmény II. függelékébe. A listára azok a fajok kerültek fel, amelyek Európa-szerte ritkák, a legtöbb európai uniós vörös listán szerepelnek, és különleges kezelést igényelnek, vagy élőhelyeik megőrzése szükséges a hosszú távú 
fennmaradásuk érdekében (DAHLBERG és CRONEBORG 2003). A 33 fajt tartalmazó listán három fajt [Geoglossum atropurpureum (Batsch) Pers., Sarcosoma globosum (Schmidel) Casp., Sarcosphaera coronaria (Jacq.) J. Schröt.] kivéve csak bazídiumos nagygombák találhatók; ezek közül tíz faj xilofág életmódú [Amylocystis lapponica (Romell) Bondartsev \& Singer ex Singer, Antrodia albobrunnea (Romell) Ryvarden, Armillaria ectypa (Fr.) Lamoure, Hapalopilus croceus (Pers.) Bondartsev \& Singer, Haploporus odorus (Sommerf.) Bondartsev \& Singer ex Singer, Hericium erinaceum (Bull.) Pers., Laricifomes officinalis (Batsch) Kotl. \& Pouzar, Podoscypha multizonata (Berk. \& Broome) Pat., Pycnoporellus alboluteus (Ellis \& Everh.) Kotl. \& Pouzar és Skeletocutis odora (Peck ex Sacc.) Ginns.] és hét a poroid nagygombák közé tartozik, amely igen magas arány ahhoz képest, hogy Európából mindösszesen 394 faj (RYVARDEN és MELO 2014) ismert ebböl a morfológiai csoportból.

Tekintettel arra, hogy a vörös listák mindösszesen csak javaslatokat fogalmazhatnak meg a gyakorlati természetvédelem számára, szükségessé vált a veszélyeztetett fajok jogi védelmének biztosítása is, amelyet a különböző európai országokban többféle módon valósították meg; a leggyakrabban alkalmazott módszerek a fajvédelem (pl. KASOM és MiLIČKOviĆ 2006; PARMASTO 2006; SENN-IRLET és mtsai. 2007; SENN-IRLET 2009; SiLlER és mtsai. 2006; STRNAD 2011), illetve a gombák gyüjtésének és kereskedelemének korlátozása. Az egyes veszélyeztetett nagygombák védelmének lehetőségei közül - más élölénycsoportokhoz hasonlóan - kiemelt jelentőségü az adott taxon preferált élőhelyének védelme, amely a lignikol nagygombák esetében a szubsztrátum vagy tágabb értelemben a többnyire holt faanyagban gazdag természetszerü, rezervátum jellegü élőhelyeket jelenti. A természetszerü és kezelt erdők lignikol nagygombadiverzitásával kapcsolatban több kutatást is végeztek (pl. ÓDOR és mtsai. 2014a,b; Peltoniemi és mtsai. 2013). A gazdasági erdőkben található holtfa mennyisége jellemzően jelentős mértékben alacsonyabb, mint a természetközeli élőhelyeken, amely különbség abból adódik, hogy az erdészeti kezelések során az elpusztult fákat rendszerint eltávolítják az erdőkből. Több tanulmány is arra a következtetésre jutott, hogy az erdőgazdálkodásnak ez a módja negatívan hat a lignikol nagygombák fajdiverzitásra (pl. LINDBLAD 1998). SIPPOLA és RENVALL (1999) vizsgálatuk során összehasonlították a lignikol bazídiumos nagygombák fajösszetételét kezelt és kezeletlen fenyvesekben és azt tapasztalták, hogy a kezelt erdőkben 50-60\%-al alacsonyabb volt a fajok száma. PENTTILÄ és munkatársai (2004) kifejezetten az indikátorcsoportnak tekinthető poroid nagygombákat vizsgálták és eredményeik még nagyobb különbséget mutattak, tekintve hogy átlagosan $80 \%$-al több fajt találtak a természetközeli állományokban, mint a kezelt erdőkben. A poroid fajok döntő többségének elhalt faanyaghoz való kötődését igazolja NIEMELÄ (2005) munkája, amely alapján a Finnországból ismert fajok 16\%-a (36 faj) fordul elő élő fán és ezek közül is 20 faj holt faanyagon is megtalálható; tehát 
eredményei alapján a taplófajok döntő többsége (207 faj, 93\%) holt fán fordul elő. Továbbá az élő fákon megjelenő taplók között is számos olyan faj található, amelyek kifejezetten - szintén a természetközeli élőhelyekre jellemzö - öreg fák jelenlétét igénylik: Ganoderma cupreolaccatum (Kalchbr.) Z. Igmándy, Hapalopilus croceus, Laricifomes officinalis, stb. (CHLEBICKI és mtsai. 2003; PAPP és SzABÓ 2013). Az élőhelyek védelmének szükségességét mutatja ZHOU és DAI (2012a) munkája is, amelyben arra a következtetésre jutottak, hogy a védett erdőkben a taplófajok diverzitása szignifikánsan magasabb, mint a védelem alatt nem álló élőhelyeken.

\subsubsection{Erdőrezervátumok és természetszerủ erdők, mint refúgiumok a lignikol nagygombák számára}

Az európai éghajlati zónákban kialakuló erdők három nagy csoportba sorolhatók: boreális-, mérsékelt égövi- és mediterrán erdők. A mediterrán erdők döntő többsége telepített és mindösszesen csak 2\%-a tekinthető elsődlegesnek (,primary forest”), amelyek legnagyobb kiterjedésben Törökországban és Bulgáriában találhatók (FAO 2013). GORJÓN és BERNICCHIA (2013) munkájukban összefoglalták a mediterráneum aphyllophoroid nagygombáinak természetvédelmi helyzetét és javaslatokat fogalmaztak meg a régió veszélyeztett fajainak megőrzése érdekében. A mediterráneumban található erdők többnyire erős emberi hatás alatt állnak, ugyanakkor ezekben is számos olyan fásszárú növény található (pl. Arbutus unedo L., Cistus monspeliensis L., Erica arborea L., Ilex aquifolium L., Juniperus spp., Nerium oleander L., Tamarix spp.), amely több szubsztrátumspecialista lignikol nagygombafaj számára nélkülözhetetlen (DUHEM 2010; GORJÓN és mtsai. 2006; GORJÓN és BERNICCHIA 2013). Ezek közül külön említést érdemel a boróka, mint szubsztrátum, amelyről számos aphyllophoroid lignikol gombafajt írtak le [pl. Antrodia juniperina (Murrill) Niemelä \& Ryvarden, Echinodontium ryvardenii Bernicchia \& Piga, Phellinus juniperinus Bernicchia \& Curreli, Piloporia sajanensis (Parmasto) Niemelä, Trametes junipericola Manjón, Moreno \& Ryvarden] (BERNiCCHIA 2000; MANJON és mtsai. 1983; NiEMELÄ 1982; NIEMELÄ és RYVARDEN 1975). Lignikol nagygombák szempontjából nagy fajdiverzitású élőhelyknek tekinthetők az Ibériai félsziget egyes védett területei. GORJóN és munkatársai (2009) kifejezetten a korticioid nagygombákat (Corticiaceae s. lato) felvételezték a Las Batuecas-Sierra de Francia (Spanyolország) rezervátumban, ahonnan 140 fajt sikerült kimutatniuk. Ezek közül 6 új fajt találtak az Ibériai-félszigetre nézve és sikerült 100 év után Európából újra igazolniuk a Hjortstamia crassa (Lév.) Boidin \& Gilles előfordulását. Kifejezetten a feketefenyő faanyagán megjelenő taplófajok diverzitását és természetességet indikáló értékét vizsgálták NORSTEDT és munkatársai (2001), akik Korzikán 17 helyszínen végeztek mintavételeket és összesen 37 faj előfordulását dokumentáltak. A megtalált taplófajok több mint 40\%-ának Korzikáról nem volt 
korábban publikált adata és több korábban boreálisként ismert fajt is sikerült kimutatniuk: Antrodia primaeva Renvall \& Niemelä, A. sordida Ryvarden \& Gilb., Skeletocutis ochroalba Niemelä.

Európa boreális zónájában nagy kiterjedésű, természetszerü állapotukat őrző, főként tűlevelü erdők találhatóak (PUUMALAINEN és mtsai. 2003), amelyek két domináns faja az eredei fenyő és a közönséges luc (AHTI és mtsai. 1968). Ezek a kezelt és természetszerü boreális erdők lignikol nagygombák szempontjából Európában a legintenzívebben kutatott élőhelyek közé tartoznak (pl. BADER és mtsai. 1995; BERGLund és JONSSON 2001, 2003, 2005, 2008; BERGLUND és mtsai. 2005; HøIland és BendiKSEn 1997; JÖNSSON és mtsai. 2008; Peltoniemi és mtsai. 2013; ROLSTAD és mtsai. 2004; SIPPOLA és mtsai. 2001; STENLID és mtsai. 2008). Az európai boreális erdők nagygombavilágát célzó vizsgálatok közül jelentős számban vannak a kifejezetten poroid gombákra irányúló ökológiai (pl. YLISIRNIÖ és mtsai. 2012) és természetvédelmi (pl. JUNNINEN és KOMONEN 2011) kutatások. PARMASTO és PARMASTO (1997) észtországi öreg erdőkben kifejezetten a lignikol aphyllophoroid nagygombákat monitorozták és munkájukban ezek közül kiemelték azokat a fajokat, amelyek alkalmasak lehetnek az erdők természetközeliségének az indikálására.

Európában fungisztikai szempontból a természetközeli lombos erdők közül a bükkös élőhelyek a legintenzívebben kutatottak (pl. ABreGo és SALCEDO 2011, 2014, 2015; GrossEBrauckmann 1999; Heilmann-Clausen 2001; Heilmann-Clausen És Christensen 2004a; KÜFFER és munkatársai 2004; ÓDOR és mtsai. 2006; ORDYNETS és NADYEINA 2013; SILLER 2004; WALLEYN és VEERKAMP 2005) és viszonylag kevés kutatást végeztek a lényegesen heterogénebb tölgyesekben (pl. IRŠĖNAITĖ és KUTORGA 2006; LINDHE és mtsai. 2004; SKIRGIEŁŁO 1998; SPIRIN 2002; URBAN 2015; ŽUPANIĆ és mtsai. 2009). Európa legnagyobb természetközeli lombos erdeje a Lengyelország és Fehéroroszország határán elterülő Białowieżai-erdő (BOBIEC 2002), amely lignikol gombavilágának feltárására számos kutatás irányult (pl. BUJAKIEWICZ 2002, 2003; DOMAŃSKI 1967; KARASIŃSKI és mtsai. 2009; PILÁT 1950; SKIRGIEŁŁO 1998) és taplóvilágáról egy monográfia is megjelent (NIEMELÄ 2013).

\subsubsection{Magyarországi erdőrezervátumokban végzett mikológiai vizsgálatok}

Magyarországon a Környezet- és Természetvédelmi Minisztérium kezdeményezésére 1991ben kezdődött el az országos erdőrezervátum-kutatási program, amelynek elsődleges célja a hazai természetközeli erdei ökoszisztémák megőrzése, valamint természetes folyamatainak megismerése (HORVÁTH és mtsai 2001). Magyarországon jelenleg 63 erdőrezervátum található (BARTHA \& ESZTÓ 2001), amelyek közül szisztematikus mikológiai vizsgálatokat viszonylag 
kevésben végeztek. A lignikol nagygombák szempontjából jól kutatottnak tekinthetők a Kékes (PAPP 2013a; Siller 1999, 2004; Siller és MAGlóCZKy 1999, 2000; Siller és TuRCSÁNYi 2002; Siller és mtsai. 2002; TURCSÁNYI és mtsai. 2000), az Öserdő (PAPP 2013a; SiLlER 1986, 2004; TAKÁCS és SiLler 1980; TAKÁCS 1983) és a Szalafői (SILlER és mtsai. 2014) erdőrezervátumok. Külön a taplófajokat felvételezték a Ropolyi (TRECKER és SzABÓ 2002), a Szabó-völgy és a Pap-erdő (PAPP 2010) erdőrezervátumokban. A Nyírségben található Fényierdőben ugyan több éván át tartó szisztematikai vizsgálatot nem végeztek, de nagygombavilágáról több publikáció is megjelent (LENTI 2007; DiMA és mtsai. 2010). A BeregiTiszaháthoz tartozó Bockereki-erdő nagygombavilágáról RIMÓCZI (2008) közölt adatokat, valamint a Cortinarius Kongresszus egyik terepnapja során is újabb fajokkal bővült a rezervátumból ismert gombafajok száma (DIMA és mtsai. 2010). A Börzsönyben található Pogány-Rózsás erdőrezervátumból BENEDEK (2011) munkájában találhatók adatok, míg a mecseki Kőszegi-Forrás Erdőrezervátum fungisztikai feltárását PÁL-FÁM (2001) végezte. A Juhdöglő-völgy Erdőrezervátum területéről ezidáig többnyire csak a hazai fungára új taxonokat vagy szórványos adatokat tartalmazó publikációk jelentek meg: Xylobolus spp. (PAPP 2011a); Frantisekia mentschulensis (PAPP 2012b); Hymenochaete spp. (PAPP 2013a); Ganoderma spp. (PAPP és SzABÓ 2013); Postia alni (PAPP 2014a). Az említetteken kívül több hazai erdőrezervátumban is voltak már korábbi mikológiai vizsgálatok, de ezek eredményeinek közlése még nem történt meg: pl. Ócsai-turjános Erdőrezervátum (PAPP unpub.), Tátika Erdőerzervátum (SILLER szóbeli közlés), Vétyemi Erdőrezervátum, Remetekert Erdőrezervátum (PÁL-FÁM szóbeli közlés).

A hazai erdőrezervátumok jelentőségét jól mutatja, hogy az ezeken az élőhelyeken végzett mikológiai vizsgálatok során több, a hazai fungára új lignikol bazídiumos nagygombafajt sikerült kimutatni: pl. Antrodiella fragrans (A. David \& Tortic) A. David \& Tortic [三 Trametes fragrans A. David \& Tortic] (TRECKER és SzABÓ 2002), Botryobasidium aureum Parmasto, Ceriporia reticulata (Hoffm.) Domanski, Climacodon septentrionalis (Fr.) P. Karst., Dentipellis fragilis (Pers.) Donk, Henningsomyces candidus (Pers.) Kuntze (SILLER 2004), Hymenochaete ulmicola Corfixen \& Parmasto (PAPP 2013a), Phanerochaete tuberculata (P. Karst.) Parmasto (SILLER 2004), Pseudomerulius aureus (Fr.) Jülich (SILlER és mtsai. 2014), Steccherinum robustius (J. Erikss. \& S. Lundell) J. Erikss. (DiMA és mtsai. 2010). Az erdőrezervátumok refúgium jelentőségét támasztja alá PAPP és munkatársainak (2015c) elemzése is, amely alapján a jellemzően holt faanyaghoz kötődő poroid nagygombák Magyarországról ismert fajainak közel 70\%-a megtalálható ezeken az élőhelyeken. Ez az arány különösen magas, tekintve, hogy a kijelölt 63 erdőrezervátum a hazai erdőterületek mintegy 0,19\%-át teszi ki és ezek közül mindösszesen csak 14-ben végeztek eddig szisztematikus fungisztikai vizsgálatokat. 


\section{ANYAG ÉS MÓDSZER}

\subsection{A vizsgált terület bemutatása}

A mintegy $314 \mathrm{~km}^{2}$ kiterjedésü Vértes, a Dunántúli-középhegységnek a Bakony és a Gerecse közé eső tagja. A Bakonytól a Móri-árok, a Gerecsétől pedig a Szár-Tatabánya törésvonal választja el. A hegység déli részén a felső-triász dolomit a jellemző alapkőzet (Fődolomit Formáció), északi részén pedig a szintén felső-triász korú dachsteini mészkő (Dachsteini Mészkő Formáció) a domináns felszíni geológiai összlet. A hegység déli régióiban a dolomitfelszín egyenlőtlen lepusztulásával meredek sziklafalak, sasbércek, és mély szurdokvölgyek alakultak ki. A meleg, száraz, délies kitettségü lejtőkön szubmediterrán fajokban gazdag sziklagyepek és karsztbokorerdők találhatóak, míg az északra tekintő hűvösebb mikroklímájú letöréseken extrazonális bükkösöket, elegyes karszterdőket, a szurdokok mélyén pedig szurdokerdőket találunk. A hegység alacsonyabban fekvő területeinek klimazonális erdőtársulásai a cseres-tölgyesek és gyertyános-tölgyesek, a magasabb, atlantikusabb klímahatás alatt álló fennsíki területeken pedig a bükkösök a jellemzőek (KERESZTESI 1968, BÉNI és VISZLÓ 1996, Budai és FodOR 2008, NAGY 2013). A Vértes nagy része természetvédelmi oltalom alatt áll, északi tömbje az Észak-Vértesi Természetvédelmi Terület része, a déli-, délnyugati területek pedig az 1976-ban létesült Vértesi Tájvédelmi Körzethez tartoznak. A Tájvédelmi Körzeten belül a legjelentősebb természeti értékek védelmére fokozottan védett területeket, és két erdőrezervátumot (Meszes-völgy, Juhdöglö-völgy) is létrehoztak (BÉNI ÉS VISZLÓ 1996).

A Juhdöglő-völgy az 1950-es években először állami tulajdonba, majd 1975-ben megyei védelem alá került, 1976 óta pedig a Vértesi Tájvédelmi Körzet része. A Juhdöglö-völgyet, mint fokozottan védett erdőterületet a 14/2000. (VI. 26.) KöM rendelet nyilvánította erdőrezervátummá, összesen 80,8 ha-os területtel „Juhdöglö-völgy Erdőrezervátum” néven (1. ábra). A rezervátum a Vértes déli oldalán, Csákberény községtől északra fekszik és a DunaIpoly Nemzeti Park Igazgatóság, valamint a Vértesi Erdő Zrt. Csákvári Erdészetének müködési területén helyezkedik el. Az erdészeti üzemtervi térképek alapján az erdőrezervátumot északkeletről a Horog-völgy, északnyugatról a Nagycseresznyés-völgy és a 22 B erdötag, délnyugatról a 40 A erdőtag és 40-es számú nyiladék, délkeleten a 24 B erdőtag határolja. Az erdőrezervátum könnyen megközelíthető, tekintve, hogy a Horog-völgyben haladva mindössze 3,5 km-re helyezkedik el a Csákvár-Söréd összekötő úttól. 


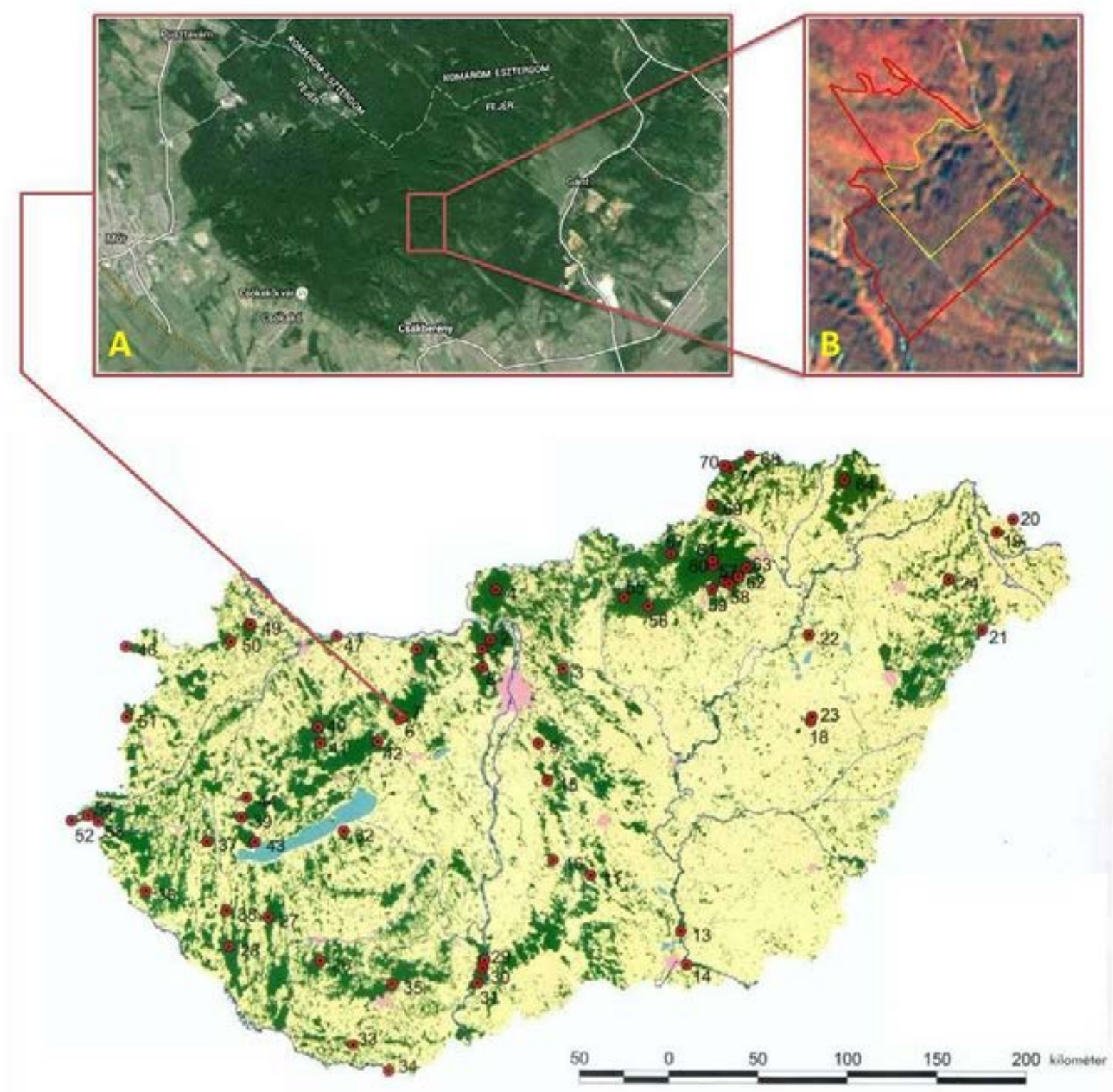

1. ábra. A Juhdöglö-völgy Erdőrezervátum földrajzi elhelyezkedése (BARTHA és ESzTÓ 2001, módosítva). A) A rezervátum területe a Vértesen belül; B) a rezervátum védőzónájának (piros keret) és magterületének határai (sárga keret) a FÖMI (Eurimage) légifelvételén (forrás: www.erdorezervatum.hu).

Klímatípusa szerint a mérsékelten hűvös, mérsékelten nedves (bükk klíma) csoportba tartozik, az évi középhőmérséklete $9{ }^{\circ} \mathrm{C}$, a csapadék mennyisége éves szinten $650-700 \mathrm{~mm}$. Tengerszint feletti magassága 300-400 m, alapkőzete felső-triász fődolomit, talajtípusa rendzina talaj, termőréteg vastagsága sekély és közép mély (TAKÁCs és TAKÁCSNÉ 1996). Az erdörezervátum 25,7 ha magterületén a természetes erdei folyamatok fenntartása érdekében erdészeti beavatkozásokat nem folytatnak és a magterületet körülvevő 55,1 ha védőzónában pedig természetszerủ erdőgazdálkodás folyik (TAKÁCS és TAKÁCSNÉ 1996). A völgy alján a nyugat-középhegységi bükkös [Daphno laureolae-Fagetum (Isépy 1970) Borhidi in Borhidi et Kevey 1996] a jellemző társulás, amely a meredek, északias kitettségü völgyoldalakban felfele 
haladva fokozatosan molyhos tölggyel (Quercus pubescens Willd.) és virágos körissel (Fraxinus ornus L.) elegyedve, valamint sziklagyepekkel mozaikolva, a platókon végül átadja helyét a mészkedvelö tölgyeseknek [Vicio sparsiflorae-Quercetum pubescentis Zólyomi ex Borhidi et Kevey 1996] (BORHIDI 2003) (2. ábra).
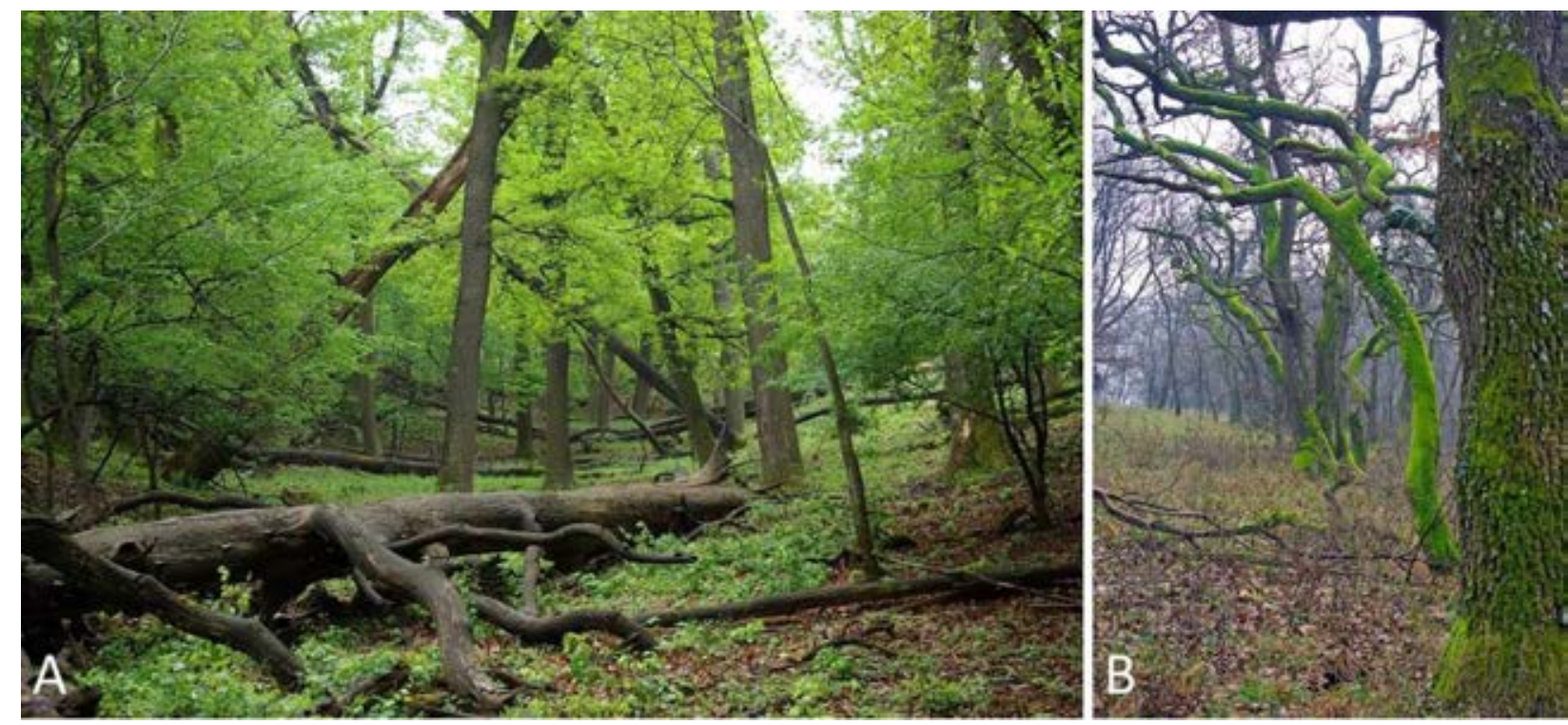

2. ábra. A Juhdöglö-völgy Erdörezervátum tölgyes élöhelyei. A) élő és elhalt kocsánytalan tölgyek a rezervátum magterületének egyik oldalvölgyében; B) molyhostölgyek a magterület határán lévő platón. Fotó: Papp V.

A rezervátum magterületének természetközeli állapotát az erdőgazdálkodási üzemtervek is alátámasztják, amelyek szerint a legidősebb bükkfák 227 évesek. A rezervátum területén igen jellemzőek a még lábon álló elhalt fák (3. ábra/B,D), valamint a nagy mennyiségben jelenlévő és változatos struktúrájú fekvő holtfák (3. ábra/A,C,E) és facsonkok (3. ábra/F). Annak köszönhetően, hogy az erdörezervátumban semmilyen gazdálkodás nem történik, az idős, elhalt fák ugyanazon a helyen korhadnak el, ahol kidőltek; a megújulás pedig magról és sarjról történik.

A Juhdöglö-völgyben a közelmúltban folytatott florisztikai kutatások számos botanikai értéket tártak fel mind a virágtalan, mind a virágos növényekre vonatkozóan. A völgy északra néző sziklafalainak országosan ritka máj- és lombosmohafajai a Leiocolea collaris (Nees) Schljakov, Pedinophyllum interruptum (Nees) Kaal., illetve a Plagiobryum zierii (Dicks. ex Hedw.) Lindb. (NÉMETH 2008). Az edényes fajok közül mindenképpen említést érdemelnek a hegység bennszülött berkenyéi, melyek közül a Vértes más pontjai mellett az itteni sziklaerdőkben is előfordulnak a Sorbus adamii Kárpáti, S. degenii Jáv., S. eugenii-kelleri Kárpáti, S. karpatii Boros, S. pseudolatifolia Boros, S. pseudovertesensis Boros, S. pyricarpa Cs. Németh és S. simonkaiana Kárpáti (NÉMETH 2006, 2015), valamint a S. vallerubusensis Cs. Németh, mely a Juhdöglö-völgy (Szedres-völgy) és a szomszédos Csersnyés-völgy saját, közös 
sztenoendemizmusa (NÉMETH 2009). A völgy további, értékes növényfajai a Calamagrostis varia (Schrad.) Host, Corydalis intermedia (L.) Mérat, Ranunculus nemorosus DC. és Viola collina Besser (BARINA és NÉMETH 2009).

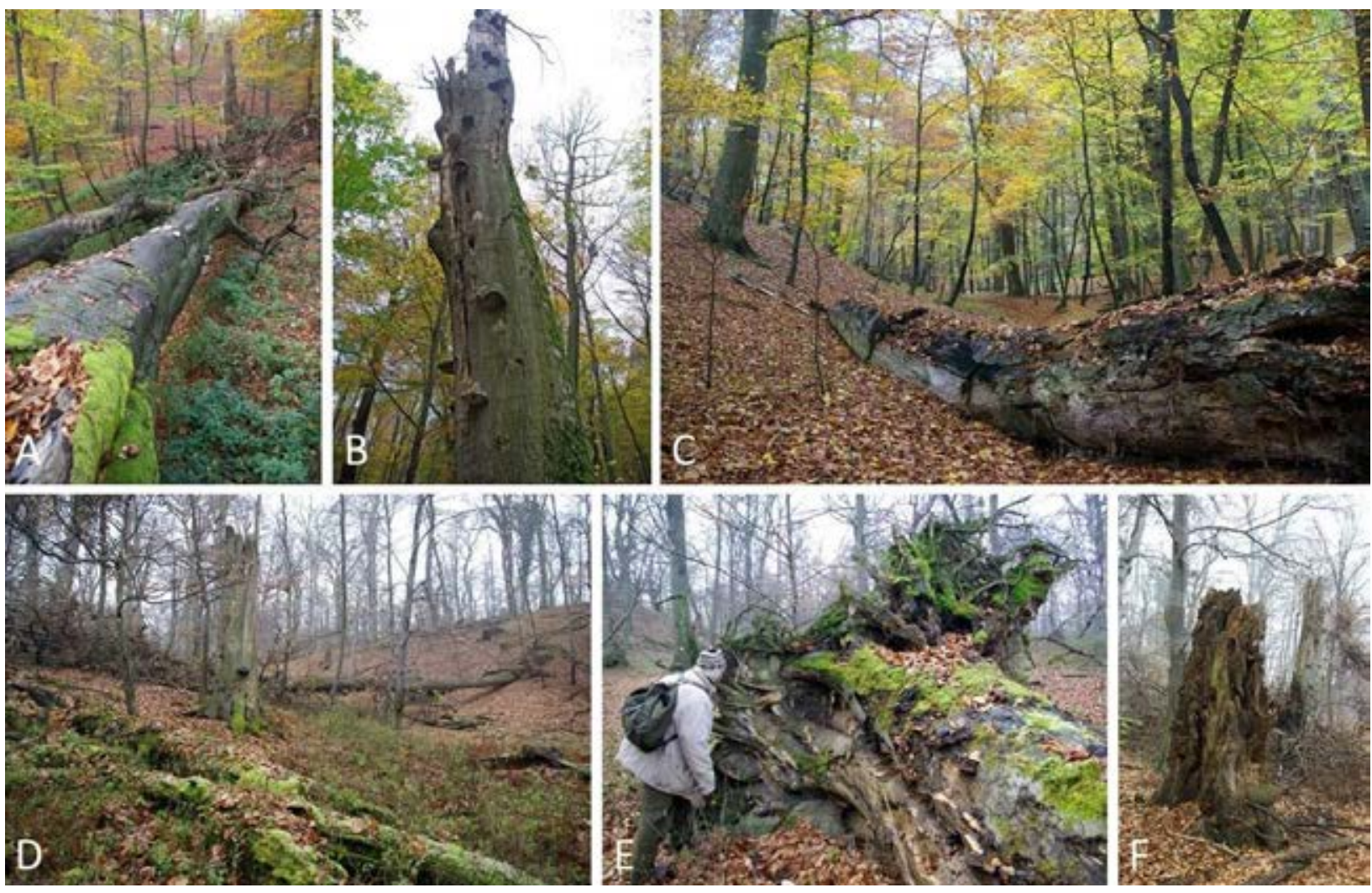

3. ábra. Álló és fekvő holtfák a Juhdöglő-völgy Erdőrezervátum bükkös élőhelyein. A) nagyméretű, iniciális korhadási fázisban lévő bükkfarönk; B) talpon elhalt, álló öreg bükkfa Fomes fomentarius termőtestekkel; C) egy a völgyet átszelö turistaútra rádölt bükkfarönk a rezervátum szubmontán bükkösében; D) késő őszi élőhelyfotó a rezervátum bükkös élőhelyén; E) nagyméretü gyökértányérostúl kidőlt bükkfarönk; F) erősen korhadt nagyméretü bükkfacsonk. Fotó: Papp V.

\subsection{Mintafák kijelölése}

A rezervátum magterületén élő lignikol bazídiumos nagygombák termőtest alapú prezenciájának minél teljesebb mértékü feltárása céljából, a taxonok életmódja alapján a területi kvadrátok helyett 121 különböző átmérőjü és korhadási fázisú mintafát (mikrohabitatot) jelöltem ki (lásd. M5. melléklet).

A sorszámmal megjelölt rönkökön előforduló lignikol bazídiumos nagygombákat, a termőtestképzés szempontjából az év mindhárom jelentősebb aspektusában (tavasz, nyár, ősz) három éven keresztül felvételeztem. A tölgy [Qercus petraea (Matt.) Liebl. és Q. pubescens Willd.] és bükk [Fagus sylvatica L.] rönkök minőségi tulajdonságainak dokumentálása mellett GPS koordináták segítségével a pontos helyüket is rögzítettem (4. ábra), amelynek köszönhetően egy adott gomba taxon lelöhelyéröl és szubsztrátumáról is részletes információk 
kaphatók. Ezeknek a háttéradatoknak a statisztikai kiértékelése nem szerepelt a jelen dolgozat célkitüzései között, de a későbbiekben ökológiai jellegü vizsgálatok alapjául is szolgálhatnak.

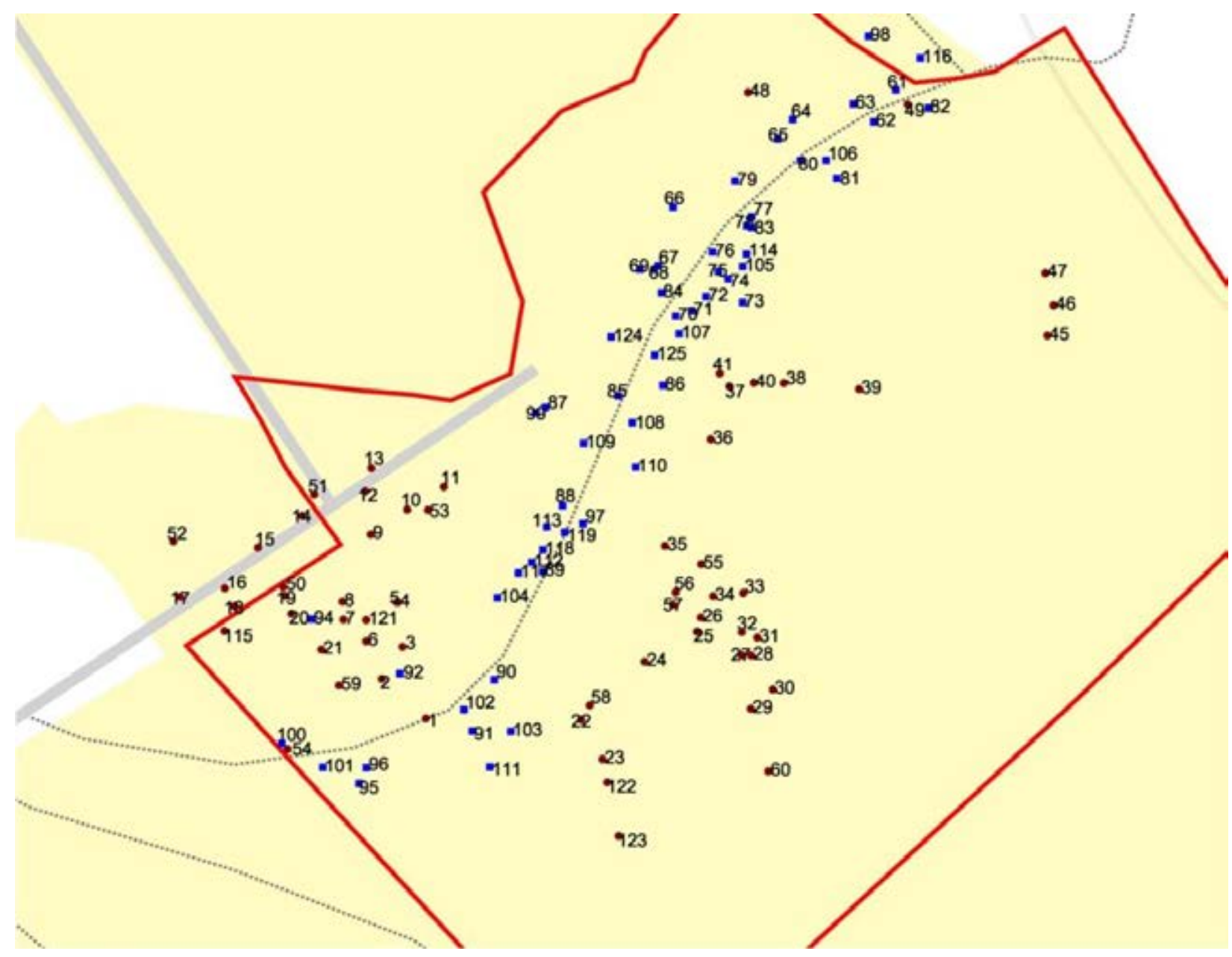

4. ábra. Kijelölt rönkök a Juhdöglö-völgy Erdőrezervátumban. Kék színü négyzettel a bükk, piros körrel a tölgy mintafákat jelöltem. A piros keret a rezervátum magterületének határát jelöli.

A mintafák korhadási állapotának megállapítását a bükkfa rönkök esetében a nemzetközileg is gyakran alakalmazott (pl. Heilmann-Clausen 2001, HeILMANN-ClaUSEN és Christensen 2003, KÜFfer és SenN-IRLET 2005, LANGE 1992) öt fázis alapján végeztem: (1-es) a kéreg ép vagy csak foltokban vált le, az ágak, gallyak még megvannak, a rönk konzisztenciája kemény, a kés csak 1-2 mm mélyre hatol, körvonala intakt, köralakú; (2-es) a kéreg hiányzik vagy borítása kisebb, mint 50\%, a gallyak már hiányoznak, csak az ágak vannak jelen, a kés legföljebb $1 \mathrm{~cm}$ mélyre hatol, körvonala intakt, köralakú; (3-as) a kéreg már hiányzik és ágak sem láthatóak, a konzisztenciája puhuló, a kés 1-5 cm mélyre hatol, felszíne hasadozott, de még köralakú; (4-es) a kés már $5 \mathrm{~cm}$-nél mélyebbre hatol, a felszínét nagy repedések tarkítják, kis darabok hiányzanak belőle, de körvonala még intakt, kör vagy elliptikus alakú; (5-ös) nagyobb darabok hiányoznak a rönkből, körvonala részben deformált, alakja elliptikus, ellaposodó. 
A bükk mintafák kijelölésénél arra törekedtem, hogy a lehetőségekhez képest minden korhadási fázis és átmérőkategória képviselve legyen (2. táblázat).

2. táblázat. A rezervátumban kijelölt Fagus sylvatica fatörzsek $(\mathrm{db})$ korhadási fázis és átmérő szerinti megoszlása. Zárójelben a kijelölt mintafák sorszáma látható (lásd. M5. melléklet).

\begin{tabular}{|c|c|c|c|c|c|c|}
\hline \multirow{2}{*}{ Átmérő } & \multicolumn{6}{|c|}{ Korhadási fázis } \\
\hline & 1-es & 2-es & 3-as & 4-es & 5-ös & $\sum$ \\
\hline$<40 \mathrm{~cm}$ & $\begin{array}{c}\mathbf{4} \\
(94 ; 83 ; 85 ; \\
114)\end{array}$ & $\begin{array}{c}\mathbf{3} \\
(74 ; 80 ; 112)\end{array}$ & $\begin{array}{c}\mathbf{4} \\
(62 ; 63 ; 99 ; \\
107)\end{array}$ & $\begin{array}{c}\mathbf{3} \\
(84 ; 97 ; 106)\end{array}$ & $\begin{array}{c}\mathbf{4} \\
(101 ; 103 ; 105 ; \\
124)\end{array}$ & 18 \\
\hline $40-60 \mathrm{~cm}$ & $\begin{array}{c}\mathbf{4} \\
(76 ; 86 ; 87 ; \\
125)\end{array}$ & $\begin{array}{c}\mathbf{6} \\
(68 ; 73 ; 82 \\
89 ; 96 ; 113)\end{array}$ & $\begin{array}{c}\mathbf{3} \\
(61 ; 111 ; 118)\end{array}$ & $\begin{array}{c}\mathbf{4} \\
(75 ; 98 ; 102 ; \\
109)\end{array}$ & $\begin{array}{c}\mathbf{2} \\
(78 ; 126)\end{array}$ & 19 \\
\hline$>60 \mathrm{~cm}$ & $\begin{array}{c}\mathbf{5} \\
(65 ; 66 ; 92 ; \\
108 ; 116) \\
\end{array}$ & $\begin{array}{c}\mathbf{2} \\
(81 ; 104)\end{array}$ & $\begin{array}{c}\mathbf{6} \\
(70 ; 71 ; 88 ; \\
91 ; 117 ; 119) \\
\end{array}$ & $\begin{array}{c}\mathbf{6} \\
(64 ; 69 ; 77 ; \\
79 ; 95 ; 100) \\
\end{array}$ & $\begin{array}{c}\mathbf{4} \\
(67 ; 72 ; 90 \\
110) \\
\end{array}$ & 23 \\
\hline$\sum$ & 13 & 11 & 13 & 13 & 10 & 60 \\
\hline
\end{tabular}

A tölgy faanyagának lebomlása eltér a bükktöl (RAHMAN és mtsai. 2008), ezért a különböző korhadási fázisok meghatározásánál más szempontokat kellett figyelembe venni: (1-es) a kéreg ép vagy csak foltokban hiányzik, a gallyak és ágak még megvannak, a szijács ép, esetleg helyenként korhadó, a geszt még nem korhad, tehát a fa belső részén nincs korhadás, de kisebb odú, lokálisan előfordulhat, a fa és a talaj határa éles, a rönk köralakú; (2-es) a kéreg nagyrészt még megvan, csak kisebb mértékben hiányzik, az ágak többnyire még jelen vannak, a szijács részben már korhadt vagy hiányzik ( $>50 \%$ ), a geszt még kemény, de minimális belső korhadás már elöfordulhat, a fa és a talaj határa éles, a rönk köralakú; (3-as) a kéreg hiányzik, vagy csak kisebb foltokban van jelen, már csak a vastagabb vázágak vannak meg, a szijács nagyrészt már korhadt vagy hiányzik, de maradványai még látszódnak, a geszt kemény, repedezett, kisebb darabok hiányozhatnak, kiterjedtebb belső korhadás már elöfordulhat, a fa és a talaj határa éles, a rönk köralakú; (4-es) a kéreg, vázágak és szijács már teljesen lebomlott, a gesztböl nagyobb darabok hiányozhatnak, kiterjedtebb a belső korhadás korhadás, a fa és a talaj határa elmosódott, a rönk még kör vagy ellipszis alakú; (5-ös) a geszt nagyobb területeken korhadt, részben már hiányzik vagy beszakadt, szétesős stádiumban van, a kiterjedt belső korhadásnak köszönhetően a rönk üregessé válik, a fa és a talaj határa részben elmosódott, a rönk alakja elliptikus.

A kijelölt tölgyfarönkök átmérő és korhadási fázis szerinti megoszlását az 3. táblázatban foglaltam össze. 
3. táblázat. A rezervátumban kijelölt Quercus petraea és $Q$. pubescens fatörzsek (db) korhadási fázis és átmérő szerinti megoszlása. Zárójelben a kijelölt mintafák sorszáma látható (lásd. M5. melléklet).

\begin{tabular}{lcccccc}
\hline \multirow{2}{*}{ Átmérö } & & \multicolumn{6}{c}{ Korhadási fázis } & & \\
& $\mathbf{1 - e s}$ & $\mathbf{2 - e s}$ & $\mathbf{3 - a s}$ & $\mathbf{4 - e s}$ & $\mathbf{5 - o ̈ s}$ & $\sum$ \\
\hline \multirow{2}{*}{$<\mathbf{4 0} \mathbf{~ c m}$} & $\mathbf{2}$ & $\mathbf{3}$ & $\mathbf{8}$ & $\mathbf{4}$ & $\mathbf{4}$ & \\
& $(60 ; 32)$ & $(40 ; 121 ;$ & $(5 ; 11 ; 22 ; 26 ;$ & $(33 ; 45 ;$ & $(49 ; 56 ; 57 ;$ & 21 \\
& & $122)$ & $27 ; 28 ; 35 ; 41)$ & $52 ; 123)$ & $59)$ & \\
$\mathbf{4 0 - 6 0} \mathbf{~ c m}$ & $\mathbf{2}$ & $\mathbf{2}$ & $\mathbf{6}$ & $\mathbf{5}$ & $\mathbf{5}$ & \\
& $(25 ; 34)$ & $(55 ; 39)$ & $(3 ; 4 ; 19 ; 36 ;$ & $(7 ; 9 ; 16 ; 24 ;$ & $(8 ; 12 ; 13 ;$ & 20 \\
& & $\mathbf{4}$ & $38 ; 53)$ & $31)$ & $21 ; 37)$ & \\
$>\mathbf{6 0} \mathbf{~ c m}$ & $(2 ; 6 ; 20 ;$ & $(10 ; 14 ; 18 ;$ & $(15 ; 46 ; 47 ;$ & $(1 ; 17 ; 23 ;$ & $\mathbf{2}$ & \\
& $48)$ & $29 ; 50)$ & $58 ; 115)$ & $54)$ & & 20 \\
\hline$\sum$ & 8 & 10 & 19 & 13 & 11 & $\mathbf{6 1}$ \\
\hline
\end{tabular}

\subsection{A mintavételek időpontjai és a gyüjtött anyag feldolgozásának módszerei}

A Juhdöglö-völgy Erdőrezervátum magterületén a terepi mintavételeket 2010 és 2014 között végeztem összesen 45 alkalommal (4. táblázat). A felvételezések időpontjainak kiválasztásánál fontos szempont volt a gombák termőtestképzésében szerepet játszó csapadékmennyiség figyelembevétele.

4. táblázat. A Juhdöglö-völgy Erdőrezervátumban töltött terepnapok száma és időpontjai, évekre és hónapokra bontva.

\begin{tabular}{|c|c|c|c|c|c|c|}
\hline \multirow{2}{*}{ Hónapok } & \multicolumn{6}{|c|}{ Évek } \\
\hline & 2010 & 2011 & 2012 & 2013 & 2014 & $\sum$ \\
\hline Január & - & - & - & - & - & $\mathbf{0}$ \\
\hline Február & - & 21 & - & - & - & 1 \\
\hline Március & - & $04,12,26$ & - & 04,11 & - & 5 \\
\hline Április & - & 25 & - & 24 & - & 2 \\
\hline Május & - & $07,18,20$ & 18 & - & - & 4 \\
\hline Junius & - & $01,10,13$ & - & 10 & - & 4 \\
\hline Július & - & $07,13,22$ & 15,28 & - & - & 5 \\
\hline Augusztus & - & $03,05,08,10$ & 01,03 & - & 16 & 7 \\
\hline Szeptember & 14,23 & - & - & 20 & 09 & 4 \\
\hline Október & 07,15 & 19,25 & $08,10,20,24$ & 11,25 & - & 10 \\
\hline November & 26 & - & 14,30 & - & - & 3 \\
\hline December & - & - & - & - & - & $\mathbf{0}$ \\
\hline$\sum$ & 5 & 20 & 11 & 7 & 2 & 45 \\
\hline
\end{tabular}

A terepi felvételezések során észlelet taxonokat jegyzőkönyvben dokumentáltam, valamint a legtöbb esetben bizonyító fungáriumi anyagot gyüjtöttem. A fajok többségéről in situ és/vagy ex situ fotódokumentációkat is készítettem. A fungáriumi mintákat elöször egy $250 \mathrm{~W}$ teljesítményü aszalógépen szárítottam, majd felcímkézett simítózáras tasakokban a Budapesti 
Corvinus Egyetem, Növénytani Tanszékén található saját fungáriumi gyüjteményemben (PV), valamint a Természettudományi Múzeum Növénytárában (BP) helyeztem el. A rezervátum területéről dokumentált lignikol bazídiumos nagygombák fungáriumi mintáinak adatait az M4.1. mellékletben tüntettem fel. A taxonok tudományos neveinek megadása során a recens szakirodalom mellett a MycoBank (ROBERT és mtsai. 2005, 2013) adatbázist is figyelembe vettem.

\subsection{A lignikol bazídiumos nagygombafajok határozásához használt eszközök}

\subsubsection{Határozókönyvek és -kulcsok}

A bazídiumos nagygombák határozásának a legelterjedtebb módszere még mindig a termőtest makro- és mikromorfológiai bélyegeinek vizsgálatán alapul. Az egyes gombacsoportok (taxonok, morfotípusok) azonosításához jelen munkában használt szakirodalmat az alábbiakban ismertetem.

\section{Agarikoid és gaszteroid fajok határozása}

Az agarikoid és gaszteroid nagygombák határozásához a Funga Nordica második bővített kiadását használtam (KNUDSEN és VESTERHOLT 2012). Tekintettel arra, hogy ez a munka a skandináv országok fungáját tartalmazza, a pontos azonosításhoz további európai monográfiákat is figyelembe vettem: Strophariaceae s. 1. (NoORdeloos 2011), Crepidotus spp. (Consiglio és SETTI 2008), Entoloma spp. (NoORdeloos 1992, 2004), Mycena spp. (RoBiCH 2003).

\section{Korticioid [incl. hidnoid, raduloid, odontioid, sztereoid] fajok határozása}

A korticioid (Corticiaceae s. 1.) fajok határozásához az észak-európai fajokat feldolgozó szakkönyveket (ERIKSSON és RYVARDEN 1973, 1975, 1976; ERIKSSON és mtsai. 1978, 1981, 1984; HJORTSTAM és mtsai. 1987, 1988), valamint KRIEGLSTEINER (2000) és JAHN (1971) munkáit, illetve BERNICCHIA és GORJON (2010) európai monográfiáját vettem alapul.

\section{Poroid fajok határozása}

A poroid nagygombák határozását Ryvarden és GILBERTSON (1993, 1994), BERNICCHIA (2005), valamint RYVARDEN és MELO (2014) európai monográfiái alapján végeztem. A nemzetséghatározók közül a következő munkákat használtam: Antrodiella spp. (MIETTINEN és mtsai. 2006, VAMPOLA és PouZAR 1996); Inonotus s. lato (RYVARDEN 2005). Tekintettel arra, hogy az európai szakirodalomban ellentmondásosak és hiányosak a Postia caesia fajkomplexbe 
[subgen. Cyanosporus (McGinty) V. Papp] tartozó európai taxonok morfológiai bélyegeinek leírásai, az ebbe a csoportba tartozó fajok azonosításához egy korábbi munkám során összeállított dichotomikus határozókulcsot vettem alapul (PAPP 2014b).

\subsubsection{Mikroszkopikus vizsgálatokhoz használt eszközök}

A poroid és korticioid fajok mintáinak mikroszkopikus vizsgálatához 5\%-os $\mathrm{KOH}$ oldatot, míg az agarikoid nagygombákhoz glicerines vizet használtam. A hialin mikroszkopikus bélyegek megfestését Cotton Blue, valamint Congo Red oldatokkal végeztem. Az amiloid (pozitív reakció, a vizsgált elem kékes, feketés elszíneződést mutat), dextrinoid (a vizsgált elem barnásan vagy vöröses-barnásan színeződik el) és inamiloid (negatív reakció, a vizsgált elem színe nem változik, vagy csak nagyon halványan sárgás-barnás elszíneződés látható) reakciók teszteléséhez Melzer reagenst használtam.

A mikroszkopikus vizsgálatokat Zeiss Axio Imager.A2 típusú fénymikroszkóppal végeztem, a felvételeket pedig Zeiss AxioCam HRc fényképezőgéppel készítettem. A preparátumokat 1000× nagyításon vizsgáltam. Az anatómiai bélyegeket bemutató ábrák (6. ábra, 13. ábra, 23. ábra, 30. ábra, 35. ábra) elkészítéséhez rajztükröt használtam, a méréseket pedig az AxioVision Release 4.8.2 program segítségével végeztem.

\subsubsection{Molekuláris vizsgálatokhoz használt eszközök és módszerek}

Jelen munkában a Juhdöglö-völgy Erdörezervátumban gyüjtött lignikol bazídiumos nagygombák közül összesen 14 taxont vizsgáltam a morfológiai bélyegek mellett molekuláris módszerekkel is: PV188, PV218, PV408, PV538 (BP 106905), PV540 (BP 106902), PV551, PV690, PV712, PV773, PV774, PV983, PV1044 (BP 106903), PV1114 (BP 106908), PV1089. Tekintettel arra, hogy molekuláris vizsgálatok elvégzésére csak korlátozott lehetőségeim voltak, a minták kiválasztásánál a morfológiai bélyegek alapján nem egyértelmủen határozható, valamint a hazai fungára új taxonokat részesítettem előnyben. A jelen munkában közölt filogenetikai törzsfákhoz további, Dima Bálint (DB) fungáriumi gyűjteményéből származó magyarországi minták (DB2529, DB3859), valamint a Crepidotus ehrendorferi Hauskn. \& Krisai faj holotípusának (WU6554) még publikálatlan szekvenciáit is felhasználtam. A Juhdöglö-völgy Erdőrezervátumban gyüjtött lignikol bazídiumos nagygombák szekvenciáit az M6.1. melléklet tartalmazza.

A DNS kinyeréséhez szükséges minták szárított fungáriumokból származnak. A DNSkivonás és a polimeráz láncreakció (PCR) a Phire ${ }^{\circledR}$ Plant Direct Kit (Thermo Scientific, USA) segítségével, egy lépésben történtek a termék gyártói utasításait követve. A PCR során a magi 
riboszómális DNS (rDNS) ITS-régiója került felszaporításra az ITS1F-ITS4 primerpár alkalmazásával (GARDES és BRUNS 1993, WHITE és mtsai. 1990). A PV983-as minta esetében az ITS-régió mellett az rDNS nagy alegységének (LSU) egy szakasza is a vizsgálat tárgyát képezte. A sikeres amplifikáció a PCR-termék elektroforézis gélen történő futtatása során került ellenőrzésre. A direkt szekvenálást a PCR-nél alkalmazott primerpárral az LGC Genomics (Berlin, Németország) végezte. A kromatogramok elemzéséhez a Staden csomag Pregap4 és Gap4 programjai szolgáltak (STADEN és mtsai. 2000).

A kapott szekvenciánkat a GenBank (http://www.ncbi.nlm.nih.gov/genbank/) és a UNITE (http://unite.ut.ee/) adatbázisokban már publikált szekvenciákkal egészítettem ki (M6.2. melléklet), figyelembe véve, hogy az előzetes morfológiai bélyegeken nyugvó azonosítás alapján a közel rokon fajok, valamint további, morfológiailag hasonló taxonok is szerepeljenek a filogenetikai elemzésekben. A szekvenciák illesztését a PRANK (LÖYTYNOJA és GOLDMAN 2005) grafikus felületén (PRANKSTER), az alapbeállítások alapján végeztem. Az illesztés eredményét vizuálisan az AliView (LARSSON 2014), valamint a SeaView 4 (GouY és mtsai 2010) programokkal értékeltem és szükségképpen manuálisan javítottam. A filogenetikai szempontból informatív indeleket (inzerciós helyek) a „simple indel coding” algoritmust alapul véve (SIMMONS és mtsai. 2001) kódoltam a FastGap 1.2 program segítségével (BORCHSENIUS 2009). Az így kapott bináris mátrix-ot NAGY és mtsai. (2012) alapján hozzáadtam az illesztett ITS-szekvenciákhoz, így a végső mátrix nukleotid- és bináris adatokat is tartalmazott. A filogenetikai rekonstrukciót Maximum Likelihood (ML) statisztikai becslés alapján a RAxML program segítségével (STAMATAKIS 2014) a raxmlGUI-ban készítettem (SILVESTRO és MiCHALAK 2012). A törzsfaelágazások statisztikai támogatottságának meghatározásához 1000 ismétléses „rapid bootstrap” analízist, a partícionált adatsorokra (ITS + indelek) GTRGAMMA szubsztitúciós modellt alkalmaztam. Az Entoloma tjallingiorum Noordel. és rokon fajainak filogenetikai elemzéséhez az ML statisztikai becslés mellett Bayes-alapú analízist is készítettem a MrBayes 3.1.2 program segítségével (HUELSENBECK és RONQUIST 2001; RoNQUIST és HUELSENBECK 2003). A nukleotid és indelkarakterek kiértékelése ebben az esetben is két partícióban $(\mathrm{GTR}+\mathrm{G}$, ill. két-paraméteres Markov-modell alapján) történt. A négy Markovláncon, 5000000 generáció futott, amelyből minden 100. generáció került mintázásra. A kiválasztott fák kalkulálása az 50\%-os többségi szabályt követő konszenzusos filogram és Bayes-féle poszterior valószínűségek (PP) alapján történt. A kapott konszenzus ITS-törzsfákat a MEGA6 programcsomaggal (TAMURA és mtsai. 2013) vizualizáltam. 


\section{EREDMÉNYEK ÉS ÉRTÉKELÉSÜK}

\subsection{A Juhdöglő-völgy Erdőrezervátum területéről dokumentált lignikol bazídiumos nagygombák bemutatása és taxonómiai értékelése}

A Juhdöglö-völgy Erdőrezervátum magterületéről a 2010 és 2014 közötti időszakban 45 terepnap során 223 lignikol bazídiumos nagygombafaj elöfordulását igazoltam. Egy további faj, az Aurantiporus alborubescens (Bourdot \& Galzin) H. Jahn (PV1089), Koszka Attila gyüjtésének köszönhetően 2015 nyarán került elő a rezervátum magterületéről. Ezt a fajt fungisztikai és természetvédelmi jelentősége miatt szintén jelen dolgozat keretein belül tárgyalom. A vizsgált időszakban, az erdőrezervátum területről gyüjtött lignikol aszkuszos nagygombák viszont jelen munkában nem kerülnek bemutatásra, de az ezidáig meghatározott fajok listáját és adatait az M4.2. mellékletben feltüntettem. Munkám során az erdőrezervátum területéről mindösszesen egy olyan lignikol bazídiumos nagygombafaj előfordulását dokumentáltam, amely a rozsdagombák [Pucciniomycotina R. Bauer et al.] közé, tehát nem a valódi bazídiumos nagygombák [Agaricomycotina R. Bauer et al.] altörzsébe tartozik: Phleogena faginea (Fr. \& Palmquist) Link. Az Agaricomycotina altörzsből az erdőrezervátum területéről kimutatott 222 faj szisztematikai megoszlását tekintve 3 osztályba, 13 rendbe, 51 családba és 121 különböző nemzetségbe tartozik. Az egyes taxonómiai csoportokban azonban eltérő a faanyagon élő gombafajok száma és aránya. A jellemzően heterobazídiumot képző, ősibb osztályok [Tremellomycetes Doweld és Dacrymycetes Doweld] fajdiverzitása lényegesen alacsonyabb volt, mint az Agaricomycetes osztályé, tekintve, hogy az Agaricomycotina altörzs fajainak alig több mint 2\%-át tették ki. Az Agaricomycetes Doweld osztályon belül található 10 rend közül a dokumentált fajszámok tekintetében kiemelkedő jelentőségűek az Agaricales Underw. (93 faj) és Polyporales Gäum. (73 faj).

Az erdőrezervátum mintegy 25,7 ha nagyságú magterületéről kimutatott és meghatározott lignikol bazídiumos nagygombafajok 55\%-ának (122 faj) esetében nem találtam a hegységből származó korábbi előfordulására utaló adatot a hazai szakirodalomban (BABOS 1989, BOHUS 1939, KoszKA 2011, 2014, RIMÓCZI 1994). A Vértesre új taxonok közül 20 faj újnak bizonyult Magyarország fungájára nézve is: Aurantiporus alborubescens (Bourdot \& Galzin) H. Jahn, Crepidotus ehrendorferi Hauskn. \& Krisai, C. malachioides Consiglio, Prydiuk \& Setti, Dendrothele commixta (Höhn. \& Litsch.) J. Erikss. \& Ryvarden, Donkia pulcherrima (Berk. \& M.A. Curtis) Pilát, Entoloma tjallingiorum var. tjallingiorum Noordel., Frantisekia mentschulensis (Pilát ex Pilát) Spirin, Hohenbuehelia auriscalpium (Maire) Singer, Hymenochaete carpatica Pilát, H. fuliginosa (Pers.) Lév., Inonotus krawtzewii (Pilát) Pilát, 
Mensularia hastifera (Pouzar) T. Wagner \& M. Fisch., Ossicaulis lachnopus (Fr.) Contu, Phanerochaete aculeata Hallenb., Phlebia fuscoatra (Fr.) Nakasone, Phlebia nothofagi (G. Cunn.) Nakasone, Pholiota squarrosoides (Peck) Sacc., Pluteus diettrichii Bres., Postia alni Niemelä \& Vampola, Xylobolus subpileatus (Berk. \& M.A. Curtis) Boidin. Az erdőrezervátum területéről a vizsgált időszakban gyüjtött és ezidáig meghatározott taxonok összesített eredményeit az 5. táblázatban foglaltam össze.

A PV983 fungáriumi számmal rendelkező taxon mikro- és makromorfológia bélyegeinek, valamint ITS és LSU génszakaszainak ezidáig elvégzett vizsgálata alapján feltételezhetően egy új faj a tudományra nézve, amely az eddig ismert fajoktól akár nemzetségszinten is elkülönülhet. Ennek igazolására azonban még további molekuláris és morfológiai vizsgálatok szükségesek.

5. táblázat. A Juhdöglö-völgy Erdőerzervátum teréletéröl dokumentált bazídiumos gombák [Basidiomycota Whittaker ex Moore] törzsébe tartozó lignikol nagygombák nemzetség- és fajszáma, rendek és családok szerinti megoszlásuk szerint.

\begin{tabular}{|c|c|c|c|c|c|}
\hline rend & család & nemz. & faj & Vértes (új) & Mo. (új) \\
\hline \multirow{2}{*}{ Atractiellales } & Phleogenaceae & 1 & 1 & 1 & 0 \\
\hline & $\sum$ & 1 & 1 & 1 & $\mathbf{0}$ \\
\hline \multirow{2}{*}{ Tremellales } & Tremellaceae & 1 & 2 & $\mathbf{0}$ & $\mathbf{0}$ \\
\hline & $\sum$ & 1 & 2 & $\mathbf{0}$ & $\mathbf{0}$ \\
\hline \multirow{2}{*}{ Dacrymycetales } & Dacrymycetaceae & 2 & 3 & 1 & $\mathbf{0}$ \\
\hline & $\sum$ & 2 & 3 & 1 & $\mathbf{0}$ \\
\hline \multirow{22}{*}{ Agaricales } & Agaricaceae & 1 & 1 & $\mathbf{0}$ & $\mathbf{0}$ \\
\hline & Bolbitiaceae & 1 & 2 & $\mathbf{0}$ & $\mathbf{0}$ \\
\hline & Clavariaceae & 1 & 1 & 1 & $\mathbf{0}$ \\
\hline & Crepidotaceae & 2 & 14 & 11 & 2 \\
\hline & Cyphellaceae & 1 & 1 & $\mathbf{0}$ & $\mathbf{0}$ \\
\hline & Entolomataceae & 2 & 3 & 2 & 1 \\
\hline & Fistulinaceae & 1 & 1 & $\mathbf{0}$ & $\mathbf{0}$ \\
\hline & Lyophyllaceae & 2 & 2 & 1 & 1 \\
\hline & Marasmiaceae & 3 & 3 & $\mathbf{0}$ & $\mathbf{0}$ \\
\hline & Mycenaceae & 3 & 11 & $\mathbf{0}$ & $\mathbf{0}$ \\
\hline & Niaceae & 1 & 2 & 2 & 1 \\
\hline & Nidulariaceae & 1 & 1 & $\mathbf{0}$ & $\mathbf{0}$ \\
\hline & Omphalotaceae & 1 & 1 & $\mathbf{0}$ & $\mathbf{0}$ \\
\hline & Physalacriaceae & 5 & 6 & 1 & $\mathbf{0}$ \\
\hline & Pleurotaceae & 2 & 5 & 2 & 1 \\
\hline & Pluteaceae & 1 & 15 & 5 & 1 \\
\hline & Psathyrellaceae & 2 & 4 & 1 & $\mathbf{0}$ \\
\hline & Pterulaceae & 1 & 1 & 1 & $\mathbf{0}$ \\
\hline & Schizophyllaceae & 1 & 1 & $\mathbf{0}$ & $\mathbf{0}$ \\
\hline & Strophariaceae & 7 & 12 & 2 & 1 \\
\hline & Tricholomataceae & 1 & 1 & 1 & $\mathbf{0}$ \\
\hline & Tubariaceae & 2 & 3 & 3 & $\mathbf{0}$ \\
\hline
\end{tabular}




\begin{tabular}{|c|c|c|c|c|c|}
\hline rend & család & nemz. & faj & Vértes (ú́j) & Mo. (ú́j) \\
\hline & Typhulaceae & 1 & 1 & 1 & $\mathbf{0}$ \\
\hline & Incertae sedis & 1 & 1 & $\mathbf{0}$ & $\mathbf{0}$ \\
\hline & $\sum$ & 44 & 93 & 34 & 8 \\
\hline \multirow{2}{*}{ Atheliales } & Atheliaceae & 1 & 1 & 1 & $\mathbf{0}$ \\
\hline & $\sum$ & 1 & 1 & 1 & $\mathbf{0}$ \\
\hline \multirow{3}{*}{ Auriculariales } & Auriculariaceae & 2 & 2 & $\mathbf{0}$ & $\mathbf{0}$ \\
\hline & Exidiaceae & 1 & 1 & $\mathbf{0}$ & $\mathbf{0}$ \\
\hline & $\sum$ & 3 & 3 & $\mathbf{0}$ & $\mathbf{0}$ \\
\hline \multirow{3}{*}{ Boletales } & Coniophoraceae & 1 & 2 & 2 & $\mathbf{0}$ \\
\hline & Serpulaceae & 1 & 1 & 1 & $\mathbf{0}$ \\
\hline & $\sum$ & 2 & 3 & 3 & $\mathbf{0}$ \\
\hline \multirow{2}{*}{ Cantharellales } & Botryobasidiaceae & 2 & 2 & 2 & $\mathbf{0}$ \\
\hline & $\sum$ & 2 & 2 & 2 & $\mathbf{0}$ \\
\hline \multirow{2}{*}{ Corticiales } & Corticiaceae & 1 & 1 & 1 & $\mathbf{0}$ \\
\hline & $\sum$ & 1 & 1 & 1 & $\mathbf{0}$ \\
\hline \multirow{2}{*}{ Gomphales } & Gomphaceae & 1 & 1 & 1 & $\mathbf{0}$ \\
\hline & $\sum$ & 1 & 1 & 1 & $\mathbf{0}$ \\
\hline \multirow{5}{*}{ Hymenochaetales } & Hymenochaetaceae & 6 & 17 & 16 & 4 \\
\hline & Oxyporaceae & 1 & 1 & 1 & $\mathbf{0}$ \\
\hline & Rickenellaceae & 1 & 2 & 1 & $\mathbf{0}$ \\
\hline & Schizoporaceae & 3 & 4 & 4 & $\mathbf{0}$ \\
\hline & $\sum$ & 11 & 24 & 22 & 4 \\
\hline \multirow{11}{*}{ Polyporales } & Fomitopsidaceae & 6 & 7 & 5 & 1 \\
\hline & Ganodermataceae & 1 & 3 & 1 & $\mathbf{0}$ \\
\hline & Grifolaceae & 1 & 1 & 1 & $\mathbf{0}$ \\
\hline & Ischnodermataceae & 1 & 1 & $\mathbf{0}$ & $\mathbf{0}$ \\
\hline & Meripilaceae & 2 & 3 & 2 & $\mathbf{0}$ \\
\hline & Meruliaceae s. 1. & 11 & 19 & 14 & 4 \\
\hline & Podoscyphaceae s. 1. & 5 & 6 & 3 & $\mathbf{0}$ \\
\hline & Polyporaceae & 10 & 24 & 11 & 1 \\
\hline & Steccherinaceae & 5 & 8 & 8 & 1 \\
\hline & Xenasmataceae & 1 & 1 & 1 & $\mathbf{0}$ \\
\hline & $\sum$ & 43 & 73 & 46 & 7 \\
\hline \multirow{5}{*}{ Russulales } & Auriscalpiaceae & 1 & 1 & $\mathbf{0}$ & $\mathbf{0}$ \\
\hline & Hericiaceae & 3 & 4 & 2 & $\mathbf{0}$ \\
\hline & Peniophoraceae & 2 & 3 & 3 & $\mathbf{0}$ \\
\hline & Stereaceae & 3 & 8 & 5 & 1 \\
\hline & $\sum$ & 9 & 16 & 10 & 1 \\
\hline$\sum$ & & 121 & 223 & 122 & 20 \\
\hline
\end{tabular}

Az alábbiakban a Juhdöglő-völgy Erdőrezervátumból dokumentált taxonokat szisztematikai sorrendben ismertetem, valamint értékelem a területről kimutatott, valamint a rokon fajok aktuális taxonómiai helyzetét, jellemző makro- és mikromorfológiai bélyegeiket, illetve hazai elterjedésüket a szakirodalomból ismert adataik és saját megfigyeléseim alapján. Az egyes 
nemzetségek elött feltüntetett zárójelben lévő szám az adott génuszba tartozó és az erdőrezervátumból ezidáig ismert fajok számát mutatja. A területröl dokumentált taxonok esetében külön jelöltem azokat, amelyeknek korábban nem volt publikált előfordulási adata a Vértes hegységből (*), valamint amelyek újnak bizonyultak a magyarországi funga egészére nézve (**). Azon taxonok esetében, ahol a szakirodalomban nevezéktani ellentmondásokat tapasztaltam, ismertetem és értékelem a különböző nómenklatúrai és taxonómiai koncepciókat (az egyes taxonokhoz tartozó magyarázatokat római számmal jelöltem).

\subsubsection{A Pucciniomycotina osztályba tartozó lignikol nagygombák \\ Phleogenaceae Weese}

(1) Phleogena Link: *P.faginea (Fr. \& Palmquist) Link (I)

Taxonómiai és nómenklatúrai megjegyzések: (I) a leírása óta több nemzetségbe [Botryochaete Corda, Ecchyna Fr. ex Boud., Onygena Pers., Pilacre Fr.] sorolt Onygena faginea Fr. \& Palmquist (DONK 1966) filogenetikai vizsgálatok alapján a monotipikus Phleogena Link génuszba, a Phleogenaceae Weese családba, valamint az Atractiellales Oberw. \& Bandoni rendbe és az Atractiellomycetes R. Bauer et al. osztályba tartozik (AIME és mtsai. 2006; HAUSNER és mtsai. 2008; OBERWINKLER és mtsai. 2006). Rendszertani besorolásának nómenklatúrai vonatkozását tekintve DowELD (2014) szerint viszont a Phleogenaceae-nek az Atractiellaceae családdal szembeni prioritása értelmében a Phleogenales Doweld és Phleogenomycetes Doweld nevek használata előnyt élvez.

A Phleogena faginea mindösszesen 5-8 mm magas, fehéres-szürkés színü, egyes „nyálkagombák” sporangiumára hasonlító jellegzetes stilboid sporokarpiumokat képez. Jellemző mikroszkopikus bélyegei a kerekded vagy kissé elliptikus, vastag falú, világosbarnás színü spórák, valamint a szeptált fragmobazídiumok (5. ábra) (pl. MCNABB 1964; TALLASCH és JAHN 1970). Első magyarországi adatát NAGY és GoRLICZAI (2007) publikálta a Tőserdőből (Alföld), cseresznyefa tuskójáról. A jelen munkában közölt adatai alapján a Juhdöglö-völgy a második ismert lelőhelye volt hazánkból (PAPP 2011b). Később LUKÁCS és munkatársai (2013) több adatát közölték a Bakonyból, Bükkből és a Zempléni-hegységből is. A P. faginea fajt több munkában is az európai bükkerdők biodiverzitás-indikátorai között említik (pl. CHRISTENSEN és mtsai. 2004; SILLER 2004); a szakirodalmi adatok alapján azonban úgy tủnik, hogy a bükkös erdőrezervátumokból származó adatai (pl. AINSWORTH 2004b, 2005; HEILMANN-ClAUSEN és WALLEYN 2007; PiltaVer és mtsai. 2003; WALLEYN és VeERKAMP 2005) ellenére nem kötődik kifejezetten természetközeli élőhelyekhez, hanem egy magas ökológiai plaszticitással rendelkező polifág faj (RIPKOVÁ és mtsai. 2004; SZCZEPKOWSKI és mtsai. 2008). 

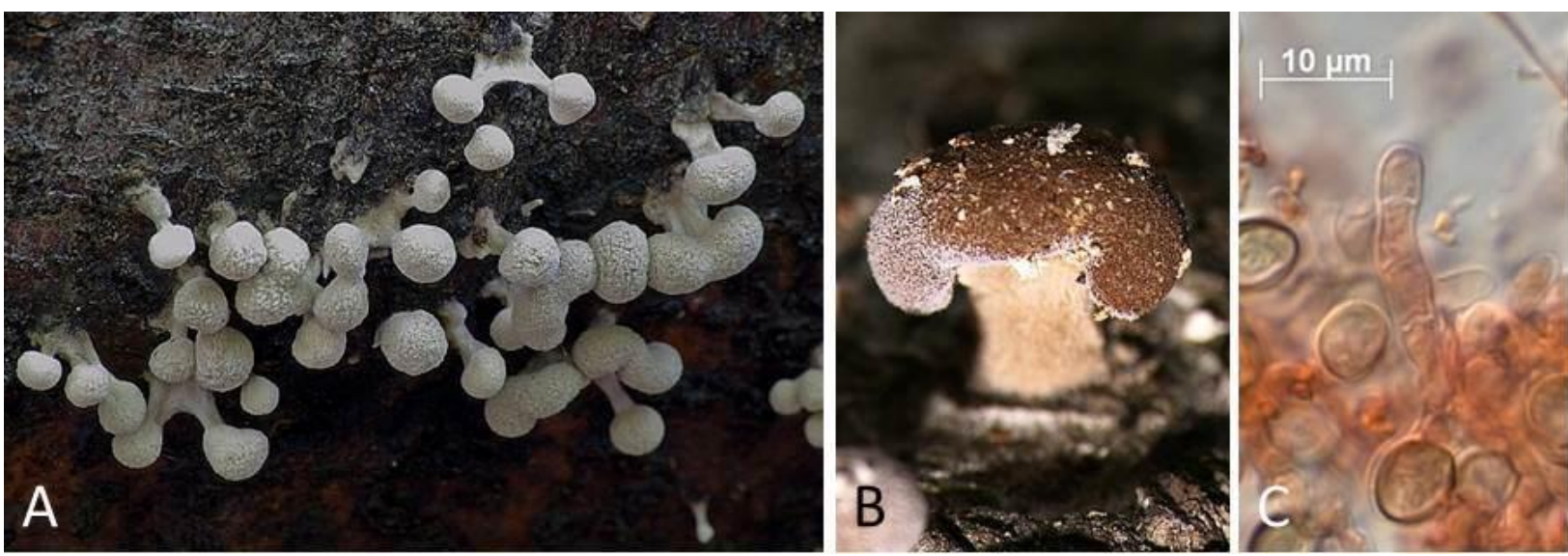

5. ábra. A Phleogena faginea morfológiai bélyegei (PV230). A) P. faginea stilboid bazídiokarpiumai a Juhdöglö-völgy Erdörezervátumban, bükkfa rönkön (in situ); B) sztereomikroszkopikus felvétel a bazídiokarpiumról (ex situ); C) szeptált fragmobazídium és bazídiospórák. Fotó: Papp V.

\subsubsection{A Tremellomycetes alosztályba tartozó lignikol nagygombák}

\section{Tremellaceae Fr.}

(2) Tremella Pers.: T. foliacea Pers., T. mesenterica (Schaeff.) Retz

A Tremella nemzetség fajai a hasonló sporokarpiumot képző taxonoktól [pl. Dacrymyces spp., Exidia spp.] a nagyméretü és többnyire gömbölyü, hosszirányban szeptált bazídiumok, valamint a gömbölyded vagy kissé elliptikus spórák alapján különíthetők el. Az erdőrezervátumból kimutatott $T$. foliaceae és $T$. mesenterica fajok Európa szerte igen gyakoriak (PIPPOLA és KotiRAnTA 2008) és Magyarországról is számos adatuk ismert (pl. BenEDEK 2011; DiMA és mtsai. 2013; SILLER és mtsai. 2013). A T. foliacea a barnás-feketés színü és leveles szerkezetü sporokarpiumáról makroszkopikus bélyegek alapján is felismerhető. Ökológiáját tekintve különböző lombos fafajokon fordul elő és jellemzően a Stereum rugosum vagy más Stereum fajok micéliumán élösködik (ROBERTS 1999). A Tremella mesenterica termőtestének színe sárga vagy narancssárga, de ritkán akár fehér is lehet; a szakirodalom alapján a korticioid Peniophora génusz taxonjait parazitálja (PIPPOLA és KOTIRANTA 2008; ZuGMAIER és mtsai. 1994). Makroszkopikusan hasonló megjelenésü a Stereum hirsutum réteggomba micéliumán élősködő T. aurantia Schwein., amely a kisebb bazídiumai [9-13 $\mu \mathrm{rn}$ széles] és bazídiospórái [5,5-9,0 × 4,5-7,0 $\mu \mathrm{rn} ; \mathrm{Q}=1,1-1,4]$ alapján különíthető el (ROBERTS 1995).

\subsubsection{A Dacrymycetes alosztályba tartozó lignikol nagygombák}

\section{Dacrymycetaceae Bref.}

(2) Calocera (Fr.) Fr. - C. cornea (Batsch) Fr., C. cf. glossoides (Pers.) Fr.

(1) Dacrymyces Nees - *D. stillatus Nees 
A Calocera cornea jellemző bélyegei a csat nélküli hifák és a jellegzetes egyszeresen szeptált bazídiospórák (MCNABB 1965). Siller (2004) ezt a fajt a Kékes és az Öserdő erdőrezervátumokból a frekvens fajok között említi. KOSZKA (2011) munkájában a Vértesből a C. cornea bükkfatörzsröl gyüjtött adatán kívül a C. furcata (Fr.) Quél. faj előfordulását jelzi lehullott égergallyról. Ez utóbbi faj több szakirodalom alapján fenyőfélék faanyagán nő (pl.

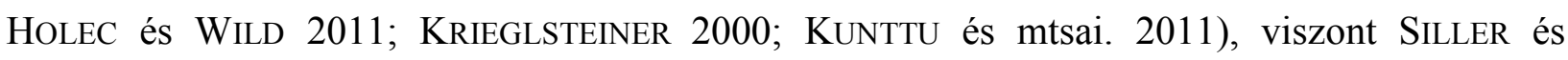
munkatársai (2013) örségi előfordulását szintén lombosfáról jelzik.

A morfológiailag hasonló Calocera glossoides föként tölgyeken nő (MCNABB 1965). Hazai előfordulását NAGY és GoRLICZAI (2007) Szegedről, a Népligetből szintén elhalt Quercus ágról jelzik, azzal a megjegyzéssel, hogy a $C$. cornea fajtól való elkülönítése csak a termőtestek alakja alapján lehetséges, amelyet bizonytalan taxonómiai bélyegnek tartanak.

A Dacrymyces stillatus Nees jellegzetes tremelloid sárgás színü sporokarpiumot és szeptált bazídiospórákat képző gyakori polifág faj, amelynek előfordulását néhány alakalommal figyeltem meg az erdőrezervátum területén tölgyek faanyagán. Ezt a fajt SILLER és munkatársai (2013) az Örségből szintén tölgy és bükk faanyagáról jelzik.

\subsubsection{Az Agaricomycetes alosztályba tartozó lignikol nagygombái}

\subsubsection{Agaricales Underw.}

Agaricaceae Chevall.

(1) Lycoperdon Pers. - L. pyriforme Schaeff. [三 Morganella pyriformis (Schaeff.) Kreisel \& D. Krüger] (I)

Taxonómiai és nómenklatúrai megjegyzések: (I) a Lycoperdon pyriforme fajnak morfológiai bélyegei, valamint filogenetikai vizsgálatok eredményei alapján, KRÜGER és KREISEL (2003) a Morganella Zeller génuszba való átsorolását javasolták. A Morganella nemzetség elkülönítését több mikológus is elfogadja (pl. ALFREDO és mtsai. 2012, 2014; BARBOSA és mtsai. 2011; CORTEZ és mtsai. 2007, 2013), ugyanakkor LARSSON és JEPPSON (2008) a Lycoperdaceae s. lato ITS és LSU szekvenciákon alapuló filogenetikai vizsgálatuk alapján a génuszt alnemzetségnek tekintik [Lycoperdon subgen. Morganella (Zeller) Jeppson \& E. Larss.]. A Morganella nemzetség taxonómiai helyzete viszont továbbra sem tisztázott, tekintettel arra, hogy LARSSON és JEPPSON (2008) munkájukban a génusz típusfaját [Morganella mexicana Zeller] nem vizsgálták.

A Lycoperdon pyriforme Európában és Magyarországon is igen gyakori faj (pl. HoLlós 1904; JEPPSON 2012a) és a Juhdöglö-völgy Erdőrezervátumban is tömegesen fordult elő főként erősen korhadt faanyagon. A lényegesen ritkább tüskés exoperídiumú L. echinatum Pers. holtfán is megjelenhet, de az erdőrezervátum területén előfordulását csak talajon tapasztaltam. 


\section{Bolbitiaceae Singer}

(2) Bolbitius Fr. - B. reticulatus (Pers.) Ricken, B. cf. titubans (Bull.) Fr. [= B. vitellinus (Pers.) Fr.; $\equiv$ B. titubans var. vitellinus (Pers.) Courtec.]

Taxonómiai és nómenklatúrai megjegyzések: (I) A Funga Nordica a Bolbitius reticulatus fajnak két formáját különbözteti meg: B. reticulatus f. reticulatus és f. aleuriatus [= B. aleuriatus (Fr.) Singer] (HAUSKNECHT és VeSterholt 2012). Az „aleuriatus” forma jellegzetessége, hogy az alapfajjal ellentétben a kalap közepén nincsenek sötétebb színü ráncok, erek (BABOS 1977). A lignikol és kis spórájú $(>10 \mu \mathrm{m})$ Bolbitius fajok közül szintén lombos fákon képez termőtestet a $B$. pluteoides M.M. Moser, amelynek kisméretü (5-15 mm) sima nyálkás kalapja van. ARNOLDS (2003) ezt a fajt szintén a $B$. reticulatus faj alá sorolta és annak változataként tárgyalja: $B$. reticulatus var. pluteoides.

BABOS (1989) munkájában a Bolbitius reticulatus három lelőhelyét említi, közte a Vértes hegységet (Szárhegy) is. A B. psittacinus Hauskn., Antonín \& Polcák fajt HAUSKNECHT és munkatársai (2007) Csehországból, bükkfa törmelékéről írták le. Ezt a fajt korábban, 1985-ben már Albert László is gyüjtötte Magyarországról (Zempléni-hegység), de felfedezését nem publikálta (Albert László, személyes közlés).

\section{Clavariaceae Chevall.}

(1) Mucronella Fr. [= Mucronia Fr.] (I) - *M. calva (Alb. \& Schwein.) Fr.

Taxonómiai és nómenklatúrai megjegyzések: (I) FRIES (1849a) elöször Mucronia néven írta le a génuszt, de ez a név érvénytelen, mert egy későbbi homonimája a Mucronea Bent. Polygonaceae családba tartozó növénynemzetségnek.

A Mucronella génusznak három, jellemzően fenyőféléken előforduló faja ismert Európából: M. bresadolae (Quél.) Corner, M. calva és M. flava Corner (BERNICCHIA és GoRJÓN 2010; BeRNiCCHIA és PAdOVAn 1997; YuAN és mtsai. 2009). A Juhdöglő-völgy Erdőrezervátumban bükkfa rönkről gyüjtött Mucronella termőtestek a fiatalon fehéres színü tüskék alapján a $M$. calva fajjal azonosak. NAGY és GoRLICZAI (2007) a M. calva fajt a szegedi Boszorkány-szigetről szintén lombfás élőhelyről (Salicetum albae-fragilis) jelzik, ugyanakkor megjegyzik, hogy a tráma színét leszámítva egyéb bélyegek alapján a $M$. flava taxontól nem különíthető el egyértelmüen, ezért a határozást bizonytalannak tekintik.

\section{Crepidotaceae (S. Imai) Singer (I)}

(12) Crepidotus (Fr.) Staude $-{ }^{*} \boldsymbol{C}$. applanatus (Pers.) P. Kumm., ${ }^{*} \boldsymbol{C}$. calolepis (Fr.) P. Karst., ${ }^{*} \boldsymbol{C}$. caspari Velen., C. crocophyllus (Berk.) Sacc., ${ }^{* *} \boldsymbol{C}$. ehrendorferi Hauskn. \& Krisai, ${ }^{*} \boldsymbol{C}$. cesatii (Rabenh.) Sacc., ${ }^{*}$ C. macedonicus Pilát \& Lindtner, $* *$. malachioides Consiglio, 
Prydiuk \& Setti, ${ }^{*} \boldsymbol{C}$. malachius Peck, $\boldsymbol{C}$. mollis (Schaeff.) Staude, ${ }^{*} \boldsymbol{C}$. variabilis (Pers.) P. Kumm., C. subverrucisporus Pilát

(2) Simocybe P. Karst. - *S. centunculus (Fr.) P. Karst., *S. sumptuosa (P.D. Orton) Singer

Taxonómiai és nómenklatúrai megjegyzések: (I) a Crepidotaceae családot egyes szerzők az Inocybaceae Jülich szinonimjának tekintik (KIRK és mtsai. 2008), de számos filogenetikai vizsgálattal alátámasztott taxonómiai munka a Crepidotaceae különállóságát támogatja (AIME és mtsai. 2005; AlvarAdo és mtsai. 2010; CANNON és KiRK 2007; MATHENY 2009; MATHENY és mtsai. 2014; PETERSEN és mtsai. 2009).

A Juhdöglö-völgy Erdőrezervátum magterületéről gyüjtött Crepidotus fajok közül a génusz típusfaja (C. mollis), valamint a C. calolepis s. lato a Crepidotus alnemzetség, Crepidotus szekciójába tartozik. Közös jellemzőjük a kalapbőr alatt lévő zselatin réteg, valamint a sima elliptikus spórák (CONSIGLIO és SETTI 2008; SENN-IRLET 2012). A Dochmiopus alnemzetség Dochmiopus szekciójából több alkalommal is sikerült megtalálni az apró, fehéres színü termőtesteket képző Crepidotus caspari, C. cesatii, C. subverrucisporus és C. variabilis fajokat, valamint bükkfa rönkön gyüjtöttem a C. macedonicus termőtesteit. Ennek a fajnak az első középeurópai előfordulását csak 2002-ben igazolták (RIPKOVÁ 2002). A C. macedonicus fajt Magyarországról LUKÁCS és HORVÁTH (2010) közölte elsőként, azonban bizonyító minta hiányában hiteles hazai adata csak a Nyírségből (DIMA és mtsai. 2010) és a szentbékálai Feketehegyről vannak (DIMA és mtsai. 2013). A gömbölyü spórás és csatos hifákat képző Sphaeruli szekció (HESLER és SMITH 1965) taxonjai közül az alábbi fajok előfordulását dokumentáltam: Crepidotus applanatus, C. malachius, C. crocophyllus, C. ehrendorferi (6. ábra) és C. malachioides.

A Crepidotus crocophyllus fajt élőhelypreferenciája és kevés adata miatt hazánkban a ritka fajok között tartották számon (pl. BABOSNÉ 1975, BABOS 1989, RiMÓCZI 1994), de az utóbbi években több újabb lelőhelyről publikálták előfordulását (pl. NAGY 2004, NAGY és GORLICZAI 2007, PÁL-FÁM és mtsai. 2009). RIPKOVÁ és munkatársai (2005) viszont filogenetikai vizsgálatok alapján arra a következtetésre jutottak, hogy a C. crocophyllus $[=C$. nephrodes (Berk. \& M.A. Curtis) Sacc.] egy Észak-Amerika és Európa lomboserdeiben elterjedt gyakori faj. A C. crocophyllus-nak közép-európai minták alapján jellemző makromorfológiai bélyege, hogy lemezei narancsos színűek. AIME (2004) szerint viszont ez nem egy stabil makroszkopikus bélyeg, tekintve, hogy kultúrában a Fulvifibrillosi szubszekcióba tartozó taxonok esetében változatos pigmentációt tapasztalt. A lemezszínt tekintve hasonló morfológiai változatosságot mutattak ki BANDALA és munkatársai (2008b) is. Az újabb munkák alapján vélhetően a $C$. crocophyllus egy kozmopolita elterjedésű faj, amelynek hazai adatainak és természetvédelmi 
státuszának revideálása szükségesnek látszik. Az erdőrezervátum területén ugyan nem volt gyakori, de több alkalommal és különböző fafajokon is megfigyeltem a termőtesteit.
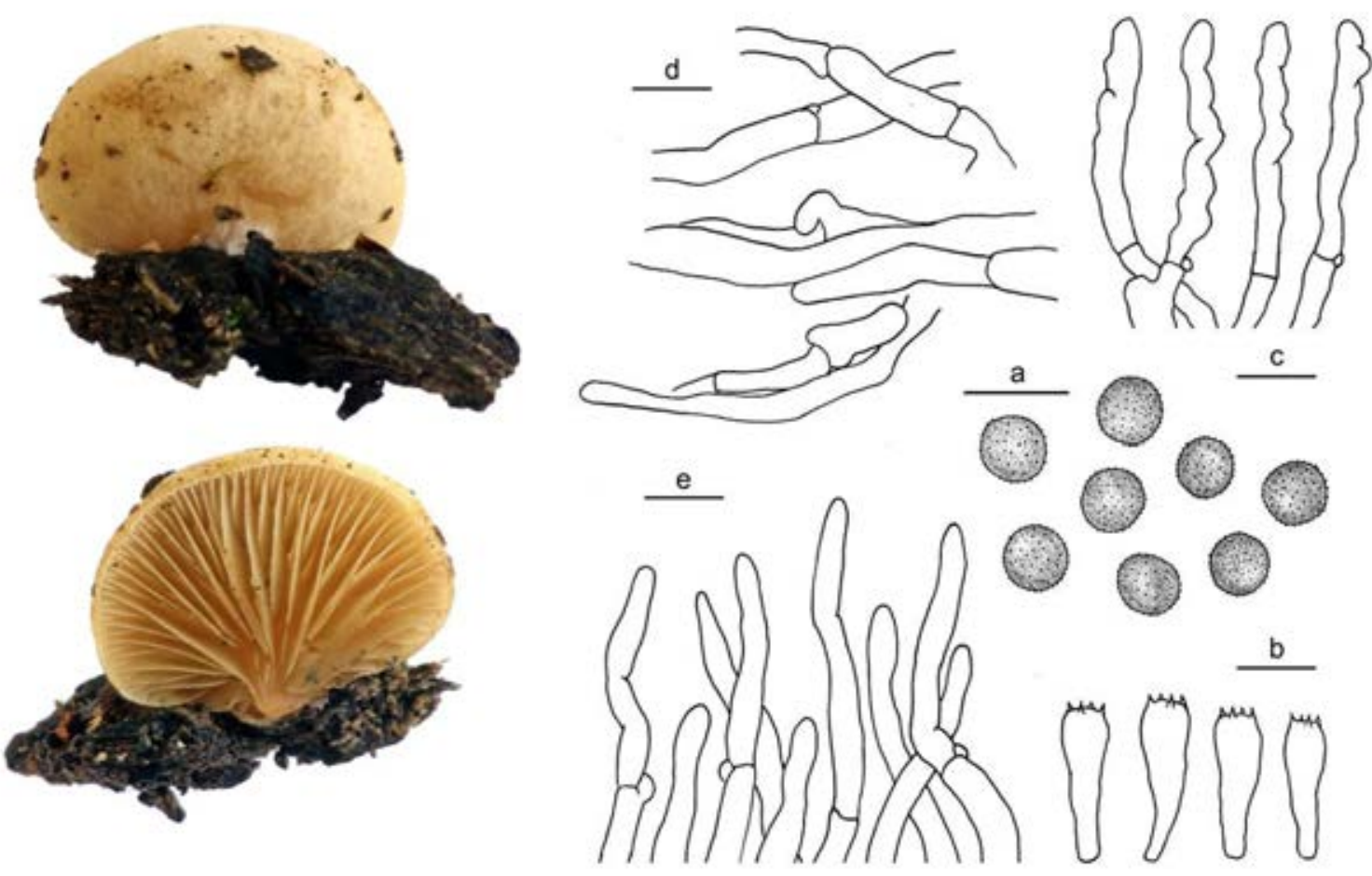

6. ábra. A Crepidotus ehrendorferi Juhdöglö-völgy Erdőrezervátumban gyüjtött termőteste és mikroszkopikus bélyegei (PV218); a) bazidiospórák; b) bazídiumok; c) cheilocisztidia; d) pileipellis; e) epicutis elemei. Mérce $=10 \mu \mathrm{m}$. Rajz: Papp V.

A Crepidotus ehrendorferi holotípusát egy Bécs közelében lévő erdőrezervátumban gyüjtötték bükkfa rönkről (HAUSKNECHT és KRISAI 1988). RIPKOVÁ és GLEJDURA (2010) munkájukban ismertetik ennek a fajnak a jellemző morfológiai bélyegeit, valamint részletesen tárgyalják ökológiai igényeit, továbbá újabb elöfordulási adatait is közlik.

A Crepidotus malachioides fajt Consiglio és munkatársai Ukrajnából gyüjtött minta alapján írták le és sokáig a locus classicus volt az egyetlen ismert lelőhelye (CONSIGLIO és SETTI 2008). JANČOVIČOVÁ és munkatársai (2014a) újabb előfordulási adatait közölték, valamint epitipifikálták egy szlovákiai minta alapján.

A Juhdöglö-völgy Erdőrezervátum területén gyüjtött Crepidotus minták közül három faj esetében végeztem ITS alapú molekuláris vizsgálatokat (7. ábra). A morfológiai bélyegek alapján C. ehrendorferi-nek határozott minta esetében a GenBank-ban nem találtam összehasonlító szekvenciát, de sikerült DNS-t kivonni a faj holotípusából (WU6554), amelynek ITS régiója azonosságot mutatott az erdőrezervátumban gyüjtött mintáéval. 


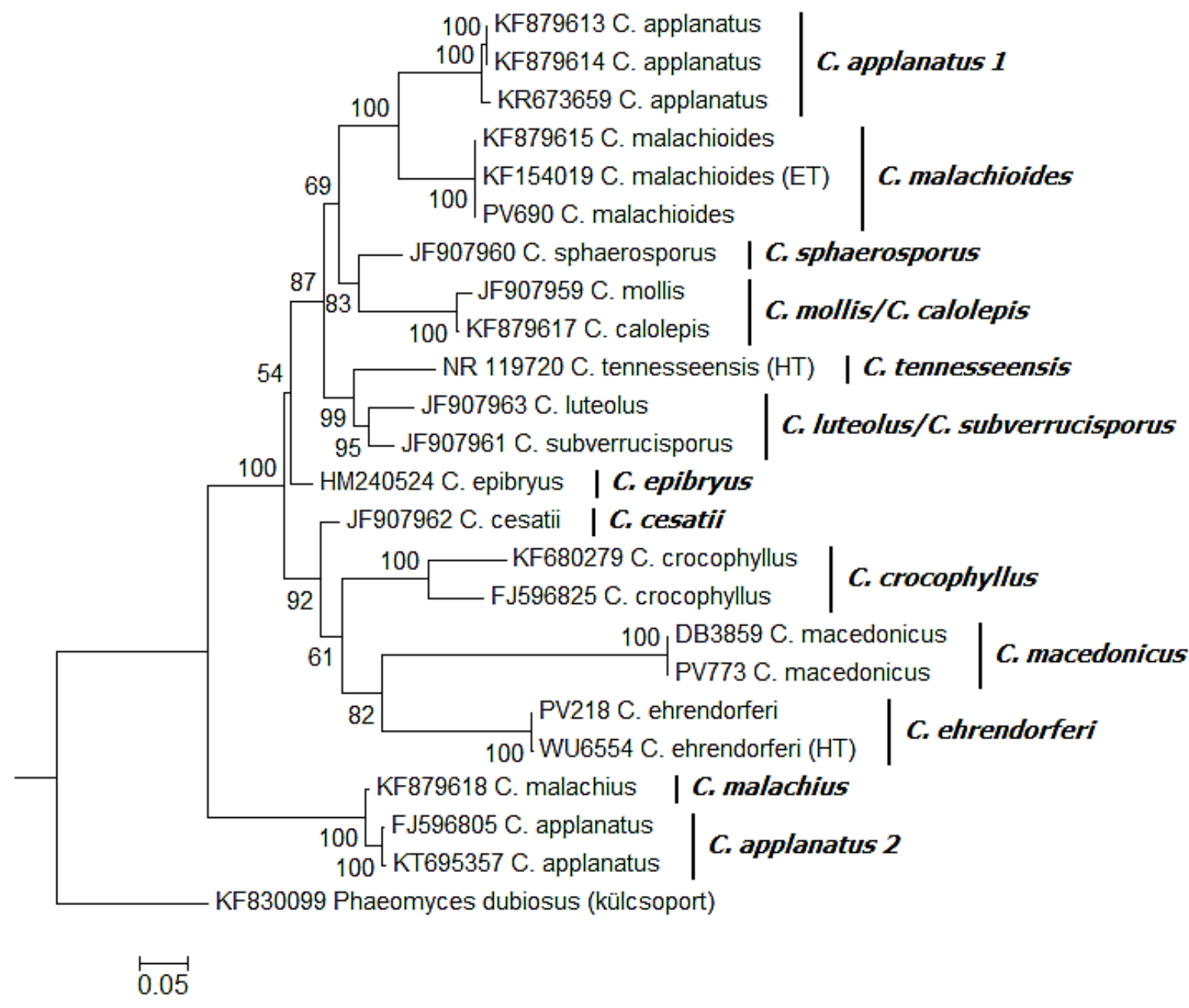

7. ábra. A rezervátumban gyüjtött Crepidotus ehrendorferi (PV218), C. macedonicus (PV773) és C. malachioides (PV690) és rokon fajainak filogenetikai fája ITS szekvenciák alapján. Az ágaknál szereplő számok a 50\%-nál magasabb ML bootstrap értékeket jelölik. A mérce 100 karakterre eső 5 szubsztitúciónak megfelelő ághosszat jelöl. A filogenetikai rekonstrukció Maximum Likelihood (ML) statisztikai becslés alapján a RAxML program segítségével GTRGAMMA szubsztitúciós modell valamint 1000 ismétléses „rapid bootstrap” elemzés alkalmazásával készült. Rövidítések: ET=epitípus; HT=holotípus.

A Crepidotus macedonicus fajnak a GenBank-ban szintén nem volt feltöltött szekvenciája; a holotípus pedig olyan rossz állapotban van, hogy nem alkalmas molekuláris vizsgálatra (Jan Holec személyes közlés), ezért összehasonlító szekvenciaként a szentbékálai Fekete-hegyről Dima Bálint által gyüjtött mintát (DB 3859) használtam. A két minta ITS régiója egyezést mutatott, amely megerősítette a morfológiai bélyegeken alapuló határozást. A C. malachioides rezervátumban gyüjtött minta szintén egyezést mutatott a JANČOVIČOVÁ és munkatársai (2014a) által kijelölt szlovákiai epitípussal (KF154019), valamint egy Ausztriai mintával (KF879615).

A Simocybe centunculus hazánkban nem ritka faj (pl. BENEDEK 2011; NAGY és GorLICZAI 2007; SILLER és mtsai. 2013) és a Juhdöglő-völgy Erdőrezervátum területén is több alkalommal gyüjtöttem. A S. sumptuosa makroszkopikusan hasonló megjelenésü, mint a S. centunculus, de a 
kalapja és a pileocisztidiumai nagyobb méretüek és hosszabbak a spórái (HAUSKNECHT 2010; KNUDSEN és Vesterholt 2012). A S. sumptuosa cseresznyefáról gyüjtött mintáit LUKÁCS (2010) első hazai adatként publikálta Budakesziről és Miskolctapolcáról, a Magyar Természettudományi Múzeum Növénytárában azonban van egy korábbi, 1992-es Vendvidékről származó fungáriumi adata is (BP 92641). Ezt a fajt az erdőrezervátumban bükkfarönkről gyüjtöttem. KoszKa (2014) a S. reducta (Fr.) P. Karst. vértesi előfordulását a pátrácos-völgyi szurdokerdőből jelzi korhadó bükkfáról. Ez a faj többnyire terrikol életmódú, de HoRAK és RONIKIER (2011) szerint ritkán elöfordulhat lombos fák faanyagán is.

\section{Cyphellaceae Lotsy}

(1) Chondrostereum Pouzar - C. purpureum (Pers.) Pouzar (I)

Taxonómiai és nómenklatúrai megjegyzések: (I) A Chondrostereum purpureum-ot POUZAR (1959) morfológiai bélyegek alapján különítette el a makroszkopikusan hasonló Stereum Hill ex Pers. génusztól. Pouzar morfológiai bélyegeken alapuló megfigyeléseit több filogenetikai vizsgálat is megerősítette (pl. KIM és JUNG 2000; BINDER és mtsai. 2005), amelyek alapján a C. purpureum a központi /Euagarics kládba tartozik.

A Chondrostereum purpureum jellegzetes bélyegei a lilás színü sima tráma, a leptocisztidiumok jelenléte, valamint az inamiloid spórák. Hazánkban nem ritka, lombos fafajokon előforduló, széles gazdanövény-spektrummal rendelkező faj (pl. KONECSNI és VÉGHELYI 1986; NAGY 2004).

Entolomataceae Kotl. \& Pouzar

(1) Clitopilus (Fr. ex Rabenh.) P. Kumm. - C. hobsonii (Berk. \& Broome) P.D. Orton

(2) Entoloma Fr. ex P. Kumm. ${ }^{*} \boldsymbol{E}$. zuccherellii var. pluteisimilis (Noordel. \& C.E. Hermos) V. Papp $[\equiv E$. pluteisimilis Noordel. \& C.E. Hermos] (I), **Entoloma tjallingiorum var. tjallingiorum Noordel. [三 Leptonia tjallingiorum (Noordel.) P.D. Orton] (II) (ex situ fotódokumentáció a sporokarpiumról, in: RIMÓCZI 2012)

Taxonómiai és nómenklatúrai megjegyzések: (I) az Entoloma nemzetség egy korábbi filogenetikai vizsgálata alapján a Turfosa szekció tagjai monofiletikus csoportot alkottak az Entoloma kláddal (CoDAVID és mtsai. 2009). BARONI és munkatársai (2011) szerint viszont morfológiai és molekuláris bélyegek alapján a szekció tagjai egy külön csoportot képeznek az Entoloma nemzetségtől és a fajokat az újonnan leírt Entocybe T.J. Baroni, V. Hofstetter \& Largent nemzetségbe sorolták. Az új nemzetséget MORGADO és munkatársai (2013) nem fogadják el és a szekció tagjait továbbra is az Entoloma nemzetségben tárgyalják. BARONI és LAMOUREUX (2013) azonban új fajként írták le Kanadából az Entocybe melleogrisea T.J. Baroni \& Y. Lamoureux fajt, valamint BERGEMAN és munkatársai (2013) továbbra is az Entocybe génuszt elfogadva publikálták az E. haastii (G. Stev.) Largent [三Entoloma haastii G. Stev.] kombinációt. (II) A KUMMER (1871) által önálló nemzetségként elkülönített Leptonia (Fr.) P. Kumm. génusz típusfaja a L. euchroa (Pers.) P. Kumm. [三Entoloma euchroum (Pers.) Donk]. A 
Leptonia nemzetség szintü elkülönítését több mikológus is elfogadja (pl. LARGENT 1994; LARGENT és mtsai. 2013; ORTON 1991), míg mások az Entoloma génusz szinonimjának tekintik és szekció szintjén tárgyalják (pl. MOROZOVA és mtsai. 2014; NOORDELOOS 1982, 2004).

Magyarországról számos Entoloma faj előfordulását sikerült már igazolni, de ezek között csak néhány olyan található, amelyek faanyagon képeznek termőtestet: E. dichroum (Pers.) P. Kumm., E. jahnii Wölfel \& Winterh., E. pluteisimilis Noordel. \& C.E. Hermos (BABOS 1989; Dima és mtsai. 2013; LuKÁCS 2007; NoORdElOOS és HAUSKNECHT 2009; RiMÓCZI 1994). Az E. pluteisimilis-hez igen közel áll két további európai Entoloma faj: az E. sclerotiogenum F. Caball., Higelmo, Català \& Vila és az E. zuccherellii (Noordel. \& Hauskn.) Noordel. \& CoDavid. A három faj jellemző morfológiai bélyegeit és ismert szubsztrátumait irodalmi adatok alapján a 6. táblázatban foglaltam össze.

6. táblázat. Az Entoloma zuccherellii csoportba tartozó fajok összehasonlítása irodalmi adatok alapján, a jellemző morfológiai bélyegeik, valamint ismert szubsztrátumaik szerint.

\begin{tabular}{|c|c|c|c|}
\hline & E.pluteisimilis & E. sclerotiogenum & E. zuccherellii \\
\hline bazionim & $\begin{array}{l}\text { E.pluteisimilis } \\
\text { Noordel. \& C.E. } \\
\text { Hermos. } 2004\end{array}$ & $\begin{array}{l}\text { E. sclerotiogenum } \mathrm{F} . \\
\text { Caball., Higelmo, } \\
\text { Català \& Vila } 2012\end{array}$ & $\begin{array}{c}\text { Rhodocybe zuccherellii Noordel. \& } \\
\text { Hauskn. } 2000\end{array}$ \\
\hline kalap & $\begin{array}{l}20-35 \mathrm{~mm} \text {, } \\
\text { egységesen piszkos } \\
\text { barna, (III); barna, } \\
\text { szürkés-barna (I) }\end{array}$ & $\begin{array}{l}\text { kék, ibolyakék, barna, } \\
\text { barnás-lila (I) }\end{array}$ & $\begin{array}{c}\text { 4-10(-17) mm, fiatalon sötétbarna, } \\
\text { később a széle felé okker-barnás } \\
\text { (II) }\end{array}$ \\
\hline tönk & $\begin{array}{l}\text { 30-45 × } 2-5 \mathrm{~mm} \text {, } \\
\text { halvány barnás, } \\
\text { fehéres rostokkal } \\
\text { borított (III); barna }(\mathrm{I})\end{array}$ & $\begin{array}{c}30 \times 2,5 \mathrm{~mm} \text {, kék, } \\
\text { ibolyakék, vagy } \\
\text { barnás-ibolyás, -lilás } \\
\text { (I) }\end{array}$ & $\begin{array}{c}7-15 \times 1,5-2,5 \mathrm{~mm} \text {, szürkés- } \\
\text { barna, enyhe acélkékes árnyalattal } \\
\text { (II) }\end{array}$ \\
\hline spórák & $\begin{array}{c}6,0-7,0 \times 5,0-6,0 \mu \mathrm{m} \\
\mathrm{Q}=1,0-1,3 \text { (III) }\end{array}$ & $\begin{array}{c}5,8-7,9 \times 5,4-6,9 \mu \mathrm{m} \\
\mathrm{Q}=1,0-1,3(\mathrm{I})\end{array}$ & $\begin{array}{c}6,0-6,5 \times 5,5-6,0 \mu \mathrm{m}, \mathrm{Q}=1,0-1,2 ; \\
\text { (holotípus) (I; II; IV) } \\
(5,6-) 6.0-7,6(-8,0) \times(5,2-) 5,6- \\
6,4(-6,8) \mu \mathrm{m}, \mathrm{Q}=1.06-1.29 \text { (II) }\end{array}$ \\
\hline bazídium & $\begin{array}{l}\text { 4-spórás, csatos } \\
\text { (mérete: n.a.) (III) }\end{array}$ & $\begin{array}{l}32,3 \times 9,1 \mu \mathrm{m} \\
\quad \text { (átlag) (I) }\end{array}$ & $27-32 \times 7.0-9.5 \mu \mathrm{m}(\mathrm{II})$ \\
\hline szubsztrátum & $\begin{array}{l}\text { Pinus }(\mathrm{III}), \text { Fagus } \\
\text { Sylvatica }(\mathrm{V})\end{array}$ & $\begin{array}{l}\text { Betula alba var. alba, } \\
\text { Pinus sylvestris (I) }\end{array}$ & $\begin{array}{l}\text { Pinus, cf. Picea (II), Alnus } \\
\text { glutinosa (I) }\end{array}$ \\
\hline
\end{tabular}

Irodalmi források: (I) CABALLERO és munkatársai (2012), (II) HOLEC és NOORDELOOS (2010), (III) NOORDELOOS (2004), (IV) NoORDELOOS (2000), valamint (V) HEILMANN-ClAUSEN és WALLEYN (2007) munkái alapján.

Az Entoloma pluteisimilis egyetlen eddig ismert magyarországi előfordulását NoORDELOOS és Hausknecht (2009) közölte. A típusfajt Pinus-ról írták le (NoORdeloos 2004), de ÉszakSpanyolországból HeILMANN-CLAUSEN és WALLEYN (2007) bükkről jelzik. Jellegzetes kisméretü, kerekded spórái alapján Noordeloos (2004) a Turfosa (Romagn.) Noordel. 
szekcióba sorolta; a termőtest makromorfológiája alapján HEILMANN-CLAUSEN és WALLEYN (2007) pedig megjegyzik, hogy igen hasonlít a Rhodocybe Maire nemzetség fajaira.

A 2012-ben Spanyolországból leírt Entoloma sclerotiogenum CABALLERO és munkatársai (2012) szerint molekuláris vizsgálat és morfológiai bélyegek alapján az E. zuccherellii (Noordel. \& Hauskn.) Noordel. \& Co-David és E. pluteisimilis fajokhoz áll közel. Az E. zuccherellii-t Olaszországból (Ravenna, Pineta di Classe) írták le Rhodocybe zuccherellii néven (NoORDELOOS 2000), majd CO-DAVID és munkatársai (2009) filogenetikai vizsgálat alapján áthelyezték az Entoloma génuszba. Az E. zuccherellii csehországi előfordulását 2010-ben mutatták ki (HOLEC és KŘíž 2010) és az itt gyüjtött fenyő (cf. Picea) faanyagáról származó minta alapján HoLEC és NoORDELOOS (2010) részletesen tárgyalják a faj infraspecifikus változatosságát és taxonómiai helyzetét.
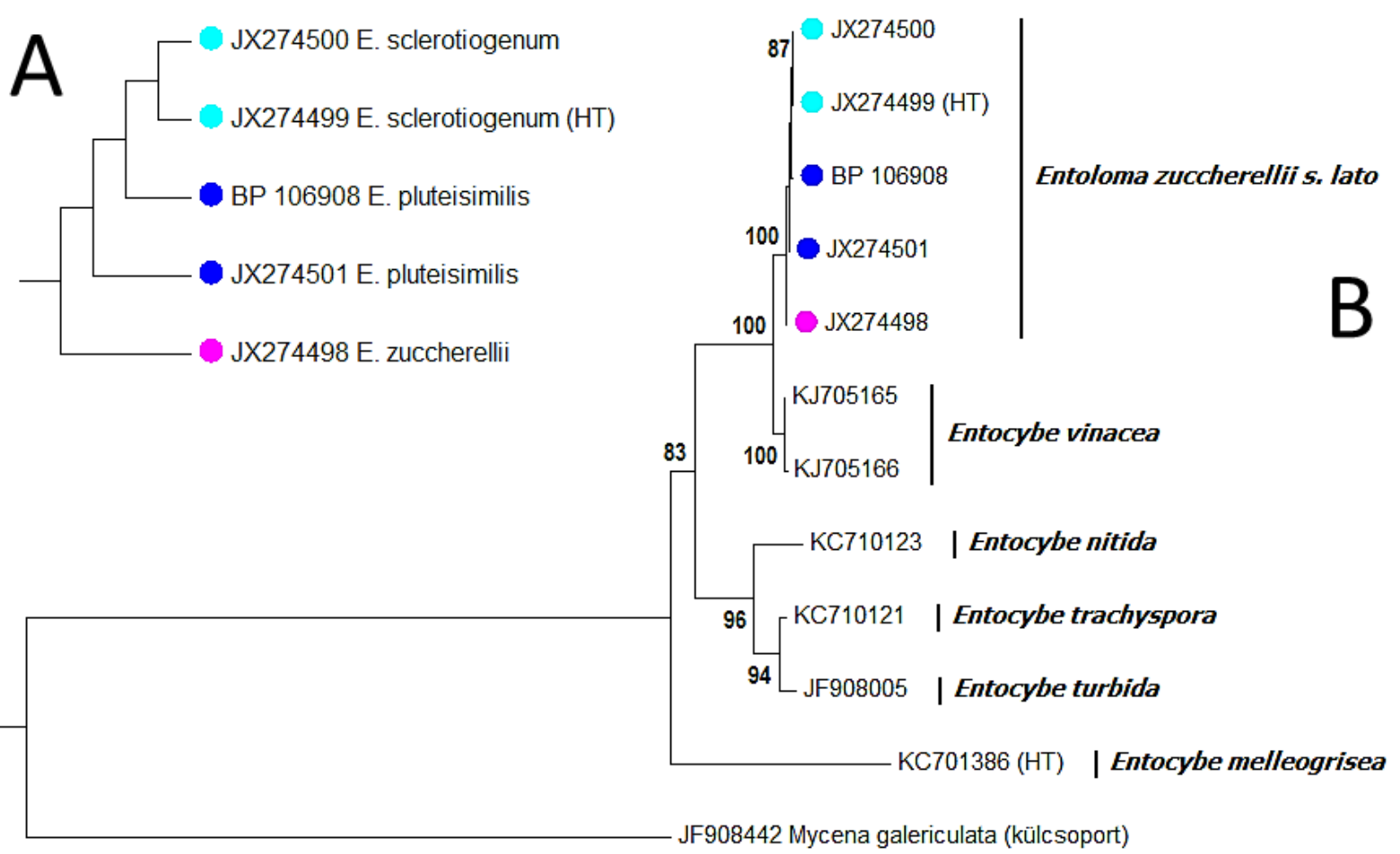

0.1

8. ábra. Az Entoloma zuccherellii var. pluteisimilis (BP 106908) és rokon fajainak filogenetikai fája ITS szekvenciák alapján. Az ágaknál szereplő számok a 70\%-nál magasabb ML bootstrap értékeket jelölik. A mérce 100 karakterre eső 10 szubsztitúciónak megfelelő ághosszat jelöl.A filogenetikai rekonstrukció Maximum Likelihood (ML) statisztikai becslés alapján a RAxML program segítségével GTRGAMMA szubsztitúciós modell valamint 1000 ismétléses „rapid bootstrap” elemzés alkalmazásával készült. 
A Juhdöglö-völgy Erdőrezervátum területén bükkfa rönkröl gyüjtött minta (BP 106908) makro- és mikroszkopikus bélyegek alapján az Entoloma pluteisimilis-el mutat hasonlóságot. A morfológiai bélyegek alapján E. pluteisimilis-nek határozott minta ITS génszakasza, a génbankba feltöltött adatokkal való összehasonlítása azt mutatta, hogy a CABALLERO és munkatársai (2012) által leírt E. sclerotiogenum holotípusától (JX274499) mindösszesen egy bázispárban különbözik (8. ábra). A Spanyolországból (Santa Maria de Martorelles), égerröl gyüjtött E. zuccherellii minta (JX274498), valamint az Olaszországból, jegenyefenyves bükkösből származó, E. pluteisimilis-ként azonosított minta (JX274501) ITS régiók összehasonlítása alapján szintén a fajhatáron belül csoportosultak.

Az Entoloma zuccherellii komplex taxonjai mellett több európán kívüli, de morfológiai bélyegek alapján hasonló fajt írtak le [pl. Clitopilus vernalis Har. Takah. \& Degawa; Entoloma lignicola Largent]. Az E. lignicola fajt LARGENT (1989) Kaliforniából, korhadó fenyőrönkről közölte. Holec és NOORDELOOS (2010) szerint morfológiai bélyegek alapján ez a faj is igen közel áll az E. zuccherellii-hez és a két taxon vélhetően ugyan abba a kládba tartozik. Az $E$. lignicola fajt BARONI és munkatársai (2011) viszont morfológiai és molekuláris vizsgálatok alapján az Entocybe génuszba sorolták: E. lignicola (Largent) Largent et al. Az Entoloma zuccherelli csoportba tartozó taxonok föként a termőtest színében mutatnak eltérést. Ez a morfológiai bélyeg viszont összefügghet az adott egyed élöhelyével, ezért faji szintű elkülönítést nem feltétlenül indokol.

Az észak-amerikai Entoloma vinaceum (Scop.) Arnolds \& Noordel. [三 Entocybe vinacea (Scop.) T.J. Baroni, V. Hofstetter \& Largent] fajnak szintén vannak olyan változatai [E. vinaceum var. fumosipes Arnolds \& Noordel., E. vinaceum var. violeipes Arnolds \& Noordel.], amelyek a lilás-kékes szín jelenlétében különböznek (ARNOLDS és NoORDELOOS 1979; HOLEC és NOORDELOOS 2010).

A morfológiai bélyegek tanulmányozása és filogenetikai vizsgálatok eredménye alapján arra a következtetésre jutottam, hogy az Entoloma pluteisimilis, E. sclerotiogenum és E. zucherrellii egy fajt alkotnak. Az egyes taxonok morfológiai bélyegekben tapasztalt különbségei alapján viszont indokoltnak látom változatok szintjén való elkülönítésüket, ezért az alábbi új kombinációkat közöltem (PAPP 2015a):

- Entoloma zuccherellii var. pluteisimilis (Noordel. \& C.E. Hermos.) V. Papp (Index Fungorum: IF551097) [三Entoloma pluteisimilis Noordel. \& C.E. Hermos.]

- Entoloma zuccherellii var. sclerotiogenum (Caball., Higelmo, Català \& Vila) V. Papp (Index Fungorum: IF551098) [三Entoloma sclerotiogenum F. Caball., Higelmo, Català \& Vila, Errotari] 


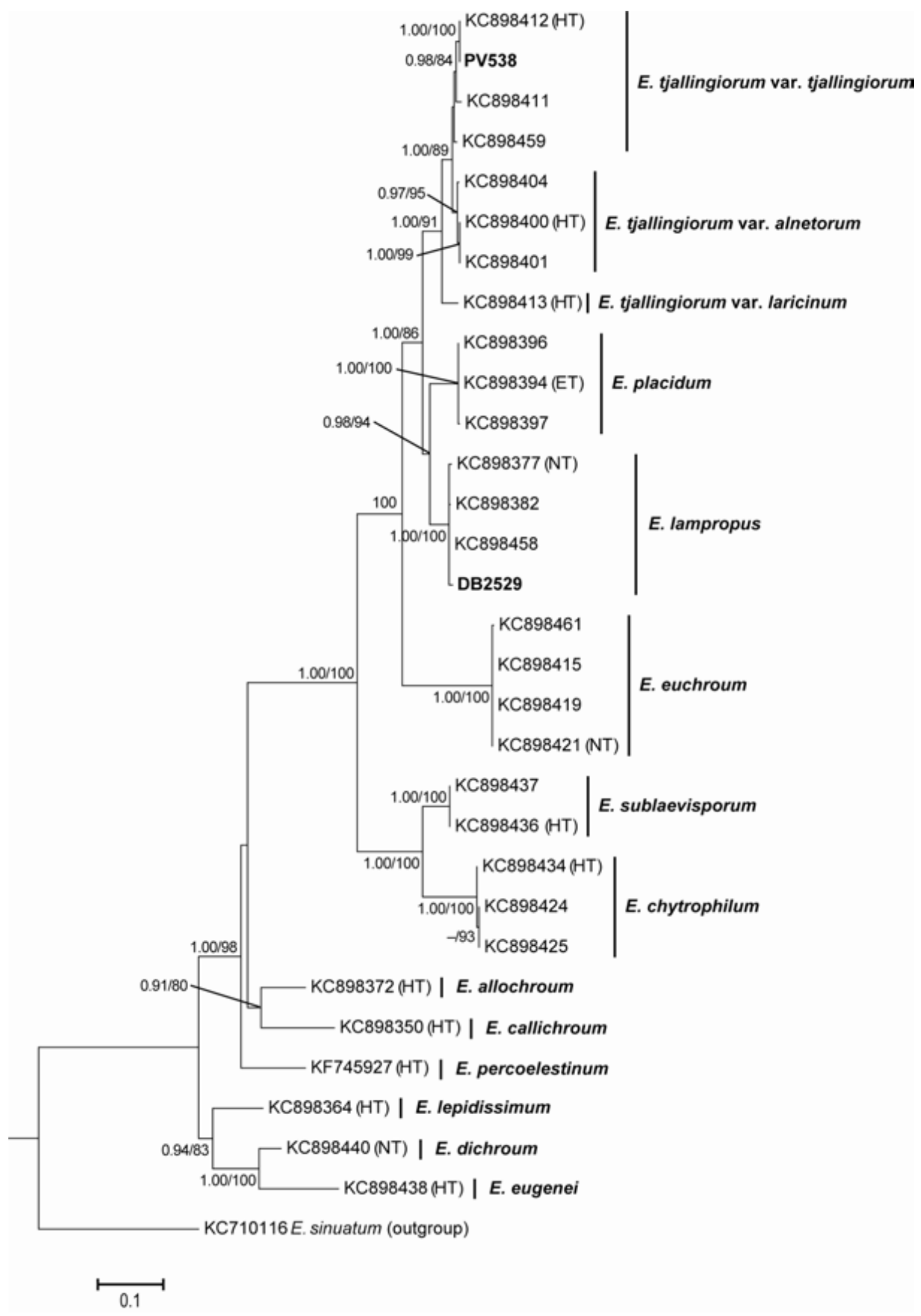

9. ábra. A Juhdöglö-völgy erdőrezervátumban gyüjtött Entoloma tjallingiorum (PV538) és rokon fajainak filogenetikai fája ITS szekvenciák alapján. A mérce 100 karakterre eső 10 szubsztitúciónak megfelelő ághosszat jelöl. A filogenetikai rekonstrukció Maximum Likelihood (ML) statisztikai becslés alapján a RAxML program segítségével GTRGAMMA szubsztitúciós modell, 1000 ismétléses „rapid bootstrap" elemzés alkalmazásával, valamint Bayes-alapú analízissel (MrBayes 3.1.2 program) készült. 
Az Entoloma tjallingiorum egy Európában széles körben elterjedt, ritka faj, amely lombhullató erdőkben, magányosan vagy kisebb csoportokban, tölgyek (Quercus spp.), vagy nyír (Betula spp.) faanyagán nő (NoORdELOOS 1992). MorozovA és munkatársai (2014) az Entoloma tjallingiorum s. lato minták molekuláris vizsgálata alapján a fajon belül két újabb változatot különítettek el: E. tjallingiorum var. alnetorum (Monthoux \& Röllin) O.V. Morozova, Noordel. et Vila [三E. alnetorum Monthoux \& Röllin] és E. tjallingiorum var. laricinum O.V. Morozova, Noordel., Vila et E.S. Popov.

A rezervátumban gyüjtött és morfológiai bélyegek alapján Entoloma tjallingiorum-nak határozott minta (PV538 /BP 106905) ITS szekvenciák alapján egyezést mutatott a MoROzOVA és munkatársai (2014) által vizsgált E. tjallingiorum var. tjallingiorum holotípusával (KC898412) (9. ábra). Ennek a gyüjtésnek az E. tjallingiorum s. str. fajjal való azonosságát mind a morfológiai, mind a molekuláris vizsgálatok igazolták.

A magyarországról korábban ismert Entoloma fajok jegyzékét SÁNTHA (2003) ismertette. A Leptonia csoportba tartozó Entoloma taxonok közül Magyarországról korábban az E. dichroum, E. lampropus, E. euchroum és E. placidum fajoknak volt ismert előfordulási adata (pl. BABOS 1989; Bohus és BABOS 1960, 1967; LUKÁCs 2007; PÁL-FÁM 1998, 2001; RIMÓCZI 1994; SILLER 1986; VASAS és LOCSMÁNDI 1995).

$\mathrm{Az}$ Leptonia csoport eltérő taxonómiai megítélése miatt, egyes újabban leírt fajok nómenklatúrai felülvizsgálata is szükséges lehet. Az Ausztráliából leírt L. ambigua Largent faj makroszkopikusan hasonló megjelenésü, mint az Entoloma tjallingiorum, de termőteste kisebb, kalapjának színe sötétszürkés-lilástól a feketés-kékig változhat, bazídiospórája szubdiametrikus és a cheilocisztidiumok és csatok hiányoznak a pileipellisből (LARGENT és mtsai. 2013). Amennyiben elfogadjuk, hogy a Leptonia, nemzetség szinten nem különül el az Entoloma génusztól, akkor ennek a fajnak ez utóbbi génuszba való kombinálása lenne szükséges. Ugyanakkor, nem zárható ki, hogy az Entoloma nemzetség mégis polifiletikus és a Leptonia csoportba tartozó taxonok valóban egy külön nemzetséget alkotnak.

Az Entolomataceae család Clitopilus nemzetségében egyes pleurotoid termőtestet képző fajok holt faanyagon vagy más lignikol gombák sporokarpiumán is megjelenhetnek [pl. $C$. daamsii Noordel., C. hobsonii, C. rhodophyllus (Bres.) Singer és C. vernalis Har. Takah. \& Degawa] (Takahasi és Degava 2011; NoOrdeloos 1984; PÉreZ-De-Gregorio és mtsai. 2009). Az erdőrezervátum területén gyüjtött PV1022-es számú, bükkfáról származó minta mikroszkopikus bélyegek alapján a C. hobsonii fajjal azonos. Ezt a fajt BABOSNÉ (1976) a ritka gombák között említi, ugyanakkor megjegyzi, hogy vélhetően a „könnyen félreismerhetö megjelenése miatt kerülte el gyakran a mikológusok figyelmét”. Ezt megerősíti NoORDELOOS (2012) véleménye, miszerint az északi mérsekelt övben nagyon gyakori faj. Relatív kevés hazai 
előfordulási adata (pl. BABOS 1989, DimA és mtsai. 2010), ezért vélhetően azzal magyarázható, hogy makroszkopikusan nagyon hasonló megjelenésűek egyes, csak mikroszkopikus bélyegek alapján határozható Crepidotus taxonok, valamint a Cheimonophyllum candidissimum (Berk. \& M.A. Curtis) Singer, illetve a Panellus mitis (Pers.) Singer fajok (DELIVORIAS és Gonou-ZAGOU 2008). A Clitopilus génusz mikroszkopikus vizsgálat alapján azonban jól elkülöníthető az előbbi taxonoktól, a hosszanti csíkokkal ornamentált elliptikus, vagy többé-kevésbé amigdaloid spórák alapján (NoORDELOOS 2012).

CO-DAVID és munkatársai (2009) RPB2, LSU és mtSSU lokuszok alapján vizsgálták az Entolomataceae családot és arra a következtetésre jutottak, hogy az Entoloma és a Clitopilus nemzetségek monofiletikus, mely utóbbi magába foglalja a korábban Rhodocybe Maire génuszba tartozó fajokat.

KLUTING és munkatársai (2014) a /Rhodocybe-Clitopilus kládba tartozó fajok három fehérje-kódoló génszakaszának (atp6, rpb2, tef1) vizsgálata alapján viszont megállapították, hogy a kládon belül öt monofiletikus csoport (nemzetség) fordul elő: Clitocella Kluting, T.J. Baroni \& Bergemann, Clitopilopsis Maire, Clitopilus, Rhodocybe és Rhodophana Kühner. KLUTING és munkatársai (2014) eredményeinek alapján szükségesnek láttam a Japánból, Pinus densiflora faanyagáról leírt Clitopilus vernalis Har. Takah. \& Degawa szisztematikai helyzetének revideálását. Ez a faj a típusláírásában közölt morfológiai bélyegek alapján (TAKAHASHI és DEGAWA 2011) nagy hasonlóságot mutat a „rhodociboid” termőtestet képző és jelen munkában is vizsgált Turfosa csoport fajaihoz, ezért indokoltnak látszott az Entoloma génuszba való átsorolása (PAPP 2015b):

- Entoloma vernalis (Har. Takah. \& Degawa) V. Papp \& Dima (Index Fungorum: IF551096) [三 Clitopilus vernalis Har. Takah. \& Degawa]

\section{Fistulinaceae Lotsy}

(1) Fistulina Bull. - F. hepatica (Schaeff.) With.

A család taxonjai közül mindösszesen egy nemzetség egyetlen faja ismert Európából: Fistulina hepatica (Schaeff.) With. (RYVARDEN és Melo 2014). A F. hepatica könnyen felsimerhető jellegzetes összetett ciphelloid sporokarpiumáról.

\section{Lyophyllaceae Jülich}

(1) Hypsizygus Singer - H. ulmarius (Bull.) Redhead (I)

(1) Ossicaulis Redhead \& Ginns - **O. lachnopus (Fr.) Contu (II) 
Taxonómiai és nómenklatúrai megjegyzések: (I) Egy recens filogenetikai vizsgálat alapján úgy tünik, hogy a Hypsizygus génusz polifiletikus és a vizsgált $H$. ulmarius minták a /hemilyophylloid kládba tartoznak, amely egy külön csoportot alkot a Lyophyllaceae s. str. családtól (HOFSTETTER és mtsai. 2014). (II) az Agaricus lachnopus Fr. Ossicaulis génuszba való kombinálását CONTU (1999) invalid módon közölte, így az O. lacnopus binomot csak egy későbbi munkájában érvényesítette (CONTU 2007).

Az Ossicaulis lachnopus közel áll a hazánkból ismert O. lignatilis (Pers.) Redhead \& Ginns fajhoz (BABOS 1989; FodOR és PÁL-FÁM 2003; LOCSMÁNDI 1993; LuKÁCS 2007, 2010; PÁLFÁM 2001; RimócZi 1994; Siller 1986, 1999; TAKÁCS és Siller 1980), de spóráinak mérete kisebb (CONTU 2007). Contu morfológaiai bélyegek alapján való megfigyelését HoLEC és KOLAŘíK (2012) európai O. lignatilis minták morfológiai és molekuláris vizsgálatok alapján is megerösítették, igazolva hogy a korábban egy fajnak tekintett $O$. lignatilis s. lato két külön fajt takar: O. lignatilis s. str. és O. lachnopus (10. ábra/A-C).

Az Ossicaulis lachnopus-nak Vértesi előfordulását Koszka Attila is említi szakdolgozatában (KoszKA 2014), melynek a saját gyüjtési adatommal való közös publikálása folyamatban van. Siller Irén is foglalkozott az $O$. lignatilis s. lato hazai fungáriumi mintákkal alátámasztott adatainak revideálásával, de a korábbi gyüjtésekből ezidáig nem sikerült az $O$. lachnopus magyarországi előfordulását igazolnia (Siller Irén szóbeli közlés).
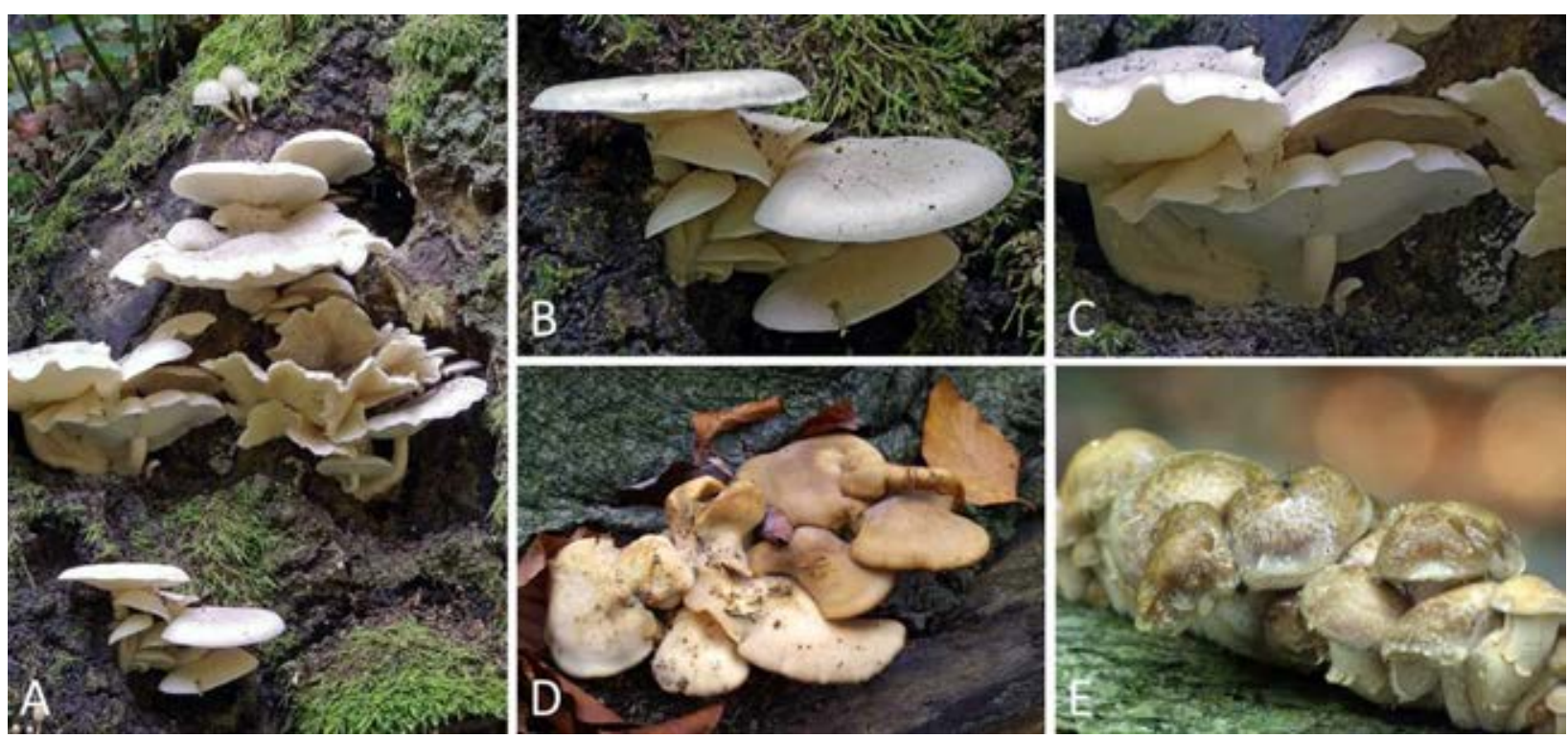

10. ábra. A Lyophyllaceae család Juhdöglö-völgy Erdőrezervátum területén dokumentált fajainak termőtestei (in situ). A-C) Ossicaulis lachnopus termőtestek elhalt, álló fa tövében. D-E) Hypsizygus ulmarius termőtestek bükkfarönkön. Fotók: Papp V.

A Hypsizygus nemzetségnek Európában mindösszesen egy faja fordul elö: H. ulmarius (HORAK 2005). Ezt a hazánkban védett gombát a rezervátumban két különböző, korai korhadási 
fázisban lévő bükkfarönkről mutattam ki (10. ábra/D-E). Ennek a polifág fajnak az előfordulását több alkalommal is megfigyeltem gazdasági erdőkben, valamint urbánus környezetben is. Korábbi hazai adatai SILLER és munkatársai (2006) munkájában kerültek bemutatásra.

\section{Marasmiaceae Roze ex Kühner}

(1) Hydropus Kühner ex Singer - H. subalpinus (Höhn.) Singer

(1) Marasmius Fr. - M. rotula (Scop.) Fr.

(1) Mycetinis Earle - M. alliaceus (Jacq.) Earle [三Marasmius alliaceus (Jacq.) Fr.]

A Hydropus subalpinus a bükkösök egyik karakterfaja (KRIEGLSTEINER 2001), amelyet korábban több hazai mikológus is a természetközeli erdők ritka indikátorfajaként említett (pl. BENEDEK és PÁL-FÁM 2012; LUKÁCs 2004; SILLER 1999). Terepi megfigyelések alapján viszont úgy tünik, hogy lényegesen gyakoribb faj, mint ahogyan azt korábban gondoltuk (Benedek Lajos szóbeli közlés).

A Mycetinis alliaceus hazánkban egy igen gyakori gomba (pl. BABOS 1989; SILLER 1986), amelynek jellemző tulajdonsága, hogy termőteste jellegzetes fokhagymaszagot áraszt (JANCSÓ 1990).

\section{Mycenaceae Overeem}

(8) Mycena (Pers.) Roussel - M. arcangeliana Bres., M. crocata (Schrad.) P. Kumm., M. galericulata (Scop.) Gray, M. galopus (Pers.) P. Kumm., M. haematopus (Pers.) P. Kumm., M. inclinata (Fr.) Quél., M. polygramma (Bull.) Gray és M. renati Quél.

(2) Hemimycena Singer (I) - H. cf. cuculata (Pers.) Singer, H. aff. tortuosa (P.D. Orton) Redhead

(1) Panellus P. Karst. - P. stipticus (Bull.) P. Karst.

Taxonómiai és nómenklatúrai megjegyzések: A Hemimycena nemzetség szisztematikai helyzete még nem kellően tisztázott (MIERSCH és ANTONíN 2013); MONCALVO és munkatársai (2012) a /hemimycena kládban tárgyalták, míg MATHENY és munkatársai (2006) szerint egy külön leszármazási vonalat alkot a /marasmioid kládon belül. A tradicionális szisztematikai kategóriák közül pedig a Mycenaceae családba tartozik (KIRK és mtsai. 2008).

A család típusnemzetsége [Mycena (Pers.) Roussel] egy igen fajgazdag kozmopolita génusz, amelynek taxonjai szaprotrófok és számos fajuk fordul elő faanyagon (RoBICH 2003). A rezervátumból eddig nyolc Mycena faj előfordulását igazoltam, amelyek többsége hazánkban gyakorinak vagy nem ritkának tekinthető: M. crocata, M. galericulata, M. galopus, M. 
haematopus, M. inclinata, M. polygramma, M. renati (pl. BABOS 1989; RIMÓCZI 1994; RUdOLF és mtsai. 2008; SILLER és mtsai. 2013).

A Mycena arcangeliana a nemzetség Filipedes szekciójába tartozik (MAAS GEESTERANUS 1984; RoBICH 2003), amelyen belül jellemző bélyegei, hogy a kalapja fehéres-szürkés színü, sárgás vagy olívos árnyalattal, valamint a pileipellisz hifái 3-8 $\mu \mathrm{m}$ szélesek (ROBICH 2009). SILLER (2005) az Öserdő és Kékes erdőrezervátumokban végzett vizsgálatai során a frekvens fajok között említi és a termőtestek alapján a legnagyobb gyakoriságát az erősen korhadt (4-es korhadási fázis) bükkfarönkökön tapasztalta. RUDOLF és munkatársai (2008) a Cserehátban mindössze egy alkalommal, de szintén bükkösben gyüjtötték. KoszKA $(2011,2014)$ a Vértesböl nem mutatta ki, de LUKÁCS (2010) Csákányospusztáról gyertyános-tölgyesből jelzi előfordulását. SILLER és munkatársai (2013) az Örségből a bükk mellett erdei fenyő faanyagáról is említik.

A Juhdöglö-völgy Erdőrezervátumhoz hasonló élőhelyeken előforduló lignikol Mycena fajok [pl. M. romagnesiana Maas Geest.; M. meliigena (Berk. \& Cooke) Sacc.] adatai alapján (pl. ADAMČÍK és mtsai. 2007; KOMOROWSKA 2010) feltételezhető, hogy a további vizsgálatok során újabb taxonok is elökerülhetnek a Juhdöglö-völgy Erdőrezervátum területéröl.

A Hemimycena nemzetség jellemző bélyegei az apró méretü, többnyire fehér színü agarikoid termőtest, valamint az inamiloid, vékonyfalú spórák és a változatos kalapbőrszerkezet (Antonín és NoOrdeloos 2004; MALysheva és Morozova 2009). A faanyagon növő Hemimycena fajok közül néhány taxon előfordulását dokumentáltam, azonban ezek faji szintü azonosítása még további vizsgálatokat igényel.

A Panellus stipticus egy igen gyakori, jellegzetes morfológiai bélyegei alapján jól határozható faj (VESTERHOLT 2012a), amelynek termőtesteit a rezervátum területén tölgy faanyagán számos alkalommal dokumentáltam.

\section{Niaceae Jülich}

(2) Dendrothele Höhn. \& Litsch. (I) [= Aleurocorticium P.A. Lemke] - *D. acerina (Pers.) P.A. Lemke; **D. commixta (Höhn. \& Litsch.) J. Erikss. \& Ryvarden

Taxonómiai és nómenklatúrai megjegyzések: (I) A korábban morfológiai bélyegek alapján körülhatárolt korticioid Dendrothele nemzetség GORANOVA és munkatársai (2003) filogenetikai vizsgálata alapján erősen polifiletikus; munkájukban arra az eredményre jutottak, hogy a korábban egy nemzetségbe sorolt fajok több leszármazási vonalon, négy különböző rendben találhatóak. A Dendrothele nemzetség típusfaja a D. papillosa Höhn. \& Litsch., amely RoGERS (1935), valamint LEMKE (1964) szerint is megegyezik a korábban leírt Corticium griseocanum Bres. fajjal [三Dendrothele griseocana (Bres.) Bourdot \& Galzin]. NAKASONE (2006) a két taxon típusvizsgálata alapján megerősítette a két faj azonosságát. BODENSTEINER és munkatársai (2004) vizsgálata alapján a Dendrothele génusz típusfaja [D. griseocana (Bres.) Bourdot \& Galzin], valamint a D. acerina is a /Nia kládba tartozik [Niaceae]. 
A Dendrothele acerina fajnak Magyarországról csak kevés adata ismert (pl. DimA és mtsai. 2010; MoEsz 1942), de a nemzetközi szakirodalmak (pl. BERNICCHIA és GORJÓN 2010) és saját megfigyeléseim alapján nagyon gyakori faj, amely főként mezei juhar, ritkábban más lombos fa (pl. Salix spp.) kérgén képez jellegzetes, foltokban megjelenő, fehéres színü, reszupinátus termőtestet.

A jellemzően tölgyeken előforduló vagy potenciálisan megjelenő európai Dendrothele fajok [D. alliacea (Quél.) P.A. Lemke, D. commixta, D. dryina (Pers.) P.A. Lemke] makroszkopikusan nem megkülönböztethetők. A D. commixta jellemző mikromorfológiai bélyegei, hogy a bazídiumokon általában kettő, ritkábban három szterigma képződik, nem képez cisztidiumokat, valamint spórái elliptikusak (ERIKSSON és RYVARDEN 1975). A Franciaországból leírt D. minima Duhem nagyon közel áll a D. commixta-hoz, de ennek a polifág fajnak a spórái kisebbek, valamint a termőtestek átmérője jellemzően kevesebb mint 5 mm (DUHEM és MiCHEL 2007).

\section{Nidulariaceae Dumort. (I)}

(1) Cyathus Haller - C. striatus (Huds.) Willd.

Taxonómiai és nómenklatúrai megjegyzések: (I) a Cyathus génusz rendszertani besorolása a szakirodalomban ellentmondásos; egyes munkákban az Agaricaceae (pl. DAS és mtsai. 2014; JEPPSON 2012b; Kirk és mtsai. 2008), míg másokban a Nidulariaceae család szerepel (pl. BARBOSA és mtsai. 2014; CRUZ és mtsai. 2014; POINAR 2014; ZHOU és mtsai. 2004). Recens filogenetikai vizsgálat hiányában, MATHENY és munkatársainak (2006) munkája alapján, jelen dolgozatban elfogadom a Nidulariaceae család Agaricaceae-töl való elkülönítését.

A három Európából ismert Cyathus faj közül a C. striatus könnyen meghatározható makroszkopikus bélyegek alapján is, tekintve, hogy a C. olla (Batsch) Pers. és C. stercoreus (Schwein.) De Toni fajok perídiumának belseje nem barázdált. Ez utóbbi fajt KoszKA (2014) Csákvár közelében a Sarok legelőn, lótrágyáról jelzi.

\section{Omphalotaceae Bresinsky (I)}

(1) Gymnopus (Pers.) Roussel (II) - G. brassicolens (Romagn.) Antonín \& Noordel. [” Micromphale brassicolens (Romagn.) P.D. Orton]

Taxonómiai és nómenklatúrai megjegyzések: (I) korábban KÄMMERER és munkatársai (1985) az Omphalotaceae családot kemotaxonómiai bélyegek (pl. jellegzetes pigmentek és cianofil spórák) alapján a Boletales rendben tárgyalták. Filogenetikai vizsgálat alapján viszont a /Marasmioid kládba, tehát az Agaricales rendbe tartozik (MATHENY és mtsai. 2006). (II) A Marasmius és Collybia s. lato nemzetség szintủ revíziója során ANTONíN és munaktársai (1997) a korábban Mycromphale-ként tárgyalt fajokat a Gymnopus génuszba sorolták. A nemzetséget egyes taxonómusok a Marasmiaceae családban, míg mások az Omphalotaceae-ben tárgyalják (JANČOVIČOVÁ és mtsai. 2014b). 
A Gymnopus brassicolens egy hazánkban igen gyakori, jellegzetes makromorfológiai bélyegekkel és szaggal rendelkező faj, amelynek jelenlétét számos alkalommal megfigyeltem bükkfarönkökön.

\section{Physalacriaceae Corner}

(2) Armillaria (Fr.) Staude (I) - A. cf. lutea Gillet [= A. bulbosa (Barla) Kile \& Watling; = A. gallica Marxm. \& Romagn.], A. mellea (Vahl) P. Kumm.

(1) Cylindrobasidium Jülich $-{ }^{*}$ C. laeve (Pers.) Chamuris [= C. evolvens (Fr.) Jülich] (II)

(1) Flammulina P. Karst. - F velutipes (Curtis) Singer

(1) Hymenopellis R.H. Petersen (III) - H. radicata (Relhan) R.H. Petersen [三 Xerula radicata (Relhan) Dörfelt]

(1) Mucidula Pat. (III) - M. mucida (Schrad.) Pat. [三 Oudemansiella mucida (Schrad.) Höhn.]

Taxonómiai és nómenklatúrai megjegyzések: (I) Az Armillaria nemzetségbe tartozó európai fajok közül több taxon nómenklatúrai helyzete sem kellően tisztázott (KOLTAY és SzÁNTÓ 1988), ebből kifolyólag a hazai szakirodalomban is számos szinonim név alatt való közlés található. Az A. mellea név több munkában csak, mint sensu lato értelmezhetö, tekintve, hogy ezt a nevet korábban több fajra is alkalmazták. A gallér nélküli Armillaria fajok [subgen. Desarmillaria] közül ANTONín és munkatársai (2006) véleménye szerint a Fries által szankcionált A socialis (DC.: Fr.) Fayod név előnyt élvez a korábban közölt $A$. tabescens (Scop.) Emel binommal szemben. REDHEAD és munkatársai (2012) viszont tekintettel arra, hogy az $A$. tabescens egy széles körben használt név, javasolták a konzerválását az $A$. socialis-al szemben. Az A. lutea fajnak több szinonimja is megtalálható a hazai szakirodalomban $[=A$. bulbosa, $=$ A. gallica , de a versengö bazionimok közül a legkorábban közölt binom, ezért prioritást élvez. A hazánkból is ismert és többnyire fenyőféléken megjelenő A. ostoyae (Romagn.) Herink BURDSALL és VOLK (2008) szerint azonos a korábban leírt $A$. solidipes Peck fajjal, amellyel szemben prioritást élvez. Tekintettel arra, hogy az $A$. ostoyae nevet széles körben használják célszerünek látszik a binom konzerválása a korábbi, de kevésbé ismert binomokkal szemben (HUNT és mtsai. 2011; REDHEAD és mtsai. 2011). (II) Tekintettel arra, hogy a Corticium laeve Pers. és a Thelephora evolvens Fr. is FRIES (1821) munkája által szankcionált bazionim, a korábban közölt névnek [Corticium laeve] van prioritása (ChAmuris 1984). (III) Petersen és Hughes (2010) monográfiájukban a Xerula/Oudemansiella komplexet revideálták morfológiai bélyegek, valamint filogenetikai vizsgálatok alapján. Munkájukban négy új nemzetséget írtak le, köztük a Hymenopellis génuszt, valamint visszaállították a Mucidula nemzetséget, amelyet korábban az Oudemansiella Speg. szinonímjának tekintettek.

A lombos fákon megjelenő Armillaria fajok közül hazánkban igen gyakoriak a rezervátumból is kimutatott $A$. mellea és A. lutea fajok. SzÁNTÓ (1994) a magyarországi Armillaria minták törzstenyészetének vizsgálata alapján azt tapasztalta, hogy a 70 izolátumból 26 az A. lutea fajjal mutatott azonosságot, amely lapján az A. mellea után a második leggyakoribb faj volt. Ugyanakkor a jelenleg is az Armillaria s. str. génuszban tárgyalt fajok közül BABOS (1989) a Növénytár nagygombagyüjteményéböl csak az A. mellea és A. tabescens (Scop.) Emel fajokat közli. Az A. lutea hazai adatait tekintve a Növénytárban jeleleg is mindösszesen három Magyarországról származó és $A$. bulbosa név alatt szereplő minta (BP 
90619; BP 94992; BP 98342) található; viszont elöfordulási adatai több hazai fungisztikai munkában is szerepelnek (pl. DiMA és mtsai. 2010; KosZKA 2011; PAPP 2009; SILlER 2004, SILLER és mtsai. 2013). Az A. lutea viszont morfológiai bélyegek alapján könnyen összetéveszthető az A. cepistipes Velen. fajjal (INTINI 1997), amelynek a hazai szakirodalomban nem találtam hazai előfordulását bizonyító adatot. Tekintettel arra, hogy az Armillaria lutea és $A$. cepistipes fajok biztos elkülönítése korábban többnyire csak molekuláris módszerek alapján volt lehetséges, ANTONÍN és munkatársai (2009) morfológiai és molekuláris vizsgálatok alapján keresték a fajspecifikus bélyegeket és ökológiai különbségeket az A. cepistipes - A. lutea komplexen belül (7. táblázat). A makroszkopikus bélyegek alapján a Juhdöglö-völgyben gyüjtött minták vélhetően az $A$. lutea fajjal azonossak. Viszont a hazai $A$. bulbosa-nak és $A$. lutea-nak határozott fungáriumi anyagok revideálása indokolt lehet.

7. táblázat. Az Armillaria cepistipes és A. lutea jellemző morfológiai bélyegeinek és ökológiájának összehasonlítása (I) ANTONíN és munkatársai (2009), valamint (II) VESTERHOLT (2012b) nyomán.

\begin{tabular}{|c|c|c|}
\hline & Armillaria cepistipes & Armillaria lutea \\
\hline Élőhely & $\begin{array}{c}\text { alacsonyabban fekvő, alföldi föként xeroterm } \\
\text { tölgyesek vagy ártéri erdők; Quercus, } \\
\text { Carpinus, ritkábban más lombos fafajok (I), } \\
\text { fenyőféléken is (II) }\end{array}$ & $\begin{array}{l}\text { föként közép-európai hegyvidéki } \\
\text { bükkösök; Fagus, Picea, ritkábban Abies, } \\
\text { Fraxinus (I), vagy talajon (II) }\end{array}$ \\
\hline Kalap & $\begin{array}{c}\text { közepén rostos, gyapjas-bolyhos, gyakran } \\
\text { felfele álló csoportokban; a kalap középső } \\
\text { részét kivéve viszont hamar lekopik és sima } \\
\text { lesz (I) }\end{array}$ & $\begin{array}{l}\text { hosszú rostok, a centrumban majdnem } \\
\text { piramis alakúak, idővel a szélek irányában } \\
\text { sima lesz, de a közepén } \pm \text { pikkelyes (I) }\end{array}$ \\
\hline Gallér & többnyire szabálytalanul felszakadozó & csillagszerüen szakadozik fel \\
\hline Tönk & $\begin{array}{l}\text { a tönkbázis jól láthatóan bunkós ( } \pm \text { jobban, } \\
\text { mint az A. lutea faj esetében); vélum } \\
\text { maradványai ritkássak (I), nem sárga színűek, } \\
\text { de tövénél lehetnek sárgás rostok (II) }\end{array}$ & $\begin{array}{c}\text { általában a tönkbázis bunkós; a } \\
\text { vélummaradványok jól láthatóak, rostosak } \\
\text { vagy gyapjas-bolyhosak (I), jellegzetesen } \\
\text { sárga színüek (II) }\end{array}$ \\
\hline Spórák & $\begin{array}{l}\text { 7,0-9,0(-10) × 4,5-6,5(-7,0) } \mu \mathrm{m} \text {, átl.: 8,3 } \times \\
5,3 \mu \mathrm{m} \text {; többnyire szélesen elliptikus vagy } \\
\text { gömbölyded (I); } 7-9 \times 5-6 \mu \mathrm{m} \text {, elliptikus (II) }\end{array}$ & 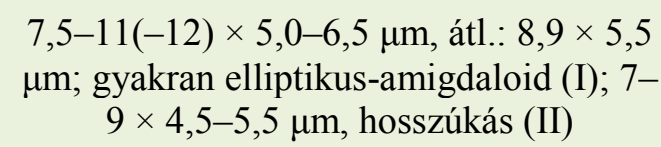 \\
\hline
\end{tabular}

A rezervátumban gyüjtött és szintén a Physalacriaceae családba tartozó fajok közül a Flammulina velutipes valamint a Hymenopellis radicata egyaránt igen gyakori fajok a hazai lomberdőkben. A Mucidula mucida viszont gyakran öreg, háborítatlan erdőkben fordul elö. A rezervátum területén egyes őszi időszakokban iniciális korhadási fázisban lévő bükkfarönkökön, valamint álló holt fákon prezenciája tömeges volt.

A Cylindrobasdium laeve a családra jellemző agarikoid termőtest helyett jellemzően reszupinátus vagy kissé kalaposodó fehéres vagy krémszínű sporokarpiumot fejleszt 
(BERNICCHIA és GORJÓN 2010); ugyanakkor ismert egy ritka csésze alakú változata is [C. evolvens var. cucullatum (Bourdot \& Galzin) Hjortstam \& Ryvarden; Cladoderris minima Berk. \& Broome] (HJortstam és Ryvarden 1984; MATtOck 2014; Reid 1962). Jellemző mikroszkopikus bélyegei a monomitikus hifarendszer, csatos generatív hifákkal, a leptocisztidiumok jelenléte, valamint az elliptikus vagy kissé körtealakú, hialin vékonyfalú bazídiospórák. Ennek az Európa szerte gyakori fajnak a kevés hazai adata (pl. SILLER 2004; SILLER és mtsai. 2013) vélhetően a korticioid fajok határozási nehézségeivel magyarázható.

\section{Pleurotaceae Kühner (I)}

(3) Hohenbuehelia Schulzer $-\boldsymbol{H}$. aff. atrocoerulea (Fr.) Singer, **H. auriscalpium (Maire) Singer (II), ${ }^{*} \boldsymbol{H}$. mastrucata (Fr.) Singer (III)

(2) Pleurotus (Fr.) P. Kumm. - P. ostreatus (Jacq.) P. Kumm., P. pulmonarius (Fr.) Quél.

Taxonómiai és nómenklatúrai megjegyzések: (I) THORN és munkatársai (2000) nukleáris 25S rDNS alapján végzett filogenetikai vizsgálata alapján a Pleurotaceae család, valamint a Pleurotus és Hohenbuehelia nemzetségek monofiletikusak. a család mindkét nemezetségére [Hohenbuehelia, Pleurotus] jellemző, hogy nematódákat fogyasztanak (BARRON és THORN 1987; HIBBETT és THORN 1994), amely alapján a Hohenbuehelia génusz anamorf alakjait korábban a Nematoctonus Drechsler, míg a Pleurotus nemzetségét az Antromycopsis Pat. \& Trab. génuszba sorolták (DRECHSLER 1941; KOZIAC és mtsai. 2007; PATOUILLARD 1897; STALPERS és mtsai. 1991; THORN és BARRON 1986). Ezek a nevek az amszterdami deklarátum alapján szinonimnak tekintendők (HAWKSWORTH 2011; THORN 2013). (II) ELBORNE (2012a) utal rá, hogy korábban a $H$. auriscalpium-ra szintén használták a $H$. petalodes nevet [H. petalodes (Bull.: Fr.) Schulzer s. auct.]. (III) KRIEGLSTEINER (2000) a korábban faji rangon tárgyalt Hohenbuehelia mastrucata-t (pl. SINGER 1951) a H. atrocoerulea változatának tekintette, de jelenleg általánosan elfogadott a faji szintủ elkülönítése (pl. KNUDSEN és VESTERHOLT 2012).

A Pleurotus nemzetségbe tartozó fajok, egyes taxonoktól eltekintve [pl. Pleurotus eryngii (DC.) Quél. koplex] lignikolok, míg a Hohenbuehelia génuszban nem ritka a terrikol életmód [pl. H. cumicola Bon; H. ilerdensis Courtec., Vila \& Rocabruna, H. longipes (Boud.) M.M. Moser; H. petalodes, H. tremula (Schaeff.) Thorn \& G.L. Barron] (CourTECuISSE és mtsai. 1999; THORN és BARRON 1986). A Hohenbuehelia nemzetség makroszkopikusan a kalapbőr és a hús között található zselatin-szerü réteg, mikroszkopikusan pedig a jellegzetes metuloidok alapján egy könnyen felismerhető génusz. KALMÁR (1966) negyed évszázad alatt összegyüjtött hazai kalaposgomba fajok előfordulásait összegző munkájában számos magyarországi adatát említi a $H$. petalodes-nek, amely binom véleménye szerint több fajt takar. Ennek ellenére BABOS (1989) munkájában mindösszesen egy mátészalkai lelőhelye szerepel, viszont a ma már szinonimnak tekintett $H$. geogenia fajnak 13 lelöhelyét, közte a Vértest is közli. A $H$. petalodesel könnyen összetéveszthető $H$. auriscalpium európai természetközeli bükkösök jellemző lignikol gombája (AINSWORTH 2005; CHRISTENSEN és mtsai. 2004). A nagyobb termetü 
termőtestet képző $H$. petalodes (Bull.) Schulzer [= H. geogenia (DC.) Singer] talajon, fürészporon vagy faforgácson terem; mikroszkopikus bélyegek közül pedig elsősorban a pileometuloidok jelenlétében különbözik (CANDUSSO 2002). Morfológiai bélyegek alapján hasonló megjelenésủ még a $H$. abietina Singer \& Kuthan, amely fenyőféléken, különösen lucon terem (ELBORNE 2012a).

A Hohenbuehelia mastrucata hazai előfordulására „Pleurotus mastrucatus” néven már találunk utalást Hollós László Szekszárd környéki gyüjtéseiben (BABOS 1984). BABOS (1989) viszont átfogó munkájában mindösszesen egy fungáriumi anyaggal alátámasztott lelőhelyét említi a Szentendrei-szigetről, Populus tuskóról. Újabb előfordulási adatát $H$. atrocoerulea var. mastrucata (Fr.) Krieglst. néven NAGY és GoRLICZAI (2007) említik a Tőserdőből, valamint ugyan ebben a munkában első magyarországi adatát közölték a $H$. angustata fajnak. A $H$. atrocoerulea hazai adatai alapján (pl. BABOS 1989; DiMA és mtsai. 2010; FoDOR és mtsai. 2001; FodOR és PÁL-FÁM 2003; LuKÁCS 2010; NAGY 2004; RiMÓCZI 1994; SiLleR 1986; VASAS és LOCSMÁNDI 2009) lényegesen gyakoribb fajnak tünik, mint a $H$. mastrucata. Viszont ez utóbbi, valamint a hazánkból csak 2010-ben kimutatott H. grisea (Peck) Singer (DIMA és mtsai. 2010) fajokkal való összetéveszthetősége miatt indokolt lehet a korábbi adatainak felülvizsgálata.

A Juhdöglö-völgy Erdőrezervátumban gyüjtött Hohenbuehelia taxonok közül három mintának (PV408, PV712, PV774) készült el az ITS szekvenciája. A GenBank adatbázisban szereplő szekvenciákkal való összevetés azonban ellentmondásos eredményt adott, amely vélhetően téves határozáson alapuló feltöltésekkel magyarázható. Ez különösen igaz a morfológiai bélyegek alapján is nehezen elkülöníthető $H$. petalodes csoport taxonjaira. A rezervátumban gyüjtött PV408-as számú Hohenbuehelia ITS szekvencia alapján azonosságot mutat a Kínából származó H. angustata (GQ142027) és H. petalodes (GQ142023) mintákkal. Az Európából származó észtországi (TU102958, TU106086) és svéd (EF409429) H. petalodes-nek határozott minták viszont némi eltérést mutatnak. A PV712-es minta ITS szekvenciája azonos a Kanadából származó $H$. mastrucata-val, ezzel megerősítve a morfológiai bélyegek alapján való határozást. A PV774-es mintát makro- és mikromorfológiai bélyegek alapján $H$. atrocoeruleanak határoztam, de a GenBank-ban szereplö szekvenciák közül a H. reniformis (GQ142024), valamint egy másik meghatározatlan Hohenbuehelia-val (GQ219732) mutat azonosságot. Elborne (2012a) a H. unguicularis (Fr.) O.K. Mill. ismertetésénél megjegyzi, hogy a $H$. reniformis (G. Mey.: Fr.) Singer nevet több különböző Hohenbuehelia fajra is használták, továbbá az Agaricus reniformis G. Mey. eredeti leírása alapján ez a taxon nem tartozik a Hohenbuehelia nemzetségbe. A H. unguicularis morfológiai bélyegeit THORN (1986) munkájában részletesen ismerteti, valamint megjegyzi, hogy a FRIES (1828) által megadott eredeti leírás vélhetően egy nomen confusum. A kanadából gyüjtött és R. G. Thorn által $H$. 
unguicularis-nak határozott minta (EF409721) ITS régió alapján viszont jelentősen eltér a rezervátumban gyüjtött mintától. Összességében a GenBank adatbázisban igen kevés Hohenbuehelia szekvencia érhető el és ez különösen igaz az európai mintákra. Ezért véleményem szerint a nemzetség fajainak molekuláris taxonómiai vizsgálatához a nómenklatúrai kérdések és típuskijelölések mellett további mintákat kellene bevonni.

A rezervátumban a Pleurotus nemzetség hazánkban két gyakori fajának $[P$. ostreatus és $P$. pulmonarius] az előfordulását tapasztalatam bükk és tölgy faanyagán. A P. ostreatus termőtesteit nagyméretü, már a törzs egyes részén korhadó, de még élő bükkfán is megfigyeltem. A szakirodalom alapján még két további lignikol Pleurotus faj is megtalálható a Vértesben. BABOS (1989) a $P$. dryinus-t fungáriumi anyagát jelzi a hegységből, míg KoszKA (2011) Mór közeléből bükkfatörzsről kimutatta a P. cornucopiae (Paulet) Rolland fajt.

Pluteaceae Kotl. \& Pouzar

(15) Pluteus Fr. (I) - P c cervinus (Schaeff.) P. Kumm., **P. cervinus var. albus Peck $[=P$. atricapillus var. albus Vellinga], P. chrysophaeus (Schaeff.) Quél. [= P. luteovirens Rea], **P. diettrichii Bres., P. cf. hiatulus Romagn. [= P. plautus (Weinm.) Gillet], P. hispidulus (Fr.) Gillet, P. leoninus (Schaeff.) P. Kumm., P. cf. luctuosus Boud., *P. petasatus (Fr.) Gillet $[=P$. patricius (Schulzer) Boud.], *P. phlebophorus (Ditmar) P. Kumm., P. cf. pseudoroberti M.M. Moser, *P. romellii (Britzelm.) Lapl., P. salicinus (Pers.) P. Kumm., *P. semibulbosus (Lasch) Gillet, P. thomsonii (Berk. \& Broome) Dennis, P. umbrosus (Pers.) P. Kumm.

Taxonómiai és nómenklatúrai megjegyzések: JUSTO és munkatársai (2011b) a család taxonjait nSSU, ITS és nLSU riboszomális lokuszok alapján vizsgálták; eredményeik alapján arra a következtetésre jutottak, hogy a Volvariella génusz polifiletikus, míg a Pluteus nemzetség monofiletikus.

A rezervátumban ezidáig gyüjtött és meghatározott taxonok közül a Pluteus bizonyult a legfajgazdagabb nemzetségnek. A területről kimutatott 16 Pluteus taxon (15 faj, 1 változat) közül a leggyakoribb a génusz Pluteus szekciójába [Pluteus sect. Pluteus] tartozó P. cervinus volt (11. ábra/A). Ennek a fajnak a termőteste igen változatos megjelenésü, de már a terepen való felismerését segíti barnás színű kalapja mellett jellegzetes retekszaga. Mikroszkopikus bélyegeit tekintve könnyen azonosítható a cervinus-típusú pleurocisztitidiumok (BONNARD 1988), valamint a pileipellisz hifáinak csat nélküli szeptáltsága alapján. A P. cervinus-nak ismert olyan változata is, amely mikroszkopikus bélyegeiben megegyezik az alapfajjal, de termőteste fehér színü: P. cervinus var. albus (VelLingA és SCHREURS 1984). A nemzetség Pluteus szekciójának fehér termőtestet képző fajai közül hasonló az Észak-Amerikából leírt és sérülésre elszürkülő P. cinerascens P. Banerjee \& Sundb. (BANERJEe és SundBERG 1993; Justo és CASTRO 2007). A Pluteus szekció holarktiszban előforduló taxonjainak monografikus 
feldolgozása során JUSTO és munkatársai (2014) morfológiai bélyegek és tef1 szekvenciák filogenetikai elemzése alapján megállapították, hogy a /cervinus klád hat fajt tartalmaz, amelyek közül kettőt tudományra újként írtak le: $P$. rangifer Justo, E.F. Malysheva \& Bulyonkova és $P$. elaphinus Justo. Az eddigi adatok alapján úgy tünik, hogy a $P$. rangifer egy föként boreális elterjedésü faj, amely a $P$. cervinus-al való parapatrikus kialakulásra utal; a $P$. elaphinus pedig egy észak-amerikai faj (JUSTO és mtsai. 2014). A rezervátumból kimutatott és szintén a génusz Pluteus szekciójába tartozó és hazánkban nem ritka $P$. petasatus, valamint $P$. salicinus jellemző bélyegei a fehéres, szürkés kalap. Ezeknek a fajoknak a hazai gyakoriságával kapcsolatban BABOSNÉ (1974) már negyven évvel ezelőtti munkájában megjegyzi, hogy a „nemzetség Pluteus szekciójának fajai - melyek közepes vagy nagy termetü gombák - hazánkban eléggé ismertek”. A lényegesen kisebb méretü termőtestet képző $P$. pseudoroberti viszont az eddigi adatai alapján a szekció ritkább fajai közé tartozik (BABOSNÉ 1974, BABOS 1989).

A nemzetség Celluloderma szekciójába tartozó taxonokra jellemző, hogy nincsenenek metuloid pleurocisztidiumaik, valamint a pileipelliszben egyaránt megtalálhatók rövid bunkó alakú sejtek valamint megnyúlt cisztidioid elemek (JUSTO és mtsai. 2011a). A rezervátumból dokumentált fajok közül ebbe a szekcióba tartozik a $P$. chrysophaeus, P. phlebophorus, P. romellii és $P$. thomsonii (JUSTO és mtsai. 2011b). KosZKA $(2011,2014)$ több mint egy évtizedes vértesi kutatómunkája során sem dokumentálta a $P$. thomsonii fajt, amelynek a hegységben (Szárliget) való előfordulására BABOS (1989) munkájában találunk utalást. Ritkaságát tekintve megjegyzendő, hogy számos hazai adatához (pl. ALBERT 1984; BABOS 1989; DiMA és mtsai 2010; LoCSMÁNDI 1993; NAGY 2004; NAGY és GorliCZAi 2007; PÁL-FÁM és mtsai. 2009; RIMÓCZI 1994; SILLER 2004) hozzájárulhat, hogy a jellegzetes ráncos-eres kalapböre (11. ábra/F) alapján a makroszkopikusan is könnyen felismerhető Pluteus fajok közé tartozik. A rezervátumban a vizsgált időszakban nem volt gyakori faj, mindösszesen néhány alkalommal sikerült megfigyelni a termőtesteit.

A Pluteus diettrichii JUSTO és munkatársai (2010) filogenetikai vizsgálata alapján a Celluloderma szekció kládjainak egy testvérfaja, amely egy külön ágon helyezkedik el. A szakirodalom alapján gyakran humuszban gazdag talajon, vagy fatörmeléken, illetve ritkábban faanyagon növő $P$. diettrichii-t (JUSTO és CASTRO 2007) a rezervátumban végső korhadási fázisban lévő (5-ös) faanyagról gyüjtöttem. Az átnézett hazai szakirodalomban ennek a fajnak nem találtam publikált magyarországi adatát. A P. diettrichii jellemző morfológiai bélyegei, hogy idősödve a kalapbőre sugárirányban felszakadozik, nincsenek pleurocisztidiumai, valamint

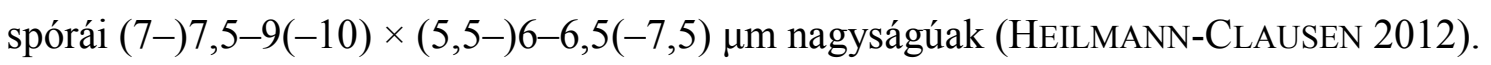



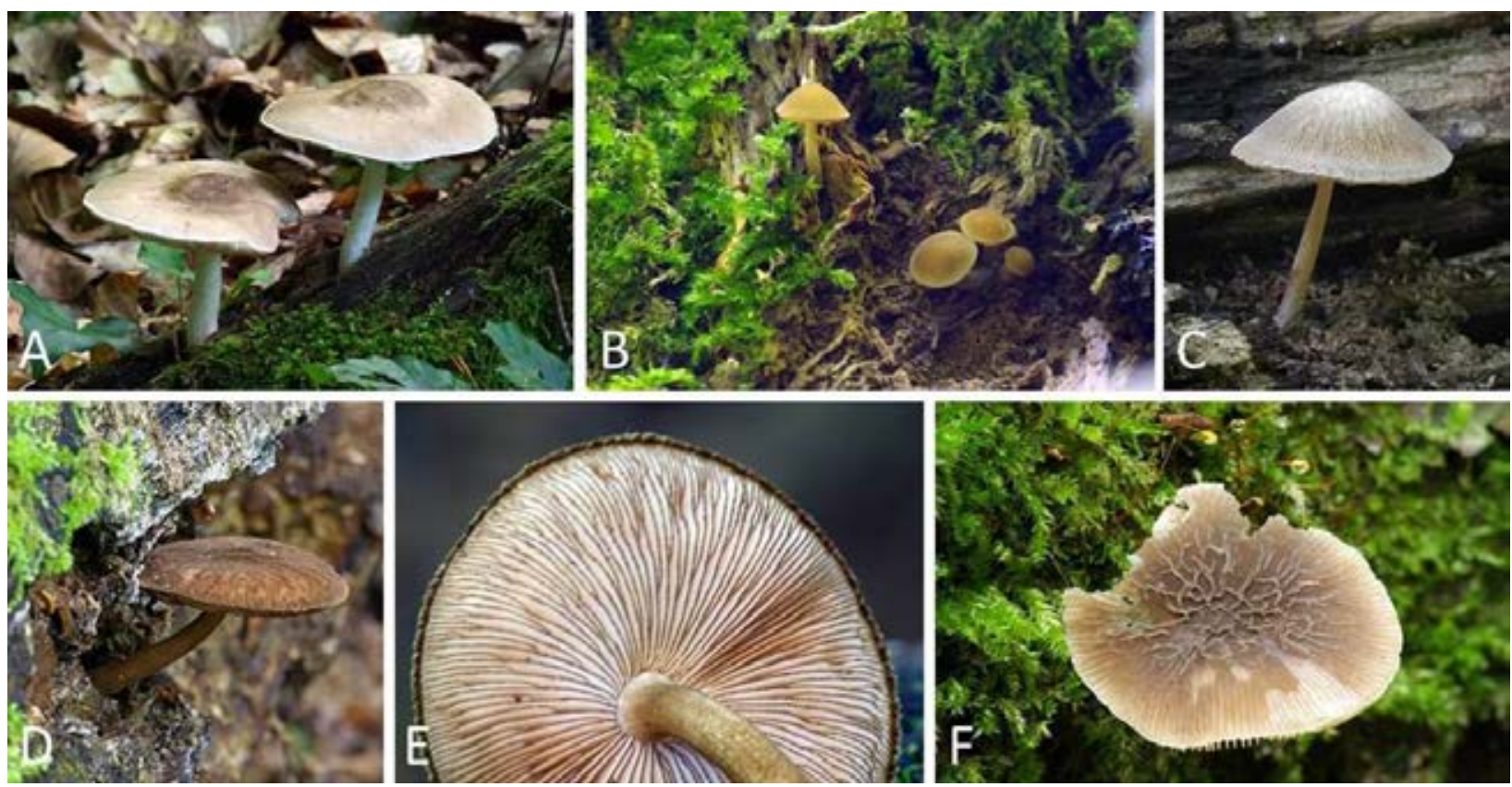

11. ábra. A Pluteus nemzetségbe tartozó fajok termőtestei a Juhdöglö-völgy Erdőrezervátumban (in situ); A) Pluteus cervinus; B) Pluteus leoninus; C) Pluteus sp.; D-E) Pluteus umbrosus; Pluteus thomsonii. Fotó: Papp V.

A rezervátumból ezidáig kimutatott fajok közül a Hispidoderma szekcióba tartozik a $P$. leoninus, $P$. semibulbosus és a hazánkban védett $P$. umbrosus. A $P$. umbrosus (11. ábra/D-E) európai adatai alapján a természeközeli bükkösök egyik indikátorfaja (CHRISTENSEN és mtsai. 2004), amelyet megerősít, hogy hazánkban is föként bükkös erdőrezervátumokból, illetve bükk faanyagáról ismert (pl. BABOS 1989; KoszKA 2011; Siller 2004; TAKÁCS és Siller 1980). Ugyanakkor BENEDEK és PÁL-FÁM (2006) a Börzsönyben lévő Morgó-patak völgyből előfordulását enyves égerről jelzik, valamint PÁL-FÁM és LUKÁCS (2002) a Mecsekben gyertyános-kocsánytalan-tölgyesben (Asperulo taurinae-Carpinetum) gyüjtötte. A $P$. hispidulus előfordulását TAKÁCS és SILLER (1980) az Őserdő erdőrezervátumból korhadó faanyagról (cf. Fagus) jelzik. ALBERT (1984) a Normafa környéki bükkösböl, mint ritka fajt közli, valamint megjegyzi, hogy a bükk faanyagán kívül több alkalommal gyüjtötte avarról is. A múzeumi gyűjteményből BABOS (1989) mindösszesen egy hazai adatát jelzi Szárligetről (Vértes) (BP 65026).

Psathyrellaceae Vilgalys, Moncalvo \& Redhead (I)

(3) Coprinellus P. Karst. - C. cf. disseminatus (Pers.) J.E. Lange, C. domesticus (Bolton) Vilgalys, Hopple \& Jacq. Johnson agg., C. cf. truncorum (Scop.) Redhead, Vilgalys \& Moncalvo

(1) Psathyrella Fr. ex Quél. - *P. spadicea (P. Kumm.) Singer agg. 
Taxonómiai és nómenklatúrai megjegyzések: (I) A korábban Coprinus Pers. és Psathyrella nemzetségekbe sorolt taxonokat a Coprinaceae Overeem \& Weese családban tárgyalták. Molekuláris vizsgálatok alapján viszont kiderült, hogy a Coprinus s. lato nemzetség polifiletikus, a típusfaja [C. comatus (O.F. Müll.) Pers.] pedig az Agaricaceae családba tartozik, ezért szükségessé vált egy új család leírása: Psathyrellaceae Vilgalys et al. (REDHEAD és mtsai. 2001).

A Coprinellus disseminatus egy sergesen megjelenő igen gyakori faj, amelynek jellemző mikroszkopikus bélyegei, hogy a keilocisztidiumok palack alakúak, valamint a vélum gömbölyded elemekből áll.

A Coprinellus domesticus a nemzetségen belül szintén a legismertebb fajok közé tartozik, bár NAGY (2008) szerint a Domestici alszekcióba tartozó taxonok fajhatárai nem egyértelmüek és gyakoriak a $C$. domesticus és $C$. xanthothrix (Romagn.) Vilgalys, Hopple \& Jacq. Johnson között lévő átmeneti formák. A C. domesticus csoporthoz makromorfológiai bélygek alapján hasonló megjelenésű a BoHUs (1970) által vadgesztenyéről leírt és jelenleg a Coprinopsis nemzetségbe sorolt C. mitraespora (Bohus) Nagy et al. (NAGY és mtsai. 2012), amelynek jellemző mikroszkopikus bélyegei, hogy a spórák szélesen orsó alakúak („,mitriform”), valamint a vélum sárgás színü (NAGY 2008). A Coprinus s. lato fajok ugyan többnyire terrikol, illetve koprofil életmódúak, de BADALYAN és munkatársai (2011) munkája alapján, a fajok közel 40\%-a faanyagon is megjelenhet. A termőtestek speciális gyüjtése, valamint a fajok határozásának nehézségei alapján a rezervátumban ennek a gombacsoportnak a további kutatása mindenképpen szükségesnek látszik.

A Psathyrella nemzetségen belül a molekuláris bélyegek alapján polifiletikus Spadiceae szekcióba több egymástól morfológiai bélyegek alapján nehezen elkülöníthető faj tartozik: $P$. olympiana A.H. Sm., P. papyracea (Pers.: Fr.) Vašutová, P. pygmaea (Bull.: Fr.) Singer, P. spadicea, P. spintrigeroides P.D. Orton, P. variata A.H. Sm. (VAŠUTOVÁ 2008; VAŠUTOVÁ és mtsai. 2008).

A Psathyrella spadicea s. str. termőteste a közelrokon fajokhoz képest viszonylag nagyobb méretü, valamint jellemző mikroszkopikus bélyegei, hogy a spórái színtelenek, valamint fuziform cisztidiumai csúcsán található kristályok „csillag”-alakúak (VAŠUTOVÁ 2008). Több makromorfológiai bélyeg alapján a Psathyrella nemzetségbe tartozó termőtestet találtam, amelyek faji szintű azonosítása még további vizsgálatokat igényel.

\section{Pterulaceae Corner}

(1) Radulomyces M.P. Christ. $-{ }^{*} \boldsymbol{R}$. molaris (Chaillet ex Fr.) M.P. Christ.

A korticioid termőtestet képző Radulomyces molaris tölgyek nagyon gyakori xilofág gombája (BERNICCHIA és GORJÓN 2010). Korábban több makroszkopikusan hasonló fajt 
különítettek el morfológiai bélyegek alapján [R. arborifer Malysheva \& Zmitr., $R$. gypseus Spirin \& Zmitr. és R. submolaris Parmasto], amelyek taxonómiai helyzetének tisztázása további vizsgálatokat igényelne (BERNICCHIA és GORJÓN 2010; MALYSHEVA 2006; PARMASTO 1968).

A Radulomyces molaris s. lato egy gyakori taxon a rezervátum tölgyes élöhelyein és egy alkalommal Fraxinus ornus elhalt faanyagáról is gyüjtöttem. Ennek a szokatlan szubsztrátumról származó mintának a spórái azonban nem mutatott szignifikáns különbséget a $R$. molaris leírásában található adatoktól.

\section{Schizophyllaceae Quél.}

(1) Schizophyllum Fr. - S. commune Fr.

A jellegzetes termőtestet képző polifág Schizophyllum commune igen gyakori faj Magyarországon és a rezervátum területén is. KosZKA (2014) a hegységből (Mór), nyárfa ágról jelzi a Schizophyllum amplum (Lév.) Nakasone előfordulását. Ennek a fajnak a Schizophyllum nemzetségbe való besorolását NAKASONE (1996) javasolta, de a legtöbb újabb munkában továbbra is az Auriculariopsis nemzetségben tárgyalják (pl. BERNICCHIA és GORJÓN 2010; BODENSTEINER és mtsai. 2004).

Strophariaceae Singer \& A.H. Sm.

(1) Agrocybe Fayod - A. firma (Peck) Singer

(2) Galerina Earle - G. marginata (Batsch) Kühner agg., *G. vittiformis (Fr.) Singer agg.

(1) Gymnopilus P. Karst. - G. spectabilis (Weinm.: Fr.) A. H. Smith (I)

(2) Hypholoma (Fr.) P. Kumm. - H. fasciculare (Huds.) P. Kumm., H. lateritium (Schaeff.) P. Kumm.

(1) Kuehneromyces Singer \& A.H. Sm. - K. mutabilis (Schaeff.) Singer \& A.H. Sm.

(4) Pholiota (Fr.) P. Kumm. - P. adiposa (Batsch) P. Kumm. (II), **P. squarrosoides (Peck) Sacc. [= P. ochropallida Romagn. ex Bon] (III), Pholiota sp. (1), Pholiota sp. (2)

(1) Stropharia (Fr.) Quél. - S. aeruginosa (Curtis) Quél.

Taxonómiai és nómenklatúrai megjegyzések: (I) A FRIES (1821) által közölt Agaricus junonius [三 Gymnopilus junonius (Fr.) P.D. Orton] eredeti leírása szerint, a faj jellemzői a kisméretű $(>5 \mathrm{~cm})$, sima kalap, valamint, hogy a termőtest magányosan nő; HOLEC (2005) szerint viszont ezt a nevet használják a G. spectabilis-re, amely robusztosabb termetü és csoportosan nő. Abban az esetben, ha a két taxon azonos, akkor a $G$. junonius név a prioritás értelmében előnyt élvez. (II) Korábban széles körben elfogadott és használt név volt a $P$. aurivella (Batsch) P. Kumm. binom (JACOBSSON 1991), amely fajnak az eredeti leírásában szereplő „száraz kalapbőre” ellentétben áll a $P$. aurivella faj modern koncepciójával (KuYPer és TJallingit-BeuKers 1986). HOlec (1998) Batsch és Fries erdeti fajleírásai alapján megállapította, hogy a $P$. adiposa nem azonos az erdeti $P$. aurivella fajjal, amelynek véleménye szerint érvényes neve a $P$. cerifera (P. Karst.) P. Karst. A csoport aktuális taxonómiai koncepciója alapján a 
korábban széles körben használt $P$. aurivella binom [P. aurivella (Batsch) P. Kumm. s. auct. p.p.] két fajt takar: P. adiposa és P. cerifera (JACOBSSON 2012; NoORDELOOS 2011). (III) a Pholiota squarrosoides [三 Agaricus squarrosoides Peck.] fajt PECK (1879) Észak-Amerikából írta le juharfa elhalt faanyagáról. Romagnesi Európából, a Párizs közelében lévő Fontainebleau erdőből közölte a Dryophila ocropallida Romagn. binomot (KÜHNER és ROMAGNESI 1953), amelynek érvénytelen leírását végül BON (1986) validálta. A Pholiota ocropallida Romagn. ex Bon és a $P$. squarrosoides morfológiai és anatómiai bélyegeken nyugvó azonosságát a génuszal foglalkozó taxonómusok egyöntetủen elfogadják (pl. HOLEC 2001; JACOBSSON 1991, 2012; NOORDELOOS 2011), így a prioritás értelmében a $P$. squarrosoides név elönyt élvez a $P$. ocropallida binommal szemben.

Az Agrocybe firma a nemzetség gallér nélküli taxonjai közé, amelyek közül jellemző tulajdonsága, hogy többnyire faanyagon képez termőtestet és csak ritkán jelenik meg fatörmeléken (RYMAN 2012). Ennek ellenére első hazai adatát NAGY és GoRLICZAI (2007) Kecskemét környéki fehérnyárasból, mulcson gyüjtötték. SILLER és munkatársai (2013) az Örségben szintén gyüjtötték talajon, valamint jelzik bükk és gyertyán faanyagáról is.

A Gymnopilus spectabilis hazánkban nem ritka faj (pl. BABOs 1989; BENEDEK 2002; NAGY 2004; RiMÓCZI 1994), de a G. junonius [三 G. spectabilis var. junonius (Fr.) Kühner \& Romagn.] előfordulásával kapcsolatban BABOS (1989) megjegyzi, hogy Magyarországról „valószínüleg kipusztult". Ennek a taxonnak az újabb hazai adatára NAGY és GORLICZAI (2007) munkájában találunk utalást. Feltételezhetően a szerzők az adat közlésénél a G. junonius fajra gondoltak, mivel NAGY (2004) korábbi munkájában szerepel a G. spectabilis is. Tekintettel arra, hogy a „G. spectabilis - G. junonius" taxonok nómenklatúrai helyzete és fajkoncepciója nem egyértelmü, indokoltnak látszik a hazai gyüjtések revideálása.

A Galerina marginata s. lato egy hazánkban gyakori lignikol gombafaj, amely gyakran fordul elő fenyőfélék korhadó faanyagán (pl. PAPP 2009). A morfológiai bélyegek alapján $G$. marginata-nak határozott minták viszont több fajt takarnak [pl. G. unicolor (Vahl) Singer, G. autumnalis (Peck) A.H. Sm. \& Singer], ezért a csoport taxonómiai helyzetének tisztázásához további vizsgálatok szükségesek (GULDEN és mtsai. 2001). GULDEN és munkatársai (2005) szerint a G. vittiformis szintén egy fajkomplexet alkot, amelynek taxonómiai felülvizsgálatát javasolják. Ennek a fajnak a hazai előfordulásáról LUKÁCS (2010) közölt adatot Budakalászról, valamint DIMA és munkatársai (2013) második előfordulását publikálták a szentbékkálai Feketehegyről, nyílt füves területről.

A Pholiota nemzetség jellemző bélyegei a sárgás vagy barnás színű kalap és a sürün álló, kezdetben sárgás lemezek, a sima barna színű spórák gyakran csírapórussal és a számos fajnál előforduló krizocisztidiumok jelenléte (JACOBSSON 1991, 2012). A P. squarrosoides (Peck) Sacc. (12. ábra) korábbi taxonómiai munkák alapján az Adiposae szekcióba tartozik (JACOBSSON 2012; NOORDELOOS 2011), amely csoport közös jellemzője a bazidikarpiumon jól 
látható pikkelyek jelenléte mellett a nedves időben nyálkás kalapbőr (FARR és mtsai. 1977; HOLEC 2001; JACOBSSON 1991).
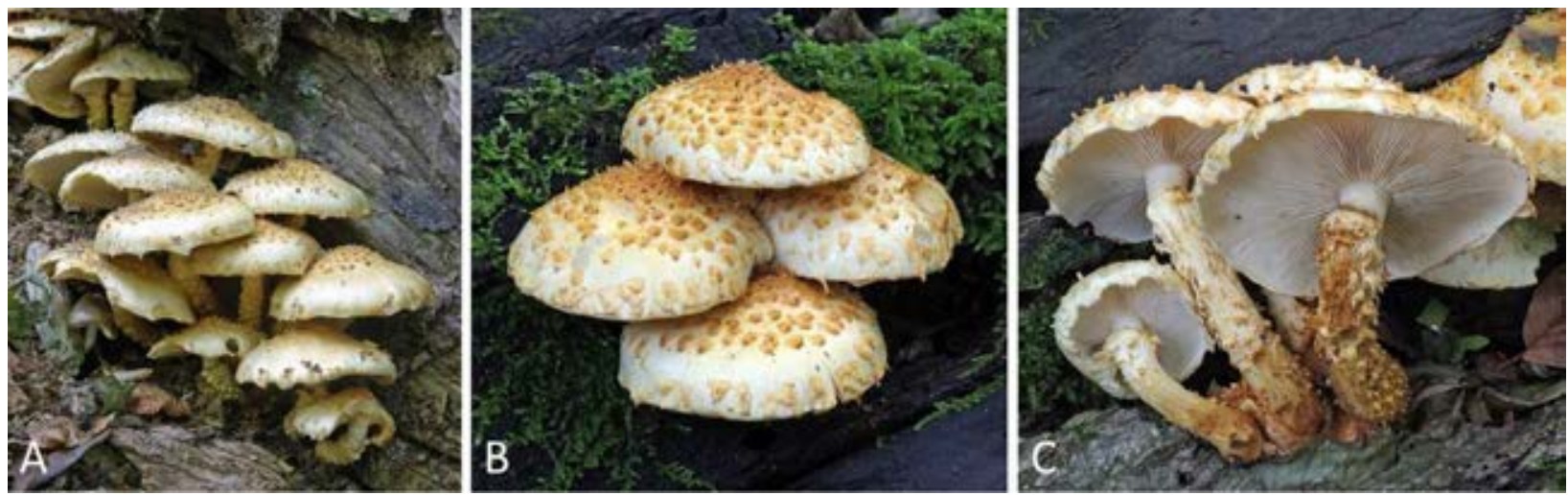

12. ábra. A Pholiota squarrosoides termőtestei a Juhdöglö-völgy Erdörezervátumban (in situ). A) kiszáradt termőtestek erősen korhadt, nagyméretű bükkfarönkön; B-C) friss termőtestek ugyan azon a bükkfarönkön. Fotó: Papp V.

A Pholiota alnemzetségen (subgen. Pholiota) belüli Adiposae szekció típusfaja [Pholiota adiposa (Batsch) P. Kumm.] taxonómiai szempontból egy bonyolult fajklompexet alkot. Jelenleg az Adiposae szekcióból Európában öt faj (P. adiposa, P. cerifera, P. limonella, P. jahnii, P. squarrosoides) található (NOORDELOOS 2011), amelyek közül négy elöfordulása korábban is ismert volt Magyarországról (BABOS 1989).

A jelenlegi fajkoncepció alapján a Pholiota squarrosoides egy kontinentális klímát kedvelő, a mérsékelt égövben széles körben elterjedt faj (JACOBSSON 1987, 1991). SMITH és HeSLER (1968) szerint Észak-Amerikában meglehetősen gyakori, míg Európában igen ritka (HALAMA 2011; HOLEC 2001) és föként rezervátum jellegü, háborítatlan erdőkben fordul elö (CHRISTENSEN és mtsai. 2004; HAUSKNECHT 1993), de ritkán akár parkokban lévő öreg, holt fákon is megtalálható (JACOBBSON 2012a). A termőtestek lombhullató fák (Fagus, Carpinus, Betula, Populus, Salix, Sorbus, Quercus) rönkjén, tuskóján vagy ritkán akár élő fákon kisebb csoportokban jelennek meg (NoORDELOOS 2011).

A Magyar Természettudományi Múzeum Növénytárában található két külföldi Pholiota squarrosoides fungárium mikroszkopikus vizsgálata során azt tapasztaltam, hogy a Juhdöglövölgy Erdőrezervátumból származó minta (PV540 /BP 106902) spóráinak mérete és alakja (átl.: $5,63 \times 3,4 \mu \mathrm{m}, \mathrm{Q}=1,64$ ) (13. ábra) nagy hasonlóságot mutat az ukrajnai (BP 19939) mintáéval (átl.: 5,4-3,4 $\mu \mathrm{m}, \mathrm{Q}=1,58)$; a kanadai P. squarrosoides minta (BP 44528) esetében viszont a spórák kisebbek voltak (átl.: 4,96 × 3,5 $\mu \mathrm{m}, \mathrm{Q}=1,47$ ). 


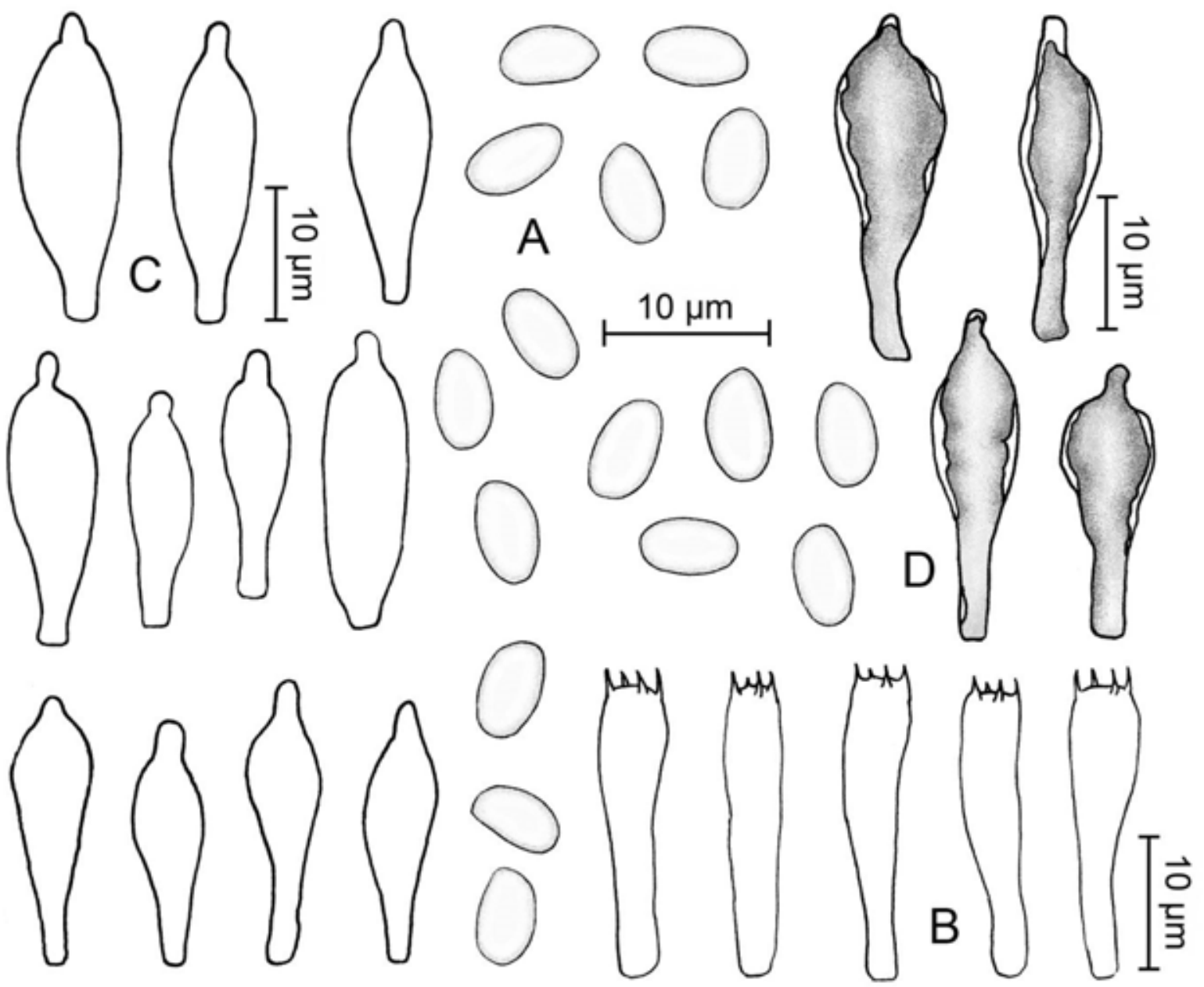

13. ábra. A Pholiota squarrosoides (PV540 /BP 106902) anatómiai bélyegei. A) bazidiospórák; B) bazidiumok; C) cheilocisztidiumok; D) chrizocisztidiumok. Rajz: Papp V. (PAPP és DiMA 2015a)

A morfológiai vizsgálathoz hasonló eredményt kaptunk az ITS-alapú filogenetikai vizsgálat során, amely alapján a Juhdöglö-völgy Erdörezervátumban gyüjtött Pholiota squarrosoides (PV540 /BP 106902) azonos a finn és észt mintákkal, ugyanakkor négy bázispár eltérés alapján némileg elkülönül az észak-amerikai eredetűektől (14. ábra). Az amerikai $P$. squarrosoides és az európai $P$. ochropallida azonosságát korábban morfológiai bélyegek alapján mutatták ki, de a jelen munkában közölt ITS-szekvenciák alapján feltételezhető, hogy az európai és északamerikai taxonok némileg különböznek. A Pholiota squarrosoides s. str. és a morfológiai bélyegek alapján közel álló fajok $[P$. barrowsii A. H. Sm. \& Hesler, $P$. ochropallida és $P$. romagnesiana A. H. Sm. \& Hesler] taxonómiai helyzetének tisztázásához azonban további minták vizsgálata szükséges. Az Új-Mexikóból, fenyő faanyagáról leírt $P$. romagnesiana az eredeti diagnózis alapján a $P$. squarrosoides-től abban különbözik, hogy spórái keskenyebbek és termőtestének nincs illata (SMITH és HESLER 1968). A két taxont egyes források azonosnak 
tekintik (JACOBSSON 1987, 1991, NoORDELOOS 1999), ugyanakkor NoORDELOOS (2011) megjegyzi, hogy HoLeC (2001) véleményét elfogadva van néhány jellegzetes anatómiai különbség a két faj között. A $P$. barrowsii elkülönítő bélyege a sárga gallér, valamint a kalap okkeres színe (Holec 2001, SMITH és HeSler 1968). A P. squarrosoides komplex taxonómiai helyzetének tisztázása érdekében több észak-amerikai és európai mintát kellene megvizsgálni morfológiai és molekuláris módszerekkel egyaránt.

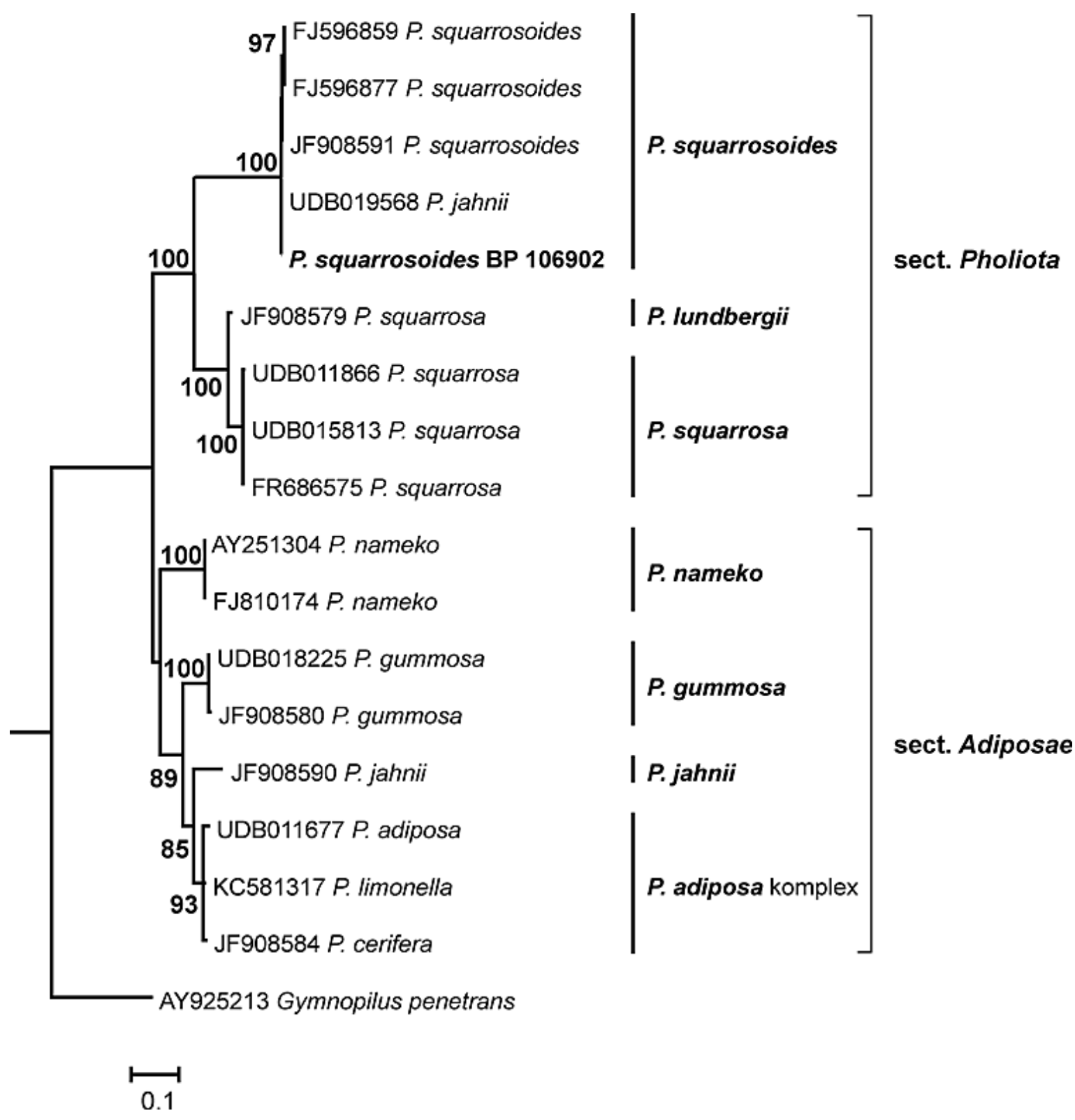

14. ábra. A Pholiota squarrosoides (PV540 /BP 106902) és rokon fajainak filogenetikai fája ITS szekvenciák alapján (PAPP és DIMA 2015). A filogenetikai rekonstrukció Maximum Likelihood (ML) statisztikai becslés alapján a RAxML Black Box program segítségével készült. Az ágaknál szereplö számok a 70\%-nál magasabb ML boostrap értékeket jelölik. A mérce 100 karakterre eső 10 szubsztitúciónak megfelelő ághosszat jelöl. 
Filogenetikai vizsgálatunk alapján az Adiposae szekció fajai közül együtt csoportosul a Pholiota adiposa, P. cerifera, P. limonella és $P$. jahnii, míg a $P$. squarrosoides minták a Pholiota alnemzetség Pholiota szekciójába tartozó Pholiota squarrosa és P. lundbergii Jacobsson fajokkal mutatnak rokonságot. Ezt az elkülönülést egy korábbi kemotaxonómiai munka is megerősíti, amely alapján a $P$. squarrosoides az Adiposae szekció többi fajától eltérően lakkázra és tirozinázra negatív reakciót mutatott (JACOBSSON 1989). Habár az ITS-régió nem teljesen megbízható a faj feletti rokonsági fokok meghatározásában, az tisztán megállapítható a vizsgálatunkból, hogy a $P$. squarrosoides és a morfológiailag Adiposae szekciónak definiált többi faj (pl. P. adiposa) nem tartozik egy kládba, sőt a nemzetségen belül eléggé távoli rokonságban állnak egymástól (> 100 bázispár különbség).

Tricholomataceae R. Heim ex Pouzar

(1) Resupinatus Gray (I) - *R. applicatus (Batsch) Gray

Taxonómiai és nómenklatúrai megjegyzések: (I) A Tricolomataceae család típusnemzetsége [Tricholoma (Fr.) Staude] mikorrhiza képző (CHRISTENSEN és HeILMANN-ClAUSEN 2013), de a xilofág Resupinatus génuszt a MycoBank adatbázis szintén ebben a családban tárgyalja. BODENSTEINER és munkatársai (2004) vizsgálata alapján a /Resupinatus kládba tartozik; egy újabb filogenetikai munkában a szerzők nem említik a Tricholomataceae s. str. családban (SÁNCHEZ-GARCÍA és mtsai. 2014).

A Resupinatus applicatus egy jellegzetes megjelenésü, kisméretü (2-8 $\mathrm{mm}$ átmérőjü), általában seregesen megjelenő ciphelloid termőtestet képző lemezes trámájú faj. Magyarországon vélhetően nem ritka faj, hazai előfordulásáról több munkában is találunk adatokat: BABOs 1989; DimA és mtsai. 2010; LuKÁCs 2010; SILlER és TURCSÁNYI 2002; SiLlER és mtsai. 2013; SZEMERE 1968.

\section{Tubariaceae Vizzini}

(2) Flammulaster Earle $-{ }^{*} \boldsymbol{F}$. limulatus (Fr.) Watling, ${ }^{*} \boldsymbol{F}$. muricatus (Fr.) Watling

(1) Phaeomarasmius Scherff. - *P. erinaceus (Fr.) Scherff. ex Romagn.

A Flammulaster génusz jellemző mikroszkopikus bélyege, hogy a paraderm vagy konioderm pileipellisz hasonlít az epithéliumra, de a sejtek szögletesek (VESTERHOLT és RALD 2012). A rezervátum területén két barna spóraporú, vastagfalú bazídiospórákat képző, lignikol Flammulaster fajt gyüjtöttem: F. limulatus (Fr.) Watling és F. muricatus (Fr.) Watling (15. ábra).

Mindkét Flammulaster faj előfordulása jellemző az európai természetközeli bükkerdőkre (CHRISTENSEN és mtsai. 2004; SILLER 2004); elkülönítésük pedig elsősorban a kalapbőr szerkezete alapján lehetséges (VELLINGA 1986). A F. limulatus s. lato ORTON (1984) véleménye 
szerint három fajt takar: F. limulatoides P.D. Orton, F. limulatus s. str. és a F. novasilvensis P.D. Orton. VELLINGA (1986) a nemzetséget feldolgozó monografikus munkájában revideálta a három taxont és a spórák alakjában talált különbség szerinte nem indokolják a faji szintü elkülönítést. Véleménye szerint a $F$. novasilvensis a $F$. limulatus változata $[F$. limulatus var. novasilvensis (P.D. Orton) Vellinga], amely a jól látható csírapórusa alapján különíthető el az alapfajtól; a $F$. limulatoides pedig makroszkopikus bélyegek alapján azonos a F. limulatus var. limulatus (Fr.) Watling fajjal. Ezen kívül az amigdaliform spórák alapján VELLINGA (1986) leírta a F. limulatus var. litus Vellinga változatot. A faj változatosságát mutatja, hogy LUDWIG (2001) még egy további változatot is elkülönített: $F$. limulatus var. intermedius E. Ludw. VESTERHOLT és RALD (2012) a F. novasilvensis-t különálló fajnak fogadja el és megkülönbözteti a $F$. limulatus var. litus változatot.
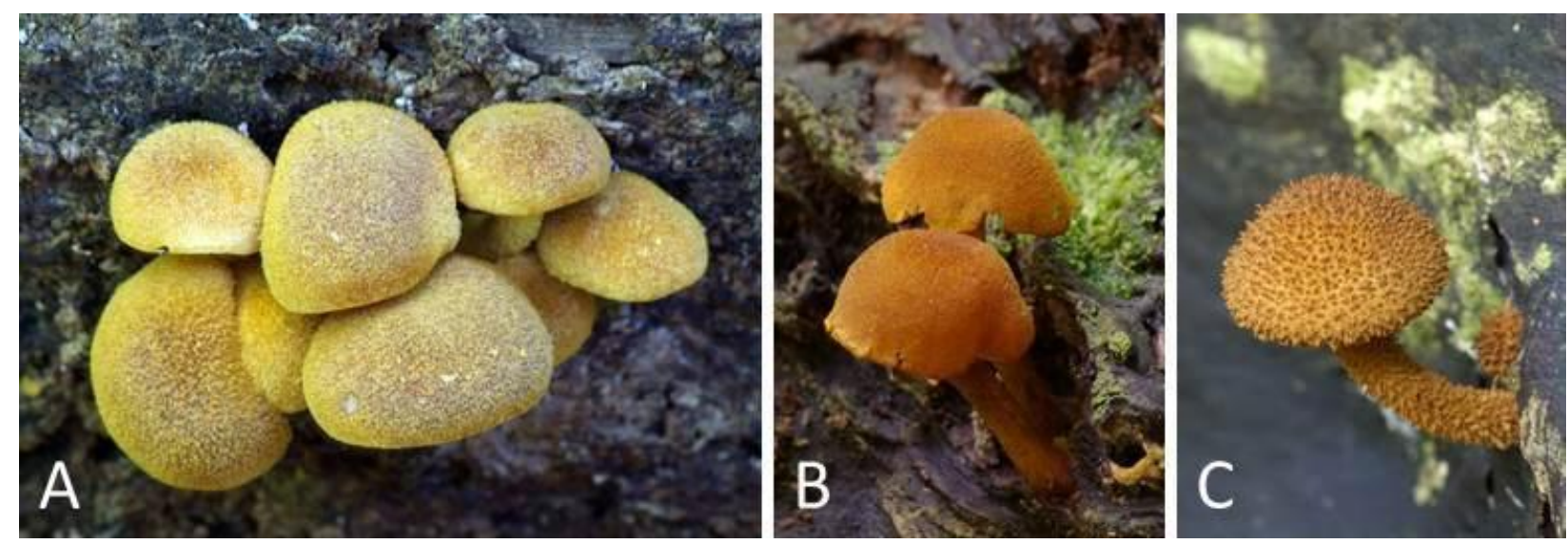

15. ábra. A Flammulaster nemzetségbe tartozó fajok termőtestei a Juhdöglö-völgy Erdőrezervátumban bükkfa rönkökön (in situ); A-B) Flammulaster limulatus termőtestek; B) F. muricatus termőtest. Fotó: Papp V.

A Flammulaster muricatus-hoz hasonló megjelenésű szintén lombos fák faanyagán növő Európa szerte ritka faj a F. wieslandri (Fr.) M.M. Moser, amelynek a spórája dextrinoid, a cheilocisztidiumai pedig gyakran tömlö alakúak (VELLINGA 1986).

A Phaeomarasmius nemzetség filogenetikai vizsgálatok alapján közel áll a Flammulaster génuszhoz (PETERSEN és mtsai. 2009; MATHENY és mtsai. 2014); anatómiai bélyegek alapján a pilleipellis szerkezete alapján lehet elkülöníteni a két nemzetség taxonjait (KNUDSEN és Vesterholt 2012). A P. erinaceus (Fr.) Scherff. ex Romagn. termőtesteit a rezervátumban egy alkalommal sikerült megtalálni talajon lévő molyhos tölgy ágán. Magyarországon ritka, veszélyeztetett fajként tartjuk számon (RIMÓCZI és mtsai. 1999), de viszonylag kevés hazai adata vélhetően a sokszor nehezen észrevehető apró termőtesteivel is magyarázható. 


\section{Typhulaceae Jülich}

(1) Typhula (Pers.) Fr. [= Macrotyphula R.H. Petersen] (I) - *T. fistulosa (Holmsk.) Olariaga [三 Macrotyphula fistulosa (Holmsk.) R.H. Petersen]

Taxonómiai és nómenklatúrai megjegyzések: (I) a Typhula nemzetségtöl a széles körben elfogadott Macrotyphula génuszt PETERSEN (1972) különítette el a Clavaria fistulosa Holmsk. [三 Macrotyphula fistulosa] típusfaj alapján. Ezt a fajt OLARIAGA és SALCEDO (2012) összehasonlították a Typhula nemzetség típusfajával, amely alapján arra a következtetésre jutottak, hogy a két nemzetség azonos és így a Clavaria fistulosa helyes rendszertani besorolása a Typhula fistulosa. A két nemzetség azonoságát alátámasztják korábbi filgenetikai munkák is (DENTINGER és MCLAUGHLIN 2006; PINE és mtsai. 1999). BERTHIER (1976) a T. contorta (Holmsk.) Olariaga [三 Clavaria contorta Holmsk.] fajt a T. fistulosa színonímjának, míg KNUDSEN (1997) változatnak tekinti. OLARIAGA és SALCEDO (2012) véleménye szerint viszont a termőtest morfológiája mellett, a nagyobb spórák alapján egy különálló faj, amelyet megerősít több korábbi megfigyelés is (pl. HARPER 1918, CORNER 1950).

A klavarioid termőtestet képző Typhula fistulosa fajt a rezervátumban, talajban lévő holt bükkfaágról gyüjtöttem. SILLER (1999) mint hazánkban ritka fajt a Kékes Erdőrezervátumból szintén bükk faanyagáról jelzi, ugyanakkor megjegyzi, hogy mindenekelőtt nyír és éger faanyagán nő.

\section{Incertae sedis}

Nagyméretü bükkfa rönkről október végén gyüjtöttem egy néhány milliméteres pleurotoid termőtestet képző gombát (16-17. ábra).

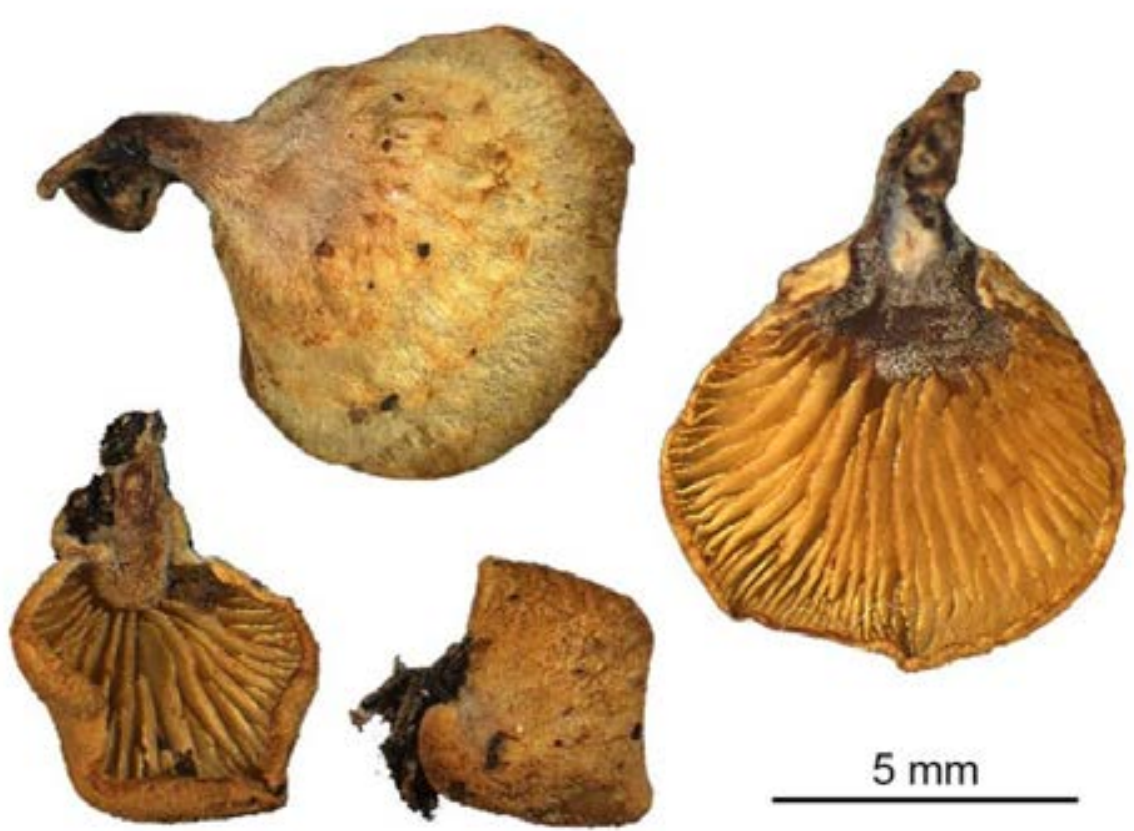

16. ábra. A nagyméretű iniciális korhadási fázisban lévő bükkfarönkről gyüjtött PV983-as számú fungáriumi minta sporokarpiumainak ex situ fotódokumentációja. Fotó: Papp V. 
Makroszkopikusan hasonlít a Strophariaceae családba tartozó Deconica horizontalis (Bull.) Noordel. [三 Melanotus horizontalis (Bull.) P.D. Orton (1984)] fajhoz, amelyet HeILMANNCLAUSEN és WALLEYN (2007) Észak-Spanyolországból szintén bükkről jeleztek. Ennek a fajnak főbb morfológiai bélyegei, hogy a kalapja 2-17 mm átmérőjü, felszíne sima vagy bársonyos; a tönk kezdetben centrális, majd később erősen excentrikus elhelyezkedésü, színe azonos vagy sötétebb, mint a kalapé; a spórák 6-8 × 4-5 $\mu$ m nagyságúak, kissé vastagfalúak, jól látható csírapórussal; a keilocisztidiumok palack alakúak (lageniform) (VESTERHOLT 2012c).

Hasonló termőtestet képeznek a Crepidotaceae családba sorolt Pleuroflammula Singer nemzetségbe tartozó taxonok, amelyek közül Európából mindösszesen egy faj ismert: $P$. ragazziana (Bres.) E. Horak (HoRAK 1986). Ennek az igen ritka fajnak jellemző bélyegei, hogy a kalapján apró, rozsdavörös pikkelyek borítják, bazídiumai 2-spórásak, keilocisztidiumai rövidek, bunkósak, valamint viszonylag nagyméretü spórái vannak (HORAK 1978).

Makroszkopikusan szintén hasonló termőtestet képeznek a jelenleg Tubariaceae családba sorolt Phaeomyces E. Horak nemzetség fajai: P. dubiosus E. Horak és P. ibericus (G. Moreno \& Esteve-Rav.) E. Horak (HORAK 2005). Morfológiai bélyegek alapján viszont nem találtam olyan fajt, illetve nemzetséget, amellyel egyértelműen azonosítani lehetne a rezervátumban gyüjtött mintát.
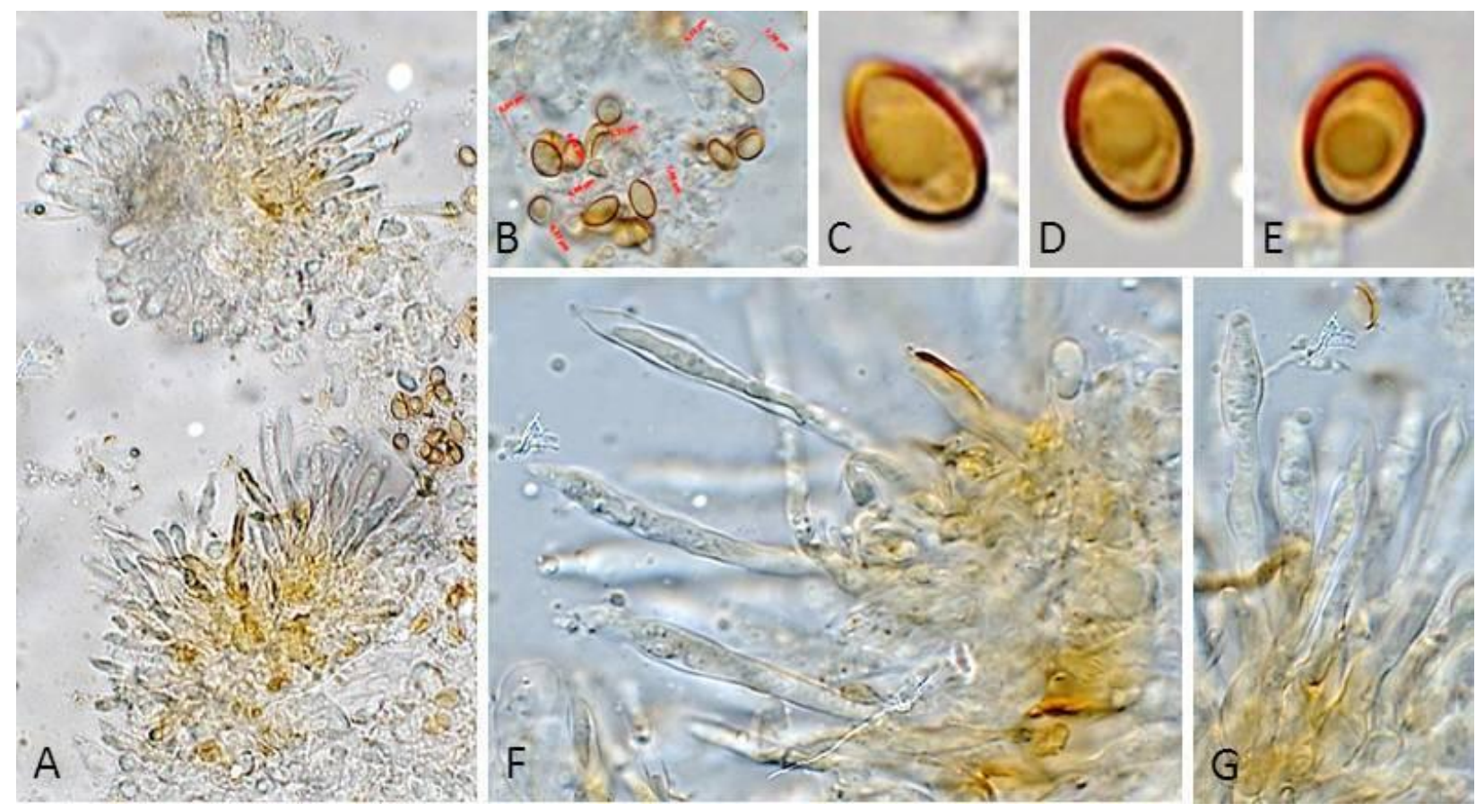

17. ábra. A Juhdöglő-völgy Erdőrzervátumban gyüjtött PV983-as számú minta mikroszkopikus bélyegei. A) a himénium elemei és a bazídiospórák; B-E) bazídiospórák; F-G) cisztidiumok. Fotó: Papp V. 
Az ITS és LSU szekvenciák alapján sem találtam a GenBank-ban hasonló fajt (a legközelebb álló taxonok a Pleuroflammula nemzetségbe tartoztak). Az eddigi filogenetikai vizsgálatok alapján a legnagyobb hasonlóságot mutató fajok is nemzetség szinten elkülönültek. A jelenleg elvégzett morfológiai és filogenetikai vizsgálataink alapján feltételezhető, hogy egy eddig ismeretlen nemzetség, tudományra új faját sikerült megtalálni a Juhdöglö-völgy erdőrezervátumban; ugyanakkor ennek bizonyítása további morfológiai és molekuláris viszgálatokat igényel.

\subsubsection{Atheliales Jülich}

\section{Atheliaceae Jülich}

(1) Athelia Pers. - *A. arachnoidea (Berk.) Jülich

Az Athelia arachnoidea egy zuzmóparazita faj, amelynek reszupinátus termőteste jellemzően élő fák törzsén jelenik meg (BERNICCHIA és GORJÓN 2010). A rezervátumban előfordulását élő gyertyán törzsén dokumentáltam. Annak ellenére, hogy az Athelia nemzetség a korticioid termőtestet képző bazídiumos nagygombák közé tartozik, ennek a fajnak a hazai előfordulásával kapcsolatban csak lichenológiai munkákban találunk utalást (pl. FARKAS és LÖKÖS 2009; FARKAS és mtsai. 2013; LÖKÖS és FARKAS 2009). A jellemzően fehéres színű reszupinátus bazídiokarpiumot képző génusz hazánkban a kevésbé kutatott gombacsoportok közé tartozik. A nemzetség taxonjai többnyire csak mikroszkopikus bélyegek alapján határozhatók, és vélhetően a rezervátum területén is előfordulhatnak további Athelia fajok.

\subsubsection{Auriculariales J. Schröt.}

Auriculariaceae Fr. ex Lindau

(2) Auricularia Bull. ex Juss. (I) - A. auricula-judae (Bull.) J. Schröt. (II); A. mesenterica (Dicks.) Pers.

Taxonómiai és nómenklatúrai megjegyzések: (I) egyes mikológiai munkákban az Auricularia-val szemben a Hirneola Fr. nevet preferálják. A Hirneola korábbi közlésével (FRIES 1825) szemben FRIES (1849b) későbbi leírását konzerválták, amelynek a Peziza nigra Fr. [三 Auricularia nigricans (Fries: Fries) Birkebak, Looney \& Sánchez-García] a típuspéldánya (LOONEY és mtsai. 2013). A VELENOVSKÝ (1939) által közölt Hirneola Velen. név pedig érvénytelen, mert a Hirneola Fr. homonimája. (II) az Auricularia nemzeteség filogenetikai vizsgálata alapján a korábban kozmopolitának tekintett $A$. auricula-judae fajhoz több hasonló termőtestet képző fajt írtak le Észak-Amerikából és Ázsiából is (BANDARA és mtsai. 2015; LOONEY és mtsai. 2013; WU és mtsai. 2014a). WU és munkatársai (2014a) szerint a Franciaországból leírt A. auricula-judae s. str. [三 Tremella auricula-judae Bull.] (BULLIARD 1789) elterjedése Európára korlátozódik. 
Az Auriculariales rend taxonjaira jellemző az Atractiellales és Tremellales rendekben is kialakult szeptált bazídium (Heterobasidiomycetes) jelenléte (BANDONI 1984). Az Auricularia auricula-judae és A. mesenterica egyaránt jellegzetes makroszkopikus bélyegekkel rendelkező, Európában és Magyarországon is gyakori polifág faj (BÁNHEGYI és mtsai. 1953; LOWY 1952).

\section{Exidiaceae R.T. Moore}

(1) Exidia Fr. - E. glandulosa (Bull.) Fr.

A rezervátum területén föként bükkfa rönkön gyakori faj az Exidia glandulosa, amelynek jellegzetes makromorfológiai bélyege a zselatinszerű, sötétbarnás vagy feketés sporokarpium szemölcsös trámával (ȚURA és mtsai. 2011). KosZKA (2011) a Vértesböl szintén bükkfáról jelzi az E. nigricans (With.) P. Roberts fajt és megjegyzi, hogy az E. glandulosa jellemzően a tavaszi aszpektusban és főként csertölgyön fordult elö. A szintén bükkfán is megjelenő Exidia taxonok közül az E. nucleata (Schwein.) Burt fajt ADAMČík és munkatársai (2007) a szlovákiai Stužica rezervátumból jelzik, míg ABREGO és SALCEDO (2011) a makroszkopikusan hasonló E. thuretiana (Lév.) Fr. előfordulását észak-spanyolországi bükkerdőből dokumentálták.

\subsubsection{Boletales E.-J. Gilbert}

Coniophoraceae Ulbr.

(2) Coniophora DC. (I) $-{ }^{*}$ C. arida (Fr.) P. Karst., ${ }^{*}$ C. puteana (Schumach.) P. Karst.

Taxonómiai és nómenklatúrai megjegyzések: AINSWORTH és RAYNER (1990) intersterilitási vizsgálatai alapján a $C$. puteana egy fajkomplexet alkot. Egy recens kutatás szerint pedig mind a három morfológiai bélyegek alapján elkülönített faj multi-lokusz DNS szekvencia vizsgálatok alapján további rejtett fajokat (,cryptic species”) tartalmaz (SKREDE és mtsai. 2012).

A monomitikus hifarendszerü európai Coniophora fajok közül a polifág C. arida jellemző bélyegei a halványsárgás spóra, valamint a reszupinátus termőtest vastagsága, amely ellentétben a C. puteana fajjal (> $2 \mathrm{~mm}$ ) nem haladja meg a 0,5 mm-t (BERNICCHIA és GorJón 2010). Hasonló megjelenésű a $C$. olivacea faj is, de a szeptált cisztidiumai alapján jól elkülöníthető az előbbi fajoktól.

A C. puteana vélhetően gyakori faj Magyarországon, ennek ellenére viszonylag kevés fungisztikai munkában találunk előfordulási adatokat (pl. NAGY 2004; TRECKER és SzABÓ 2002). A C. arida első és ezidáig egyetlen hazai adatát NAGY és GoRLICZAI (2007) közölték. 
Serpulaceae Jarosch \& Bresinsky

(1) Serpula (Pers.) Gray - *S. himantioides (Fr.) P. Karst.

COOKE (1957) szerint a reszupinátus termőtestet képző Serpula himantioides (18. ábra) a $S$. lacrymans (Wulfen) P. Karst. vadontermő változata [S. lacrymans var. himantioides (Fr.) W.B. Cooke]. HARMSEN (1960) véleménye alapján viszont az $S$. lacrymans és $S$. himantioides két különálló biológiai faj. Harmsen álláspontját a legújabb molekuláris munkák eredményei is alátámasztják (SKREDE és mtsai. 2011).
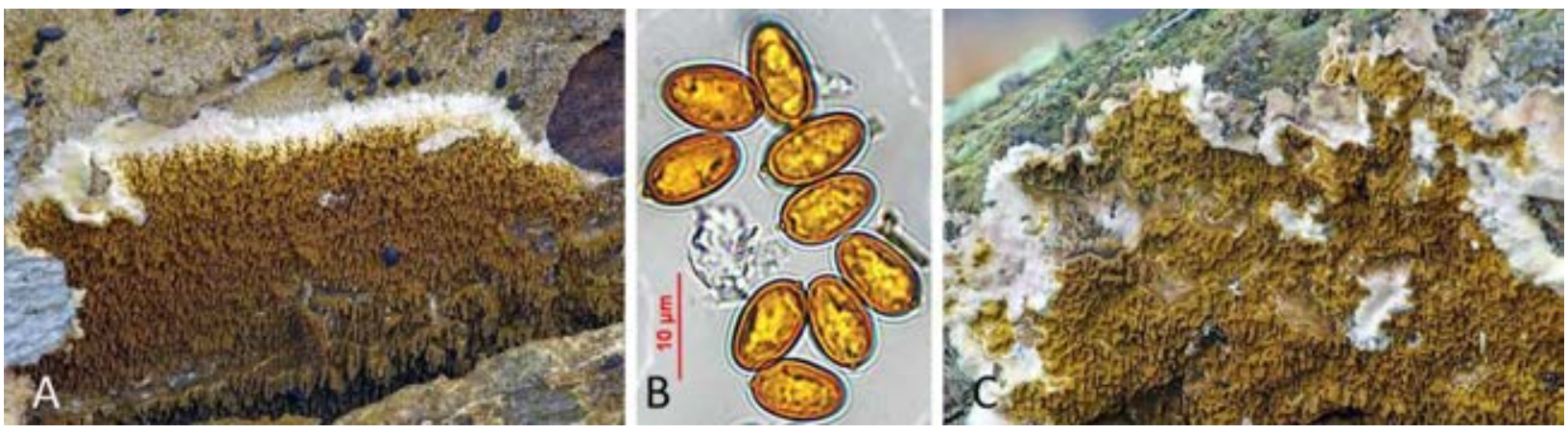

18. ábra. A rezervátumban gyüjtött Serpula himantioides makro- és mikroszkopikus bélyegei. A) a $S$. himantioides (fung.: PV269) termőteste korhadó bükkfarönkön (in situ); B) A PV269-es minta bazídiospórái; C) A PV269-es minta lelőhelyétől néhány méterre található tölgyfarönkön dokumentált $S$. himantioides (PV1034) termőteste (in situ). Fotó: Papp V.

Filogenetikai vizsgálatok alapján a Serpula himantioides nem egy fajt takar; KAUSERUD és munkatársai (2006) három, míg CARLSEN és munkatársai (2011) két újabb különálló genetikai vonalat különítettek el, amely azt mutatja, hogy a $S$. himantioides s. lato egy fajkomplexet alkot.

A Serpula himantioides első hazai adatát a Tőserdőből, NAGY és GoRLICZAI (2007) publikálták, de hazai előfordulását a Soproni-hegység területén lévő fenyvesekben is több alkalommal megfigyelték (Szabó Ilona, szóbeli közlés).

SZEMERE (1968) a Bakony-hegység nagygombáit ismertető munkájában pontosabb gyüjtési hely megjelölése nélkül gyakori fajként említi a Serpula lacrymans-t (三 Merulius lacrymans), amely Európában jellemzően épületek faanyagán nő (MOESZ 1934; WATKINSON és EASTWOOD 2012), ezért ezen gyüjtések revideálása szükségesnek látszik. A S. lacrymans és S. himantioides morfológiai bélyegek alapján nagyon közel állnak egymáshoz, egyedül a termőtest vastagsága alapján lehet biztosan elkülöníteni a két fajt (BERNICCHIA és GORJÓN 2010). 


\subsubsection{Cantharellales Gäum.}

Botryobasidiaceae (Parmasto) Jülich

(1) Botryobasidium Donk - *B. aureum Parmasto

(1) Botryohypochnus Donk $-{ }^{*}$ B. isabellinus (Fr.) J. Erikss. [三 Botryobasidium isabellinum (Fr.) D.P. Rogers]

A szaprotróf életmódú és reszupinátus sporokarpiumot képző fajokat tartalmazó Botryobasidium Donk s. lato génusz filogenetikai vizsgálatok alapján a /központi cantharelloid klád testvércsoportja (MonCALVo és mtsai. 2006). A rezervátumból ezidáig két Botryobasidium s. lato faj előfordulását mutattam ki, amelyek közül a $B$. aureum első hazai előfordulását SILLER (2004) közölte. A Juhdöglö-völgy Erdörezervátum területén, jelenlétét főként erősen korhadt bükkfarönkökön figyeltem meg.

A polifág Botryohypochnus isabellinus egy igen gyakori faj Európában (BERNICCHIA és GORJÓN 2010) és a Juhdöglö-völgy Erdőrezervátum területén is. Ennek ellenére MoESZ (1942) munkája óta egyetlen fungisztikai felvételezés során sem mutatták ki hazánkból.

\subsubsection{Corticiales K.H. Larss.}

Corticiaceae Herter [= Vuilleminiaceae Höhn.]

(1) Vuilleminia Maire $-* V$. comedens (Nees) Maire

A korticioid Vuilleminia nemzetség fajai gyakran elhalt ágakon jelennek meg (GHOBADNEJHAD és mtsai. 2010). A $V$. comedens jellemző bélyegei a nemzetségen belül, hogy nincsenek cisztidiumai, valamint bazídiospórái allantoidok (BERNICCHIA és mtsai. 2008; GHOBAD-NEJHAD és DUHEM 2014). MoESz (1942) Budapest és környékének gombáit feldolgozó munkájában a budai erdőkből elhalt tölgyágakról jelzi, valamint már BÁNHEGYI és munkatársai (1953) is megjegyzik, hogy egy egész éveben megtalálható gyakori gomba hazánkban. Ezt a megfigyelést saját tapasztalataim is alátámasztják, ugyanakkor meg kell jegyezni, hogy igen kevés azoknak a hazai fungisztikai munkáknak a száma, amelyekben ennek a fajnak az előfordulási adatait közlik: DiMA és mtsai. 2010; RIMÓcZI és mtsai. (1997).

A makroszkopikusan nagyon hasonló Vuilleminia alni Boidin, Lanq. \& Gilles első hazai előfordulását NAGY (2004) publikálta a Tőserdőből, enyves éger ágakról. Az említett két Vuilleminia fajon kívül több taxon magyarországi előfordulása is valószínűsíthető, szubsztrátumpreferenciájuk és ökológiai igényeik alapján. 


\subsubsection{Gomphales Jülich}

Gomphaceae Donk [= Ramariaceae Corner]

(1) Ramaria Fr. ex Bonord. - *R. stricta (Pers.) Quél.

Annak ellenére, hogy a Ramaria nemzetségbe tartozó taxonok jellemzően ektomikorrhiza képzők (NouHRA és mtsai. 2005), egyes Ramaria fajok holt faanyagon fordulnak elö: $R$. moelleriana (Bres. \& Roum.) Corner, R. circinans (Peck) Marr \& D.E. Stuntz és $R$. stricta (KNUDSON 2012). Ezek közül ezidáig az egyetlen Európából is ismert faj a $R$. stricta (CHRISTAN 2008), amelyet a JDV ER területén erősen korhadó bükk faanyagáról több alkalommal is sikerült megfigyelni (19. ábra).
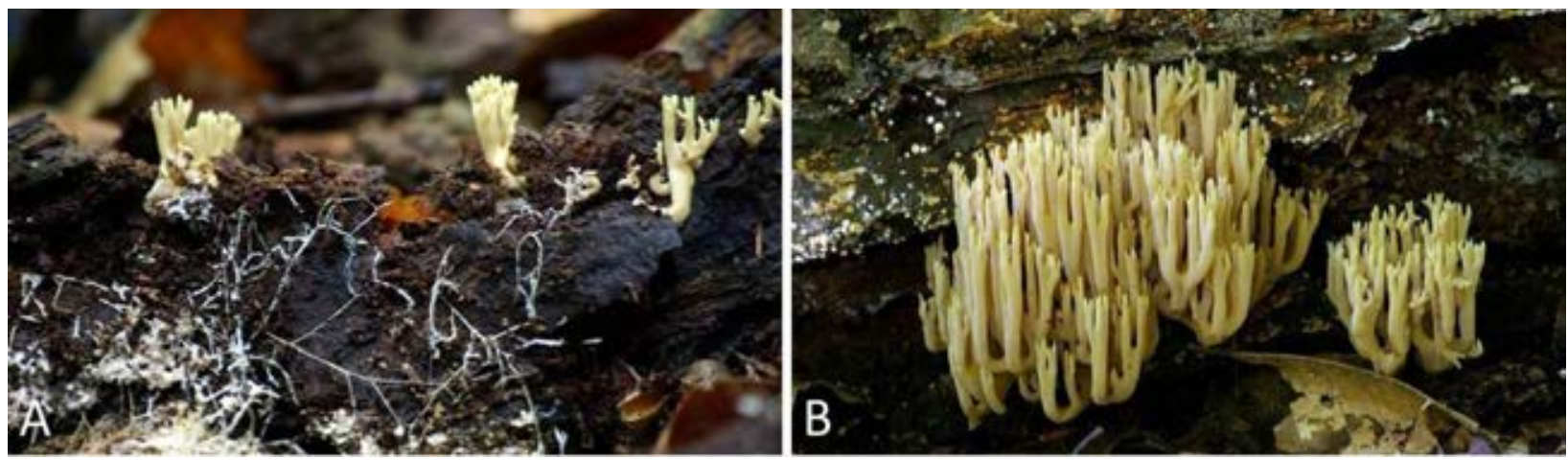

19. ábra. A Ramaria stricta sporokarpiumai a Juhdöglő-völgy Erdőrezervátumban (in situ). A) termőtestek és rizomorfák erősen korhadt faanyagon; B) R. stricta termőtestek. Fotó: Papp V.

A Ramaria fajokhoz hasonló koralloid termőtestet képeznek a Lentaria génusz fajai, amelyek jellemző morfológiai bélyegei a fehér spórák és a csatos hifák (PETERSEN 2000). HEILMANN-CLAUSEN és WALLEYN (2007) Észak-Spanyolországból bükkfa rönkröl jelzik a Lentaria epichnoa (Fr.) Corner fajt, amely véleményük szerint európai öreg erdőkben fordul elö és sok esetben elkerüli a mikológusok figyelmét.

\subsubsection{Hymenochaetales Oberw.}

Hymenochaetaceae Donk [= Inonotaceae Fiasson \& Niemelä; = Phellinaceae Jülich]

(1) Fomitiporia Murrill (I) $-{ }^{*} \boldsymbol{F}$. robusta (P. Karst.) Fiasson \& Niemelä [三 Phellinus robustus (P. Karst.) Bourdot \& Galzin]

(4) Fuscoporia Murrill (II) - *F. contigua (Pers.) G. Cunn. [” Phellinus contiguus (Pers.) Pat.]; *F. ferrea (Pers.) G. Cunn. [ $\equiv$ Phellinus ferreus (Pers.) Bourdot \& Galzin]; *F. ferruginosa (Schrad.) Murrill [三 Phellinus ferruginosus (Schrad.) Pat.]; F. torulosa (Pers.) T. Wagner \& M. Fisch. [三Phellinus torulosus (Pers.) Bourdot \& Galzin] 
(4) Hymenochaete Lév. $-{ }^{* *}$ H. carpatica Pilát; *H. cinnamomea (Pers.) Bres. subsp. cinnamomea; **H. fuliginosa (Pers.) Lév. [= H. subfuliginosa Bourdot \& Galzin] (III); *H. rubiginosa (Dicks.) Lév.

(5) Inonotus P. Karst. (IV) - **I. krawtzewii (Pilát) Pilát (V); *I. cuticularis (Bull.) P. Karst.; *I. dryadeus (Pers.) Murrill [三 Pseudoinonotus dryadeus (Pers.) T. Wagner \& M. Fisch.], *I. nidus-pici Pilát ex Pilát; *I. obliquus (Ach. ex Pers.) Pilát

(2) Mensularia Lázaro Ibiza (VI) - **M. hastifera (Pouzar) T. Wagner \& M. Fisch. [三 Inonotus hastifer Pouzar]; *M. nodulosa (Fr.) T. Wagner \& M. Fisch. [三Inonotus nodulosus (Fr.) P. Karst.]

(1) Phylloporia Murrill (VII) - *P. ribis (Schumach.) Ryvarden [ $\equiv$ Phellinus ribis (Schumach.) Quél.]

Taxonómiai és nómenklatúrai megjegyzések: (I) MURRILL (1907) a Fomitiporia génusz típusfajának a reszupinátus termőtestet képző $F$. langloisii Murrill fajt jelölte meg. Az F. langlosii vélhetően azonos a 2004-ben leírt $F$. hesleri M. Fisch. fajjal, amely FISCHER és BINDER (2004) molekuláris vizsgálata alapján egy kládot alkot a $F$. robusta-val. Kozervatív taxonómiai munkákban továbbra is a Phellinus nevet használják (pl. RYVARDEN és MELo 2014), de molekuláris eredményeket elfogadva számos mikológus elfogadja a Fomitiporia nemzetséget (pl. AMALFI és mtsai. 2014; ClOETE és mtsai. 2014; CAMPOS-SANTANA és mtsai. 2014; ZHOU és XUE 2012). (II) A Fuscoporia nemzetség típusfaja a F. ferruginosa (MURRILL 1907). DONK (1974) munkájában a Mucronoporus Ellis \& Everh. típusfajának a M. gilvus (Schwein.) Ellis \& Everh. fajt tekintette, amely WAGNER és FISCHER (2002) filogenetikai munkája alapján a Fuscoporia nemzetségbe tartozik [三 Fuscoporia gilva (Schwein.) T. Wagner \& M. Fisch.]. SPIRIN és munkatársai (2006) ez alapján több új Mucronoporus kombinációt közöltek, tekintve, hogy a nemzetség prioritást élvez a Fuscoporia-val szemben. JAHN (1978) hivatkozik MACBRIDE 1895-ös munkájára (irodalomjegyzékben nincs feltüntetve), amelyben véleménye szerint kijelölte a Polyporus gilvus-t a Mucronoporus nemzetség típusfajának. Áttekintve MacBride 1895-ben írt munkáit (MACBRIDE 1895; ELLIS és MACBRIDE 1895) nem találtam típus kijelölés, csupán négy taxon közlését a Mucronoporus génusz alatt: M. rufitinctus (Berk. \& M.A. Curtis ex Cooke) Ellis \& T. Macbr., M. tabacinus (Mont.) Ellis \& Everh., M. gilvuus, M. lichenoides (Mont.) Ellis \& Everh. Tehát a Mucronoporus első publikált típuskijelölése a MURRILl (1903) által választott Polyporus circinatus (Fr.) Fr. (DONK 1960, 1962b). A jelenleg széles körben elfogadott Onnia P. Karst. nemzetség típusfaja szintén a P. circinatus (KARSTEN 1889), amely alapján az Mucronoporus és az Onnia nemzetségek szinonimok. Mindkét nemzetséget ugyan abban az évben közölték, de ELLIS és EVERHARTH (1889) munkája korábban jelent meg, ezért a Mucronoporus prioritást élvez az Onnia névvel szemben. (III) A Hymenochaete subfuliginosa nagyon hasonló megjelenésü, mint a $H$. fuliginosa faj, de spórái kisebbek [4.5-5.5(-6) × 2.75-3(-3.5) $\mu \mathrm{m}$ ] és jellemzően lombos fák, különösen tölgyek faanyagán nő (JAHN 1971, KARADELEV és RUSEVSKA 2005). GERHOLD (1998) véleménye szerint viszont a $H$. subfuliginosa a $H$. fuliginosa alfaja, Bernicchia és Gorjón (2010) pedig a két taxont azonosnak tartják. (IV) Az Inonotus génusz a molekuláris vizsgálatok alapján polifiletikus és több kisebb nemzetségre oszlik (GOTLIEB és mtsai. 2002; JIN és mtsai. 2005; ŢURA és mtsai. 2011, WAGNER és FISCHER 2002). Az egyes génuszok elfogadottsága azonban nem egységes; RYVARDEN (2005) világmonográfiájában és az európai taplómonográfiákban (BERNICCHIA 2005; RYVARDEN és MELO 2014) továbbra is az összes nemzetséget az Inonotus s. str. alatt tárgyalják. Mások viszont elfogadják a génusz polifiletikusságát (pl. DAI 2010; KOTIRANTA és mtsai. 2009, SHARMA és mtsai. 2013). (V) ElLIS és EVERHART (1890) az Egyesült Államokból Mucronoporus andersonii Ellis \& Everh. néven írta le ezt a fajt egy poroid termőtest alapján, amelyet F. W. Anderson gyüjtött. Korábban viszont ugyan ennek a fajnak a sárga spóratömegét Saccardo és Ellis (SACCARDO és 
BERLESE 1885) Chromosporium vitellinum-ként írták le. Továbbá LOWE (1966) szerint a még korábbi Corticium pactolinum Cooke \& Harkn. (COOKE és HARKNESS 1881) szintén azonos az Inonotus andersonii spórájával. A PILÁT (1932) által Ázsiából leírt Xanthochrous krawtzewii Pilát, RYVARDEN (2005) szerimt azonos az I. andersonii-val. ZHOU és munkatársai (2014) viszont ITS és tefla génszakaszok vizsgálata alapján arra a következtetésre jutottak, hogy a két faj különbözik és az európai (szlovák és cseh) minták az I. krawtzewii fajhoz tartoznak. (VI) A Mensularia génuszt SHARMA és munkatársai (2013) elutasítják, míg a legtöbb munkában elfogadják (pl. ZHOU 2014). (VII) A Phylloporia nemzetséget MURRILl (1904) írta le a P. parasitica Murrill faj alapján, amely Kolumbiában egy Bignonia sp. élö levelének fonákán növekedett. Ez a taxon ökológiáját tekintve különbözik az összes többi jelenleg Phylloporia nemzetségben tárgyalt fajtól, továbbá nem ismertek a szekvenciái sem, így a filogenetikai vizsgálatokban sem került feltüntetésre (pl. VALENZUELLA és mtsai. 2011; WAGNER és RYVARDEN 2002; ZHOU és DAI 2012b). Véleményem szerint megalapozottnak látszik annak a lehetősége, hogy a $P$. parasitica nem tartozik egy génuszba a többi jelenleg Phylloporia nemzetségben tárgyalt fajjal. Ebben az esetben ezeket a fajokat a Phaeolopsis Murrill [típus: Polyporus verae-crucis Berk.] (MURRILL 1905) és/vagy a Cryptoderma Imazeki [típus: Boletus ribis Schumach.] (IMAZEKI 1943) nemzetségekbe kellene átsorolni. Cony Decock személyes közlése alapján viszont (az újabb, de részben még publikálatlan filogenetikai eredmények alapján) jelenleg nem látszik igazoltnak, hogy a Phaeolopsis és Cryptoderma külön kládot alkotnának. A Phylloporia génusz az utóbbi években egy intenzíven kutattott taxonómiai csoport. ZHOU és DAI (2012b) munkájukban Kínából öt tudományra új fajt publikáltak, valamint közölték a nemzetség 23 fajának a határozókulcsát. Ezt követően további Phylloporia fajokat is leírtak Francia Guyanaból (DECOCK és mtsai. 2013), Kínából (ZHOU 2013, 2015) és Üzbegisztánból (GAFFOROV és mtsai. 2014). Az újabb taxonómiai eredmények tükrében az európai $P$. ribis minták revideálása is szükséges lehet.

A Fomitiporia robusta-hoz Európából számos közeli fajt írtak le (F. punctata-robusta komplex; F. robusta csoport), amelyek közös tulajdonsága, hogy spóráik többé-kevésbé kerekdedek és dextrinoidok (RYVARDEN és MELo 2014). Az F. robusta jellemző bélyege, hogy cisztidiumai hasasak és a termőtest jellemzően tölgyeken jelenik meg (GILBERTSON 1979), de egyes munkákban egyéb lombos fafajokról is jelzik (pl. RYVARDEN és GILBERTSON 1994; RYVARDEN és MELO 2004). IGMÁNDY (1991) szerint akácfákon szintén az $F$. robusta reszupinátus formája szokott megjelenni. Ezeknek a mintáknak a revideálását a jövőben szükségesnek tartom, mert a hazánkból még nem ismert, reszupinátus $F$. pseudopunctata (A. David, Dequatre \& Fiasson) Fiasson számos mikroszkopikus bélyegben hasonlít a $F$. robustahoz (DAVID és mtsai. 1982; FIASSON és NIEMELÄ 1984). Az F. robusta a rezervátum területén nem ritka faj, mind a kocsánytalan-tölgyes, mind a molyhos-tölgyes állományban több alkalommal is megfigyeltem a termőtesteket élő fákon és rönkökön is (20. ábra/A-B).

Az európai Fuscoporia fajok közül az F. contigua könnyen határozható faj, tekintve, hogy a pórusai lényegesen nagyobbak (2-3/mm), mint a többi reszupinátus fajnak. IGMÁNDY (1991) munkájában részletesen nem tárgyalja az $F$. ferruginosa-t, de megjegyzi, hogy erdei környezetben, lombos fafajokon nő és előfordulása ritkább, mint az $F$. contigua fajé. A Mátra lomberdeinek szisztematikus vizsgálata alapján viszont az $F$. ferruginosa a harmadik leggyakoribb taplófaj volt (PAPP és mtsai. 2014ab). Az F. ferrea makroszkopikusan hasonló, mit 
az F. ferruginosa, de a spórái nagyobbak és nincsenek szetális hifái a húsban (RYVARDEN 2004). A rezervátumban mindhárom reszupinátus fajt tölgy faanyagáról gyüjtöttem. Az $F$. torulosa konzolos krusztotéciumot fejleszt, ezért morfológiai bélyegek alapján korábban FIASSON és NIEMELÄ (1984) a Phellinus s. str. nemzetségbe sorolták. Molekuláris vizsgálatok alapján viszont WAGNER és FISCHER (2001) igazolták, hogy a Fuscoporia nemzetségbe tartozik. Ennek a fajnak Közép-Európában a leggyakoribb gazdanövénye a tölgy, de megtalálható számos egyéb lombos fafajon és ritkán fenyőféléken is (PANCONESI és mtsai. 1994; FISCHER és BRESINSKY 1992; Gilbertson és Burdsall 1972; KotLÁBA 1975; Rizzo és mtsai. 2003; TOMŠOvsKÝ és JANKOVSKÝ 2007).

A Hymenochaete s. str. nemzetség magyarországi elterjedését és a hazai fungára új fajok ismertetését egy korábbi cikkben foglaltam össze (PAPP 2013a). A H. carpatica reszupinátus termőteste jellemzően öreg hegyi juhar (Acer pseudoplatanus) felrepedező kérgének belső oldalán növekszik (CHLEBICKI 2003; KRIEGLSTEINER and LAWRYNOWICZ 2003, RÜCKER és FORSTINGER 1991, TOMŠOVSKÝ 2001). Ez a speciális termőtestképzési stratégia magyarázhatja, hogy sokáig ez a faj elkerülte a hazai fungisztikai felvételezéseket végző mikológusok figyelmét.

A Hymenochaete cinnamomea jellemző bélyegei a reszupinátus, fahéj vagy rozsdabarnás színű termőtest, valamint a szeták rendezettsége a húsban (AINSWORTH 2004a; BERNICCHIA és GORJÓN 2010). PARMASTO (2000) véleménye szerint az Észak-Amerikából leírt H. spreta Peck, csak a termőtest struktúrájában tér el a $H$. cinnamomea-tól, ezért közölte a $H$. cinnamomea subsp. spreta (Peck) Parmasto kombinációt. BERNICCHIA és GORJÓN (2010) monográfiájukban mindkét taxon európai előfordulását elfogadják. A rezervátum területén talált minták a $H$. cinnamomea subsp. cinnamomea alapfajjal mutattak azonosságot.

A Hymenochaete fuliginosa termőteste szintén reszupinátus, de sötétbarna színü és szabálytalanul felrepedező, továbbá a szetái szélesebbek, mint a H. cinnamomea-nak (PAPP 2013a). Európában előfordul fenyőfélék (pl. Abies, Picea) és lombos fák (Quercus, Fagus sylvatica) faanyagán is (BERNICCHIA és GORJÓN 2010); Magyarországon ezidáig juhar és tölgy fajokról ismert (PAPP 2013a). Annak ellenére, hogy korábban ez a faj nem volt ismert Magyarországról, az eddigi tapasztalataim alapján nem ritka hazánkban.

A Hymenochaete rubiginosa szinte az egész ország területén megtalálható, ahol gazdanövényének (Quercus spp.) holt faanyaga előfordul. Saját megfigyeléseim szerint ez a faj egy kifejezetten gyakori, a tölgyesek jellegzetes és könnyen azonosítható kísérőfaja.

Az Inonotus krawtzewii termőteste az I. obliquus ivaros alakjához hasonlóan a szijács külső rétegei vagy a kéreg alatt fejlődik és azt idővel felszakítja (20. ábra/C). Utóbbi fajtól abban különbözik, hogy spórája sárga színü és kisebb, valamint a pórusai nagyobbak. ÉszakAmerikában viszonylag gyakori polifág faj; európai előfordulását viszont csak 1963-ban sikerült 
igazolni (ČERNÝ 1963) és az eddigi tapasztalatok alapján kontinensünkön ritka és jellemzően csertölgyön nő (RYVARDEN 2005; RYVARDEN és MELO 2014). Ennek az erdészeti szempontból is jelentős fajnak nem volt korábbi ismert hazai előfordulása, viszont Igmándy Zoltán fungáriumi gyüjteményében számos csertölgyröl származó és I. obliquus-nak határozott minta található, amelyek revideálása szükségesnek látszik.

Az I. obliquus ivartalan áltermőtestei élő nyírfákon nőnek, de poroid ivaros alakja gyakran fordul elö bükk faanyagán. IGMÁNDY (1964a) a Mátra és a Bükk hegységek bükköseiből jelzi, valamint véleménye szerint (IGMÁNDY 1981) hazánkban ritka vagy szórványos faj, amely „idös, rezervátumként kezelt bükkösökben, nem ritka”. Ezt a megfigyelést SILLER (2004) eredményei, valamint saját a Juhdöglö-völgy Erdőrezervátumban gyüjtött tapasztalataim is alátámasztják, tekintve hogy több alaklommal is sikerült megfigyelni ezt a fajt iniciális korhadási fázisban lévő elhalt bükk faanyagán. Az I. obliquus-nak Igmándy Zoltán fungáriumi gyüjteményében azonban van egy 1964-ben Sitkén gyüjtött és szilfáról származó mintája is (BP 47584 / BP 89660), amely mikroszkopikus vizsgálataim alapján a hazánkból korábban nem ismert és csak 1990-ben leírt $I$. ulmicola Corfixen (CORFIXEN 1990) fajjal azonos (PAPP unpubl.).

IgMÁNDy (1953, 1957a, 1958) az I. obliquus korábbi nevein [Fomes obliquus (Pers.) Fr., Xanthochrous obliquus (Pers.) B. et G.] közöl adatokat, de ezek az I. nidus-pici fajra vonatkoznak. Egy későbbi Pagony Huberttel írt cikkükben a Xanthochrous obliquus f. cavernatus-t már, mint a X. nidus-pici (Pilát) Z. Igmándy [三Inonotus nidus-pici] szinonimjaként említik (IGMÁNDY és PAGONY 1965). Az I. nidus-pici elsősorban, mint erdészeti kórokozó került a figyelem középpontjába; számos hazai munka foglalkozik a cserállományban való károsításával (HARACSI 1941; IGMÁNDY 1953, PADÁNYI 1972), csertölgyben való korhasztásával (IGMÁNDY 1977, 1981), újabb gazdanövényen való előfordulásával (HARACSI és IGMÁNDY 1956, 1957a), az elterjedését befolyásoló környezeti tényezőkkel (IGMÁNDY 1957a), valamint az ivaros termőtest és spóraképzésével (IGMÁNDY 1970a). A Juhdöglö-völgy Erdőrezervátumban tölgyfajokon (Quercus cerris és $Q$. pubescens) kívül élő odvas bükkfa alatt talajra lehullva is megtaláltam ivaros sporokarpiumát.

Az I. cuticularis a nemzetségen belül egy könnyen azonosítható faj, tekintve, hogy az egyetlen európai Inonotus s. 1. amelynek elágazódó horgas szetális hifák vannak a kalapfelszínén (RYVARDEN és Melo 2014). Magyarországon egy igen gyakori taplófaj (pl. IGMÁNDY 1964b, 1981; NAGY 2004; PAPP és mtsai. 2012; RiMÓcZI és mtsai. 1997; RUdOLF és mtsai. 2008; SILLER 2004; TRECKER és SzABÓ 2002). Annak ellenére, hogy egy széleskörben elterjedt polifág faj, CHRISTENSEN és munkatársai (2004) szerint a természetközeli bükkös egyik indikátorafaja (20. ábra/D-E). 

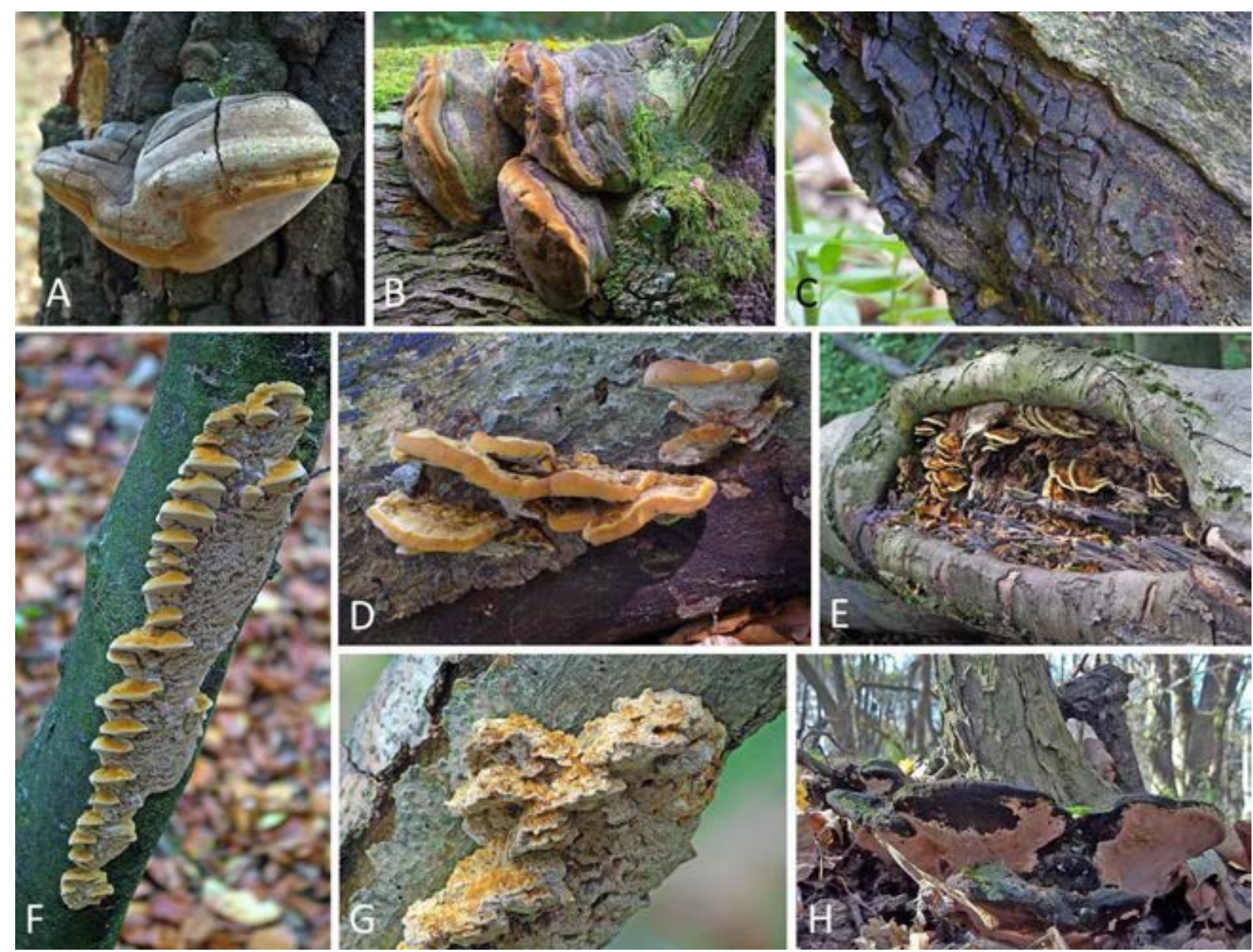

20. ábra. Inonotus s. lato és Phellinus s. lato fajok a Juhdöglö-völgy Erdörezervátumban. A) a Fomitiporia robusta többéves sporokarpiuma csertölgyön (in situ); B) F. robusta termötestek kidölt kocsánytalan tölgyön (in situ); C) az Inonotus krawtzewii elöregedett sporokarpiuma kidől csertölgyön (in situ); D) I. cuticularis fejlődésben lévő termőtestei bükkfarönkön; E) kidőlt nagyméretű bükkfa odvas részében fejlődő I. cuticularis termőtestek (In situ); F-G) a Mensularia nodulosa termőteste elhalt bükkfatörzsön (in situ); H) a Phylloporia ribis termőtestei élő Cornus tövében (in situ). Fotó: Papp V.

A Mensularia nodulosa a bükkösök egyik karakterfaja (20. ábra/F-G). Hasonló megjelenésű, mint a $M$. radiata (Sowerby) Lázaro Ibiza, de a himéniumban lévő szetái egyenesek, a csövek bázisánál pedig hiányoznak. A M. hastifera szintén főként bükk faanyagán képez termőtestet, de termőteste közel reszupinátus és trámában jelen vannak a szetális hifák (POUZAR 1981). Ez a faj szerepel a magyarországi nagygombák vörös listáján (RIMÓczi 1997; RIMÓCZI és mtsai. 1999) ugyanakkor nem találtam a hazai szakirodalomban publikált előfordulási adatát.

A Phylloporia ribis Magyarországon nem ritka faj és főként cserjék vagy kis fák (pl. Cornus, Crataegus, Euonymus, Ribes) tövében jelennek meg a termőtestei (IGMÁNDY 1970c, 1981). Igmándy munkái óta viszont igen kevés publikált hazai adata van (pl. NAGY 2004), amely vélhetően nem a $P$. ribis ritkulásával, hanem a Phellinus s. lato fajok határozási nehézségeivel magyarázható. A rezervátum területén egy öregebb Cornus tövében gyüjtöttem (20. ábra/H). A 
Phylloporia nemzetségből Európában jelenlegi ismereteink alapján csak ez az egy faj fordul elő (RYVARDEN és MELO 2014).

Oxyporaceae Zmitr. et V. Malysheva (I)

(1) Oxyporus (Bourdot \& Galzin) Donk (II) - *O. populinus (Schumach.) Donk

Taxonómiai és nómenklatúrai megjegyzések: (I) Az Oxyporaceae családot [típus: Oxyporus] ZMITROVICH és MALYSHEVA (2014) írta le LSU szekvánciákon alapuló filogenetikai vizsgálat alapján. Ezt az elkülönítést LARSSON és munkatársai (2006) korábbi molekuláris vizsgálata is alátámasztja. (II) LÁZARO IBIZA (1917) korábban publikálta a Boudiera nemzetséget a Polyporus connatus Schwein. [三 Oxyporus populinus (Schumach.) Donk] típusfaj alapján; a Boudiera Lázaro Ibiza viszont a Boudiera Cooke homonimája (COOKE 1877).

A számos gazdanövényről ismert Oxyporus populinus egyéves vagy évelő termőteste kalaposodik és élő fákon is megjelenhet. IGMÁNDY (1981) hazai előfordulásával kapcsolatban azt írja, hogy „...elsösorban a Bükk hegység idős bükköseiben gyüjtöttük és figyeltük meg a gombát, ahol azonban nem ritka". SILLER (2004) a Kékes Erdőrezervvátumból nem, de az Öserdőből jelzi előfordulását. Igmándy óta viszonylag kevés adatát publikálták Magyarországról, pedig vélhetően nem ritka faj hazánkban. Az Oxyporus s. lato nemzetség taxonjai közül IGMÁNDY (1981) három faj hazai adatát közli: O. latemarginatus (Durieu \& Mont.) Donk, O. populinus és O. ravidus (Fr.) Bondartsev \& Singer. Az O. latemarginatus morfológiai és molekuláris vizsgálatok alapján jelenleg az Emmia Zmitr. et al. nemzetségbe tartozik (ZMITROVICH és mtsai. 2006; Zmitrovich és Malysheva 2014). IgmÁndy (1981) az O. ravidus-t Sopronból luc faanyagáról jelzi, ugyanakkor RYVARDEN és MELO (2014) szerint ez a faj jellemzően lombos fák faanyagán nő. Ennek a gyüjtésnek a revideálása a későbbiekben szükségesnek látszik.

\section{Rickenellaceae Vizzini}

(2) Rickenella Raithelh. $-\boldsymbol{R}$. fibula (Bull.) Raithelh., *R. swartzii (Fr.) Kuyper $[=R$. setipes (Fr.) Raithelh. ss. auct.] (I)

Taxonómiai és nómenklatúrai megjegyzések: (I) KUYPER (1984) szerint az Agaricus setipes Fr. [= Rickenella setipes (Fr.) Raithelh.] eredeti leírása alapján egy Mycena fajjal lehet azonos, ezért véleménye szerint ennek a fajnak az érvényes bazionimja az Agaricus swartzii Fr.

A Rickenella nemzetség fajai apró méretü agarikoid-omphalotoid termőtestet képeznek és brioparazita életmódot folytatnak (ELBORNE 2012b). A génuszon belül a hazánkban nem ritka $R$. fibula jellegzetes makroszkopikus bélyege a higrofán sárgás vagy narancsszínű kalap. A lilás, szürkés-barna színü sporokarpiumot képző R. swartzii magyarországi adatai (pl. BABOS 1989; SILLER és mtsai. 2013) alapján ritkább fajnak tünik. 


\section{Schizoporaceae Jülich}

(1) Basidioradulum Nobles $-{ }^{*}$ B. radula (Fr.) Nobles [ $\equiv$ Hyphoderma radula (Fr.) Donk; $\equiv$ Xylodon radula (Fr.) Tura, Zmitr., Wasser \& Spirin] (I)

(2) Schizopora Velen. - *S. flavipora (Berk. \& M.A. Curtis ex Cooke) Ryvarden [= S. carneolutea (Rodway \& Cleland) Kotl. \& Pouzar]; *S. paradoxa (Schrad.) Donk agg.

(1) Xylodon (Pers.) Fr. - *X. quercinus (Pers.) Gray [三 Hyphodontia quercina (Pers.) J. Erikss.]

Taxonómiai és nómenklatúrai megjegyzések: (I) a Basidioradulum radula a hazai szakirodalomban Hyphoderma radula név alatt szerepel, míg ȚURA és munkatársai (2011) szerint indokolt a Xylodon (Pers.) Fr. nemzetségbe való átsorolása. LARSSON és munkatársai (2006) filogenetikai vizsgálata alapján viszont a Xylodon nemzetség típusfaja [X. quercinus (Pers.) Gray], valamint a Basidioradulum radula külön ágon találhatóak, amely alapján jelen munkában ez utóbbi nevet preferálom.

A Basidioradulum nemzetség közel áll a Hyphoderma Wallr. génuszhoz, amelytől elsősorban az irpikoid himenofor alapján különíthető el (BERNICCHIA és GORJÓN 2010; NOBLES 1967). A Basidioradulum radula egy igen gyakori faj, amely saját megfigyeléseim, valamint hazai adatai alapján (pl. TRECKER és SzABÓ 2002) jellemzően vadcseresznye faanyagán képez termőtestet, de BERNICCHIA és GORJÓN (2010) szerint megtalálható egyéb lombosfán vagy ritkábban fenyőféléken is.

A Schizopora nemzetség taxonjai közül Európából három faj ismert: S. flavipora, $S$. paradoxa és $S$. radula (RYVARDEN és MELo 2014). A génuszon belül az egyes fajok termőtestei igen nagy változatosságot mutatnak és ez különösen igaz a $S$. paradoxa-ra. IGMÁNDY (1991) szerint ez a faj hazánkban mindenütt elöfordul és megjegyzi, hogy ,talán a leggyakoribb faj a taplók közül’. Ezt a megfigyelést a Mátrában, lomberdőkben végzett szisztematikus vizsgálataink is megerősítik (PAPP és mtsai. 2014a,b). Ennek ellenére vértesi előfordulására nem találtam publikált adatot, ami vélhetően a faj felismerhetőségének nehézségével magyarázható. A szintén gyakori $S$. flavipora elkülönítése a $S$. paradoxa s. str. fajtól föként a kisebb méretü spórái, valamint a többnyire szögletes pórusai alapján lehetséges.

A Schizopora radula pórusai szintén szögletesek, de többnyire tágabbak (1-3/mm), valamint a hifarendszere monomitikus és gyakoribbak a fejecskés hifavégek a himéniumban (Hallenberg 1983a). RyVARden és Melo (2014) szerint a S. radula Közép- és Dél-Európában gyakoribb faj, mint a $S$. paradoxa s. str., ugyanakkor megjegyzik, hogy jelenleg a két taxon egy változatos komplexet alkot. Vélhetően ezzel magyarázható, hogy Hallenberg munkája óta az elmúlt több mint 30 évben, ennek a fajnak egyedül az 1995-ös Cortinarius Kongresszuson gyüjtött taxonokat ismertető összefoglalóban a $S$. paradoxa változataként jelzett néven találtam 
hazai publikált adatát. Ennek a gyüjtésnek viszont adathiányos közlése miatt szükséges lenne revideálni a fungáriumi bizonyító példányát.

A Xylodon quercinus jellemzői, hogy termőteste raduloid, cisztidiumai fejecskések, valamint tölgyfajokhoz kötődik (BERNICCHIA és GORJÓN 2010). Ez az Európában igen gyakori faj hazánkban vélhetően az alulreprezentált taxonok közé tartozik.

\subsubsection{Polyporales Gäum.}

\section{Fomitopsidaceae Jülich}

(1) Antrodia P. Karst. - *A. albida (Fr.) Donk

(1) Buglossoporus Kotlába \& Pouzar - *B. quercinus (Schrad.) Kotlába \& Pouzar [三 Piptoporus quercinus (Schrad.) P. Karst.; = Buglossoporus pulvinus (Pers.) Donk] (I)

(1) Daedalea Pers. - D. quercina (L.) Pers.

(1) Fomitopsis P. Karst. $-{ }^{*}$ F. pinicola (Sw.) P. Karst.

(1) Laetiporus Murrill - L. sulphureus (Bull.) Murrill

(2) Postia Fr. (II) - **P. alni Niemelä \& Vampola; *P. stiptica (Pers.) Jülich

Taxonómiai és nómenklatúrai megjegyzések: (I) A Boletus quercinus Schrad. típusfaj alapján a kezdetben monotipikus Buglossoporus nemzetséget KOTLÁBA és POUZAR (1966) mikroszkopikus bélyegek alapján írta le. A nemzetség elkülönítését RYVARDEN és GILBERTSON (1994), valamint BERNICCHIA (2005) sem fogadta el és a fajt a Piptoporus P. Karst. nemzetségben tárgyalták. A filogenetikai vizsgálatok (pl. BINDER 2013) viszont igazolták a génusz létjogosultságát. A versengő bazionimok közül a legkorábban közölt binom a Boletus quercinus Schrad., amely alapján KoTLÁBA és POUZAR (1966) közölték a Buglossoporus quercinus nevet. DONK (1971) viszont a PERSOON (1799) által közölt Boletus pulvinus Pers. bazionim prioritása mellett érvel. RYVARDEN és GILBERTSON (1994) szerint viszont a $B$. pulvinus típuspéldánya nem vizsgálható, ezért megalapozottabbnak látják a $B$. quercinus (三 Piptoporus quercinus) név használatát. (II) a FRIES (1874) által közölt Postia Fr. génusz validitásának megítélése sokáig megosztotta a taxonómusokat (pl. GILBERTSON és RYVARDEN 1985, LARSEN és LOMBARD 1986, PIERI és RivOIRE 1998, RENVALL 1992, RYVARDEN 1991, RYVARDEN és GiLBERTSON 1994, WALKER 1996), ezért korábban a többnyire egyéves, fehéres színü termőtestet képző, monomitikus hifarendszerü fajokat egységesen a Tyromyces génuszba sorolták (DONK 1960, JAHN 1963, LOWE 1975). A Tyromyces nemzetség típusfaja, a Polyporus chioneus Fr. [三 Tyromyces chioneus (Fr.) P. Karst.] azonban fehérkorhasztó, ezért DAVID (1980) a barnakorhasztó fajokat a Spongiporus Murrill génuszba, míg JÜLICH (1982) ugyan ezt a csoportot a Postia Fr., GILBERTSON és RYVARDEN (1985) pedig az Oligoporus Bref. nemzetségekbe sorolták. Egy korábbi filogenetikai vizsgálat azt mutatta, hogy nincs különbség a Postia és Oligoporus nemzetségek között (YAO és mtsai. 1999); azonban egy újabb kutatás (KoTIRANTA és mtsai. 2009) szerint a két nemzetség különbözik és az Oligoporus nemzetségbe azon fajok tartoznak, amelyeknek vastagfalú és cianofil spóráik vannak. PILDAIN és RAJCHENBERG (2012) ITS és LSU szekvencia vizsgálatok alapján viszont ellentétes véleményre jutottak, mert eredményeik alapján a Postia s. lato fajok a 'Postia clade'-ba tartoznak függetlenül attól, hogy a spórák vékony vagy vastag falúak. ORTIZ-SANTANA és munkatársai (2013) vizsgálatai alapján a Postia csoport két fó kládot tartalmaz [/core postia klád, /sarcoporia klád], amelyek közül a központi postia kládon belül négy további szubklád különült el [/spongiporus klád, /oligoporus klád, /postia sensu stricto klád, /spongiporus undosus klád]. Az eredmények alapján ORTIZ-SANTANA és mtsai. (2013) elfogadják az Oligoporus, Postia és Spongiporus nemzetségeket is. 
A legtöbb Antrodia faj fenyőféléken fordul elö és viszonylag kevés taxon kötődik lombos fák faanyagához (SPIRIN és mtsai. 2013). A rezervátumba tölgyről gyüjtött Antrodia albida-t, mint ritka fajt RiMÓCZI és munkatársai (2009) a Bátorligeti Őslápról, nyárfa és kőris faanyagáról jelzik. BERNICCHIA (2005) szerint Európában egy gyakori polifág faj, amely alapján feltételezhető hogy hazánkban a kevéssé ismert, alulreprezentált taxonok közé tartozik.

A Buglossoporus quercinus könnyen felismerhető a halványbarnás kérgü, lédús, nagyméretü termőtestéről (21. ábra/A), amely jellemzően még élő vagy iniciális korhadási fázisban lévő tölgyeken terem. IGMÁNDY $(1968,1981)$ két hazai adatát említi, Debrecenből és Soporonból, Quercus faanyagáról. RIMÓCZI és munkatársai (1997) a Bátorligeti Öslápról jelzik, valamint SILLER (2002) munkájában Kálóról szokatlan szubsztrátumról (ismeretlen gyümölcsfaj) publikálta. Ismert adata van még a Csanyik-völgyből (DIMA és mtsai. 2010), valamint LUKÁCS (2010) több adatát publikálta a Mecsekből, Visegrádi-hegységből, Pilisből és a Budaihegységből, valamint egy salgóbányai tölgyesből. A szakirodalmi adatok alapján ezt az Európa szerte ritka fajt első alkalommal sikerült kimutatni a Vértes hegységből.
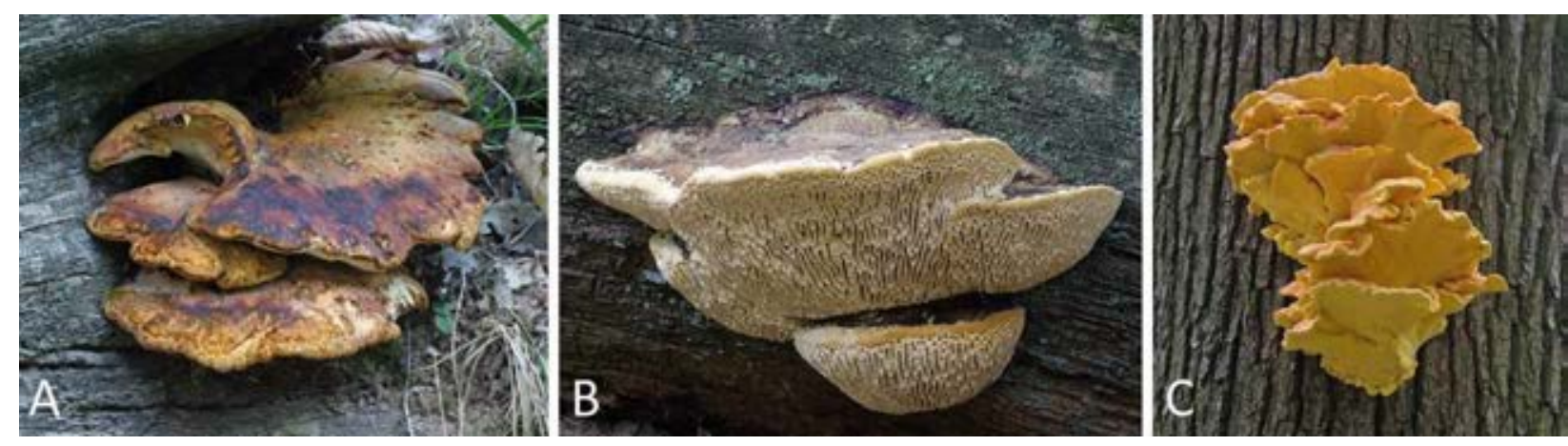

21. ábra. A Fomitopsidaceae családba tartozó barnakorhasztó taplófajok a Juhdöglő-völgy Erdőrezervátumban. A) A Buglossoporus quercinus termőtestei korhadt tölgyfarönkön (in situ); B) A Daedalea quercina áttelelö termőteste tölgyfarönkön (in situ); C) élö kocsánytalan tölgyön növö Laetiporus sulphureus rozettás termőtestei (in situ). Fotó: Papp V.

Szintén tölgyfákra specializálódott barnakorhasztó faj a Daedalea quercina, amely a hazai tölgyerdőknek egy igen gyakori taplófaja. A rezervátum területén is a tölgyfa rönkök egyik jellemző gombája volt, amely a megnyúlt pórusai alapján makroszkopikusan is könnyen azonosítható (21. ábra/B). A tráma azonban igen változatos lehet, ezért több mikológus különböző formáit különítette el (pl. BONDARTSEV 1953; DOMANSKI és mtsai. 1967; PARMASTO 1959). A Daedalea nemzetségnek Európában csak ez az egy faja honos (RYVARDEN és MELO 2014), de Dél-Amerikából, illetve Kínából az utóbbi években több tudományra új fajt írtak le a génuszból (pl. DRECHSLER-SANTOS és mtsai. 2012a; Li és CUi 2013; LINDNER és mtsai. 2011). 
A Fomitopsis pinicola a fenyőfélék egyik leggyakoribb évelő termőtestet képző nekrotróf taplófaja. Ezt a számos lombos fafajról is ismert barnakorhasztó taplót (IGMÁNDY 1991; RYVARDEN és MELO 2014) a rezervátum területén bükkfa rönkről gyüjtöttem.

A Laetiporus nemzetség taxonjai könnyen felismerhetőek az élénk narancsszínü, zsindelyszerüen összenövő termőtestek (21. ábra/C), hialin bazídiospórák, valamint a dimitikus hifarendszer és jellegzetes kötőhifák alapján (BANIK és mtsai. 2010; LINDNER és BANIK 2008). A rezervátumba főként élő és elhalt tölgyek faanyagán is megfigyeltem a L. sulphureus s. str. termőtesteit. Bár korábban is voltak már arra utaló megfigyelések, hogy az európai Laetiporusok egy fajkomplexet alkothatnak (BURDSALL és BANIK 2001; ČERNÝ 1989; RoGERS és mtsai. 1999), az európai tapló monográfiákban továbbra is az adatokat egységesen a génusz típusfajával, a L. sulphureus-al azonosították (BERNICCHIA 2005; RYVARDEN és GILBERTSON 1993). Az újabb filogenetikai vizsgálatok eredményei alapján viszont sikerült igazolni, hogy Európában jelenlegi ismereteink szerint három Laetiporus faj fordul elő: L. persicinus (Berk. \& Curt.) Gilb., L. montanus Černý ex Tomšovský \& Jankovský és L. sulphureus s. str. (GILBERTSON 1981; RYVARDEN és Melo 2014; TOMŠOVSKÝ és JANKOVSKÝ 2008; VASAITIS és mtsai. 2009).
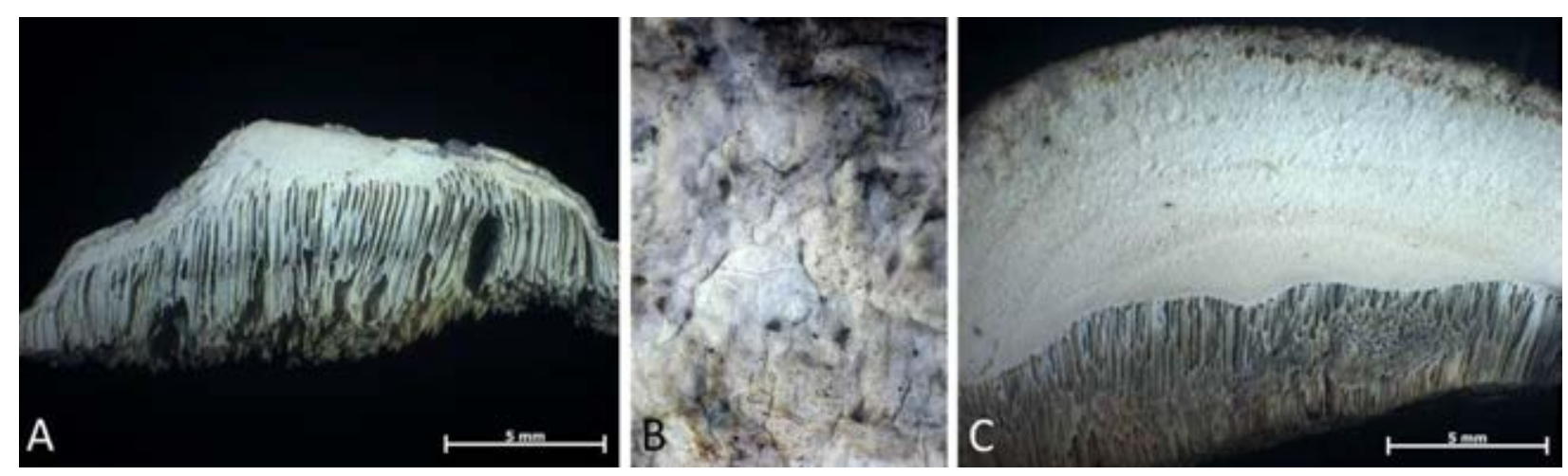

22. ábra. A Juhdöglő-völgy Erdőrezervátumban gyüjtött Postia alni (PV188) jellemző makromorfológiai bélyegei. A) $P$. alni termőtestének keresztmetszete (ex situ); B) P. alni sima kalapfelszíne szárított fungáriumi példányon (ex situ); C) Az Ócsai-turjános Erdőrezervátumban gyüjtött $P$. subcaesia (fung.: PV43) termőtestének keresztmetszete (ex situ). Fotó: Papp V.

A barnakorhasztó Postia nemzetség jellemző bélyegei az egyéves, többnyire puha, fehéres színű termőtest, a vékony falú, hialin spórák, valamint a monomitikus hifarendszer, csatos generatív hifákkal (JÜLICH 1982). A génusz fajai közül a $P$. stiptica mikroszkopikus bélyegek alapján könnyen összetéveszthető a $P$. guttulata (Peck) Jülich fajjal, amelynek a kalapfelszíne nem rücskös. A $P$. alni a bonyolult $P$. caesia komplexbe tartozik és a rezervátumban gyüjtött minta újnak bizonyult a hazai fungára nézve (PAPP 2014a), tekintve, hogy Magyarországról korábban ebből a csoportból csak a P. caesia (Schrad.) P. Karst. és P. subcaesia (A. David) 
Jülich fajoknak volt ismert előfordulási adata (pl. IGMÁNDY 1981, SZABÓ 2012). A fajkomplex taxonjaira jellemző morfológiai bélyegek, valamint a recens filogenetikai vizsgálatok (pl. ORTIZSANTANA és mtsai. 2013; PiLdAIn és RAJCHENBERG 2012) alapján a $P$. caesia típusfaj alapján a nemzetségen belül egy külön alnemzetséget különítettem el (PAPP 2014b):

- Postia subgen. Cyanosporus (McGinty) V. Papp, Mycotaxon 129 (2): 411 (2015) (MycoBank: MB 810903) [三 Cyanosporus McGinty, in Lloyd, Mycol. Notes 33: 436 (1909)]

A Cyanosporus alnemzetség európai fajain belül a Postia alni jellemző bélyegei, hogy a különböző elhalt lombos fafajokon növő termöteste kisméretü $[>3(-5) \mathrm{cm}]$, fehér vagy krémszínű, később enyhén kékes-szürke árnyalatú. A kalapfelszín matt vagy enyhén pelyhes, de nem bolyhos, szőrös (22. ábra/A-B), mint a szintén lombos fafajokon növő $P$. subcaesia fajé (22. ábra/C).

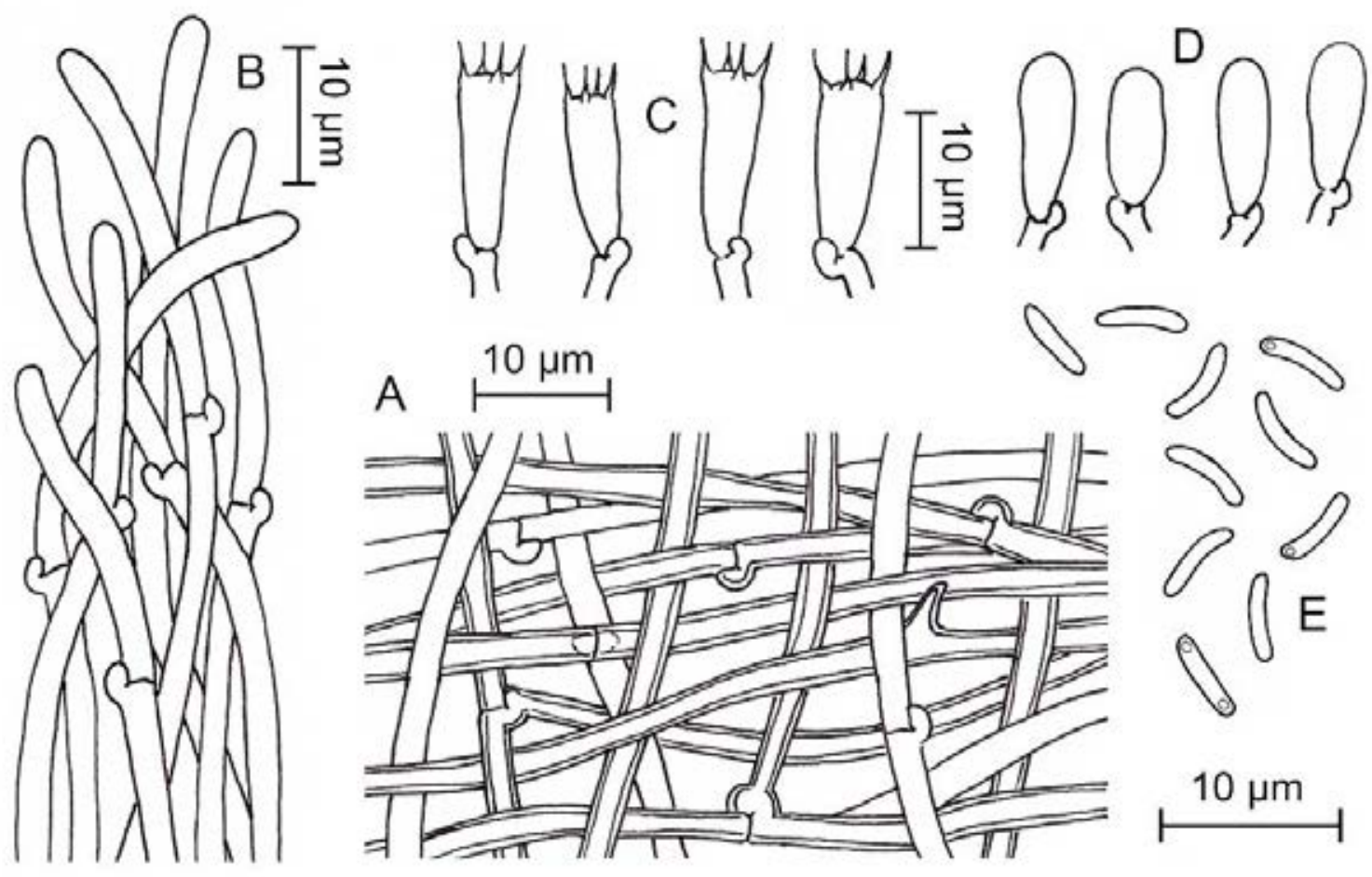

23. ábra. A rezervátumban gyüjtött Postia alni (PV188) mikromorfológiai bélyegei (PAPP 2014a alapján). A) monomitikus hifarendszer vékony- vagy kissé vastag falú csatos hifákkal; B) a csövek szélén található hifavégek; C) bazídiumok négy szterigmával; D) bazídiolumok E) bazídiospórák. Rajz: Papp V.

Bazídiospórái allantoidok, vékony falúak és kevesebb, mint 1,5 $\mu \mathrm{m}$ szélesek (NIEMELÄ és mtsai. 2001) (23. ábra). A típusfajt égerről írták le, de az újabb adatai alapján egy lombos fafajokon előforduló polifág fajnak tünik (ADAMČíK és mtsai. 2007; PIĄTEK 2003a). Európából a 
Posti alni-n kívül további négy olyan taxon ismert, amely a Cyanosporus alnemzetségbe tartozik (PAPP 2014a). A komplex legkorábban közölt faja a Posti caesia, amely Európában jellemzően fenyőfélék faanyagán nő. A P. subcaesia (A. David) Jülich makroszkopikusan hasonló, de jellemzően lombosfákon terem és a spórái keskenyebbek. A P. luteocaesia (A. David) Jülich egy ritka közép-európai faj, amely az eddigi adatai alapján Pinus fajokhoz kötődik. Jellemző makromorfológiai bélyege a termőtest élénksárga színe a kékes-szürkés elszíneződés mellett (NIEMElÄ és mtsai. 2004). A mediterráneumból leírt P. mediterraneocaesia M. Pierre \& B. Rivoire spórái a $P$. caesia és $P$. luteocaesia fajokhoz hasonlóan szélesebbek, mint 1,5 $\mu \mathrm{m}$ (PIERI és RIVOIRE 2005a).

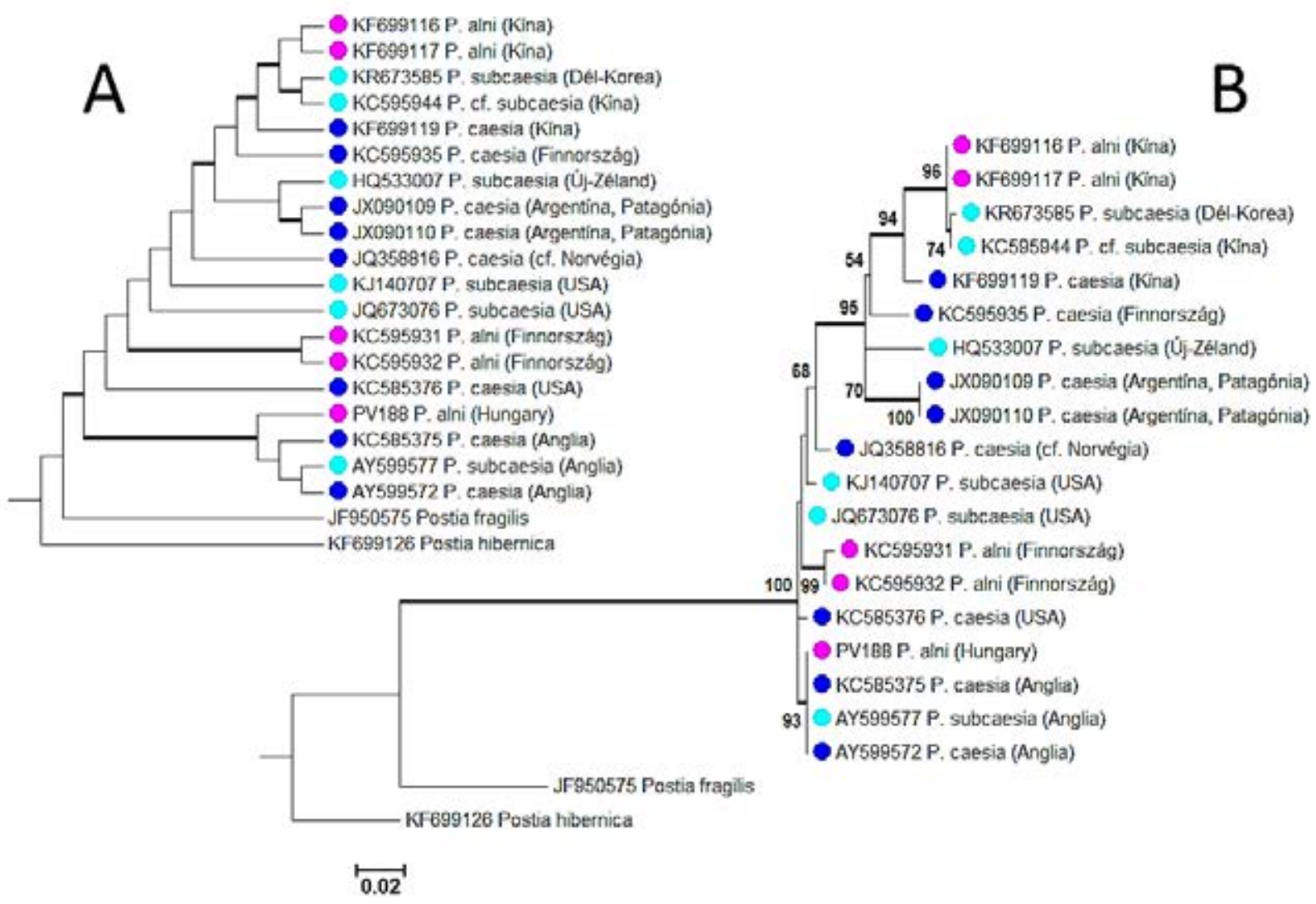

24. ábra. A Juhdöglő-völgy Erdőrezervátumban gyüjtött és morfológiai bélyegek alapján Postia alni-nak határozott minta (PV188), valamint a Postia subgen. Cyanosporus alnemzetség GenBank-i adatainak törzsfája ITS szekvenciák alapján. Az ágaknál szereplő számok a 50\%-nál magasabb ML bootstrap értékeket jelölik (a 70\%-nál magasabb ML bootstrap értékeket megvastagított vonal jelöli). A filogenetikai rekonstrukció Maximum Likelihood (ML) statisztikai becslés alapján a RAxML program segítségével GTRGAMMA szubsztitúciós modell valamint 1000 ismétléses „,rapid bootstrap” elemzés alkalmazásával készült. Az „A” jelü ábra a taxonok ághosszak nélküli topológiai törzsfáját mutatja. A „B” jelü törzsfán a mérce 100 karakterre eső 2 szubsztitúciónak megfelelő ághosszat jelöl.

A Juhdöglö-völgy Erdőrezervátumból gyüjtött és morfológiai bélyegek alapján Postia alninak határozott minta ITS szekvenciájának GenBank-i adatokkal való összehasonlítása 
ellentmondásos eredményt adott (24. ábra). A legközelebb álló minták az Egyesült Királyságból származó, YAO és munkatársai (2005) által P. caesia (AY599572, KC585375) és P. subcaesiaként (AY599577) azonosított minták voltak. Ezeknek a mintáknak a bizonytalan meghatározására utal, hogy a $P$. caesia-ként azonosított KC585375 minta lombos faanyagról származik, továbbá mindkét minta távol áll a skandináviai P. caesia gyüjtésektől (KC595935, JQ358816). A finn $P$. alni-ként azonosított minták ITS szekvenciái faji szintű (2\%-os) különbséget mutatnak. A kínai $P$. alni-ként azonosított minták pedig egy külön ágat alkotnak, amely nem meglepő tekintve, hogy ȚURA és munkatársai (2008) már korábban morfológiai bélyegek alapján is felhívták a figyelmet arra, hogy a kínai $P$. alni és $P$. subcaesia minták nem azonosak az Európából leírt fajokkal. WEI és DAI (2006) munkájukban például a kínai $P$. alni spórájának méreténél azt írják, hogy hossza kevesebb $4 \mu \mathrm{m}$, míg az európai minták esetében, a típusfaj leírásánál NIEMELÄ és munkatársai (2001) a 4.4-6 بm spórahosszt közölték.

A fajkomplex bonyolultságát mutatja, hogy a Pildain és RajChenberg (2012) által Postia caesia-nak határozott argentin (JX090109, JX090110), valamint az Új-Zélandon gyüjtött $P$. subcaesia minták az ITS régiók alapján szintén külön fajoknak tünnek.

Összességében a jelen munkában vizsgált minták filogenetikai elemzése alapján az alábbi következtetéseket vonhatjuk le: (1) feltételezhető, hogy morfológiai bélyegek alapján tévesen meghatározott minták hibás név alatt lettek a GenBank-ba feltöltve, (2) valamint az adatbázisban nem található $P$. mediterraneocaesia és $P$. luteocaesia fajokhoz tartozó szekvencia, amely bizonytalanná teszi és tovább nehezíti az európai minták faji szintű azonosítását, (3) az amerikai és ázsiai $P$. caesia-ként azonosított taxonok szekvenciái különböznek az európai mintákéitól, ezért szükségesnek látszik az Európán kívül leírt, korábban a $P$. caesia faj szinonimájaiként kezelt taxonok revideálása, (4) a típuspéldányok vizsgálata nélkül az egyes taxonok fajhatárai jelenleg molekuláris módszerekkel nem tisztázhatók.

Megvizsgálva a bazionimok leírása alapján Postia caesia komplexbe tartozó fajok taxonómiai és nómenklatúrai helyzetét, négy olyan afrikai [Oligoporus africanus Ryvarden], malajziai [Tyromyces amyloideus Corner; T. coeruleivirens Corner] és dél-amerikai [Polyporus caesioflavus Pat.] locus classicus-al rendelkező taxont találtam, amelyek a Postia nemzetség nómenklatúrai és szisztematikai helyzetének recens filogenetikai munkákon alapuló tisztázása következtében helyes rendszertani besorolása új binomok létrehozását indokolta (PAPP 2014b):

- Postia africana (Ryvarden) V. Papp, Mycotaxon 129 (2): 411 (2015) (MycoBank: MB810904) [三 Oligoporus africanus Ryvarden, Mycotaxon 31 (2): 407 (1988)]

- Postia amyloidea (Corner) V. Papp, Mycotaxon 129 (2): 411 (2015) (MB810905) [Tyromyces amyloideus Corner, Beihefte zur Nova Hedwigia 96: 160 (1989)] 
- Postia caesioflava (Pat.) V. Papp, Mycotaxon 129 (2): 411 (2015) (MB810907) [三 Polyporus caesioflavus Pat., Bulletin de la Société Mycologique de France 8 (2): 114 (1892)]

- Postia coeruleivirens (Corner) V. Papp, Mycotaxon 129 (2): 411 (2015) (MB810908) [三 Tyromyces coeruleivirens Corner, Beihefte zur Nova Hedwigia 96: 163 (1989)]

\section{Ganodermataceae (Donk) Donk}

(3) Ganoderma P. Karst. - G. applanatum (Pers.) Pat. [= G. lipsiense (Batsch) G.F. Atk.] (I), *G. cupreolaccatum (Kalchbr.) Z. Igmándy [= G. pfeifferi Bres.] (II), G. lucidum (Curtis) P. Karst. [三 G. lucidum (Leyss.) P. Karst.] (III)

Taxonómiai és nómenklatúrai megjegyzések: (I) a Ganoderma applanatum [G. lipsiense (Batsch) G.F. Atk.] nevezéktani helyzetének tisztázása érdekében több cikket is közöltek a Taxon szaklapban (REDHEAD és mtsai. 2006; NiEMELÄ és MietTinen 2008; DEMOUlin 2010), míg végül a gombák nómenklatúrai bizottsága (Nomenclature Committee for Fungi) szankcionálta a Boletus applanatus Pers. (PERSOON 1799) binomot a korábbi és ez alapján prioritást élvező B. lipsiensis Batsch (BATSCH 1786) névvel szemben (NORVELl 2010, 2011a). (II) Kalchbrenner Károly a Ganoderma cupreolaccatum holotípusát Polyporus cupreolaccatus névvel jelölte, de Wettstein a faj publikálása során P. laccatus-ra egyszerüsítette (WETTSTEIN 1885). Ez a név viszont egy későbbi homonimája a Polyporus laccatus (Timm) Pers. fajnak, amely a Ganoderma lucidum szinonimja. Tekintettel arra, hogy az eredeti leírásban szerepel a „cupreolaccatus” faji jelző is, a $P$. cupreolaccatus Kalchbr. binom közlése érvényes. Európában viszont vélhetően ugyan erre a fajra széleskörben használt név a Ganoderma pfeifferi Bres., amelyet PATOUILLARD (1889) jegenyefenyőről publikált. A típusleírások alapján a két binomot szinonimnak tekinthetjük, viszont a későbbiekben a két taxon típuspéldányának összehasonlítása szükséges lenne az azonosság egyértelmü bizonyításához. Amennyiben elfogadjuk, hogy a két binom azonos fajt takar, a G. cupreolaccatum név prioritást élvez, tekintve, hogy a Polyporus cupreolaccatus bazionim korábbi, mint a Ganoderma pfeifferi Bres. (IGMÁNDY 1968; PAPP és SILler 2011). (III) KARSTEN (1881) a génusz leírása során a G. lucidum kombinációt nem CURTIS (1781), hanem LEYSSER (1783) típusa alapján adta meg. Ennek oka lehet, hogy a Flora Halensis első kiadásában Friedrich Wilhelm von Leysser már publikálta ezt a fajt Boletus flabelliformis néven (LEYSSER 1761). A második kiadásban azonban Curtis munkája alapján a faj nevét megváltoztatta $B$. lucidus-ra. Ezért véleményem szerint a $G$. lucidum s. str. tipizálásánál - amely a nemzetség további filogenetikai vizsgálatához mindenképpen szükséges lesz - célszerü lenne Leysser közlését konzerválni és az általa megadott leírás és lelőhely alapján epitípust kijelölni.

A Ganoderma lucidum a nemzetség típusfaja (KARSTEN 1881), de ennek ellenére taxonómiai helyzete bizonytalan, tekintve, hogy a morfológiailag hasonló fajokat gyakran tévesen világszerte G. lucidum-ként azonosítják (MonCALVO és mtsai. 1995; SEO és KIRK 2000), így sok esetben nehéz meghatározni, hogy mely taxonok azonosak a CURTIS (1781) által közölt Boletus lucidus s. str. [三 Ganoderma lucidum] fajjal (PARK és mtsai. 2012; SzEDLAY 2002; WASSER 2005). Számos újabb munkában molekuláris vizsgálatokkal igazolták, hogy a kínai termesztett és vadon termő „Ganoderma lucidum” minták különböznek az európai G. lucidum s. str. mintáktól (CAO és mtsai. 2012, WANG és mtsai. 2009, WANG és mtsai. 2012). Az európai Ganoderma fajok közül jelenleg két további taxon tartozik a G. lucidum komplexbe (RYVARDEN 
és Melo 2014); a főként jegenyefenyőn növő G. carnosum Pat. és a vörösfenyőhöz kötődő $G$. valesiacum Boud. (JAHN és mtsai. 1980; PAPP és SzABÓ 2013). Magyarországról a két faj közül csak a G. carnosum-nak van ismert előfordulási adata (SZABÓ 2012; PAPP és SzABÓ 2013).

A Ganoderma resinaceum Boud. a G. lucidum-hoz hasonlóan szintén egyéves termőtestet fejleszt (IGMÁNDY 1991, MATTOCK 2001, MoHANTY és mtsai. 2011), de egyes szerzők szerint a termőteste évelő (BERNICCHIA 2005, RYVARDEN és GILBERTSON 1993). A G. resinaceum mikroszkopikus bélyegek alapján is nagyon hasonlít a G. lucidum-hoz. IGMÁNDY (1991) szerint a G. resinaceum a G. lucidum-tól a tönk hiánya, a kalap mérete és a fakultatív nekrotróf jellege alapján különíthető el. Az említett bélyegeken kívül saját megfigyeléseim alapján a $G$. resinaceum húsának zónázottsága is egy jellemző makromorfológiai bélyeg.

Az évelő és matt kéreggel rendelkező Ganoderma applanatum (25. ábra/A) hasonló megjenésü, mint a G. adspersum, amely szintén a G. applanatum-australe komplexbe tartozik. A G. applanatum a $G$. adspersum-tól kisebb spórái $(6-8,5 \times 4,5-6 \mu \mathrm{m})$, vékonyabb kérge (kevesebb, mint 0,5 mm), a húsban található fehéres színű micéliumok jelenléte, valamint a tráma csövei közötti jól látható réteg alapján különíthető el (LEONARD 1998, MARRIOTT 1998, RYVARDEN és GILBERTSON 1993). A morfológiai bélyegeken kívül a G. applanatum föként erdei környezetben, holt faanyagon található, míg a G. adspersum főként élő lombos fákon növekszik és gyakran fordul elő városi környezetben (IGMÁNDY 1991; PAPP 2013b; PAPP és SZABÓ 2013).
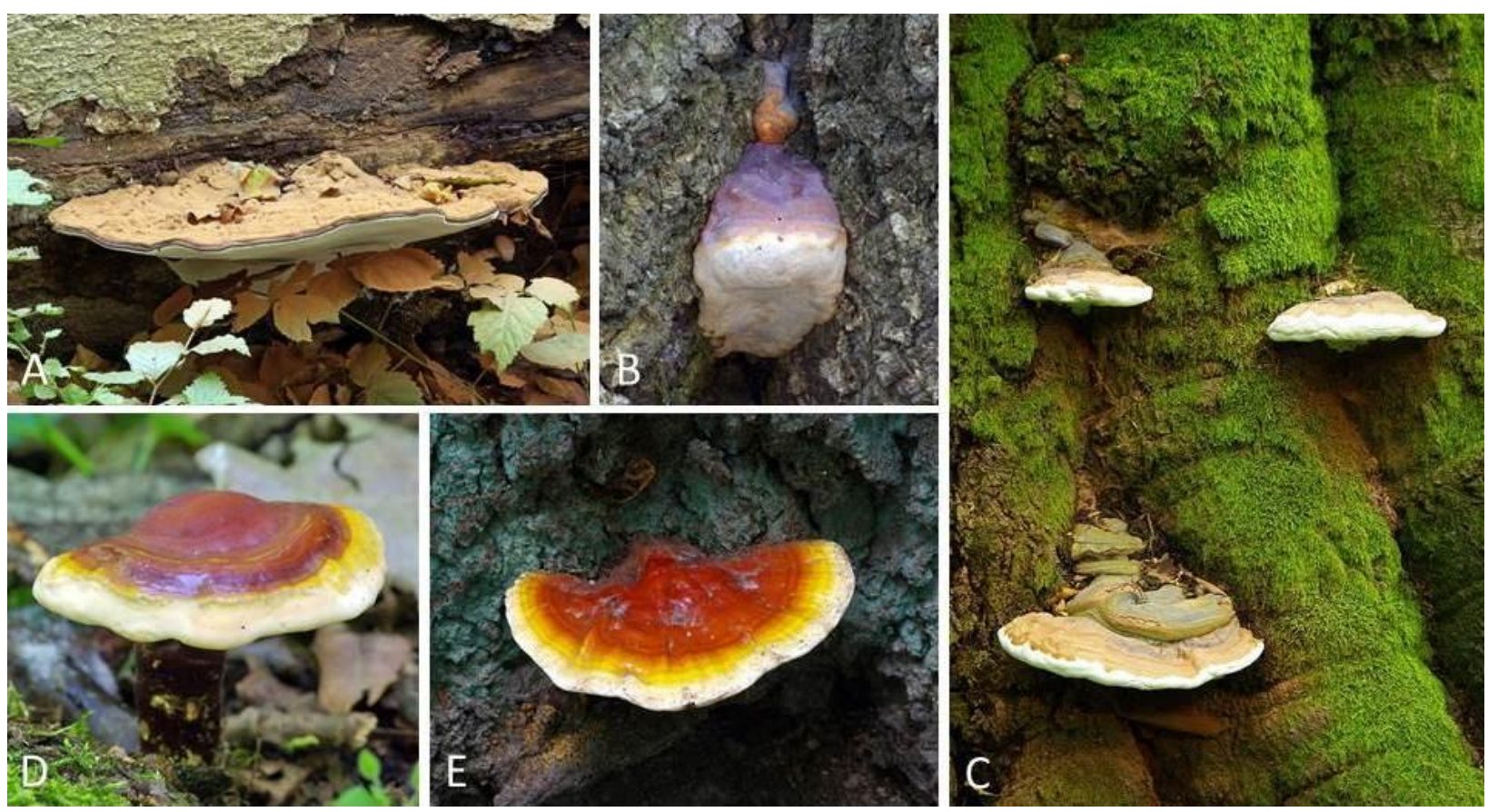

25. ábra. Ganoderma fajok sporokarpiumai a Juhdöglö-völgy Erdőrezervátumban. A) G. applanatum évelő sporokarpiuma bükkfa rönkön (in situ); B) fiatal G. cupreolaccatum termőtest élö bükkfa törzsén (in situ); C) többéves G. cupreolaccatum termőtestek nagyméretü élő bükkfa törzsén (in situ); D) talajban lévő tölgy faanyagán növő $G$. lucidum termőtest (in situ); E) tönk nélküli $G$. cf. lucidum termőtest tölgyfa tövében (in situ). Fotók: Papp V. 
A Ganoderma cupreolaccatum európai természetközeli bükkerdök karakterfaja, amely főként öreg, élő bükkfák tövében képez termőtestet (25. ábra/B-C) (CHRISTENSEN és mtsai. 2004; RYVARDEN és GILBERTSON 1993). Európai adatai alapján a bükkön kívül ritkán más lombos fafajokon is megjelnehet (PAPP és SZABÓ 2013; PETERSEN 1987; RYvARden és GILBERTSON 1993; SzCZEPKOWSKI és PIĘTKA 2003). Annak ellenére, hogy a G. cupreolaccatum évelö termőtestének öregebb példányai (25. ábra/C), hasonló megjelenése miatt könnyen összetéveszthető a G. applanatum-mal (NIEMELÄ és MIETTINEN 2008), a molekuláris vizsgálatok alapján a $G$. resinaceum-hoz áll közel (MoNCALVO és mtsai. 1995). Jellemző morfológiai bélyegei a viaszos kéreg, a sötétbarna hús és a bazídiospórák mérete. Hazai adatai többnyire bükkös erdőrezervátumokból származnak (IGMÁNDY 1970b; PÁL-FÁM és LUKÁCs 2002; PAPP és SzABÓ 2013; SILLER 2004), de egy az MTM Növénytárában található mintát (BP 20323) juharról gyüjtöttek, míg Igmándy Zoltán gyüjteményében (IZ 639) megtalálható egy tölgyön nött termőtest fungáriumi anyaga.

\section{Grifolaceae Jülich}

(1) Grifola Gray - *G. frondosa (Dicks.) Gray

A Grifola frondosa nagyméretü, egyéves összetett termőtestet fejleszt, amely jellemzően tuskókon vagy élö fák gyökerén, illetve tövében fejlödik. A makroszkopikusan hasonló megjelenésű Meripilus giganteus-tól eltérően hifái csatosak, valamint a termőtest sérülésre nem feketedik el. Annak ellenére, hogy a Grifola frondosa-t Clusius 1601-ben megjelent „Fungorum in Pannoniis observatorum brevis historia” címü müvében „bokros gomba” néven már említi, valamint az ábrája megtalálható az 1611-ben megjelent Clusius-kódexben is, csak néhány előfordulási adata ismert hazánkból (FőDI és PAPP 2013; RUDOLF és mtsai. 2015). A rezervátumban egy alkalommal kocsánytalan tölgy alatt dokumentáltam jelenlétét.

\section{Ischnodermataceae Jülich}

(1) Ischnoderma P. Karst. [= Lasiochlaena Pouzar] (I) - I. resinosum (Schrad.) P. Karst.

Taxonómiai és nómenklatúrai megjegyzések: (I) POUZAR (1990) véleménye szerint az Ischnoderma resinosum (Fr.) P. Karst. típusa azonos a Fomitopsis pinicola (Sw.) P. Karst. fajjal, ezért közölte a Lasiochlaena nemzetséget a $L$. anisea Pouzar [= Ischnoderma resinosum (Schrad.) P. Karst. sensu auct.] típusfaj alapján. A nemzetközi szakirodalom (pl. BERNICCHIA 2005; RYVARDEN és MELO 2014) viszont továbbra is az Ischnoderma génusz használatát preferálja. 
Az Ischnoderma resinosum (26. ábra) számos szakirodalomban bükkhöz kötődő fajként szerepel, amely a morfológiailag nagyon hasonló, jellemzően fenyőféléken növő I. benzoinumtól gyakran a szubsztrátum alapján különítettek el (POUZAR 1971).

Az Ischnoderma resinosum a Juhdöglö-völgy Erdőrezervátum területén gyakori fajnak látszik. KoszKA (2014) Mór közelében lévő Harmatos-völgyből szintén bükkfarönkről gyüjtötte. HEILMANN-CLAUSEN és WALLEYN (2007) szerint a közép-európai természetközeli bükkösökben meglehetősen gyakori faj. Szakirodalmi adatok alapján a bükk mellett ritkán megtalálható egyéb lombos fafajon is (KOTIRANTA és mtsai. 2007), amelyet alátámaszt, hogy az erdőrezervátumban tölgy faanyagán is megtaláltam (26. ábra/B).
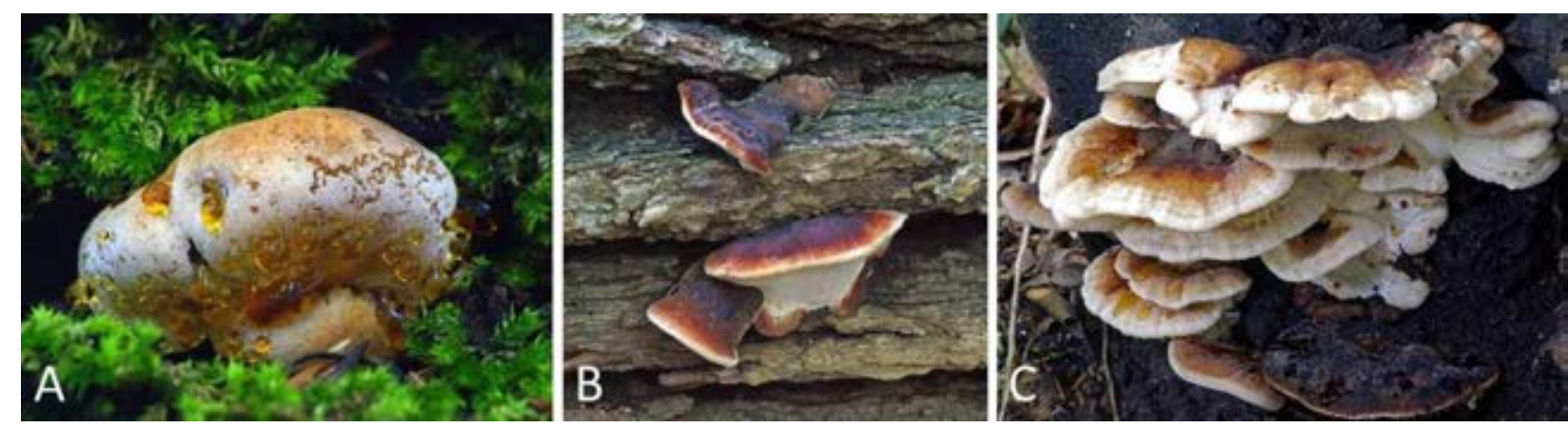

26. ábra. Az Ischnoderma resinosum termőtestei a Juhdöglő-völgy Erdőrezervátumban. A) fejlődő, guttuláló termőtest (in situ); B) I. resinosum termőtestei iniciális korhadási fázisban lévő tölgyfarönkön (in situ); C) bükkfarönkön csoportosan növő termötestek (in situ). Fotó: Papp V.

\section{Meripilaceae Jülich}

(1) Meripilus P. Karst. - Meripilus giganteus (Pers.) P. Karst.

(2) Physisporinus P. Karst. - *P. sanguinolentus (Alb. \& Schwein.) Pilát [三 Rigidoporus sanguinolentus (Alb. \& Schwein.) Donk] *P. vitreus (Pers.) P. Karst. [三 Rigidoporus vitreus (Pers.) Donk]

A Meripilus giganteus a rezervátumban igen gyakori volt élő és már elhalt bükkfák tövében, illetve faanyagán (27. ábra). Erről a fajról IGMÁNDY (1981) azt írja, hogy hazánkban általánosan elterjedt és kórtani jelentősége ugyan még nem tisztázott, de „idős bükkösökben valószínüleg tőkorhasztó”. SILLER (1986) bükkös állományokban végzett vizsgálatai alapján a fakultatív paraziták (nekrotróf paraziták) között említi és eredményei alapján a nagy-kerekhegyi gazdasági bükkösben az egyik legnagyobb produkciójú faj volt. A Kékes Erdőrezervátum ritka fajait ismertető cikkében pedig megjegyzi (SILLER 1999), hogy véleménye szerint az öreg erdők ritkulása miatt veszélyeztetett faj. Ugyanakkor öreg, rezervátum jellegü bükkerdőkben gyakori fajnak látszik (pl. IGMÁNDY 1991), amelynek megfigyeléseim szerint jelentős szerepe lehet a 
lékesedésben, azáltal, hogy a nagyméretü élö öreg fák gyökereit elkorhasztja, amelyeknek stabilitása így csökken és idő elött gyökértányérostul kidőlhetnek (27. ábra/C).
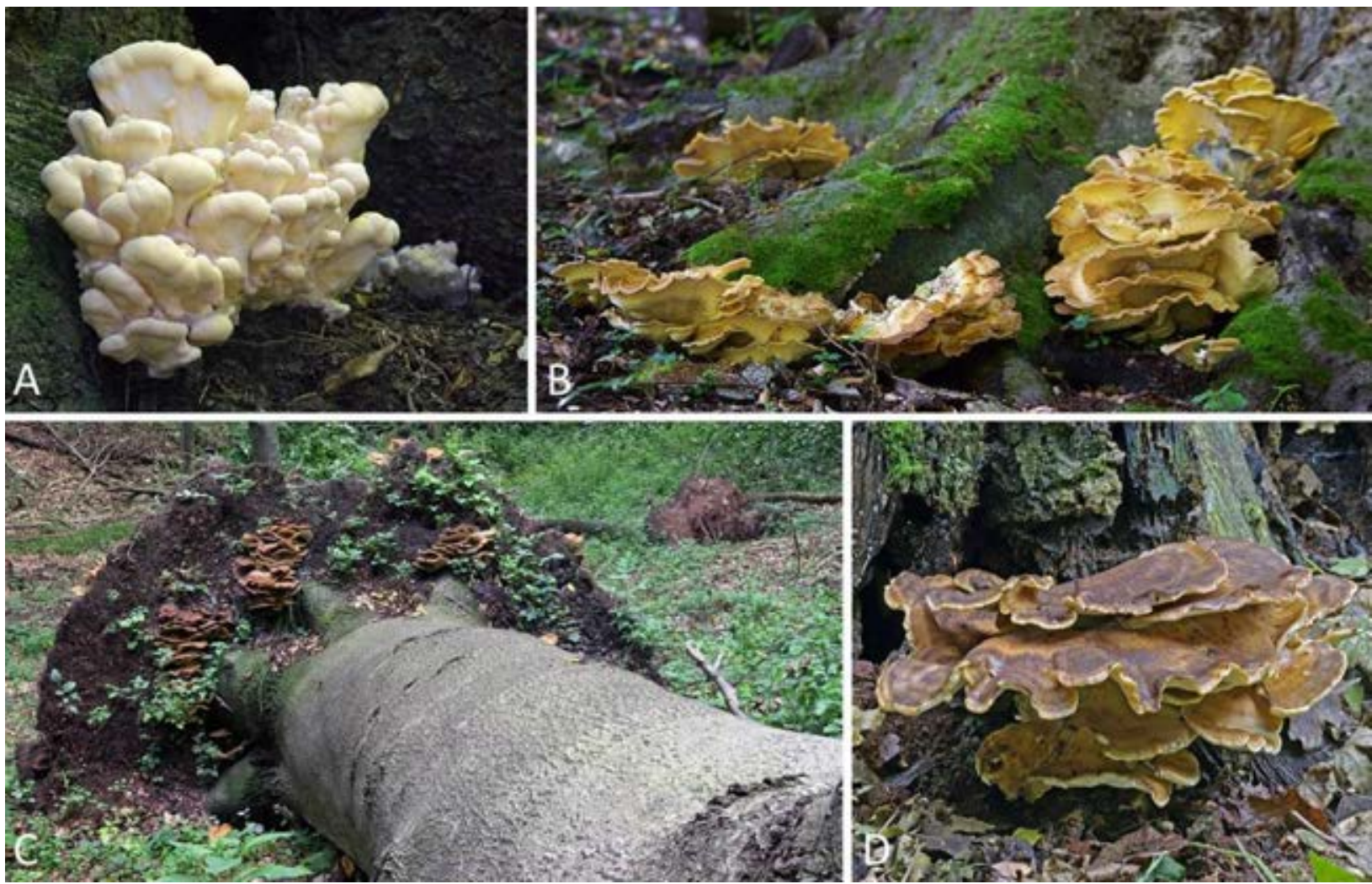

27. ábra. A Meripilus giganteus bazídiokarpiumai a Juhdöglö-völgy Erdőrezervátumban. A) fiatal, még fejlődő termőtest élő nagyméretü bükkfa tövében (in situ); B) talpon álló elhalt bükkfa tövében és gyökerein növekvő termőtestek (in situ); C) gyökértányorostul kifordult nagyméretű bükkfa gyökérnyakán lévő Meripilus giganteus termőtestek (in situ); D) kifejlett termőtest erősen korhadt bükkfatuskó tövében (in situ). Fotók: Papp V.

A Physisporinus nemzetség mindkét Európában honos faját megtaláltam az erdörezervátum területén. A P. sanguinolentus fehéres reszupinátus termőtestének jellemzője, hogy sérülésre vörösesen elszíneződik (28. ábra/A), amely tulajdonság alapján már a terepen is felismerhető. Ez a polifág faj hazánkban korábban igen ritkának látszott (IGMÁNDY 1981; RIMÓcZI 1997; RIMÓCZI és mtsai. 1999) és az utóbbi években is csak néhány előfordulási adatát publikálták (pl. RIMÓCZI és mtsai. 1997; NAGY 2004; NAGY és GORLICZAI 2007).

A Physisporinus vitreus-nak (28 ábra/B) korábbi magyarországi adatai bányákból és pincékből származnak (MOESZ 1941; IGMÁNDY 1981). Természetes környezetben való előfordulására utaló adatot az 1995-ben megrendezett Cortinarius Kongresszus fajlistáján találunk, valamint SILLER és munkatársai (2013) is gyüjtötték az Örségben. A P. vitreus-t gyakran összetévesztik a Rigidoporus undatus (Pers.) Donk fajjal, amelynek jellegzetes többnyire kristályokkal borított koronás cisztidiumai vannak (RYVARDEN és MELO 2014). 

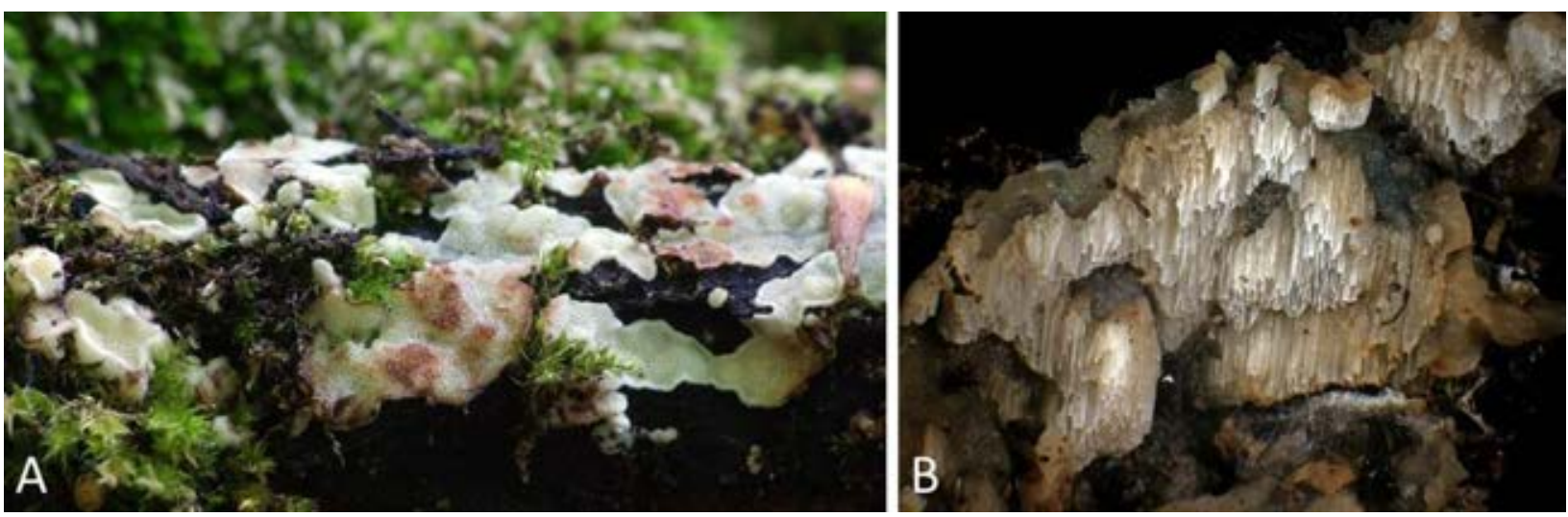

28. ábra. A Juhdöglö-völgy Erdőrezervátumból gyüjtött Physisporinus fajok termőtestei. A) a $P$. sanguinolentus sérülésre vörösödő termőteste erősen korhadt bükkfarönk faanyagán (in situ); B) A $P$. vitreus termőtestének ex situ fotódokumentációja. Fotó: Papp V.

Meruliaceae Rea s. lato [incl. Irpicaceae Spirin \& Zmitr.; Phanerochaetaceae Jülich]

(1) Bjerkandera P. Karst. - B. adusta (Willd.) P. Karst.

(1) Byssomerulius Parmasto $-{ }^{*}$ B. corium (Pers.) Parmasto [三 Meruliopsis corium (Pers.) Ginns]

(2) Ceriporia Donk $-{ }^{*} \boldsymbol{C}$. excelsa (S. Lundell) Parmasto, ${ }^{*} \boldsymbol{C}$. purpurea $(\mathrm{Fr}$.) Donk

(1) Donkia Pilát (I) $-* *$ D. pulcherrima (Berk. \& M.A. Curtis) Pilát [三 Climacodon pulcherrimus (Berk. \& M.A. Curtis) Nikol.]

(1) Emmia Zmitr., Spirin \& Malysheva (II) - *E. latemarginata (Durieu \& Mont.) Zmitr., Spirin \& Malysheva [三 Oxyporus latemarginatus (Durieu \& Mont.) Donk]

(1) Gelatoporia Niemelä - *G. pannocincta (Romell) Niemelä [三 Ceriporiopsis pannocincta (Romell) Gilb. \& Ryvarden]

(1) Irpex Fr. - I. lacteus (Fr.) Fr.

(3) Phanerochaete P. Karst. - **P. aculeata Hallenb. [= P. raduloides J. Erikss. \& Ryvarden] (III), $\boldsymbol{P}$. cf. sanguinea (Fr.) Pouzar, * P. velutina (DC.) P. Karst.

(6) Phlebia Fr. [= Merulius Fr.; = Mycoacia Donk] - **P. fuscoatra (Fr.) Nakasone; **P. nothofagi (G. Cunn.) Nakasone [三 Mycoacia nothofagi (G. Cunn.) Ryvarden] (IV); P. radiata Fr. $[=P$. merismoides (Fr.) Fr.] (V); *P. rufa (Pers.) M.P. Christ.; P. tremellosa (Schrad.) Nakasone \& Burds., *P. uda (Fr.) Nakasone [三 Mycoacia uda (Fr.) Donk]

(1) Porostereum Pilát - *P. spadiceum (Pers.) Hjortstam \& Ryvarden [三Lopharia spadicea (Pers.) Boidin]

(1) Trametopsis Tomsovský (VI) - *T. cervina (Schwein.) Tomsovský [三 Trametes cervina (Schwein.) Bres.]

Taxonómiai és nómenklatúrai megjegyzések: (I) a monotipikusként leírt Donkia nemzetséget PILÁT (1936) a Hydnum pulcherrimum Berk. \& M.A. Curtis típusfaj alapján közölte. Később MAAS GEESTERANUS (1967) szintén ebbe a génuszba sorolta a H. sanguineum Beeli fajt, majd néhány évvel később közölte a Climacodon sanguineus (Beeli) Maas Geest. kombinációt (1971). Jelenleg 
széleskörben elfogadott, hogy a Donkia és Climacodon nemzetségek szinonimok (pl. BERNICCHIA és GORJón 2010; KIRK és mtsai. 2008). (II) Az Emmia nemzetséget [típus: Polyporus latemarginatus Durieu \& Mont.] morfológiai bélyegek alapján ZMITROVICH és munkatársai (2006) különítették el. Ezt a taxonómiai koncepciót később ZMITROVICH és MALYSHEVA (2014) filogenetikai vizsgálatok alapján is igazolták. (III) A MycoBank adatbázis szerint a Phanerochaete aculeata érvényes neve a korábban közölt P. magnoliae (Berk. \& M.A. Curtis) Burds. BERNICCHIA és GORJÓN (2010) viszont a két taxont külön fajként kezeli. (IV) Az Új-Zélandról leírt Phlebia nothofagi-tól [三Odontia nothofagi G. Cunn.] (CUNNINGHAM 1959), REID (1963) korábban morfológiai bélyegek alapján elkülönítette az Odontia nothofagi var. australiensis D.A. Reid változatot, amelyet Hjortstam a Mycoacia [Mycoacia nothofagi var. australiensis (D.A. Reid) Hjortstam] (HJORTSTAM és LARSSON 1995), COURTECUISSE (2008) pedig a Phlebia nemzetségbe helyezett át [Phlebia nothofagi var. australiensis (D.A. Reid) Courtec]. (V) A Merulius merismoides Fr. binomot Fries 1818-ban publikálta (FRIES 1818), majd későbbi munkájában (FRIES 1821) közölte a Phlebia merismoides kombinációt. Ugyan ebben a müvében írta le a fakultatív szinonimoknak tekinthető $P$. contorta Fr. és $P$. radiata Fr. fajokat. Jelenleg ez utóbbi nevet használják széles körben, viszont a $P$. merismoides binomnak lenne prioritása. (VI) A Trametopsis cervina faj Trametes génusztól való leválasztását TOMŠOvSKÝ (2008) javasolta LSU és SSU régiók alapján végzett filogenetikai vizsgálat alapján. RYVARDEN és MELO (2014) nem fogadják el a Trametosis génusz elkülönítését és a $T$. cervina-t továbbra is a Trametes nemzetségen belül tárgyalják. BINDER és munkatársai (2013) több lokuszon végzett filogenetikai vizsgálata viszont igazolta Tomšovský taxonómiai koncepcióját, és eredményeik alapján ez a faj a /Phlebioid kládba tartozik.

A család poroid termőtestet képző taxonjai közül a polifág kozmopolita Bjerkandera adusta Európában szinte minden fás élőhelyen megtalálható (RYVARDEN és MELO 2014). Megfigyeléseim alapján a rezervátumban is a leggyakoribb taplók közé tartozik.

A Byssomerulius sima vagy merulioid trámájú taxonjainak jellemző mikroszkopikus bélyegei a monomitikus hifarendszert alkotó csat nélküli generatív hifák, valamint, hogy a spóráik hialinok, simák, inamilod és indextrinoidok. A B. corium egy nagyon gyakori, lombos fafajokon megjelenő polifág faj. A makroszkopikusan hasonló megjelenésü $B$. hirtellus (Burt) Parmasto fajtól a többnyire kalaposodó termőteste, a cisztidiumok hiánya, valamint a nagyobb spórái alapján különíthető el (BERNICCHIA és GORJÓN 2010).

A Ceriporia nemzetségbe egyéves, reszupinátus termőtestet képző taxonok tartoznak, amelyek jellemzői, hogy monomitikus hifarendszerüket főként szimplán szeptál generatív hifák alkotják, valamint a himéniumban nem találhatók cisztidiumok vagy más steril sejtek. A $C$. excelsa morfológiai bélyegek alapján való elkülönítése a nemzetség többi fajától a pórusok (2$3 / \mathrm{mm})$ és a spórák mérete $(3,5-5 \times 2-2,5 \mu \mathrm{m})$, valamint a termőtest színének (rózsaszín) száradás során bekövetkező változása alapján lehet. A C. purpurea jellemző bélyegei a termőtest lilás színe mellett a pórusok nagysága $(3-4 / \mathrm{mm})$, valamint a bazídiospórák viszonylag nagy mérete $(5-7 \times 2-2,5 \mu \mathrm{m})$ és allantoid alakja (RYVARDEN és MELO 2014). Igmándy munkássága során három Ceriporia fajt mutatott ki hazánkból: C. excelsa, C. mellita (Bourdot) Bondartsev \& Singer és C. viridans (Berk. \& Broome) Donk (IGMÁnDy 1981; SzABÓ 2012). A C. purpurea-t NAGY (2004), valamint NAGY és GORLICZAI (2007) több élőhelyről kocsányos tölgy és enyves 
éger ágakról jelzik. SILLER (2004) a Ceriporia excelsa-t a határozási nehézségek miatt a $C$. viridans-al együtt tárgyalta ( $C$. excelsa s. lato), továbbá közölte a $C$. reticulta (Hoffm.) Domanski fajt az Őserdő és Kékes erdőrezervátumokból. A Ceriporia nemzetség hazánkban az alulkutatott taplócsoportok közé tartozik, amely vélhetően azzal magyarázható, hogy a határozás a termőtestek makroszkopikus bélyegei alapján a legtöbb esetben nem lehetséges és olykor mikroszkopikus jellemzőik alapján is nehézkes.

A Climacodon P. Karst. nemzetséget KARSTEN (1881) írta le a Hydnum septentrionale Fr. [三 Climacodon septentrionalis (Fr.) P. Karst.] típusfaj alapján. A génusz jellemzői az egyéves konzolos hidnoid termőtest, a csatos generatív hifákból álló monomitikus hifarendszer, valmint a sima, vékonyfalú elliptikus bazídiospórák (BERNICCHIA és GORJÓN 2010). Makroszkopikusan hasonló termőtestet képeznek a Hericium fajok, amelyek azonban amilod spórájúak (HALlENBERG 1983b; JAHN 1965b). A két nemzetség filogenetikai szempontból is távol áll egymástól; a Hericium típusfaja [Hydnum coralloides Scop.] a Russulales rendbe, míg a Climacodon septentrionalis a taplóalkatúak (Polyporales) közé tartozik (LARSSON 2007).

A Climacodon pulcherrimus (29. ábra) egy kozmopolita elterjedésü faj, de a szakirodalmi adatok alapján főként a trópusi területekre eső súlypontokkal (MORENO és mtsai. 2007). Európából ismert Franciaországból (CANDOUSSEAU 1981), Oroszországból (PILÁT 1933) és Spanyolországból (SALCEDO és mtsai. 2006).
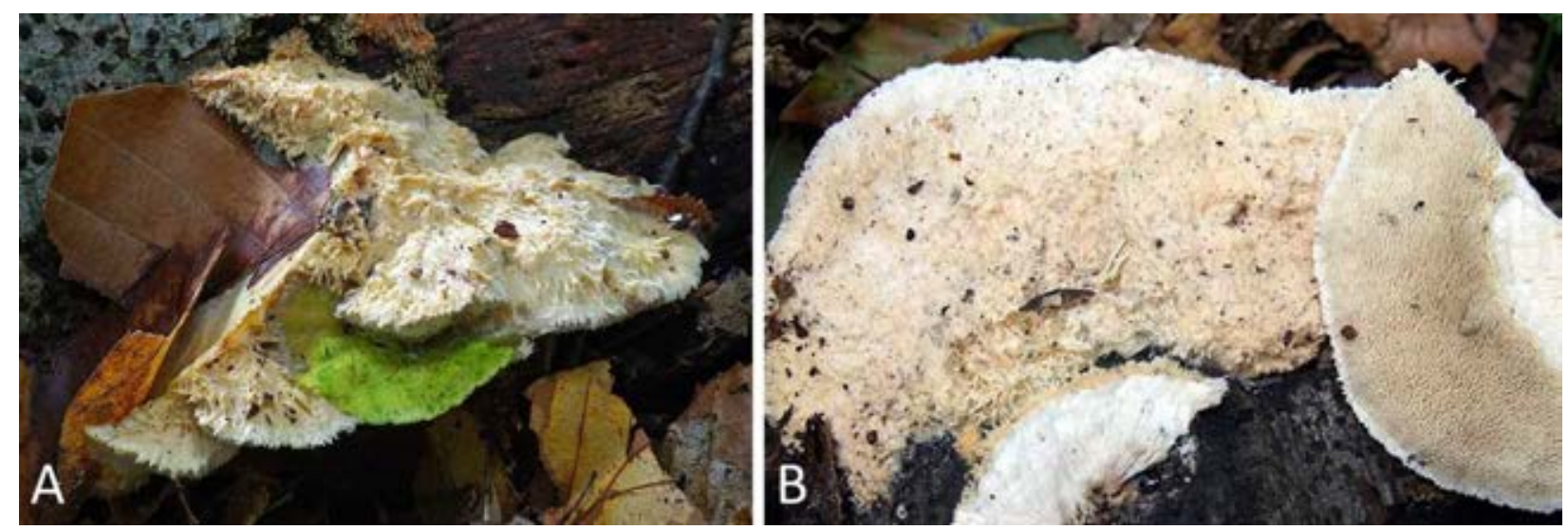

29. ábra. A Juhdöglö-völgy Erdörezervátumban gyüjtött Donkia pulcherrima [ $[\equiv$ Climacodon pulcherrimus] termöteste [PAPP és mtsai. (2015b) nyomán]. A) bükkfarönkön növő termötest kalapfelszíne (in situ) (Fotó: Papp V.); B) ugyan azon a rönkön növő rózsaszínes árnyalatú termőtest kalapfelszíne, keresztmetszete, valamint hidnoid termőrétegtartója (in situ) (Fotó: Koszka A.).

MORENO és munkatársai (2007) munkájukban a Climacodon pulcherrimus típuspéldánya [fung.: $\mathrm{K}(\mathrm{M})$ 135348] és más minták vizsgálata alapján a következő jellegzetes mikromorfológiai bélyegeket emelték ki: (1) a pileipelliszben és trámában lévő hifák kettő, három vagy négy csatosak, (2) a trámában gyakoriak az olajcseppek, (3) a cisztidiumok 
hiányoznak, de olykor láthatók hifavégek a himéniumban, (4) a bazídiospórák 4-5 × 1,5-2 $\mu \mathrm{m}$ nagyságúak, hialinok, elliptikusak vagy allantoidok. Mikroszkopikus vizsgálataink alapján a Juhdöglö-völgyben gyüjtött minta egyezést mutat a típuspéldánnyal (30. ábra).

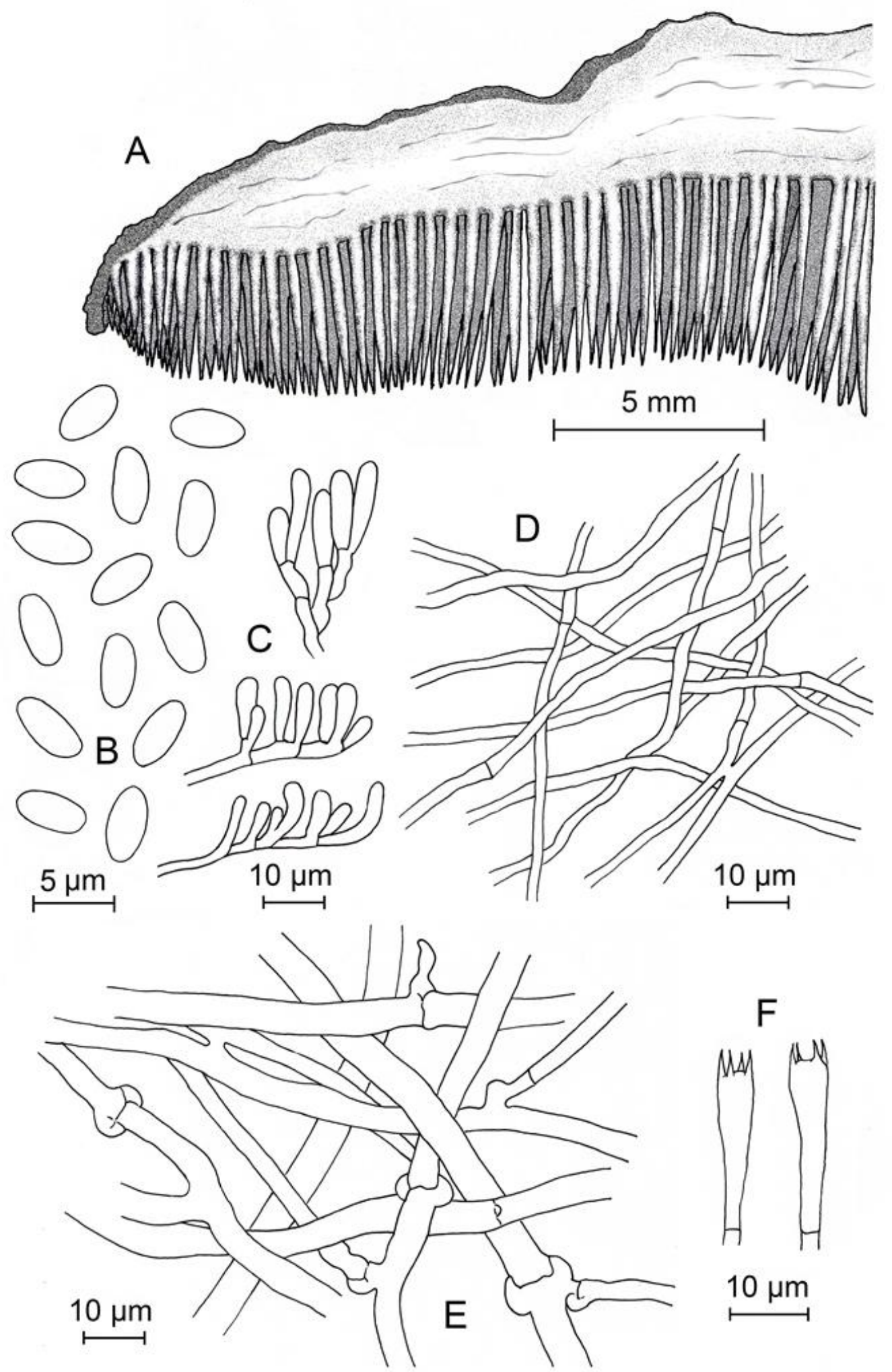

30. ábra. A Donkia pulcherrima (PV1044) morfológiai bélyegei (PAPP és mtsai. 2015a). A) bazidiokarpium keresztmetszete, B) bazídiospórák, C) bazídiolumok, D) hifák a trámában, E) kontextuális hifák, F) bazídiumok. Rajz: Papp V. 
A határozás molekuláris vizsgálatokkal való megerösítéshez nem találtam sem a GenBank, sem a UNITE adatbázisokban Climacodon pulcherrimus összehasonlító szekvenciát. MORENO és munkatársai (2007) viszont munkájukban megemlítik, hogy az Ibériai-félszigetröl gyüjtött mintából molekuláris vizsgálat céljából küldtek mintát Dr. Larsson-nak, aki azt a választ adta, hogy a legközelebbi szekvenciák a Phanerochaete spp. és Phlebia deflectens voltak.

A magyarországi minta ITS szekvenciájához a GenBank-ba feltöltött taxonok közül egyes Phanerochaete, valamint Flavodon és Hyphodermella taxonok álltak a legközelebb (31. ábra). A hazai minta filogenetikai vizsgálata során elég jelentős különbség mutatkozott a GenBank-ban található Climacodon septentrionalis mintákkal való összevetés során.

Egy recens, a /Phlebioid klád több lokuszon alapuló filogenetikai vizsgálata alapján a $C$. septentrionalis minták a Phanerochaetaceae család típusaként kijelölt Phanerochaete nemzetség típusfajától [P. velutina (DC.) P. Karst.] igen távol találhatók (BINDER és mtsai 2013). Egy külön ágat alkotnak, amely akár indokolhatná JÜLICH (1981) morfológiai bélyegeken alapuló megfigyelését és a Climacodontaceae Jülich család létjogosultságát. BINDER és munkatársainak (2013) eredményei alapján a /Phlebioid kládon belül viszont több nemzetség is polifiletikus (pl. Phanerochaete, Phlebia), ezért további vizsgálatok lennének szükségesek az egyes családok határainak megállapításához.

Az Észak-Amerikából leírt Hydnum pulcherrimum taxonómiai helyzete már morfológiai bélyegek alapján is kérdéses volt, tekintve hogy a NIKOLAJEVA (1961) által közölt és széles körben elfogadott Climacodon nemzetségbe való besorolását több mikológus is megkérdőjelezte (pl. MoRENO és mtsai. 2008; NAKASONE 1990). Ennek a fajnak az ITS szekvenciáit jelen munkában elsőként közölöm, ezért taxonómiai helyzetének tisztázásához további minták vizsgálatára is szükség lenne. Ugyanakkor az erdőrezervátumban gyüjtött minta filogenetikai távolsága a GenBank-ban található Climacodon septentrionalis mintáktól megerősítik azt a morfológiai bélyegeken alapuló taxonómiai koncepciót, amely szerint a Hydnum pulcherrimum a Phanerochaetaceae családon belül egy külön leszármazási vonalat alkot. Ez alapján véleményem szerint indokolt lehet a PILÁT (1936) által a Hydnum pulcherrimum típusfaj alapján leírt Donkia nemzetség elfogadása és a Donkia pulcherrima binom használata.

A reszupinátus, poroid termőtestet képző polifág Emmia latemarginata Magyarországon ökológiai igényei és eddigi adatai alapján nem ritka faj (pl. DiMA és mtsai. 2010; EsZES és IGMÁNDY 1978; IGMÁNDY 1981); jellemző mikorszkopikus bélyegei a gloeo-, valamint az enkrusztált cisztidiumok jelenléte (PIĄTEK 2003b). Makroszkopikusan hasonlít az Oxyporus corticola (Fr.) Ryvarden fajra, azonban a hifák vastagsága és a cisztidiumok alapján elkülöníthető a két taxon egymástól (RYVARDEN és MELO 2014). 
A Phanerochaetaceae család típusnemzetsége az igen fajgazdag kozmopolita Phanerochaete génusz, amelynek jellemző morfológiai bélyegei a reszupinátus termőtest, a cisztidiumok jelenléte, a monomitikus hifarendszer, valamint a közepes méretü elliptikus vagy allantoid, vékony-falú inamiloid bazídiospórák (BERNICCHIA és GORJÓN 2010; ERIKSSON és mtsai. 1975).

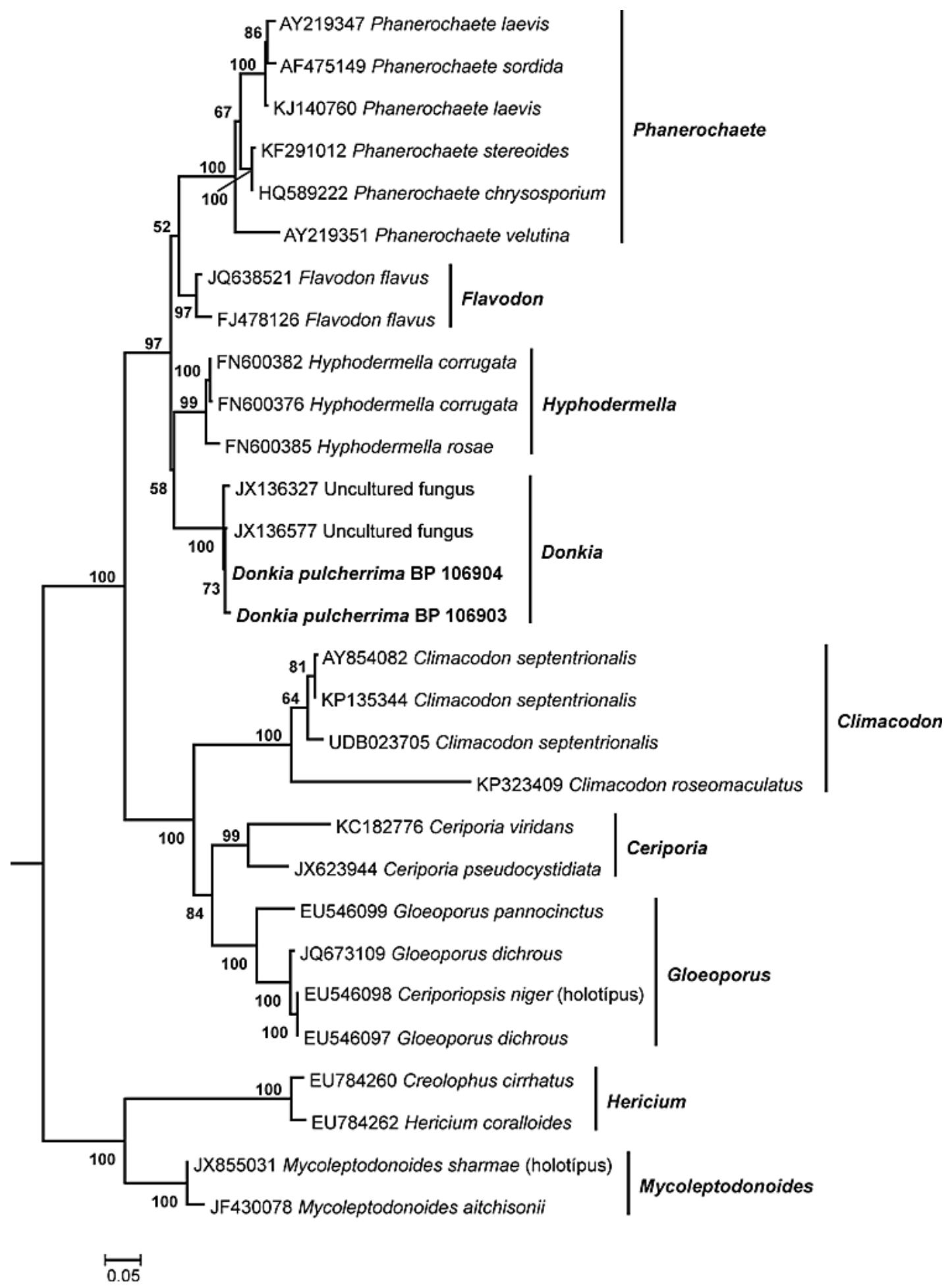

31. ábra. A rezervátumban gyüjtött Donkia pulcherrima [三Climacodon pulcherrimus] és rokon fajainak filogenetikai fája ITS szekvenciák alapján (PAPP és mtsai. 2015). A filogenetikai rekonstrukció Maximum Likelihood (ML) statisztikai becslés alapján készült. Az ágaknál szereplő számok az 50\%-nál magasabb ML boostrap értékeket jelölik. A mérce 100 karakterre eső 5 szubsztitúciónak megfelelő ághosszat jelöl. 
A mikroszkopikus bélyegek alapján sem egységes nemzetség BINDER és munkatársai (2013) filogenetikai vizsgálata alapján polifiletikus, ezért az egyes fajok szisztematikia helyzetének tisztázása még további vizsgálatokat igényel. A rezervátumban gyüjtöttt Phanerochaete aculeata-nak határozott minta közel áll a $P$. sordida fajhoz, de a raduloid tráma és a kisebb méretü spórák alapján a két taxon egyértelmüen elkülöníthető egymástól (BERNICCHIA és GORJÓN 2010).
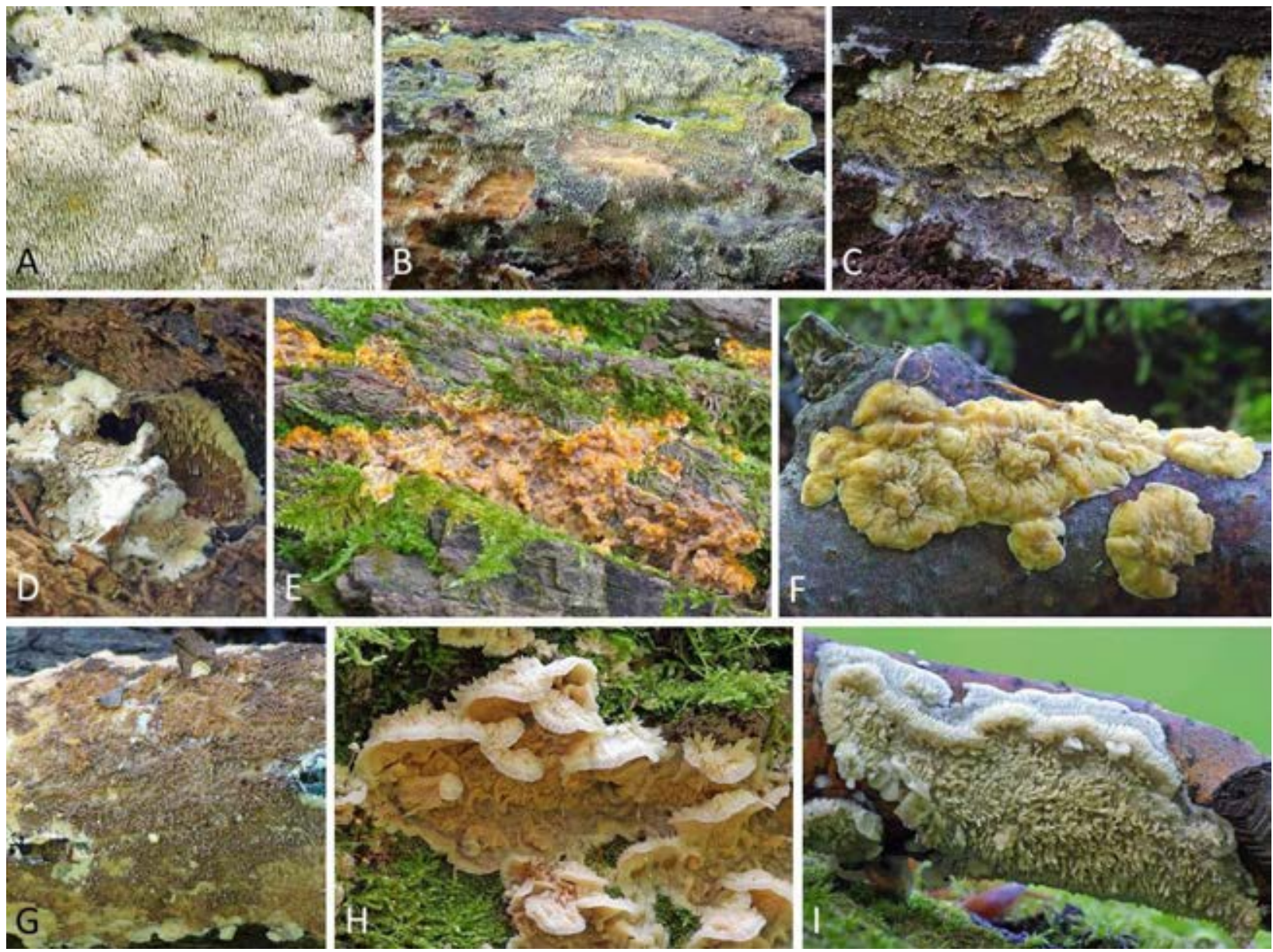

32. ábra. A rezervátumban gyüjtött Phlebia fajok termőtestei. A) P. fuscoatra termőteste bükkfarönkön (in situ); B) P. uda termőteste bükkfarönkön (in situ); C-D) P. nothofagi termőtestek erösen korhadt bükkfarönkön (in situ); E-F) P. radiata termőtestek tölgyfa rönkön és ágon (in situ); G) $P$. rufa termőtest bükkfarönkön (in situ); H) P. tremellosa termőtest (in situ); I) P. aff. centrifuga termőtest lombosfa ágdarabon (in situ). Fotó: Papp V.

A jelenleg Phlebia nemzetségbe sorolt fajok makromorfológiai bélyegeiket tekintve igen változatos megjelenésűek. A hidnoid-raduloid trámájú taxonok közül a $P$. fuscoatra (32. ábra/A) és $P$. uda (32. ábra/B) fajokra jellemző, hogy termőtestük $\mathrm{KOH}$ hatására vörösödik. Elöbbi faj idővel feketedő tüskéinek csúcsán a hifák erősen enkrusztáltak, míg a $P$. uda esetében egyik tulajdonság sem jellemző (BERNICCHIA és GORJÓN 2010; NAKASONE 1997). A P. nothofagi (32. ábra/C-D) karakterisztikus morfológiai bélyegei, hogy hifarendszere monomitikus, valamint a 
himéniális cisztidiumai vastagfalúak és kristályokkal sürün berakódottak. A $P$. radiata, $P$. rufa és $P$. acerina Peck egymáshoz közel álló, de morfológiai bélyegek, molekuláris és intersterilitási vizsgálatok alapján külön fajokat alkotnak (NAKASONE és SYTSMA 1993).

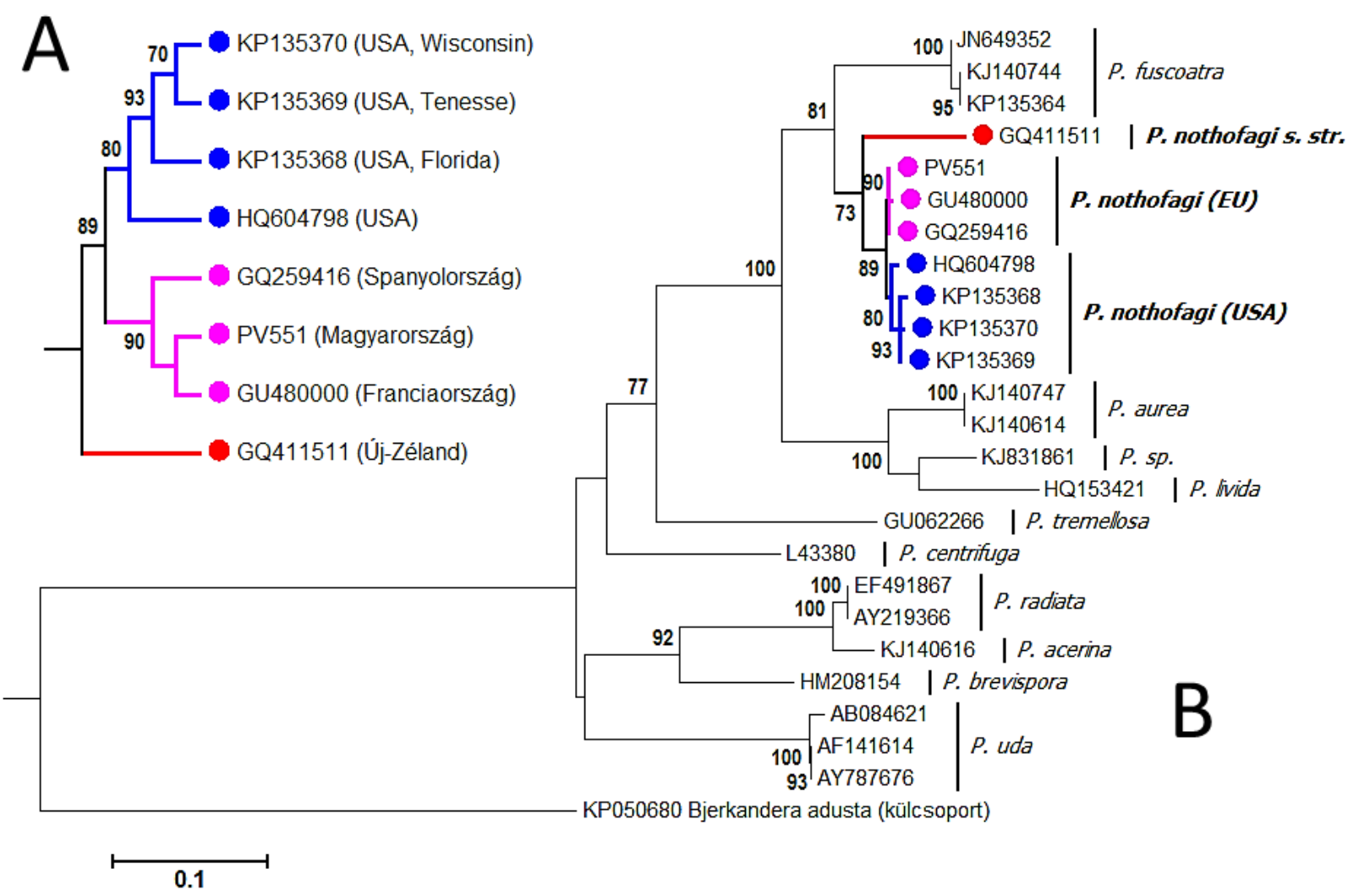

33. ábra. A rezervátumban gyüjtött Phlebia nothofagi (PV551) és rokon fajainak filogenetikai fája ITS szekvenciák alapján. Az ágaknál szereplő számok a 70\%-nál magasabb ML bootstrap értékeket jelölik. A filogenetikai rekonstrukció Maximum Likelihood (ML) statisztikai becslés alapján a RAxML program segítségével GTRGAMMA szubsztitúciós modell valamint 1000 ismétléses „rapid bootstrap” elemzés alkalmazásával készült. Az „A” jelü ábra a Phlebia nothofagi s. lato minták ághosszak nélküli topológiai törzsfáját mutatja. A „B” jelü törzsfán a mérce 100 karakterre eső 10 szubsztitúciónak megfelelő ághosszat jelöl.

A Phlebia radiata egy Európában és hazánkban is gyakori makromorfológiai szempontból azonban igen változatos megjelenésü faj (32. ábra/E-F). Jellemző mikroszkopikus bélyegei, hogy cisztidiumai nem enkrusztáltak, valamint kisméretü $(4-5 \times 1,8-2 \mu \mathrm{m})$ szuballatioid bazídiospórái vannak. ERIKSSON és munkatársai (1981) szerint a $P$. rufa mikroszkopikus struktúrája gyakorlatilag azonos a $P$. radiata-éval, de a himéniuma mindig merulioid-poroid és sohasem sugárirányban redőzött (32. ábra $/ \mathrm{G})$. A $P$. tremellosa hazánkban a leggyakoribb és legismertebb fajok közé tartozik a nemzetségböl. 
A rezervátumban gyüjtött és morfológiai bélyegek alapján Phlebia nothofagi-nak határozott minta (PV551) ITS régiója egyezést mutatott a MORENO és munkatársai (2011) által vizsgált spanyolországi (GQ259416) és a GenBank-ba szintén ezen a néven feltöltött franciaországi (GU480000) minták szekvenciáival (33. ábra). Az Észak-Amerikából származó P. nothofagi minták (KP 135368, KP135369, KP135370), valamint egy Hyphoderma fajnak határozott minta (HQ604798) külön ágon csoportosultak, míg az Új-Zélandról származó „Mycoacia nothofagi” (GQ411511) faji szintű eltérést mutat. Ez különösen figyelemre méltó, tekintve, hogy a Phlebia nothofagi-t CunNingham (1959) Új-Zélandról írta le Odontia nothofagi néven. Amennyiben a FUKAMI és munkatársai (2010) által vizsgált minta (GQ411511) egyezést mutatna a Phlebia nothofagi típuspéldányával (fung.: PDD7281), akkor jelen vizsgálat alapján az európai $P$. nothofagi-ként tárgyalt minták vélhetően egy tudományra új fajhoz, míg az észak-amerikaiak egy új változathoz tartoznak. Ennek a feltételezésnek a tisztázásához viszont további minták morfológiai és filogenetikai vizsgálata is szükséges lenne.

\section{Podoscyphaceae D.A. Reid $\underline{\text { s. lato }}$ [incl. Hyphodermataceae Jülich]}

(1) Abortiporus Murrill - *A. biennis (Bull.) Singer

(1) Cerrena Gray $-{ }^{*}$ C. unicolor (Bull.) Murrill

(1) Hyphoderma Wallr. - H. cf. medioburiense (Burt) Donk

(1) Panus Fr. - P. neostrigosus Drechsler-Santos \& Wartchow [ $[$ Lentinus strigosus Fr.; = Panus lecomtei (Fr.) Corner; = Panus rudis Fr.] (I)

(2) Spongipellis Pat. - S. delectans (Peck) Murrill [三 Sarcodontia delectans (Peck) Spirin]; *S. litschaueri Lohwag [= S. irpex (Schulz.) Z. Igmándy ss. auct.] (II)

Taxonómiai és nómenklatúrai megjegyzések: (I) FRIES (1825) ugyan abban az évben közölte a Lentinus lecomtei Fr. [三 Panus lecomtei (Fr.) Corner] és L. strigosus Fr. fajokat. A L. strigosus Panus nemzetségbe való kombinálása a $P$. strigosus Berk. \& M.A. Curtis $[=$ Lentinus levis (Berk. \& M.A. Curtis) Murrill] miatt nem lehetséges. DRECHSLER-SANTOS és munkatársai (2012b) viszont új névként (nomen novum) javasolták a Panus neostrigosus binomot. A Panus nemzetség szisztematikai helyzetének megítélése nem egységes. ZMITROVICH és MALYSHEVA (2013) a Meruliaceae családban tárgyalják. (II) IGMÁNDY (1957b) vélhetően a Spongipellis litschaueri fajra a Schulzer által korábban közölt [Polyporus irpex Schulz.] és ezért véleménye szerint prioritással rendelkező S. irpex (Schulz.) Z. Igmándy nevet használta. TORTIĆ (1975) szerint a Polyporus irpex viszont azonos a P. schulzeri Fr. fajjal, amely az igen ritka Piptoporus soloniensis (Dubois) Pilát szinonimja.

Az Abortiporus biennis gyakran fordul elő talajon, gyökereken vagy talajban lévő faanyagon. Más tönkkel rendelkező taplóktól elsősorban a gloeocisztidiumok, valamint a klamidospórák jelenléte alapján különíthető el (RYVARDEN és MELO 2014). Anamorf alakjára [ $A$. biennis f. distortus (Schwein.) Bondartsev; Sporotrichopsis terrestris (Schulzer) Stalpers] 
jellemző, hogy az eltorzult termőtest teljes felszínét pórusok borítják (STALPERS 2000). Korábbi hazai munkákban, mint ritka fajt említik (pl. IGMÁNDY 1968; SILLER és TÓBI 1999); újabb lelőhelyei ismertek a Tőserdőből (NAGY 2004; NAGY és GORLICZAI 2007), valamint a Bockerekerdőből (DIMA és mtsai. 2010), továbbá LUKÁCS (2010) számos adatát közölte a Budai hegységből, Mátrából, Örségből és a Vend vidékről. KAPOSVÁRI (2013) urbánus környezetben, a miskolci Népkertből mutatta ki. Az erdörezervátumban mindösszesen egy alkalommal, talajban lévő bükk faanyagán találtam. A kisebb termetü, fehéres vagy krémszínü termőtestet képző $A$. fractipes (Berk. \& M.A. Curtis) Gilb. \& Ryvarden több lombos fafaj (Alnus, Carpinus, stb.) mellett ismert bükkről is (RYVARDEN és MELO 2014), ám ezidáig nincs publikált magyarországi adata.

A Cerrena nemzetség egyetlen európai faja a C. unicolor, amely makroszkopikus bélyegek alapján is könnyen felismerhető a szőrös kalapfelszín, valamint a hús és a tráma között lévő fekete réteg alapján. Ökológiáját tekintve lombos fafajokon megjelenő, széles gazdanövényspektrummal rendelkező szaprotróf faj, amely szerepet játszhat élő fák elrákosodásában is (BLANCHETTE 1982 cit. in RYVARDEN és GILBERTSON 1993). Az élő fákon való megjelenésének oka lehet, hogy egyes tanulmányok szerint mutualista kapcsolatban él a hazánkban is honos sárgagyürüs fadarázzsal (Tremex fuscicornis Fabr.) (PALMA és mtsai. 2005; PAŽOUTOVÁ és ŠRU゚TKA 2007). A rezervátum területén előfordulását élő fán nem tapasztaltam, mindösszesen néhány alkalommal iniciális korhadási fázisban lévő bükkfarönkről gyüjtöttem. HoLLÓs (1933) szekszárd környékéről, mint gyakori gombát említi és főként bükkfa tuskón figyelte meg a jelenlétét. IGMÁNDY (1981) szerint hazánkban mindenütt megtalálható, de leggyakrabban bükkös és cseres vágásterületek tuskóin fordul elö.

Az agarikoid termőtestet képző Panus neostrigosus hazai adatai alapján (pl. BABOS 1989, Benedek 2011; Nagy 2004; Nagy és Gorliczai 2007; KoszKa 2011; PÁl-FÁm 2001; PapP 2009; RIMÓCZI 1994; RIMÓcZI és mtsai. 1997; SILLER 1999; TRECKER és SZABÓ 2002; VASAS 1995) egy széleskörben elterjedt, vélhetően nem ritka faj. A rezervátumban iniciális korhadásban lévő bükkfarönkökön gyüjtöttem.

A Spongipellis nemzetségbe tartozó fajok hasonlóak, mint a Tyromyces génusz taxonjai, de bazídiospóráik vastagfalúak és cianofilok. A nemzetség négy európai faja közül a kifejezetten bükk faanyagához kötődő Spongipellis delectans morfológiai bélyegei a termőtestek zsindelyszerü növekedése, valamint a szabálytalan, labirintusos vagy daedaleoid pórusok (TOMŠOVSKÝ 2012). Korábbi hazai adatai Tormaföldéről (Vétyem Erdőrezervátum) (IGMÁNDY 1981), valamint a Kékes és Őserdő Erdőrezervátumokból vannak (SILLER 2004). KoSZKA (2011) ezt a fajt a Vértesből (Pusztavám, Kö-völgy) kidőlt csertölgyről jelzi (mint Sarcodontia delectans). A szokatlan szubsztrátum miatt ennek az adatnak a revideálást szükségesnek tartom. 
A nemzetség föként tölgyön megjelenő faja a $S$. litschaueri, amely az igen hasonló $S$. spumeus (Sowerby) Pat. fajtól nagyobb pórusai és spórái alapján különíthető el (TOMŠOVSKÝ 2012). A S. litschaueri-t hazánkból DIMA és munkatársai (2013) a szentbékállai Fekete-hegyen gyüjtötték, míg KoszKA (2014) Csákberény közelében (Nyári-állás) korhadó csertölgy törzséről jelzi. Igmándy vélhetően a S. irpex név alatt erre a fajra gondolt (SZABÓ 2012) és munkájában (IGMÁNDY 1981) számos lelőhelyét közli. Az eltérő nevezéktani értelmezések miatt, valamint az inkább S. spumeus-ra jellemző szubsztrátumok (pl. Acer, Ailanthus, Populus) alapján ezeknek a fungáriumi mintáknak a revideálását szükségesnek látom, annak érdekében, hogy a faj hazai elterjedéséről megbízható képet kapjunk.

\section{Polyporaceae Corda}

(2) Aurantiporus Murrill (I) $-{ }^{* *}$ A. alborubescens (Bourdot \& Galzin) H. Jahn [ $\equiv$ Tyromyces alborubescens (Bourdot \& Galzin) Bondartsev]; *A. fissilis (Berk. \& M.A. Curtis) H. Jahn ex Ryvarden [ $\equiv$ Tyromyces fissilis (Berk. \& M.A. Curtis) Donk]

(1) Datronia Donk (II) - *D. mollis (Sommerf.) Donk

(1) Dichomitus D.A. Reid - *D. campestris (Quél.) Domanski \& Orlicz

(1) Fomes (Fr.) Fr. - F. fomentarius (L.) Fr.

(2) Funalia Pat. (III) $-{ }^{*} \boldsymbol{F}$. gallica (Fr.) Bondartsev \& Singer [三 Coriolopsis gallica (Fr.) Ryvarden]; *F. trogii (Berk.) Bondartsev \& Singer [三 Coriolopsis trogii (Berk.) Domański]

(1) Hapalopilus P. Karst. - H. rutilans (Pers.) Murrill [三 H. nidulans (Fr.) P. Karst.] (IV)

(1) Pachykytospora Kotlába \& Pouzar - *P. tuberculosa (Fr.) Kotl. \& Pouzar [三 Haploporus tuberculosus (Fr.) Niemelä \& Y.C. Dai] (V)

(8) Polyporus P. Micheli ex Adans. (VI) - P. alveolaris (DC.) Bondartsev \& Singer $[=$ P. mori (Pollini) Fr.]; P. arcularius (Batsch) Fr.; P. badius (Pers.) Schwein. [三 Royoporus badius (Pers.) A.B. De] (VII); P. brumalis (Pers.) Fr.; *P. ciliatus Fr.; $\boldsymbol{P}$. squamosus (Huds.) Fr.; $\boldsymbol{P}$. tuberaster (Jacq. ex Pers.) Fr. (VIII); P. varius (Pers.) Fr.

(6) Trametes Fr. $-{ }^{*} \boldsymbol{T}$. betulina (L.) Pilát [三 Lenzites betulina (L.) Fr.], T. gibbosa (Pers.) Fr.; *T. hirsuta (Wulfen) Lloyd; *T. ochracea (Pers.) Gilb. \& Ryvarden [= T. zonata (Nees) Pilát]; ${ }^{*} \boldsymbol{T}$. pubescens (Schumach.) Pilát; T. versicolor (L.) Lloyd

(1) Tyromyces P. Karst. - *T. chioneus (Fr.) P. Karst.

Taxonómiai és nómenklatúrai megjegyzések: (I) Ryvarden korábban az Aurantiporus nemzetségben tárgyalta az A. fissilis és A. alborubescens fajokat (pl. RYVARDEN és GILBERTSON 1993), de újabb munkájában az egyéves és fehéres színű termőtestet képző taplók taxonómiai helyzetének bizonytalansága miatt újra a Tyromyces génuszt preferálja (RYVARDEN és MELO 2014). Más taxonómusok viszont a tyromycetoid fajok szisztematikai revíziójáig elfogadják az Aurantiporus nemzetség elkülönítését (pl. DVOŘAK és mtsai. 2014; NIEMELÄ 2013). (II) A génusz filogenetikai vizsgálata alapján LI és munkatársai (2014) arra az eredményre jutottak, hogy a nemzetség típusfaja $[D$. mollis] valamint a $D$. stereoides egy monofiletikus kládot alkotnak, míg a többi korábban Datronia-ként 
azonosított taxon [pl. D. scutellata] külön csoportosul, ezért több tudományra új faj mellett leírták a Datroniella B.K. Cui, et al. és Neodatronia B.K. Cui, et al. nemzetségeket. (III) A Coriolopsis nemzetség típusfaja a Polyporus occidentalis Klotzsch [Coriolopsis polyzona (Pers.) Ryvarden], amely filogenetikai vizsgálatok alapján a Trametes nemzetségbe tartozik (Justo és HIBBETT 2011; WeLTI és mtsai. 2012). A korábban Coriolopsis-ként tárgyalt $C$. gallica és $C$. trogii fajokat egyes szerzők a Trametes (RYVARDEN és Melo 2014; ZMitrovich és mtsai. 2012), míg mások a Funalia nemzetségekbe sorolják (ZMitrovich és MALYSHEVA 2013). (IV) RYVARDEN és Melo (2014) a Hapalopilus nidulans binom használatát preferálja. (V) KOTLÁBA és POUZAR (1963) a Polyporus tuberculosus Fr. faj alapján írta le a monotipikus Pachykytospora nemzetséget; DAI és munkatársai (2002) szerint viszont a típusfajok alapján a Haploporus és a Pachykytospora génuszok nem különülnek el egymástól és tekintettel arra, hogy a Haploporus nevet közölték korábban prioritást élvez a Pachykytospora névvel szemben. Ezt a taxonómiai koncepciót több mikológus is elfogadta (pl. PIĄTEK 2003c, 2005; YU és mtsai. 2005), míg mások továbbra is külön taxonokként tárgyalják a két nemzetséget (RYVARDEN és MELO 2014; ZMITROVICH és mtsai. 2007). (VI) A tradícionálisan agarikoid termőtestű Lentinus nemzetség genetikailag közel áll a poroid Polyporus génuszhoz, amely alapján KRÜGER (2002) a „Polyporellus” csoport fajait átkombinálta a Lentinus nemzetségbe (ezek a közlések vélhetően invalidok). ZMITROVICH (2010) szintén közölte a $L$. arcularius, L. brumalis, valamint a L. ciliatus kombinációkat, mely utóbbi a L. ciliatus Lév. későbbi homonimája. KRÜGER és GARGAS (2004) viszont a Polyporus név megtartása mellett érvelve a Lentinus nemzetség fajait kombinálták a Polyporus génuszba két új nevet (nom. nov.) javasolva: Polyporus phyllostipes D. Krüger [三Lentinus crinitus (L.) Fr.] és P. gerdai D. Krüger. [三Lentinus tigrinus (Bull.) Fr.]. (VII) DE (1997) morfológiai bélyegek alapján arra a következtetésre jutott, hogy a $P$. badius nemzetség szinten elkülönül a Polyporus típusfajától, ezért létrehozta a Royoporus génuszt. DAI és munkatársai (2014) filogenetikai vizsgálatai alapján viszont a Polyporus nemzetség /Melanopus kládjába tartozik. (VIII) A Polyporus génusz széleskörben elfogadott típusfaja a P. tuberaster (BINDER és mtsai, 2013), ugyanakkor a nemzetség típizálása nem egyértelmü (pl. KRÜGER és GARGAS 2004; SOTOME és mtsai. 2008).

Az Aurantiporus fissilis hazánkban egy szórványosan megjelenő, kevéssé ismert polifág faj, amelyet a rezervátumban korhadó bükkfáról gyüjtöttem. IGMÁNDY (1958) Sopronból almafáról jelzi, majd későbbi munkájában (IGMÁNDY 1981) megjegyzi, hogy egyéb lombos fafajok mellett ,föleg idős törzsekből álló, elhanyagolt gyümölcsösökben található”. Az A. fissilis-re jellemző morfológiai bélyeg, hogy a fehéres színü, lédús és kissé viaszos termőtest száradás során jelentős mértékben összezsugorodik, valamint a húsban klamidospórák képződnek.

Hasonló megjelenésű faj a jellemzően természetközeli élőhelyeket kedvelő, igen ritka Aurantiporus alborubescens (Bourdot \& Galzin) H. Jahn, amelynek termöteste kezdetben fehéres, rózsaszínes árnyalatú, majd megszáradva narancsos-, barnás, valamint $\mathrm{KOH}$ hatására borvörös színü (DVOŘAK és mtsai. 2014).

A Datronia mollis a hazai bükkösök egyik karakterfaja (pl. IGMÁNDY 1964a; PÁL-FÁM és mtsai. 2007; SiLler 1999; SiLler és TURCSÁNYi 2002), amelynek előfordulása ismert egyéb lombos fafajokról is (IGMÁNDY 1981). A nemzetség európai fajain [D. mollis, D. scutellata (Schwein.) Gilb. \& Ryvarden és D. stereoides (Fr.) Ryvarden] belül jellemző morfológiai bélyege, hogy pórusai nagyok (1-2/mm) és szabálytalan alakúak. 
A Dichomitus campestris Magyarországon a kevésbé ismert taplófajok közé tartozik; Igmándy Zoltán gyüjteményében is mindösszesen két hazai lelőhelyről származó mintája ismert tölgy faanyagáról (IGMÁNDY 1979; SzABÓ 2012). Európából két Dichomitus faj [D. campestris és D. squalens (P. Karst.) D.A. Reid] ismert (VlasáK és mtsai. 2010), amelyek közül a $D$. squalens jellemzően Pinus faanyagán nő (RYVARDEN és GILBERTSON 1993).

A rezervátumban mind az élő fákon, mind a holt faanyagon az egyik leggyakoribb gombafaj a Fomes fomentarius volt, amelynek különösen a völgyben végighúzódó bükkös élöhelyen tájképet meghatározó jelentősége van. A F. fomentarius hazánkban az egyik leggyakoribb, évelő termőtestet képző taplófaj, amely számos fafajról ismert, de különösen gyakori természetközeli bükkerdőkben (IGMÁNDY 1991). Ez a széles gazdaspektrummal rendelkező polifág faj GÁPER és GÁPEROVÁ (2014) munkája alapján csak Európából 61 fafajról ismert. Szubsztrátumpreferenciája régiónként viszont eltérő; míg Közép-Európában kedvelt gazdanövénye a bükk, addig Észak-Európában és Skóciában nyíren, a mediterráneumban pedig tölgyön gyakori (SCHWARZE 1994). Az eltérő élőhelyek és szubsztrátumok miatt a termőtest morfológiája (pl. színe) igen nagy változatosságot mutat (JAHN 1965a). MUKHIN és VOTINTSEVA (2002) munkájukban vizsgálták F. fomentarius bazídiospóráinak csírázását, valamint megfigyelték a konídium képzését. Eredményeik alapján arra a következtetésre jutottak, hogy az aszexuális reprodukciós képesség hozzájárulhat a $F$. fomentarius ökológiai plaszticitásához. JUDOVA és munkatársai (2012) molekuláris vizsgálatok alapján kimutatták, hogy a $F$. fomentarius fajon belül két genotípus különíthető el, amely akár két szimpatrikus rejtett fajt takarhat.

A polifág Funalia trogii és F. gallica makro- és mikromorfológiai bélyegeiket tekintve is hasonlóak, de karakterisztikus különbséget mutatnak a hús, valamint a tráma színében. Magyarországi adatai alapján a főként kőrisről kimutatott $F$. gallica ritkább fajnak látszik, mint a F. trogii (pl. Dima és mtsai. 2010; IGMÁNDY 1981; NAGY 2004; NAGY és GorLICZAi 2007; PÁLFÁM 2001; RimóCZI 1994; RUdolf és mtsai. 2008; SILLER és mtsai. 2013). Ez utóbbi faj hazánkban mindenütt megtalálható, különösen puhafák (Populus spp., Salix spp.) faanyagán fordul elő (IGMÁNDY 1981). Az erdőrezervátum területén egyik faj sem volt gyakori.

A Hapalopilus rutilans saját tapasztalataim alapján a hazai tölgyerdők egyik gyakori taplógombája. A faj Magyarországi elterjedését és ökológiai igényeit IGMÁNDY (1968) részletesen ismerteti, majd későbbi munkájában, mint hazánkban általánosan elterjedt fajról ír (IGMÁNDY 1981). A rezervátumban többnyire tölgyfaágakon tapasztaltam a megjelenését, amely összhangban van RYVARDEN és MELO (2014) véleményével, miszerint ez a polifág taplófaj Közép-Európában föként tölgy fajokon nő. 
A föként tölgyfajokhoz kötődő Pachykytospora tuberculosa jellemzője a reszupinátus vagy kalaposodó, többnyire világos kávészínü (izabellaszínü) egyéves vagy évelő termőtest, valamint az ornamentált bazídiospóra. IGMÁNDY (1981) diósjenői, soproni és szekszárdi adatát közli szil (Ulmus sp.) és kocsánytalan tölgy faanyagáról. Az újabb hazai fungisztikai munkák közül RIMÓCZI és munkatársai (1997) a Bátorligeti Öslápról, míg SILLER (2004) az Öserdő Erdőrezervátumból jelzik. Oroszország európai részéről (Zhiguli Bioszféra Rezervátum) írták le Padus avium-ról a Pachykytospora wasseri Zmitr., Malysheva \& Spirin fajt, amely főként kisebb spórái $\left[(7,8-) 8-9(-10,4) \times 3.9-5.2 \mu \mathrm{m} ; \mathrm{Q}_{\text {átl. }}=1,90\right]$ alapján különíthető el a $P$. tuberculosa-tól (ZMITROVICH és mtsai. 2007).

A rezervátum területéről dokumentált összesen nyolc Polyporus s. lat. faj közül, a „Polyporellus”-csoportba tartozókból hazánkban a $P$. arcularius egy igen gyakori, míg a $P$. brumalis a nem ritka fajok közé tartoznak. A P. ciliatus hazai elterjedéséről viszont kevesebb információval rendelkezünk. KREISEL (1963) a P. brumalis komplex fajait ismertető munkájában Közép-Európában a csoport leggyakoribb fajaként említi. Ezzel szemben IGMÁNDY (1981) munkájában megjegyzi, hogy ezt a fajt „... a mikológiai irodalomban többnyire P. brumalis (Fr.) Pers. névvel ismertetik”, valamint véleménye szerint a magyarországi adatai „herbáriumi példányok hiányában kétesnek tekintendők" és hazai előfordulása igen ritkának látszik. Az újabb magyarországi fungisztikai munkák eredményei Igmándy álláspontját részben alátámasztják, tekintve, hogy csak néhány újabb élőhelyről közölték az előfordulási adatait (pl. BABOS 1989; BENEDEK 2011; FODOR és mtsai. 2001; SILLER és mtsai. 2013).

A Polyporus alveolaris a nemzetség taxonjai közül könnyen felismerhető szögeletes pórusai valamint a laterálisan elhelyezkedő tönkje alapján. PIĄTEK (2004) Lengyelországból a $P$. tuberaster és $P$. rhizophilus mellett, mint nagyon ritka fajt említi, amelyet részben magyarázhat a $P$. alveolaris elterjedésének szubmediterrán jellege. IGMÁNDY (1981) Magyarországon szintén ritka fajnak tartja, de több adatát is közli Cornus, Crataegus, Fagus, Maclura és Syringa gazdanövényekröl. Ezeken kívül a $P$. alveolaris újabb adatait közölték több fungisztikai munkából is (pl. BABOS 1984, 1989; FoDOR és mtsai. 2001; NAGY 2004; NAGY és GORLICZAI 2007; RIMÓCZI és mtsai. 1997; SILLER és mtsai. 2013).

A /Melanopus kládba tartozó Polyporus badius és P. melanopus fajok morfológia bélyegek alapján közel állnak egymáshoz, de többek között a két faj a hifák szeptáltsága alapján stabilan elkülöníthető egymástól (JAHN 1973). IGMÁNDY (1981) szerint a P. melanopus kevés magyarországi adata azzal magyarázható, hogy hazánkban nagyon ritka vagy elképzelhető az is, hogy a „megfigyelések hiányoznak a gombára vonatkozóan”. BABOS (1989) a növénytári herbáriumi anyagokat ismertető munkájában mindösszesen három lelőhelyét említi. Az újabb munkák közül VASAS és LOCSMÁNDI (2009) Aggtelekről, míg LUKÁCS (2010) a Mátrából közli 
elöfordulási adatát. A $P$. varius Magyarországon az egyik leggyakoribb faj a nemzetségböl. Morfológiáját tekintve igen közel áll a PIERI és RIVOIRE (2005b) által leírt P. hygrocybe M. Pieri \& B. Rivoire fajhoz, amely kisebb spórái $(6,5-8 \times 3,5-4,5 \mu \mathrm{m})$ és nagyobb pórusai $(4-6 / \mathrm{mm})$ alapján különbözik. Ezt a fajt a francia Alpokból, Salix elaeagnos-ról írták le, de RYVARDEN és MELO (2014) szerint a Közép-európai országok herbáriumaiban található $P$. varius minták revideálása szükséges lehet.

A kozmopolita Trametes s. lato nemzetség taxonómiai helyzetének tisztázása érdekében az elmúlt években számos munka jelent meg (pl. CARLSON és mtsai. 2014; JUSTO és HIBBETT 2011; Welti és mtsai. 2012; Zmitrovich és mtsai. 2012; Zmitrovich és MALYSheVA 2013), de az eredmények értékelésében továbbra is koncepcionális különbségek vannak. RYVARDEN és MELO (2014) munkájukban a génusz jellemző bélyegeinek a kalapos termőtestet, a trimitikus hifarendszert, a valódi cisztidiumok hiányát és a Melzer reagensre negatív vékonyfalú spórákat tartják. A Trametes betulina a nemzetségen belül már makroszkopikus bélyegek alapján is könnyen felismerhető a szőrös, zónázott kalapfelszíne a lemezes trámája alapján. Hasonlóan szőrös a T. hirsuta kalapfelszíne is, de kerekded (3-4/mm) idővel hamuszürke színü pórusai alapján már a terepen is azonosítható. A rezervátumban mindkét fajt korai korhadási fázisban lévő bükkfarönkökön figyeltem meg. A T. pubescens hazánkban IGMÁNDY (1981) szerint ritka fajnak látszik, de több lombos fáról is jelzi előfordulását. MALYSHEVA és ZMITROVICH (2011) morfológiai és molekuláris bélyegek alapján vizsgálták a T. hirsuta komplexet és véleményük szerint a /T. pubescens klád jellemzője az anizodiametrikus pórusok, a kalapfelszínen lévő szőrözöttség hiánya, valamint a pórusfelszín színe (fehéres, krém vagy mézszínü).

Az igen gyakori Trametes versicolor kalapfelszínét tekintve nagyon változatos megjelenésü faj; karakterisztikus bélyegei, hogy termőteste vékony és rugalmas, valamint a kalap színeit tekintve kontrasztosan zónázott. A $T$. ochracea morfológia bélyegek alapján nagyon hasonló a $T$. versicolor-hoz; RYVARDEN és MELO (2014) a kalap színe, zónázottsága és a fekete réteg hiánya alapján különíti el a két fajt. TOMŠOVSKÝ és HOMOLKA (2004) intersterilitási vizsgálatokat végeztek a $T$. versicolor komplexben és munkájuk során igazolták a $T$. ochracea és $T$. versicolor különállóságát. CARLSON és munkatársai (2014) a komplex multigénes (ITS, RPB1, RPB2, TEF1) filogenetikai vizsgálata során megerösítették a T. ochracea, T. pubescens, T. versicolor, valamint a $T$. ectypa faji szintü elkülönítését. A $T$. ochracea magyarországi adataival kapcsolatban IGMÁNDY (1981) megjegyzi, hogy korábban több hazai mikológus (Schulzer, Hazslinszky, Hollós, Moesz) is, mint közönséges gombát említi. Véleménye szerint „valószínü, hogy a versicolor egyes változatait határozták meg zonata-ként, mivel a tapló hazánkban ritka". Igmándy fungáriumában is mindösszesen három lelöhelyröl származó minta szerepel (SzABÓ 2012). Véleményem szerint annak érdekében, hogy pontosabb képet kapjunk ennek a fajnak a 
hazai elterjedésével és ökológiai igényeivel kapcsolatban a T. versicolor komplex fungáriumi mintáinak revideálására lenne szükség.

A Trametes gibbosa a bükkfa egyik jellemző taplója, amely ritkán megjelenhet más lombos fafajokon is. A nemzetség európai fajain belül unikális bélyege, hogy a pórusai sugár irányban megnyúltak. Megfigyeléseim alapján a rezervátumban bükkfarönkökön igen gyakori faj.

A fehérkorhasztó Tyromyces s. str. nemzetség fajaira általánosan jellemző a fehéres színü, kalaposodó poroid termőtest, valamint a csatos generatív hifák és a vékonyfalú hialin bazídiospórák. A polifág T. chioneus hazai előfordulásáról viszonylag kevés adatunk van. Igmándy fungáriumában mindösszesen két lelöhelyről származó, bükk és tölgy faanyagáról gyüjtött minta szerepel (SzABÓ 2012). Újabb adatait BENEDEK (2011) a Börzsönyből, SILLER és munkatársai (2013) pedig Szalafőről jelzik, valamint a Cortinarius Kongresszus alatt Bellú gyüjtötte a Csanyik-völgyben (Bükk) (DIMA és mtsai. 2010). A rezervátumban bükkfarönkről dokumentáltam. Európai adatai alapján vélhetően hazánkban sem ritka faj.

\section{Steccherinaceae Parmasto}

(3) Antrodiella Ryvarden \& I. Johans. - *A. foliaceodentata (Nikol.) Gilb. \& Ryvarden, *A. fragrans (A. David \& Tortič) A. David \& Tortič [三 Trametes fragrans A. David \& Tortic], *A. serpula (P. Karst.) Spirin \& Niemelä [= A. hoehnelii (Bres.) Niemelä]

(1) Ceriporiopsis Domanski $-*$ C. gilvescens (Bres.) Domanski

(1) Frantisekia Spirin \& Zmitr. (I) $-* * \boldsymbol{F}$. mentschulensis (Pilát ex Pilát) Spirin [三 Antrodiella mentschulensis (Pilát ex Pilát) Ryvarden \& Melo]

(1) Junghuhnia Corda - *J. nitida (Pers.) Ryvarden

(2) Steccherinum Gray $-{ }^{*} \boldsymbol{S}$. bourdotii Saliba \& A. David, *S. ochraceum (Pers. ex J.F. Gmel.) Gray agg.

Taxonómiai és nómenklatúrai megjegyzések: (I) a Frantisekia nemzetséget SPIRIN és ZMITROVICH (2007) írta le a Poria fissiliformis Pilát alapján; az új nemzetségbe három fajt soroltak: Frantisekia fissiliformis (Pilát) Spirin et Zmitr. [ $\equiv$ Antrodiella fissiliformis (Pilát) Gilb. et Ryvarden], F. mentschulensis (Pilát ex Pilát) Spirin, F. ussuri (Y. C. Dai et Niemelä) Spirin [三 Antrodiella ussuri Y. C. Dai et Niemelä]. A Poria fissiliformis Pilát fajnak, leírását követően a taxonómiai helyzete többször is változott: GILBERTSON és RYVARDEN (1985) előbb a Perenniporia Murrill, majd az Antrodiella (GILBERTSON és RYVARDEN 1987), KotLÁBA és POUZAR (1988) pedig a Tyromyces nemzetségbe sorolta. PILÁt (1953) Ukrajnában gyüjtött típuspéldány alapján írta le a Poria mentschulensis-t, amelyet BONDARTSEV (1953) Tyromyces mentschulensis-re nevezett át. KOTLÁBA és POUZAR (1988) viszont a T. mentschulensis-t azonosnak találta a T. fissiliformis (Pilát) Kotl. et Pouzar fajjal. SPIRIN és ZMITROVICH (2007) megvizsgálva a holotípusokat és számos herbáriumi példányt arra a következtetésre jutottak, hogy az A. fissiliformis s. lato számos morfológiai bélyegben (pl. pszeudodimitikus hifarendszer, bazídium alakja, spóra) különbözik mind az Antrodiella, mind a Tyromyces fajoktól, ezért indokolt új nemzetségbe sorolni. Véleményük szerint az észak-amerikai holotípusról leírt A. fissiliformis s. str. Európából kimutatott adatai egy másik fajra, a Frantisekia mentschulensis-re [三 Poria mentschulensis Pilát ex Pilát] 
vonatkoznak. A két faj újbóli szétválasztása morfológiai bélyegek alapján VAMPOLA (2011) szerint is indokolt. A legújabb molekuláris eredmények alapján az Antrodiella nemzetség polifiletikus, és a korábban ide sorolt fajok 10 különálló kládba tartoznak, melyek között szerepel a Frantisekia is (MieTtinen és mtsai. 2012). Tehát a morfológiai bélyegek mellett a molekuláris eredmények is alátámasztják a Frantisekia nemzetség létjogosultságát. Ennek ellenére RYVARDEN és MELO (2014) morfológiai bélyegek alapján közölték az Antrodiella mentschulensis (Pilát ex Pilát) Ryvarden \& Melo kombinációt.

A kozmopolita Antrodiella nemzetségbe tartozó fajok, a korhasztás módja, a hifarendszer szerkezete (többnyire dimitikus), a spórák típusa alapján közel állnak a Junghuhnia génuszhoz. A két nemzetség közti fő morfológiai különbség a Junghuhnia fajokra jellemző enkrusztált szkeletocisztidium jelenléte (RYVARDEN és MELO 2014). Magyarországon eddigi ismereteink alapján az egyik leggyakoribb Antrodiella faj az A. serpula (pl. IGMÁNDY 1981; SILLER és mtsai. 2013), amelyet korábban az Észak-Amerikából leírt A. semisupina (Berk. \& M.A. Curtis) Ryvarden fajjal azonosítottak (MIETTINEN és mtsai. 2006).

$\mathrm{Az}$ Antrodiella foliaceodentata jellemző makroszkopikus bélyege, hogy a csövek felszakadozottak, csaknem hidnoidok. Ennek a fajnak korábban csak egy lelőhelyről származó adata volt ismert hazánkból, amely szintén bükk faanyagáról származik (SzABÓ 2012). Az $A$. fragrans már a terepen könnyen felismerhető erős kumarinra emlékeztető illata alapján. Első hazai adatát TRECKER és SzABÓ (2002) közölték a Ropolyi Erdőrezervátumból. Terepi megfigyeléseim alapján hazánkban nem ritka faj.

A Frantisekia mentschulensis Juhdöglö-völgyböl származó első hazai adatának részletes leírását egy korábbi munkában foglaltam össze (PAPP 2012b). A F. mentshulensis jellemző makromorfológiai bélyegei az egyéves narancsos színü sporokarpium (34. ábra/A,D), a szögletes apró pórusok (34. ábra/B-C), valamint hogy a kiszáradt termőtest elveszíti élénk színét és gyakran barázdáltá és ráncossá válik (34. ábra/E).

A külön fajként leírt, majd összevont Frantisekia fissiliformis és F. mentschulensis SPIRIN és ZMITROVICH (2007) szerint nem csupán földrajzilag különülnek el egymástól, hanem számos morfológiai bélyegben is különböznek: a F. fissiliformis szigorúan reszupinátus termőtestet képez, a húsa vékony, alig látható, pórusai többnyire kisebbek $(8-10 / \mathrm{mm})$, valamint a termőrétegben is pszeudodimitikus, míg a $F$. mentschulensis monomitikus (34-35. ábra).

A Frantisekia mentschulensis szakirodalmi adatok alapján főként közép-európai elterjedésü faj és jellemzően a lombos erdőket kedveli, de ritkán előfordulhat fenyőféléken is. Ismert szubsztrátumai a korai juhar, a közönséges gyertyán, a bükk, a rezgő nyár, a kocsányos tölgy és a kislevelü hárs (SPIRIN és ZMITROVICH 2007); a fenyők közül megtalálható jegenyefenyőn (RYVARDEN és GILBERTSON 1993) és lucon is (KARASIŃKI és mtsai. 2009). Közép-Európán kívül ismert Olaszország északi részéről (BERNICCHIA 2005), valamint HEILMANN-CLAUSEN és 
WALLEYN (2007) szintén bükkfarönkröl gyüjtötték (mint Antrodiella fissiliformis)

Spanyolországból. Elterjedésének északi határát tekintve HEILMANN-ClaUSEN (2006)

Svédországból is kimutatta.
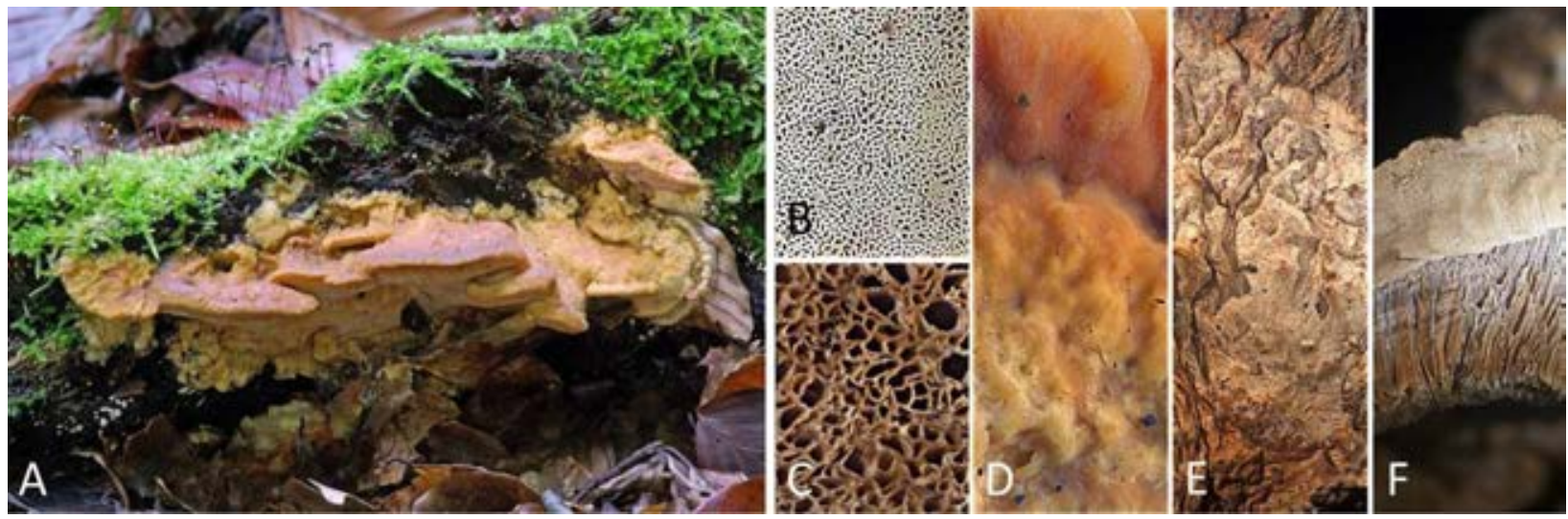

34. ábra. A Frantisekia mentschulensis (PV678) termőteste és jellemző makromorfológiai bélyegei (PAPP 2012b alapján). A) F. mentschulensis termöteste erösen korhadt bükk faanyagán (in situ); B) friss pórusfelszín (ex situ); C) száraz pórusfelszín (ex situ); D) friss kalapfelszín (ex situ); E) száraz kalapfelszín (ex situ); F) száraz termőtest keresztmetszete (ex situ). Fotók: Papp V.
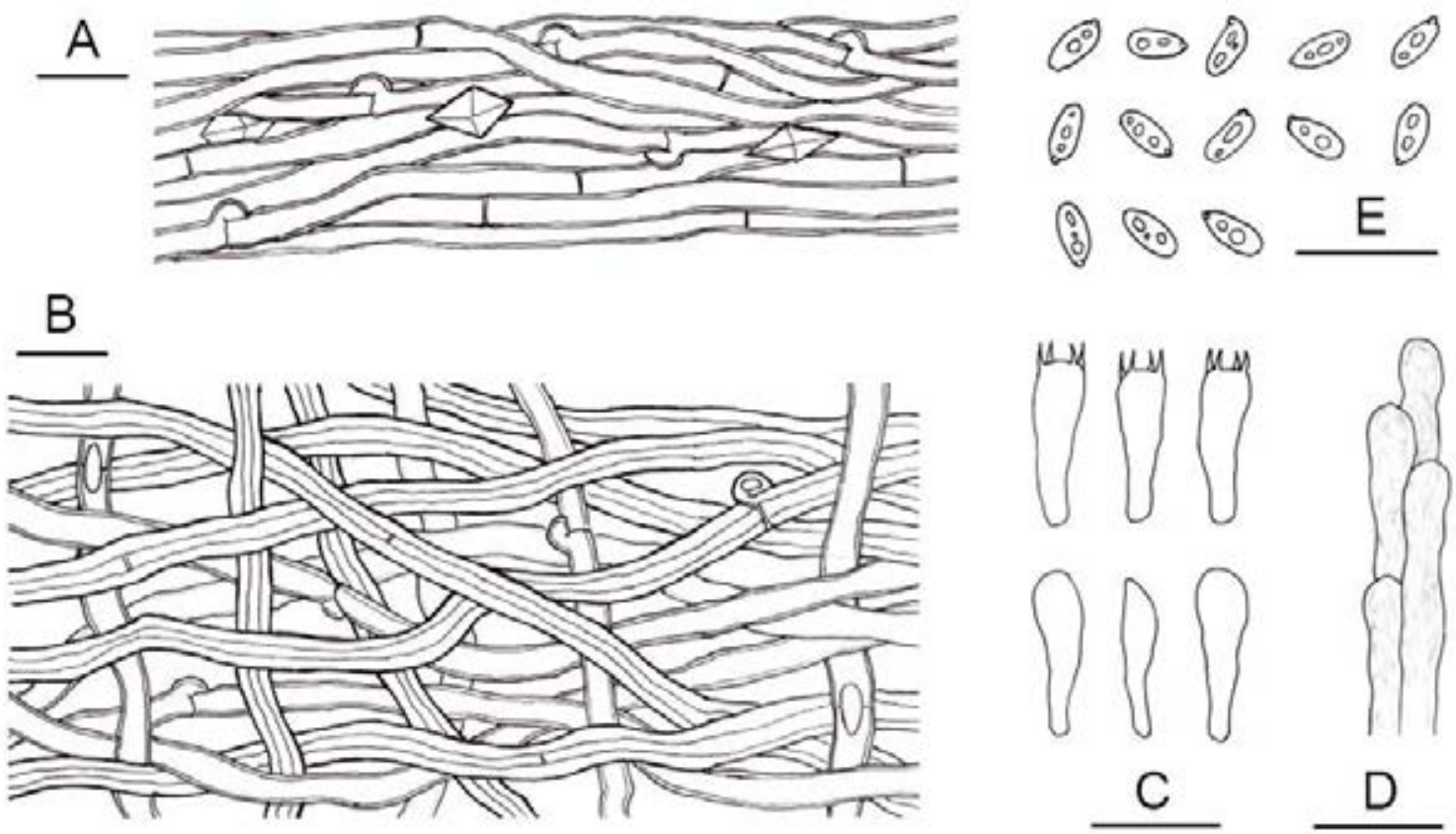

35. ábra. A Frantisekia mentschulensis (PV678) mikromorfológiai bélyegei (PAPP 2012b alapján). A) monomitikus hifarendszer a termőrétegben; B) pszeudodimitikus hifarendszer a húsban; C) bazídium és hifoid cisztídium; D) gloeocisztídium; E) bazídiospórák. Mérce $=10 \mu \mathrm{m}$. Rajz: Papp V.

A Steccherinum nemzetség jellemző morfológiai bélyegei a hidnoid-odontioid tráma, a kristályokkal borított pszeudocisztidiumok és a kis méretű bazídiospórák. A rezervátumban és hazánkban is igen gyakori faj a $S$. ochraceum, amelynek jellemzője, hogy a tüskék hossza nem 
haladja meg az $1 \mathrm{~mm}-\mathrm{t}(0,5-1 \mathrm{~mm})$. Makroszkopikusan viszont igen változatos faj és morfológiai bélyegek alapján nem lehet egyértelmüen elkülöníteni az intersterilitási vizsgálatok alapján leírt S. meridiochraceum Saliba \& A. David és S. pseudochraceum Saliba \& A. David fajoktól (SALIBA és DAVID 1988). Amennyiben SALIBA és DAVID (1988) által végzett kompatibilitási vizsgálatok alapján elkülönített taxonok faji rangon való tárgyalását elfogadjuk, a legyezőszerü és szőrös felszínű, valamint kettős kontextet képző egyedek a $S$. rhois (Schwein.) Banker fajjal azonosak (BANKER 1906). A S. albidum morfológiai bélyegek alapján szintén közel áll a $S$. ochraceum fajhoz, de trámája fehér, valamint spórái kisebbek és keskenyebbek (LEGON és ROBERTS 2002).

Xenasmataceae Oberw.

(1) Phlebiella P. Karst. [=Xenasmatella Oberw.] - *P. vaga (Fr.) P. Karst. [三Trechispora vaga (Fr.) Liberta]

A Phlebiella nemzetség típusfaja a $P$. vaga, amelynek jellemző morfológiai bélyegei, hogy a reszupinátus, sárgás színű termőteste $\mathrm{KOH}$ hatására vöröses színreakciót mutat, valamint szemölcsösen ornamentált spórái elliptikusak, 5-5,5(-6) × 4-4,5 $\mu$ m nagyságúak. BERNICCHIA és GORJÓN (2010) szerint ez a fenyőfélék és lombosfák anyagán egyaránt megjelnő polifág, európaszerte elterjedt gyakori faj. Ezt megerösíti, hogy a Juhdöglö-völgy Erdőrezervátum területén is számos alkalommal dokumentáltam termőtesteit. Hazai elterjedéséről viszont igen keveset tudunk, tekintve hogy csak néhány korábbi publikált előfordulási adata ismert (pl. NAGY és GORLICZAI 2007).

\subsubsection{Russulales Kreisel ex P.M. Kirk, P.F. Cannon \& J.C. David} Auriscalpiaceae Maas Geest.

(1) Artomyces Jülich - A. pyxidatus (Pers.) Jülich [三 Clavicorona pyxidata (Pers.) Doty]

Az örvösen elágazodó ramarioid holotéciumot képző Artomyces pyxidatus, az ágak csészeszerüen bemélyedő, fogazott szélü végződése alapján makroszkopikusan is könnyen felismerhető faj. Az A pyxidatus biogreográfiai helyzetét molekuláris módszerek alapján LICKEY és munkatársai (2002) tárgyalták., majd egy későbbi munkájukban hét tudományra új fajt is közöltek a nemzetségből (LICKEY és mtsai. 2003). Ezek a fajok többnyire Európán kívüli területekről ismertek, ugyanakkor az A. pyxidatus-hoz makromorfológiai bélyegekben nagyon hasonló Japánból leírt A. microsporus (Qiu X. Wu \& R.H. Petersen) Lickey előfordulását FRAITURE és munkatársai (2008) Ukrajnából is igazolták. Ez utóbbi taxon viszont kisebb 
spórákat képez, amely alapján stabilan el lehet különíteni az A. pyxidatus s. str. fajtól. Az A. pyxidatus ökológiai igényei, hazai adatai (pl. BENEDEK 2011; EGRI 2009; LUKÁCS 2002; NAGY 2004; NAGY és Gorliczai 2007; PÁL-FÁm és LuKÁCs 2002; PÁL-FÁm és mtsai. 2009; RimócZi és mtsai. 2009; SILLER 1999; SILLER és mtsai. 2013) és saját tapasztalataim alapján holt faanyagban gazdagabb élőhelyeken nem tünik ritka fajnak.

\section{Hericiaceae Donk}

(1) Dentipellis Donk (I) - *D. fragilis (Pers.) Donk

(2) Hericium Pers. - H. cirrhatum (Pers.) Nikol. [三 Creolophus cirrhatus (Pers.) P. Karst.], H. coralloides (Scop.) Pers. [三H. clathroides (Pall.) Pers.]

(1) Laxitextum Lentz $-*$ L. bicolor (Pers.) Lentz

Taxonómiai és nómenklatúrai megjegyzések: (I) ZHOU és DAI (2013b) filogenetikai vizsgálata alapján a Dentipellis génusz polifiletikus és az Európában is honos Dentipellis leptodon faj az újonnan leírt Dentipellicula Y.C. Dai \& L.W. Zhou nemzetségbe tartozik: Dentipellicula leptodon (Mont.) Y.C. Dai \& L.W. Zhou.

A Dentipellis fragilis jellemző morfológiai bélyegei a reszupinátus hidnoid tráma, a monomitikus hifarendszer, a gloeocisztidiumok jelenléte, valamint az ornamentált amiloid bazídiospórák (NIEMELÄ és SAARENOKSA 1985). A Dentipellis nemzetségből Európában BERNICCHIA és GORJÓN (2010) munkája alapján két makroszkopikusan nagyon hasonló faj fordul elö: D. fragilis (Pers.) Donk és D. leptodon (Mont.) Maas Geest. A rezervátumban gyüjtött Dentipellis minta spóráinak mérete alapján a D. fragilis fajjal azonos (8. táblázat).

8. táblázat. Európai Dentipellis s. lato fajok spóráinak mérete (I) BERNICCHIA és GORJÓN (2010), (II) DAI és munkatársai (2009), (III) GINNS (1986), (IV) KOSKI-KotIRANTA és NIEMELÄ (1987), valamint (V) MAAS GEESTERANUS (1974) munkái alapján.

\begin{tabular}{|c|c|c|}
\hline Irodalom & Dentipellis fragilis & Dentipellicula leptodon \\
\hline (I) & $4,5-6 \times 4-5 \mu \mathrm{m}$ & $3,5-5 \times 3-4 \mu \mathrm{m}$ \\
\hline (II) & $5-5,8(-6) \times(3,8-) 4,1-4,9(-5,1) \mu \mathrm{m}$ & $(3,4-) 3,6-4,2(-4,8) \times 2,8-3,3(-3,6) \mu \mathrm{m}$ \\
\hline (III) & átl.: $5,4 \times 4,5 \mu \mathrm{m}(\mathrm{n}=240)$ & átl.: $3.7 \times 2.8 \mu \mathrm{m}(\mathrm{n}=214)$ \\
\hline (IV) & $5-5,5 \times 4,2-4,9 \mu \mathrm{m}$ & - \\
\hline$(\mathrm{V})$ & - & $3,8-4,5 \times 2,7-3,1 \mu \mathrm{m}$ \\
\hline PV1113 & \multicolumn{2}{|c|}{$\begin{array}{c}(4,7-) \mathbf{5}, \mathbf{1}-\mathbf{5}, \mathbf{3}(-5,5) \times(3,9-) \mathbf{4}, \mathbf{1}-\mathbf{4}, \mathbf{3}(-4,6) \mu \mathrm{m} ; \text { átl.: } \mathbf{5 , 2 2} \times \mathbf{4 , 3} \mu \mathrm{m} \\
\mathrm{Q}=(1,15-) 1,19-\mathbf{1}, \mathbf{2 3}-1,25(-1,35) ; \mathrm{n}=1 / 30\end{array}$} \\
\hline
\end{tabular}

Magyarországról az Európában honos két Dentipellis s. lato faj közül ezidáig csak a $D$. fragilis fajnak van ismert előfordulási adata az Öserdő és Kékes erdőrezervátumokból (SILLER 2004), valamint az Örségből (SILLER és mtsai. 2013). 

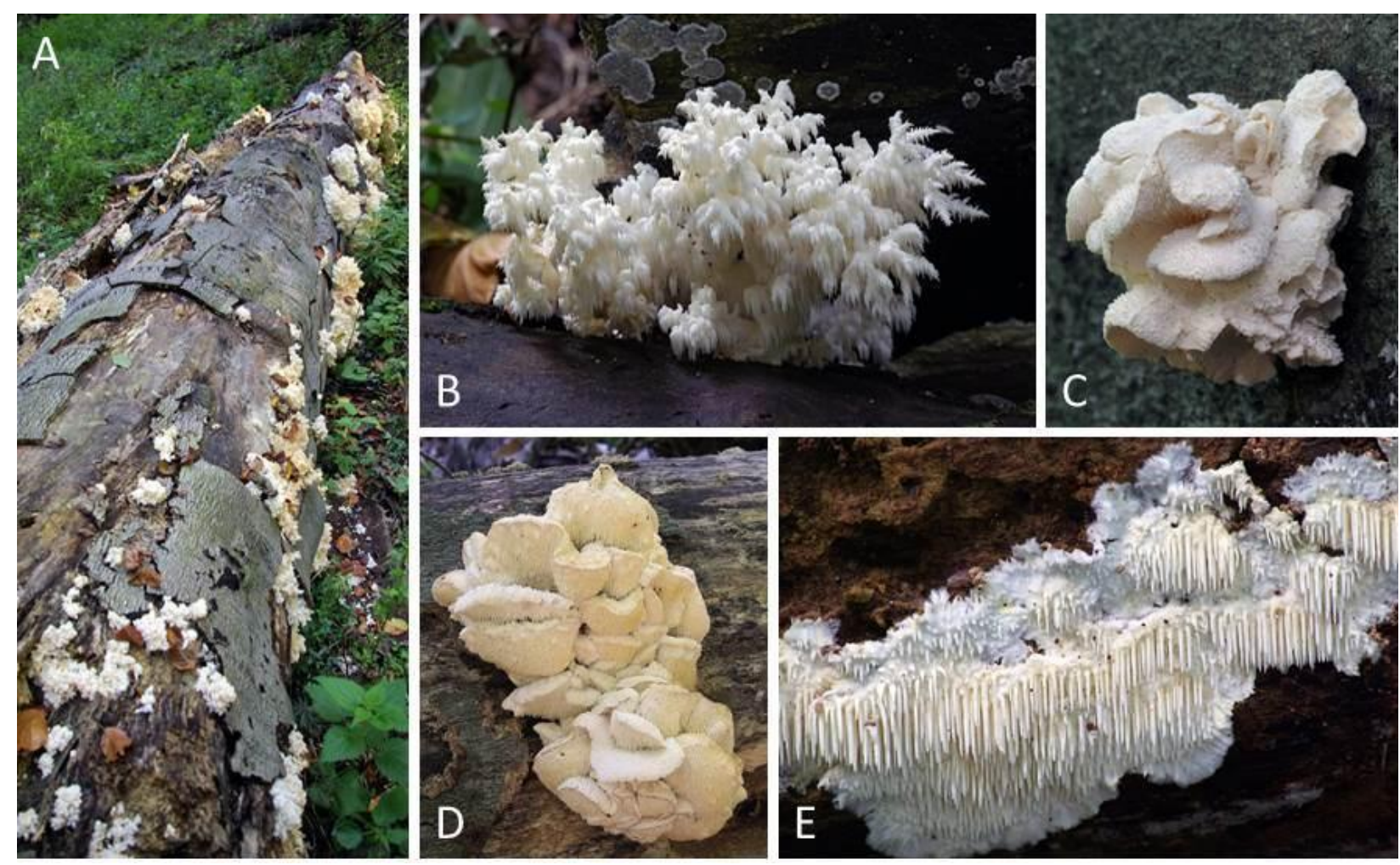

36. ábra. A Hericiaceae család hidnoid fajainak termőtestei a Juhdöglő-völgy erdőrezervátumban. A) Hericium coralloides termőtestek bükkfa rönkön (in situ); B) A Hericium coralloides termőteste (in situ); C-D) a Hericium cirrhatum sporokarpiuma ugyan azon a bükkfa rönkön, különböző időpontban (in situ); E) a Dentipellis fragilis termöteste (in situ). Fotók: Papp V.

A Hericium nemzetség négy Európában honos faja (BERNICCHIA és GORJÓN 2010) közül három fordul elő lombosfák faanyagán: $H$. cirrhatum, $H$. coralloides és $H$. erinaceus (Bull.) Pers. Ennek a három, európaszerte ritkának tartott fajnak, BODDY és munkatársai (2011) az ökológiai igényeit vizsgálták az Egyesült Királyságban. Megállapították, hogy mindhárom Hericium faj közel hasonló ökológiai igényekkel rendelkezik; az egyes szubsztrátumon való megjelenésükben pedig jelentős szerepe lehet a konkurens gombafajok prezenciájának (WALD és mtsai. 2004).

A Vértesből mindhárom faj előfordulása ismert (KoszKA 2014); a vizsgált időszakban az erdőrezervátum területéről a Hericium cirrhatum (36. ábra/C-D) és $H$. coralloides $(\mathbf{3 6}$. ábra/AB) előfordulását igazoltam.

Az európai Hericium fajok makroszkopikus bélyegek alapján is elkülöníthetőek egymástól. A H. cirrhatum termőteste kalaposodik, tüskéi 1-2 cm hosszúak, míg a $H$. erinaceus termőteste gumószerü és tüskéi hosszabbak (1-4 cm) (BERNICCHIA és PADOVAN 1997; BERNICCHIA és GORJóN 2010). A H. alpestre és H. coralloides termőtestei elágazodóak, de előbbi faj tüskéi többnyire vastagabbak és hosszabbak $(<2 \mathrm{~cm})$, valamint szétágaznak, rojtosak és lelógók, továbbá jellemzően fenyőfélék (pl. Abies alba) faanyagán nő (HALLENBERG 1983b). 
Peniophoraceae Lotsy [incl. Lachnocladiaceae D.A. Reid]

(2) Peniophora Cooke $-{ }^{*} \boldsymbol{P}$. nuda (Fr.) Bres., *P. quercina (Pers.) Cooke

(1) Scytinostroma Donk - *S. hemidichophyticum Pouzar (I)

Taxonómiai és nómenklatúrai megjegyzések: (I) korábban a POUZAR (1966) által leírt Scytinostroma hemidichophyticum-ot gyakorta az Észak-Amerikából korábban közölt S. portentosum (Berk. \& M.A. Curtis) Donk fajjal azonosították. BERNICCHIA és GORJÓN (2010) szerint viszont az európai taxon érvényes neve a $S$. hemidichophyticum.

A Peniophora quercina, a lilás színü tráma, a himéniumban gyakori lamprocisztidiumok, valamint a hosszúkás spórák (8-12 × 3-4 $\mu \mathrm{m})$ alapján egy könnyen felismerhető korticioid faj. Megfigyeléseim alapján a hazai tölgyesek egy igen gyakori, általában vékonyabb ágakon megjelenő gombája. A szintén tölgyeken növő $P$. nuda jellemző mikroszkopikus bélyegei a kerekded gloeocisztidiumok, valamint a lényegesen ritkább, vastagfalú, a csúcsukon enkrusztált lamprocisztidiumok jelenléte.

A reszupinátus termőtestet képző Scytinostroma nemzetség hifarendszere dimitikus, amelyben a szkeletális hifák gyakran dendrohifákat alkotnak. A S. hemidichophyticum jellemző bélyegei, hogy a spórák teljesen amiloidok, valamint a termőtest naftalinszagú. Hazai adataira TRECKER és SZABÓ (2002) munkájában találtam utalást.

\section{Stereaceae Pilát}

(1) Aleurocystidiellum P.A. Lemke $-*$ A. disciforme (DC.) Tellería [三Aleurodiscus disciformis (DC.) Pat.]

(5) Stereum Hill ex Pers. - *S. gausapatum (Fr.) Fr.; S. hirsutum (Willd.) Pers.; *S. ochraceoflavum (Schwein.) Sacc.; S. cf. rugosum Pers.; S. subtomentosum Pouzar

(2) Xylobolus P. Karst. $-{ }^{*} \boldsymbol{X}$. frustulatus (Pers.) Boidin; ${ }^{* *} \boldsymbol{X}$. subpileatus (Berk. \& M.A. Curtis) Boidin [三Lloydella subpileata (Berk. \& M.A. Curtis) Höhn. \& Litsch.]

Az Aleurocystidiellum nemzetség európai taxonjai sztereoid (diszkoid) termőtestet képeznek, valamint közös jellemzőjük, hogy spóráik elliptikusak, ornamentáltak és amiloidok. Az A. disciforme már terepen is könnyen felismerhető a korong alakú, kissé sztereoid termőtestekről, amelyek élő tölgyek kérgén növekednek (BERNICCHIA és GORJÓN 2010). Ennek ellenére, ennek a vélhetően hazánkban sem ritka fajnak viszonylag kevés publikált adata van. MoEsz (1942) munkája mellett SILLER és munkatársai (2013) az Örség több lelöhelyéröl, kocsánytalan tölgyről jelzik.

A Stereum hirsutum a hazai középhegységi lomberdők egyik leggyakoribb xilofág gombája. A makroszkopikusan hasonló S. ochraceoflavum termőrétegtartója a S. hirsutum-tól eltérően 
halvány krémszínü vagy szürkés, valamint a hús és a tomentum között nincsen fekete réteg. A sérülésre vörös cseppeket kiválasztó lombos fafajokon megjelenő európai fajok közül a $S$. gausapatum-ot elsősorban az akanthocisztidiumok hiánya alapján lehet elkülöníteni a $S$. rugosum-tól (ERIKSSON és mtsai. 1984). A S. subtomentosum sérülésre szintén cseppeket választ ki, de az előbbi fajoktól eltérően sárga színüt (BERNICCHIA és GORJÓN 2010).

A Xylobolus nemzetség hazai adatait és a fajok ökológiai igényeit egy korábbi cikkben ismertettem (PAPP 2011a). A nemzetség jellemzője, hogy Stereum-októl eltérően a pleurocisztídiumok (vagy olajtartó hifák) szürkésfeketék lesznek szulfovanillin hatására. Spóráik simák, amiloidok, elliptikusak és rövidebbek a Stereum fajok spóráinál (BERNICCHIA és GORJÓN 2010; HJORTSTAM és mtsai. 1988, JAHN 1971).

A Xylobolus subpileatus Európában leginkább tölgyfajokon fordul elő (BERNICCHIA és GORJON 2010; JANH 1971); TORTIĆ (1975) szerint valószínüsíthető, hogy föként a csertölgyhöz (Quercus cerris) kötődik. Ezt megerősíti, hogy Csehország és Szlovákia területén is föleg ezen a fafajon találták (POUZAR cit in., JAHN 1971). Hazai előfordulásával kapcsolatban BÁNHEGYI és munkatársai (1953) azt írják, hogy Magyarországon ritka faj, ami “lombosfák, föleg tölgyfélék korhadó tönkjén vagy megmunkált faanyagán (bányákban) terem, inkább összel”. A szerzők megfigyeléseit alátámasztó előfordulási adatokat, azonban nem sikerült fellelni. MOESZ (1942) Budapest környékének gombáit feldolgozó munkájában Lloydella subpileata néven közöl a budapesti Rózsadombon korhadó lécről gyüjtött adatot. Azonban sem a szubsztrátum anyagáról, sem a gyüjtés időpontjáról, illetve a preparátum helyéről nem közöl további információt. 


\subsection{Természetvédelmi értékelés}

\subsubsection{A Juhdöglő-völgy Erdőrezervátum természetvédelmi jelentősége lignikol nagygombák szempontjából}

Az öreg, természetközeli erdők indikálására gyakran az erdő-szerkezetből következtetnek, noha ez nem szükségszerủen mutatja meg az élöhely biodiverzitásának mértékét (BLASI és mtsai. 2010). A különböző élölénycsoportok (pl. moha, rovar, gomba) diverzitásának felmérésén keresztül szintén lehet az erdők természetességére következtetni (JONSSON és mtsai. 2005; TORTIĆ 1998). Egyes taxonok jelenléte vagy hiánya, valamint populációik denzitása mérő jelzőszámként szolgálhat az élőhely természetességének indikálására (LANDRES és mtsai. 1988). Az egyik ilyen kulcscsoportot képviselik a lignikol nagygombák, tekintve hogy egyes taxonok jelenlétéhez és fennmaradásához szükséges az erdők természetközeli állapotának megörzése. Ennek oka, hogy számos specialista nekrotróf vagy kéreglakó faj számára csak az öreg élő fák szolgálhatnak szubsztrátumként, amelyek a gazdasági erdőkben többnyire hiányoznak. A xilofág nagygombák egy jelentős részének a megjelenéséhez pedig nélkülözhetetlen a megfelelö minőségü és mennyiségü holt faanyag jelenléte, amely azokra az erdőkre jellemző, ahol a természetes folyamatok zavartalanul érvényesülhetnek.

A CHRISTENSEN és munkatársai (2004) által összeállított 21 lignikol nagygombafajt tartalmazó listát több európai ország mikológusai is használják a bükkösök természetközeliségének indikálására (pl. ADAMČíK és mtsai. 2007, AINSWORTH 2005). A listán szerepló fajok az alábbiak: Aurantiporus alborubescens (Bourdot \& Galzin) H. Jahn; Camarops tubulina (Alb. \& Schwein.) Shear; Ceriporiopsis gilvescens (Bres.) Domanski; Ceriporiopsis pannocincta (Romell) Gilb. \& Ryvarden; Climacodon septentrionalis (Fr.) P. Karst.; Dentipellis fragilis (Pers.) Donk; Flammulaster limulatus (Fr.) Watling; Flammulaster muricatus (Fr.) Watling; Ganoderma pfeifferi Bres.; Hericium coralloides (Scop.) Pers.; Hericium erinaceum (Bull.) Pers.; Hohenbuehelia auriscalpium (Maire) Singer; Inonotus cuticularis (Bull.) P. Karst.; Ischnoderma resinosum (Schrad.) P. Karst.; Lentinellus vulpinus (Sowerby) Kühner \& Maire; Lentinellus ursinus (Fr.) Kühner; Mycoacia nothofagi (G. Cunn.) Ryvarden; Ossicaulis lignatilis (Pers.) Redhead \& Ginns; Pholiota squarrosoides (Peck) Sacc.; Pluteus umbrosus (Pers.) P. Kumm.; Spongipellis delectans (Peck) Murrill. Ezek közül a Juhdöglö-völgy Erdörezervátum területéről ezidáig 16 faj előfordulását sikerült igazolni. Ennek alapján az erdőrezervátum „ősbükkös” élöhelye kis mérete ellenére mikológiai szempontból Európa legértékesebb bükkerdői közé tartozik (9. táblázat). 
9. táblázat. A 10 legértékesebb európai bükkös erdőterület a 21 indikátorfaj jelenléte alapján; CHRISTENSEN és munkatársai (2004), valamint AINSWORT (2004b) munkái nyomán.

\begin{tabular}{|c|c|c|c|c|c|c|c|c|c|c|}
\hline & 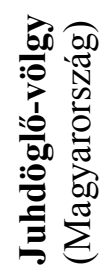 & 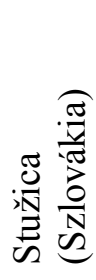 & 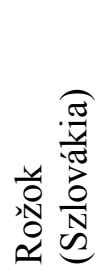 & 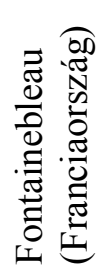 & 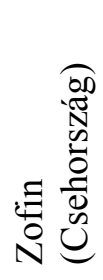 & 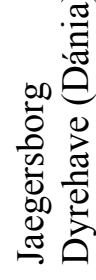 & 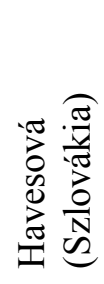 & 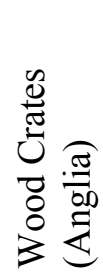 & 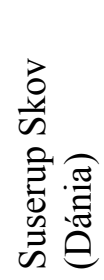 & 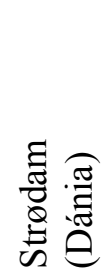 \\
\hline \multicolumn{11}{|c|}{ Aurantip. alborubescens } \\
\hline \multicolumn{11}{|c|}{ Camarops tubulina } \\
\hline \multicolumn{11}{|c|}{ Ceriporiopsis gilvescens } \\
\hline \multicolumn{11}{|c|}{ Ceriporio. pannocincta* } \\
\hline \multicolumn{11}{|c|}{ Climac. septentrionalis } \\
\hline \multicolumn{11}{|c|}{ Dentipellis fragilis } \\
\hline \multicolumn{11}{|c|}{ Flammulaster limulatus } \\
\hline \multicolumn{11}{|c|}{ Flammulaster muricatus } \\
\hline \multicolumn{11}{|c|}{ Ganoderma pfeifferi* ${ }^{*}$} \\
\hline \multirow{2}{*}{\multicolumn{11}{|c|}{$\begin{array}{l}\text { Hericium coralloides } \\
\text { Hericium erinaceum }\end{array}$}} \\
\hline \multirow{2}{*}{\multicolumn{5}{|c|}{ Hericium erinaceum }} & & & & & & \\
\hline \multicolumn{9}{|c|}{ Hohenb. auriscalpium } & & \\
\hline \multicolumn{11}{|c|}{ Inonotus cuticularis } \\
\hline \multicolumn{11}{|c|}{ Ischnoderma resinosum } \\
\hline \multicolumn{11}{|c|}{ Lentinellus vulpinus } \\
\hline \multicolumn{11}{|c|}{ Lentinellus ursinus } \\
\hline \multicolumn{11}{|c|}{ Mycoacia nothofagi* } \\
\hline \multicolumn{11}{|c|}{ Ossicaulis lignatilis* } \\
\hline \multicolumn{11}{|c|}{ Phol. squarrosoides } \\
\hline \multirow{2}{*}{\multicolumn{11}{|c|}{$\begin{array}{l}\text { Pluteus umbrosus } \\
\text { Spongipellis delectans }\end{array}$}} \\
\hline \multicolumn{2}{|c|}{ Spongipellis delectans } & & & & & & & & & \\
\hline$\sum$ lignikol faj & 239 & 179 & 158 & 133 & 69 & 140 & 134 & - & 193 & 168 \\
\hline$\sum$ Indikátor faj & 16 & 16 & 16 & 15 & 15 & 14 & 13 & 13 & 12 & 12 \\
\hline
\end{tabular}

*A Ceriporiopsis pannocincta jelenleg elfogadott neve a Gelatoporia pannocincta (Romell) Niemelä (NIEMELÄ 1985). A Ganoderma pfeifferi érvényes neve a Ganoderma cupreolaccatum (Kalchbr.) Z. Igmándy (IGMÁNDY 1968, PAPP \& SILLER 2012). A Mycoacia nothofagi-t NAKASONE (1997), valamint BERNICCHIA és GORJÓN (2010) is a Phlebia nemzetségben tárgyalja. CONTU (2007) Fries által leírt Agaricus lachnopus alapján közölte az Ossicaulis lachnopus binomot, amely faj termőteste makroszkopikusan igen hasonló az Ossicaulis lignatilis-éhez. HoLEC és KOLAŘíK (2012) a két fajt megvizsgálták morfológiai és molekuláris taxonómiai módszerekkel is és igazoltnak látták az $O$. lachnopus faji szintü elkülönítését. Véleményük szerint a rezervátum jellegü, természetszerü élőhelyeken inkább az $O$. lachnopus fordul elő.

A vizsgálati időszak során a Hericium erinaceum-ot nem sikerült kimutnom, de korábban KoszKA (2011, 2014) közölte egy 2009-es előfordulási adatát a közeli Horog-völgyböl. A rezervátumból ezidáig nem dokumentált listás indikátorfajok közül mindkét Lentinellus fajnak van publikált hazai adata és a L. vulpinus a Vértesből is ismert (BABOS 1989). A Climacodon septentrionalis-t Magyarországról először az Őserdő Erdőrezervátumból sikerült kimutatni (SILLER 2004) és azóta is ez az egyetlen ismert lelöhelye hazánkból. Az aszkuszos Camarops tubulina fajoknak nincsen publikált magyarországi adatuk. A CHRISTENSEN és munkatársai 
(2004) által összeállított listán szereplö 21 faj mellett több olyan taxon is ismert, amelyeket öreg európai bükkerdőkre jellemzőként tartanak számon. A Nat-Man projekt keretein belül korábban Heilmann-Clausen és Christensen (2000) még 41 olyan fajt jelöltek ki (ebben szerepel a később 21 fajra szükített lista mindegyike), amelyek utalnak a termőhely értékességére, illetve magas biodiverzitására. Ezek közül SILLER (2004) az Öserdő és Kékes erdőrezervátumokból összesen 25 faj előfordulását mutatta ki. A 41 fajos listán a Juhdöglő-völgy Erdőrezervátumból kimutatott lignikol nagygombák közül a fentebb említett 15-ön kívül szerepel még az Aurantiporus fissilis, Eutypa spinosa, Inonotus nodulosus, I. obliquus, Phleogena faginea, Pholiota adiposa [P. aurivellus s. auct.], Pluteus luctuosus, P. phlebophorus, Polyporus badius és Stereum subtomentosum.

Az élőhely természetességére nem csak a ritka fajok alapján lehet következtetni. MÜLLER és munkatársai (2007) statisztikai módszerek alapján 10 indikátorfajt határoztak meg, köztük a Fomes fomentarius-t. Eredményük alapján ez az évelő termőtestet képző, Európaszerte elterjedt taplófaj egy egész évben vizsgálható indikátora lehet a bükkerdők természetességének. Hasonló eredményre jutottak HALME és munkatársai (2009), akik munkájukban kimutatták, hogy az évelő termőtestet képző taplófajok jelenléte indikálja az egyéves, vörös listás taplófajok prezenciáját.

Az európai tölgyesek klimatikusan és szerkezetileg is változatosabbak, mint a bükkös élőhelyek, ebből adódóan nehézkesebbnek látszik egy széleskörben érvényes indikátor gombafajlista összeállítása. A rezervátumból viszont számos olyan faj előfordulását sikerült kimutatni, amelyek a szakirodalom alapján jellemzően öreg tölgyekhez kötődnek: pl. Buglossoporus quercinus, Grifola frondosa, Inonotus krawtzewii, Xylobolus subpileatus.

\subsubsection{Ritka, veszélyeztetett és védett lignikol nagygombák a Juhdöglö-völgy Erdőrezervátumban}

A Juhdöglö-völgy Erdőrezervátum magterületéről a 12 hazánkban védett lignikol nagygomba (SILLER és mtsai. 2005; FolCZ és PAPP 2014) közül az eddigi felvételezések során 7 faj előfordulását sikerült kimutatni: Ganoderma cupreolaccatum, Grifola frondosa, Hericium cirrhatum, Hypsizygus ulmarius, Pholiota squarrosoides, Pluteus umbrosus, Polyporus tuberaster. Ezek közül a Pholiota squarrosoides-nek ezidáig a rezervátum az egyetlen publikált élőhelye Magyarországról. A Ganoderma cupreolaccatum pedig jelenlegi ismereteink alapján a hegységben egyedül a rezervátumban fordul elő. A Grifola frondosa első és egyben ezidáig egyetlen vértesi előfordulását Dravecz Tibor 1988. október 2-án dokumentálta Gántról (FőDI és PAPP 2014). KoszKa $(2011,2014)$ több mint tíz éves kutatómunkája során összesen 18 védett gombafajt mutatott ki a Vértes területéről. Ezek között található a rezervátum területén a vizsgált 
időszakban nem dokumentált, de BABOS (1989) által a hegységből már korábban is jelzett polifág Volvariella bombycina (Schaeff.) Singer (SzCZEPKOWSKI és mtsai. 2013) és a Hericium erinaceus (Bull.) Pers.

A jelen munkában közölt eredmények alapján a Vértes területéről összesen 20 védett nagygombafaj ismert (BABOS 1989; KoszKA 2014; SILLER és mtsai. 2006), amelyek közül 9 lignikol életmódú. A több európai országban szintén védett (pl. PARMASTO 2006; IVANČEviĆ 2009; ANONYMUS 2011), valamint a 33 európai védendő faj között is szereplő (DAHLBERG és CRONEBORg 2003) Hapalopilus croceus (Pers.) Bondartsev \& Singer jellemzően idős élő tölgyeken fordul elő (RYVARDEN és MELO 2014). Magyarországon az egyetlen ismert lelőhelyét IGMÁNDY (1968, 1971, 1981) publikálta a Rába árterületéről, az egyik évszázados tölgyek egyikéről, amelyen éveken át sikerült megfigyelnie a termőtesteket.

A Polyporus umbellatus (Pers.) Fr. élöhelypreferenciáját tekintve a tölgyeseket (cser kivételével), gyertyánosokat és bükkösöket kedveli (KUNCA és mtsai. 2011). SILLER és munkatársai (2006) ezt a fajt lignikol szaprotrófként jellemzik, azonban KuNCA és munkatársai (2011) Szlovákiában végzett vizsgálataik alapján arra a következtetésre jutottak, hogy a $P$. umbellatus kifejezetten terrikol életmódot folytat és termőteste a talajban lévő szklerociumon növekszik. Megfigyeléseik alapján a lankásabb $\left(<10^{\circ}\right.$ lejtés) és délies, melegebb fekvésü hegyoldalakat kedveli. Ilyen körülmények a Juhdöglö-völgy Erdőrzervátumban a platókon lévő molyhos-tölgyesben adottak.

A Rhodotus palmatus (Bull.) Maire makroszkopikusan is felismerhető jellegzetes megjelenésű agarikoid termőtestet képez, amely különböző lombos fafajokon (pl. Ulmus, Populus, Aesculus, Fagus, stb.) jelenik meg (SundBERg és mtsai. 1997; Siller 2004; TANG és mtsai. 2014). Összességében megállapítható, hogy gazdanövény-preferenciájuk és ökológiai igényeik alapján, a rezervátum területén ezidáig nem dokumentált öt védett lignikol nagygombafaj is potenciálisan elöfordulhat.

A jelen munkában közölt eredmények és a feldolgozott szakirodalmi adatok alapján több taxon természetvédelmi státuszának megvitatása, esetleges revideálása is szükségesnek látszik. A Magyarországi nagygombák vörös listáján (RIMÓCZI és mtsai. 1999) a „kihalással fenyegetett” (CR) kategóriában szereplö 6 lombos fákon növő bazídiumos nagygombafaj közül 5 a rezervátumban is megtalálható: Clitopilus hobsonii, Crepidotus crocophyllus, Hericium cirrhatum, Hohenbuehelia mastrucata, Physisporinus sanguinolentus. Ezek közül a Clitopilus hobsonii-t RIMÓCZI (1997) a vörös lista tervezetet megalapozó munkájában még a Magyarországról kihalt fajok között említi, amelynek az lehetett az oka, hogy a korábban BABOS (1989) által közölt egyetlen ismert magyarországi termőhelyét kiparcellázták és beépítették. Az elmúlt években viszont több újabb adatát sikerült kimutatni (Dima Bálint személyes közlés). Ezt 
a fajt a Nyíregyházán megrendezett 27. Európai Cortinarius Kongresszus terepnapjai során Anton Hausknecht a Bóckerek-erdőben kukoricacsutkáról gyüjtötte (BP 101775) (DIMA és mtsai. 2010), amely jól mutatja, hogy a C. hobsonii milyen változatos szubsztrátumokon képes megjelenni. Továbbá ritkaságának elletmond NoORDELOOS (2012) megállapítása is, miszerint az északi mérsekelt övben nagyon gyakori faj. Véleményem szerint a szakirodalmi adatok, valamint saját tapasztalataim alapján ennek a makromorfológiai bélyegek alapján nehezen felismerhető fajnak a vörös listás besorolása felülvizsgálatra szorul.

A Crepidotus crocophyllus-nak a vörös lista közlése előtt csak néhány hazai adata volt ismert (BABOSNÉ 1975, BABOS 1989, RiмÓCZI 1994, TóTH 1999), azonban az újabb lelöhelyei és a változások a faj taxonómiai megítélésében indokoltá teszik természetvédelmi helyzetének revízióját. A Hericium cirrhatum magyarországi elterjedésével kapcsolatban számos újabb adattal lettünk gazdagabbak a vörös lista megjelenése óta (ALBERT és DiMA 2005; LUKÁCS 2002, 2010; KosZKa 2011; SiLler és mtsai. 2006). KosZKA (2011) ezzel a fajjal kapcsolatban munkájában megjegyzi, hogy „a gomba elterjedése nem indokolja az 1-es fokozatot, ezért jelen munkámban 2-es besorolású fajként kezeltem". A faj ökológiája és újabb hazai adatainak alapján egyetértek Koszka álláspontjával és szükségesnek tartom a $H$. cirrhatum vörös listás besorolásának felülvizsgálatát.

A Physisporinus sanguinolentus kevés magyarországi adatában szerepet játszhat, hogy a hazai fungisztikai munkákban a reszupinátus poroid taxonok jellemzően alulreprezentáltak. Európai szinten viszont nem látszik kifejzetten ritka fajnak (RYVARDEN és MELO 2014), ezért véleményem szerint természetvédelmi helyzetének megítéléséhez további vizsgálatokra lenne szükség.

A rezervátum magterületén gyüjtött nagygombák közül a vörös listán (RIMÓcZI és mtsai. 1999) számos faj az „erősen veszélyeztetett” kategóriába került besorolásra: Artomyces pyxidatus, Ceriporia spp., Crepidotus cesatii, Emmia latemarginata, Flammulaster spp., Hemimycena spp., Hohenbuehelia atrocoerulea, Hydropus subalpinus, Hypsizygus ulmarius, Ischnoderma resinosum, Ossicaulis lignatilis s. lato, Phaeomarasmius spp., Pluteus umbrosus, Macrotyphula fistulosa, Meripilus giganteus, Phlebia uda, Simocybe sumptuosa. A poroid termőtestet képző Ischnoderma resinosum és Meripilus giganteus kifejezetten gyakoriak voltak a vizsgált területen. A $M$. giganteus, mint veszélyeztetett faj egy európai vörös listán sem szerepel. A Ceriporia génusz Magyarországon az alulreprezentált taxonok közé tartozik, így igen keveset tudunk a nemzetség fajainak hazai elterjedéséről és ökológiájáról. Az egyes Ceriporia fajok természetvédelmi helyzetének megítélése ezért további szisztematikus fungisztikai és taxonómiai vizsgálatokat igényel. Az Emmia latemarginata egy erősen polifág, Európában szubmediterrán jellegü taplófaj (KoTLABA 1997; RYVARDEN és MELO 2014), amely természetközeli erdők 
mellett gyakran fordul elő urbánus környezetben is (PIĄTEK 2003b). Hazai adatait (pl. IGMÁNDY 1981) és ökológiai igényeit tekintve, véleményem szerint indokoltnak látszik az E. latemarginata vörös listás besorolásának felülvizsgálata.

Az agarikoid termőtestet képző taxonok közül a Flammulaster limulatus-nak az elmúlt másfél évtizedben számos újabb lelőhelyét publikálták hazánkból (pl. DiMA és mtsai. 2010; FODOR és mtsai. 2001; RUDOLF és mtsai 2008; SILLER 2004) és a rezervátum területén is egyes időszakokban a megjelenése tömeges volt. Az adatainak száma is növekvő tendenciát mutat a vörös lista megjelenése óta, viszont figyelembe kell venni, hogy a természetközeli bükkösök megóvása nélkül jelentősen visszaszorulhat. A $F$. limulatus-hoz viszonyítva a $F$. muricatus termőtestei a felvételezési időszakban ritkábban és kisebb számban jelentek meg a rezervátum területén. Ugyanakkor hazai adatai alapján szélesebb szubsztrátum-spektrummal (Alnus, Fagus, Fraxinus, Populus, Quercus) rendelkezik (NAGY 2004, Rudolf és mtsai. 2008) és úgy tünik, hogy nem kötődik kizárólag természetközeli bükkösökhöz.

A polifág Crepidotus cesatii [incl. C. subsphaerosporus (J.E. Lange) Kühner \& Romagn. ex Hesler \& A.H. Sm.] nemzetközi szakirodalmak alapján a nemzetség leggyakoribb faja Európában (CONSIGLio és SETTI 2008; SENN-IRLET 1995), ezért vélhetően hazánkban sem ritka. A vörös lista megjelenése előtt publikált viszonylag kevés magyarországi adata (pl. BABOS 1989; RIMÓCZI és mtsai. 1997) feltételezhetően a génusz makroszkopikusan nagyon hasonló fajainak határozási nehézségeivel is magyarázható. A Simocybe sumptuosa magyarországi elterjedésének pontosabb megismeréséhez a gyakoribb $S$. centunculus-hoz való hasonlósága miatt, ez utóbbi faj adatainak revideálása is szükséges. Az Ossicaulis lignatilis ritkaságának és pontos hazai elterjedésének megítéléséhez szükséges a korábban gyüjtött fungáriumi minták revideálása, tekintve, hogy a vörös lista publikálásakor az O. lachnopus a tudomány számára még ismeretlen faj volt.

LUKÁCS (2010), valamint LUKÁCS és munkatársai (2013) több a rezervátum területéröl is kimutatott és a vörös listán nem szereplő faj esetében fogalmaztak meg veszélyeztetettségi kategóriába való besorolásra javaslatot: Agrocybe firma (EN), Phleogena faginea (EN), Xylobolus frustulatus (CR). A Xylobolus frustulatus fajt DIMA és munkatársai (2010) is a ritka fajok között említik és véleményük szerint a faj fennmaradása összefügg a háborítatlan erdök megőrzésével. PAPP (2011a) a kevés hazai adata és nemzetközi vörös listák alapján a „veszélyeztetett” (VU), míg LUKÁCS és munkatársai (2013) ritkasága miatt a „kihalással fenyegetett” (CR) vörös lista kategóriába való felvételét javasolták. A Mátrában és Börzsönyben végzett szisztematikus terepi vizsgálataink alapján a $X$. frustulatus számára szubsztrátumaként szolgáló tölgy rönkök és tuskók jelenléte többnyire nem csak a háborítatlan erdőkre jellemző. A tölgy fájának lassú korhadása miatt fiatal gazdasági erdőkben gyakran fordulnak elő 
visszamaradt nagyméretü tölgytuskók, amelyeken helyenként igen gyakri volt ez a faj. Az ország nyugati részén ugyanakkor nem sikerült kimutatni sem az Örség (SILLER és mtsai. 2013) sem a Soproni-hegység (FOLCZ és mtsai. 2013) területéről. Az újabb terepi megfigyeléseim alapján, a Xylobolus frustulatus ökológiai igényei nem indokolják a vörös listára való felvételét. 


\section{5. ÚJ TUDOMÁNYOS EREDMÉNYEK}

1. Első alkalommal végeztem szisztematikus fungisztikai vizsgálatokat a Juhdöglö-völgy Erdőrezervátum területén. A 2010 és 2014 közötti időszakban 45 terepnap során 223 lignikol bazídiumos nagygombafajt mutattam ki. Jelen eredmények alapján lignikol bazídiumos nagygombák szempontjából a Juhdöglö-völgy Erdőrezervátum Magyarország legnagyobb fajdiverzitású élőhelye.

1.1. A Vértesben végzett korábbi fungisztikai vizsgálatokat és szórványos adatokat tartalmazó szakirodalmak alapján, a jelen munkában közölt fajok közül 122 újnak bizonyult a hegységre nézve.

1.2. A vizsgálati időszakban dokumentált és ezidáig meghatározott taxonok közül 20 faj újnak bizonyult Magyarország fungájára nézve: Aurantiporus alborubescens (Bourdot \& Galzin) H. Jahn, Crepidotus ehrendorferi Hauskn. \& Krisai, C. malachioides Consiglio, Prydiuk \& Setti, Dendrothele commixta (Höhn. \& Litsch.) J. Erikss. \& Ryvarden, Donkia pulcherrima (Berk. \& M.A. Curtis) Pilát, Entoloma tjallingiorum var. tjallingiorum Noordel., Frantisekia mentschulensis (Pilát ex Pilát) Spirin, Hohenbuehelia auriscalpium (Maire) Singer, Hymenochaete carpatica Pilát, $H$. fuliginosa (Pers.) Lév., Inonotus krawtzewii (Pilát) Pilát, Mensularia hastifera (Pouzar) T. Wagner \& M. Fisch., Ossicaulis lachnopus (Fr.) Contu, Phanerochaete aculeata Hallenb., Phlebia fuscoatra (Fr.) Nakasone, Phlebia nothofagi (G. Cunn.) Nakasone, Pholiota squarrosoides (Peck) Sacc., Pluteus diettrichii Bres., Postia alni Niemelä \& Vampola, Xylobolus subpileatus (Berk. \& M.A. Curtis) Boidin. Továbbá a Pluteus cervinus fehéres színű termőtestet képző változatát [P. cervinus var. albus Peck] is első alkalommal mutattam ki hazánkból.

2. Lignikol bazídiumos nagygombák vizsgálata alapján a Juhdöglö-völgy Erdőrezervátum természetvédelmi megítéléséhez az alábbi új tudományos eredményekkel járultam hozzá.

2.1. Az európai bükkerdők természetességét indikáló, 106 erdőrezervátum adatainak elemzése alapján összeállított 21 nagygombafajt tartalmazó lista taxonjai közül a Juhdöglő-völgy Erdőrezervátum magterületén az alábbi 16 faj előfordulását igazoltam: Aurantiporus alborubescens (Bourdot \& Galzin) H. Jahn, Ceriporiopsis gilvescens (Bres.) Domanski, Dentipellis fragilis (Pers.) Donk, Flammulaster limulatus (Fr.) 
Watling, F. muricatus (Fr.) Watling, Ganoderma cupreolaccatum (Kalchbr.) Z. Igmándy, Gelatoporia pannocincta (Romell) Niemelä, Hericium coralloides (Scop.) Pers., Hohenbuehelia auriscalpium (Maire) Singer, Inonotus cuticularis (Bull.) P. Karst., Ischnoderma resinosum (Schrad.) P. Karst., Ossicaulis lignatilis (Pers.) Redhead \& Ginns s. lato; Phlebia nothofagi (G. Cunn.) Nakasone, Pholiota squarrosoides (Peck) Sacc., Pluteus umbrosus (Pers.) P. Kumm. és Spongipellis delectans (Peck) Murrill.

Ez a fajszám a legmagasabb a vizsgált hazai erdörezervátumok közül és szakirodalmi adatok alapján európai szinten is csak a szlovákiai Stužica és Rožok őserdőkben mutattak ki ennyi indikátorfajt.

2.2. A Juhdöglő-völgy Erdőrezervátum magterületéről a 12 hazánkban védett lignikol nagygomba közül az eddigi felvételezések során az alábbi 7 faj előfordulását mutattam ki: Ganoderma cupreolaccatum (Kalchbr.) Z. Igmándy, Grifola frondosa (Dicks.) Gray, Hericium cirrhatum (Pers.) Nikol., Hypsizygus ulmarius (Bull.) Redhead, Pholiota squarrosoides (Peck) Sacc., Pluteus umbrosus (Pers.) P. Kumm., Polyporus tuberaster (Jacq. ex Pers.) Fr.

Ezek közül a Vértesből egyedül erről az élőhelyről ismert a Ganoderma cupreolaccatum és Pholiota squarrosoides. Jelenlegi ismereteink alapján a hazai erdőrezervátumok közül a Juhdöglö-völgyben fordul elő a legtöbb védett, lignikol nagygombafaj.

3. Taxonómiai és nómenklatúrai vizsgálataim során az alábbi új eredményeket és tudományra új binomokat közöltem:

3.1. ITS szekvenciák alapján igazoltam, hogy az Entoloma zucherrelii, E. pluteisimilis és E. sclerotiogenum nem különülnek el faji szinten. A három taxon makromorfológiai bélyegeinek különbségei alapján viszont változatok szintjén való megkülönböztetésük indokoltnak látszik. Tekintettel arra, hogy a komplexből a Rhodocybe zuccherellii Noordel. \& Hauskn. binom a legkorábban közölt bazioním, az alábbi két új kombinációt hoztam létre:

- Entoloma zuccherellii var. pluteisimilis (Noordel. \& C.E. Hermos.) V. Papp (Index Fungorum: IF551097) [三Entoloma pluteisimilis Noordel. \& C.E. Hermos.] 
- Entoloma zuccherellii var. sclerotiogenum (Caball., Higelmo, Català \& Vila) V. Papp (Index Fungorum: IF551098) [三Entoloma sclerotiogenum F. Caball., Higelmo, Català \& Vila, Errotari]

Az Entoloma és Clitopilus nemzetségek taxonómiai és nómenklatúrai helyzetének áttekintése alapján az alábbi új kombinációt közöltem:

- Entoloma vernalis (Har. Takah. \& Degawa) V. Papp \& Dima (IF551096) [三 Clitopilus vernalis Har. Takah. \& Degawa]

3.2. Recens filogenetikai vizsgálatok eredményei, valamint a Postia caesia komplex nómenklatúrai helyzetének revíziója során a korábban nemzetség szinten elkülönített Cyanosporus McGinty alapján létrehoztam egy új alnemzetséget a Postia génuszon belül:

- Postia subgen. Cyanosporus (McGinty) V. Papp, Mycotaxon 129 (2): 411 (2015) (MycoBank: MB 810903) [三 Cyanosporus McGinty, in Lloyd, Mycol. Notes 33: 436 (1909)]

A Postia/Oligoporus nemzetségek taxonómiai és nómenklatúrai helyzetének áttekintése alapján az alábbi új kombinációkat közöltem:

- Postia africana (Ryvarden) V. Papp, Mycotaxon 129 (2): 411 (2015) (MycoBank: MB810904) [三 Oligoporus africanus Ryvarden, Mycotaxon 31 (2): 407 (1988)]

- Postia amyloidea (Corner) V. Papp, Mycotaxon 129 (2): 411 (2015) (MB810905) [Tyromyces amyloideus Corner, Beihefte zur Nova Hedwigia 96: 160 (1989)]

- Postia caesioflava (Pat.) V. Papp, Mycotaxon 129 (2): 411 (2015) (MB810907) [三 Polyporus caesioflavus Pat., Bulletin de la Société Mycologique de France 8 (2): 114 (1892)]

- Postia coeruleivirens (Corner) V. Papp, Mycotaxon 129 (2): 411 (2015) (MB810908) [三 Tyromyces coeruleivirens Corner, Beihefte zur Nova Hedwigia 96: $163(1989)]$ 
3.3. A PV1044 sorszámú fungáriumi minta morfológiai vizsgálata alapján egyezést mutatott a jelenleg a szakirodalom alapján Climacodon pulcherrimus-ként tárgyalt faj holotípusával. Az átnézett genetikai adatbázisok alapján első alkalommal készítettem ebből a fajból ITS szekvenciát, amely alapján filogenetikai vizsgálattal igazoltam, hogy ez a faj nemzetségszinten elkülönül a Climacodon típusfajától és vélhetően a Donkia génuszba tartozik: Donkia pulcherrima (Berk. \& M.A. Curtis) Pilát.

3.4. A Magyarországról első alkalommal a Juhdöglő-völgy Erdőrezervátumból dokumentált és 2013-ban védetté nyilvánított Pholiota squarrosoides filogenetikai vizsgálata alapján elöször mutattam ki, hogy ez a faj nem az Adiposae, hanem a Pholiota szekcióba tartozik. 


\section{6. ÖSSZEFOGLALÁS}

Az emberi tevékenység hatására csökkenőben lévő, magas biodiverzitású erdei élőhelyek védelmében szükségessé vált a még természetszerü állapotukat őrző erdők megóvása. Ennek érdekében dolgozták ki Magyarországon az Erdőrezervátum Programot, amely során törvényi védelmet élvező erdőterületeket jelöltek ki.

A Vértesben található és holt faanyagban gazdag Juhdöglö-völgy Erdőrezervátumban (JDV ER) korábban nem végeztek szisztematikus fungisztiakai vizsgálatokat. Jelen munkában a nagygombák közül kifejezetten a faanyagon élő bazídiumos taxonok feltárására koncentráltam. Munkám során az alábbi főbb célokat tüztem ki: (1) a JDV ER lignikol bazídiumos nagygombavilágának feltárása, taxonómiai értékelése mikro- és makromorfológiai bélyegek alapján, kiegészítve filogenetikai módszerekkel is; (2) a JDV ER területéről dokumentált gombafajok természetvédelmi helyzetének értékelése és a vizsgált terület valós természeti értékének meghatározása; (3) a kutatás során felmerülő szisztematikai és nevezéktani kérdések tisztázása.

A JDV ER magterületéröl 2010 és 2014 közötti időszakban 45 terepnap során összesen 232 lignikol bazídiumos nagygombafajt mutattam ki. Az ezidáig meghatározott taxonok közül 122 faj újnak bizonyult a Vétesre, míg 20 faj Magyarország fungájára nézve. Az európai bükkerdők természetességét indikáló, 106 erdőrezervátum adatainak elemzése alapján összeállított 21 nagygombafajt tartalmazó lista taxonjai közül a JDV ER magterületén 16 faj előfordulását igazoltam, amely a legmagasabb a vizsgált hazai erdőrezervátumok közül és szakirodalmi adatok alapján európai szinten is csak a szlovákiai Stužica és Rožok őserdőkben mutattak ki ennyi indikátorfajt. A 12 hazánkban védett lignikol nagygomba közül az eddigi felvételezések során 7 faj előfordulását mutattam ki a JDV ER területéről. Ezek közül a Vértesből egyedül erről az élőhelyről ismert a Ganoderma cupreolaccatum (Kalchbr.) Z. Igmándy és Pholiota squarrosoides (Peck) Sacc. Jelenlegi ismereteink alapján a hazai erdőrezervátumok közül a Juhdöglö-völgyben fordul elö a legtöbb védett, lignikol nagygombafaj. Jelen eredmények alapján lignikol bazídiumos nagygombák szempontjából a JDV ER Magyarország legnagyobb fajdiverzitású élőhelye.

Taxonómiai és nómenklatúrai vizsgálataim során összesen 8 új kombinációt közöltem: Entoloma zuccherellii var. pluteisimilis (Noordel. \& C.E. Hermos.) V. Papp, E. zuccherellii var. sclerotiogenum (Caball., Higelmo, Català \& Vila) V. Papp, E. vernalis (Har. Takah. \& Degawa) V. Papp \& Dima, Postia subgen. Cyanosporus (McGinty) V. Papp, Postia africana (Ryvarden) V. Papp, P. amyloidea (Corner) V. Papp, P. caesioflava (Pat.) V. Papp, P. coeruleivirens (Corner) V. Papp. 
A Magyarországról első alkalommal a JDV ER területéről dokumentált és 2013-ban védetté nyílvánított Pholiota squarrosoides esetében először mutattam ki filogenetikai vizsgálat alapján, hogy ez a faj nem az Adiposae, hanem a Pholiota szekcióba tartozik. A PV1044 sorszámú fungáriumi minta morfológiai vizsgálata alapján egyezést mutatott a jelenleg a szakirodalom alapján Climacodon pulcherrimus-ként tárgyalt faj holotípusával. Az átnézett genetikai adatbázisok alapján első alkalommal készítettünk ebből a fajból ITS szekvenciát, amely alapján filogenetikai vizsgálattal igazoltam, hogy ez a faj nemzetségszinten elkülönül a Climacodon P. Karst. típusfajától [C. septentrionalis (Fr.) P. Karst.] és vélhetően a Donkia Pilát génuszba tartozik: D. pulcherrima (Berk. \& M.A. Curtis) Pilát.

A dolgozat elkészítése során több olyan taxonómiai és nevezéktani kérdés merült fel, amelyek megválaszolása további vizsgálatokat igényel és túlmutat a disszertáció keretei adta lehetőségeken. Az egyik ilyen kérdéses taxon a JDV ER területén iniciális korhadási fázisban lévő nagyméretü bükkfarönkről gyüjtött pleurotoid termőtestet képző gomba (fung.: PV983), amely mikro- és makromorfológia bélyegeinek, valamint ITS és LSU génszakaszainak vizsgálata alapján különbözik az átnézett vonatkozó szakirodalomból ismert fajoktól. Továbbá a GenBankban található szekvenciák alapján nemzetség szintü elkülönülést mutat a legközelebbi fajoktól, így az eddigi vizsgálatok szerint vélhetően új a tudományra nézve, továbbá egy eddig ismeretlen génuszba tartozik. A begyüjtött fungáriumi anyagok közül az eddig elvégzett vizsgálatok során még nem sikerült az összes mintát meghatározni, ezért várható, hogy a későbbiekben tovább bővül a rezervátumból ismert lignikol bazídiumos nagygombafajok száma. 


\section{SUMMARY}

As a result of human activity, the forest habitats with high biodiversity are decreasing. Those forests which still maintain their natural state are need to be protected. For this purpose the Forest Reserve Programme of Hungary was established, and several forest areas were selected and are protected by the law.

No systematic fungistical examinations were carried out before in the Juhdöglö-völgy Forest reserve (JDV ER) located in the Vértes Mts, and is rich in dead wood. In the present study the following main aims were pursued: (1) to reveal the diversity of lignicolous macromycetes of Basidiomycota in the JDV ER, and carry out their taxonomic evaluation based on micro- and macromorphological characteristics, supplied by phylogenetic methods; (2) to assess the nature protection state of the documented fungal species, and to define the real natural value of the area; (3) to clarify any arising systematic or nomenclatural question.

Altogether 232 lignicolous basidiomycetes were identified in the core area of JDV ER during the 45 field days between 2010 and 2014. Of these taxa 122 species are new to Vértes Mts, and 20 to the Hungarian funga. A list of 21 macrofungi species have been assembled before to indicate the naturalness of beech forests, based on the data of 106 European beech forest reserves. In the JDV ER 16 species from this list were found. This is the highest number among the studied Hungarian forest reserves, and even in European level, only in the Slovakian Stužica és Rožok forests were similar number of indicator species showed. There are 12 protected macrofungi species in Hungary, and 7 of these were found during my assessments. From this 7 protected species Ganoderma cupreolaccatum (Kalchbr.) Z. Igmándy and Pholiota squarrosoides (Peck) Sacc. are new to Vértes Mts. As far as we know, among the Hungarian forest reserves, the highest number of protected lignicolous basidiomycetes can be found in Juhdöglö-völgy. Based on my results, considering the lignicolous macromycetes of Basidiomycota, the highest species diversity of Hungarian habitats is in JDV ER.

As a result of my taxonomic and nomenclatural studies, altogether eight new combinations were published: Entoloma zuccherellii var. pluteisimilis (Noordel. \& C.E. Hermos.) V. Papp, E. zuccherellii var. sclerotiogenum (Caball., Higelmo, Català \& Vila) V. Papp, E. vernalis (Har. Takah. \& Degawa) V. Papp \& Dima, Postia subgen. Cyanosporus (McGinty) V. Papp, Postia africana (Ryvarden) V. Papp, P. amyloidea (Corner) V. Papp, P. caesioflava (Pat.) V. Papp, P. coeruleivirens (Corner) V. Papp.

Based on phylogenetic examinations we came to the conclusion, that Pholiota squarrosoides belongs to the section Pholiota instead of the section Adiposae. Based on morphological evaluation, the sample numbered PV1044 in the fungarium was identical to the holotype of the 
species referred as Climacodon pulcherrimus (Berk. \& M.A. Curtis) Nikol. by the literature. According to the genetic databases, the ITS sequence of this species have been prepared for the first time, which proved that this species can be separated from the type species [Climacodon septentrionalis (Fr.) P. Karst.] of Climacodon P. Karst. at the level of genus, thus it possibly belongs to the genus Donkia Pilát: D. pulcherrima (Berk. \& M.A. Curtis) Pilát.

As a conclusion of my results, several taxonomical and nomenclatural questions arose, which can only be answered through further examinations that go beyond the frames of the dissertation. One of the questionable taxa is a fungi with pleurotoid basidiocarp collected in JDV FR from a large sized beech log in first decay phase, which, based on both micro- and macromorphological characteristics, ITS and LSU sequence analysis is not identical to any species found in the literature. Furthermore, comparing it with the sequences of GeneBank, it differs even from the closest species at the level of genus. It is possibly a new species to science, and it belongs to an unknown genus, based on the results to date. All the collected materials could not be identified so far, hence it can be expected that the number of lignicolous basidiomycetes known from the Juhdöglö-völgy Forest Reserve will grow further in the future. 


\section{MELLÉKLETEK}

M1. Irodalomjegyzék

M2. Ábrák jegyzéke

M3. Táblázatok jegyzéke

M4. A Juhdöglő-völgy Erdőrezervátum területén gyüjtött lignikol nagygombák fajlistája

M4.1. A Juhdöglő-völgy Erdőrezervátum területén gyüjtött lignikol bazídiumos nagygombák fajlistája alfabetikus sorrendben.

M4.2. A Juhdöglö-völgy Erdőrezervátum területén gyüjtött lignikol aszkuszos nagygombák fajlistája alfabetikus sorrendben

M5. Kijelölt mintafák adatai

M6. Filogenetikai vizsgálatokhoz használt minták adatai

M6.1. A GenBank és Unite adatbázisokból letöltött és a jelen munkában ismertetett filogenetikai vizsgálathoz felhasznált ITS-szekvenciák lelöhelyi adatai, valamint herbáriumi és génbanki azonosítói

M6.2. A Juhdöglö-völgy Erdőrezervátumban gyüjtött lignikol bazídiumos nagygombák jelen dolgozat során vizsgált mintáinak szekvenciái 


\section{M1. IRODALOMJEGYZÉK}

1. AbReGO, N. \& SALCEDO, I. (2011): How does fungal diversity change based on woody debris type? A case study in Northern Spain. - Ekologija 57(3): 109-119.

http://dx.doi.org/10.6001/ekologiia.v57i3.1916

2. ABREGO, N. \& SALCEDO, I. (2014): Response of wood-inhabiting fungal community to fragmentation in a beech forest landscape. - Fungal Ecology 8: 18-27.

http://dx.doi.org/10.1016/i.funeco.2013.12.007

3. ABREGO, N. \& SALCEDO, I. (2015): Taxonomic gap in wood-inhabiting fungi: identifying understudied groups by a systematic survey. - Fungal Ecology 15: 82-85.

http://dx.doi.org/10.1016/i.funeco.2015.01.005

4. AdAmČík, S., Christensen, M., Heilmann-Clausen, J. \& Walleyn, R. (2007): Fungal diversity in the Poloniny National Park with emphasis on indicator species of conservation value of beech forests in Europe. - Czech Mycol. 59(1): 67-81.

5. AgERER, R. (1973): Rectipilus, eine neue gattung cyphelloider pilze. - Persoonia 7: 389-436.

6. AGERER, R. (1978): Lachnella-Crinipellis, Stigmatolemma-Fistulina: zwei Verwandtschaftsreihen? Z. Mykol. 44: 51-70.

7. Agerer, R. (1979): Flagelloscypha sect. Lachnelloscypha, a link between the genera Lachnella and Flagelloscypha. - Persoonia 10: 337-346.

8. AgERER, R. (1980): Contribution to neotropical cyphellaceous fungi I. Three new species of Flagelloscypha. - Mycologia 72: 908-915. http://dx.doi.org/10.2307/3759733

9. AgERER, R. (1986): "Cyphellaceae" versus Tricholomataceae, or what is a family? La Famiglia delle Tricholomataceae. Atti del Convegno Internazionale del 10-15 settembre 1984. Borgo Val di TaroItaly. Atti del Centro Studi per la Flora Mediterranea 6: 9-27.

10. Aнti, T., HÄмet-Ahti, L. \& JALAS, J. (1968): Vegetation zones and their sections in northwestern Europe. - Annales Botanici Fennici 5: 169-211.

11. Aime, M. C., BAROni, T. J. \& Miller, O. K. (2002): Crepidotus thermophilus comb nov., a reassessment of Melanomphalia thermophila, a rarely collected tropical agaric. - Mycologia 94: 1059-1065. http://dx.doi.org/10.2307/3761871

12. AIME, M. C. (2004): Intercompatibility tests and phylogenetic analysis in the Crepidotus Sphaerula group complex: concordance between ICGs and nuclear rDNA sequences highlight phenotypic plasticity within Appalachian species. In: CL Cripps (ed.), Fungi in forest ecosystems: systematics, diversity, and ecology, p. 71-92. Bronx, NY.

13. Aime, M. C., Vilgalys, R. \& Miller, O. K. (2005): The Crepidotaceae (Basidiomycota, Agaricales): Phylogeny and taxonomy of the genera and revision of the family based on molecular evidence. American Journal of Botany 92: 74-82. http://dx.doi.org/10.3732/ajb.92.1.74

14. Aime, M. C., Matheny, P. B., Henk, D. A., Frieders, E. M., Nilsson, R. H., Piepenbring, M., Mclaughlin, D. J., Szabo, L. J., Begerow, D., Sampaio, J. P., Bauer, R., Weiss, M., OBERWINKLER, F. \& HiBBETT, D. S. (2006): An overview of the higher-level classification of Pucciniomycotina based on combined analyses of nuclear large and small subunit rDNA sequences. - Mycologia 98: 896-905. http://dx.doi.org/10.3852/mycologia.98.6.896

15. Aime, M. C., Vila, J. \& MoreaU, P. A. (2009): Crepidotus subfulviceps comb. nov., a stipitate Crepidotus from temperate North America and Europe. - Mycotaxon 110: 283-287. http://dx.doi.org/10.5248/110.283

16. Aime, M. C., Toome, M. \& McLaughlin, D. J. (2014): Pucciniomycotina. In: McLaughlin DJ, Spatafora JW (Eds.) The Mycota: Systematics and Evolution, 2nd edition, vol 7A. Springer-Verlag, Berlin, 271-294.

17. Ainsworth, M. (2004a): Hymenochaete carpatica in Southern England: sites, spores, setae and how to distinguish it from H. cinnamomea et al. - Field Mycology 5(1): 5-10.

http://dx.doi.org/10.1016/s1468-1641(10)60229-0 
18. AINSWORTH, M. (2004b): Developing tools for assessing fungal interest in habitats I: beech woodland saprotrophs. - English Nature Research Reports 597, p. 75.

19. AINSWORTH, M. (2005): Identifying important sites for beech deadwood fungi. - Field Mycology 6: 41-61. http://dx.doi.org/10.1016/s1468-1641(10)60303-9

20. Ainsworth, M. \& RAYNER A. D. M. (1990): Mycelial interactions and outcrossing in the Coniophora puteana complex. - Mycological Research 94: 627-634.

http://dx.doi.org/10.1016/s0953-7562(09)80664-3

21. Ainsworth, M. \& RAYNeR, A. D. M. (2004): Aerial mycelial transfer by Hymenochaete corrugata between stems of hazel and other trees. - Mycological Research 94(2): 263-288. http://dx.doi.org/10.1016/s0953-7562(09)80625-4

22. ALBERT L. (1984): Néhány ritka csengettyügomba (Pluteus) előfordulása a Normafa környéki bükkösökben. - Mikológiai Közlemények, Clusiana (2-3): 123-131.

23. AlBerT L. és DimA B. (2005): Ritka nagygombafajok (Basidiomycetes) előfordulása Magyarországon I. - Mikológiai Közlemények, Clusiana 44(1-2): 3-22.

24. Alfredo, D. S., Leite, A. G., Braga-Neto, R. \& Baseia, I. G. (2012): Two new Morganella species from the Brazilian Amazon rainforest. - Mycosphere 3(1): 66-71.

http://dx.doi.org/10.5943/mycosphere/3/1/8

25. Alfredo, D. S., Accioly, T. \& BASEIA, I. G. (2014): Morganella arenicola, a new species record from North and Northeast Brasil. - Turkish Journal of Botany 38: 595-599.

http://dx.doi.org/10.3906/bot-1307-68

26. Alvarado, P., Manjón, J. L., Matheny, P. B. \& Esteve-Reventós, F. (2010): Tubariomyces, a new genus of Inocybaceae from the Mediterranean region. - Mycologia 102(6): 1389-1397.

http://dx.doi.org/10.3852/10-041

27. AMAlFi, M., RoBledo, G. \& DeCOCK, C. (2014): Fomitiporia baccharidis comb. nov., a little known species from high elevation Andean forests and its affinities within the neotropical Fomitiporia lineages. - Mycological Progress 13:995 http://dx.doi.org/10.1007/s11557-014-0995-x

28. Ames, A. (1913): A consideration of structure in relation t o genera of the Polyporaceae. - Annales Mycologici 11: 211-263.

29. Antonín, V., Halling, R. E. \& Noordeloos, M. E. (1997): Generic concepts within the groups Marasmius and Collybia sensu lato. - Mycotaxon 63: 359-368.

30. Antonín, V. \& Noordeloos, M. E. (2004): A monograph of the genera Hemimycena, Delicatula, Fayodia, Gamundia, Myxomphalia, Resinomycena, Rickenella and Xeromphalina (tribus Mycenae sensu Singer, Mycena excluded) in Europe. Eching. p. 279.

31. Antonín, V., Jankovský, L., Lochman, J. \& TOMŠOvskÝ, M. (2006): Armillaria socialis morphological-anatomical and ecological characteristics, pathology, distribution in the Czech Republic and Europe and remarks in its genetic variation. - Czech Mycol. 58(3-4): 209-224.

32. Antonín, V., TOMŠOvskÝ, M., SEdLÁK, P., MÁJEK, T. \& JANKOvsKÝ, L. (2009): Morphological and molecular characterization of the Armillaria cepistipes - A. gallica complex in the Czech Republic and Slovakia. - Mycological Progress 8(3): 259-271. http://dx.doi.org/10.1007/s11557-009-0597-1

33. ARNOLDS, E. (2003): Notulae ad floram agaricinam neerlandicam - XXXIX. Bolbitius. - Persoonia 18(2): 201-214.

34. ARnOlds, E. J. M. \& Noordeloos, M.E. (1979): New taxa of Entoloma from Grasslands in Drenthe, the Netherlands. - Persoonia 10(2): 283-300.

35. Aron, A., Kahr, H., Michelitsch, S., Piedlich-Aigner, H. \& Prelicz, D. (2005): Vorläufige Rote Liste gefährdeter Großpilze der Steiermark. - Joaenna Bot. 4: 45-80.

36. BABos M. (1977): A magyarországi Bolbitius fajok. - Mikológiai Közlemények (1-2): 41-47.

37. Babos, M. (1978): Pluteus studies, I. (Basidiomycetes, Pluteaceae). - Annales Historico-Natureles Musei Nationalis Hungarici 70: 93-97.

38. BABos M. (1981): Mycological examination of sawdust depots in Hungary. - Studia Botanica Hungarica 15: 31-44. 
39. BABos M. (1984): Hollós nyomában Szekszárd környékén. I. - Mikológiai Közlemények (2-3): 141156.

40. BABOS M. (1989): Magyarország kalaposgombáinak (Agaricales s.l.) jegyzéke - I. - Mikológiai Közlemények, Clusiana (1-3): 1-234.

41. BABOSNÉ G. M. (1974): Adatok Magyarország ritka kalaposgombáinak és pöfetegféléinek ismeretéhez V. - Studia Bot. Hung. 9: 3-11.

42. BABOSNÉ G. M. (1975): Adatok Magyarország ritka kalaposgombáinak és pöfetegféléinek ismeretéhez VI. - Studia Bot. Hung. 10: 27-39.

43. BABOSNÉ G. M. (1976): Magyarországi homokterületek ritka és érdekes gombafajai. II. - Studia Bot. Hung. 11: 3-15.

44. Badalyan, S. M., Szafranski, K., Hoegger, P. J., NAVArRo-GonzÁlez, M., MajCherczyK, A. \& KÜES, U. (2011): New Armenian wood-associated coprinoid mushrooms: Coprinopsis strossmayeri and Coprinellus aff. radians. - Diversity 3: 136-154.

http://dx.doi.org/10.3390/d3010136

45. BADER, P., JANSSON, S. \& JONSSON, B.G. (1995): Wood-inhabiting fungi and substratum decline in selectively logged boreal spruce forests. - Biological Conservation 72: 335-362.

http://dx.doi.org/10.1016/0006-3207(94)00029-p

46. BAldRian, P. \& VAlaskova, V. (2008): Degradation of cellulose by basidiomycetous fungi. FEMS Microbiol. Rev. 32: 501-521. http://dx.doi.org/10.1111/i.1574-6976.2008.00106.x

47. Bandala, V. M, Esteve-Raventós, F. \& Montoya, L. (2008a): Two remarkable brown-spored agarics from Spain: Simocybe parvispora sp. nov. and Crepidotus ibericus comb. nov. - Sydowia 60: 181-196.

48. Bandala, V. M, Montoya, L. \& MATA, M. (2008b): Crepidotus crocophyllus found in Costa Rica and Mexico and revision of related species in subsection Fulvifibrillosi. - Mycologia 100(2): 335346. http://dx.doi.org/10.3852/mycologia.100.2.335

49. Bandara, A. R., Chen, J., Karunarathna, S., Hyde, K. D. \& KaKumyan, P. (2015): Auricularia thailandica sp. nov. (Auriculariaceae, Auriculariales) a widely distributed species from Southeastern Asia. - Phytotaxa 208(2): 147-156. http://dx.doi.org/10.11646/phytotaxa.208.2.3

50. BANDONI, R. J (1984): The Tremellales and Auriculariales: an alternative classification. - Trans Mycol Soc Jpn 25: 489-530.

51. BAnerJeE, P. \& SundBerg,W. J. (1993): Three new species and a new variety of Pluteus from the United States. - Mycotaxon 47: 389-394.

52. BÁNHEgYi J., BoHUS G., KALMÁR Z. \& UBRIZSY G. (1953): Magyarország nagygombái - a kalaposgombák kivételével. Akadémiai Kiadó, Budapest, 368 pp.

53. BANIK, M. T., LiNDNER, D. L., OTA, Y. \& HATTORI T. (2010): Relationships among North American and Japanese Laetiporus isolates inferred from molecular phylogenetics and single-spore incompatibility reactions. - Mycologia 102(4): 911-917. http://dx.doi.org/10.3852/09-044

54. BANKER, H. J. (1906): A contribution to a revision of the North American Hydnaceae. - Memoirs of the Torrey Botanical Club 12: 99-194. http://dx.doi.org/10.5962/bhl.title.97394

55. Barbosa, M. M. B., Silva, M. A., Cruz, R. H. S. F., Calonge, F. D. \& Basiea, I. G. (2011): First report of Morganella compacta (Agaricales, Lycoperdaceae) from South America. - Mycotaxon 116: 381-386. http://dx.doi.org/10.5248/116.381

56. BARINA Z. \& NÉMETH CS. (2009): A Vértes és környéke florisztikai kutatásának eredményei II. Flora Pannonica 7: 33-42.

57. BAROni, T. J., Hofstetter, V., LARgent, D. L. \& Vilgalys, R. (2011): Entocybe is proposed as a new genus in the Entolomataceae (Agaricomycetes, Basidiomycota) based on morphological and molecular evidence. - North American Fungi 6(12): 1-19.

http://dx.doi.org/10.2509/naf2011.006.012

58. BARONI \& LAMOUREUX (2013): A new species of Entocybe (Entolomataceae, Agaricomycetes) from Québec, Canada. - Mycotaxon 123: 353-361. http://dx.doi.org/10.5248/123.353 
59. BARron, G. L. \& ThORN, R. G. (1987): Destruction of nematodes by species of Pleurotus. - Canad. J. Bot. 65: 774-778. http://dx.doi.org/10.1139/b87-103

60. BARTHA D. \& EszTÓ P. (2001): Az országos erdőrezervátum-hálózat bemutatása az országos erdőállomány-adattár alapján. - ER 1(1): 21-44.

61. BATSCH, A. J. G. K. (1786): Elenchus fungorum. Continuatio prima. p. 1-279.

62. Bauer, R., Begerow, D., SAmpaio, J. P., Weiss, M. \& Oberwinkler, F. (2006): The simple-septate basidiomycetes: a synopsis. - Mycological Progress 5(1): 41-66. http://dx.doi.org/10.1007/s11557006-0502-0

63. BenEDEK L. (2002): Nagygombák A Pilis- és a Visegrádi-hegységből. - Mikol. Közlem., Clusiana 41(2-3): 3-34.

64. BENEDEK L. (2011): A Központi-Börzsöny nagygombái: fungisztikai, szünbiológiai és természetvédelmi értékelés. Doktori (PhD) értekezés, kézirat. Kertészettudományi Doktori Iskola, Budapest.

65. BENEDEK L. \& PÁL-FÁM F. (2006): Rare macrofungi from Central Börzsöny I. Hungarian occurrence data and habitat preference. - International Journal of Horticultural Science 12(1): 45-52.

66. BENEDEK L. \& PÁL-FÁM F. (2012): A Központi-Börzsöny fás élőhelyeinek jellemzése indikátornagygombafajok alapján. - Mikol. Közlem., Clusiana 51(1): 64-65.

67. BÉNI K. \& ViSZLÓ L. (1996): Egy cseppnyi Magyarország, A Vértes hegység és környéke. Pro Vértes Természetvédelmi Közalapítvány. pp. 409.

68. Bergeman, S. E., LARgent, D. L. \& Abell-Davis, S. E. (2013): Entocybe haastii from Watagans National Park, New South Wales, Australia. - Mycotaxon 126: 61-70. http://dx.doi.org/10.5248/126.61

69. Berglund, H. \& JONSSON, B. G. (2001): Predictability of plant and fungal species richness of oldgrowth boreal forest islands. - J. Veg. Sci. 12: 857-866. http://dx.doi.org/10.2307/3236874

70. BERGLUND, H. \& JONSSON, B. G. (2003): Nested plant and fungal communities; the importance of area and habitat quality in maximizing species capture in boreal old-growth forests. - Biol. Conserv. 112: 319-328. http://dx.doi.org/10.1016/s0006-3207(02)00329-4

71. Berglund, H. \& JONSSON, B. G. (2005): Verifying an extinction dept among lichens and fungi in northern Swedish boreal forests. - Conserv. Biol. 19: 338-348. http://dx.doi.org/10.1111//.15231739.2005.00550.x

72. BERGLUND, H. \& JONSSON, B. G. (2008): Assessing the extinction vulnerability of woodinhabiting fungal species in fragmented northern Swedish boreal forests. - Biol. Conserv. 141: 3029-3039. http://dx.doi.org/10.1016/i.biocon.2008.09.007

73. Berglund, H., EDMAN, M. \& ERICSON, L. (2005): Temporal variation of wood-fungi diversity in boreal old-growth forests: implications for monitoring. - Ecol. Appl. 15: 970-982. http://dx.doi.org/10.1890/04-0628

74. BERNICCHIA, A. (2000): Wood-inhabiting Aphyllophoraceous fungi on Juniperus spp. in Italy. Mycotaxon 75: 241-256.

75. BerNiCCHIA, A. (2005): Polyporaceae s. 1. - In: Fungi Europaei 10, Edizioni Candusso, Alassio, 1008 pp.

76. BernicChiA, A. \& PAdOVAn, F. (1997): Preliminary distributional data on Hericiaceae (Basidiomycetes) in Italy. - Bocconea 5: 853-859.

77. BERNICCHIA, A., ARRAS, L. \& GORJÓN, S. P. (2008): Il genere Vuilleminia in Italia. - Micol. e Veget. Medit. 23(1): 3-20.

78. BernicChiA, A. \& GorJón, S. P. (2010): Corticiaceae s. 1. (Fungi Europaei 12). Edizioni Candusso, $1008 \mathrm{pp}$.

79. Berthier, J. (1976): Monographie des Typhula Fr., Pistillaria Fr. et genres voisins. - Bull. Mens. Soc. Linn. Lyon. Special issue. 
80. Binder, M., Hibbett, D. S. LARsson, K. H. Larsson, E., LANGer, E. \& LANGer, G. (2005): The phylogenetic distribution of resupinate forms across the major clades of mushroom-forming fungi (Homobasidiomycetes). - Systematics and Biodiversity 3(2): 1-45.

http://dx.doi.org/10.1017/s1477200005001623

81. BINDER, M. \& HiBBETT, D. S. (2006): Molecular systematics and biological diversification of Boletales. - Mycologia 98(6): 971-981. http://dx.doi.org/10.3852/mycologia.98.6.971

82. Binder, M., LARSSON, K.-H., MATHENY, P. B. \& HiBBETT, D. S. (2010): Amylocorticiales ord. nov. and Jaapiales ord. nov.: early diverging clades of Agaricomycetidae dominated by corticioid forms. - Mycologia 102: 865-880. http://dx.doi.org/10.3852/09-288

83. Binder, M., Justo, A., Riley, R., SAlamov, A., Lopez-Giraldez, F., SJöKVist, E., Copeland, A., Foster, B., Sun, H., Larsson, E., Larsson, K.-H., Townsend, J., GrigorieV, I. V. \& HibBetT, D. S. (2013): Phylogenetic and phylogenomic overview of the Polyporales. - Mycologia 105(6): 1350-1373. http://dx.doi.org/10.3852/13-003

84. Blasi, C., Marchetti, M., Chiavetta, U., Aleffi, M., Audisio, P., Azzella, M. M., Brunialti, G., Capotorti, G., Del Vico, E., Lattanzi, E., Persiani, A. M., Ravera, S., Tilia, A. \& BURRASCANO, S. (2010): Multi-taxon and forest structure sampling for identification of indicators and monitoring of old-growth forest. - Plant Biosystems 144(1): 160-170.

http://dx.doi.org/10.1080/11263500903560538

85. BoBIEC, A. (2002): Białowieża Primeval Forest, the largest area of natural deciduous lowland forest in Europe. - International Journal of Wilderness 8(3): 33-37.

86. Boddy, L., Crockatt, M. E. \& Ainsworth, A. M. (2011): Ecology of Hericium cirrhatum, H. coralloides and H. erinaceus in the UK. - Fungal Ecology 4(2): 163-173.

http://dx.doi.org/10.1016/i.funeco.2010.10.001

87. Bodensteiner, P., Binder, M., Moncalvo, J.-M., Agerer, R. \& Hibbett, D. S. (2004): Phylogenetic relationships of cyphelloid homobasdiomycetes. - Molecular Phylogenetics and Evolution 33: 501-515. http://dx.doi.org/10.1016/i.ympev.2004.06.007

88. BoHUS G. (1939): Additamenta ad cognitionem fungorum montium Vértes. - Borbásia 1: 112.

89. BoHus G. (1970): A new Coprinus species from Aesculus trunks. - Botanikai Közlemények 57: 1522.

90. BohUs G. \& BABOS M. (1960): Coenology of terricolous macroscopic fungi of deciduous forests. Bot. Jahrb. 80(1): 1-100.

91. BoHUS G. \& BABOS M. (1967): Mycocoenological investigation of acidophilous decidous forests in Hungary. - Bot. Jahrb. 87(1): 304-360.

92. BON, M. (1986): Novitates - Combinaisons nouvelles et validations de taxons (ouvrages en cours). Documents Mycologiques 16(62): 66-66.

93. BONDARTSEV, A. S. (1953): Trutovye griby Evropeiskoi chasti SSSR i Kavkaza [The Polyporaceae of the European USSR and Caucasia]. - Leningrad, Moszkva, 1105 pp.

94. Bonnard, J. (1988): Les cystides de la section Pluteus (Agaricales). - Mycol. Helvetica 3: 53-72.

95. BORCHSENIUS, F. (2009): FastGap 1.2. - http://www.aubot.dk/FastGap_home.htm, Department of Biosciences, Aarhus University, Denmark.

96. BORHIDI A. (szerk.) (2003): Magyarország növénytársulásai. Akadémiai Kiadó, Bp., 610 pp.

97. BöSZE Sz. \& FODOR L. (2005): A nagygombák védelmének helyzete az Európai Unió országaiban. Mikológiai Közlemények, Clusiana 44(1-2): 45-56.

98. Brandrud, T. E., Bendiksen, E., HoftOn, T. H., Høiland, K., Jordal, J. B. (2010): Sopp. [Fungi]. - In: KÅlÅs, J. A., Viken, Å., HenRiksen, S., SkJElSETH, S. (szerk.) Norsk Rødliste for arter 2010. [The 2010 Norwegian Red List for Species]. Artsdatabanken, Trondheim, pp. 87-123.

99. BUDAI T. \& FODOR L. (2008): A Vértes hegység földtana. Magyar Állami Földtani Intézet. pp. 368.

100. Bujakiewicz, A. (2002): New, rare and endangered fungi in the Białowieża Primeval Forest (E Poland). - Polish Bot. J. 47(2): 113-124. 
101. Bujakiewicz, A. (2003): The Białowieża Forest - refuge for endangered macrofungi. - Parki Narodowe i Rezerwaty Przyrody 22(3): 323-346.

102. Bulliard, J. B. F. (1789): Herbier de la France 9: 385-432.

103. Burdsall, H. H., VOLK, T. J. \& AMmiRATI, J. F. (1996): Bridgeoporus, a new genus to accomodate Oxyporus nobilissimus (Basidiomycotina, Polyporaceae). - Mycotaxon 60: 387-395.

104. Burdsall, H. H. JR. \& BANIK, M. T. (2001): The genus Laetiporus in North America. - Harvard Papers in Botany 6(1): 43-55.

105. Burdsall, H. H., JR., \& VOLK, T. J. (2008): Armillaria solidipes, an older name for the fungus called Armillaria ostoyae. - North American Fungi 3(7): 261-267.

http://dx.doi.org/10.2509/naf2008.003.00717

106. Campos-Santana, M., Amalfi, M., Robledo, G., Borges Da Silveira, R. \& DeCock, C. (2014): Fomitiporia neotropica, a new species from South America evidenced by multilocus phylogenetic analyse. - Mycological Progress 13: 601-615. http://dx.doi.org/10.1007/s11557-013-0943-1

107. CANDUSSO, M. (2002): Hohenbuehelia auriscalpium (Maire) Singer, una rara Tricholomataceae. Famm, N. S. 22: 13-18.

108. CANNON, P. F. \& KIRK, P. M. (2007): Fungal families of the world. CABI, Egham, Surrey, U.K.

109. CAO, Y., WU, S. H. \& DAI, Y. C. (2012): Species clarification of the prize medicinal Ganoderma mushroom „Lingzhi”. - Fungal Diversity 56(1): 49-62. http://dx.doi.org/10.1007/s13225-0120178-5

110. Carlsen, T., Engh, I. B., Decock, C., Rajchenberg, M. \& Kauserud, H. (2011): Multiple cryptic species with divergent substrate affinities in the Serpula himantioides species complex.Fungal Biology 115: 54-61. http://dx.doi.org/10.1016/j.funbio.2010.10.004

111. Carlson, A., Justo, A. \& HibBett, D. S. (2014): Species delimitation in Trametes: a comparison of ITS, RPB1, RPB2 and TEF1 gene phylogenies. - Mycologia 106(4): 735-745. http://dx.doi.org/10.3852/13-275

112. ČERNÝ, A. (1963): Inonotus andersonii (Ellis et Everhart) Černý comb. nov. - A new polypore for Czechoslovakia. - Česká Mykologie 17(1): 1-8.

113. ČERNÝ, A. (1968): Phellinus pilatii sp. nov., ein sehr schädlicher parasit an Populus alba L. und Populus canescens Smith. - Ceská Mykologie 22(1): 1-13.

114. ČERNÝ, A. (1989): Paraziticke Drevokazne Houby. Statni Zemedelske Nakladatelstvi, Praha, 104 pp.

115. CHAMURIS, G. P. (1984): Nomenclatural adjustments in Stereum and Cylindrobasidium according to the Sydney Code. - Mycotaxon 20(2): 587-588.

116. CHLEBICKI, A. (2003): Hymenochaete carpatica Pilát, an inconspicuous fungus growing on chips of bark of a plane-tree maple (Acer pseudoplatanus L.). - Acta Mycol. 38: 21-26.

117. Chlebicki, A., Mukhin, V. A. \& Ushakova, N. (2003): Fomitopsis officinalis on Siberian Larch int he Urals. - Mycologist 17(3): 116-120. http://dx.doi.org/10.1017/s0269915x03003057

118. Christan, J. (2008): Die Gattung Ramaria in Deutschland. Monografie zur Gattung Ramaria in Deutschland, mit Bestimmungsschlüssel zu den europäischen Arten. IHW-Verlag, Eching. 352 pp.

119. Christensen, M., Heilmann-Clausen, J., Walleyn, R. \& AdAmČIK, S. (2004): Wood-inhabiting fungi as indicators of nature value in European beech forests. - In: MARCHETTI, M. (ed.): Monitoring and indicators of forest biodiversity in Europe from ideas to operationality. EFI Proceedings 51: 229-237.

120. Christensen, M. \& Heilmann-Clausen, J. (2013): The genus Tricholoma (Fungi of Northern Europe 4). Danish Mycological Society, p. 228.

121. CLÉMENÇON, H. (1998): Anatomy of the Hymenomycetes. - Teufen: Fluck-Wirth.

122. CLÉMENÇON, H. (2005): Rhizomorph anatomy of Ossicaulis lignatilis (Tricholomatales), with special attention to its haustoria-lik intrahyphal hyphae. - Mycological Progress 4(2): 167-173. http://dx.doi.org/10.1007/s11557-006-0120-x

123. Cloete, M., Fischer, M., Mostert, L. \& Halleen, F. (2014): A novel Fomitiporia species associated with esca on grapevine in South Africa. - Mycol. Progress. 13: 303-311. 
http://dx.doi.org/10.1007/s11557-013-0915-5

124. Co-David, D., Langeveld, D. \& Noordeloos, M. E. (2009): Molecular phylogeny and spore evolution of Entolomataceae. - Persoonia 23: 147-176.

http://dx.doi.org/10.3767/003158509x480944

125. Consiglio, G. \& SetTI, L. (2008): Il genere Crepidotus in Europe. Vicenza, 344 pp.

126. Contu, M. (1999): Funghi della Sardegna. Note e descrizioni, III. - Bollettino dell'Associazione Micologica ed Ecologica Romana 48: 3-15.

127. ConTU, M. (2007): Agarics of Sardinia: notes and descriptions: VII. - Micologia e Vegetazione Mediterranea 22(1): 29-40.

128. CoOKE, M. C. (1877): New British fungi. - Grevillea 6(38): 71-76.

129. COOKE, M. C. \& HARKNESS, W. H. (1881): Californian fungi. - Grevillea 9(51): 81-87.

130. CoOKe, W. B. (1957): The genera Serpula and Meruliporia. - Mycologia 49: 197-225. http://dx.doi.org/10.2307/3755630

131. CoOKe, W. B. (1961a): The cyphellaceous fungi. A study in Porotheleaceae. - Sydowia Beihefte 4: $1-144$.

132. CooKe, W. B. (1961b): The Genus Schizophyllum. - Mycologia 53(6): 575-599. http://dx.doi.org/10.2307/3756459

133. CORFIXEN, P. (1990): A new species of Inonotus (Hymenochaetaceae) from Scandinavia. - Nordic Journal of Botany 10(4): 451-455. http://dx.doi.org/10.1111/i.1756-1051.1990.tb01788.x

134. CoRner, E. J. H. (1932a): The fruit-body of Polystictus xanthopus Fr. - Annals of Botany, London 46: 71-111.

135. CORNER, E. J. H. (1932b): A Fomes with two systems of hyphae. - Transactions of the British Mycological Society 17(5): 1-81. http://dx.doi.org/10.1016/s0007-1536(32)80026-4

136. Corner, E. J. H. (1950): A monograph of Clavaria and allied genera. - Ann. Bot. Mem. 1. 740 p.

137. Cortez, V. G., CAlonge, F. D., Baseia, I. G. (2007): Rick's species revision 2: Lycoperdon benjaminii recombined in Morganella. - Mycotaxon 102: 425-429.

138. Cortez, V. G., BASEIA, I. G. \& Silveira, R. M. B. (2013): Gasteroid mycobiota of Rio Grande do Sul, Brasil: Lycoperdon and Vascellum. - Mycosphere 4(4): 745-758.

http://dx.doi.org/10.5943/mycosphere/4/4/11

139. Couch, J. N. (1938): The Genus Septobasidium. Univ. of North Carolina Press, 480 p.

140. CourTeCuisse, R. (2008): Novitates. 5. Nouvelles combinaisons et nouveaux noms nécessaires suite à la mise au point du référentiel des noms de champignons présents sur le territoire national métropolitain (1 - Basidiomycètes). - Documents Mycologiques 34(135-136): 48-52.

141. CoX, D. E. (1976): A new homobasidiomycete with anomalous basidia. - Mycologia 68: 481-510. http://dx.doi.org/10.2307/3758974

142. Cruz, R. H. S. F., Barbosa, M. M. B. \& BASeiA, I. G. (2012): Cyathus badius and C. earlei reported from the Brazilian Atlantic rainforest. - Mycotaxon 121: 365-369.

http://dx.doi.org/10.5248/121.365

143. CruZ, R. H. S. F., Assis, N. M., Silva, M. A. \& BASEIA, I. G. (2014): Revision of the genus Cyathus (Basidiomycota) from the herbaria of northeast Brasil. - Mycospheare 5(4): 531-540.

144. CUI, B.-K. \& DECOCK, C. (2013): Phellinus castanopsidis sp. nov. (Hymenochaetaceae) from southern China, with preliminary phylogeny based on rDNA sequences. - Mycological Progress 12(2): 341-351. http://dx.doi.org/10.1007/s11557-012-0839-5

145. Courtecuisse, R., Villa, J. \& Llimona, X. (1999): Hohenbuehelia ilerdensis, a new graminicolous species from semisteppe areas of Lleida (western Catalonia, Spain). - Mycotaxon 70: $1-6$.

146. Cunningham, G. H. (1954). Hyphal systems as aids in identification of species and genera of the Polyporaceae. - Transactions of the British Mycological Society 37: 44-50.

http://dx.doi.org/10.1016/s0007-1536(54)80066-0 
147. Cunningham, G. H. (1959): Hydnaceae of New Zealand. II. The genus Odontia. - Transactions and Proceedings of the Royal Society of New Zealand 86(1): 65-103.

148. CURTIS, W. (1781): Flora Londinensis 4: 72, t. 224.

149. Dahlberg, A. \& CRoneborg, H. (2003): 33 threatened fungi in Europe (T- PVS (2001) 34 rev. 2). Swedish EPA \& ECCF, Uppsala.

150. Dahlberg, A., Krikorev, M., Hansen, K., Jacobsson S., Jeppson, M., Knutsson, T., KuoljoK S., LARSSON, K. H., NordÉN, B., NitARe, J., SVEnsSON S. \& TEDEBRAND, J. O. (2010): Rödlistade arter i Sverige 2010 [The 2010 Red List of Swedish species]. - Uppsala: ArtDatabanken.

151. Dahlberg, A. \& MUeller. G. M. (2011): Applying IUCN Red Listing Criteria for assessing and reporting on the conservation status of fungal species. - Fungal Ecology 4: 147-162.

http://dx.doi.org/10.1016/i.funeco.2010.11.001

152. DAI, Y.-C. (2010): Hymenochaetaceae (Basidiomycota) in China. - Fungal Diversity 45: 131-343. http://dx.doi.org/10.1007/s13225-010-0066-9

153. DAi, Y.-C., Niemelä, T. \& Kinnunen, J. (2002): The polypore genera Abundisporus and Perenniporia (Basidiomycota) in China, with notes on Haploporus. - Annales Botanici Fennici 39(3): 169-182.

154. DAI, Y.-C., YUAN, H. S., ZHANG, X. Q. \& WANG, Z. (2007): Systematic revisit of Sparsitubus (Basidiomycota, Aphyllophorales), an unusual cyphelloid polypore from China. - Fungal Diversity 25: 37-47.

155. DAI, Y.-C., XIONG, H.-X. \& WU, S.-H. (2009): Notes on Dentipellis (Russulales, Basidiomycota). Mycosystema 28(5): 668-671.

156. DAI Y.-C. \& CUI B.-K. (2011): Fomitiporia ellipsoidea has the largest fruiting body among the fungi. - Fungal. Biol. 115:813-814. http://dx.doi.org/10.1016/i.funbio.2011.06.008

157. Das, K., Hembrom, M. E., Parihar, A. \& ZhaO, R. L. (2014): A new species of Cyathus (Agaricaceae) from India. - Turkish Journal of Botany. http://dx.doi.org/10.3906/bot-1311-38

158. David, A., DeQuatre, B. \& Fiasson, J.-L. (1982): Two new Phellinus with globose, cyanophilous spores. - Mycotaxon 14(1): 160-174.

159. DE, A. B. (1997): Taxonomy of Royoporus badius comb. nov. - Mycotaxon 65: 469-474.

160. DEACON, J. (2006): Fungal biology. Blackwell Publishing, 371 pp.

161. DRECHSLER, C. (1941): Some hyphomycetes parasitic on free-living terricolous nematodes. Phytopathology 31: 773-802.

162. De QueIroz, K., \& Donoghue, M. J. (2011): Phylogenetic nomenclature, three-taxon statements, and unnecessary name changes. - Systematic Biology 60: 887-892.

163. Decock, C., Amalfi, M., Robledo, G. \& Castillo, G. (2013): Phylloporia nouraguensis, an undescribed species on Myrtaceae in French Guiana. - Cryptogamie Mycologie 34: 15-27.

http://dx.doi.org/10.7872/crym.v34.iss1.2013.15

164. Delivorias, P. \& GONOU-ZAGOU, Z. (2008): On Cheimonophyllum candissimum from Greece with notes on its implied aphyllophoroid ancestry. - Mycotaxon 104: 1-8.

165. Demoulin, V. (2010): Why conservation of the name Boletus applanatus should be rejected. Taxon 59(1): 283-286.

166. Denchev, C. M. \& Gyosheva, M. M. (2010): Conservation of fungi in Bulgaria, 2006-2009 (Country reports and/or responses to the questionnaire) Council for the Conservation of Fungi: Newsletter 15/2010: 6-7.

167. Dentinger, B. T. M. \& MCLAUghlin, D. J. (2006): Reconstructing the Clavariaceae using nuclear large subunit rDNA sequences and a new genus segregeted from Clavaria. - Mycologia 98(5): 746-762. http://dx.doi.org/10.3852/mycologia.98.5.746

168. Desjardin, D. E. \& RYVARDEN, L. (2003): The genus Gloiodon. - Sydowia 55(2): 153-161.

169. DiAmANDIS, S. (2000): List of threatened macrofungi in Greece. - European Council for the Conservation of Fungi: Newsletter 10: 11-13. 
170. DiAmANDIS, S. (2010): The necessity of political will in fungal conservation: the case of Greece. Mycologia Balcanica 7: 25-27.

171. Dima B., Siller, I., Albert L., Rimóczi I. \& BenedeK L. (2010): A 27. európai Cortinarius Konferencia mikológiai eredményei. - Mikológiai Közlemények, Clusiana 49(1-2): 5-66.

172. DimA B., PÁL-FÁM F. \& TAKÁCS K. (2013): Nagygombafelmérés a Szentbékkálai Fekete-hegyen. Folia Musei Historico-Naturalis Bakonyiensis 29: 17-28.

173. DOMAŃSKI, S. (1967): Specificity of wood-inhabiting mycoflora of the Białowieża National Park with a special regard to Aphyllophorales (Basidiomycetes). - Sylwan 111(1): 17-27.

174. DonK, M. A. (1959): Notes on 'Cyphellaceae.' - I. - Persoonia 1(1): 25-110.

175. DonK, M. A. (1960): The generic names proposed for Polyporaceae. - Persoonia 1(2): 173-302.

176. DonK, M. A. (1962a): Notes on 'Cyphellaceae.' - II. - Persoonia 2(3): 331-348.

177. DonK, M. A. (1962b): The generic names proposed for Polyporaceae. - Persoonia 2(2): 201-210.

178. DonK, M. A. (1962c): Notes on resupinate Hymenomycetes - VI. - Persoonia 2(2): 217-238.

179. DonK, M. A. (1964): A conspectus of the families of Aphyllophorales. - Persoonia 3(2): 199- 324.

180. DonK, M. A. (1966): Check list of European Hymenomycetous Heterobasidiae. - Persoonia 4 (2-3): $145-335$.

181. DonK, M. A. (1971): Notes on European Polypores - VI (A). - Proceedings van de Koninklijke Nederlandse Akademie van Wetenschappen Section C. 74(1): 1-14.

182. DonK, M. A. (1974): Check List of European Polypores. - Verh. Koninkl. Nederlandse Akad. Wetensch. Afd. Natuurk. Tweede Reeks 62: 1-469.

183. Doweld, A. B. (2014): Phleogenales Doweld, ord. nov.; Phleogenomycetes Doweld, class. nov. Index Fungorum no. 79.

184. Drechsler-Santos, E. R., Cavalcanti, M. A. Q., Loguercio-Leite, C. \& Robledo, G. L. (2012a): On Neotropical Daedalea species: Daedalea ryvardenica sp. nov. - Kurtziana 37(1): 6572 .

185. Drechsler-SAntos, E. R., WARtchow, F., COIMBRA, V. R. M., Gibertoni, T. B. \& CAVAlcanti, M. A. Q. (2012b): Studies on lentinoid fungi (Lentinus and Panus) from the semi-arid region of Brazil. - Journal of the Torrey Botanical Society 139: 437-446. http://dx.doi.org/10.3159/torrey-d$12-00019.1$

186. DuHEM, B. (2010): Deux corticiés nouveaux méditerranéens à spores allantoïdes. - Cryptogamie Mycologie 31(2): 143-152.

187. Duhem, B. \& MiChel, H. (2007): Deux espèces nouvelles de Dendrothele. - Cryptogamie Mycologie 28(1): 39-54.

188. DVOŘAK, D., BĚŤAK J. \& TOMŠOVSKY, M. (2014): Aurantiporus alborubescens (Basidiomycota, Polyporales) - first record in the Carpathians and notes on its systematic position. - Czech Mycol. 66(1): 71-84.

189. EGRI K. (2009): Sárospatak környéki nagygombák fungisztikai, ökológiai és természetvédelmi jellemzése. Doktori (PhD) értekezés, Budapesti Corvinus Egyetem, Kertészettudományi Doktori Iskola. $87 \mathrm{pp}$.

190. Elborne, S. A. (2012a): Hohenbuehelia Schulzer - In: KnUdSEN, H. \& VeSterholt, J. (szerk.), Funga Nordica. Agaricoid, Boletoid and Cyphelloid Genera. Nordsvamp, Copenhagen, p. 366-374.

191. ElbORne, S. A. (2012b): Rickenella Raithelh. - In: KNUDSEN, H. \& Vesterholt, J. (szerk.), Funga Nordica. Agaricoid, Boletoid and Cyphelloid Genera. Nordsvamp, Copenhagen, p. 86-87.

192. Ellis, J. B. \& MACBRIDE, T. H. (1895): Nicaraguan Hymenomycetes. - Bulletin from the laboratories of natural history of the State University of Iowa 3(4): 190-194.

193. ElLIS, J. B. \& EVERHART, B. M. (1890): Mucronoporus andersoni, n. s. Journal of Mycology 6(2): 79-79

194. ERIKSSON, J. \& RYVARDEN, L. (1973): The Corticiaceae of North Europe. Vol. 2: 59-286 (Aleurodiscus - Confertobasidium). Fungiflora, Oslo. 
195. ERIKSSON, J. \& RYVARDEN, L. (1975) The Corticiaceae of North Europe. Vol. 3: 287-546 (Coronicium - Hyphoderma). Fungiflora, Oslo.

196. ERIKSSON, J. \& RYVARDEN, L. (1976) The Corticiaceae of North Europe. Vol. 4: 547-886 (Hyphodermella-Mycoacia). Fungiflora, Oslo.

197. Eriksson, J., HJORTSTAM, K. \& RYVARdEN, L. (1978) The Corticiaceae of North Europe. Vol. 5: 887-1048 (Mycoaciella - Phanerochaete). Fungiflora, Oslo.

198. Eriksson, J., HJORTSTAM, K. \& RYVARDEN, L. (1981) The Corticiaceae of North Europe. Vol. 6 : 1049-1276 (Phlebia - Sarcodontia). Fungiflora, Oslo.

199. ERIKSSON, J., HJortstam, K. \& RYVARDEN, L. (1984) The Corticiaceae of North Europe. Vol. 7: 1279-1449 (Schizopora - Suillosporium). Fungiflora, Oslo.

200. Essig, F. M. (1922): The morphology, development, and economic aspects of Schizophyllum commune Fries. - Univ Cali Publ Bot 7: 447-498.

201. ESZES F. \& IGMÁNDY Z. (1978): Az akác csövestaplói. - Mikológiai Közlemények (1-2): 18-20.

202. Evans, S. E., HenricI, A. \& ING B. (2006): Preliminary Assessment: The Red Data List of Threatened British Fungi. [www.fieldmycology.net]

203. FAO (2013): State of mediterranean forests 2013. FAO, $171 \mathrm{pp}$.

204. FAYOD, V. (1889): Prodrome d'une historie naturelle des Agaricinés. - Annales des Sciences Naturelles, Botanique Ser. 7(9): 181-411.

205. FARKAS E. \& LŐKÖS L. (2009): Zuzmók biodiverzitás-vizsgálata Gyürüfü környékén. - Mikológiai Közlemények, Clusiana 48(2): 145-153.

206. FARKAS E., LÖKÖS L. \& MOLNÁR K. (2013): Zuzmók biodiverzitás-vizsgálata a szentbékállai „Fekete-hegy” mintaterületen. - Folia Musei Historico Naturalis Bakonyiensis 29: 29-46.

207. FARR, E. R., Miller, O. K. \& FARR, D. F. (1977): Biosystematic studies in the genus Pholiota stirps Adiposa. - Can. J. Bot. 55: 1167-1180. http://dx.doi.org/10.1139/b77-136

208. FIASSON, J.-L. \& NIEMELÄ, T. (1984): The Hymenochaetales: a revision of the European poroid taxa. - Karstenia 24: 14-28.

209. Floudas, D., Binder, M., Riley, R., Barry, K., Blanchette, R. A., Henrissat, B., Martínez, A. T., Ortillar, R., Spatafora, J. W., Yadav, J. S., Aerts, A., Benoit, I., Boyd, A., CARlson, A., Copeland, A., Coutinho, P. M., De Vries, R. P., Ferreira, P., Findley, K., Foster, B., Gaskell, J., Glotzer, D., Górecki, P., Heitman, J., Hesse, C., Hori, C., Igarashi, K., Jurgens, J. A., Kallen, N., Kersten, P., Khajamohiddin, A., Kohler, A., Kues, U., Kumar, T. K. A., KuO, A., LABUtTi, K., LARrondo, L. F., Lindquist, E., Ling, A., LuCAS, S., Lundell, T., Martin, R., Mclaughlin, D. J., Morgenstern, I., Morin, E., Murat, C., Nolan, M., OhM, R. A., Patyshakuliyeva, A., Rokas, A., Ruiz-Dueñas, F. J., Sabat, G., Salamov, A., Samejima, M., Schmutz, J., Slot, J. C., John, F. S., Stenlid, J., Sun, H., Sun, S., Tsang, A., Wiebenga, A., Young, D., Pisabarro, A., Eastwood, D. C., Martin, F., Cullen, D., GrigorieV, I. V. \& HibBetT, D. S. (2012): The Paleozoic origin of enzymatic lignin decomposition reconstructed from 31 fungal genomes. - Science 336(6089): 1715-1719.

http://dx.doi.org/10.1126/science.1221748

210. Floudas, D., Held, B. W., Riley, R., Nagy G. L., Koehler, G., Ransdell, A. S., Younus, H., Chow, J., Chiniquy, J., Lipzen, A., Tritt, A., Sun, H., Haridas, S., LaButti, K., OHM, R. A., Kües, U., Blanchette, R. A., Grigoriev, I. V., Minto, R. E. \& Hibbett, D. S. (2015): Evolution of novel wood decay mechanisms in Agaricales revealed by the genome sequences of Fistulina hepatica and Cylindrobasidium torrendii. - Fungal Genetics and Biology 76: 78-92.

http://dx.doi.org/10.1016/i.fgb.2015.02.002

211. FISCHER, M. \& BRESINSKY, A. (1992): Phellinus torulosus - sexuality and evidence of intersterility groups. - Mycologia 84: 823-833. http://dx.doi.org/10.2307/3760279

212. FISCHER, M. \& BINDER, M. (2004): Species recognition, geographic distribution and host-pathogen relationships: a case study in a group of lignicolous basidiomycetes, Phellinus s.1. - Mycologia 96(4): 799-811. http://dx.doi.org/10.2307/3762113 
213. FŐDI A. \& PAPP V. (2014): Az ehető és gyógyhatású, védett taplófaj, a Grifola frondosa (Polyporales, Basidiomycota) magyarországi elterjedése és újabb lelőhelyei [New localities and Hungarian distribution of the protected, culinary-medicinal mushroom Grifola frondosa (Dicks.) Gray (Polyporales, Basidiomycota)]. - Aktuális Flóra- és Vegetációkutatás a Kárpát-medencében $X$., Sopron. p. 152.

214. FODOR L., PÁL-FÁM F. \& RIMÓCZI I. (2001): Adatok a Szigetköz nagygombáinak ismeretéhez. Mikológiai Közlemények, Clusiana 40(3): 47-58.

215. FODOR L. \& PÁL-FÁM F. (2003): A szigetközben előforduló ritka, veszélyeztetett fajok élőhelyi jellemzése és hazai elterjedése. - Mikol. Közl., Clusiana 42(1-2): 15-44.

216. FolCz Á. \& PAPP V. (2014): Az erdei holtfa gombavilága; in: CsÓKA GY. \& LAKATOS F. szerk.: Silva Naturalis $V$., A Holtfa; pp.: 49-74.

217. Fraiture, A., HAYOVA, V. \& LiCKey, E. (2008): First record of Artomyces microsporus in Europe. - Cryptogamie Mycologie 29(3): 219-229.

218. Fraiture, A. (2010): General Situation in Fungal Conservation in Belgium. - Council for the Conservation of Fungi: Newsletter 15: 5-6.

219. FrANK N. (1997): Adatok a soproni Dudlesz-erdő gombavilágához. - Mikol. Közlem., Clusiana 36(1): 13-20.

220. FRIEDRICH, S. (2011): New locations of threatened and protected Gasteromycetes s.l. in Northwestern Poland. - Polish J. of Environ. Stud. 20(3): 559-564.

221. FRIES, E. M. (1818): Observationes mycologicae. 2: 1-372.

222. FRIES, E. M. (1821): Systema Mycologicum, vol. 1.

223. FRIES, E. M. (1825): Systema Orbis Vegetabilis. 1:1-374.

224. FRIES, E. M. (1828): Elenchus Fungorum 1: 1-238.

225. FRIES, E. M. (1849a): Summa vegetabilium Scandinaviae. 2: 259-572.

226. FRIES, E. M. (1849b): Fungi Natalenses. pp. 121-154.

227. FRIES, E. M. (1874): Hymenomycetes Europaei, 755 pp.

228. Fukami, T., Dickie, I. A., Paula Wilkie, J., Paulus, B. C., Park, D., Roberts, A., Buchanan, P. K. \& ALLEN, R. B. (2010): Assembly history dictates ecosystem functioning: evidence from wood decomposer communities. - Ecol Lett. 13(6): 675-684. http://dx.doi.org/10.1111/j.1461$\underline{0248.2010 .01465 . x}$

229. GAFFOROV, Y. TOMŠOVSKÝ, M., LANGER, E. \& ZHOU, L. W. (2014): Phylloporia yuchengii sp. nov. (Hymenochaetales, Basidiomycota) from Western Tien Shan Mountains of Uzbekistan based on phylogeny and morphology. - Cryptogamie Mycologie 35(4): 313-322.

http://dx.doi.org/10.7872/crym.v35.iss4.2014.313

230. GÁPER, J. \& GÁPEROVÁ, S. (2014): A worldwide geographical distribution and host preferences of Fomes fomentarius. in zborník referátov z vedeckej konferencie: „dendrologické dni v arboréte mlyňany sav 2014“, 18.09.2014. vieska nad žitavou: arborétum mlyňany sav. s. 57-63.

231. GAMS, W. \& JAKLITSCH, W. (2011): A critical response to the 'Amsterdam Declaration'. Mycotaxon 116: 501-512. http://dx.doi.org/10.5248/116.501

232. GARDES, M. \& BRUNS, T. D. (1993): ITS primers with enhanced specifity for basidiomycetes. Application to the identification of mycorrhizae and rusts. - Mol. Ecol. 2: 113-118. http://dx.doi.org/10.1111/i.1365-294x.1993.tb00005.x

233. Garraway, M. O., Huttermann, A., \& Wargo, P. M. (1991). Ontogeny and physiology Armillaria Root Disease. USDA Agricultural Handbook, Washington, D.C., 691: 21-47.

234. Gerhold, N. (1998): Zur Verbreitung des Dunkelbraunen Borstenscheiblings, Hymenochaete fuliginosa (Pers.) Bres., in Österreich. - Ber. nat.-med. Verein Innsbruck 85: 17-33.

235. Ghobad-NeJHad, M., Nilsson, R. H. \& HallenberG, N. (2010): Phylogeny and taxonomy of the genus Vuilleminia (Basidiomycota) based on molecular and morphological evidence, with new insights into Corticiales. - Taxon 59: 1519-1534. 
236. Ghobad-Nejhad, M. \& Duhem, B. (2014): Novelties in the Corticiales: Vuilleminia nilsii sp. nov. and Dendrominia gen. nov. (Basidiomycota). - Mycol Progress 13: 1-11.

http://dx.doi.org/10.1007/s11557-012-0881-3

237. Giachini, A. J., Hosaka, K., Nouhra, E. R., Spatafora, J. W. \& Trappe, J. M. (2010): Phylogenetic relationships of the Gomphales based on nuc-25S-rDNA, mit-12SrDNA and mitatp6-DNA combined sequences. - Fungal Biol 114: 224-234.

http://dx.doi.org/10.1016/j.funbio.2010.01.002

238. GiLBERTSON, R. L. (1979): The genus Phellinus (Aphyllophorales: Hymenochaetaceae) in Western North America. - Mycotaxon 9(1): 51-89.

239. GILBERTSON, R. L. (1981): North American wood-rotting fungi that cause brown rots. - Mycotaxon 12(2): 372-416.

240. Gilbertson R. L. \& Burdsall H. H. (1972): Phellinus torulosus in North America. - Mycologia 64: 1258-1269. http://dx.doi.org/10.2307/3757963

241. Gilbertson, R. L. \& Ryvarden, L. (1985): Some new combinations in the Polyporaceae. Mycotaxon 22: 363-365.

242. GILBERTSON, R. L. \& RYVARDEN, L. (1987): North American polypores 2. Megasporoporia to Wrightoporia. - Oslo, Fungiflora, pp. 434-885.

243. GINNS, J. (1986): The genus Dentipellis (Hericiaceae). - Windahlia 16: 35-45.

244. Goranova, G., Binder, M. \& HibBett, D. S. (2003): Molecular phylogenetics indicate that the corticioid genus Dendrothele is highly polyphyletic. - Inoculum 54: 22.

245. GORJÓN, S. P., BERNICCHIA, A. \& GIBERTONI, T. B. (2006): Aphyllophoraceous wood-inhabiting fungi on Arbutus unedo in Italy. - Mycotaxon 98: 159-162.

246. Gorjón, S. P., HALlenberg, N. \& BernicChia, A. (2009): A survey of the corticioid fungi from the Biosphere Reserve of Las Batuecas-Sierra de Francia (Spain). - Mycotaxon 109: 161-164.

247. GORJÓN, S. P. \& BERNICCHIA, A. (2013): Threats and state of conservation of aphyllophoroid fungi in the Mediterranean. - Acta Mycologica 48(2): 247-255. http://dx.doi.org/10.5586/am.2013.026

248. GORJÓN, S. P. \& JESUS, M. A. (2014): Rectipilus stromatoides sp. nov. (Agaricales, Basidiomycota), a new cyphelloid fungus from the Brazilian Amazon. - Mycosphere 5(2): 393-396.

http://dx.doi.org/10.5943/mycosphere/5/2/12

249. Gotlieb, A. M., Wright, J. E. \& Moncalvo, J.-M. (2002): Inonotus s. 1. in Argentina morphology, cultural characters and molecular analyses. - Mycological Progress 1(3): 299-313. http://dx.doi.org/10.1007/s11557-006-0028-5

250. GOUY, M., GUINDON, S. \& GASCUEL, O. (2010): SeaView version 4: a multiplatform graphical user interface for sequence alignment and phylogenetic tree building. - Molecular Biology \& Evolution 27(2): 221-224. http://dx.doi.org/10.1093/molbev/msp259

251. GREGORY, P. H. (1984): The first benefactor's lecture the fungal mycelium: an historical perspective. - Trans. Br. mycol. Soc. 82(1): 1-11. http://dx.doi.org/10.1016/s0007-1536(84)80206$\underline{5}$

252. GROSSE-BraucKmanN, H. (1999): Holzbewohnende Pilze aus dem Naturwaldreservat Kniebrecht (Odenwald, Südhessen). - Z. Mykol. 65(2): 115-171.

253. GROVE, S. J. (2002): Saproxylic insect ecology and the sustainable management of forests. - Ann Rev Ecol Syst 33:1-23. http://dx.doi.org/10.1146/annurev.ecolsys.33.010802.150507

254. Gulden, G., Dunham, S. \& Stockman, J. (2001): DNA studies in the Galerina marginata complex. - Mycological Research 105(4): 432-440.

http://dx.doi.org/10.1017/s0953756201003707

255. Gulden, G., StensRud, Ø., Shalchian-TABrizi, K. \& KAuSERUd, H. (2005): Galerina Earle: A polyphyletic genus in the consortium of dark-spored agarics. - Mycologia 97(4): 823-837.

http://dx.doi.org/10.3852/mycologia.97.4.823

256. Gyosheva, M. M., Denchev, C. M., Dimitrova E. G., Assyov, B., Petrova, R. D. \& Stoichev, G. T. (2006): Red List of fungi in Bulgaria. - Mycologica Balcanica 3: 81-87. 
257. Halama, M. (2011): First record of the rare species Pholiota squarrosoides (Agaricales, Strophariaceae) in southwestern Poland. - Polish Botanical Journal 56(2): 327-332.

258. HALlenBerg, N. (1983a): On the Schizopora paradoxa complex (Basidiomycetes). - Mycotaxon 18(2): 303-313.

259. HallenberG, N. (1983b): Hericium coralloides and H. alpestre (Basidiomycetes) in Europe. Mycotaxon 18: 181-189.

260. Halme, P., Kotiaho, J.S., Ylisirniö, A.-L., Hottola, J., Junninen, K., Kouki, J., Lindgren, M., Mönkkönen, M., Penttilä, R., Renvall, P., Sittonen, J. \& Similä, M. (2009): Perennial polypores as indicators of annual and red-listed polypores. - Ecological Indicators 9: 256-266. http://dx.doi.org/10.1016/j.ecolind.2008.04.005

261. HARACSI L. (1941): A cseresek veszedelme: a kétalakú csertapló (Fomes obliquus (Pers.) Fr.). Erdészeti Kisérletek 43: 1-31.

262. HARACSI L. \& IGMÁNDY Z. (1956): A csertapló (Xanthochrous obliquus B. et G.) előfordulása lombfáinkon. - Erdömérnöki Föiskola Közleményei 1: 73-87.

263. HARACSI L. \& IGMÁNDY Z. (1957): A fekete csertapló (Xanthochrous obliquus B. et G.) előfordulása magaskörisen. - Erdömérnöki Föiskola Közleményei 2: 85-96.

264. HAWKSWORTH, D. L. (2011): A new dawn for the naming of fungi: impacts of decisions made in Melbourne in July 2011 on the future publication and regulation of fungal names. - MycoKeys 1: 7-20. http://dx.doi.org/10.3897/mycokeys.1.2062

265. HARDTKE, J. \& OTTO, P. (1999): Materialien zu Naturschutzund Landschaftspflege 1999. Rote Liste Pilze. Sächsische Druck- und Verlagshaus AG, Dresden.

266. HARMSEN, L. (1960). Taxonomic and cultural studies on brown spored species of the genus Merulius. - Friesia 6: 233-277.

267. HAUSKNECHT, A. (1993): Néhány érdekes nagygomba egy alsó-ausztriai Abieto Fagetum (Jegenyefenyves-Bükkös) növénytársulásból. - Mikológiai Közlemények, Clusiana 32(1-2): 91-95.

268. HAUSKNECHT, A. (2010): The genus Simocybe in Austria. - Österreichische Zeitschrift für Pilzkunde 21: 31-45.

269. HauskneCht, A. \& Krisai, I. (1988): A new species of Crepidotus (Crepidotaceae). - Plant Systematics and Evolution 161(3-4): 183-188. http://dx.doi.org/10.1007/bf00937298

270. Hausknecht, A., Antonín, V. \& PolcÁK, J. (2007): A new, conspicuously coloured Bolbitius species from the Czech Republic. - Czech Mycology 59(1): 1-9.

271. Hausknecht, A. \& Vesterholt, J. (2012): Bolbitius Fr. In: Knudsen, H. \& Vesterholt, J. Funga Nordica. Nordsvamp, Coppenhagen, pp. 733-735.

272. Hausner, G., Reid, J. EyjólfsdóttiR, G. G., IRANPOUR, M. \& LOEwen, P. C. (2008): Basidiopycnides albertensis gen. et sp. nov., a new anamorphic fungus with phylogenetic affinities in the Atractiellales (Basidiomycota). - Mycotaxon 103: 279-297.

273. Hayova, V. (2010) Responses to the Questionnaire - Ukraine (Country reports and/or responses to the questionnaire). - Council for the Conservation of Fungi: Newsletter 15: 28-29.

274. HARPER, E. T. (1918): The Clavaria fistulosa group. - Mycologia 10(2): 53-57. http://dx.doi.org/10.2307/3753225

275. Hattori, T., Sotome, K., OtA, Y., Thi, B.-K., Lee, S.-S. \& SAlleh, B. (2011): Postia stellifera sp. nov., a stipitate and terrestrial polypore from Malaysia. - Mycotaxon 114: 151-161. http://dx.doi.org/10.5248/114.151

276. HeilmanN-Clausen, J. (2001): A gradient analysis of communities of macrofungi and slime moulds on decaying beech logs. - Mycological Research 105(5): 575-596.

http://dx.doi.org/10.1017/s0953756201003665

277. HeilmanN-Clausen, J. (2006): Vedlevande svampar på bok i Halland. - Svensk Mycol. Tidskr. 27(2): 19-28.

278. Heilmann-Clausen, J. (2012): Pluteus Fr. In: Knudsen, H. \& Vesterholt, J. - Funga Nordica. Nordsvamp, Coppenhagen, pp. 386-395. 
279. Heilmann-Clausen, J. \& Christensen, M. (2000): Svampe på bøgestammer - indikatorer for vaerdifulde lovskoslokaliteter. - Svampe 42: 35-47.

280. Heilmann-Clausen, J. \& Christensen, M. (2003): Fungal diversity on decaying beech logs implications for sustainable forestry. - Biodiversity and Conservation 12: 953-973.

281. HeILMANN-ClAuSEN, J. \& CHRISTENSEN, M. (2004a): Wood-inhabiting macrofungi in Danish beech-forests - conflicting diversity patterns and their implications in a conservation perspective. Biological Conservation 122: 633-642. http://dx.doi.org/10.1016/i.biocon.2004.10.001

282. HeilmanN-Clausen, J. \& Walleyn (2007): Some records of wood-inhabiting fungi on Fagus sylvatica in Northern Spain. - Revista Catalana de Micologia 29: 67-80.

283. Hesler, L. R. \& SMith, A. H. (1965): North American species of Crepidotus. Hafner Publishing Company, New York and London, 126 pp.

284. HibBETT, D. S. (2006): A phylogenetic overview of the Agaricomycotina. - Mycologia 98: 917-925. http://dx.doi.org/10.3852/mycologia.98.6.917

285. HiBBETT, D. S. (2007): After the gold rush, or before the flood? Evolutionary morphology of mushroom-forming fungi (Agaricomycetes) in the early 21st century. - Mycological Research 111: 1001-1018. http://dx.doi.org/10.1016/j.mycres.2007.01.012

286. HibBeTt, D. S. \& ThORN, R. G. (1994): Nematode-trapping in Pleurotus tuberregium. - Mycologia 86(5): 696-699. http://dx.doi.org/10.2307/3760542

287. HiBBetT, D. S. \& THORN, R. G. (2001): Basidiomycota. Homobasidiomycetes. In the Mycota VIIB: Systematics and Evolution (in: McLaughlin, D. J., Meglaughlin, E. G. \& Lemke, P. A.). Berlin, Spinger-Verlag, pp. 121-168.

288. HibBeTt, D. S. \& BindeR, M. (2002): Evolution of complex fruiting body morphologies in homobasidiomycetes. - Proceedings of the Royal Society B. 269: 1963-1969. http://dx.doi.org/10.1098/rspb.2002.2123

289. Hibbett, D. S., Nilsson, R. H., Snyder, M., Fonseca, M., Costanzo, J., \& Shonfeld, M. (2005): Automated phylogenetic taxonomy: an example in the Homobasidiomycetes (mushroomforming fungi). - Syst. Biol. 54: 660-668. http://dx.doi.org/10.1080/10635150590947104

290. Hibbett, D. S., Binder, M., Bischoff, J. F., Blackwell, M., Cannon, P. F., ERiksson, O. E., Huhndorf, S., James, T., Kirk, P. M., StalPers, J. A., Crous, P. W., GAMS, W ., ET AL. (2007): A higher-level phylogenetic classification of the Fungi. - Mycological Research 111(5): 509-547. http://dx.doi.org/10.1006/mpev.2001.1043

291. Hibbett, D. S., Bauer, R., Binder, M., Giachini, A. J., Hosaka, K., Justo, A., Larsson, E., Larsson, K. H., Lawrey, J. D., Miettinen, O., Nagy L. G., Nilsson, R. H., Weiss, M. \& THORN, R. G. (2014): Agaricomycetes. In the Mycota VIIA: Systematics and Evolution 2nd Edition (in: McLaughlin, D. J. \& Spatafora, J. W.). Berlin, Springer-Verlag, pp. 373-429.

292. HJORTSTAM, K. \& RYVARDEN, L. (1984): Some new and noteworthy Basidiomycetes (Aphyllophorales) from Nepal. - Mycotaxon 20(1): 133-151.

293. HJORTSTAM, K., LARSSON, K.-H. \& RYVARDEN, L. (1987): The Corticiaceae of North Europe. Vol. 1: 1-58 (Introduction and keys). Fungiflora, Oslo.

294. Huortstam, K., LARSSON, K.-H. \& RYVARDEN, L. (1988): The Corticiaceae of North Europe. Vol. 8: 1450-1631 (Thanatephorus - Ypsilonidium). Fungiflora, Oslo.

295. HJORTSTAM, K. \& LARSSON, K.-H. (1995): Annotated check-list to genera and species of corticioid fungi (Aphyllophorales, Basidiomycotina) with special regards to tropical and subtropical areas. Windahlia 21: 1-75.

296. Hofstetter, V., Clémençon, H., Vilgalys, R. \& Moncalvo, J. M. (2002): Phylogenetic analyses of the Lyophylleae (Agaricales, Basidiomycota) based on nuclear and mitochondrial rDNA sequences. - Mycol. Res. 106(9): 1043-1059.

http://dx.doi.org/10.1017/s095375620200641x

297. Hofstetter, V., Redhead, S. A., Kauff, F., Moncalvo J. M., Matheny, P. B. \& Vilgalys R. (2014): Taxonomic revision and examination of ecological transitions of the Lyophyllaceae 
(Basidiomycota, Agaricales) based on a multigene phylogeny. - Cryptogamie Mycologie 35(4): 399-425. http://dx.doi.org/10.7872/crym.v35.iss4.2014.399

298. HøILAND, K. \& BENDIKSEN, E. (1997): Biodiversity of wood-inhabiting fungi in a boreal coniferous forest in Sor-Tondelag county, Central Norway. - Nordic Journal of Botany 16: 643-659.

http://dx.doi.org/10.1111/i.1756-1051.1996.tb00283.x

299. HOLEC, J. (1998): The taxonomy of Pholiota aurivella and Pholiota adiposa: A return to Batsch and Fries. - Czech Mycology 50(3): 201-221.

300. Holec, J. (2001): The genus Pholiota in central and western Europe. Libri Botanici 20, IHW Verlag, Eching. 220 pp.

301. Holec, J. (2005): The genus Gymnopilus (Fungi, Agaricales) in the Czech Republic with respect to collections from other European countries. - Acta Mus. Nat. Pragae, Ser. B, Hist. Nat. 61(1-2): 152.

302. HOLEC, J. \& BERAN, M. (2006): Červený seznam hub (makromycetů) České republiky [Red list of fungi (macromycetes) of the Czech Republic]. Prríroda, Praha, 24: 1-282.

303. Holec, J \& NoORdeloos, M. E. (2010): On the infraspecific variability and taxonomic position of Entoloma zuccherelii. - Mycotaxon 112: 283-289. http://dx.doi.org/10.5248/112.283

304. HoleC, J. \& WILD, J. (2011): Fungal diversity in sandstone gorges of the Bohemian Switzerland National Park (Czech Republic): impact of climatic inversion. - Czech Mycol. 63(2): 243-263.

305. HoleC, J. \& KolAŘíK, M. (2012): Ossicaulis lachnopus (Agaricales, Lyophyllaceae), a species similar to O. lignatilis, is verified by morphological and molecular methods. - Mycological Progress 12(3): 589-597. http://dx.doi.org/10.1007/s11557-012-0866-2

306. HoLEC, J. \& KŘíž, M. (2010): Entoloma zuccherelli, a smal lignicolous fungus with violet-blue stipe and almost globose spores, new for the Czech Republic. - Mykologické listy 113: 8-13.

307. Hollós L. (1904): Die Gasteromyceten Ungarns. Leipzig, 275 pp.

308. HoLlós L. (1933): Szekszárd vidékének gombái. - Mathematikai Természettudományi Közlemények 37: $1-215$.

309. HoraK, E. (1978): Pleuroflammula. - Persoonia 9(4): 439-451.

310. HorAK, E. (1986): Beiträge zur Systematik und Oekologie von Pleuroflammula (Agaricales, Fungi). - Veröff. Geobot. Inst. ETH, Stiftung Rübel, Zürich 87: 31-42.

311. HoraK, E. (2005): Röhrlinge und Blätterpilze in Europa. Spectrum Academisher Verlag: Heidelberg.

312. HorAK, E. \& RonikiER, A. (2011): Simocybe montana (Crepidotaceae, Agaricales), a new species from the alpine belt in the Swiss Alps and the Romanian Carpathians. - Mycol Progress 10: 439443. http://dx.doi.org/10.1007/s11557-010-0714-1

313. HoRVÁTH F., MÁzSA K. \& TEMESI G. (2001): Az erdőrezervátum-program. - ER 1(1): 5-20.

314. Hosaka, K., Bates, S. T., Beever, R. E., Castellano, M. A., Colgan, W., Dominguez, L. S., Nouhra, E. R., Geml, J., Giachini, A. J., Kenney, S. R., Simpson, N. B., SPAtafora, J. W. \& TRAPPE, J. M (2006): Molecular phylogenetics of the gomphoid-phalloid fungi with an establishment of the new subclass Phallomycetidae and two new orders. - Mycologia 98: 949-959. http://dx.doi.org/10.3852/mycologia.98.6.949

315. HroudA, P. (2001): Pleurotoid fungi of the family Polyporaceae in the Czech Republic and Slovakia. - Czech Mycology 53(1): 29-87.

316. HuelsenbeCK, J. P. \& RonQuist, F. (2001): MrBayes: Bayesian inference of phylogenetic trees. Bioinformatics 17: 754-755. http://dx.doi.org/10.1093/bioinformatics/17.8.754

317. Hunt, R. S., MORRISON, D. J. \& BÉRUBÉ, J. (2011): Armillaria solidipes is not a replacement name for A. ostoyae. - Forest Pathology 41(4): 253-254.

http://dx.doi.org/10.1111/j.1439-0329.2011.00730.x

318. IGMÁNDY Z. (1953): A kétalakú tapló (Fomes obliquus (Pers.) Fr.) károsítása elegyetlen cserállományban. - Erdömérnöki Föiskola Évkönyve, Sopron, 1951-52: 93-106. 
319. IGMÁNDY Z. (1957a): A csertapló (Xanthochrous obliquus (Pers) B. et G.) elterjedését befolyásoló környezeti tényezők hegy- és dombvidéki csereseinkben. - Erdészeti Lapok (4): 121-124.

320. IGMÁNDY Z. (1957b): A fehér csertapló (Leptoporus irpex Schulz.) előfordulása és károsítása hazánkban. - Erdömérn. Főisk. Közl. (1): 67-73.

321. IGMÁNDY Z. (1958): Sopron és környékének gombái. I. Polyporaceae. - Soproni Szemle 12: 119135.

322. IGMÁNDY Z. (1964a): Bükköseink farontó taplógombái. - Erdészeti és Faipari Egyetem Tudományos Közleményei 1: 101-107.

323. IGMÁNDY Z. (1964b): A szenes tölgytapló [Xanthochrous cuticularis (Bull.) Pat.] előfordulása és károsítása hazánkban. - Mikológiai Közlemények (1): 38-45.

324. IGMÁNDY Z. (1968): Hungarian Polyporaceae and their phytopathological significance. - Acta Phytopathologica Academiae Scientiarum Hungaricae 3: 221-238.

325. IGMÁNDY Z. (1970a): A kétalakú csertapló (Xanthochrous nidus-pici (Pil.) Igm.) ivaros termőtest- és spóraképzése. - Erdészeti és Faipari Egyetem tudományos közleményei (1-2): 7-16.

326. IGMÁNDY Z. (1970b): Magyarország taplógombái (II. rész.) - Mikológiai Közlemények (3): 109112.

327. IGMÁNDY Z. (1970c): Die porlinge Ungarns und ihre phytopathologische bedeutung (Polypori Hungariae). IV. - Acta Phytopath. Acad. Sci. Hung. 5: 279-301.

328. IGMÁNDY Z. (1971): Magyarország taplógombái (III. rész). - Mikológiai Közlemények (2): 51-56.

329. IGMÁNDY Z. (1977): Holzmassenverluste in Zerreichenbeständen durch Inonotus nidus-pici Pilát. Europ. Journ. of For. Path. 7: 230-236.

330. IGMÁNDY Z. (1979): Porlinge in der Umgebung des Meusiedler See. - Natur u. Umwelt in Burgenland 2: 17-20.

331. IGMÁNDY Z. (1981): Hazánk csövestapló (Polyporaceae s.1.) flórája és a fajok növénykórtani jelentősége. Doktori értekezés, Sopron. kézirat.

332. IGMÁNDY Z. (1991): A magyar erdők taplógombái. Akadémiai Kiadó, Budapest. 112 pp.

333. IGMÁNDY Z. \& PAGONY H. (1965): Fehér- és szürkenyárasaink veszélyes gesztkorhasztó gombája. Erdészeti Lapok 1: 19-25.

334. IngOLD, C. T. (1983): A view of the basidium. - Bulletin of the British Mycological Society 17(2): 82-94. http://dx.doi.org/10.1016/s0007-1528(83)80033-9

335. InTINI, M. G. (1997): Armillaria cepistipes and A. gallica (Agaricales, Tricholomataceae) in Italy. Bocconea 5: 861-866.

336. IRŠĖNAITĖ, R. (2010): Conservation of fungi in Lithuania (Country reports and/or responses to the questionnaire). - Council for the Conservation of Fungi: Newsletter 15: 15-17.

337. IRŠĖNAITĖ, R. \& KUTORGA, E. (2006): Diversity of fungi on decaying common oak coarse woody debris. - Ekologija 4: 22-30.

338. IVANČEVIĆ, B. (2009): ECCF questionnaire for Serbia. December 2009 (Country reports and/or responses to the questionnaire) Council for the Conservation of Fungi: Newsletter 15/2010: 28-29.

339. JAHN, H. (1963): Mitteleuropäische Porlinge (Polyporaceae s. lato) und ihr Vorkommen in Westfalen. - Westfälische Pilzbriefe 4: 1-143.

340. JAHN, H. (1965a): Entwicklung und Formen der Fruchtkörper beim Zunderschwamm, Fomes fomentarius. - Westfälische Pilzbriefe 5: 117-131.

341. JAHN, H. (1965b): Die Stachelbärte (Hericium, Creolophus) und ihr Vorkommen Westfalen. Westfälische Pilzbriefe 5: 90-100.

342. JAHN, H. (1971): Stereoide Pilze in Europa (Stereaceae Pil. emend. Parm. u.a., Hymenochaete), mit besonderer Berücksichtigung ihres Vorkommens in der Bundesrepublik Deutschland. Westfälische Pilzbriefe 8: 69-176.

343. JaHn, H. (1973): Polyporus melanopus und P. badius (picipes) - ein Vergleich. - Westfälische Pilzbriefe 9: 50-60. 
344. JAHN, H. (1978): Die Gattung Onnia P. Karst., Filzporlinge. - Westfälische Pilzbriefe 10-11: 79-92.

345. Jahn, H., KotlabA, F. \& PouZAR, Z. (1980): Ganoderma atkinsonii Jahn, Kotl. \& Pouz., spec. nova, a parellel species to Ganoderma lucidum. - Westfälische Pilzbriefe 10-11: 97-120.

346. JACOBSSON, S. (1987): On the correct interpretation on Pholiota adiposa and a taxonomic survey of section Adiposae. - Windhalia 17: 1-18.

347. JACOBSSON, S. (1989): Studies on Pholiota in culture. - Mycotaxon 36(1): 95-145.

348. JACOBSSON, S. (1991): Pholiota in northern Europe. - Windhalia 19: 1-86.

349. Jacobsson, S. (2012): Pholiota P. Kumm. In: Knudsen, H. és Vesterholt, J. (szerk.): Funga Nordica - Agaricoid, Boletoid, Clavarioid, Cyphelloid and Gastroid genera.

350. JAKUCS E. \& DiMA B. (2013): A gombarendszertan változásai az új évezredben. - Mikol. Közl., Clusiana 52(1-2): 95-114.

351. JANČOVIČOVÁ, S., TOMŠOVSKỳ, M., URBAN, A. \& KRISAI-GrEILHUBER, I. (2014a): New records and epitypification of Crepidotus malachioides (Crepidotaceae, Agaricales). - Sydowia 66(1): 79-97.

352. JanČOviČOvÁ, S., TOMKA, P. \& ANTONÍN, V. (2014b): Gymnopus vernus (Omphalotaceae, Agaricales) recorded in Slovakia. - Czech Mycology 66(1): 85-97.

353. JANCSÓ G. (1990): A gombák szaga. - Mikológiai Közlemények 1-3: 63-88.

354. JAROSCH, M. \& BESL, H. (2001): Leucogyrophana, a polyphyletic genus of the order Boletales (Basidiomycetes). - Plant Biology 3(4): 443-448.

355. Jeppson, M. (2012a): Lycoperdon Pers.: Pers. In: KnUdSen, H. \& Vesterholt, J. - Funga Nordica. Nordsvamp, Coppenhagen, pp. 643-650.

356. Jeppson, M. (2012b): Cyathus Haller. In: Knudsen, H. \& Vesterholt, J. - Funga Nordica. Nordsvamp, Coppenhagen, pp. 616-617.

357. Jin, J. W., LIM, Y. W., LeE, J. S. \& JUNG, H. S. (2005): Phylogeny of Phellinus and related genera inferred from combined data of ITS and mitochondrial SSU rDNA sequences. - J. Microbiol. Biotechnol. 15: 1028-1038.

358. Jonsson, B. G., KRUYS, N. \& RANIUS, T. (2005): Ecology of species living on dead wood - lessons for dead wood management. - Silva Fennica 39(2): 289-309. http://dx.doi.org/10.14214/sf.390

359. JÖnsson, M., EDMAN, M. \& Jonsson, B. G. (2008): Colonization and extinction patterns of wooddecaying fungi in a boreal Picea abies forest. -J. Ecol. 96: 1065-1075.

http://dx.doi.org/10.1111/i.1365-2745.2008.01411.x

360. Judova, J., Dubikova, K., Gaperova, S., Gaper, J. \& Pristas, P. (2012): The occurence and rapid discrimination of Fomes fomentarius genotypes by ITS-RFLP analysis. - Fungal Biology 116: 155-160. http://dx.doi.org/10.1016/i.funbio.2011.10.010

361. JÜLICH, W. (1981): Higher taxa of Basidiomycetes. - Bibliotheca Mycologica 85: 1-485.

362. JÜLICH, W. (1982): Notes on some Basidiomycetes (Aphyllophorales and Heterobasidio-mycetes). Persoonia 11(4): 421-428.

363. Junninen, K. \& KomOnen, A. (2011): Conservation ecology of boreal polypores: A review. Biological Conservation 144, 11-20. http://dx.doi.org/10.1016/..biocon.2010.07.010

364. Justo, A. \& CASTRO, M. L. (2007). An annotated checklist of Pluteus in the Iberian Peninsula and Balearic Islands. - Mycotaxon 102: 231-234.

365. Justo, A. \& HibBetT, D. S. (2011): Phylogenetic classification of Trametes (Basidiomycota, Polyporales) based on a five-marker dataset. - Taxon 60(6): 1567-1583.

366. Justo, A., Minnis, A. M., Ghignone, S., Menolli, N. JR., Capelari, M., Rodríguez, O., Malysheva, E., Contu, M. \& Vizzini, A. (2011a): Species recognition in Pluteus and Volvopluteus (Pluteaceae, Agaricales): morphology, geography and phylogeny. - Mycol Progress 10: 453-479. http://dx.doi.org/10.1007/s11557-010-0716-z

367. Justo, A., Vizzini, A., Minnis, A. M., Menolli, N., CAPelari, M., Rodríguez, O., Malysheva, E., Contu, M., Ghignone, S. \& HibBett, D. S. (2011b): Phylogeny of the Pluteaceae (Agaricales, Basidiomycota): taxonomy and character evolution. - Fungal Biology 115: 1-20. 


\section{http://dx.doi.org/10.1016/j.funbio.2010.09.012}

368. Justo, A., Malysheva, E., Bulyonkova, T., Vellinga, E. C., Cobain, G., NGuyen, N., Minnis, A. M. \& HiBBETT, D. S. (2014): Molecular phylogeny and phylogeography of Holarctic species of Pluteus section Pluteus (Agaricales: Pluteaceae), with description of twelve new species. Phytotaxa 180(1): 1-85. http://dx.doi.org/10.11646/phytotaxa.180.1.1

369. KÁNYÁSI I. (1992): Adatok a Tokaj-Zempléni-hegyvidék gombaflórájához. - Calandrella 6(2): 1223.

370. KARAdeleV, M. (2000): A preliminary Red List of Macromycetes int he Republic of Macedonia. Institute of Biology, Faculty of Natural Science, Skopje. [www.wsl.ch]

371. KARADELEV, M. \& RUSEVSKA, K. (2005): Ecology and distribution of genus Hymenochaete (Hymenochaetaceae) in the Republic of Macedonia. - Biol. Macedonica 57/58: 39-53.

372. KARASCH, P. \& HAHN, C. (2009): Rote Liste gefährdeter Großpilze Bayerns. Bayerisches Landesamt für Umwelt (LfU). Druck- \& Medienservice Schulz, Oberkotzau.

373. Karasińki, D., Kujawa, A., PiąTeK, M., Ronikier, A. \& WoŁKowycki, M. (2009): Contribution to biodiversity assessment of European primeval forests: new records of rare fungi in the Białowieża Forest. - Polish Bot. J. 54(1): 55-97.

374. KALAMES, K. (2007): Checklist of some pleurotoid fungi (Agaricomycetidae, Basidiomycetes) of Estonia. - Folia Cryptog. Estonica, Fasc. 43: 13-15.

375. KALMÁR Z. (1966): A kalaposgombafajok gyakorisága Magyarországon. - Mikológiai Közlemények (1): 17-26.

376. KÄMMERER, A., BeSL, H. \& BRESINSKY, A. (1985): Omphalotaceae fam. nov. und Paxillaceae, ein chemotaxonomischer Vergleich zweier Pilzfamilien der Boletales. - Plant Systematics and Evolution 150: 101-117. http://dx.doi.org/10.1007/bf00985571

377. Karsten, P. A. (1868): Auriculariei, Clavariei et Tremellini, in paroecia Tammela crescentes. Notiser ur Sällskapets pro Fauna et Flora Fennica Förhandlingar 9: 365-374.

378. Karsten, P. A. (1881): Enumeratio Hydnearum Fr. Fennicarum, systemate novo dispositarum. Revue Mycologique Toulouse 3(9): 19-21.

379. KASOM, G. \& MiLičKOviĆ, N. (2006): Protected speciies of Macromycetes int he Republic of Montenegro.

380. Kauserud, H., Stensrud, Ø., Decock, C., Shalchian-Tabrizi, K. \& Schumacher, T. (2006). Multiple gene genealogies and AFLPs suggest cryptic speciation and long-distance dispersal in the basidiomycete Serpula himantioides (Boletales). - Molecular Ecology 15: 421-431. http://dx.doi.org/10.1111/i.1365-294x.2005.02768.x

381. Kauserud, H., Colman, J. E. \& Ryvarden, L. (2008): Relationship between basidiospore size, shape and life history characteristics: a comparison of polypores. - Fungal Ecology 1: 19-23. http://dx.doi.org/10.1016/i.funeco.2007.12.001

382. KAWAI, G. BABASAKI, K. \& NeDA, H. (2008): Taxonomic position of a Chinese Pleurotus "BaiLing-Gu": it belongs to Pleurotus eryngii (DC.: Fr.) Quél. and evolved independently in China. Mycoscience 49: 75-87. http://dx.doi.org/10.1007/s10267-007-0392-2

383. KERESZTESI B. (1968): Magyar Erdők. Akadémiai Kiadó, Budapest. pp. 303-304.

384. KIM, S. Y. \& JUNG, H. S. (2000): Phylogenetic relationships of the Aphyllophorales inferred from sequence analysis of nuclear small subunit ribosomal DNA. - Journal of Microbiology 38: 122131.

385. Kirk, P. M., Cannon, P. F., Minter, D. W. \& Stalpers, J. A. (2008): Ainsworth \& Bisby's dictionary of the fungi. 10th ed. - CAB International, Wallingford, Oxon, $771 \mathrm{pp}$.

386. Kluting, K. L., BARONI, T. J. \& BERgEMAnN, S. E. (2014): Toward a stable classification of genera within the Entolomataceae: a phylogenetic re-evaluation of the Rhodocybe-Clitopilus clade. Mycologia 106(6): 1127-1142. http://dx.doi.org/10.3852/13-270

387. KNUdSEN, H. (1997): Typhulaceae Jülich. 256-260, in: HANSEN, L. \& KNUDSEN, H. (szerk.). Nordic Macromycetes. Vol. 3. 
388. KnUdSen, H. \& Vesterholt, J. (szerk.) (2012): Funga Nordica. 2nd edition. Agaricoid, Boletoid, Clavarioid, Cyphelloid and Gasteroid genera. Nordsvamp, Copenhagen, 1064 pp.

389. KNUdSON, A. G. (2012): The genus Ramaria in Minnesota. Doctoral Thesis.

390. Koltay A. \& SzÁNTÓ M. (1988): Az Armillaria nemzetség Magyarországon 1. Nevezéktani és növénykórtani kérdések a nemzetségen belül. - Mikológiai Közlemények (3): 184-188.

391. KONECSNI I. \& VÉGHELYI K. (1986): Adatok a cseresznye és meggyfák nagygombáiról. Mikológiai Közlemények 2-3: 145-155.

392. Koski-KotiRanta, S. \& Niemelä, T. (1987): Hydnaceous fungi of the Hericiaceae, Auriscalpiaceae and Climacodontaceae in northwestern Europe. - Karstenia 27: 43-70.

393. KoszKA A. (2011): Adatok a Vértes déli részének gombavilágához. - Mikológiai Közlemények, Clusiana 50(2): 149-172.

394. KoszKa A. (2014): Fungisztikai vizsgálatok a Vértes déli részén. Szakdolgozat. Kézirat.

395. KotiRAnTA, H. (2006): 9. Finland 2000-2005 (Country reports for the period 2000-2005). - Council for the Conservation of Fungi: Newsletter 14: 17-19.

396. Kotiranta, H., Ushakova, N. \& Mukhin, V. A. (2007): Polypore (Aphyllophorales, Basidiomycetes) studies in Russia. 2. Central Ural. - Ann. Bot. Fennici 44: 103-127.

397. Kotiranta, H., SAarenoksa, R. \& KytÖvUori, I. (2009): Aphyllophoroid fungi of Finland. A check-list with ecology, distribution, and threat categories. - Norrlinia 19: 1-223.

398. KотLÁBA, F. (1975): Geographical distribution and ecology of the polypore Phellinus torulosus (Pers. ex Pers.) Bourd. et Galz. with special regard to Czechoslovakia. - Česká mykologie 29: 524.

399. KotlÁBA, F. \& PouZAR, Z. (1963): A new genus of the Polypores - Pachykytospora gen. nov. Ceská Mykologie 17(1): 27-34.

400. KotlÁBA, F. \& POUZAR, Z. (1966): Buglossosporus gen. nov. - a new genus of Polypores. - Ceská Mykologie 20(2): 81-89.

401. KotlÁBA, F. \& POUZAR, Z. (1972): Taxonomic and nomenclatural notes on some Macromycetes. Ceská Mykologie 26(4): 217-222.

402. Kotlába, F. \& PouZAR, Z. (1988): Type studies of polypores described by A. Pilát 1. - Česka Mykol. 42: 129-136.

403. Koukol, O., Kotlába, F. \& PouZAR, Z. (2014): Taxonomic evaluation of the polypore Daedaleopsis tricolor based on morphology and molecular data. - Czech Mycology 66(2): 107119.

404. KreISEL, H. (1963): Über Polyporus brumalis und verwandte Arten. - Feddes Rep. 68: 129-138.

405. KRIEGLSTEINER, G. J. (2000): Die Großpilze Baden-Württembergs. Band 1. - Ulmer, Stuttgart, 629 pp.

406. KRIEGLSTEINER, G. J. (2001): Verbreitungsatlas der Grosspilze Deutschlands. 1. Ulmer, Stuttgart.

407. KRIEGLSTEINER, L. \& LAWRYNOWICZ, M. (2003): Hymenochaete carpatica from Częstochowa Upland (S Poland). - Acta Mycol. 38(1-2): 27-30. http://dx.doi.org/10.5586/am.2003.003

408. KRISAI-GREILHUBER, I. (2005): 2. A short report on protection, mapping and monitoring of fungi in Austria (2005) (Country reports for the period 2000-2005). - Council for the Conservation of Fungi: Newsletter 14: 3-4.

409. KRÜGER, D. (2002): "Monographic Studies in the Genus Polyporus (Basidiomycotina). PhD diss., University of Tennessee.

410. KrÜger, D., Binder, M., Fischer, M. \& Kreisel, H. (2001): The Lycoperdales. A molecular approach to the systematics of some gasteroid mushrooms. - Mycologia 93: 947-957. http://dx.doi.org/10.2307/3761759

411. KRÜGER, D. \& KREISEL, H. (2003): Proposing Morganella subgen. Apioperdon subgen. nov. for the puffball Lycoperdon pyriforme. - Mycotaxon 86: 169-177. 
412. KRÜGer, D. \& Gargas, A. (2004): The basidiomycete genus Polyporus - an emendantion based on phylogeny and putative secondary structure of ribosomal RNA molecules. - Feddes Repertorium 115(7-8): 530-546. http://dx.doi.org/10.1002/fedr.200311052

413. KÜFFER, N., LOVAS, P. S., SENN-IRLET, B. (2004): Diversity of wood-inhabiting fungi in natural beech forests in Transcarpathia (Ukraine): a preliminary survey. - Mycologia Balcanica 1: 129134.

414. KÜFFER, N. \& SENN-IRLET, B. (2005): Diversity and ecology of wood-inhabiting aphyllophoroid basidiomycetes on fallen woody debris in various forest types in Switzerland. - Mycological Progress 4(1): 77-86. http://dx.doi.org/10.1007/s11557-006-0110-z

415. KÜHNER, R. \& ROMAGNESI, H. (1953): Flore Analytique des Champignons Supérieurs. p.1-556.

416. Kummer, P. (1871): Der Führer in die Pilzkunde. p. 1-146.

417. KUNCA, V. (2011): Ecology and incidence of Polyporus umbellatus in Slovakia. - Czech Mycol. 63(1): 39-53.

418. Kunttu, P., Kulju, M., Pennanen, J., Kotiranta, H. \& Halme, P. (2011): Additions to the Finnish aphyllophoroid fungi. - Folia Cryptog. Estonica, Fasc. 48: 25-30.

419. KUYPER, T. W. (1984): Notulae ad Floram agaricinam neerlandicam VI-VII. Rickenella and Omphalina. - Persoonia 12(2): 188.

420. Kuyper, T. W. \& TJallingiI-Beukers, D. (1986): Notes on Pholiota. - Persoonia 13(1): 77-82.

421. LANDRES, P. B., VERnER, J., THOMAS, J. W. (1988): Ecological use of vertebrate indicator species: A critique. - Conserv Biol 2: 316-328. http://dx.doi.org/10.1111/j.1523-1739.1988.tb00195.x

422. LANGE, M. (1992): Sequence of macromycetes on decaying beech logs. - Persoonia 14: 449-456.

423. LANGER, E. (2000): Rote Liste der Großpilze Hessens. Hessisches Ministerium für Umwelt, Landwirtschaft und Forsten, Wiesbaden.

424. LARGENT, D. L. (1989): A new, lignicolous species of Entoloma (Entolomataceae, Agaricales) from California. - Mycotaxon 34(1): 129-131.

425. LARGENT, D. L. (1994): Entolomatoid fungi of the western United States and Alaska. Mad River Press Inc: Eureka, California.

426. Largent, D. L., Bergemann, S. E., Abell-Davis, S. E., Kluting, K. L. \& Cummings, G. A. (2013): Five Leptonia species from New South Wales and Queensland, Australia. - Mycotaxon 125: 11-35. http://dx.doi.org/10.5248/125.11

427. LARSSON, E. \& JEPPSON, M. (2008): Phylogenetic relationships among species and genera of Lycoperdaceae based on ITS and LSU sequence data from North European taxa. - Mycological Research 112(1): 4-22. http://dx.doi.org/10.1016/i.mycres.2007.10.018

428. LARSSON, K.-H. (2007): Re-thinking the classification of corticioid fungi. - Mycol. Research 111: 1040-1063. http://dx.doi.org/10.1016/i.mycres.2007.08.001

429. LARSSON, A. (2014): AliView: a fast and lightweight alignment viewer and editor for large data sets. - Bioinformatics 30(22): 3276-3278. http://dx.doi.org/10.1093/bioinformatics/btu531

430. LARSSON, K.-H., LARSSON, E. \& KÕLJALG, U. (2004): High phylogenetic diversity among corticioid homobasidiomycetes. - Mycol. Res. 108(9): 983-1002.

http://dx.doi.org/10.1017/s0953756204000851

431. Larsson, K.-H., Parmasto, E., Fischer, M., Langer, E., Nakasone, K. K. \& Redhead, S. A. (2006): Hymenochaetales: a molecular phylogeny for the hymenochaetoid clade. - Mycologia 98(6): 926-936. http://dx.doi.org/10.3852/mycologia.98.6.926

432. LÁZARO IBIZA, B. (1917): Los poliporáceos de la flora española. Estudio crítico y descriptivo de los hongos de esta familia. - Rev. Acad. Ci. Madrid 14: 833-836.

433. Lechner, B. E., Wright, J. E. \& Albertó, E. (2004): The genus Pleurotus in Argentina. Mycologia 96(4): 845-858. http://dx.doi.org/10.2307/3762117

434. LEGON, N. W. \& ROBERTS, P. (2002): Steccherinum albidum: a new species from southern England. - Czech Mycology 54(1-2): 7-9. 
435. Lee, M.-W., Hur, H., Chang, K.-C., LeE, T.-S., KA, K.-H. \& JANKovsKy, L. (2008): Introduction to distribution and ecology of sterile conks of Inonotus obliquus. - Mycobiology 36(4): 199-202. http://dx.doi.org/10.4489/myco.2008.36.4.199

436. LENTI I. (2007): A bátorligeti Fényi-erdő nagygombái. - Szabolcs-Szatmár-Beregi szemle 42(2): 203-217.

437. LenTZ, L. (1954): Modified hyphae of Hymenomycetes. - Bot. Rev. 20: 215-233. http://dx.doi.org/10.1007/bf02872369

438. LEONARD, A. C. (1998): Two Ganoderma species compared. - Mycologist 2: 65-68. http://dx.doi.org/10.1016/s0269-915x(98)80047-5

439. LEYSSER, F.W. VON (1761): Flora halensis. First edition.

440. LEYSSER, F.W. VON (1783): Flora halensis. Second edition.

441. LI, H.-J. \& CUI, B.-K. (2013): Two new Daedalea species (Polyporales, Basidiomycota) from South China. - Mycoscience 54: 62-68. http://dx.doi.org/10.1016/i.myc.2012.07.005

442. LI, W. \& GUO, L. (2014): Three new species of Septobasidium from Yunnan and Guangxi in China. - Mycotaxon 127: 25-31. http://dx.doi.org/10.5248/127.25

443. LI, H. J., CUI, B. K. \& DAI, Y.-C. (2014): Taxonomy and multi-gene phylogeny of Datronia (Polyporales, Basidiomycota). - Persoonia 32: 170-182.

http://dx.doi.org/10.3767/003158514x681828

444. Lickey, E. B., Hughes, K. W. \& Petersen, R. H. (2002): Biogeographical patterns in Artomyces pyxidatus. - Mycologia 94(3): 461-471. http://dx.doi.org/10.2307/3761780

445. Lickey, E. B., Hughes, K. W. \& Petersen, R. H. (2003): Phylogenetic and taxonomic studies in Artomyces and Clavicorona (Homobasidiomycetes: Auriscalpiaceae). - Sydowia 55(2): 181-254.

446. LINDBLAD, I. (1998): Wood-inhabiting fungi on fallen logs of Norway spruce: Relations to forest management and substrate quality. - Nordic Journal of Botany 18: 243-255.

http://dx.doi.org/10.1111//.1756-1051.1998.tb01877.x

447. LindHe, A., Åsenblad, N. \& Toresson, H.-G. (2004): Cut logs and high stumps of spruce, birch, aspen and oak - nine years of saproxylic fungi succession. - Biological Conservation 119: 443454. http://dx.doi.org/10.1016/i.biocon.2004.01.005

448. LindeR, D. H. (1933): The genus Schizophyllum. I. Species of the western hemisphere. - Am J Bot 20: 552-564. http://dx.doi.org/10.2307/2436215

449. LINDNER, D. L. \& BANIK, M. T. (2008): Molecular phylogeny of Laetiporus and other brown rot polypore genera in North America. - Mycologia 100(3): 417-430. http://dx.doi.org/10.3852/07$\underline{124 r 2}$

450. Lindner, D. L., RYVARDEN, L. \& BARONI, T. J. (2011): A new species of Daedalea (Basidiomycota) and a synopsis of core species in Daedalea sensu stricto. - North American Fungi 6(4): $1-12$.

451. LIZON, P. (2001): Red List of slovak fungi. [http://www.wsl.ch/eccf/Slovakia.pdf]

452. LoCsMÁNDI Cs. (1993): Az Aggteleki-karszt gombaflorisztikai és gombataxonómiai vizsgálata. Egyetemi Doktori Értekezés. ELTE TTK, Növényrendszertani és Ökológiai Tanszék, Budapest. 90 pp.

453. LÖKÖS L. \& FARKAS E. (2009): Revised checklist of the Hungarian lichen-forming and lichenicolous fungi. (Magyarországi zuzmók és zuzmólakó mikrogombák revideált fajlistája). [http://www.nhmus.hu/hu/novenytar/gyujtemenyek/zuzmogyujtemeny/mozuzmolista2]

454. LÖYTYNOJA, A. \& Goldman, N. (2005): An algorithm for progressive multiple alignment of sequences with insertions. - Proceedings of the National Academy of Sciences of the U.S.A. 102(30): 10557-10562. http://dx.doi.org/10.1073/pnas.0409137102

455. Lonsdale, D., Pautasso, M. \& Holdenrieder, O. (2008): Wood-decaying fungi in the forest: conservation needs and management options. - Eur J Forest Res 127: 1-22.

http://dx.doi.org/10.1007/s10342-007-0182-6 
456. Looney, B. P., BirkebaK, J. M. \& Matheny, P. B. (2013): Systematics of the genus Auricularia with an emphasis on species from the southeastern United States. - North American Fungi 8(6): 125. http://dx.doi.org/10.2509/naf2013.008.006

457. Lowy, B. (1952): The genus Auricularia. - Mycologia 44: 656-692.

458. LudWIG, E. (2001): Pilzkompendium 1. Die kleineren Gattungen der Makromyzeten mit lamelligem Hymenophor aus den Ordnungen Agaricales, Boletales und Polyporales: Abbildungen. IHV Verlag, p. 758.

459. LUKÁCS Z. (2002): Újabb adatok Magyarország nagygomba világához I. - Mikológiai Közlemények, Clusiana 41(2-3): 45-52.

460. LUKÁCS Z. (2007): Újabb adatok Magyarország gombavilágához III. - Mikológiai Közlemények, Clusiana 46(2): 187-210.

461. LUKÁCS Z. (2010): Újabb adatok Magyarország gombavilágához IV. - Mikológiai Közlemények, Clusiana 49(1-2): 79-119.

462. LUKÁCS Z. \& HoRVÁTH I. (2010): Makedón kacskagomba (Crepidotus macedonicus Pilát 1949). Magyar Gombász 8(1): 15-16.

463. LukÁcs Z., Hernádi A., PrutKay E., Szilvásy E. \& Koczuba J. (2013): Újabb adatok Magyarország gombavilágához V. - Mikol. Közl., Clusiana 52(1-2): 21-43.

464. MAAS GeESTERANUS, R. A. (1962): Hyphal structures in hydnums. - Persoonia 2(3): 377-405.

465. MAAS GeESTERANUS, R. A. (1967): Quelques champignons hydnoïdes du Congo. - Bulletin du Jardin botanique national de Belgique 37(1): 77-107. http://dx.doi.org/10.2307/3667529

466. MAas GeESTERANUS, R. A. (1974): Studies in the genera Irpex and Steccherinum. - Persoonia 7(4): 443-581.

467. MaAs GeEsteranus, R. A. (1984): Conspectus of the Mycenas of the Northern Hemisphere - 3 . Section Filipedes. - Proc. Kon. Ned. Akad. Wetensch. Ser. C 87: 413-447.

468. MACBRIDE, T. H. (1895): Saprophytic fungi of Eastern Iowa - The Polyporaceae. - Bulletin from the laboratories of natural history of the State University of Iowa 3(2): 1-30.

469. MAGYAR D. \& TÓTH S. (2003): Data to the knowledge of the microscopic fungi in the forests around Budakeszi (Buda Hills, Hungary). - Acta Phytopathologica et Entomologica Hungarica 38(1-2): $61-72$.

470. MalysheVA, V. F. (2006): Notes on rare species of aphyllophoroid fungi found in Zhiguli Nature Reserve (Samara Region, European Russia). - Karstenia 46(1): 25-32.

471. MalysheVA, E. F. \& Morozova, O. V. (2009): Notes on Hemimycena from European Russia. Czech Mycol. 61(1): 27-71.

472. MalysheVA, V. F. \& ZMitrovich, I. (2011): Testing the Trametes hirsuta complex. - Nova Hedwigia 93(1-2): 57-71. http://dx.doi.org/10.1127/0029-5035/2011/0093-0057

473. Manimohan, P., Noordeloos, M. E. \& DhanyA, A. M. (2006): Studies on the genus Entoloma (Basidiomycetes, Agaricales) in Kerala State, India. - Persoonia 19(1): 45-93.

474. MANJon, J. L., Moreno, G. \& RYVARDEN, L. (1983): Trametes junipericola sp. nov. - Boletín de la Sociedad Micologica Castellana 8: 47-50.

475. MARRIOTT, J. V. R. (1998): Spore size distribution in Ganoderma. - Mycologist 3: 131. http://dx.doi.org/10.1016/s0269-915x(98)80018-9

476. MAtheny, P. B. (2009): A Phylogenetic Classification of the Inocybaceae. - McIlvainea 18 (1): 11 21.

477. Matheny, P. B., J. M. Curtis, V. Hofstetter, M. C. Aime, J.-M. Moncalvo, Z.-W. Ge, Z.-L. YAng, J. C. Slot, J. F. Ammirati, T. J. BAROni, N. L. Bougher, K. W. Hughes, D. J. Lodge, R. W. Kerrigan, M. T. Seidl, D. K. Aanen, M. Denitis, G. M. Daniele, D. E. Desjardin, B. R. Kropp, L. L. NorVell, A. Parker, E. C. Vellinga, R. Vilgalys \& D. S. HibBett (2006): Major clades of Agaricales: a multilocus phylogenetic overview. - Mycologia 98: 982-995.

http://dx.doi.org/10.3852/mycologia.98.6.982 
478. Matheny, P. B., Moreau P. A., Vizzini, A., Harrower, E., De HaAn, A., Contu, M. \& Curti, M. (2014): Crassisporium and Romagnesiella: two new genera of dark-spored Agaricales. Systematics and Biodiversity 13(1): 28-41. http://dx.doi.org/10.1080/14772000.2014.967823

479. Маттоск, G. (2001): Notes on British Ganoderma species - emphasising the annual species and $G$. carnosum. - Field Mycol. 2: 60-64. http://dx.doi.org/10.1016/s1468-1641(10)60517-8

480. MAтTоск, G. (2014): Growth forms of Cylindrobasidium laeve. - Field Mycology 15(2): 42-44. http://dx.doi.org/10.1016/i.fldmyc.2014.03.004

481. MCNABB, R. F. R. (1964): New Zealand Tremellales I. - New Zealand Journal of Botany 2(4): 403414. http://dx.doi.org/10.1080/0028825x.1964.10428761

482. MCNABB, R. F. R. (1965): Taxonomic studies in the Dacrymycetaceae II. Calocera (Fr.) Fr. - New Zealand Journal of Botany 3(1): 31-58. http://dx.doi.org/10.1080/0028825x.1965.10428712

483. MCNeILl, J. \& TURLAND, N. J. (2011): Major changes to the Code of Nomenclature - Melbourne, July 2011. - Taxon 60(5): 1495-1497.

484. McNeill, J., Barrie, F. R., Buck, W. R., Demoulin, V., Greuter, W., Hawksworth, D. L., Herendeen, P. S., KNAPP, S., Marhold, K., Prado, J., Prud’homme VAn Reine, W. F., SMith, G. F., WiersemA, J. H. \& TURLAND, N. J. (szerk.) (2012): International Code of Nomenclature for Algae, Fungi, and Plants (Melbourne Code) adopted by the Eighteenth International Botanical Congress Melbourne, Australia, July 2011 [Regnum Vegetabile, 154], A.R.G. Ganter Verlag, Ruggell, p. 140.

485. Melo, I., RAmos, P. \& CAETANO, M. F. F. (2002): First record of Inonotus rickii (Basidiomycetes, Hymenochaetaceae) in Portugal. - Portugaliae Acta Biol. 20: 265-269.

486. Menoldi, N., Breternitz, B. S. \& CAPelari, M. (2014): The genus Pleurotus in Brasil: a molecular and taxonomic overview. - Mycoscience 55: 378-389. http://dx.doi.org/10.1016/j.myc.2013.12.001

487. Miersch, J. \& ANTONíN, V. (2013): Hemimycena longipilosa (Agaricales), a new species from Germany. - Czech Mycol. 65(2): 151-156.

488. Miettinen, O., Niemelä, T. \& SpiRin, W. (2006): Northern Antrodiella species: the identity of $A$. semisupina, and type studies of related taxa. - Mycotaxon 96: 211-239.

489. Miettinen, O., LARsson, E., SJÖKvist, E. \& LARSSON, K. H. (2012): Comprehensive taxon sampling reveals unaccounted diversity and morphological plasticity in a group of dimitic polypores (Polyporales, Basidiomycota). - Cladistics 28(3): 251-270.

http://dx.doi.org/10.1111/j.1096-0031.2011.00380.x

490. Millanes, A. M., Diederich, P., Ekman, S. \& Wedin, M. (2011): Phylogeny and character evolution int he jelly fungi (Tremellomycetes, Basidiomycota, Fungi). - Molecular Phylogenetics and Evolution 61: 12-28. http://dx.doi.org/10.1016/j.ympev.2011.05.014

491. Millanes, A., Diederich, P., Westberg, M., Knutsson, T. \& Wedin, M. (2014): Tremella rhizocarpicola sp. nov. and other interesting lichenicolous Tremellales and Filobasidiales in the Nordic countries. - MycoKeys 8: 31-41. http://dx.doi.org/10.3897/mycokeys.8.8176

492. MINTER, D. (2014): Fungal conservation and the CBD: focus on Belgium. A Micheli Guide Review. - Fungal Conservation 4: 58-67.

493. MoEsz G. (1934): A házigomba és az épületek elgombásodása. Kir. Magyar Term. Tud. Társ. 206 pp.

494. MoEsz G. (1941): A bányák és barlangok gombái Magyarországon. - Botanikai Közlemények 38: 411.

495. MoEsz G. (1942): Budapest és környékének gombái. Királyi Magyar Természettudományi Társulat, Budapest, $142 \mathrm{pp}$.

496. MOHANTY, P.S., HARSH, N.S.K. \& PANDEY, A. (2011): First report of Ganoderma resinaceum and G. weberianum from north India based on ITS sequence analysis and micromorphology. Mycosphere 4: 469-474. 
497. Moncalvo, J. M., Wang, H. F. \& HSeU, R. S. (1995): Gene phylogeny of the Ganoderma lucidum complex based on ribosomal DNA sequences: comparison with traditional taxonomic characters. Mycol. Res. 99: 1489-1499. http://dx.doi.org/10.1016/s0953-7562(09)80798-3

498. Moncalvo, J. M., Nilsson, R. H., Koster, B., Dunham, S. M., Bernauer, T., Matheny, P. B., Mclenon, T., Margaritescu, S., Weir, M., Garnica, S., Danell, E., Langer, G., Langer, E., LARSSON, E., LARSSON, K. H. \& Vilgalys, R. (2006): The cantharelloid clade: dealing with incongruent gene trees and phylogenetic reconstruction methods. - Mycologia 98: 937-948. http://dx.doi.org/10.3852/mycologia.98.6.937

499. Moore, D. (1994): Tissue formation. In: Gow, N. A. R. \& Gadd, G. M.: The growing fungus. Chapman \& Hall, London, 21: 423-465.

500. MoORE, G. (1998). A comparison of traditional and phylogenetic nomenclature. - Taxon 47: 561579.

501. Moreno, G., Blanco, M. N., Olariaga, I. \& CheCA, J. (2007): Climacodon pulcherrimus a badly known tropical species, present in Europe. - Cryptogamie Mycologie 28(1): 3-11.

502. Moreno, G., Blanco, M. N., Checa, J., Platas, G. \& Peláez F. (2011): Taxonomic and phylogenetic revision of three rare irpicoid species within the Meruliaceae. - Mycol Progress 10: 481-491. http://dx.doi.org/10.1007/s11557-010-0717-y

503. Morgado, L. N., Noordeloos, M. E., LamoureuX, Y. \& Geml, J. (2013): Multi-gene phylogenetic analyses reveal species limits, phylogeographic patterns, and evolutionary histories of key morphological traits in Entoloma (Agaricales, Basidiomycota). - Persoonia 31: 159-178. http://dx.doi.org/10.3767/003158513x673521

504. Morozova, O. V., Noordeloos, M. E. \& VILA, J. (2014): Entoloma subgenus Leptonia in borealtemperate Eurasia: towards a phylogenetic species concept. - Persoonia 32: 141-169.

http://dx.doi.org/10.3767/003158514x681774

505. Mukhin, V. A. \& VotintseVA, A. A. (2002): Basidiospore germination and conidial stages in the life cycles of Fomes fomentarius and Fomitopsis pinicola (Fungi, Polyporales). - Polish Botanical Journal 47(2): 265-272.

506. MÜLLER. J., ENGEL, H. \& BLASChKe, M. (2007): Assemblages of woodinhabiting fungi related to silvicultural management intensity in beech forests in southern Germany. - Eur J For Res 126: 513-527. http://dx.doi.org/10.1007/s10342-007-0173-7

507. MURRILL, W. A. (1903): A historical review of the genera of the Polyporaceae. - The Journal of Mycology 9(2): 87-102. http://dx.doi.org/10.2307/3752511

508. MurRILL, W. A. (1904): A new polyporoid genus from South America. - Torreya 4: 141-142.

509. MurriLl, W. A. (1905): The Polyporaceae of North America: XII. A synopsis of the white and bright-colored pileate species. - Bulletin of the Torrey Botanical Club 32(9): 469-493.

http://dx.doi.org/10.2307/2478463

510. MURRILL, W. A. (1907): Polyporaceae, Part 1. North American Flora. 9(1): 1-72.

511. NAGY L. (2004): Fungisztikai vizsgálatok az Alföldön 1997 és 2003 között. - Mikológiai Közlemények, Clusiana 43(1-3): 15-46.

512. NAGY L. (2008): Határozókulcs az Európából ismert Coprinus fajokhoz. - Mikológiai Közlemények, Clusiana 47(1): 31-44.

513. NAGY L. (2013): A sokszínü Vértes hegység. - Erdészeti Lapok 148(7-8): 210.

514. NAGY L. \& GoRLICZAI Zs. (2007): Újabb adatok az Alföld gombavilágához. - Mikológiai Közlemények, Clusiana 46(2): 211-256.

515. Nagy G. L., Kocsubé S., Csanádi Z., Kovács G. M., PetKovits T., VÁGVÖlgYi Cs. \& PAPp T. (2012): Re-mind the gap! Insertion - deletion data reveal neglected phylogenetic potential of the nuclear ribosomal internal transcribed spacer (ITS) of fungi. - PLOS ONE 7: e49794.

http://dx.doi.org/10.1371/iournal.pone.0049794 
516. Nagy G. L., DesJardin, D. E., VÁGVÖLgyi Cs., KeMP, R. \& PAPP T. (2013): Phylogenetic analyses of Coprinopsis section Lanatuli and Atramentarii identify multiple species within morphologically defined taxa. - Mycologia 105(1): 112-124. http://dx.doi.org/10.3852/12-136

517. NAKASONE, K. K. (1996): Morphological and molecular studies on Auriculariopsis albomellea and Phlebia albida and a reassessment of A. ampla. - Mycologia 88: 762-775.

http://dx.doi.org/10.2307/3760971

518. NAKASONE, K. K. (1997): Studies in Phlebia. Six species with teeth. - Sydowia 49(1): 49-79.

519. NAKASONE, K. K. (2006): Dendrothele griseocana (Corticiaceae) and related taxa with hyphal pegs. - Nova Hedwigia 83(1-2): 99-108. http://dx.doi.org/10.1127/0029-5035/2006/0083-0099

520. NAKASONE, K. K. \& SytSMA, K. J. (1984): Biosystematic studies on Phlebia acerina, P. rufa, and P. radiata in North America. - Mycologia 85(6): 996-1016. http://dx.doi.org/10.2307/3760683

521. Navarro-Rosinés, P., EgeA, J. M. \& Llimona, X. (2000): Caloplaca cancarixiticola, a new species from South-East Spain growing on ultrapotassic rocks. - Lichenologist 32(2): 129-138. http://dx.doi.org/10.1006/lich.1999.0252

522. NÉMETH CS. (2006): Hibrid eredetü, bennszülött Sorbus taxonok elterjedése a Vértesben és környékén. - Flora Pannonica 4: 17-33.

523. NÉMETH Cs. (2008): Adatok a Súri-Bakonyalja, a Bakony és a Vértes mohaflórájához. - Flora Pannonica 6: 79-87.

524. NÉMETH Cs. (2009): Új berkenye (Sorbus) kisfajok a Vértesböl. - Kitaibelia 14(1): 89-103.

525. NÉMETH CS. (2015): Taxonomic revision of Sorbus pseudosemiincisa (Rosaceae), a stenoendemic whitebeam from Vértes Mts, Hungary, with the description of a new species, Sorbus pyricarpa.Studia Botanica Hungarica 46 (2): in press.

526. NiemelÄ, T. (1982): On Fennoscandian polypores 8. New genus Piloporia. - Karstenia 22: 13-16.

527. NIEMELÄ, T. (1985): On Fennoscandian polypors 9. Gelatoporia $\mathrm{n}$. gen. and Tyromyces canadensis, plus notes on Skeletocutis and Antrodia. - Karstenia 25: 21-40.

528. NIEMELÄ, T. (2005): Polypores - lignicolous fungi (in Finnish with a summary in English). Norrlinia 13, 1-320.

529. NiEMELÄ, T. (2013): Polypores of the Białowieża Forest. Białowieża, p. 135.

530. Niemelä, T. \& Ryvarden, L. (1975): Studies in the Aphyllophorales of Africa 4. Antrodia juniperina, new to Africa. - Transactions of the British Mycological Society 65(3): 427-432. http://dx.doi.org/10.1016/s0007-1536(75)80040-4

531. NIEMELÄ, T. \& SAARENOKSA, R. (1985): Dentipellis fragilis and Steccherinum oreophilum: Finnish records of hydnaceous fungi. - Karstenia 25: 70-74.

532. Niemelä, T., Kinnunen, J., Lindgren, M., Manninen, O., Miettinen, O., Penttilë, E. \& TURUNEN, O. (2001): Novelties and records of poroid Basidiomycetes in Finland and adjacent Russia. - Karstenia 41(1): 1-21.

533. Niemelä, T., DAI, Y.-C., Kinnunen, J. \& Schigel, D. S. (2004): New and in North Europe rare polypore species (Basidiomycota) with annual, monomitic basidiocarps. - Karstenia 44: 67-77.

534. Niemelë, T. \& MieTtinen, O. (2008): The identity of Ganoderma applanatum (Basidiomycota). Taxon 57 (3): 963-966.

535. NiKOlaJEVA, T. L. (1961). Flora plantarum cryptogamarum URSS. Fungi. Familia Hydnaceae (in Russian) 6(2). Moscow, Leningrad. p. 194.

536. NoBles, M. K. (1967): Conspecifity of Basidioradulum (Radula) radula and Corticium hydnans.Mycologia 59: 192-211. http://dx.doi.org/10.2307/3756793

537. NoBlES, M. K. (2011): Studies in forest pathology: VI. Identification of cultures of wood-rotting fungi. - Canadian Journal of Research 1948, 26c(3): 281-431. http://dx.doi.org/10.1139/cjr48c$\underline{026}$

538. NOORDELOOS, M. E. (1982): Entoloma subgenus Leptonia in northwestern Europe. I. Introduction and a revision of its section Leptonia. - Persoonia 11: 451-471. 
539. NoORdELOOS, M. E. (1984): Notulae ad floram agaricinam neerlandicam IV-V. Clitopilus and Leucopaxillus. - Persoonia 12(2): 155-167.

540. NoORdeloos, M. E. (1988): Entoloma in North America. The species described by L.R. Hesler, A.H. Smith \& S.J. Mazzer: type-species and comments. Cryptogamic Studies, Vol. 2 Gustav Fisher Verlag, Stuttgart, Germany.

541. Noordeloos, M. E. (1992): Entoloma s.l. Fungi Europaei, vol. 5. Giovanna Biella, Italy. p. 429.

542. Noordeloos, M. E. (1999): Strophariaceae. In: BAS, C., KuYPER, T. W., Noordeloos, M. E. \& Vellinga, E. C. Flora Agaricina Neerlandica 4. A. A. Balkema, Rotterdam, pp. 27-106.

543. NoORdeloos, M. E. (2000): Tre nuove Entolomataceae (Agaricales) dall'Italia. - Bollettino del Gruppo Micologico "G. Bresadola" 43(3): 23-33.

544. NoORdeloos, M. E. (2004): Entoloma s. 1. Supplemento. Fungi Europaei vol. 5a. Ed. M. Candusso (Alassio, Italia), p. 761-1378.

545. NoORDELOOS, M. E. (2008): Entoloma in North America 2: the species described by C.H. Peck type studies and comments. - Österreichische Zeitschrift für Pilzkunde 17: 87-152.

546. NOORDELOOS, M.E. (2011): Strophariaceae s.l. Fungi Europaei, vol. 13. Ed. M. Candusso (Alassio, Italia), $648 \mathrm{pp}$.

547. NoORdeloos, M.E. (2012): Clitopilus (Fr.: Fr.) P. Kumm. In: KnUdSen, H. \& Vesterholt, J. Funga Nordica. Nordsvamp, Coppenhagen, pp. 515-517.

548. Noordeloos, M. E. \& HAUSKNECHT, A. (2009): New and interesting Entoloma species from Central Europe. - Österreichische Zeitschrift für Pilzkunde 18: 169-182.

549. Noordeloos, M. E. \& Morozova, O. V. (2010): New and noteworthy Entoloma species from the Primorsky Territory, Russian Far East. - Mycotaxon 112: 231-255.

http://dx.doi.org/10.5248/112.231

550. NoORdeloOs, M. E. \& GATES, G. M. (2012): The Entolomataceae of Tasmania. Fungal Diversity Research Series. Vol. 22 Springer Dordrecht, Heidelberg, New York, London.

551. NoOrdeloos, M. E., Co-DAVID, D. \& GMINDER, A. (2010): Clitopilus byssisedoides, a new species from a hothouse in Germany. - Mycotaxon 112: 225-229. http://dx.doi.org/10.5248/112.225

552. Norstedt, G., BADER, P. \& ERICSON, L. (2001): Polypores as indicators of conservation value in Corsican pine forests. - Biological Conservation 99: 347-354. http://dx.doi.org/10.1016/s00063207(00)00220-2

553. NORVELL, L. L. (2010): Report of the Nomenclature Committee for Fungi: 15. - Taxon 59(1): 291293.

554. NORVELL, L. L. (2011a): Report of the Nomenclature Committee for Fungi: 18. - Taxon 60(4): 1199-1201.

555. NORVELL, L. L. (2011b): Fungal nomenclature. Melbourne approves a new Code. - Mycotaxon 116: 481-490. http://dx.doi.org/10.5248/116.481

556. Nouhra, E. R., Horton, T. R., CAzares, E., Castellano, M. A. (2005): Morphological and molecular characterization of selected Ramaria mycorrhizae. - Mycorrhiza 15: 55-59. http://dx.doi.org/10.1007/s00572-004-0294-5

557. OBERWINKLER, F. (1993): Genera in a monophyletic group: the Dacrymycetales. - Mycologia Helvetica 6: 35-72.

558. OBerwinkLeR, F. (2014): Dacrymycetes. In: MCLAUghlin, D. J. \& Spatafora, J. W. (szerk.) The Mycota, Vol. VII, Part B: systematics and evolution. Springer, Heidelberg.

559. OBERWINKLER, F. \& BANDONI, R. J. (1982): A taxonomic survey of the gasteroid, auricularioid heterobasidiomycetes. - Can J Bot 60: 1726-1750. http://dx.doi.org/10.1139/b82-221

560. OBERWINKLER, F. \& BAUER, R. (1989): The systematics of gasteroid, auricularioid Heterobasidiomycetes. - Sydowia 41: 224-256.

561. Oberwinkler, F., BAUER, R. \& BANDONI, R. J. (1990): Heterogastridiales: a new order of basidiomycetes. - Mycologia 82: 48-58. http://dx.doi.org/10.2307/3759962 
562. Oberwinkler, F., Kirscner, R., Arenal, F., Villareal, M., Rubio, V., Begerow, D. \& Bauer, R. (2006): Two new pycnidial members of the Atractiellales: Basidiopycnis hyalina and Proceropycnis pinicola. - Mycologia 98(4): 637-649.

http://dx.doi.org/10.3852/mycologia.98.4.637

563. Ódor, P., Heilmann-Clausen, J., Christensen, M., Aude, E., Dort, K.W., Piltaver, A., Siller, I., Veerkamp, M.T., Walleyn, R., Standovár, T., Hees, A.F.M., KoseC, J., MatoČeC, N., KRAIGHER, H. \& GREBENC, T. (2006): Diversity of dead wood inhabiting fungi and bryophytes in semi-natural beech forests in Europe. - Biological Conservation 131: 58-71.

http://dx.doi.org/10.1016/j.biocon.2006.02.004

564. ÓdOR P., PApp V., Kutszegi G., BenedeK L., GubA E. \& JónÁs J. (2014): Effect of forest management on the amount of dead wood and saproxylic diversity in the Hungarian Carpathians. 3nd Forum Carpaticum: Local Responses to Global Challenges. Lviv, Ukraine. p. 71.

565. ÓdOR P., Kutszegi G., PAPP V., GuBA E., JÓNÁs J. \& BENEDEK L. (2014b): Az erdőgazdálkodás holtfa viszonyokra és szaproxil biodiverzitásra gyakorolt hatása a Mátrában. - IX. Magyar Természetvédelmi Biológiai Konferencia, Szeged. p. 98.

566. Olariaga, I. \& SAlCEDO, I. (2012): New combinations and notes in clavarioid fungi. - Mycotaxon 121: 37-44. http://dx.doi.org/10.5248/121.37

567. ORDYNETS, O. \& NADYEINA, O. (2013): Wood-inhabiting Fungi of Uholka-Shyrokyi Luh (Carpathian Mountains, Ukraine): Current Knowledge and Research Perspectives. International Conference Primeval Beech Forests. http://www.wsl.ch

568. ORton, P. D. (1984): Notes on British Agarics VIII. - Notes from the Royal Botanical Garden Edinburgh 41: 565-624.

569. ORTON, P. D. (1991): A revised list of the British species of Entoloma sensu lato. - Mycologist 5(3): 123-138. http://dx.doi.org/10.1016/s0269-915x(09)80307-8

570. PADÁNYI G. G. (1972): A kétalakú csertapló (Xanthochrous nidus-pici) és jelentősége a cserfa károsításában. - Mikológiai Közlemények (1): 9-15.

571. PÁL-FÁM F. (1998): Adatok a Mecsek hegység makroszkopikus gombáiról. - Mikológiai Közlemények 37(1-3): 5-28.

572. PÁL-FÁM F. (2001): A Mecsek hegység nayggombái (és néhány mikrogomba). Fungisztikai, ökológiai vizsgálatok. Doktori értekezés, kézirat. Kertészettudományi (Multidiszciplináris Agrártudományok) Doktori Iskola, Budapest.

573. PÁL-FÁM F. \& LUKÁCS Z. (2002): A Mecsek hegység nagygombái 2. - Mikológiai Közlemények, Clusiana 41 (2-3): 35-44.

574. PÁL-FÁM F., SILLER I. \& FODOR L. (2007): Mycological monitoring in the Hungarian Biodiversity Monitoring System. - Acta Mycol. 42(1): 35-58. http://dx.doi.org/10.5586/am.2007.003

575. PÁL-FÁM F., MORSCHHAUSER T. \& RUdOLF K. (2009): Nagygomba-felmérés Gyürüfü környékén. Natura Somogyiensis 13: 9-18.

576. Palma, M. A., Valenzuela, E., Parra, P., Gutierrez, M. \& Silva L. T. (2005): Cerrena unicolor (Bull.) Murr. (Basidiomycota) aislado de micangio de Tremex fuscicornis Fabr. (Hymenoptera, Siricidae) asociado a decaimiento y pudrición del álamo (Populus sp.) en Chile. Bol. Micol. 202: 57-61.

577. PANCONESI, A., SANTINI, A. \& CASINI, N. (1994): Phellinus torulosus on Cupressus sempervirens in Italy. - European Journal of Forest Pathology 24: 238-240. http://dx.doi.org/10.1111//.14390329.1994.tb00990.x

578. PAPP V. (2009): Újabb adatok Dobogókő és környékének nagygombavilágához. - Mikológiai Közlemények, Clusiana 48(1): 45-62.

579. PAPP V. (2011a): Adatok a Xylobolus nemzetség magyarországi előfordulásáról. - Mikológiai Közlemények, Clusiana. 50(2): 173-182.

580. PAPP V. (2011b): Some rare, lignicolous macrofungi suggested to protect in Hungary. - 1. Transilvanian Horticulture and Landscape Studies Conference. Tirgu-Mures, Marosvásárhely, Romania. p. 58. 
581. PAPP V. (2012a): Bükkösök természetközeli állapotát indikáló lignikol nagygombák a Juhdöglővölgy Erdörezervátumból/Lignicolous macrofungi as indicators of nature value of beech forest from the Juhdöglö-völgy Forest Reserve. V. Magyar Mikológiai Konferencia. - Mikológiai Közlemények, Clusiana 51(1):75-76.

582. PAPP V. (2012b): A Frantisekia mentschulensis első magyarországi előfordulása. - Mikológiai Közlemények, Clusiana 51(2): 181-186.

583. PAPP V. (2013a): Corticioid basidiomycetes of Hungary I. The genus Hymenochaete. - Mikológiai Közlemények, Clusiana 52(1-2): 45-56.

584. PAPP V. (2013b): The occurence of Hungarian Ganoderma species in urban habitat. 2. Transilvanian Horticulture and Landscape Studies Conference. Tirgu-Mures, Marosvásárhely, Romania. p. 2627.

585. PAPP V. (2014a): Postia alni Niemelä \& Vampola (Basidiomycota, Polyporales) - member of the problematic Postia caesia complex - has been found for the first time in Hungary. - Biodiversity Data Journal 2:e1034. http://dx.doi.org/10.3897/bdj.2.e1034

586. PAPP V. (2014b): Nomenclatural novelties in the Postia caesia complex. - Mycotaxon 129(2): 407413. http://dx.doi.org/10.5248/129.407

587. PAPP V. (2015a): Entoloma vernalis (Har. Takah. \& Degawa) V. Papp \& Dima, comb.nov. - Index Fungorum no. 223. (ISSN 2049-2375)

588. PAPP V. (2015b): Entoloma zuccherellii var. pluteisimilis (Noordel. \& C.E. Hermos.) V. Papp, comb.nov.; Entoloma zuccherellii var. sclerotiogenum (Caball., Higelmo, Català \& Vila) V. Papp, comb.nov. - Index Fungorum no. 224. (ISSN 2049-2375)

589. PAPP V. \& SILLER I. (2012): A Ganoderma cupreolaccatum (syn. Ganoderma pfeifferi) taxonómiai helyzete és magyarországi elterjedése [The hungarian distribution and taxonomic status of Ganoderma cupreolaccatum (syn. G. pfeifferi)]. - V. Magyar Mikológiai Konferencia. Mikológiai Közlemények, Clusiana 51(1):76-77.

590. PAPP V., RiMÓCZI I. \& ERÖS-HONTI ZS. (2012): Adatok a hazai és európai platánok (Platanus spp.) taplóihoz. - Növényvédelem 48(9): 405-411.

591. PAPP V. \& SZABÓ I. (2013): Distribution and host preference of poroid basidiomycetes in Hungary I. - Ganoderma. - Acta Silv. Lign. Hung. 9: 71-83. http://dx.doi.org/10.2478/as/h-2013-0006

592. Papp V., Kutszegi G., BenedeK L., GubA E., JÓNÁS J. \& ÓdOR P. (2014a): A Mátra taplógombáinak diverzitása gazdasági erdőkben és erdőrezervátumokban. - IX. Magyar Természetvédelmi Biológiai Konferencia. Szeged. p. 100.

593. PApP V., KUtSZEgi G., BenEdeK L., GuBA E., JóNÁs J. \& ÓdOR P. (2014b): Preliminary survey of polypores in Mátra Mts (Hungarian Carpathians). - 3nd Forum Carpaticum: Local Responses to Global Challenges. Lviv, Ukraine. p. 72.

594. PAPP V. \& DIMA B. (2015a): A Pholiota squarrosoides első Magyarországi előfordulása és szisztematikájának revíziója előzetes filogenetikai vizsgálatok alapján. - Mikológiai Közlemények, Clusiana 53(1-2): 33-42.

595. PAPP V., KosZKA A. \& DiMA B. (2015b): A Donkia pulcherrima (Polyporales, Basidiomycota) első magyarországi előfordulása és taxonómiai értékelése. - Mikológiai Közlemények, Clusiana 53(12): $43-53$.

596. PAPP V., Siller I., Kutszegi G., PÁl-FÁm F., BENEdeK L. \& ÓdOR P. (2015c): Forest reserves as refugies for polypores in Hungary. - Fungi Of Central European Old-Growth Forests (International Symposium), Český Krumlov, Czech Republic. - Czech Mycology 67(1): 110.

597. Park, Y. J., Kwon, O. C., Son, E. S., Yoon, D. E., Han, W., NAM, J. Y., YoO, Y. B. \& LeE, C. S. (2012): Genetic diversity analysis of Ganoderma species and development of a specific marker for identification of medicinal mushroom Ganoderma lucidum. - African Journal of Microbiology Research 6(25): 5417-5425. http://dx.doi.org/10.5897/ajmr12.846 
598. PARMASTO, E. (1959): De speciebus et formis novis Polyporacearum in RSS Estonica inventis. Botanicheskie Materialy Otdela Sporovyh Rastenij Botanicheskogo Instituti Imeni V.L. Komarova 12: 237-242.

599. PARMasto, E. (1968): Conspectus Systematis Corticiacearum. p. 1-261.

600. PARMASTO, E. (1970): The Lachnocladiaceae of the Soviet Union. Tartu, 204 pp.

601. PARMASTO, E. (2000): New taxa and new combinations in hymenochaetoid fungi (Hymenomycetes). - Folia Cryptogamica Estonica 37: 55-66.

602. PARMASTO, E. (2006): 8. A New Estonian Nature Conservation Act (Country reports for the period 2000-2005). - Council for the Conservation of Fungi: Newsletter 14: 16-17.

603. PARMASTO, E. \& PARMASTO, I. (1987): Variation of basidiospores in the Hymenomycetes and its significance to their taxonomy. - Bibliotheca Mycologia 115: 1-168.

604. PARMASTO, E. \& PARMASTO, I. (1997): Lignicolous Aphyllophorales of old and primeval forests in Estonia. 1. The forests of northern Central Estonia with a preliminary list of indicator species. Folia Cryptogamica Estonica 31:38-45.

605. Patouillard, N. (1887): Les Hymenomycétes d'Europe. Paris, Paul Klincksieck.

606. PAtouillard, N. (1897): Additions au catalogue des champignons de la Tunisie. - Bulletin de la Société Mycologique de France 13: 197-216.

607. Patouillard, N. T. (1889): Le genre Ganoderma. - Bulletin de la Société Mycologique de France 5: 64-80.

608. Patouillard, N. (1900): Essai taxonomique sur les familles et les genres des Hymenomycétes. Lous le Saunier.

609. PAŽOUTOVÁ, S. \& ŠRU゚TKA, P. (2007): Symbiotic relationship between Cerrena unicolor and the horntail Tremex fuscicornis recorded in the Czech Republic. - Czech Mycology 59(1): 83-90.

610. PeCK, C. H. (1879): Report of the botanist. - Annual Report on the New York State Museum of Natural History 31: 19-60.

611. Pegler, D. N. (1983): The Genus Lentinus: A World Monograph. - Kew Bull., Add. Ser. 10.

612. PegleR, D. N. (1996): Hyphal analysis of basidiomata. - Mycological Research 100(2): 129-142. http://dx.doi.org/10.1016/s0953-7562(96)80111-0

613. PegleR, D. N. \& Young, T. W. K. (1971): Basidiospore morphology in the Agaricales. - Beiheste zur Nova Hedwigia 35: 1-210.

614. Peltoniemi, M., PentTILÄ, R. \& MÄKIPÄÄ, R. (2013): Temporal variation of polypore diversity based on modelled dead wood dynamics in managed and natural Norway spruce forests. - Forest Ecology and Management 310: 523-530. http://dx.doi.org/10.1016/i.foreco.2013.08.053

615. Penttilä, R., SiItonen, J. \& KUUSINEN, M. (2004): Polypore diversity in managed and old-growth boreal Picea abies forests in southern Finland. - Biological Conservation 117: 271-283.

http://dx.doi.org/10.1016/j.biocon.2003.12.007

616. PéreZ-De-Gregorio, M. À., Roqué, C. \& MACAU, N. (2009): Clitopilus daamsii Noordel., una espècie molt interessant trobada durant el XV Congrés de la CEMM. Annals C.E.M.M., p. 95-100.

617. Perić, B. \& PERIĆ, O. (2006): The Provisory Red List of Endangered Macromycetes of Montenegro. -European Council for the Conservation of Fungi, Newsletter 14: 29-31.

618. Persoon, C. H. (1794): Neuer Versuch einer systematischen Eintheilung der Schwamme. - Neues Magazin für die Botanik 1: 63-80.

619. PERSOON, C. H. (1799): Observationes mycologicae 2. p.: 1-106.

620. Petersen, R. H. (1972): Notes on clavarioid fungi. XII. Miscellaneous notes on Clavariadelphus, and a new segregate genus. - Mycologia 64(1): 137-152. http://dx.doi.org/10.2307/3758022

621. Petersen, R. H. (2000): New species of Lentaria (Fungi: Aphyllophorales): redescription and mating systems of L. surculus and L. byssiseda. - Rev. Biol. Trop. 48(2-3): 555-567.

622. Petersen, R. H. \& Hughes, K. W. (2010): The Xerula/Oudemansiella complex (Agaricales). Beihefte zur Nova Hedwigia 137: 1-625. 
623. Petersen, G., Knudsen, H. \& Seberg, O. (2009): Alignment, clade robustness and fungal phylogenetics - Crepidotaceae and sister families revisited. - Cladistics 26: 62-71.

http://dx.doi.org/10.1111/i.1096-0031.2009.00279.x

624. PiąteK, M. (2003a): Notes on Polish polypores. 1. Oligoporus alni, comb. nov. - Polish Botanical Journal 46(2): 183-190.

625. PiąteK, M. (2003b): Notes on Polish polypores. 2. Oxyporus latemarginatus. - Polish Botanical Journal 48(1): 63-68.

626. PiĄTEK, M. (2003c): Haploporus tuberculosus, a new polypore genus and species in Belarus, with a new combination in Haploporus. - Polish Botanical Journal 48(1): 81-83.

627. PiĄTEK, M. (2004): Notes on Polish polypores 4. Polyporus alveolaris. - Karstenia 44: 61-66.

628. Pieri, M. \& Rivoire, B. (1998): Postia inocybe (David Malençon) Julich f. inocybe et f. pileatus, f. nov. Notes nomenclaturales sur le genre Postia. - Bulletin de la Société Mycologique de France 114(3): 19-34.

629. PIERI, M. \& RiVOIRE, B. (2005a): Postia mediterraneocaesia, une nouvelle espèce de polypore découverte dans le sud de l'Europe. - Bulletin Semestriel de la Fédération des Associations Mycologiques Méditerranéennes 28: 33-38.

630. PIERI, M. \& RIVOIRE, B. (2005b): À propos de quelques polypores rares, critiques ou nouveaux - III. - Bulletin de la Société Mycologique de France 121(1): 1-16.

631. PILÁT, A. (1932): Additamenta ad floram Sibiriae Asiaeque orientalis mycologicam. Pars prima: Polyporaceae. - Bulletin de la Société Mycologique de France 48(1): 1-52.

632. PilÁt, A. (1933): Additamenta ad floram Sibiriae Asiaeque orientalis mycologicam. Pars secunda. Bulletin de la Société Mycologique de France 49(3-4): 256-339.

633. PilÁt, A. (1936): Additamenta ad floram Sibiriae, Asiae centralis orientalisque mycologicam. IV. Bulletin Trimestriel de la Société Mycologique de France 52(3): 305-336.

634. PILÁT, A. (1950): Contribution to the knowledge of the Hymenomycetes of Białowieża virgin forest in Poland. - Stud. Bot. Čechoslovaca 11: 145-173.

635. Piltaver, A., Matocec, N., Kosec, J., JurC, D. (2003): Macrofungi on beech wood in Slovenian forest reserves Rajhenavski Rog and Krokar. Zbornik gozdarstva in lesarstva 69: 171-196.

636. Pine, E. M., HibBett, D. S. \& Donoghue, M. J. (1999): Phylogenetic relationships of cantharelloid and clavarioid Homobasidiomycetes based on mitochondrial and nuclear rDNA sequences. Mycologia 91: 944-963. http://dx.doi.org/10.2307/3761626

637. Pippola, E. \& Kotiranta, H. (2008): The genus Tremella (Basidiomycota, Tremellales) in Finland. - Ann. Bot. Fennici 45: 401-434. http://dx.doi.org/10.5735/085.045.0601

638. POINAR JR, G. (2014): Bird's nest fungi (Nidulariales: Nidulariaceae) in Baltic and Dominician amber. - Fungal Biology 118(3): 325-329. http://dx.doi.org/10.1016/i.funbio.2014.01.004

639. PouZAR, Z. (1958): Nova genera macromycetum II. - Ceská Mykologie 12(1): 31-36.

640. POUZAR, Z. (1959): New genera of higher fungi III. - Ceská Mykologie 13(1): 10-19.

641. POUZAR, Z. (1966): Scytinostroma hemidichophyticum Pouz. spec. nov. a new species of resupinate Hymenomycetes. - Ceská Mykologie 20(4): 217-220.

642. POUZAR, Z. (1971): Notes on taxonomy and nomenclature of Ischnoderma resinosum (Fr.) P. Karst. and I. benzoinum (Wahlenb.) P. Karst. (Polyporaceae). - Ceská Mykologie 25(1): 15-21.

643. PouZAR, Z. (1972): Contribution to the knowledge of the genus Albatrellus (Polyporaceae). I. A conspectus of species of the North Temperate Zone. - Česká Mykologie 26: 194-200.

644. POUZAR, Z. (1981): Notes on the taxonomy and nomenclature of the polypore Inonotus polymorphus. - Ceská Mykologie 35(1): 25-28.

645. POUZAR, Z. (1990): Additional notes on the taxonomy and nomenclature of Ischnoderma (Polyporaceae). - Ceská Mykologie 44(2): 92-100.

646. PRICE, P. I. (1973): A study of cystidia in effused Aphyllophorales. - Nova Hedwigia 24: 515-617. 
647. PuUmalainen, J., Kennedy, P. \& Folving, S. (2003): Monitoring forest biodiversity: a European perspective with reference to temperate and boreal forest zone. - Journal of Environmental Management 67: 5-14. http://dx.doi.org/10.1016/s0301-4797(02)00183-4

648. RAHMAN, M. M., FrANK, G., RUPRECHT, H. \& VACIK, H. (2008): Structure of coarse woody debris in Lange-Leitn Natural Forest Reserve, Austria. - Journal of Forest Science 54(4): 161-169.

649. RASSI, P., Hyvärinen, E., JusléN, A. \& MANNERKoski, I. (2010): Suomen lajien uhanalaisuus Punainen kirja 2010. The 2010 Red List of Finnish Species. Ympäristöministeriö \& Suomen ympäristökeskus, Helsinki. pp. 233-263.

650. REA, C. (1922): British Basidiomycetae - A handbook to the larger British fungi. 799 p.

651. Redberg, G. L., Hibbett, D. S., Ammirati, J. F. \& Rodriguez, R. J. (2003): Phylogeny and genetic diversity of Bridgeoporus nobilissimus inferred using mitochondrial and nuclear rDNA sequences. - Mycologia 95(5): 836-845. http://dx.doi.org/10.2307/3762012

652. ReDHEAD, S. A. (2000): „The PhyloCode” - a commentary. - Inoculum [Suppl. to Mycologia 51(3)]: $1-4$.

653. Redhead, S. A., Vilgalys, R., Moncalvo, J.-M., Johnson, J., Hopple, J. S. JR. (2001): Coprinus Persoon and the disposition of Coprinus species sensu lato. - Taxon 50(1): 203-241.

654. Redhead, S. A., Ginns, J. \& Moncalvo, J. M. (2006): Proposal to conserve the name Boletus applanatus against B. lipsiensis (Basidiomycota). - Taxon 55(4): 1029-1030.

655. Redhead, S. A., Bérubé, J., Cleary, M. R., Holdenrieder, O., Hunt, R. S., Korhonen, K., MARXMÜLler, H. \& MORRISON, D. J. (2011): (2033) Proposal to conserve Armillariella ostoyae (Armillaria ostoyae) against Agaricus obscurus, Agaricus occultans, and Armillaria solidipes (Basidiomycota). - Taxon 60(6): 1770-1771.

656. Redhead, S. A., Antonín, V., Tomšovský, M., Volk, T. J., Munda, A. \& Piltaver, A. (2012): (2044) Proposal to conserve the name Agaricus tabescens against A. socialis (Basidiomycota). Taxon 61(1): 252-253.

657. REID, D. A. (1962): Notes on fungi which have been referred to the Thelephoraceae sensu lato. Persoonia 2(2): 109-170.

658. REID, D. A. (1963): New or interesting records of Australasian Basidiomycetes: V. - Kew Bulletin 17(2): 267-308. http://dx.doi.org/10.2307/4118959

659. RIEPPEL, O. (2006): The PhyloCode: a critical discussion of its theoretical foundation. - Cladistics 22: 186-197. http://dx.doi.org/10.1111/j.1096-0031.2006.00097.x

660. Riley, R., Salamov, A. A., Brown, D. W., Nagy, L. G., Floudas, D., Held, B. W., Levasseur, A., Lombard, V., Morin, E., Otillar, R., Lindquist, E. A., Sun, H., LAButti, K. M., SchmutZ, J., Jabbour, D., Luo, H., Baker, S. E., Pisabarro, A. G., Walton, J. D., Blanchette, R. A., Henrissat, B., Martin, F., Cullen, D., Hibbett, D. S. \& Grigoriev, I. V. (2014): Extensive sampling of basidiomycete genomes demonstrates inadequacy of the white-rot/brown-rot paradigm for wood decay fungi. - Proc. Natl. Acad. Sci. U.S.A. 111(27): 9923-9928.

http://dx.doi.org/10.1073/pnas.1400592111

661. RIMÓCZI I. (1994): Nagygombák cönológiai és ökológiai jellemzése. - Mikológiai Közlemények, Clusiana 33(1-2): 1-180.

662. RiMÓCZI I. (1997): Magyarország nagygombáinak természetvédelmi helyzete és Vörös Könyvének terve. - Mikológiai Közlemények, Clusiana 36(2-3): 65-108.

663. RIMÓCZI I. (2008): A Bockerek-erdő nagygombái. In: BARTHA D. \& VIDÉKI R. (szerk): A Bockerekerdő. Nyírerdő Nyírségi Erdészeti Zrt., Nyíregyháza-Sopron, pp. 107-114.

664. RIMÓCZI I. (2012): Gombaválogató 10. Szaktudás Kiadó Ház, Budapest, 167 p.

665. RiMÓCZI I., MÁTÉ J. \& LENTI I. (1997): Osztott bazídiumú- és nem lemezes nagygombák a Bátorligeti-őslápon. - Mikológiai Közlemények 36(2): 13-34.

666. Rimóczi I., Siller I., VASAS G., Albert L., VetTer J. \& BrateK Z. (1999): Magyarország nagygombáinak javasolt vörös listája. - Mikológiai Közlemények, Clusiana 38(1-3): 107-132. 
667. RiMÓCZI I., BENEDEK L. \& ForSTINGER, H. (2009): Wood-inhabiting macrofungi proposed for conservation from the primeval bog of Bátorliget. - Acta Silv. Ling. Hung. 5: 19-25.

668. RIMÓCZI I., JEPPSON, M. \& BENEDEK L. (2011): Characteristic and rare species of Gasteromycetes in Eupannonicum. - Fungi non delineati, Edizioni Candusso, $226 \mathrm{p}$.

669. RipKovÁ, S. (2002): Crepidotus macedonicus, a new species for central Europe. - Mycotaxon 84: 111-118.

670. RipkovÁ, S., KuČERA, V., AdAMČíK, S. \& MereĎA, P. (2004): The occurrence of Phleogena faginea in Slovakia. - Bulletin Slovenskej Botanickej Spoločnosti 26: 19-22.

671. RipkovÁ, S., Aime, M. C. \& LizoŇ, P. (2005): Crepidotus crocophyllus includes C. nephrodes. Mycotaxon 91: 397-403.

672. RIPKOVÁ, S. \& GleJdURA, S. (2010): Crepidotus ehrendorferi in Slovakia and taxonomic notes on related species. - Czech Mycol. 61(2): 175-185.

673. Rizzo, D. M., Gieser, P. T. \& BuRdsall, H. H. (2003): Phellinus coronadensis: A new species from southern Arizona, USA. - Mycologia 95: 74-79. http://dx.doi.org/10.2307/3761963

674. Robert, V., Stegehuis, G. \& Stalpers, J. (2005): The MycoBank engine and related databases. http://www.mycobank.org

675. Robert, V., Vu, D., Amor, A. B. H., van de Wiele, N., Brouwer, C., Jabas, B., Szoke, Sz., Dridi, A., Triki, M., Ben DaOud, S., Chouchen, O., VaAs, L. De Cock, A., Stalpers, J. A., Stalpers, D., Verkley, G. J. M., Groenewald, M., dos Santos, F. B., Stegehuis, G., Li, W., WU, L., Zhang, R., MA, J., ZhOU, M., GORJóN, S. P., EurWilaichitr, L., IngSRiswang, S., Hansen, K., Schoch, C., Robbertse, B., Irinyi, L., Meyer, W., CARdinali, G., Hawksworth, D. L., TAYLOR, J. W. \& CROUS, P. W. (2013): MycoBank gearing up for new horizons. - IMA Fungus 4(2): 371-379. http://dx.doi.org/10.5598/imafungus.2013.04.02.16

676. RoBerTS, P. (1995): British Tremella species I: Tremella aurantia \& T. mesenterica. - Mycologist 9(3): 110-114. http://dx.doi.org/10.1016/s0269-915x(09)80270-x

677. RoberTs, P. (1999): British Tremella species II: T. encephala, T. steidleri \& T. foliacea. Mycologist 13(3): 127-131. http://dx.doi.org/10.1016/s0269-915x(99)80044-5

678. Rogers, D. P. (1935): Notes on the lower Basidiomycetes. - Stud. Nat. Hist. Iowa Univ. 17: 3-43.

679. Rolstad, J., SÆtersdal, M., GJerde, I. \& Storaunet, K.O. (2004): Wood-decaying fungi in boreal forest: are species richness and abundances influenced by small-scale spatiotemporal distribution of dead wood? - Biological Conservation 117: 539-555.

http://dx.doi.org/10.1016/j.biocon.2003.09.008

680. RomagneSI, H. (1944): La cystide chez le Agaricacées. - Rev. Mycologie, N.S. 9: 4-21.

681. RyMAn, S. (2012): Agrocybe Fayod. In: KnUdSEN, H., Vesterholt, J. (szerk.), Funga Nordica. Agaricoid, Boletoid and Cyphelloid Genera. Nordsvamp, Copenhagen, p. 928-931.

682. RyVARDEN, L. (2004): Neotropical Polypores. Part 1. Introduction, Hymenochaetaceae and Ganodermataceae. - Synopsis Fungorum 19: 1-227.

683. RYVARDEN, L. (2005): The genus Inonotus. - Synopsis Fungorum 21: 1-149.

684. RYVARDEN, L. \& GILBERTSON R. L. (1993): European polypores 1. Abortiporus to Lindtneria. Synopsis Fungorum 6: 1-387, Oslo.

685. RYVARDEN, L. \& GILBERTSON R. L. (1994): European polypores 2. Meripilus to Tyromyces. Synopsis Fungorum 7: 388-743, Oslo.

686. RyVARDEN, L. \& MelO, I. (2014): Poroid fungi of Europe. - Synopsis Fungorum 31: 1-455.

687. Rudolf K., PÁl-FÁM F. \& Morschauser T. (2008): A Cserehát nagygombái. - Mikológiai Közlemények, Clusiana 47(1): 45-74.

688. Rudolf K., Morschauser T. \& PÁL-FÁM F. (2015): Ritka nagygombák új előfordulási adatai a Mecsek hegységböl és Kaposvár környékéröl. - Mikológiai Közlemények, Clusiana 53(1-2): 5563. 
689. RÜCKER, T. H. \& FORSTINGER, H. (1991): Hymenochaete carpatica Pilat, ein weit verbreiteter, häufig übersehener borstenscheibling. - Linzer biol. Beitr. 23(1): 417-424.

690. SACCARDO, P. A. (1899): Sylloge Fungorum omnium hucusque cognitorum, vol. 14.

691. SacCARdo, P. A. \& Berlese, A. N. (1885): Miscellania mycologica. Series II. Atti dell'Istituto Veneto Scienze 3: 711-742.

692. SAlcedo, I., SARrionandia, E., Olariaga, I. \& PiCÓN, R. M. (2006): Nuevas aportaciones al catálogo micológico de la reserva de Urdaibai (Bizkaia). II. - Zizak 3: 30-41.

693. SALIBA, J. \& DAVID, A. (1988): Apports des caractères culturaux et des confrontations dans l'étude des représentants européens du genre Steccherinum (Basidiomycètes, Aphyllophorales). Cryptogamie Mycologie 9(2): 93-110.

694. SÁnchez-García, M., Matheny, P. B., Götz, P. \& Lodge, D. J. (2014): Deconstructing the Tricholomataceae (Agaricales) and introduction of the new genera Albomagister, Corneriella, Pogonoloma and Pseudotricholoma. - Taxon 63(5): 993-1007.

695. SÁNTHA T. (2003): Adatok a Kárpát-medence közép-keleti részének Entoloma (Agaricales) kutatásáról. - Mikológiai Közlemények 42(1-2): 107-122.

696. Schembri, P. J. \& SultanA, J. (1989): Red Data Book for the Maltese Islands. Department of information, Malta.

697. Schwarze, F. W. M. R. (1994): Wood rotting Fungi: Fomes fomentarius (L: Fr.) Fr. Hoof or Tinder Fungus. - Mycologist 8(1): 32-34. http://dx.doi.org/10.1016/s0269-915x(09)80679-4

698. Schwarze, F. W. M. R. (2007): Wood decay under the microscope. - Fungal Biology Reviews 21(4): 133-170. http://dx.doi.org/10.1016/j.fbr.2007.09.001

699. SEIFERT, K. A. (1983): Decay of wood by the Dacrymycetales. - Mycologia 75: 1011-1018. http://dx.doi.org/10.2307/3792657

700. SEO, G. S. \& KIRK, P. M. (2000): Ganodermataceae: nomenclature and classification. In: FLOOD, J., BRIDGe , P. D. \& Holderness, M. (szerk.): Ganoderma Diseases of Perennial Crops. CABI, Wallingford. pp. 3-22.

701. SenN-IRLET, B. (1995): The genus Crepidotus (Fr.) Staude in Europe. - Persoonia 16(1): 1-80.

702. SENN-IRLET, B. (2009): The state of conservation of fungi in Switzerland 2009 - from the Red list to species and site protection (Country reports and/or responses to the questionnaire) Council for the Conservation of Fungi: Newsletter 15/2010: 24-25.

703. SenN-IRLeT, B. (2012): Crepidotus (Fr.) P. Kumm. In: Knudsen, H. \& Vesterholt, J. - Funga Nordica. Nordsvamp, Coppenhagen, pp. 977-980.

704. Senn-Irlet, B., Heilmann-Clausen, J., Genney, D. \& Dahlberg, A. (2007): Guidance for Conservation of Macrofungi in Europe. ECCF, Strasbourg.

705. Shirouzu, T., Hirose, D. \& Tokumasu, S. (2009): Taxonomic study of the Japanese Dacrymycetes. - Persoonia 23: 16-34. http://dx.doi.org/10.3767/003158509x468443

706. Shirouzu, T., Hirose, D., Oberwinkler, F., Shimomura, N., Maekawa, N. \& Tokumasu, S. (2013): Combined molecular and morphological data for improving phylogenetic hypothesis in Dacrymycetes. - Mycologia 105(5): 1110-1125. http://dx.doi.org/10.3852/12-147

707. SIEPE, K. \& KASPAREK, F. (2002): Phaeosolenia densa, a cyphelloid basidiomycete recorded for the first time in Germany. - Z. Mykol. 68(2): 153-164.

708. SiePE, K. \& WÖLfEL, G. (2009): Rote Liste und Artenverzeichnis der Nichtblätterpilze Aphyllophorales - in Nordrhein-Westfalen. Landesamt für Natur, Umwelt und Verbraucherschutz NRW.

709. SILLER I. (1986): Nagygombák cönológiai vizsgálata rezervátum és gazdasági bükkös állományokban. Mikológiai Közlemények, Clusiana (2-3): 95-116.

710. SILLER I. (1999): Ritka nagygombafajok a Kékes Észak Erdőrezervátumban (1.). - Mikológiai Közlemények, Clusiana 38(1-3): 11-24. 
711. SILlER I. (2002): Buglossoporus pulvinus (Pers.) Donk újabb adata Magyarországon. - Mikológiai Közlemények, Clusiana 41(2-3): 63-66.

712. SILlER I. (2004): Hazai montán bükkös erdőrezervátumok (Mátra: Kékes Észak, Bükk: Öserdő) nagygombái. PhD értekezés, kézirat. Kertészettudományi (Multidiszciplináris Agrártudományok) Doktori Iskola, Budapest.

713. SILLER I. (2005): Hazai montán bükkös erdőrezervátumok (Mátra: Kékes Észak, Bükk: Öserdő) nagygombái. - Mikológiai Közlemények, Clusiana 44(1-2): 91-122.

714. SILLER I. \& MAGLÓCKY Zs. (1999): Mycological investigations in the "Kékes North" forest reserve. - Acta Microbiol. et Immun. Hung. 46: 327.

715. Siller I. \& TÓBI GY. (1999): Az Abortiporus biennis (Bull.: Fr.) Sing. 30 év után ismét előkerült Magyarországon. - Mikológiai Közlemények, Clusiana 38(1-3): 7-10.

716. SiLleR I. \& MAGLÓCKY ZS. (2000): A Kékes Észak erdőrezervátum nagygombáinak indikátorértéke. - Acta Biologica Debrecina, Supplementum Oecologica Hungarica 11(1): 138.

717. Siller I. \& TURCSÁNYI G. (2002): New and rare macrofungi species of two forest reserves in Hungary. - Fritschiana 42: 48-58.

718. Siller I., TURCSÁNYI G., MAGLÓCZKY ZS. \& CZÁJLIK P. (2002): Lignicolous macrofungi of the Kékes north forest reserve in the Mátra Mountains, Hungary. - Acta Microbiol. et Immun. Hung. 49(2-3): 193-205. http://dx.doi.org/10.1556/amicr.49.2002.2-3.5

719. Siller I., Dima B., Albert L., VASAs G., FodOR L., PÁl-FÁm F., BrateK Z., ZAGYVA I. (2006): Védett nagygombafajok Magyarországon. Mikológiai Közlemények, Clusiana 45(1-3): 3-158.

720. Siller I., Kutszegi G., TAKÁCs K., VARGa T., Merényi ZS., TurCsÁnyi G., Ódor P. \& Dima B. (2013): Sixty-one macrofungi species new to Hungary in Örség National Park. - Mycosphere 4(5): 871-924. http://dx.doi.org/10.5943/mycosphere/4/5/3

721. Siller I., DiMA B., GUBA E. \& TURCSÁNYI G. (2014): A Szalaföi Öserdő Erdőrezervátum nagygombái. In: Silva Naturalis 3. A Szalafői Őserdő (szerk.: BARTHA D. \& HORVÁTH J.). Nyugatmagyarországi Egyetem Kiadó, Sopron, pp. 137-156.

722. Silvestro, D. \& MichAlAK, I. (2012): raxmlGUI: a graphical front-end for RAxML. - Organisms Diversity \& Evolution 12: 335-337. http://dx.doi.org/10.1007/s13127-011-0056-0

723. Simmons, M. P., OCHOTERENA, H. \& CARR, T. G. (2001): Incorporation, relative homoplasy, and effect of gap characters in sequence-based phylogenetic analysis. - Systematic Biology 50(3): 454462. http://dx.doi.org/10.1080/10635150120427

724. SingeR, R. (1986): The Agaricales in modern taxonomy. 4th ed. Königstein, Germany: Koeltz Scientific Books. 981 p.

725. SiPPOLA, A.-L. \& RENVALL, P. (1999): Wood-decomposing fungi and seed-tree cutting: A 40-year perspective. - Forest Ecology and Management 115: 183-201. http://dx.doi.org/10.1016/s03781127(98)00398-3

726. Sippola, A.-L., Lehesvirta, T. \& RenVall, P. (2001): Effects on selective logging on coarse woody debris and of wood-decaying polypores in eastern Finland. - Ecological Bulletins 49: 243254.

727. SkirgieŁŁo, A. (1998): Macromycetes of oak-hornbeam forests in the Białowieża National Park monitoring studies. - Acta Mycol. 33: 171-189. http://dx.doi.org/10.5586/am.1998.017

728. Skrede, I., Engh, I. B., Binder, M., CArlsen, T., Kauserud, H. \& Bendiksby, M. (2011): Evolutionary history of Serpulaceae (Basidiomycota): molecular phylogeny, historical biogeography and evidence for a single transition of nutritional mode. - BMC Evolutionary Biology 11: 230. http://dx.doi.org/10.1186/1471-2148-11-230

729. Skrede, I., CARlsen, T., Stensrud, Ø. \& Kauserud, H. (2012): Genome wide AFLP markers support cryptic species in Coniophora (Boletales). - Fungal Biology 116(7): 778-84.

http://dx.doi.org/10.1016/j.funbio.2012.04.009

730. SMith, A. H. \& HeSleR, L. R. (1968): The North American species of Pholiota. Hafner, New York. 
731. Sotome, K., Hattori, T., Ota, Y., To-Anun, C., Salleh, B. \& Kakishima, M. (2008) Phylogenetic relationships of Polyporus and morphologically allied genera. - Mycologia 100: 603615. http://dx.doi.org/10.3852/07-191r

732. Sotome, K., MaeKawa, N., NAKagiri, A., Lee, S. S. \& Hattori, T. (2014): Taxonomic study of Asian species of poroid Auriculariales. - Mycological Progress 13: 987-997.

http://dx.doi.org/10.1007/s11557-014-0984-0

733. SPIRIN V. (2002): Aphyllophoroid macromycetes in oak forests of Nizhny Novgorod Region [Афиллофороидные макромицеты дубрав Нижегородскои области]. - Mikologiya $i$ Fitopatologiya 36(2): 43-52.

734. Spirin, V., ZMitrovich, I. V. \& MAlysheVA, V. F. (2006): К систематике Phellinus s. 1. и Inonotus s. 1. (Mucronoporaceae, Hymenochaetales) [To the systematics of Phellinus s.l. and Inonotus s.l. (Mucronoporaceae, Hymenochaetales)]. - Novosti Sistematiki Nizshikh Rastenii 40: $153-188$.

735. SpIRIN, V. \& ZMIRTOVICH, I. (2007): Frantisekia - a new polypore genus (Polyporales, Basidiomycota). - Czech Mycol. 59(2): 141-151.

736. Spirin, V., ZMiRTOvich, I. \& MALYSheVA, V. (2007): Steccherinum tenuispinum (Polyporales, Basidiomycota), a new species from Russia, and notes on three other species. - Ann. Bot. Fennici 44: 298-302.

737. Spirin, V., Miettinen, O. \& Pennanen, J. (2013): Antrodia hyalina, a new polypore from Russia, and A. leucaena, new to Europe. - Mycol Progress 12(1): 53-61. http://dx.doi.org/10.1007/s11557$\underline{012-0815-0}$

738. Staden, R., BeAl, K. F. \& Bonfield, J. K. (2000): The Staden package, 1998. - Methods in Molecular Biology 132: 115-130. http://dx.doi.org/10.1385/1-59259-192-2:115

739. StAlPers, J. A. (2000): The genus Ptychogaster. - Karstenia 40: 167-180.

740. Stalpers, J. A., Seifert, K. A. \& SAmson, R. A. (1991): A revision of the genera Antromycopsis, Sclerostilbum, and Tilachlidiopsis (Hyphomycetes). - Can. J. Bot. 69: 6-15.

http://dx.doi.org/10.1139/b91-002

741. STAMATAKIS, A. (2014): RAxML version 8: a tool phylogenetic analysis and post-analysis of large phylogenies. - Bioinformatics 30: 1312-1313. http://dx.doi.org/10.1093/bioinformatics/btu033

742. STEnlid, J., Penttilä, R. \& DAhlBerg, A. (2008): Wood-decay basidiomycetes in boreal forests: Distribution and community development. - British Mycological Society Symposia Series 28: 239262. http://dx.doi.org/10.1016/s0275-0287(08)80015-x

743. Stokland, J. N., Sittonen, J. \& Jonson, B. G. (2012): Biodiversity in Dead Wood (Ecology, Biodiversity and Conservation). - Cambridge University Press. p. 524. http://dx.doi.org/10.1017/cbo9781139025843

744. Stoltze, M. \& Pihl, S. (1998): Rødliste 1997 over planter og dyr i Danmark. Miljø- og Energiministeriet, Danmarks Miljøundersøgelser og Skov- og Naturstyrelsen. pp. 30-54.

745. StRnAD, M. (2011): Conservation status of Fungi in the Czech Republic (Implementation of Recommendation No. 132 (2007) on the conservation of fungi in Europe) T-PVS/Files (2011) 19: 5.

746. Sundberg, W. J., MethVen, A. S. \& Monoson, H. L. (1997): Rhodotus palmatus (Basidiomycetes, Agaricales, Tricholomataceae) in Illinois. - Mycotaxon 65: 403-410.

747. SzABÓ I. (2012): Poroid Fungi of Hungary in the Collection of Zoltán Igmándy. - Acta Silv. Lign. Hung. 8: 113-122. http://dx.doi.org/10.2478/v10303-012-0009-0

748. SzÁNTÓ M. (1994): Gyürüs Armillaria fajok a hazai erdőkben. - Mikológiai Közlemények 33(3): $73-74$.

749. SzczePKOwsKi, A. \& PIĘTKA, J. (2003): New localities and new host of Ganoderma pfeifferi in Poland. - Acta Mycologica 38: 59-63. http://dx.doi.org/10.5586/am.2003.007 
750. SzCZePKowski, A., Kujawa, A., Bujakiewicz, A., Nita, J., KARAsińsKi, D., WoŁKowycki, M. \& WILGA, M. S. (2008): Phleogena faginea (Pucciniomycotina, Atractiellales) in Poland - notes on ecology and distribution. - Polish Botanical Journal 53(1): 81-90.

751. SzczePKOwsKi, A., KuJAwA, A. \& HAlama, M. (2013): Volvariella bombycina (Schaeff.) Singer in Poland: Notes on its ecology, distribution and conservation status. - Pol. J. Environ. Stud. 22(1): 41-51.

752. SZEDLAY GY. (2002): Is the widely used medicinal fungus the Ganoderma lucidum (Fr.) Karst. sensu stricto? - Acta Microbiol Immunol Hung 49: 235-243.

http://dx.doi.org/10.1556/amicr.49.2002.2-3.9

753. SZEMERE L. (1968): A Bakony-hegység nagygombái. - A Veszprém megy. múz. Közlem. 7: 147-170.

754. RoBich, G. (2003): Mycena d'Europa. A.M.B. Fondazione, Centro Studi Micologici, Trento. 728 pp.

755. RoBICH, G. (2009): Mycena truncimuscicola, a new species of section Filipedes (Agaricales, Tricholomataceae) from Switzerland. - Österr. Z. - Pilzk. 18: 117-122.

756. RonQuist, F. \& HUELSENBECK J. P. (2003): MrBayes 3: Bayesian phylogenetic inference under mixed models. - Bioinformatics 19: 1572-1574. http://dx.doi.org/10.1093/bioinformatics/btg180

757. TAKÁCS B. (1983): Florisztikai, ökológiai és produkció biológiai vizsgálatok eredményei a Bükk hegységi Őserdő nagygombáinál. Doktori disszertáció, Eger, 101 pp.

758. TAKÁCS B. \& SILLER I. (1980): A Bükk hegységi Ösbükkös gombái. - Mikológiai Közlemények, Clusiana 3: 121-132.

759. TAKÁCS A. \& TAKÁCSNÉ K. A. (1996): A Juhdöglő-völgy vegetációtérképe. Pro Vértes Természetvédelmi Alapítvány. Kézirat.

760. TAKAHASHI, H. \& DEgawA, Y. (2011): Two new species of Agaricales and a new Japanese record for Boletellus betula from Japan. - Mycoscience 52(5): 312-318. http://dx.doi.org/10.1007/s10267011-0109-4

761. TAllasch, H. \& JAHN, H. (1970): Phleogena faginea (Fr.) Link im Naturscchutzgebiet 'Hasbruch' bei Bremen. - Westfälische Pilzbriefe 8(2): 31-35.

762. Tamura, K., Stecher, G., Peterson, D., Filipski, A. \& Kumar, S. (2013): MEGA6: Molecular Evolutionary Genetics Analysis version 6.0. - Mol. Biol. Evol. 30: 2725-2729. http://dx.doi.org/10.1093/molbev/mst197.

763. TANASE, C. (2006): 18. Achievements and perspectives in the preservation of macromycetes' diversity in Romania (Country reports for the period 2000-2005). - Council for the Conservation of Fungi: Newsletter 14: 37-39.

764. TANG, L.-P., HAO, Y.-J., CAI, Q., TOLGOR, B. \& YANG, Z. L. (2014): Morphological and molecular evidence for a new species of Rhodotus from tropical and subtropical Yunnan, China. - Mycol Progress 13: 45-53. http://dx.doi.org/10.1007/s11557-013-0890-x

765. TAYLOR, J. W. (2011): One Fungus = One Name: DNA and fungal nomenclature twenty years after PCR. - IMA Fungus 2(2): 113-120. http://dx.doi.org/10.5598//imafungus.2011.02.02.01

766. ThORN, R. G. (1986): The "Pleurotus silvanus" complex. - Mycotaxon 25(1): 27-66.

767. THORN, R. G. (2013): Index Fungorum no. 16.

768. ThORN, R. G. \& BARRon, G. L. (1986): Nematoctonus and the tribe Resupinateae in Ontario, Canada. - Mycotaxon 25(2): 321-453.

769. Thorn, R. G., Moncalvo, J.-M., RedDy, C. A. \& Vilgalys, R. (2000): Phylogenetic analyses and the distribution of nematophagy support a monophyletic Pleurotaceae within the polyphyletic pleurotoid-lentinoid fungi. - Mycologia 92: 241-252. http://dx.doi.org/10.2307/3761557

770. Thorn, R. G., Moncalvo, J. M., Redhead, S. A., Lodge, D. J. \& Martín, M. P. (2005): A new poroid species of Resupinatus from Puerto Rico, with a reassessment of the cyphelloid genus Stigmatolemma. - Mycologia 97(5): 1140-1151. http://dx.doi.org/10.3852/mycologia.97.5.1140

771. TKALČEC, Z., MEŠIĆ, A., MATOČEC, N. \& KUŠAN, I. (2008): Crvena knjiga gljiva Hrvatske. Zagreb, studeni 2008. 
772. TOMmerup, C., Bougher, N. L. \& MALAJCZUK, N. (1991): Laccaria fraterna, a common ectomycorrhizal fungus with mono- and bi-sporic basidia and multinucleate spores: comparison with the quadristerigmate, binucleate spored L. laccata and the hypogeous relative Hydnangium carneum. - Mycol. Res. 95(6): 689-698. http://dx.doi.org/10.1016/s0953-7562(09)80816-2

773. TOMŠOVSKÝ, M. (2001): Remarks on the distribution of Hymenochaete carpatica in Central and Eastern Europe. - Czech Mycol. 53(2): 141-148.

774. TOMŠOVSKÝ, M. \& HOMOLKA, L. (2004): Mating tests among geographically separated collections of the Trametes versicolor (Fr.) Pilat (Basidiomycetes, Polyporales) group. - Nova Hedwigia 79: 425-431. http://dx.doi.org/10.1127/0029-5035/2004/0079-0425

775. TOMŠOVSKÝ, M. \& JANKOVSKÝ, L. (2007): DNA sequence analysis of extraordinary fruiting specimens of Fuscoporia torulosa (Phellinus torulosus) on Pyrus spp. - Czech Mycology 59(1): 91-99.

776. TOMŠOVSKÝ, M. \& JANKOVSKÝ, L. (2008): Validation and typification of Laetiporus montanus. Mycotaxon 106: 289-295.

777. TOMŠOVSKÝ, M. (2008): Molecular phylogeny and taxonomic position of Trametes cervina and description of the new genus Trametopsis. - Czech Mycology 60(1): 1-11.

778. TOMŠOVSKÝ, M. (2012): Delimitation of an almost forgotten species Spongipellis litschaueri (Polyporales, Basidiomycota) and its taxonomic position within the genus. - Mycological Progress 11(2): 415-424. http://dx.doi.org/10.1007/s11557-011-0756-z

779. ToOme, M. \& AIME, M. C. (2014): Pycnopulvinus aurantiacus gen. et sp. nov., a new sporocarpforming member of Pucciniomycotina. - MycoKeys 8: 43-50.

http://dx.doi.org/10.3897/mycokeys.8.7676

780. TORTIĆ, M. (1975): On the identity of Polyporus schulzeri Fr. - Persoonia 8: 249-258.

781. TORTIĆ, M. (1998): An attempt to a list of indicator fungi (Aphyllophorales) for old forests of beech and fir in former Yugoslavia. - Folia Cryptog. Estonica 33: 139-146.

782. Tо́тн B. (1999): Adatok a Gyepes-völgy (Heves-Borsodi dombság) nagygombáiról. - Kitaibelia 4(2): 261-270.

783. Tо́тH S. (1967): Data for the knowledge of microscopic fungi in Hungary VI. - Fragmenta Botanica 5(1-4): 1-22.

784. TRECKER K. \& SZABÓ I. (2002): Farontó gombák a Ropolyi Erdőrezervátumban. - Mikológiai Közlemények, Clusiana 41(2-3): 67-94.

785. ŢURA, D., Zmitrovich, I. V., Wasser, S. P. \& NeVo, E. (2008): The genus Stereum in Israel. Mycotaxon 106: 109-126.

786. ŢURA, D., Zmitrovich, I. V., Wasser, S. P., Spirin, W. A. \& NeVO, E. (2011): Biodiversity of Heterobasidiomycetes and non-gilled Hymenomycetes (former Aphyllophorales) of Israel. A.R.G. Gantner Verlag Kommandit Gesellschaft, Ruggel, 566 pp.

787. TURCSÁNYI G., SiLleR I., MAGLÓCZKY ZS. \& CZÁJLIK P. (2000): Makrogomba-diverzitás a Kékes Észak erdőrezervátumban. - Acta Biologica Debrecina, Supplementum Oecologica Hungarica 11(1): 164.

788. URBAN, A. (2015): Substrate specificity does matter - macrofungal succession on coarse woody debris in an old-growth oak forest. - Czech Mycol 67(1): 117.

789. Valenzuella, R., Raymundo, T., Cifuentes, J., Castilla, G., Amalfi, M. \& Decock, C. (2011): Two undescribed species of Phylloporia from Mexico based on morphological and phylogenetic evidence. - Mycological Progress 10: 341-349. http://dx.doi.org/10.1007/s11557010-0707-0

790. VAMPOLA, P. \& POUZAR, Z. (1996): Contribution to the knowledge of the Central European species of the genus Antrodiella. - Czech Mycol 49(1): 21-33.

791. VAmpola, P. (2011): Notes on the European species of the genus Antrodiella. - Mykol. Listy 116: $1-23$. 
792. VAN DER Linde, S., AleXANDER, I. \& ANDERSON, I. C. (2008): A PCR-based method for detecting the mycelia of stipitate hydnoid fungi in soil. - J Microbiol Meth 75: 40-46.

http://dx.doi.org/10.1016/i.mimet.2008.04.010

793. Van Driel, K. G. A., Humbel, B. M., VerkleiJ, A. J., StAlpers, J., Müller, W. H. \& Boekhout, T. (2009): Septal pore complex morphology in the Agaricomycotina (Basidiomycota) with emphasis on the Cantharellales and Hymenochaetales. - Mycological Research 113: 559-576. http://dx.doi.org/10.1016/j.mycres.2008.12.007

794. Vasaitis, R., Menkis, A., Lim, Y. W., SeOK, S., TomšovskÝ, M., JankovskÝ, L., Lygis, V., SLIPPERS, B. \& STENLID, J. (2009): Genetic variation and relationships in Laetiporus sulphureus s. lat., as determined by ITS rDNA sequences and in vitro growth rate. - Mycological Research 113: 326-336. http://dx.doi.org/10.1016/i.mycres.2008.11.009

795. VASAS G. (1985): Telepített fenyvesek és természetes lomberdei társulások nagygombáinak vizsgálata a Bükk és Pilis hegységekben. Doktori disszertáció, ELTE. 119 pp.

796. VASAS G. \& LOCSMÁNDI Cs. (1995): The macroscopic fungi (Basidiomycetes) of Örség, Western Hungary. - Savaria 22(2): 265-294.

797. VASAS G. \& LOCSMÁNDI Cs. (2009): The Basidiomycetes of the Aggtelek National Park. - In: PAPP B. (szerk.): Flora of the Aggtelek National Park, Cryptogams. Hungarian National History Museum, Budapest, pp. 53-107.

798. VASS A. (1978): Cönológiai és ökológiai adatok a Mecsek hegység makroszkopikus gombáinak ismeretéhez. - A Janus Pannonius Múzeum évkönyve, XXII.: 13-22.

799. VeERman, C. P. (2004): Rode lijst Paddestoelen. Besluit van de Minister van Landbouw, Natuur en Voedselkwaliteit. TRCJZ/2004/5727.

800. VELENOVSKÝ, J. (1939): Novitates mycologicae. p. 1-211.

801. VellingA, E. C. (1986): The genus Flammulaster (Agaricales) in the Netherlands and adjacent regions. - Persoonia 13 (1): 1-26.

802. VellingA, E. C. \& SchreURS, J. (1984): Notulae ad Floram Agaricinam Neerlandicam - VIII. Persoonia 12(4): 337-373.

803. Venturella, G. (2000): Typification of Pleurotus nebrodensis. - Mycotaxon 75: 229-231.

804. Venturella, G. (2002): On the real identity of Pleurotus nebrodensis in Spain. - Mycotaxon 84: 445-446.

805. Venturella, G. (2006): Pleurotus nebrodensis. The IUCN Red List of Threatened Species. Version 2014.3. www.iucnredlist.org. [Letöltés időpontja: 2015.04.13]

806. Vesterholt, J. (2012a): Panellus P. Karst. In: Knudsen, H., Vesterholt, J. (szerk.), Funga Nordica. Agaricoid, Boletoid and Cyphelloid Genera. Nordsvamp, Copenhagen, p. 443.

807. Vesterholt, J. (2012b): Armillaria (Fr.:Fr.) Staude - In: KNUDSEN, H. \& VeSTERHOlt, J. (szerk.), Funga Nordica. Agaricoid, Boletoid and Cyphelloid Genera. Nordsvamp, Copenhagen, p. 324-326.

808. Vesterholt, J. (2012c): Deconica (W.G. Sm.) P. Karst. - In: Knudsen, H. \& Vesterholt, J. (szerk.), Funga Nordica. Agaricoid, Boletoid and Cyphelloid Genera. Nordsvamp, Copenhagen, p. 931-936.

809. Vesterholt, J. és RAld, E. (2012): Flammulaster Earle. In: KnUdSEN, H., Vesterholt, J. (szerk.), Funga Nordica. Agaricoid, Boletoid and Cyphelloid Genera. Nordsvamp, Copenhagen, p. 970-973.

810. Villegas, M., De Luna, E., Cifuentes, J. \& Torres, A. E. (1999): Phylogenetic studies in Gomphaceae sensu lato (Basidiomycetes). - Mycotaxon 70: 127-147.

811. VizZINI, A. \& ZоTTI, M. (2008): Postia ptychogaster, an unusual two-stage polypore new to Italian mycobiota. - Mycotaxon 103: 319-328.

812. VlasÁk, J., Kout, J. \& DVoŘÁK, D. (2010): Taxonomical position of polypore Dichomitus albidofuscus: Donkioporia albidofusca comb. nov. - Mycological Progress 9: 147-150. http://dx.doi.org/10.1007/s11557-009-0617-1 
813. VolobueV, S. V. (2013): Aphyllophoroid fungi of the Naryshkinskij Natural Park, Orel Region, Russia. - Folia Cryptogamica Estonica 50: 81.

814. WAGNER, T. \& FISCHER, M. (2001): Natural groups and a revised system for the European poroid Hymenochaetales (Basidiomycota) supported by nLSU rDNA sequence data. - Mycological Research 105(7): 773-782. http://dx.doi.org/10.1017/s0953756201004257

815. WAGNER, T. \& FISCHER, M. (2002): Classification and phylogenetic relationships of Hymenochaete and allied genera of the Hymenochaetales, inferred from rDNA sequence data and nuclear behaviour of vegetative mycelium. - Mycological Progress 1(1): 93-104. http://dx.doi.org/10.1007/s11557-006-0008-9

816. WagneR, T. \& RYVARDEN, L. (2002): Phylogeny and taxonomy of the genus Phylloporia (Hymenochaetales). - Mycological Progress 1(1): 105-116. http://dx.doi.org/10.1007/s11557-0060009-8

817. WALD, P., PITKÄNEN, S. \& BODDY, L. (2004): Interspecific interactions between the rare tooth fungi Creolophus cirrhatus, Hericium erinaceus and H. coralloides and other wood decay species in agar and wood. - Mycological Research 108(12): 1447-1457.

http://dx.doi.org/10.1017/s0953756204001340

818. WALLEYN, R. \& VERBEKEN, A. (2000): Een gedocumenteerde Rode Lijist van enkeke groepen paddestoelen (macrofungi) van Vlaanderen. Instituut voor Natuurbehoud. pp. 86.

819. WALlEyn, R. \& VeERKAMP, M. (2005): Houtzwammen op beuk. Kensoorten voor soortenrijke bossen in België en Nederland. - Natuur.focus 4(3): 82-88.

820. Wang, D.-M., Wu, S.-H., Su, C.-H., Peng, J.-T., ShiH, Y.-H. \& ChEN, L.-C. (2009): Ganoderma multipileum, the correct name for 'G. lucidum' in tropical Asia. - Botanical Studies 50: 451-458.

821. WANG, X.-C., XI, R.-J., LI, Y., WANG, D.-M. \& YAO, Y.-J. (2012): The species identity of the widely cultivated Ganoderma, 'G. lucidum' (Ling-zhi), in China. - Plos One 7(7): e40857.

http://dx.doi.org/10.1371/iournal.pone.0040857

822. WASSER, S. P. (2005): Reishi or Ling Zhi (Ganoderma lucidum). in: COATES, P. M., BetZ, J. M., Blackman, M. R., CragG, G. M., Levine, M., Moss, J. \& White, J. D. (szerk.): Encyclopedia of dietary supplements. Marcel Dekker, New York (USA), pp. 3-622. http://dx.doi.org/10.1201/b13959-62

823. WAtKinson, S. C. \& EASTwood, D. C. (2012): Serpula lacrymans, Wood and Buildings. In: LASKIN, A. I., SARIASLANI, S. \& GADD, G. M. (szerk.) - Advances in Applied Microbiology, Vol. 78, Burlington: Academic Press, pp. 121-149. http://dx.doi.org/10.1016/b978-0-12-3948052.00005-1

824. Watling, R. \& Milne, J. (2008): The identity of European and North American Boletopsis spp. (Basidiomycota; Thelephorales, Boletopsidaceae). - North American Fungi 3(7): 5-15. http://dx.doi.org/10.2509/naf2008.003.0072

825. WebsteR, J. \& WeBer, R. (2007): Introduction to fungi. 3rd ed. Cambridge, United Kingdom: Cambridge University Press, $841 \mathrm{pp}$.

826. Weiss, M. \& OBERWInkler, F. (2001): Phylogenetic relationships in Auriculariales and related groups -hypotheses derived from nuclear ribosomal DNA sequences. - Mycological Research 105: 403-415. http://dx.doi.org/10.1017/s095375620100363x

827. Weiss, M., Selosse, M. A., ReXer, K. H., Urban, A. \& OberwinKLer, F. (2004): Sebacinales: a hitherto overlooked cosm of heterobasidiomycetes with a broad mycorrhizal potential. Mycological Research 108(9): 1003-1010. http://dx.doi.org/10.1017/s0953756204000772

828. Weiss, M., BAUER, R., SAMPAIO, J. P. \& OBERWINKLER, F. (2014): Tremellomycetes and related groups. In: The Mycota, vol. VII, Second Ed., Part A. Systematics and Evolution (MCLAUGHLIN, D. J. ÉS SPATAFORA, J. W. szerk.). Springer Verlag. http://dx.doi.org/10.1007/978-3-642-55318$\underline{9} 12$

829. Welti, S., Moreau, P. A., Favel, A., Courtecuisse, R., Haon, M., Navarro, D., Taussac, S. \& LESAGE-MEESEN, L. (2012): Molecular phylogeny of Trametes and related genera, and description 
of a new genus Leiotrametes. - Fungal Diversity 55: 47-64. http://dx.doi.org/10.1007/s13225-0110149-2

830. WetTSTEIN, R. (1885): Ueber einen neuen Polyporus aus Niederösterreich. - Österreichische Botanische Zeitschrift 35(3): 81-82.

831. White, T. J., BRuns, T. D., LeE S. \& TAYLOR, J. (1990): Amplification and direct sequencing of fungal ribosomal RNA genes for phylogenetics. - In: Michael, A. J., Gelfand, D. H., Sninsky, J. J. és mtsai (szerk.): PCR protocols: a guide to the methods and applications. Academic Press, USA, pp. 315-322. http://dx.doi.org/10.1016/b978-0-12-372180-8.50042-1

832. WOJEWODA, W. \& ŁAWRYNOWICZ, M. (2006): Czerwona Lista grzybów Polski. [www.grzyby.net]

833. WU, S. H. \& ZANG, M. (2000): Cryptoporus sinensis sp. nov., a new polypore found in China.Mycotaxon 74(2): 415-422.

834. Wu, F., Yuan, Y., Malysheva, V. F., DU, P. \& DaI, Y.-C. (2014a): Species clarification of the most important and cultivated Auricularia mushroom "Heimuer": evidence from morphological and molecular data. - Phytotaxa 186(5): 241-253. http://dx.doi.org/10.11646/phytotaxa.186.5.1

835. Wu, G., Feng, B., XU, J., ZhU, X.-T., LI, Y.-C., ZenG, N.-K., Hosen, M. I. \& YANG, Z. L. (2014b): Molecular phylogenetic analyses redefine seven major clades and reveal 22 new generic clades int he fungal family Boletaceae. - Fungal Diversity 69: 93-115. http://dx.doi.org/10.1007/s13225-014$\underline{0283-8}$

836. YANG, Z. L. (2011): Molecular techniques revolutionize knowledge of basidiomycete evolution. Fungal Diversity 50: 47-58. http://dx.doi.org/10.1007/s13225-011-0121-1

837. Ylisirniö, A.-L., Penttilä, R., Berglund, H., Hallikainen, V., Isaeva, L., Kauhanen, H., Koivula, M. \& MiKKolA, K. (2012): Dead wood and polypore diversity in natural post-fire succession forests and managed stands - Lessons for biodiversity management in boreal forests. Forest Ecology and Management 286: 16-27. http://dx.doi.org/10.1016/i.foreco.2012.08.018

838. Yoshimura, I. \& SHIMADA, R. (1980): Fine structures of lichen plectenchymas viewed with the scanning electron microscope. - Bulletin of Kochi Gakuen Junioz College 11: 13-28.

839. YU, C. Y., ZUO, L. \& DAI, Y.-C. (2005): Three polypores from Xizang new to China. - Fung. Sci. 20(3-4): 61-68.

840. YUAN, H.-S., WEI, Y.-L., QIN, W.M. \& ZHOU, L.-W. (2009): Lignicolous fungi of eastern Lesser Hinggan Mts. of Heilongjiang Province. - Mycosystema 28(1): 36-43.

841. ZEHFUß, H. D., EBERT, H. J. \& WinTERHOFF, W. (2000): Großpilze. Rote Liste der ausgestorbenen, verschollenen und gefährdeten Großpilze in Rheinland-Pfalz. Ministerium für Umwelt und Forsten, Rheinland-Pfalz.

842. ZhaO, R-L., Jeewon, R., Desjardin, D. E., Soytong, K. \& Hyde, K. D. (2007): Ribosomal DNA phylogenies of Cyathus: Is the current infrageneric classification appropriate? - Mycologia 99 (3): 385-395. http://dx.doi.org/10.3852/mycologia.99.3.385

843. Zhao, R-L, Desjardin, D. E., Soytong, K. \& Hyde, K. D. (2008): A new species of bird's nest fungi: characterization of Cyathus subglobisporus sp. nov. based on morphological and molecular data. - Persoonia 21: 71-76. http://dx.doi.org/10.3767/003158508×370578

844. ZHOU, L. W. (2013): Phylloporia tiliae sp. nov. from China. - Mycotaxon 124: 361-365. http://dx.doi.org/10.5248/124.361

845. Zhou, L. W. (2015): Phylloporia osmanthi and P. terrestris spp. nov. (Hymenochaetales, Basidiomycota) from Guangxi, South China. - Nova Hedwigia 100(1-2): 239-249.

http://dx.doi.org/10.1127/nova hedwigia/2014/0220

846. ZHOU, L. W. \& DAI, Y. C. (2012): Recognizing ecological patterns of wood-decaying polypores on gymnosperm and angiosperm trees in northeast China. - Fungal Ecology 5: 230-235.

http://dx.doi.org/10.1016/j.funeco.2011.09.005

847. Zhou, L. W. \& XUE, H. J. (2012): Fomitiporia pentaphylacis and F. tenuitubus spp. nov. (Hymenochaetales, Basidiomycota) from Guangxi, southern China. - Mycological Progress 11: 907-913. http://dx.doi.org/10.1007/s11557-012-0806-1 
848. ZHOU, L. W. \& DAI, Y. C. (2012): Phylogeny and taxonomy of Phylloporia (Hymenochaetales): new species and a worldwide key to the genus. - Mycologia 104(1): 211-222.

http://dx.doi.org/10.3852/11-093

849. ZHOU, L. W. \& DAI, Y. C. (2013a): Phylogeny and taxonomy of poroid and lamellate genera in the Auriculariales (Basidiomycota). - Mycologia 105(5): 1219-1230. http://dx.doi.org/10.3852/12-212

850. ZHOU, L. W. \& DAI, Y. C. (2013b): Taxonomy and phylogeny of wood-inhabiting hydnoid species in Russulales: two new genera, three new species and two new combinations. - Mycologia 105(3): 636-649. http://dx.doi.org/10.3852/12-011

851. ZHOU, L. W., VLASÁK, J. JR. \& VLASÁK J. (2014): Inonotus andersonii and I. krawtzewii: another case of molecular sequencing-based diagnosis of morphologically similar species. - Chiang Mai J. Sci. 41(4): 789-797.

852. ZhOU, T. X., ZhaO, L. H., ZHAO, R. L. \& CHEN, Y. H. (2004): Bird's nest fungi from China. Fungal Diversity 17: 243-251.

853. ZMITROVICH, I. V. (2010): The taxonomical and nomenclatural characteristics of medicinal mushrooms in some genera of Polyporaceae. - International Journal of Medicinal Mushrooms 12(1): 87-89. http://dx.doi.org/10.1615/intimedmushr.v12.i1.80

854. ZMITROVICH, I. V. \& WASSER, S. P. (2004): Modern view on the origin and phylogenetic reconstruction of Homobasidiomycetes fungi (in: Wasser, S. P. - Evolutionary Theory and Processes: Modern Horizons, Papers in Honour of Eviatar Nevo). Kluwer Academic Publishers, p. 231-263. http://dx.doi.org/10.1007/978-94-017-0443-4 13

855. Zmitrovich, I. V., Malysheva, V. F., Malysheva, E. F. \& Spirin, W. A. (2004): Pleurotoid fungi of Leningrad Region (with notes on rare and interesting East-European taxa). - Folia Cryptogamica Petropolitana 1: 1-124.

856. ZMitrovich, I., MALYSheVA V. F. \& SPIRIN, W. A. (2006): A new morphological arrangement of the Polyporales. I. Phanerochaetineae. - Mycena 6: 4-56.

857. Zmitrovich, I. V., MalysheVA, V. F. \& Spirin, W. A. (2007): A new Pachykytospora species (Basidiomycota, Polyporales) from Zhiguli, European Russia. - Укр. ботан. журн. [Ukr. Botan. Journ.] 64(1): 42-46.

858. ZMitrovich, I., MalysheVA V. F. \& MalysheVA E. F. (2009): Типы гиф полипороидных и плевротоидных грибов: терминологическая ревизия [Hyphal systems of polyporoid and pleurotoid fungi. 1. Types of hyphae]. - Укр. ботан. журн. [Ukr. Botan. Journ.] 66(1): 71-87.

859. ZMITROVICH, I. \& WASSER, S. P. (2012): Phylogenetic conundrum of the mushroom-forming fungi (Agaricomycetes) (in: Misra, J. K., Tewari, J. P. \& DeshmuKh, S. K. - Systematics and Evolution of Fungi). Science Publishers, p. 207-252. http://dx.doi.org/10.1201/b11606-9

860. Zmitrovich, I., EZhov, O. N. \& WASSER, S. P. (2012): A survey of species of genus Trametes Fr. (higher basidiomycetes) with estimation of their medicinal source potential. - International Journal of Medicinal Mushrooms 14(3): 307-319. http://dx.doi.org/10.1615/intjmedmushr.v14.i3.70

861. ZMITROVICH, I. \& MALYShEVA V. F. (2013): Towards a phylogeny of Trametes alliance (Basidiomycota, Polyporales). - Mikologiya i Fitopatologiya 47(6): 358-380.

862. Zmitrovich,I. V. \& MalysheVA,V. F. (2014): Studies on Oxyporus I. Segregation of Emmia and general topology of phylogenetic tree. - Mikologiya i Fitopatologiya 48(3): 161-171.

863. ZMitrovich,I. V., WASSER, S. P. \& ȚURA, D. (2015): Wood-Inhabiting Fungi. In: Mishra, J. K., TEWARI, J. P., DESMUKH, S. K. \& VÁGVÖLGYI Cs. (szerk.): Fungi from different substrates. CRC Press, p. 17-74. http://dx.doi.org/10.1201/b17646-3

864. ZUGMAIER, W., BAUER, R. \& OBERWINKLER, F. (1994): Mycoparasitism of some Tremella species. - Mycologia 86: 49-56. http://dx.doi.org/10.2307/3760718

865. ŽUPAnić, M., MatoŠEviĆ, D., PerneK, M. \& Diminić, D. (2009): Lignicolous fungi on Pedunculate oak in lowland forests of Central Croatia. - Periodicum Biologorum 111(4): 397-403. 


\section{M2. ÁBRÁK JEGYZÉKE}

1. ábra. A Juhdöglő-völgy Erdörezervátum földrajzi elhelyezkedése .......................................26

2. ábra. A Juhdöglö-völgy Erdörezervátum tölgyes élöhelyei ................................................27

3. ábra. Álló és fekvő holtfák a Juhdöglő-völgy Erdőrezervátum bükkös élőhelyein. ...............28

4. ábra. Kijelölt rönkök a Juhdöglö-völgy Erdőrezervátumban ...............................................29

5. ábra. A Phleogena faginea morfológiai bélyegei (PV230) ...................................................39

6. ábra. A Crepidotus ehrendorferi Juhdöglő-völgy Erdőrezervátumban gyüjtött termőteste és mikroszkopikus bélyegei (PV218)

7. ábra. A rezervátumban gyüjtött Crepidotus ehrendorferi (PV218), C. macedonicus (PV773) és C. malachioides (PV690) és rokon fajainak filogenetikai fája ITS szekvenciák alapján

8. ábra. Az Entoloma zuccherellii var. pluteisimilis (BP 106908) és rokon fajainak filogenetikai fája ITS szekvenciák alapján

9. ábra. A Juhdöglö-völgy erdőrezervátumban gyüjtött Entoloma tjallingiorum (PV538) és rokon fajainak filogenetikai fája ITS szekvenciák alapján

10. ábra. A Lyophyllaceae család Juhdöglö-völgy Erdőrezervátum területén dokumentált fajainak termőtestei (in situ) .52

11. ábra. A Pluteus nemzetségbe tartozó fajok termőtestei a Juhdöglö-völgy Erdőrezervátumban (in situ)

12. ábra. A Pholiota squarrosoides termőtestei a Juhdöglö-völgy Erdörezervátumban (in situ)...

13. ábra. A Pholiota squarrosoides (PV540 /BP 106902) anatómiai bélyegei 67

14. ábra. A Pholiota squarrosoides (PV540 /BP 106902) és rokon fajainak filogenetikai fája ITS szekvenciák alapján

15. ábra. A Flammulaster nemzetségbe tartozó fajok termőtestei a Juhdöglö-völgy Erdőrezervátumban bükkfa rönkökön (in situ).

16. ábra. A nagyméretü iniciális korhadási fázisban lévő bükkfarönkről gyüjtött PV983-as számú fungáriumi minta sporokarpiumainak ex situ fotódokumentációja

17. ábra. A Juhdöglő-völgy Erdőrzervátumban gyüjtött PV983-as számú minta mikroszkopikus bélyegei

18. ábra. A rezervátumban gyüjtött Serpula himantioides makro- és mikroszkopikus bélyegei.....

19. ábra. A Ramaria stricta sporokarpiumai a Juhdöglö-völgy Erdőrezervátumban (in situ). 
20. ábra. Inonotus s. lato és Phellinus s. lato fajok a Juhdöglö-völgy Erdörezervátumban .82

21. ábra. A Fomitopsidaceae családba tartozó barnakorhasztó taplófajok a Juhdöglö-völgy Erdőrezervátumban.

22. ábra. A Juhdöglö-völgy Erdőrezervátumban gyüjtött Postia alni (PV188) jellemző makromorfológiai bélyegei

23. ábra. A rezervátumban gyüjtött Postia alni (PV188) mikromorfológiai bélyegei 88

24. ábra. A Juhdöglö-völgy Erdörezervátumban gyüjtött és morfológiai bélyegek alapján Postia alni-nak határozott minta (PV188), valamint a Postia subgen. Cyanosporus alnemzetség GenBank-i adatainak törzsfája ITS szekvenciák alapján 89

25. ábra. Ganoderma fajok sporokarpiumai a Juhdöglő-völgy Erdőrezervátumban .92

26. ábra. Az Ischnoderma resinosum termőtestei a Juhdöglö-völgy Erdőrezervátumban .94

27. ábra. A Meripilus giganteus bazídiokarpiumai a Juhdöglö-völgy Erdőrezervátumban .95

28. ábra. A Juhdöglö-völgy Erdőrezervátumból gyüjtött Physisporinus fajok termőtestei .96

29. ábra. A Juhdöglö-völgy Erdőrezervátumban gyüjtött Donkia pulcherrima [ $\equiv$ Climacodon pulcherrimus] termöteste. 98

30. ábra. A Donkia pulcherrima (PV1044) morfológiai bélyegei 99

31. ábra. A rezervátumban gyüjtött Donkia pulcherrima $[\equiv$ Climacodon pulcherrimus $]$ és rokon fajainak filogenetikai fája ITS szekvenciák alapján 101

32. ábra. A rezervátumban gyüjtött Phlebia fajok termőtestei. 102

33. ábra. A rezervátumban gyüjtött Phlebia nothofagi (PV551) és rokon fajainak filogenetikai fája ITS szekvenciák alapján 103

34. ábra. A Frantisekia mentschulensis (PV678) termőteste és jellemző makromorfológiai bélyegei

35. ábra. A Frantisekia mentschulensis (PV678) mikromorfológiai bélyegei 113

36. ábra. A Hericiaceae család hidnoid fajainak termőtestei a Juhdöglö-völgy erdőrezervátumban 116 


\section{M3. TÁBLÁZATOK JEGYZÉKE}

1. táblázat. A lignikol bazídiumos nagygombák kládok és termőrétegtartó (himenofor) alapján való megoszlása. 16

2. táblázat. A rezervátumban kijelölt Fagus sylvatica fatörzsek (db) korhadási fázis és átmérő szerinti megoszlása 30

3. táblázat. A rezervátumban kijelölt Quercus petraea és $Q$. pubescens fatörzsek $(\mathrm{db})$ korhadási fázis és átmérő szerinti megoszlása

4. táblázat. A Juhdöglö-völgy Erdőrezervátumban töltött terepnapok időpontjai, évekre és hónapokra bontva 31

5. táblázat. A Juhdöglö-völgy Erdőerzervátum teréletéről dokumentált bazídiumos gombák [Basidiomycota Whittaker ex Moore] törzsébe tartozó lignikol nagygombák nemzetség- és fajszáma, rendek és családok szerinti megoszlásuk szerint .36

6. táblázat. Az Entoloma zuccherellii csoportba tartozó fajok összehasonlítása irodalmi adatok alapján, a jellemző morfológiai bélyegeik, valamint ismert szubsztrátumaik szerint .46

7. táblázat. Az Armillaria cepistipes és A. lutea jellemző morfológiai bélyegeinek és ökológiájának összehasonlítása .57

8. táblázat. Európai Dentipellis s. lato fajok spóráinak mérete 115

9. táblázat. A 10 legértékesebb európai bükkös erdőterület a 21 indikátorfaj prezenciája alapján . 


\section{M4. A JUHDÖGLÖ-VÖLGY ERDÖREZERVÁTUM TERÜLETÉN GYÜJTÖTT LIGNIKOL NAGYGOMBÁK FAJLISTÁJA}

M4.1. A Juhdöglö-völgy Erdőrezervátum területén gyüjtött lignikol bazídiumos nagygombák fajlistája alfabetikus sorrendben. A tudományos név után az adott taxon aktuális szisztematikai besorolása (család és rend), a szubsztrátumként szolgáló fafaj neve, a kijelölt rönk sorszáma zárójelben feltüntetve (lásd. M5. melléklet), a gyüjtés dátuma, a gyüjtő (leg.) és határozó (det.) személye, valamint a Budapesti Corvinus Egyetem Növénytani Tanszékén elhelyezett fungáriumi minta (PV) adatai következnek.

1. Abortiporus biennis (Bull.) Singer [Podoscyphaceae D.A. Reid s. lato; Polyporales Gäum.] Fagus sylvatica, 2010.10.07., leg. et det.: Papp V. (fung.: PV212)

2. Agrocybe firma (Peck) Singer [Strophariaceae Singer \& A.H. Sm.; Agaricales Underw.] - Quercus sp., 2012.07.15., leg. et det. Papp V. (fung.: PV655)

3. Aleurocystidiellum disciforme (DC.) Tellería; $\equiv$ Aleurodiscus disciformis (DC.) Pat. [Stereaceae Pilát; Russulales Kreisel ex P.M. Kirk, P.F. Cannon \& J.C. David] - élő Quercus cerris kérgén, 2011.03.04., leg. et det.: Papp V. (fung.: PV274); 2011.08.08. (10); Quercus petraea rönkön (2), 2011.08.10., leg. et det.: Papp V. (fung.: PV1032)

4. Antrodia albida (Fr.) Donk [Fomitopsidaceae Jülich; Polyporales Gäum.] - Fagus sylvatica, 2012.08.01., leg. et det.: Papp V. (fung.: PV710)

5. Antrodiella cf. foliaceodentata (Nikol.) Gilb. \& Ryvarden [Steccherinaceae Parmasto; Polyporales Gäum.] - Fagus sylvatica, 2012.10.20., leg. et det.: Papp V. (fung.: PV793)

6. Antrodiella fragrans (A. David \& Tortič) A. David \& Tortič [Steccherinaceae Parmasto; Polyporales Gäum.] - Fagus sylvatica ágon, 2010.09.14., leg. et det.: Papp V. (fung.: PV162); Fagus sylvatica, 2011.05.20., leg. et det.: Papp V. (fung.: PV317); Fagus sylvatica ágon, 2011.08.03., leg. et det.: Papp V. (fung.: PV595); Fagus sylvatica ágon, 2012.07.28., leg. et det.: Papp V. (fung.: PV680)

7. Antrodiella serpula (P. Karst.) Spirin \& Niemelä; = A. hoehnelii (Bres.) Niemelä [Steccherinaceae Parmasto; Polyporales Gäum.] - Quercus sp., 2011.08.08., leg. et det.: Papp V. (fung.: PV436)

8. Armillaria gallica Marxm. \& Romagn.; = A. lutea Gillet [Physalacriaceae Corner; Agaricales Underw.] - Fagus sylvatica, 2010.09.23., leg. et det.: Papp V. (fung.: PV196)

9. Armillaria mellea (Vahl) P. Kumm. [Physalacriaceae Corner; Agaricales Underw.] - Fagus sylvatica, 2010.10.07., leg. et det.: Papp V.

10. Artomyces pyxidatus (Pers.) Jülich [Auriscalpiaceae Maas Geest.; Russulales Kreisel ex P.M. Kirk, P.F. Cannon \& J.C. David] - Fagus sylvatica rönkön, 2011.06.10., leg. et det.: Papp V. (fung.: PV338); Fagus sylvatica rönkön, 2011.08.05., leg. et det.: Papp V. (fung.: PV419) 
11. Aurantiporus alborubescens (Bourdot \& Galzin) H. Jahn; 三 Tyromyces alborubescens (Bourdot \& Galzin) Bondartsev [Polyporaceae Corda; Polyporales Gäum.] - Fagus sylvatica rönkön, 2015.08.06., leg.: Koszka A., det.: Papp V. (fung.: PV1089)

12. Aurantiporus fissilis (Berk. \& M.A. Curtis) H. Jahn ex Ryvarden; $\equiv$ Tyromyces fissilis (Berk. \& M.A. Curtis) Donk [Polyporaceae Corda; Polyporales Gäum.] - Fagus sylvatica (91), 2011.10.15., leg. et det.: Papp V. (fung.: PV493), 2012.08.03. (fung.: PV730)

13. Auricularia auricula-judae (Bull.) Quél. [Auriculaceae Fr. ex Lindau; Auriculariales J. Schröt.] Fagus sylvatica (71) (91), 2012.10.20., leg. et det.: Papp V.; Quercus sp., 2010.09.14., leg. et det.: Papp V.; Sambucus nigra, 2010.09.14., leg. et det.: Papp V.; Hedera helix: 2010.09.14., leg. et det.: Papp V.

14. Auricularia mesenterica (Dicks.) Pers. [Auriculaceae Fr. ex Lindau; Auriculariales J. Schröt.] Fagus sylvatica, 2010.09.14., leg. et det.: Papp V. (fung.: PV163); Fagus sylvatica (114), 2011.08.03., leg. et det.: Papp V.; Fagus sylvatica (68), 2011.08.10., leg. et det.: Papp V.; Fagus sylvatica ágdarabon, 2011.10.29., leg. et det.: Papp V. (fung.: PV525)

15. Basidioradulum radula (Fr.) Nobles; $\equiv$ Hyphoderma radula (Fr.) Donk; $\equiv$ Xylodon radula (Fr.) Tura, Zmitr., Wasser \& Spirin [Schizoporaceae Jülich; Hymenochaetales Oberw.] - Prunus avium subsp. avium, 2011.08.08., leg. et det.: Papp V. (fung.: PV1110)

16. Bjerkandera adusta (Willd.) P. Karst. [Meruliaceae Rea; Polyporales Gäum.] - Quercus sp., 2010.09.23., leg. et det.: Papp V.; Quercus sp. (20), 2011.08.08., leg. et det.: Papp V.; Quercus sp. (6), 2011.08.10., leg. et det.: Papp V.; Fagus sylvatica, 2010.09.23., leg. et det.: Papp V. (fung.: PV197); Fagus sylvatica (76), 2011.08.03., leg. et det.: Papp V.; Fagus sylvatica (85), 2011.08.03., leg. et det.: Papp V.; Fagus sylvatica (87), 2011.08.03., leg. et det.: Papp V.; Fagus sylvatica (112), 2011.08.03., leg. et det.: Papp V.; Fagus sylvatica (73), 2011.08.10., leg. et det.: Papp V. (fung.: PV594); Fagus sylvatica elhalt faanyagán, 2012.08.01., leg. et det.: Papp V. (fung.: PV708)

17. Bolbitius reticulatus (Pers.) Ricken [Bolbitiaceae Singer; Agaricales Underw.] - erősen korhadt Fagus sylvatica rönkön, 2011.06.01., leg. et det. Papp V. (fung.: PV327)

18. Bolbitius cf. titubans (Bull.) Fr. $[=$ B. vitellinus (Pers.) Fr.; $\equiv$ B. titubans var. vitellinus (Pers.) Courtec.] [Bolbitiaceae Singer; Agaricales Underw.] - erösen korhadt Fagus sylvatica rönk törmelékén, 2012.08.10., leg. et det. Papp V. (fung.: PV1109)

19. Botryobasidium aureum Parmasto [Botryobasidiaceae (Parmasto) Jülich; Cantharellales Gäum.] Fagus sylvatica rönkön, 2011.06.10., leg. et det.: Papp V. (fung.: PV1033)

20. Botryohypochnus isabellinus (Fr.) J. Erikss.; 三 Botryobasidium isabellinum (Fr.) D.P. Rogers [Botryobasidiaceae (Parmasto) Jülich; Cantharellales Gäum.] - Fagus sylvatica (61), 2011.08.03., leg. et det.: Papp V. (fung.: PV583); Fagus sylvatica (71), 2011.08.03., leg. et det.: Papp V. (PV582); Fagus sylvatica (75), 2011.08.03., leg. et det.: Papp V. (fung.: PV562); Fagus sylvatica (107), 2011.08.03., leg. et det. Papp V. (fung.: PV563); Fagus sylvatica (73), 2011.08.10. leg. et 
det.: Papp V. (fung.: PV584); 2012.10.20. (71); Quercus petraea (121), 2011.08.10., leg. et det.: Papp V. (fung.: PV585)

21. Buglossoporus quercinus (Schrad.) Kotlába \& Pouzar; = B. pulvinus (Pers.) Donk; झ Piptoporus quercinus (Schrad.) P. Karst. [Fomitopsidaceae Jülich; Polyporales Gäum.] - Quercus sp., 2011.08.10., leg. et det.: Papp V. (fung.: PV496); Quercus sp., 2012.07.28., leg. et det.: Papp V. (fotó)

22. Byssomerulius corium (Pers.) Parmasto; $\equiv$ Meruliopsis corium (Pers.) Ginns [Meruliaceae Rea; Polyporales Gäum.] - cf. Fagus sylvatica ágon, 2010.10.07. leg. et det.: Papp V. (fung.: PV243); Fagus sylvatica ágon, 2011.08.10., leg. et det.: Papp V. (fung.: PV990)

23. Calocera cornea (Batsch) Fr. [Dacrymycetaceae Bref.; Dacrymycetales Lindau] - Fagus sylvatica (91), 2011.08.05., leg. et det. Papp V.; Fagus sylvatica (96), 2011.08.05., leg. et det. Papp V.; Quercus sp. (9), 2011.08.08., leg. et det. Papp V.; Quercus sp. (19), 2011.08.08., leg. et det. Papp $\mathrm{V}$.

24. C. cf. glossoides (Pers.) Fr. [Dacrymycetaceae Bref.; Dacrymycetales Lindau] - Quercus sp., 2012.08.01., leg. et det.: Papp V. (fung.: PV1111)

25. Ceriporia excelsa (S. Lundell) Parmasto [Meruliaceae Rea; Polyporales Gäum.] - Fagus sylvatica (82), 2012.07.28., leg. et det.: Papp V. (fung.: PV696)

26. Ceriporia purpurea (Fr.) Donk [Meruliaceae Rea; Polyporales Gäum.] - Quercus sp., 2011.10.29., leg. et det.: Papp V. (fung.: PV535)

27. Ceriporiopsis gilvescens (Bres.) Domanski [Meruliaceae Rea; Polyporales Gäum.] - Fagus sylvatica (89), 2011.10.29., leg et det.: Papp V. (fung.: PV520)

28. Cerrena unicolor (Bull.) Murrill [Podoscyphaceae D.A. Reid s. lato; Polyporales Gäum.] - Fagus sylvatica, 2011.04.25., leg. et det.: Papp V. (fung.: PV288); Quercus sp. (10), 2011.08.08., leg. et det.: Papp V.

29. Chondrostereum purpureum (Pers.) Pouzar [Cyphellaceae Lotsy; Agaricales Underw.] - Fagus sylvatica, 2010.10.07., leg. et det. Papp V. (fung.: PV215)

30. Clitopilus hobsonii (Berk. \& Broome) P.D. Orton [Entolomataceae Kotl. \& Pouzar; Agaricales Underw.] - Fagus sylvatica, 2012.08.01., leg.: Papp V., det.: Papp V. et Dima B. (fung.: PV1022)

31. Coniophora arida (Fr.) P. Karst. [Coniophoraceae Ulbr.; Boletales E.-J. Gilbert] - Fagus sylvatica, 2010.09.14., leg. et det.: Papp V.; Hedera helix léggyökerén, 2010.09.14., leg. et det.: Papp V. (fung.: PV164); Quercus sp. rönkön, 2011.04.25., leg. et det.: Papp V. (fung.: PV289)

32. Coniophora puteana (Schumach.) P. Karst. [Coniophoraceae Ulbr.; Boletales E.-J. Gilbert] Fagus sylvatica rönkön, 2010.10.15., leg. et det.: Papp V. (fung.: PV256)

33. Coprinellus disseminatus (Pers.) J.E. Lange [Psathyrellaceae Vilgalys, Moncalvo \& Redhead; Agaricales Underw.] - álló fa tövében tömegesen, 2013.09.20., leg. et det.: Papp V. 
34. Coprinellus domesticus (Bolton) Vilgalys, Hopple \& Jacq. Johnson [Psathyrellaceae Vilgalys, Moncalvo \& Redhead; Agaricales Underw.] - Fagus sylvatica rönkön, 2010.10.15., leg. et det.: Papp V.

35. Coprinellus cf. truncorum (Scop.) Redhead, Vilgalys \& Moncalvo [Agaricaceae Chevall.; Agaricales Underw.] - Fagus sylvatica (113), 2011.08.03., leg. et det. Papp V.

36. Crepidotus applanatus (Pers.) P. Kumm. [Crepidotaceae (S. Imai) Singer; Agaricales Underw.] Fagus sylvatica, 2011.08.03., leg. et det. Papp V. (fung.: PV401); Fagus sylvatica (90), 2011.08.03., leg. et det. Papp V.; Fagus sylvatica (109), 2011.08.03., leg. et det. Papp V.; Fagus sylvatica rönkön, 2012.08.01., leg. et det.: Papp V. (fung.: PV709)

37. Crepidotus calolepis (Fr.) P. Karst. [Crepidotaceae (S. Imai) Singer; Agaricales Underw.] - Fagus sylvatica, 2011.08.05., leg. et det. Papp V. (fung.: PV420)

38. Crepidotus caspari Velen. [Crepidotaceae (S. Imai) Singer; Agaricales Underw. ] - Fagus sylvatica, 2010.09.14., leg. et det. Papp V. (fung.: PV165); Fagus sylvatica, 2011.08.03., leg.: Papp V. det.: Papp V. et Dima B. (fung.: PV404)

39. Crepidotus cesatii (Rabenh.) Sacc. [Crepidotaceae (S. Imai) Singer; Agaricales Underw.] -Fagus sylvatica, 2010.10.07., leg.: Papp V., det.: Papp V. és Dima B. (fung.: PV217)

40. Crepidotus crocophyllus (Berk.) Sacc. [Crepidotaceae (S. Imai) Singer; Agaricales Underw.] Fagus sylvatica, 2010.09.14., leg. et det. Papp V. (fung.: PV166); Fagus sylvatica, 2011.06.10., leg. et det. Papp V. (fung.: PV339); Fagus sylvatica, 2011.08.10., leg. et det. Papp V. (fung.: PV454); Fagus sylvatica, 2013.10.25., leg. et det. Papp V. (fung.: PV1020)

41. Crepidotus ehrendorferi Hauskn. \& Krisai [Crepidotaceae (S. Imai) Singer; Agaricales Underw.] Fagus sylvatica, 2011.07.07., leg. et det. Papp V. (fung.: PV360); Fagus sylvatica (77), 2011.08.03., leg. et det. Papp V. (fung.: PV402); Quercus sp., 2010.10.07., leg. et det. Papp V. (fung.: PV218), 2011.08.08., leg. et det. Papp V. (fung.: PV437/PV438).

42. Crepidotus macedonicus Pilát \& Lindtner [Crepidotaceae (S. Imai) Singer; Agaricales Underw.] Fagus sylvatica, 2012.10.24., leg. Papp V., det. Papp V. et Dima B. (fung.: PV773)

43. Crepidotus malachius Peck [Crepidotaceae (S. Imai) Singer; Agaricales Underw.] - Fagus sylvatica, 2010.09.23., leg. et det. Papp V. (fung.: PV199)

44. Crepidotus malachioides Consiglio, Prydiuk \& Setti [Crepidotaceae (S. Imai) Singer; Agaricales Underw.] - Fagus sylvatica, 2011.08.03., leg. Papp V., det. Papp V. et Dima B. (fung.: PV403); Quercus cerris, 2012.07.28., leg. Papp V., det. Papp V. et Dima B. (fung.: PV690).

45. Crepidotus mollis (Schaeff.) Staude [Crepidotaceae (S. Imai) Singer; Agaricales Underw.] - Fagus sylvatica (96), 2011.08.05., leg. Papp V., det. Papp V. et Dima B. (fung.: PV422)

46. Crepidotus subverrucisporus Pilát [Crepidotaceae (S. Imai) Singer; Agaricales Underw.] Quercus sp., 2011.08.05., leg.: Papp V., det.: Papp V. et Dima B. (fung.: PV421)

47. Crepidotus variabilis (Pers.) P. Kumm. [Crepidotaceae (S. Imai) Singer; Agaricales Underw.] Fagus sylvatica, 2011.08.05., leg. Papp V., det. Dima B. et Papp V. (fung.: PV427) 
48. Cyathus striatus (Huds.) Willd. [Agaricaceae Chevall.; Agaricales Underw.] - Fagus sylvatica (71), 2011.08.03., leg. et det. Papp V.; Fagus sylvatica (74), 2011.08.03., leg. et det. Papp V. (fung.: PV596); Fagus sylvatica (107), 2011.08.03., leg. et det. Papp V.; Quercus sp., 2010.09.14., leg. et det. Papp V. (fung.: PV167)

49. Cylindrobasidium laeve (Pers.) Chamuris; = C. evolvens (Fr.) Jülich [Physalacriaceae Corner; Agaricales Underw.] - cf. Tilia cordata, 2011.04.25., leg. et det. Papp V. (fung.: PV290); Fagus sylvatica (114), 2011.08.03., leg. et det.: Papp V. (fung.: PV560); Fagus sylvatica elszáradt ágán, 2011.10.29., leg. et det.: Papp V. (fung.: PV524); Fagus sylvatica (114), 2012.10.20., leg. et det.: Papp V.

50. Dacrymyces stillatus Nees [Dacrymycetaceae Bref.; Dacrymycetales Lindau] - Quercus sp. rönkön, 2010.10.07., leg. et det.: Papp V. (fung.: PV1112)

51. Daedalea quercina (L.) Pers. [Fomitopsidaceae Jülich; Polyporales Gäum.] - Quercus sp. rönkön, 2010.09.14., leg. et det.: Papp V.; Quercus sp. rönkön, 2010.10.07., leg. et det.: Papp V. (fung.: PV220); Quercus sp. (9), 2011.08.08., leg. et det.: Papp V. (fung.: PV439); Quercus sp. (22), 2011.08.10., leg. et det.: Papp V.; Quercus sp. (33), 2011.08.10., leg. et det.: Papp V.; Quercus sp. (55), 2011.08.10., leg. et det.: Papp V.; Quercus sp. (57), 2011.08.10., leg. et det.: Papp V.; Quercus sp. (123), 2011.08.10., leg. et det.: Papp V.

52. Datronia mollis (Sommerf.) Donk [Polyporaceae Corda; Polyporales Gäum.] - Fagus sylvatica rönkön, 2010.09.14., leg. et det.: Papp V. (fung.: PV168); Fagus sylvatica rönkön, 2010.10.15., leg. et det.: Papp V. (fung.: PV260)

53. Dendrothele acerina (Pers.) P.A. Lemke [Corticiaceae Herter; Corticiales K.H. Larss.] - élő Acer campestre kérgén, 2010.09.14., leg. et det.: Papp V. (fung.: PV169)

54. Dendrothele commixta (Höhn. \& Litsch.) J. Erikss. \& Ryvarden [Corticiaceae Herter; Corticiales K.H. Larss.] - élő Quercus sp. kérgén, 2011.10.29., leg. et det.: Papp V. (fung.: PV532)

55. Dentipellis fragilis (Pers.) Donk [Hericiaceae Donk; Russulales Kreisel ex P.M. Kirk, P.F. Cannon \& J.C. David] - meghatározatlan lombos fa anyagán, 2014.09.09., leg. et det.: Papp V. (fung.: PV1113 /BP 106907)

56. Dichomitus campestris (Quél.) Domanski \& Orlicz [Polyporaceae Corda; Polyporales Gäum.] Quercus sp. (3), 2011.08.05., leg. et det.: Papp V. (fung.: PV992)

57. Donkia pulcherrima (Berk. \& M.A. Curtis) Pilát; $\equiv$ Climacodon pulcherrimus (Berk. \& M.A. Curtis) Nikol. [Meruliaceae Rea s. lato; Polyporales Gäum.] - Fagus sylvatica rönkön, 2014.09.09., leg. et det.: Papp V. (fung.: PV1044 / BP106903).

58. Emmia latemarginata (Durieu \& Mont.) Zmitr., Spirin \& Malysheva; 三 Oxyporus latemarginatus (Durieu \& Mont.) Donk [Meruliaceae Rea s. lato; Polyporales Gäum.] - Quercus sp. (20), 2011.10.29., leg. et det.: Papp V. (fung.: PV510) 
59. Entoloma tjallingiorum var. tjallingiorum Noordel. [Entolomataceae Kotl. \& Pouzar; Agaricales Underw.] - Quercus sp., 2010.10.07., leg. et det. Papp V. (fung.: PV538 /BP 106905) [Erröl a mintáról készült ex situ fotódokumentáció RIMÓcZI (2012) munkájában látható.]

60. Entoloma zuccherellii var. pluteisimilis (Noordel. \& C.E. Hermos) V. Papp; $\equiv$ E. pluteisimilis Noordel. \& C.E. Hermos. [Entolomataceae Kotl. \& Pouzar; Agaricales Underw.] - Fagus sylvatica rönkön, 2012.11.30., leg. Papp V., det. Dima B. et Papp V. (fung.: PV1114 /BP 106908)

61. Exidia glandulosa (Bull.) Fr. [Auriculaceae Fr. ex Lindau; Auriculariales J. Schröt.] - Fagus sylvatica, 2011.10.29., leg. et det.: Papp V. (fung.: PV518)

62. Fistulina hepatica (Schaeff.) With. [Fistulinaceae Lotsy; Agaricales Underw.] - élő Quercus sp. tövében, 2010.09.23., leg. et det.: Papp V.; Quercus sp. (10), 2011.08.08., leg. et det.: Papp V.

63. Flammulaster limulatus (Fr.) Watling [Tubariaceae Vizzini; Agaricales Underw.] - Fagus sylvatica rönkön, 2010.09.23., leg. et det. Papp V. (fung.: PV200); Fagus sylvatica rönkön, 2011.07.07., leg. et det. Papp V. (fung.: PV363); Fagus sylvatica rönkön, 2011.07.13., leg. et det. Papp V. (fung.: PV375); Fagus sylvatica (79), 2011.08.03., leg. et det. Papp V. (fung.: PV541); Fagus sylvatica (88), 2011.08.03., leg. et det. Papp V. (fung.: PV543); Fagus sylvatica (109), 2011.08.03., leg. et det. Papp V. (fung.: PV542); Fagus sylvatica (101), 2011.08.10., leg. et det. Papp V. (fung.: PV544).

64. Flammulaster muricatus (Fr.) Watling [Tubariaceae Vizzini; Agaricales Underw.] - Fagus sylvatica rönkön, 2010.09.23., leg. et det. Papp V.; Fagus sylvatica rönkön, 2010.10.15., leg. et det. Papp V. (fung.: PV262); Fagus sylvatica rönkön, 2011.07.22. (fung.: PV385); Fagus sylvatica (64), 2011.08.03., leg. et det. Papp V. (fung.: PV406); Fagus sylvatica (79), leg. et det. Papp V. (fung.: PV407).

65. Flammulina velutipes (Curtis) Singer [Physalacriaceae Corner; Agaricales Underw.] - Fagus sylvatica rönkön, 2012.10.08., leg. et det.: Papp V. (fung.: PV1036)

66. Fomes fomentarius (L.) J. Kickx f. [Polyporaceae Corda; Polyporales Gäum.] - Fagus sylvatica rönkön, 2010.09.14., leg. et det.: Papp V.; Fagus sylvatica (63), 2011.08.03., leg. et det.: Papp V.; Fagus sylvatica (70), 2011.08.03., leg. et det.: Papp V.; Fagus sylvatica (71), 2011.08.03., leg. et det.: Papp V.; Fagus sylvatica (72), 2011.08.03., leg. et det.: Papp V.; Fagus sylvatica (82), 2011.08.03., leg. et det.: Papp V.; Fagus sylvatica (83), 2011.08.03., leg. et det.: Papp V.; Fagus sylvatica (116), 2011.08.03., leg. et det.: Papp V.; Fagus sylvatica (62), 2011.08.05., leg. et det.: Papp V.; Fagus sylvatica (81), 2011.08.05., leg. et det.: Papp V.; Fagus sylvatica (95), 2011.08.05., leg. et det.: Papp V.; Fagus sylvatica (68), 2011.08.10., leg. et det.: Papp V.; Fagus sylvatica (73), 2011.08.10., leg. et det.: Papp V.; Fagus sylvatica (71), 2012.10.20., leg. et det.: Papp V.; még élö Quercus cerris törzsén, 2010.09.14., leg. et det.: Papp V.

67. Fomitiporia robusta (P. Karst.) Fiasson \& Niemelä; $\equiv$ Phellinus robustus (P. Karst.) Bourdot \& Galzin [Hymenochaetaceae Donk; Hymenochaetales Oberw.] - Quercus sp., 2010.10.07., leg. et 
det.: Papp V.; Quercus sp., 2011.05.18., leg. et det.: Papp V. (fung.: PV315); Quercus sp. (20), 2012.10.20., leg. et det.: Papp V.

68. Fomitopsis pinicola (Sw.) P. Karst. [Fomitopsidaceae Jülich; Polyporales Gäum.] - Fagus sylvatica rönkön, 2011.04.25., leg. et det.: Papp V. (fung.: PV292)

69. Frantisekia mentschulensis (Pilát ex Pilát) Spirin; $\equiv$ Antrodiella mentschulensis (Pilát ex Pilát) Ryvarden \& Melo [Steccherinaceae Parmasto; Polyporales Gäum.] - Fagus sylvatica erősen korhadt faanyagán, 2010.10.14., leg. et det.: Papp V. (fung.: PV678).

70. Funalia gallica (Fr.) Bondartsev \& Singer; $\equiv$ Coriolopsis gallica (Fr.) Ryvarden [Polyporaceae Corda; Polyporales Gäum.] - Fagus sylvatica ágdarabon, 2013.10.11., leg. et det.: Papp V. (fung.: PV986)

71. Funalia trogii (Berk.) Bondartsev \& Singer; $\equiv$ Coriolopsis trogii (Berk.) Domański [Polyporaceae Corda; Polyporales Gäum.] - Fagus sylvatica, 2010.09.23., leg. et det.: Papp V. (fung.: PV198)

72. Fuscoporia contigua (Pers.) G. Cunn.; झ Phellinus contiguus (Pers.) Pat. [Hymenochaetaceae Donk; Hymenochaetales Oberw.] - Quercus sp., 2011.04.25., leg. et det.: Papp V. (fung.: PV298); Quercus sp. 2012.07.15., leg. et det.: Papp V. (fung.: PV654); cf. Quercus sp. rönkön, 2012.10.08., leg. et det.: Papp V. (fung.: PV1035), Quercus petraea (9), 2011.08.03., leg. et det.: Papp V. (fung.: PV1023)

73. Fuscoporia ferrea (Pers.) G. Cunn.; $\equiv$ Phellinus ferreus (Pers.) Bourdot \& Galzin [Hymenochaetaceae Donk; Hymenochaetales Oberw.] - Quercus sp., 2011.04.25., leg. et det.: Papp V. (fung.: PV299)

74. Fuscoporia ferruginosa (Schrad.) Murrill; $\equiv$ Phellinus ferruginosus (Schrad.) Pat. [Hymenochaetaceae Donk; Hymenochaetales Oberw.] - Quercus cerris, 2011.06.13., leg. et det.: Papp V. (fung.: PV349); Quercus cerris rönk ágán, 2012.08.03., leg. et det.: Papp V. (fung.: PV731)

75. Fuscoporia torulosa (Pers.) T. Wagner \& M. Fisch.; झ Phellinus torulosus (Pers.) Bourdot \& Galzin [Hymenochaetaceae Donk; Hymenochaetales Oberw.] - Quercus pubescens, 2012.10.24., leg. et det.: Papp V.

76. Galerina marginata (Batsch) Kühner; = G. unicolor (Vahl) Singer [Strophariaceae Singer \& A.H. Sm.; Agaricales Underw.] - Quercus sp., 2010.09.23., leg. et det.: Papp V. (fung.: PV201)

77. Galerina vittiformis (Fr.) Singer (1950) agg. [Strophariaceae Singer \& A.H. Sm.; Agaricales Underw.] - Fagus sylvatica faanyagán, mohában, 2011.08.08., leg.: Papp V., det.: Dima B. \& Papp V. (fung.: PV1115)

78. Ganoderma applanatum (Pers.) Pat.; = G. lipsiense (Batsch) G.F. Atk. 1908 [Ganodermataceae (Donk) Donk; Polyporales Gäum.] - Fagus sylvatica rönkön, 2010.09.14., leg. et det.: Papp V.; Fagus sylvatica (89), 2011.08.03., leg. et det.: Papp V.; Fagus sylvatica (117), 2011.08.03., leg. et det.: Papp V.; Fagus sylvatica (118), 2011.08.03., leg. et det.: Papp V.; Fagus sylvatica (67), 
2011.08.05., leg. et det.: Papp V.; Fagus sylvatica (81), 2011.08.05., leg. et det.: Papp V.; Quercus sp. (47), 2011.08.10., leg. et det.: Papp V.

79. Ganoderma cupreolaccatum (Kalchbr.) Z. Igmándy; = G. pfeifferi Bres. [Ganodermataceae (Donk) Donk; Polyporales Gäum.] - öreg, élő Fagus sylvatica tövében, 2010.10.15., det.: Papp V. (fotó); öreg, élő Fagus sylvatica tövében, 2011.03.04., det.: Papp V. (fotó)

80. Ganoderma lucidum (Curtis) P. Karst. [Ganodermataceae (Donk) Donk; Polyporales Gäum.] Quercus cerris elhalt álló fa tövében, 2010.09.14., leg. et det.: Papp V. (fotó); Fagus sylvatica (98), 2012.10.20., leg. et det.: Papp V. (fung.: PV789)

81. Gelatoporia pannocincta (Romell) Niemelä; 三 Ceriporiopsis pannocincta (Romell) Gilb. \& Ryvarden [Meruliaceae Rea s. lato; Polyporales Gäum.] - Fagus sylvatica rönkön (77), 2011.07.07., leg. et det.: Papp V. (fung.: PV359); Fagus sylvatica, 2011.10.15. leg. et det.: Papp V. (fung.: PV550)

82. Grifola frondosa (Dicks.) Gray [Grifolaceae Jülich; Polyporales Gäum.] - élő Quercus petraea tövében, 2013.10.11., leg. et det.: Papp V. (fotó)

83. Gymnopilus junonius (Fr.) P.D. Orton [Strophariaceae Singer \& A.H. Sm.; Agaricales Underw.] Fagus sylvatica, 2010.09.14., leg. et det.: Papp V. (fung.: PV170)

84. Gymnopus brassicolens (Romagn.) Antonín \& Noordel.; = Micromphale brassicolens (Romagn.) P.D. Orton [Omphalotaceae Bresinsky; Agaricales Underw.] - Fagus sylvatica rönkön, 2010.10.07., leg. et det.: Papp V. (fung.: PV221); Fagus sylvatica (118), 2011.08.03., leg et det.: Papp V.

85. Hapalopilus rutilans (Pers.) Murrill; $\equiv H$. nidulans (Fr.) P. Karst. [Polyporaceae Corda; Polyporales Gäum.] - Quercus sp., 2011.08.05., leg. et det.: Papp V.; talpon álló, elhalt Quercuson, 2011.08.08., leg. et det.: Papp V. (fung.: PV456)

86. Hemimycena cf. cuculata (Pers.) Singer [Mycenaceae Overeem; Agaricales Underw.] - Fagus sylvatica (81), 2011.08.05., leg. et det.: Papp V. (fung.: PV1116)

87. Hemimycena aff. tortuosa (P.D. Orton) Redhead [Mycenaceae Overeem; Agaricales Underw.] cf. Fagus sylvatica ágdarabon, 2012.10.10., leg. et det.: Papp V. (fung.: PV801)

88. Hericium cirrhatum (Pers.) Nikol.; 三 Creolophus cirrhatus (Pers.) P. Karst. [Hericiaceae Donk; Russulales Kreisel ex P.M. Kirk, P.F. Cannon \& J.C. David] - Fagus sylvatica (76), 2010.10.07., leg. et det.: Papp V. (fotó)

89. Hericium coralloides (Scop.) Pers. [Hericiaceae Donk; Russulales Kreisel ex P.M. Kirk, P.F. Cannon \& J.C. David] - Fagus sylvatica rönkön, 2010.09.14., leg. et det.: Papp V. (fung.: PV171); Quercus sp. rönkön, 2011.08.08., leg. et det.: Papp V. (fung.: PV440)

90. Hohenbuehelia aff. atrocoerulea (Fr.) Singer [Pleurotaceae Kühner; Agaricales Underw.] Quercus petraea rönkön, 2012.10.24., leg. et det.: Papp V. (fung.: PV774); Fagus sylvatica rönkön, 2012.10.24., leg. et det.: Papp V. (fung.: PV776) 
91. Hohenbuehelia auriscalpium (Maire) Singer [Pleurotaceae Kühner; Agaricales Underw.] - Fagus sylvatica rönkön, 2011.07.13., leg. et det. Papp V. (fung.: PV377); 2011.07.22., leg. et det. Papp V. (PV386); Fagus sylvatica (90), 2011.08.03., leg. et det. Papp V.; Fagus sylvatica (98), 2011.08.03., leg. et det. Papp V. (fung.: PV408); Fagus sylvatica (95), 2011.08.05., leg. et det. Papp V. (fung.: PV423).

92. Hohenbuehelia mastrucata (Fr.) Singer [Pleurotaceae Kühner; Agaricales Underw.] - Fagus sylvatica rönkön, 2012.08.01., leg. et det. Papp V. (fung.: PV712); Fagus sylvatica rönkön, 2013.10.25., leg. et det. Papp V. (fung.: PV1019)

93. Hydropus subalpinus (Höhn.) Singer [Marasmiaceae Roze ex Kühner; Agaricales Underw.] Fagus sylvatica, 2012.08.03., leg. et det.: Papp V. (fung.: PV732)

94. Hymenochaete carpatica Pilát [Hymenochaetaceae Donk; Hymenochaetales Oberw.] - élö, öreg Acer pseudoplatanus kérgének belső oldalán, 2011.05.20., leg. et det.: Papp V. (fung.: PV319)

95. Hymenochaete cinnamomea (Pers.) Bres. [Hymenochaetaceae Donk; Hymenochaetales Oberw.] Fagus sylvatica ágon, 2010.10.15., leg. et det.: Papp V. (fung.: PV259)

96. Hymenochaete fuliginosa (Pers.) Lév.; = H. subfuliginosa Bourdot \& Galzin [Hymenochaetaceae Donk; Hymenochaetales Oberw.] - Quercus sp. (52), 2011.08.08., leg. et det.: Papp V. (fung.: PV558)

97. Hymenochaete rubiginosa (Dicks.) Lév. [Hymenochaetaceae Donk; Hymenochaetales Oberw.] Quercus cerris, 2010.09.14., leg. et det.: Papp V. (fung.: PV172); Quercus sp., 2011.08.03., leg. et det.: Papp V. (fung.: PV586); Quercus petraea, 2011.10.15., leg. et det. Papp V. (fung.: PV498)

98. Hymenopellis radicata (Relhan) R.H. Petersen; $\equiv$ Xerula radicata (Relhan) Dörfelt [Physalacriaceae Corner; Agaricales Underw.] - talajon, fatörmeléken, 2010.09.23., leg. et det.: Papp V. (fung.: PV210)

99. Hyphoderma cf. medioburiense (Burt) Donk [Podoscyphaceae D.A. Reid s. lato; Polyporales Gäum.] - cf. Fagus sylvatica, 2011.06.01., leg. et det.: Papp V. (fung.: PV330)

100. Hypholoma fasciculare (Huds.) P. Kumm. [Strophariaceae Singer \& A.H. Sm.; Agaricales Underw.] - Fagus sylvatica rönkön, 2010.09.14., leg. et det.: Papp V. (fung.: PV173)

101. Hypholoma lateritium (Schaeff.) P. Kumm. [Strophariaceae Singer \& A.H. Sm.; Agaricales Underw.] - Fagus sylvatica rönkön, 2010.10.07., leg. et det.: Papp V. (fung.: PV223)

102. Hypsizygus ulmarius (Bull.) Redhead [Lyophyllaceae Jülich; Agaricales Underw.] - Fagus sylvatica, 2012.10.08., leg. et det.: Papp V.; Fagus sylvatica (108), 2012.10.20., leg. et det.: Papp V. (fotó)

103. Inonotus cuticularis (Bull.) P. Karst. [Hymenochaetaceae Donk; Hymenochaetales Oberw.] Fagus sylvatica rönkön (95), 2011.10.29., leg. et det.: Papp V. (fung.: PV515); Fagus sylvatica iniciális korhadási fázisban lévő rönk odvas részén, 2012.08.03., leg. et det.: Papp V. (fung.: PV725); Fagus sylvatica rönkön, 2012.08.03., leg. et det.: Papp V. (fung.: PV728); Fagus sylvatica rönkön, 2012.10.10., leg. et det.: Papp V. (fung.: PV794) 
104. Inonotus dryadeus (Pers.) Murrill; $\equiv$ Pseudoinonotus dryadeus (Pers.) T. Wagner \& M. Fisch. [Hymenochaetaceae Donk; Hymenochaetales Oberw.] - élö Quercus sp. tövében, 2010.10.07., leg. et det.: Papp V.; élő Quercus petraea tövében, 2011.06.01., leg. et det.: Papp V. (fung.: PV331); élő Quercus petraea tövében, 2012.08.03., leg. et det.: Papp V. (fung.: PV726)

105. Inonotus nidus-pici Pilát ex Pilát [Hymenochaetaceae Donk; Hymenochaetales Oberw.] anamorf: élő Quercus pubescens törzsén lévő odú körül, 2012.08.03., leg. et det.: Papp V. (fung.: PV727); teleomorf: Fagus sylvatica élő odvas fa alatt talajra lehullva, 2012.10.24., leg. et det.: Papp V. (fung.: PV778)

106. Inonotus obliquus (Ach. ex Pers.) Pilát [Hymenochaetaceae Donk; Hymenochaetales Oberw.] Fagus sylvatica talajon fekvő ágán, 2013.04.24., leg. et det.: Papp V. (fung.: PV980)

107. Inonotus krawtzewii (Pilát) Pilát [Hymenochaetaceae Donk; Hymenochaetales Oberw.] - Quercus cerris, 2012.08.01., leg. et det.: Papp V. (fung.: PV715)

108. Irpex lacteus (Fr.) Fr. [Meruliaceae Rea; Polyporales Gäum.] - Quercus sp. ágon, 2010.10.07., leg. et det.: Papp V. (fung.: PV213); Fagus sylvatica, 2012.10.10., leg. et det.: Papp V. (fung.: PV791); Fagus sylvatica ágdarabon, 2012.10.24., leg. et det.: Papp V. (fung.: PV779)

109. Ischnoderma resinosum (Schrad.) P. Karst.; झ Lasiochlaena anisea Pouzar [Ischnodermataceae Jülich; Polyporales Gäum.] - Fagus sylvatica rönkön, 2010.09.14., leg. et det.: Papp V. (fung.: PV173); Fagus sylvatica rönkön, 2010.10.07., leg. et det.: Papp V.; Fagus sylvatica (61), 2011.08.03., leg. et det.: Papp V.; Fagus sylvatica (70), 2011.08.03., leg. et det.: Papp V.; Fagus sylvatica (71), 2011.08.03., leg. et det.: Papp V.; Fagus sylvatica (104), 2011.08.03., leg. et det.: Papp V.; Fagus sylvatica (117), 2011.08.03., leg. et det.: Papp V.; Fagus sylvatica (118), 2011.08.03., leg. et det.: Papp V.; Fagus sylvatica (62), 2011.08.05., leg. et det.: Papp V.; Fagus sylvatica (81), 2011.08.05., leg. et det.: Papp V.; Fagus sylvatica (95), 2011.08.05., leg. et det.: Papp V.; Fagus sylvatica (100), 2011.08.05., leg. et det.: Papp V.; Fagus sylvatica (111), 2011.08.10., leg. et det.: Papp V.; Fagus sylvatica (71), 2012.10.20., leg. et det.: Papp V.; Fagus sylvatica (102), 2012.10.20., leg. et det.: Papp V.; iniciális korhadási fázisban lévő Quercus cerris rönkön, 2012.10.20., leg. et det.:Papp V.

110. Junghuhnia nitida (Pers.) Ryvarden [Steccherinaceae Parmasto; Polyporales Gäum.] - Fagus sylvatica, 2011.06.01., leg. et det.: Papp V. (fung.: PV328)

111. Kuehneromyces mutabilis (Schaeff.) Singer \& A.H. Sm. [Strophariaceae Singer \& A.H. Sm.; Agaricales Underw.] - Fagus sylvatica (79), 2012.10.20., leg. et det.: Papp V.; Fagus sylvatica (102), 2012.10.20., leg. et det.: Papp V.

112. Laetiporus sulphureus (Bull.) Murrill [Fomitopsidaceae Jülich; Polyporales Gäum.] - Carpinus betulus, 2010.09.14., leg. et det.: Papp V. (fung.: PV176); Quercus sp., 2011.08.08., leg. et det.: Papp V. (fung.: PV444); álló, holt Quercus sp. tövében, 2012.03.15., leg. et det.: Papp V. (fung.: PV600); élő Quercus petraea törzsén, 2013.09.20., leg. et det.: Papp V. (fung.: PV984); elhalt, álló Quercus cerris, 2013.09.20., leg. et det.: Papp V. (fung.: PV985) 
113. Laxitextum bicolor (Pers.) Lentz [Hericiaceae Donk; Russulales Kreisel ex P.M. Kirk, P.F. Cannon \& J.C. David] - Fagus sylvatica rönkön, 2010.10.15., leg. et det.: Papp V. (fung.: PV265)

114. Lycoperdon pyriforme Schaeff.; $\equiv$ Morganella pyriformis (Schaeff.) Kreisel \& D. Krüger [Agaricaceae Chevall.; Agaricales Underw.] - Fagus sylvatica (78) , 2011.08.03., leg. et det. Papp V.; Fagus sylvatica (95), 2011.08.05., leg. et det.:Papp V. (fung.: PV597); Fagus sylvatica (78), 2012.10.20., leg. et det.: Papp V.; Quercus sp., 2010.09.14., leg. et det.: Papp V. (fung.: PV177)

115. Marasmius rotula (Scop.) Fr. [Marasmiaceae Roze ex Kühner; Agaricales Underw.] - Fagus sylvatica, 2010.10.07., leg. et det.: Papp V. (fung.: PV224); Fagus sylvatica (95), 2011.08.05., leg. et det.: Papp V.; Fagus sylvatica (106), 2011.08.05., leg. et det.: Papp V.; Fagus sylvatica (73), 2011.08.10., leg. et det.: Papp V.

116. Mensularia hastifera (Pouzar) T. Wagner \& M. Fisch.; $\equiv$ Inonotus hastifer Pouzar [Hymenochaetaceae Donk; Hymenochaetales Oberw.] - Fagus sylvatica, 2011.06.01., leg. et det.: Papp V. (fung.: PV334),;Fagus sylvatica, 2011.10.29., leg et det.: Papp V. (fung.: PV517)

117. Mensularia nodulosa (Fr.) T. Wagner \& M. Fisch. $\equiv$ Inonotus nodulosus (Fr.) P. Karst. [Hymenochaetaceae Donk; Hymenochaetales Oberw.] - Fagus sylvatica, 2011.08.08., leg. et det.: Papp V. (fung.: PV442)

118. Meripilus giganteus (Pers.) P. Karst. [Meripilaceae Jülich; Polyporales Gäum.] - Fagus sylvatica, 2010.09.14., leg. et det.: Papp V. (fung.: PV178); Fagus sylvatica (65), 2011.08.03., leg. et det.: Papp V.; Fagus sylvatica (81), 2011.08.05., leg. et det.: Papp V.; Fagus sylvatica, 2011.08.10., leg. et det.: Papp V. (fung.: PV458)

119. Mucidula mucida (Schrad.) Pat.; $\equiv$ Oudemansiella mucida (Schrad.) Höhn. [Physalacriaceae Corner; Agaricales Underw.] - Fagus sylvatica, 2010.09.14., leg. et det.: Papp V.; Fagus sylvatica (108), 2011.08.03., leg. et det.: Papp V.

120. Mucronella calva (Alb. \& Schwein.) Fr. [Clavariaceae Chevall.; Agaricales Underw.] - Fagus sylvatica (78), 2012.10.20., leg. et det.: Papp V., (fung.: PV795)

121. Mycena arcangeliana Bres. [Mycenaceae Overeem; Agaricales Underw.] - Fagus sylvatica, 2011.10.29., leg. et det. Papp V. (fung.: PV513)

122. Mycena crocata (Schrad.) P. Kumm. [Mycenaceae Overeem; Agaricales Underw.] - Fagus sylvatica, 2010.09.14., leg. et det.: Papp V. (fung.: PV179); Fagus sylvatica rönkön, 2011.08.03., leg. et det.: Papp V.; Fagus sylvatica (78), 2012.10.20., leg. et det.: Papp V.

123. Mycena galericulata (Scop.) Gray [Mycenaceae Overeem; Agaricales Underw.] - Fagus sylvatica (90), 2011.08.03., leg. et det.: Papp V.; Fagus sylvatica (115), 2011.08.08., leg. et det.: Papp V.; Fagus sylvatica, 2011.10.29., leg. et det.: Papp V. (fung.: PV527); Quercus sp., 2010.10.07., leg. et det.: Papp V. (fung.: PV225); Quercus sp., 2011.10.29., leg. et det.: Papp V. (fung.: PV533); Quercus sp. (4), 2012.10.20., leg. et det.: Papp V.; Quercus sp. (50), 2012.10.20., leg. et det.: Papp V.; Quercus petraea (54), leg. et det.: Papp V. (fung.: PV1024) 
124. Mycena galopus (Pers.) P. Kumm. [Mycenaceae Overeem; Agaricales Underw.] - Fagus sylvatica, 2011.10.29., leg. et det.: Papp V. (fung.: PV521)

125. Mycena haematopus (Pers.) P. Kumm. [Mycenaceae Overeem; Agaricales Underw.] - Fagus sylvatica, 2010.09.14., leg. et det.: Papp V. (fung.: PV180); Fagus sylvatica (74), 2011.08.03., leg. et det.: Papp V.; Fagus sylvatica (75), 2011.08.03., leg. et det.: Papp V.; Fagus sylvatica (98), 2011.08.03., leg. et det.: Papp V.; Fagus sylvatica (71), 2012.10.20., leg. et det.: Papp V.; Quercus sp. (14), 2010.09.14., 2011.08.08., leg. et det.: Papp V.

126. Mycena inclinata (Fr.) Quél. [Mycenaceae Overeem; Agaricales Underw.] - Quercus sp., 2011.10.29., leg. et det.: Papp V. (fung.: PV511)

127. Mycena polygramma (Bull.) Gray [Mycenaceae Overeem; Agaricales Underw.] - Fagus sylvatica, 2010.10.07., leg. et det.: Papp V. (fung.: PV226)

128. Mycena renati Quél. [Mycenaceae Overeem; Agaricales Underw.] - Fagus sylvatica (90), 2011.08.03., leg. et det.: Papp V.; Fagus sylvatica (104), 2011.08.03., leg. et det.: Papp V.; Fagus sylvatica (62), 2011.08.05., leg. et det.: Papp V.; Fagus sylvatica (67), 2011.08.05., leg. et det.: Papp V.; Fagus sylvatica (115), 2011.08.08., leg. et det.: Papp V.; Quercus sp. (43), 2011.08.05., leg. et det.: Papp V.

129. Mycetinis alliaceus (Jacq.) Earle; = Marasmius alliaceus (Jacq.) Fr. [Marasmiaceae Roze ex Kühner; Agaricales Underw.] - Fagus sylvatica, 2011.06.01., leg. et det.: Papp V. (fung.: PV332); Fagus sylvatica (63), 2011.08.03., leg. et det.: Papp V.; Fagus sylvatica (84), 2011.08.05., leg. et det.: Papp V.; Fagus sylvatica (100), 2011.08.05., leg. et det.: Papp V.; Fagus sylvatica (106), 2011.08.05., leg. et det.: Papp V.

130. Ossicaulis lachnopus (Fr.) Contu [Lyophyllaceae Jülich; Agaricales Underw.] - Fagus sylvatica, 2010.09.14., leg. Papp V., det. Papp V. et Siller I. (fung.: PV181), 2010.09.23., leg. Papp V., det. Papp V. et Siller I. (fung.: PV203); Fagus sylvatica, 2012.10.24., leg. et det.: Papp V. (fung.: PV772).

131. Oxyporus populinus (Schumach.) Donk [Oxyporaceae Zmitr. et V. Malysheva; Hymenochaetales Oberw.] - Fagus sylvatica, 2012.07.28., leg. et det.: Papp V. (fung.: PV1118)

132. Pachykytospora tuberculosa (Fr.) Kotl. \& Pouzar; $\equiv$ Haploporus tuberculosus (Fr.) Niemelä \& Y.C. Dai [Polyporaceae Corda; Polyporales Gäum.] - Quercus sp. (3), 2011.08.10., leg. et det.: Papp V.; Quercus sp. (34), 2011.10.29., leg. et det.: Papp V. (fung.: PV516); Quercus sp. rönkön, 2012.07.28., leg. et det.: Papp V. (fung.: PV699)

133. Panellus stipticus (Bull.) P. Karst. [Mycenaceae Overeem; Agaricales Underw.] - Fagus sylvatica, 2011.04.25., leg. et det.: Papp V. (fung.: PV297)

134. Panus neostrigosus Drechsler-Santos \& Wartchow; $\equiv$ Lentinus strigosus Fr.; = Panus lecomtei (Fr.) Corner; = Panus rudis Fr. [Podoscyphaceae D.A. Reid s. lato; Polyporales Gäum.] - Fagus sylvatica rönkön, 2010.09.23., leg. et det.: PappV. (fung.: PV202); Fagus sylvatica rönkön, 2011.08.03., leg. et det.: Papp V. (fung.: PV409) 
135. Peniophora nuda (Fr.) Bres. [Peniophoraceae Lotsy; Russulales Kreisel ex P.M. Kirk, P.F. Cannon \& J.C. David - Quercus sp., 2012.03.15., leg. et det.: Papp V. (fung.: PV602)

136. Peniophora quercina (Pers.) Cooke [Peniophoraceae Lotsy; Russulales Kreisel ex P.M. Kirk, P.F. Cannon \& J.C. David] - Quercus sp., 2012.03.15., leg. et det.: Papp V. (fung.: PV598)

137. Phaeomarasmius erinaceus (Fr.) Scherff. ex Romagn. [Tubariaceae Vizzini; Agaricales Underw.] - Quercus pubescens ágon, 2013.10.25., leg. et det. Papp V. (fung.: PV1021)

138. Phanerochaete aculeata Hallenb. [Meruliaceae Rea s. lato; Polyporales Gäum.] - Fagus sylvatica elhalt faanyagán, 2012.10.10., leg. et det.: Papp V. (fung.: PV797)

139. Phanerochaete velutina (DC.) P. Karst. [Meruliaceae Rea s. lato; Polyporales Gäum.] - Quercus cerris rönkön, 2011.07.22., leg. et det.: Papp V. (fung.: PV384)

140. Phanerochaete cf. sanguinea (Fr.) Pouzar [Meruliaceae Rea s. lato; Polyporales Gäum.] - Fagus sylvatica, 2012.10.08., leg. et det.: Papp V. (fung.: PV765)

141. Phlebia nothofagi (G. Cunn.) Nakasone; = Mycoacia nothofagi (G. Cunn.) Ryvarden [Meruliaceae Rea s. lato; Polyporales Gäum.] - Fagus sylvatica, 2011.07.22., leg. et det.: Papp V. (fung.: PV387); Fagus sylvatica, 2011.07.22., leg. et det.: Papp V. (fung.: PV549); Fagus sylvatica (79), 2011.08.03., leg. et det.: Papp V. (fung.: PV551); Fagus sylvatica (77), 2012.10.20., leg. et det.: Papp V. (fung.: PV1031).

142. Phlebia fuscoatra (Fr.) Nakasone [Meruliaceae Rea s. lato; Polyporales Gäum.] - Fagus sylvatica rönkön, 2011.06.10., leg. et det.: Papp V. (fung.: PV340)

143. Phlebia radiata Fr. [Meruliaceae Rea s. lato; Polyporales Gäum.] - Quercus petraea (20), 2011.10.29., leg. et det.: Papp V. (fung.: PV508); Fagus sylvatica rönkön, 2011.10.29., leg. et det.: Papp V. (fung.: PV514); Quercus sp., (20), 2012.10.20., leg. et det.: Papp V.

144. Phlebia rufa (Pers.) M.P. Christ. [Meruliaceae Rea s. lato; Polyporales Gäum.] - cf. Fagus sylvatica rönkön, 2011.08.05., leg. et det.: Papp V. (fung.: PV426); Fagus sylvatica rönkön, 2012.10.08., leg. et det.: Papp V. (fung.: PV762)

145. Phlebia tremellosa (Schrad.) Nakasone \& Burds.; $\equiv$ Merulius tremellosus Schrad. [Meruliaceae Rea s. lato; Polyporales Gäum.] - Fagus sylvatica rönkön, 2010.09.14., leg. et det.: Papp V. (fung.: PV183); Fagus sylvatica (71), 2012.10.20., leg. et det.: Papp V.

146. Phlebia uda (Fr.) Nakasone; इ Mycoacia uda (Fr.) Donk [Meruliaceae Rea s. lato; Polyporales Gäum.] - cf. Fagus sylvatica, 2012.10.10., leg. et det.: Papp V. (PV1117)

147. Phlebiella vaga (Fr.) P. Karst.; 三 Trechispora vaga (Fr.) Liberta [Xenasmataceae Oberw.; Polyporales Gäum.] - Quercus sp., 2011.08.08., leg. et det.: Papp V. (fung.: PV448); Quercus petraea (7), 2011.08.10., leg. et det.: Papp V. (fung.: PV581)

148. Phleogena faginea (Fr. \& Palmquist) Link [Phleogenaceae Weese; Atractiellales Oberw. \& Bandoni; = Phleogenales Doweld] - iniciális korhadási fázisban lévő Fagus sylvatica rönkön, 2010.10.07., leg. et det. Papp V. (fung.: PV230); Fagus sylvatica rönkön, 2010.10.15., leg. et det. Papp V. (fung.: PV266) 
149. Pholiota adiposa (Batsch) P. Kumm. [Strophariaceae Singer \& A.H. Sm.; Agaricales Underw.] Fagus sylvatica rönkön, 2010.10.07., leg. et det.: Papp V. (fung.: PV231); Fagus sylvatica rönkön, 2011.10.29., leg. et det.: Papp V. (fung.: PV512)

150. Pholiota squarrosoides (Peck) Sacc. [Strophariaceae Singer \& A.H. Sm.; Agaricales Underw.] Fagus sylvatica rönkön, 2010.10.07., leg. et det.: Papp V., (fung: PV335), 2011.06.01., leg. et det.: Papp V. (fung.: PV495/PV540 /BP 106902).

151. Pholiota sp. (1) [Strophariaceae Singer \& A.H. Sm.; Agaricales Underw.] - Fagus sylvatica rönkön, 2010.10.07., leg. et det.: Papp V. (fung.: PV232)

152. Pholiota sp. (2) [Strophariaceae Singer \& A.H. Sm.; Agaricales Underw.] - Prunus avium subsp. avium rönkön, 2011.10.15., leg. et det.: Papp V. (fung.: PV486)

153. Phylloporia ribis (Schumach.) Ryvarden; $\equiv$ Phellinus ribis (Schumach.) Quél. [Hymenochaetaceae Donk; Hymenochaetales Oberw.] - élő Cornus mas tövében, 2013.10.25., leg. et det.: Papp V. (fung.: PV982)

154. Physisporinus sanguinolentus (Alb. \& Schwein.) Pilát; $\equiv$ Rigidoporus sanguinolentus (Alb. \& Schwein.) Donk [Meripilaceae Jülich; Polyporales Gäum.] - Fagus sylvatica rönkön, 2012.07.28., leg. et det.: Papp V. (fung.: PV689); Fagus sylvatica (78), 2012.10.20., leg. et det.: Papp V.

155. Physisporinus vitreus (Pers.) P. Karst.; 三 Rigidoporus vitreus (Pers.) Donk [Meripilaceae Jülich; Polyporales Gäum.] - Fagus sylvatica rönkön, 2012.10.08., leg. et det.: Papp V. (fung.: PV763); Fagus sylvatica (124), 2012.10.24., leg. et det.: Papp V. (fung.: PV783)

156. aff. Pleuroflammula [Incertae sedis; Agaricales Underw.] - Fagus sylvatica (92), 2013.10.28., leg.: Papp V. (fung.: PV983)

157. Pleurotus ostreatus (Jacq.) P. Kumm. [Pleurotaceae Kühner; Agaricales Underw.] - Fagus sylvatica rönkön, 2010.10.07., leg. et det.: Papp V. (fung.: PV233); Fagus sylvatica rönkön, 2011.04.25., leg. et det.: Papp V. (fung.: PV300); Fagus sylvatica (65), 2011.08.03., leg. et det.: Papp V.; Fagus sylvatica (86), 2011.08.03., leg. et det.: Papp V.; Fagus sylvatica (87), 2011.08.03., leg. et det.: Papp V.; Fagus sylvatica (108), 2011.08.03., leg. et det.: Papp V.

158. Pleurotus pulmonarius (Fr.) Quél. [Pleurotaceae Kühner; Agaricales Underw.] - Fagus sylvatica rönkön, 2010.10.07., leg. et det.: Papp V. (fung.: PV234)

159. Pluteus cervinus (Schaeff.) P. Kumm. [Pluteaceae Kotl. \& Pouzar; Agaricales Underw.] - Fagus sylvatica rönkön, 2010.10.07., leg et det.: Papp V.; Fagus sylvatica rönkön, 2011.05.18., leg et det.: Papp V. (fung.: PV316); Fagus sylvatica rönkön, 2011.06.01., leg et det.: Papp V. (fung.: PV336); Fagus sylvatica rönkön, 2011.06.10., leg et det.: Papp V. (fung.: PV341); Fagus sylvatica rönkön, 2011.07.07., leg et det.: Papp V. (fung.: PV365); Fagus sylvatica (72), 2011.08.03., leg et det.: Papp V. (fung.: PV412); Fagus sylvatica (77), 2011.08.03., leg et det.: Papp V. (fung.: PV413); Fagus sylvatica (118), 2011.08.03., leg et det.: Papp V.; Fagus sylvatica (67), 2011.08.05., leg et det.: Papp V.; Fagus sylvatica (81), 2011.08.05., leg et det.: Papp V.; Fagus sylvatica (69), 2011.08.10., leg et det.: Papp V. 
Pluteus cervinus var. albus Peck [Pluteaceae Kotl. \& Pouzar; Agaricales Underw.] - Fagus sylvatica rönkön, 2011.07.13., leg. et det.: Papp V. (fung.: PV379); Fagus sylvatica rönkön, 2012.08.01., leg. et det.: Papp V. (fung.: PV704)

160. Pluteus chrysophaeus (Schaeff.) Quél.; = P. luteovirens Rea [Pluteaceae Kotl. \& Pouzar; Agaricales Underw.] - Fagus sylvatica (124), 2011.08.05., leg. et det.: Papp V. (fung.: PV1119); Fagus sylvatica, 2012.08.01., leg. et det.: Papp V. (fung.: PV720)

161. Pluteus diettrichii Bres. [Pluteaceae Kotl. \& Pouzar; Agaricales Underw.] - Fagus sylvatica rönkön, 2012.10.28. leg. et det.: Papp V. (fung.: PV1120).

162. Pluteus cf. hiatulus Romagn.; = P. plautus (Weinm.) Gillet [Pluteaceae Kotl. \& Pouzar; Agaricales Underw.] - cf. Fagus sylvatica, 2012.08.01., leg. et det.: Papp V. (fung.: PV1121)

163. Pluteus hispidulus (Fr.) Gillet [Pluteaceae Kotl. \& Pouzar; Agaricales Underw.] - Fagus sylvatica, 2012.10.10., leg. et det.: Papp V. (fung.: PV796)

164. Pluteus leoninus (Schaeff.) P. Kumm. [Pluteaceae Kotl. \& Pouzar; Agaricales Underw.] - Fagus sylvatica rönkön, 2010.09.23., leg et det.: Papp V. (fung.: PV204); Fagus sylvatica (98), 2011.08.03., leg et det.: Papp V.; Fagus sylvatica rönkön, 2011.08.03., leg. et det.: Papp V.; Quercus cerris rönkön, 2011.06.13., leg. et det.: Papp V. (fung.: PV350)

165. Pluteus luctuosus Boud. [Pluteaceae Kotl. \& Pouzar; Agaricales Underw.] - Fagus sylvatica, 2010.08.10., leg. et det.: Papp V. (fung.: PV1122)

166. Pluteus petasatus (Fr.) Gillet [Pluteaceae Kotl. \& Pouzar; Agaricales Underw.] - Fagus sylvatica rönkön, 2011.07.07., leg. et det.: Papp V. (fung.: PV366)

167. Pluteus phlebophorus (Ditmar) P. Kumm. [Pluteaceae Kotl. \& Pouzar; Agaricales Underw.] Fagus sylvatica rönkön, 2010.09.14., leg. et det.: Papp V. (fung.: PV184)

168. Pluteus cf. pseudoroberti M.M. Moser [Pluteaceae Kotl. \& Pouzar; Agaricales Underw.] - Fagus sylvatica rönkön, 2011.08.10., leg et det.: Papp V. (fung.: PV459)

169. Pluteus romellii (Britzelm.) Lapl. [Pluteaceae Kotl. \& Pouzar; Agaricales Underw.] - Fagus sylvatica rönkön, 2010.09.14., leg. et det.: Papp V. (fung.: PV185)

170. Pluteus salicinus (Pers.) P. Kumm. [Pluteaceae Kotl. \& Pouzar; Agaricales Underw.] - Fagus sylvatica rönkön, 2010.09.14., leg. et det.: Papp V. (fung.: PV186); Fagus sylvatica (77), 2011.08.03., leg. et det.: Papp V. (fung.: PV414)

171. Pluteus semibulbosus (Lasch) Gillet [Pluteaceae Kotl. \& Pouzar; Agaricales Underw.] - Fagus sylvatica rönkön, 2011.06.10., leg. et det.: Papp V. (fung.: PV342)

172. Pluteus thomsonii (Berk. \& Broome) Dennis [Pluteaceae Kotl. \& Pouzar; Agaricales Underw.] Fagus sylvatica rönkön, 2011.07.13., leg. et det.: Papp V. (fung.: PV382), Fagus sylvatica rönkön, 2011.08.05., leg. et det.: Papp V. (fung.: PV430)

173. Pluteus umbrosus (Pers.) P. Kumm. [Pluteaceae Kotl. \& Pouzar; Agaricales Underw.] - Fagus sylvatica rönkön, 2010.10.07., leg. et det.: Papp V.; Fagus sylvatica rönkön, 2014.09.09., leg. et det.: Papp V. (fotó) 
174. Polyporus alveolaris (DC.) Bondartsev \& Singer; $\equiv$ Polyporellus alveolaris (DC.) Pilát; = Polyporus mori (Pollini) Fr. [Polyporaceae Corda; Polyporales Gäum.] - Fagus sylvatica rönkön, 2012.08.03., leg. et det.: Papp V. (fung.: PV736)

175. Polyporus arcularius (Batsch) Fr.; $\equiv$ Polyporellus arcularius (Batsch) P. Karst. [Polyporaceae Corda; Polyporales Gäum.] - Fagus sylvatica, 2011.05.07., leg. et det.: Papp V. (fung.: PV312); Fagus sylvatica, 2011.06.10., leg. et det.: Papp V. (fung.: PV345); Fagus sylvatica, 2011.08.05., leg. et det.: Papp V. (fung.: PV431); Fagus sylvatica, 2012.08.03., leg. et det.: Papp V. (fung.: PV735)

176. Polyporus badius (Pers.) Schwein.; $\equiv$ Royoporus badius (Pers.) A.B. De [Polyporaceae Corda; Polyporales Gäum.] - Fagus sylvatica rönkön, 2010.09.14., leg. et det.: Papp V. (fung.: PV187); Fagus sylvatica rönkön, 2012.08.01., leg. et det.: Papp V. (fung.: PV714); Fagus sylvatica rönkön (103), 2012.10.20., leg. et det.: Papp V. (fung.: PV787)

177. Polyporus brumalis (Pers.) Fr.; $\equiv$ Polyporellus brumalis (Pers.) P. Karst. [Polyporaceae Corda; Polyporales Gäum.] - Fagus sylvatica rönkön, 2010.10.07., leg. et det.: Papp V. (fung.: PV238); Fagus sylvatica rönkön, 2010.10.15., leg. et det.: Papp V. (fung.: PV267); Fagus sylvatica ágdarabon, 2012.10.08., leg. et det.: Papp V. (fung.: PV761)

178. Polyporus ciliatus Fr. [Polyporaceae Corda; Polyporales Gäum.] - Fagus sylvatica rönkön, 2013.09.20., leg. et det.: Papp V. (fung.: PV1131)

179. Polyporus squamosus (Huds.) Fr. [Polyporaceae Corda; Polyporales Gäum.] - élő, öreg Acer campestre törzsén, 2011.05.07., leg. et det.: Papp V. (fung.: PV313); Fagus sylvatica (63), 2011.08.03., leg. et det.: Papp V.

180. Polyporus tuberaster (Jacq. ex Pers.) Fr. [Polyporaceae Corda; Polyporales Gäum.] - Fagus sylvatica, 2011.08.08., leg. et det.: Papp V. (fotó)

181. Polyporus varius (Pers.) Fr.; = Polyporus leptocephalus (Jacq.) Fr. [Polyporaceae Corda; Polyporales Gäum.] - Fagus sylvatica ágdarabon, 2012.07.15., leg. et det.: Papp V. (fung.: PV670); Fagus sylvatica ágdarabon, 2012.08.01., leg. et det.: Papp V. (fung.: PV717); Quercus sp., 2011.08.10., leg. et det.: Papp V.

182. Porostereum spadiceum (Pers.) Hjortstam \& Ryvarden; $\equiv$ Lopharia spadicea (Pers.) Boidin [Polyporaceae Corda; Polyporales Gäum.] - Quercus sp., 2011.08.08., leg. et det.: Papp V. (fung.: PV445); Quercus petraea (20), 2011.10.29. leg. et det. Papp V. (fung.: PV509)

183. Postia alni Niemelä \& Vampola [Fomitopsidaceae Jülich; Polyporales Gäum.] - Fagus sylvatica rönkön, 2010.09.14., leg. et det.: Papp V. (fung.: PV188).

184. Postia stiptica (Pers.) Jülich [Fomitopsidaceae Jülich; Polyporales Gäum.] - Fagus sylvatica (118), 2011.08.03., leg. et det.: Papp V. (fung.: PV411)

185. Psathyrella spadicea (Schaeff.) Singer agg. [Psathyrellaceae Vilgalys, Moncalvo \& Redhead; Agaricales Underw.] - Fagus sylvatica (71), 2012.10.20., leg. et det.: Papp V. (fung.: PV1023) 
186. Radulomyces molaris (Chaillet ex Fr.) M.P. Christ. [Pterulaceae Corner; Agaricales Underw.] Quercus sp., 2011.03.04., leg. et det.: Papp V. (fung.: PV277); Quercus pubescens (60), 2011.08.10.; Fraxinus ornus, 2011.08.08., leg. et det.: Papp V. (fung.: PV443)

187. Ramaria stricta (Pers.) Quél. [Gomphaceae Donk; Gomphales Jülich] - Fagus sylvatica (77), 2010.09.23., leg. et det.: Papp V., 2012.10.20., leg. et det.: Papp V.; Fagus sylvatica, 2013.10.25., leg. et det.: Papp V. (fung.: PV981)

188. Resupinatus applicatus (Batsch) Gray [Tricholomataceae R. Heim ex Pouzar; Agaricales Underw.] - Fagus sylvatica, 2011.08.05., leg. et det.: Papp V. (fung.: PV432)

189. Rickenella fibula (Bull.) Raithelh. [Rickenellaceae Vizzini; Hymenochaetales Oberw.] - Fagus sylvatica (100), 2011.08.05., leg. et det.: Papp V.; Quercus sp. (49), 2011.08.03., leg. et det.: Papp V. (fung.: PV1124)

190. Rickenella swartzii (Fr.) Kuyper $[=R$. setipes (Fr.) Raithelh. [Rickenellaceae Vizzini; Hymenochaetales Oberw.] - Fagus sylvatica (100), 2011.08.05., leg. et det.: Papp V. (fung.: PV1125)

191. Schizophyllum commune Fr. [Schizophyllaceae Quél.; Agaricales Underw.] - Acer campestre, 2010.09.14., leg. et det.: Papp V.; Fagus sylvatica (65), 2011.08.03., leg. et det.: Papp V. (fung.: PV415)

192. Schizopora flavipora (Berk. \& M.A. Curtis ex Cooke) Ryvarden [Schizoporaceae Jülich; Hymenochaetales Oberw.] - Fagus sylvatica, 2012.07.15., leg. et det.: Papp V. (fung.: PV661); Fagus sylvatica, 2012.07.15., leg. et det.: Papp V. (fung.: PV658); Tilia sp., 2010.09.23., leg. et det.: Papp V. (fung.: PV205)

193. Schizopora paradoxa (Schrad.) Donk agg. [Schizoporaceae Jülich; Hymenochaetales Oberw.] Quercus sp. rönkön, 2012.07.15., leg. et det.: Papp V. (fung.: PV666); Fagus sylvatica rönkön, 2012.10.10., leg. et det.: Papp V. (fung.: PV800); Quercus petraea (58), leg. et det.: Papp V.

194. Scytinostroma hemidichophyticum Pouzar [Lachnocladiaceae D.A. Reid; Russulales Kreisel ex P.M. Kirk, P.F. Cannon \& J.C. David] - Fagus sylvatica holt fekvő rönkön, 2011.10.29., leg. et det.: Papp V. (fung.: PV522); Quercus petraea holf fekvő rönkön, 2011.10.29., leg. et det.: Papp V. (fung.: PV529)

195. Serpula himantioides (Fr.) P. Karst. [Serpulaceae Jarosch \& Bresinsky; Boletales E.-J. Gilbert] Fagus sylvatica rönkön, 2010.10.15., leg. et det.: Papp V. (fung.: PV269); Quercus petraea rönkön, 2012.10.08., leg. et det.: Papp V. (fung.: PV1034)

196. Simocybe centunculus (Fr.) P. Karst. [Crepidotaceae (S. Imai) Singer; Agaricales Underw.] Fagus sylvatica rönkön, 2011.08.03., leg. et det.: Papp V. (fung.: PV1126)

197. Simocybe sumptuosa (P.D. Orton) Singer [Crepidotaceae (S. Imai) Singer; Agaricales Underw.] Fagus sylvatica, 2010.09.23., leg.: Papp V., det.: Papp V. és Dima B. (fung.: PV191); Fagus sylvatica, 2011.08.03., leg. et det. Papp V. (PV416) 
198. Spongipellis delectans (Peck) Murrill [Podoscyphaceae D.A. Reid s. lato; Polyporales Gäum.] Fagus sylvatica rönkön, 2010.10.07., leg. et det.: Papp V. (fung.: PV244), 2010.10.15., leg. et det.: Papp V. (fung.: PV270)

199. Spongipellis litschaueri Lohwag; = S. irpex (Schulz.) Z. Igmándy ss. auct. [Podoscyphaceae D.A. Reid s. lato; Polyporales Gäum.] - Quercus sp., 2010.09.23., leg. et det.: Papp V. (fung.: PV208); Quercus cerris, 2012.08.03., leg. et det.: Papp V. (fung.: PV737)

200. Steccherinum bourdotii Saliba \& A. David [Steccherinaceae Parmasto; Polyporales Gäum.] Quercus sp., 2011.08.08., leg. et det.: Papp V. (fung.: PV989); Fagus sylvatica, 2011.03.04., leg. et det.: Papp V. (fung.: PV278); Fagus sylvatica, 2012.07.15., leg. et det.: Papp V. (fung.: PV660); Quercus sp., 2011.10.29., leg. et det.: Papp V. (fung.: PV531)

201. Steccherinum ochraceum (Pers. ex J.F. Gmel.) Gray agg. [Steccherinaceae Parmasto; Polyporales Gäum.] - Quercus pubescens, 2011.07.07., leg. et det.: Papp V. (fung.: PV372)

202. Stereum gausapatum (Fr.) Fr. [Stereaceae Pilát; Russulales Kreisel ex P.M. Kirk, P.F. Cannon \& J.C. David] - Quercus sp., 2010.10.07., leg. et det.: Papp V. (fung.: PV245)

203. Stereum hirsutum (Willd.) Pers. [Stereaceae Pilát; Russulales Kreisel ex P.M. Kirk, P.F. Cannon \& J.C. David] - Fagus sylvatica, 2010.10.07. leg. et det.: Papp V. (fung.: PV246); Fagus sylvatica (64), 2011.08.03., leg. et det.: Papp V.; Fagus sylvatica (113), 2011.08.03., leg. et det.: Papp V.; Quercus sp. (43), 2011.08.05., leg. et det.: Papp V.; Quercus sp. (10) 2011.08.08., leg. et det.: Papp V.; Quercus sp. (14) 2011.08.08., leg. et det.: Papp V.; Quercus sp. (16) 2011.08.08., leg. et det.: Papp V.; Quercus sp. (18) 2011.08.08., leg. et det.: Papp V.; Quercus sp. (20) 2011.08.08., leg. et det.: Papp V.; Quercus sp. (25), 2011.08.10., leg. et det.: Papp V.; Quercus sp. (20), 2012.10.20., leg. et det.: Papp V.; Carpinus betulus rönkön, 2011.04.25., leg. et det.: Papp V. (fung.: PV301)

204. Stereum ochraceoflavum (Schwein.) Sacc. [Stereaceae Pilát; Russulales Kreisel ex P.M. Kirk, P.F. Cannon \& J.C. David] - Quercus sp., 2011.08.03., leg. et det.: Papp V. (fung.: PV1132)

205. Stereum cf. rugosum Pers. [Stereaceae Pilát; Russulales Kreisel ex P.M. Kirk, P.F. Cannon \& J.C. David] - Quercus sp., 2010.09.14., leg. et det.: Papp V. (fung.: PV189)

206. Stereum subtomentosum Pouzar [Stereaceae Pilát; Russulales Kreisel ex P.M. Kirk, P.F. Cannon \& J.C. David] - Fagus sylvatica, 2010.09.14., leg. et det.: Papp V. (fung.: PV190); Fagus sylvatica, 2011.07.22., leg. et det.: Papp V. (fung.: PV389); Fagus sylvatica rönkön, 2011.08.03., leg. et det.: Papp V.; Quercus sp., 2010.09.14., leg. et det.: Papp V.

207. Stropharia aeruginosa (Curtis) Quél. [Strophariaceae Singer \& A.H. Sm.; Agaricales Underw.] Fagus sylvatica rönk tövében, 2012.10.20., leg. et det.: Papp V. (fung.: PV788)

208. Trametes betulina (L.) Pilát; $\equiv$ Lenzites betulina (L.) Fr. [Polyporaceae Corda; Polyporales Gäum.] - Fagus sylvatica, 2011.08.03., leg. et det.: Papp V. (fung.: PV410)

209. Trametes gibbosa (Pers.) Fr. [Polyporaceae Corda; Polyporales Gäum.] - Fagus sylvatica, 2010.09.14., leg. et det.: Papp V.; Fagus sylvatica, 2011.04.25., leg. et det.: Papp V. (fung.: 
PV302); Fagus sylvatica (70), 2011.08.03., leg. et det.: Papp V.; Fagus sylvatica (113), 2011.08.03., leg. et det.: Papp V. (fung.: PV593)

210. Trametes hirsuta (Wulfen) Lloyd [Polyporaceae Corda; Polyporales Gäum.] - Fagus sylvatica, 2010.09.14., leg. et det.: Papp V. (fung.: PV192); Fagus sylvatica, 2011.04.25., leg. et det.: Papp V. (fung.: PV303); Fagus sylvatica, 2011.08.03., leg. et det.: Papp V. (fung.: PV417); Fagus sylvatica (65), 2011.08.03., leg. et det.: Papp V.; Fagus sylvatica (112), 2011.08.03., leg. et det.: Papp V.

211. Trametes ochracea (Pers.) Gilb. \& Ryvarden; = T. zonata (Nees) Pilát [Polyporaceae Corda; Polyporales Gäum.] - Fagus sylvatica rönkön, 2012.07.15., leg. et det.: Papp V. (fung.: PV659)

212. Trametes pubescens [Polyporaceae Corda; Polyporales Gäum.] - Fagus sylvatica, 2012.08.03., leg. et det.: Papp V. (fung.: PV733)

213. Trametes versicolor (L.) Lloyd [Polyporaceae Corda; Polyporales Gäum.] - Fagus sylvatica, 2010.09.14., leg. et det.: Papp V. (fung.: PV193); Fagus sylvatica, 2010.10.07., leg. et det.: Papp V. (fung.: PV247); Quercus sp. (25), 2011.08.10., leg. et det.: Papp V.

214. Trametopsis cervina (Schwein.) Tomsovský; $\equiv$ Trametes cervina (Schwein.) Bres. [Meruliaceae Rea s. lato; Polyporales Gäum.] - Fagus sylvatica, 2010.10.07., leg. et det.: Papp V. (fung.: PV248); Fagus sylvatica rönkön, 2011.03.04., leg. et det.: Papp V. (fung.: PV279); Fagus sylvatica (68), 2011.08.10., leg. et det.: Papp V.); Quercus cerris rönkön, 2010.09.14., leg. et det.: Papp V. (fung.: PV194)

215. Tremella foliacea Pers. [Tremellaceae Fr.; Tremellales Fr.] - Fagus sylvatica faanyagán lévő Stereum faj termőtestén, 2010.10.07., leg. et det. Papp V. (fung.: PV249)

216. Tremella mesenterica (Schaeff.) Retz. [Tremellaceae Fr.; Tremellales Fr.] - Carpinus betulusi ágon, 2011.08.08., leg. et det. Papp V. (fung.: PV451)

217. Trichaptum biforme (Fr.) Ryvarden [Polyporaceae Corda; Polyporales Gäum.] - Fagus sylvatica rönkön, 2010.09.23., leg. et det.: Papp V. (fung.: PV209), Fagus sylvatica (65), 2011.08.03., leg. et det.: Papp V. (fung.: PV418); Quercus sp. (20), 2011.08.08., leg. et det.: Papp V.; Quercus sp. (25), 2011.08.10., leg. et det.: Papp V.

218. Typhula fistulosa (Holmsk.) Olariaga; $\equiv$ Macrotyphula fistulosa (Holmsk.) R.H. Petersen [Typhulaceae Jülich; Agaricales Underw.] - Fagus sylvatica talajban lévő faanyagán, 2012.10.10., leg. et det.: Papp V. (fung.: PV1127)

219. Tyromyces chioneus (Fr.) P. Karst. [Polyporaceae Corda; Polyporales Gäum.] - Fagus sylvatica rönkön, 2014.08.16., leg. et det.: Papp V. (fung.: PV1128)

220. Xylobolus frustulatus (Pers.) Boidin [Stereaceae Pilát; Russulales Kreisel ex P.M. Kirk, P.F. Cannon \& J.C. David] - Quercus petraea rönkön, 2010.10.07., leg. et det.: Papp V. (fung.: PV250); Quercus sp., 2011.03.04., leg. et det.: Papp V. (fung.: PV280); Quercus petraea rönkön, 2011.04.25., leg. et det.: Papp V. (fung.: PV304); Quercus pubescens, 2011.02.21.; Quercus sp. (49), 2011.08.03., leg. et det.: Papp V. (fung.: PV564); Quercus sp. (21), 2011.08.08., leg. et det.: 
Papp V. (fung.: PV452); Quercus sp. (53), 2011.08.08., leg. et det.: Papp V.; Quercus sp. (31), 2011.08.10., leg. et det.: Papp V.; Quercus sp. (56), 2011.08.10., leg. et det.: Papp V.

221. Xylobolus subpileatus (Berk. \& M.A. Curtis) Boidin [Stereaceae Pilát; Russulales Kreisel ex P.M. Kirk, P.F. Cannon \& J.C. David] - elhalt álló Quercus cerris törzsén, 2010.10.07., leg. et det.: Papp V. (fung.: PV251); Quercus cf. cerris holt fekvő rönkön, 2011.04.25., leg. et det.: Papp V. (fung.: PV305); Quercus cf. cerris rönkön, 2011.08.08., leg. et det.: Papp V. (fung.: PV453).

222. Xylodon quercinus (Pers.) Gray; $\equiv$ Hyphodontia quercina (Pers.) J. Erikss. [Schizoporaceae Jülich; Hymenochaetales Oberw.] - Quercus sp., 2011.08.08., leg. et det.: Papp V. (fung.: PV1129)

223. Vuilleminia comedens (Nees) Maire [Corticiaceae Herter; Corticiales K.H. Larss.] - Quercus pubescens ágon, 2012.10.08., leg. et det.: Papp V. (fung.: PV1130) 
M4.2. A Juhdöglö-völgy Erdőrezervátum területén gyüjtött lignikol aszkuszos nagygombák fajlistája alfabetikus sorrendben. A tudományos név után az adott taxon aktuális szisztematikai besorolása (család és rend), a szubsztrátumként szolgáló fafaj neve, a kijelölt rönk sorszáma zárójelben feltüntetve (lásd. M5. melléklet), a gyüjtés dátuma, a gyüjtő (leg.) és határozó (det.) személye, valamint a Budapesti Corvinus Egyetem Növénytani Tanszékén elhelyezett fungáriumi minta (PV) adatai következnek.

224. Ascocoryne cylichnium (Tul.) Korf [Helotiaceae Rehm; Helotiales Nannf.] - Fagus sylvatica, 2011.08.03., leg. et det.: Papp V.

225. Biscogniauxia nummularia (Bull.) Kuntze [Xylariaceae Tul. \& C. Tul.; Xylariales Nannf.] Fagus sylvatica, 2010.10.15., leg. et det.: Papp V. (fung.: PV254)

226. Bisporella citrina (Batsch) Korf \& S.E. Carp. agg. [Helotiaceae Rehm; Helotiales Nannf.] - Fagus sylvatica, 2010.10.15., leg. et det.: Papp V. (fung.: PV255)

227. Bulgaria inquinans (Pers.) Fr. [Bulgariaceae Fr.; Helotiales Nannf.] - Quercus cerris rönkön, leg. et det.: Papp V.

228. Chlorociboria sp. [Helotiaceae Rehm; Helotiales Nannf.] - Fagus sylvatica faanyagán látható kékes elszíneződés (aszkokarpiumok nem voltak), 2011.03.04., leg. et det.: Papp V.

229. Daldinia sp. [Xylariaceae Tul. \& C. Tul.; Xylariales Nannf.] - Carpinus betulus, 2011.04.25., leg. et det.: Papp V. (fung.: PV291)

230. Eutypa spinosa (Pers.) Tul. \& C. Tul. [Diatrypaceae Nitschke; Xylariales Nannf.] - Fagus sylvatica rönkön, 2010.10.15., leg. et det.: Papp V. (fung.: PV261); Fagus sylvatica (61), 2011.08.03., leg. et det.: Papp V.; Fagus sylvatica (70), 2011.08.03., leg. et det.: Papp V.; Fagus sylvatica (71), 2011.08.03., leg. et det.: Papp V.; Fagus sylvatica (74), 2011.08.03., leg. et det.: Papp V.; Fagus sylvatica (76), 2011.08.03., leg. et det.: Papp V.; Fagus sylvatica (82), 2011.08.03., leg. et det.: Papp V.; Fagus sylvatica (89), 2011.08.03., leg. et det.: Papp V.; Fagus sylvatica (98), 2011.08.03., leg. et det.: Papp V.; Fagus sylvatica (107), 2011.08.03., leg. et det.: Papp V.; Fagus sylvatica (114), 2011.08.03., leg. et det.: Papp V.; Fagus sylvatica (117), 2011.08.03., leg. et det.: Papp V.; Fagus sylvatica (118), 2011.08.03., leg. et det.: Papp V.; Fagus sylvatica rönkön, 2011.08.03., leg. et det.: Papp V.; Fagus sylvatica (67), 2011.08.05., leg. et det.: Papp V.; Fagus sylvatica (80), 2011.08.05., leg. et det.: Papp V.; Fagus sylvatica (100), 2011.08.05., leg. et det.: Papp V.; Fagus sylvatica (124), 2011.08.05., leg. et det.: Papp V.; Fagus sylvatica (68), 2011.08.10., leg. et det.: Papp V.; Fagus sylvatica (73), 2011.08.10., leg. et det.: Papp V.; Fagus sylvatica (111), 2011.08.10., leg. et det.: Papp V.; Fagus sylvatica (71), 2012.10.20., leg. et det.: Papp V.; Fagus sylvatica (114), 2012.10.20., leg. et det.: Papp V.

231. Hypoxylon fragiforme (Pers.) J. Kickx f. [Xylariaceae Tul. \& C. Tul.; Xylariales Nannf.] - Fagus sylvatica, 2010.10.15., leg. et det.: Papp V. (fung.: PV263); Fagus sylvatica (76), 2011.08.03., leg. et det.: Papp V.; Fagus sylvatica (83), 2011.08.03., leg. et det.: Papp V.; Fagus sylvatica (113), 2011.08.03., leg. et det.: Papp V.; Fagus sylvatica (114), 2011.08.03., leg. et det.: Papp V. 
232. Hypoxylon cf. rubiginosum (Pers.) Fr. [Xylariaceae Tul. \& C. Tul.; Xylariales Nannf.] - Fagus sylvatica, 2010.05.28., leg. et det.: Papp V. (fung.: PV64)

233. Kretzschmaria deusta (Hoffm.) P.M.D. Martin; 三 Hypoxylon deustum (Hoffm.) Grev. [Xylariaceae Tul. \& C. Tul.; Xylariales Nannf.] - Fagus sylvatica, 2010.09.14., leg. et det.: Papp V. (fung.: PV175); Fagus sylvatica, 2011.04.25., leg. et det.: Papp V. (fung.: PV296); Fagus sylvatica, 2011.05.20., leg. et det.: Papp V. (fung.: PV320); Fagus sylvatica (78), 2011.08.03., leg. et det.: Papp V.; Fagus sylvatica rönkön, 2011.08.03., leg. et det.: Papp V.; Fagus sylvatica (81), 2011.08.05., leg. et det.: Papp V.; Fagus sylvatica (69), 2011.08.10., leg. et det.: Papp V.

234. Peziza micropus Pers. [Pezizaceae Dumort., Pezizales J. Schröt.] - Fagus sylvatica, 2010.09.14., leg. et det.: Papp V.; Fagus sylvatica (95), 2011.08.05., leg. et det.: Papp V. (fung.: PV425)

235. Scutellinia scutellata (L.) Lambotte agg. [Pyronemataceae Corda; Pezizales J. Schröt.] - Fagus sylvatica, 2010.09.23., leg. et det.: Papp V. (fung.: PV206); Fagus sylvatica (81), 2011.08.05., leg. et det.: Papp V.

236. Xylaria hypoxylon (L.) Grev. [Xylariaceae Tul. \& C. Tul.; Xylariales Nannf.] - Fagus sylvatica, 2010.09.23., leg. et det.: Papp V. (fung.: PV211)

237. Xylaria longipes Nitschke [Xylariaceae Tul. \& C. Tul.; Xylariales Nannf.] - Fagus sylvatica, 2010.09.14., leg. et det.: Papp V. (fung.: PV195)

238. Xylaria polymorpha (Pers.) Grev. [Xylariaceae Tul. \& C. Tul.; Xylariales Nannf.] - Fagus sylvatica, 2010.09.14., leg. et det.: Papp V.; Fagus sylvatica (83), 2011.08.03., leg. et det.: Papp V.; Fagus sylvatica (81), 2011.08.05., leg. et det.: Papp V.

239. Sarcoscypha coccinea (Jacq.) Boud. [Sarcoscyphaceae Le Gal ex Eckblad; Pezizales J. Schröt.] cf. Fagus sylvatica talajban lévő ágdarabon, 2013.03.11., leg. et det.: Papp V. 


\section{M5. KIJELÖLT MINTAFÁK ADATAI}

A Juhdöglő-völgy Erdőrezervátum területén kijelölt mintafák adatai. A kijelölt rönk sorszáma (SSZ), fafaja, átmérője, korhadási fázisa (KORHF), valamint lelőhelye GPS koordináták megadásával (a mérés pontosságát $\mathrm{cm}$-ben tüntettem fel).

\begin{tabular}{|c|c|c|c|c|c|c|}
\hline \multirow[t]{2}{*}{ SSZ } & \multirow[t]{2}{*}{ Fafaj } & \multirow{2}{*}{$\begin{array}{c}\text { Átmérō } \\
(\mathrm{cm})\end{array}$} & \multirow{2}{*}{$\begin{array}{c}\text { KORHF } \\
(1-5)\end{array}$} & \multicolumn{2}{|c|}{ GPS koordináták } & \multirow{2}{*}{$\begin{array}{c}\text { Pontosság } \\
(\mathrm{cm})\end{array}$} \\
\hline & & & & $\mathbf{N}$ & EO & \\
\hline 1 & Qercus petraea & 67 & 4 & $47^{\circ} 22.647^{\prime}$ & $18^{\circ} 19.498^{\prime}$ & 335 \\
\hline 2 & Qercus petraea & 82 & 1 & $47^{\circ} 22.660^{\prime}$ & $18^{\circ} 19.476^{\prime}$ & 366 \\
\hline 3 & Qercus petraea & 43 & 3 & $47^{\circ} 22.671^{\prime}$ & $18^{\circ} 19.486^{\prime}$ & 366 \\
\hline 4 & Qercus petraea & 52 & 3 & $47^{\circ} 22.686^{\prime}$ & $18^{\circ} 19.484^{\prime}$ & 305 \\
\hline 5 & Qercus petraea & 24 & 3 & $47^{\circ} 22.686^{\prime}$ & $18^{\circ} 19.483^{\prime}$ & 305 \\
\hline 6 & Qercus petraea & 65 & 1 & $47^{\circ} 22.673^{\prime}$ & $18^{\circ} 19.468^{\prime}$ & 366 \\
\hline 7 & Qercus petraea & 58 & 4 & $47^{\circ} 22.680^{\prime}$ & $18^{\circ} 19.457^{\prime}$ & 274 \\
\hline 8 & Qercus petraea & 51 & 5 & $47^{\circ} 22.686^{\prime}$ & $18^{\circ} 19.456^{\prime}$ & 274 \\
\hline 9 & Qercus petraea & 54 & 4 & $47^{\circ} 22.709^{\prime}$ & $18^{\circ} 19.470^{\prime}$ & 305 \\
\hline 10 & Qercus petraea & 65 & 2 & $47^{\circ} 22.717^{\prime}$ & $18^{\circ} 19.488^{\prime}$ & 274 \\
\hline 11 & Qercus petraea & 30 & 3 & $47^{\circ} 22.725^{\prime}$ & $18^{\circ} 19.506^{\prime}$ & 305 \\
\hline 12 & Qercus petraea & 40 & 5 & $47^{\circ} 22.723^{\prime}$ & $18^{\circ} 19.467^{\prime}$ & 366 \\
\hline 13 & Qercus petraea & 51 & 5 & $47^{\circ} 22.731^{\prime}$ & $18^{\circ} 19.470^{\prime}$ & 305 \\
\hline 14 & Qercus petraea & 76 & 2 & $47^{\circ} 22.715^{\prime}$ & $18^{\circ} 19.436^{\prime}$ & 274 \\
\hline 15 & Qercus petraea & 85 & 3 & $47^{\circ} 22.704^{\prime}$ & $18^{\circ} 19.414^{\prime}$ & 274 \\
\hline 16 & Qercus petraea & 53 & 4 & $47^{\circ} 22.690^{\prime}$ & $18^{\circ} 19.398^{\prime}$ & 274 \\
\hline 17 & Qercus petraea & 65 & 4 & $47^{\circ} 22.687^{\prime}$ & $18^{\circ} 19.376^{\prime}$ & 274 \\
\hline 18 & Qercus petraea & 70 & 2 & $47^{\circ} 22.684^{\prime}$ & $18^{\circ} 19.403^{\prime}$ & 274 \\
\hline 19 & Qercus petraea & 55 & 3 & $47^{\circ} 22.688^{\prime}$ & $18^{\circ} 19.428^{\prime}$ & 335 \\
\hline 20 & Qercus petraea & 64 & 1 & $47^{\circ} 22.682^{\prime}$ & $18^{\circ} 19.431^{\prime}$ & 274 \\
\hline 21 & Qercus petraea & 46 & 5 & $47^{\circ} 22.670^{\prime}$ & $18^{\circ} 19.446^{\prime}$ & 274 \\
\hline 22 & Qercus petraea & 22 & 3 & $47^{\circ} 22.647^{\prime}$ & $18^{\circ} 19.575^{\prime}$ & 396 \\
\hline 23 & Qercus petraea & 74 & 4 & $47^{\circ} 22.634^{\prime}$ & $18^{\circ} 19.586^{\prime}$ & 396 \\
\hline 24 & Qercus petraea & 56 & 4 & $47^{\circ} 22.667^{\prime}$ & $18^{\circ} 19.606^{\prime}$ & 274 \\
\hline 25 & Qercus petraea & 51 & 1 & $47^{\circ} 22.677^{\prime}$ & $18^{\circ} 19.632^{\prime}$ & 274 \\
\hline 26 & Qercus petraea & 30 & 3 & $47^{\circ} 22.682^{\prime}$ & $18^{\circ} 19.634^{\prime}$ & 305 \\
\hline 27 & Qercus petraea & 37 & 3 & $47^{\circ} 22.669^{\prime}$ & $18^{\circ} 19.654^{\prime}$ & 305 \\
\hline 28 & Qercus petraea & 24 & 3 & $47^{\circ} 22.669^{\prime}$ & $18^{\circ} 19.659^{\prime}$ & 305 \\
\hline 29 & Qercus petraea & 68 & 2 & $47^{\circ} 22.651^{\prime}$ & $18^{\circ} 19.659^{\prime}$ & 457 \\
\hline 30 & Qercus petraea & 64 & 5 & $47^{\circ} 22.658^{\prime}$ & $18^{\circ} 19.670^{\prime}$ & 305 \\
\hline 31 & Qercus petraea & 59 & 4 & $47^{\circ} 22.675^{\prime}$ & $18^{\circ} 19.662^{\prime}$ & 335 \\
\hline 32 & Qercus petraea & 39 & 2 & $47^{\circ} 22.677^{\prime}$ & $18^{\circ} 19.654^{\prime}$ & 305 \\
\hline 33 & Qercus petraea & 39 & 4 & $47^{\circ} 22.690^{\prime}$ & $18^{\circ} 19.655^{\prime}$ & 487 \\
\hline 34 & Qercus petraea & 43 & 1 & $47^{\circ} 22.689^{\prime}$ & $18^{\circ} 19.640^{\prime}$ & 305 \\
\hline 35 & Quercus pubescens & 19 & 3 & $47^{\circ} 22.706^{\prime}$ & $18^{\circ} 19.616^{\prime}$ & 335 \\
\hline 36 & Quercus pubescens & 46 & 3 & $47^{\circ} 22.742^{\prime}$ & $18^{\circ} 19.638^{\prime}$ & 274 \\
\hline 37 & Quercus pubescens & 57 & 5 & $47^{\circ} 22.760^{\prime}$ & $18^{\circ} 19.647^{\prime}$ & 274 \\
\hline 38 & Quercus pubescens & 42 & 3 & $47^{\circ} 22.761^{\prime}$ & $18^{\circ} 19.674^{\prime}$ & 274 \\
\hline 39 & Quercus pubescens & 40 & 2 & $47^{\circ} 22.759^{\prime}$ & $18^{\circ} 19.711^{\prime}$ & 274 \\
\hline 40 & Quercus pubescens & 30 & 3 & $47^{\circ} 22.761^{\prime}$ & $18^{\circ} 19.659^{\prime}$ & 274 \\
\hline 41 & Quercus pubescens & 29 & 3 & $47^{\circ} 22.764^{\prime}$ & $18^{\circ} 19.642^{\prime}$ & 396 \\
\hline 45 & Quercus pubescens & 36 & 4 & $47^{\circ} 22.778^{\prime}$ & $18^{\circ} 19.804^{\prime}$ & 487 \\
\hline 46 & Quercus pubescens & 85 & 3 & $47^{\circ} 22.788^{\prime}$ & $18^{\circ} 19.807^{\prime}$ & 366 \\
\hline
\end{tabular}




\begin{tabular}{|c|c|c|c|c|c|c|}
\hline \multirow[t]{2}{*}{ SSZ } & \multirow[t]{2}{*}{ Fafaj } & \multirow{2}{*}{$\begin{array}{c}\text { Átmérō } \\
\text { (cm) }\end{array}$} & \multirow{2}{*}{$\begin{array}{c}\text { KORHF } \\
(1-5)\end{array}$} & \multicolumn{2}{|c|}{ GPS koordináták } & \multirow{2}{*}{$\begin{array}{c}\text { Pontosság } \\
(\mathrm{cm})\end{array}$} \\
\hline & & & & $\mathbf{N}$ & EO & \\
\hline 47 & Quercus pubescens & 63 & 3 & $47^{\circ} 22.799^{\prime}$ & $18^{\circ} 19.803^{\prime}$ & 579 \\
\hline 48 & Qercus petraea & 82 & 1 & $47^{\circ} 22.859^{\prime}$ & $18^{\circ} 19.655^{\prime}$ & 274 \\
\hline 49 & Qercus petraea & 26 & 5 & $47^{\circ} 22.855^{\prime}$ & $18^{\circ} 19.734^{\prime}$ & 366 \\
\hline 50 & Qercus petraea & 83 & 2 & $47^{\circ} 22.691^{\prime}$ & $18^{\circ} 19.427^{\prime}$ & 305 \\
\hline 51 & Qercus petraea & 69 & 5 & $47^{\circ} 22.722^{\prime}$ & $18^{\circ} 19.442^{\prime}$ & 274 \\
\hline 52 & Qercus petraea & 23 & 4 & $47^{\circ} 22.706^{\prime}$ & $18^{\circ} 19.372^{\prime}$ & 274 \\
\hline 53 & Qercus petraea & 54 & 3 & $47^{\circ} 22.717^{\prime}$ & $18^{\circ} 19.498^{\prime}$ & 274 \\
\hline 54 & Qercus petraea & 86 & 4 & $47^{\circ} 22.636^{\prime}$ & $18^{\circ} 19.430^{\prime}$ & 274 \\
\hline 55 & Qercus petraea & 56 & 2 & $47^{\circ} 22.700^{\prime}$ & $18^{\circ} 19.634^{\prime}$ & 396 \\
\hline 56 & Qercus petraea & 28 & 5 & $47^{\circ} 22.690^{\prime}$ & $18^{\circ} 19.621^{\prime}$ & 305 \\
\hline 57 & Qercus petraea & 34 & 5 & $47^{\circ} 22.686^{\prime}$ & $18^{\circ} 19.620^{\prime}$ & 305 \\
\hline 58 & Qercus petraea & 68 & 3 & $47^{\circ} 22.652^{\prime}$ & $18^{\circ} 19.579^{\prime}$ & 518 \\
\hline 59 & Qercus petraea & 36 & 5 & $47^{\circ} 22.658^{\prime}$ & $18^{\circ} 19.455^{\prime}$ & 671 \\
\hline 60 & Quercus pubescens & 26 & 1 & $47^{\circ} 22.630^{\prime}$ & $18^{\circ} 19.668^{\prime}$ & 274 \\
\hline 61 & Fagus sylvatica & 51 & 3 & $47^{\circ} 22.860^{\prime}$ & $18^{\circ} 19.728^{\prime}$ & 427 \\
\hline 62 & Fagus sylvatica & 36 & 3 & $47^{\circ} 22.849^{\prime}$ & $18^{\circ} 19.717^{\prime}$ & 457 \\
\hline 63 & Fagus sylvatica & 26 & 3 & $47^{\circ} 22.855^{\prime}$ & $18^{\circ} 19.707^{\prime}$ & 457 \\
\hline 64 & Fagus sylvatica & 65 & 4 & $47^{\circ} 22.850^{\prime}$ & $18^{\circ} 19.677^{\prime}$ & 335 \\
\hline 65 & Fagus sylvatica & 97 & 1 & $47^{\circ} 22.843^{\prime}$ & $18^{\circ} 19.670^{\prime}$ & 335 \\
\hline 66 & Fagus sylvatica & 75 & 1 & $47^{\circ} 22.820^{\prime}$ & $18^{\circ} 19.618^{\prime}$ & 305 \\
\hline 67 & Fagus sylvatica & 67 & 5 & $47^{\circ} 22.800^{\prime}$ & $18^{\circ} 19.611^{\prime}$ & 305 \\
\hline 68 & Fagus sylvatica & 59 & 2 & $47^{\circ} 22.799^{\prime}$ & $18^{\circ} 19.609^{\prime}$ & 396 \\
\hline 69 & Fagus sylvatica & 63 & 4 & $47^{\circ} 22.799^{\prime}$ & $18^{\circ} 19.602^{\prime}$ & 427 \\
\hline 70 & Fagus sylvatica & 76 & 3 & $47^{\circ} 22.783^{\prime}$ & $18^{\circ} 19.620^{\prime}$ & 305 \\
\hline 71 & Fagus sylvatica & 82 & 3 & $47^{\circ} 22.785^{\prime}$ & $18^{\circ} 19.628^{\prime}$ & 396 \\
\hline 72 & Fagus sylvatica & 67 & 5 & $47^{\circ} 22.790^{\prime}$ & $18^{\circ} 19.635^{\prime}$ & 274 \\
\hline 73 & Fagus sylvatica & 60 & 2 & $47^{\circ} 22.788^{\prime}$ & $18^{\circ} 19.653^{\prime}$ & 335 \\
\hline 74 & Fagus sylvatica & 28 & 2 & $47^{\circ} 22.796^{\prime}$ & $18^{\circ} 19.646^{\prime}$ & 335 \\
\hline 75 & Fagus sylvatica & 42 & 4 & $47^{\circ} 22.798^{\prime}$ & $18^{\circ} 19.641^{\prime}$ & 305 \\
\hline 76 & Fagus sylvatica & 40 & 1 & $47^{\circ} 22.805^{\prime}$ & $18^{\circ} 19.638^{\prime}$ & 457 \\
\hline 77 & Fagus sylvatica & 70 & 4 & $47^{\circ} 22.817^{\prime}$ & $18^{\circ} 19.657^{\prime}$ & 335 \\
\hline 78 & Fagus sylvatica & 47 & 5 & $47^{\circ} 22.814^{\prime}$ & $18^{\circ} 19.655^{\prime}$ & 549 \\
\hline 79 & Fagus sylvatica & 100 & 4 & $47^{\circ} 22.829^{\prime}$ & $18^{\circ} 19.649^{\prime}$ & 457 \\
\hline 80 & Fagus sylvatica & 24 & 2 & $47^{\circ} 22.836^{\prime}$ & $18^{\circ} 19.681^{\prime}$ & 23 \\
\hline 81 & Fagus sylvatica & 62 & 2 & $47^{\circ} 22.830^{\prime}$ & $18^{\circ} 19.699^{\prime}$ & 674 \\
\hline 82 & Fagus sylvatica & 55 & 2 & $47^{\circ} 22.854^{\prime}$ & $18^{\circ} 19.744^{\prime}$ & 305 \\
\hline 83 & Fagus sylvatica & 36 & 1 & $47^{\circ} 22.813^{\prime}$ & $18^{\circ} 19.657^{\prime}$ & 305 \\
\hline 84 & Fagus sylvatica & 22 & 4 & $47^{\circ} 22.791^{\prime}$ & $18^{\circ} 19.613^{\prime}$ & 305 \\
\hline 85 & Fagus sylvatica & 19 & 1 & $47^{\circ} 22.756^{\prime}$ & $18^{\circ} 19.592^{\prime}$ & 305 \\
\hline 86 & Fagus sylvatica & 51 & 1 & $47^{\circ} 22.760^{\prime}$ & $18^{\circ} 19.614^{\prime}$ & 305 \\
\hline 87 & Fagus sylvatica & 52 & 1 & $47^{\circ} 22.752^{\prime}$ & $18^{\circ} 19.556^{\prime}$ & 274 \\
\hline 88 & Fagus sylvatica & 84 & 3 & $47^{\circ} 22.719^{\prime}$ & $18^{\circ} 19.565^{\prime}$ & 305 \\
\hline 89 & Fagus sylvatica & 40 & 2 & $47^{\circ} 22.697^{\prime}$ & $18^{\circ} 19.555^{\prime}$ & 305 \\
\hline 90 & Fagus sylvatica & 94 & 5 & $47^{\circ} 22.660^{\prime}$ & $18^{\circ} 19.532^{\prime}$ & 305 \\
\hline 91 & Fagus sylvatica & 65 & 3 & $47^{\circ} 22.643^{\prime}$ & $18^{\circ} 19.521^{\prime}$ & 305 \\
\hline 92 & Fagus sylvatica & 115 & 1 & $47^{\circ} 22.662^{\prime}$ & $18^{\circ} 19.485^{\prime}$ & 305 \\
\hline 94 & Fagus sylvatica & 20 & 1 & $47^{\circ} 22.680^{\prime}$ & $18^{\circ} 19.441^{\prime}$ & 305 \\
\hline 95 & Fagus sylvatica & 102 & 4 & $47^{\circ} 22.625^{\prime}$ & $18^{\circ} 19.465^{\prime}$ & 487 \\
\hline 96 & Fagus sylvatica & 42 & 2 & $47^{\circ} 22.630^{\prime}$ & $18^{\circ} 19.469^{\prime}$ & 396 \\
\hline 97 & Fagus sylvatica & 36 & 4 & $47^{\circ} 22.713^{\prime}$ & $18^{\circ} 19.575^{\prime}$ & 518 \\
\hline
\end{tabular}




\begin{tabular}{|c|c|c|c|c|c|c|}
\hline \multirow[t]{2}{*}{ SSZ } & \multirow[t]{2}{*}{ Fafaj } & \multirow{2}{*}{$\begin{array}{c}\text { Átmérö } \\
\text { (cm) }\end{array}$} & \multirow{2}{*}{$\begin{array}{c}\text { KORHF } \\
(1-5)\end{array}$} & \multicolumn{2}{|c|}{ GPS koordináták } & \multirow{2}{*}{$\begin{array}{c}\text { Pontosság } \\
(\mathrm{cm})\end{array}$} \\
\hline & & & & $\mathbf{N}$ & EO & \\
\hline 98 & Fagus sylvatica & 54 & 4 & $47^{\circ} 22.878^{\prime}$ & $18^{\circ} 19.714^{\prime}$ & 274 \\
\hline 99 & Fagus sylvatica & 27 & 3 & $47^{\circ} 22.750^{\prime}$ & $18^{\circ} 19.551^{\prime}$ & 305 \\
\hline 100 & Fagus sylvatica & 93 & 4 & $47^{\circ} 22.638^{\prime}$ & $18^{\circ} 19.427^{\prime}$ & 305 \\
\hline 101 & Fagus sylvatica & 36 & 5 & $47^{\circ} 22.630^{\prime}$ & $18^{\circ} 19.447^{\prime}$ & 366 \\
\hline 102 & Fagus sylvatica & 54 & 4 & $47^{\circ} 22.650^{\prime}$ & $18^{\circ} 19.517^{\prime}$ & 274 \\
\hline 103 & Fagus sylvatica & 26 & 5 & $47^{\circ} 22.643^{\prime}$ & $18^{\circ} 19.540^{\prime}$ & 274 \\
\hline 104 & Fagus sylvatica & 97 & 2 & $47^{\circ} 22.688^{\prime}$ & $18^{\circ} 19.533^{\prime}$ & 305 \\
\hline 105 & Fagus sylvatica & 24 & 5 & $47^{\circ} 22.800^{\prime}$ & $18^{\circ} 19.653^{\prime}$ & 305 \\
\hline 106 & Fagus sylvatica & 18 & 4 & $47^{\circ} 22.836^{\prime}$ & $18^{\circ} 19.694^{\prime}$ & 396 \\
\hline 107 & Fagus sylvatica & 28 & 3 & $47^{\circ} 22.777^{\prime}$ & $18^{\circ} 19.622^{\prime}$ & 457 \\
\hline 108 & Fagus sylvatica & 66 & 1 & $47^{\circ} 22.747^{\prime}$ & $18^{\circ} 19.599^{\prime}$ & 24 \\
\hline 109 & Fagus sylvatica & 54 & 4 & $47^{\circ} 22.740^{\prime}$ & $18^{\circ} 19.575^{\prime}$ & 24 \\
\hline 110 & Fagus sylvatica & 67 & 5 & $47^{\circ} 22.732^{\prime}$ & $18^{\circ} 19.6011^{\prime}$ & 427 \\
\hline 111 & Fagus sylvatica & 50 & 3 & $47^{\circ} 22.631^{\prime}$ & $18^{\circ} 19.530^{\prime}$ & 305 \\
\hline 112 & Fagus sylvatica & 25 & 2 & $47^{\circ} 22.700^{\prime}$ & $18^{\circ} 19.550^{\prime}$ & 579 \\
\hline 113 & Fagus sylvatica & 40 & 2 & $47^{\circ} 22.712^{\prime}$ & $18^{\circ} 19.557^{\prime}$ & 20 \\
\hline 114 & Fagus sylvatica & 35 & 1 & $47^{\circ} 22.804^{\prime}$ & $18^{\circ} 19.655^{\prime}$ & 396 \\
\hline 115 & Qercus petraea & 68 & 3 & $47^{\circ} 22.676^{\prime}$ & $18^{\circ} 19.398^{\prime}$ & 457 \\
\hline 116 & Fagus sylvatica & 75 & 1 & $47^{\circ} 22.871^{\prime}$ & $18^{\circ} 19.740^{\prime}$ & 579 \\
\hline 117 & Fagus sylvatica & 70 & 3 & $47^{\circ} 22.696^{\prime}$ & $18^{\circ} 19.543^{\prime}$ & 396 \\
\hline 118 & Fagus sylvatica & 51 & 3 & $47^{\circ} 22.704^{\prime}$ & $18^{\circ} 19.555^{\prime}$ & 549 \\
\hline 119 & Fagus sylvatica & 84 & 3 & $47^{\circ} 22.710^{\prime}$ & $18^{\circ} 19.566^{\prime}$ & 518 \\
\hline 121 & Qercus petraea & 26 & 2 & $47^{\circ} 22.680^{\prime}$ & $18^{\circ} 19.468^{\prime}$ & 366 \\
\hline 122 & Qercus petraea & 22 & 2 & $47^{\circ} 22.626^{\prime}$ & $18^{\circ} 19.588^{\prime}$ & 487 \\
\hline 123 & Qercus petraea & 21 & 4 & $47^{\circ} 22.608^{\prime}$ & $18^{\circ} 19.594^{\prime}$ & 427 \\
\hline 124 & Fagus sylvatica & 37 & 5 & $47^{\circ} 22.776^{\prime}$ & $18^{\circ} 19.588^{\prime}$ & 396 \\
\hline 125 & Fagus sylvatica & 56 & 1 & $47^{\circ} 22.770^{\prime}$ & $18^{\circ} 19.610^{\prime}$ & 427 \\
\hline
\end{tabular}

Megjegyzések: a 42, 43, 44 (tölgy) és 120-as (bükk) sorszámú rönköket a kijelölés utáni felvételezés során nem vizsgáltam. A 93-as sorszámú fa tévesen lett kijelölve, ezért nem szerepel a táblázatban. 


\title{
M6. FILOGENETIKAI VIZSGÁLATOKHOZ HASZNÁLT MINTÁK ADATAI
}

M6.1. A Juhdöglö-völgy Erdőrezervátumban gyüjtött lignikol bazídiumos nagygombák jelen dolgozatban molekuláris módszerekkel vizsgált mintáinak ITS szekvenciái.

1. Aurantiporus alborubescens (Bourdot \& Galzin) H. Jahn

\section{> PV1089_Aurantiporus_alborubescens_ITS}

CGTAGGTGÄACCTGCGGaAGGATCATTAACGÄGTTTTGAAACAGGGTTGTAGGCTGGTCTTTCTTAATGGAG AGACATGTGCACGCCCTGCTCAATCCACTCTCAAACCCCTGTGCACTTACTGTAGGTTATGGTGGGATAGCT GGCCCTGGGCCAGTATTGAAAGCCTTGCCTATGTTTTATTACAAACGCTTCAGTCAAAGAATGTAACATTGG ATTTAATGGAATAAAATACAACTTTTAGCAACGGATCTCTTGGCTCTCGCATCGATGAAGAACGCAGCGAAA TGCGATAAGTAATGTGAATTGCAGAATTCAGTGAATCATCGAATCTTTGAACGCACCTTGCGCTCCTTGGTA TTCCGAGGAGCATGCCTGTTTGAGTGTCATGGAATTCTCAACTTTCAAAGCTTTTTGCAATGAAAGCTTGGA TkTGGAGGTAGTGTTGGTTTGCAAAAGTCAACTCCTCTGAAATGTATTAGTGTGAACCTTACGGATCACCTT CAGTGTGATAATTGTCTACACTGTGGTGTTGAAGTATCTTAGTGTTTGTGCTTCTAACTGTCTGTATAGACA AGTTTAyTTGACAATCTGACCTCAAATCAGGTAGGACTACCCGCTGAACTTAAGCATATCAaTA

2. Crepidotus ehrendorferi Hauskn. \& Krisai

\begin{abstract}
>PV218_Crepidotus_ehrendorferi_ITS
CATTAAC̈GAAATAAACCTGGTGAACTGTCGCTGGCATTCTTTGCATGTGCACGTTCATCATCTTTATCTAT TCCCACCTGTGCACCTTTTGTAGACCTGGTTCGCGAGCTTTTATTCAGAGGTCAAACTCTGGTGTCGGGAT CGTCGGCGTCCTTTGTGATATCGGCTTTCCTTGGTGGCTCTATTCAGAGGTAAAACTCTGTCGTTGGGATC GTCGGCGTCCTTTGTGATATCGGCTTTCCTTGTTGCGTCCAGTGCTCTATGTCTACTATACACACCAACGC ATGTAACAGAATGAAATTATAAAGGTCTTTGCACCTATAATAAAACTATACAACTTTCAGCAACGGATCTC TTGGCTCTCGCATCGATGAAGAACGCAGCGAAATGCGATAAGTAATGTGAATTGCAGAATTCAGTGAATCA TCGAATCTTTGAACGCATCTTGCGCTCCTTGGTATTCCGAGGAGCATGCCTGTTTGAGTGTCATTAAATTA TCAACCTTACCAGCTTTGCTGCTGGTCTGGCTTGGATGTGGGAGGTTTTGCAGGCCCTTTGGGTCAGCTCT CCTGAAATACATTAGTGGTGTCCTTGCGGGTGTAACAACTATTGGTGTGATAACTATCTACGCCATTAGAC TCGTGATGGATCAGATCGCTTTCTAACCGTCCTTTACTGGACAACATGACAATTTGACCTCAAATCAG
\end{abstract}

3. Crepidotus malachioides Consiglio, Prydiuk \& Setti

\begin{abstract}
>PV690_Crepidotus_malachioides_ITS
CATTAATGAATAAACTTGGTGGATTGTC GCTGGCTTCTTAGGGAGCATGTGCACGTCTGTCATATTTATGT TTCCACCTGTGCACCTTCTGTAGACCTGGACACACACAACTTCTCTGAGGCAGCTCAGGCATGAGGATTGC AGGCATTACATGTCAGCTTTCCTTGACGTATCCAGGCCTATGTATTTTCACATACACCTAATTAATGTATC AGAATGTCAATGAAAGGTCTTTGTACCTATAACAATTATACAACTTTCAGCAACGGATCTCTTGGCTCTCG CATCGATGAAGAACGCAGCGAAATGCGATAAGTAATGTGAATTGCAGAATTCAGTGAATCATCGAATCTTT GAACGCATCTTGCGCTCCTTGGTATTCCGAGGAGCATGCCTGTTTGAGTGTCATTAAATTCTCAACCTTAC CATCTTTGCTGCATGGTTTGGATTGGACTTGGGGGTACTTTTTTGCAGGCTTCTACAAGTCAGCTCCCCTG AAATACATTAGCAGTGCCCTTGTGGTATACAGCTATTGGTGTGATAACCTATCTACGCCATTAGCTGCCCA TAATTATTGGGGTTGTGCTGCTTCTAACTGTCTTCTTTACTGAGACAAATTTGACCATCTGGCCTCAAATC AG
\end{abstract}

4. Crepidotus macedonicus Pilát \& Lindtner
>PV773_Crepidotus_macedonicus_ITS
CATTAA $\bar{C}$ GAAATAAACCTGGTGGACTGTTGCTGGCTCTTCCGAGGGCAATGTGCACGTCTGTCATCTTTAT CTTTCCACCTGTGCACCCTGTGTAGATCTAGAGAACAATCATCCCATGTGTTTTAAACCGTTGGGGGAGCT TGTGCAGGCATACACCAATGTCTGCTCTCCCTGAGTATCTAGGTCTATGTCTTTTCTTACACACACCAATA AAATGTAAAAGAATGACCATGTTCAGTAGAACAATAAAAAAAAAAACTTTATACAACTTTCAGCAACGGAT CTCTTGGCTCTCGCATCGATGAAGAACGCAGCGAAATGCGATAAGTAATGTGAATTGCAGAATTCAGTGAA TCATCGAATCTTTGAACGCATCTTGCGCTCCTTGGTATTCCGAGGAGCATGCCTGTTTGAGTGTCATTAAA TTCTCAAAACCTCATCAGAGTTTGCACTCTTGATGTCTGGGTTTTTGGATGTGGGAGTATCTGCAGGCCTT TTACAAAAGGTCAGCTCTCCTGAAATGCATTAGCGGTACTCTCAGTGGTTGAGCAGCTATTGGTGTGATAA 
CTATCTACGCTACAAGCTGTTCTCTTCCCACTTCCTCAGGGAGGGAGAGTGACACTGCTTCCCAACTGTCC ATTGGCTTGGACAAGATAAATGACCAATTTGACCTCAAATCAG

5. Donkia pulcherrima (Berk. \& M.A. Curtis) Pilát

\begin{abstract}
>PV1044_BP106903_Donkia_pulcherrima_ITS

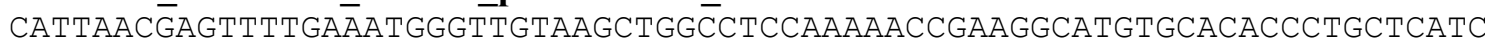
CACTCTTCAACCTCTGTGCACTTATTGTAGGAAGGTGGAAAAGTTGAGCTTCGCTGTTTAATCGCGGCTTG AGGTTCCTTCGAAGCCTTCTTATGTTTTATTTTACAAACACTTCAGTTATAGAATGTCAATTTGCGAATAA CGCAATACAATACAACTTTCAGCAACGGATCTCTTGGCTCTCGCATCGATGAAGAACGCAGCGAAATGCGA TAAGTAATGTGAATTGCAGAATTCAGTGAATCATCGAATCTTTGAACGCACCTTGCGCTCCCTGGTATTCC GGGGAGCACGCCTGTTTGAGTGTCATGGTATCCTCAACCTTCATAATTTTTGTTTTCAAAAGTTATTGAAG GCTTGGACTTGGAGGTTTGTGCTGGCTCTCTTAATTGAGGTCGGCTCCTCTTAAATGTATTAGCGTGAACG TTTACGGATCGCTATCAGTGTGATAATTATCTGCGCTGTTAGTGTTGAAGTATCATTTGGTGTCTCGCTTC TAACCGTCCTTTTGCAAGGACAAAATTTACTTTGACATCTGACCTCAAATCAG
\end{abstract}

6. Entoloma zuccherellii var. pluteisimilis (Noordel. \& C.E. Hermos) V. Papp

\begin{abstract}
>PV1114_BP106908_Entoloma_zuccherellii_var_pluteisimilis_ITS
CATTATTGAATAAACTTGGTTAGGTTGCTGCTGGTCTTTAGGGACATGTGCACATCTAATTCAAATTTTAA CCACCTGTGCACCTTTTGTAGACTTGGATAATTTCTCTGAGGAAACTCAGTATGAGGATTGCTGTGCGAAA GTCAGCTTTTCTTGCATTTCCTAGTCTATGTTTTATATACCCCAATAAGCAAGTAATAGAATGTAATTAAT AGGCCTTTTGTGCCTTTAAAACAAATATAACTTTCAACAACGGATCTCTTGGCTCTCGCATCGATGAAGAA CGCAGCGAAATGCGATAAGTAATGTGAATTGCAGAATTCAGTGAATCATCGAATCTTTGAACGCACCTTGC GCTCCTTGGTATTCCGAGGAGCATGCCTGTTTGAGTGTCATGAATCTCTCAACCTTTTCAGTTTTTATTAA CTGGTCTGGCTTGGATTGTGGGGGTTGCTGGCTTTATCCAAAGTTTGCTCTCCTTAAATGTATTAGCAATG CCTTTGCTGACCATCTCTGGTGTGATAATTATCTACGCCATTGGGAAATCAGCATATGCTTCCTAATAGTC TGTTTGGACAATTTTTGACAATTTGACCTCAAATCAG
\end{abstract}

7. Entoloma tjallingiorum Noordel. var. tjallingiorum

\begin{abstract}
>PV538_BP106905_Entoloma_tjallingiorum_var_tjallingiorum_ITS
CATTATT̈GATAAATTTGGTTAGAGTTGTTGCTGACTCTTTGGAGTATGTG_CACACTCGCACCATTTTTAA CCACCTGTGCACTATCTGTAGATTGTGAATACTTGAGGATGTGGCCAAATCAGCTGTTCmTCGTATTTACG TCTATGTCTTTATATATACCATGACTGTTTAAGAATGTTATATTTAGGCTTTTGTGCCTTTAAAATTGAAA CAACTTTCAACAACGGATCTCTTGGCTCTCGCATCGATGAAGAACGCAGCGAAATGCGATAAGTAATGTGA ATTGCAGAATTCAGTGAATCATCGAATCTTTGAACGCACCTTGCGCTCCTTGGTATTCCGAGGAGCATGCC TGTTTGAGAGTCATTATATTCTCAACCTCATCAGCTTTTTGAAAGCTAAATGAGGCTTGGATATGGAAGTT GCAGGTTTCTCACTGAAATCAGCTCTTCTTAAATGTATTAGCAGGATTTCTACTGATTATCTTTTGGTATG ATAATTATCGATATCAATAAAGACTCAGTCTATTCCGCTACCAACTGTCTTTTGTTAGACArCATATATGA CTATETGACCTCAAATCAG
\end{abstract}

8. Hohenbuehelia auriscalpium (Maire) Singer

\begin{abstract}
>PV408_Hohenbuehelia_cf_auriscalpium_ITS
CATTATTGTATTCACCTGCGATGCTGTTGCTGGCTCCTTGTGGGCATGTGCACGCTTCGTAAGTTAATTTC AACCACCTGTGAACCTTTTGTAGTCTTGGGTGACGCTATAAATCAAAGGAAACTTTGGACTTGAATGCTGC TGGCTTGTAAAAAGGTCGGCTTCATTCTACAGCAGAGCCCGGGTACTATGCTTTACACACCCCATTGTATG TCACAGAATGTAATTCAAGGGCTTCAATGCCTTTAAACTTAATACAACTTTCAGCAACGGATCTCTTGGCT CTCGCATCGATGAAGAACGCAGCGAAATGCGATAAGTAATGTGAATTGCAGAATTCAGTGAATCATCGAAT CTTTGAACGCACCTTGCGCCCTTTGGTATTCCGAAGGGCATGCCTGTTTGAGTGTCATTAAATTCTCAACC TTAGGAGGCTTTGTCTTTTCTAAGGCTTGGATGTGGAGGTTGCGGGCTTCTCAAGTCGGCTCCTCTGAAAT GCATTAGCTGGGTTTGCGCCTTCAGCCTATTGGTGTGATAATTATCTACrCCTCTTGGGTCGTTAGCGTGT ATAAATCTTTCCAGCTTCTAACCGTCCrCAAGGACAATACTTGACCATTTGACCTCAAATCAG
\end{abstract}




\title{
9. Hohenbuehelia mastrucata (Fr.) Singer
}

>PV712_Hohenbuehelia_mastrucata_ITS

CATTATTGAATCGCCTTTGAAGTTGTTGCTGGCCCCTTAGGGGTATGTGCACACTTCATAAGTCATTTCA ACCACCTGTGCACCTTTTGTAGTCTTGGGTGACGCTCCTATCAAAGGAAACTTTGGATTTGAATGCTGCAG GCGCAAGTCCGCTTCATTCTACAGCTGATCCCGGGTCTATACTTTATACACCCTATTTATGTCCTAGAATG TGATTCAGGGGCTTCAATGCCTTTAAAATCTATACAACTTTCAGCAACGGATCTCTTGGCTCTCGCATCGA TGAAGAACGCAGCGAAATGCGATAAGTAATGTGAATTGCAGAATTCAGTGAATCATCGAATCTTTGAACGC ACCTTGCGCCCTTTGGTATTCCGAAGGGCATGCCTGTTTGAGTGTCATTAAATTCTCAACCTTGAAAGGCT CTTGTAGTCTTCCAAGGCTTGGATATGGGGGTTGCGGGCTTTAACAAGTCGGCTCCTCTTAAATGTATTAG CTGGGTTTGCGCCTTCAGCCTATTGGTGTGATAATTATCTACGCCTCTTGGGTCGTTTGCGTGTTTATCTT TCTAGCTTCTAwTCGTCCGCAAGGACAACACTTGACCATTTGACCTCAAATCAG

10. Hohenbuehelia aff. atrocoerulea (Fr.) Singer

\section{$>$ PV774_Hohenbuehelia_aff_atrocoerulea_ITS}

CATTATTGAATTCGGGCGAA GTTGTTGCTGGTACCCAATGTGGTTCATGTGCACACTTCGTATCCCACTTC AACCACCTGTGAACTTTTTGTAGTCCTTGGGGGACGCTACAGCTCAAAGGAAACTTTGGATTTGAGTGCTG CAGGCCTTTGTTACAAAGGTCGGCTTCATTCTACAGCTGAACCCGGGTCTATGCTTTATATACACCAATTT GTATGTCTATGAATGTGATTGAAGGGCTTCAATGCCTGTAAATCTTATACAACTTTCAGCAACGGATCTCT TGGCTCTCGCATCGATGAAGAACGCAGCGAAATGCGATAAGTAATGTGAATTGCAGAATTCAGTGAATCAT CGAATCTTTGAACGCACCTTGCGCCCCTTGGTATTCCGAGGGGCATGCCTGTTTGAGTGTCATTAAATTCT CAACCTTGAAAGGCTTTTGAAGTCCTTCGAGGCTTGGATGTGGAGGCTGCGGGCCCTTGTTGGTCGGCTCC TCTTAAATGCATTAGCTGGGTTTGCGCCTTCAGCCTACTGGTGTGATAATTATCTACGCCTCTGGGACGTT AGCGTGTTTACTTCTCCAGCTTCTAATCGTCCGCAAGGACAATACTTTGACCATTTGACCTCAAATCAG

11. Phlebia nothofagi (G. Cunn.) Nakasone

\begin{abstract}
$>$ PV551_Phlebia_nothofagi_ITS
CATTATCGAATCTTCTGAGGGTTGTTGCTGGGTTCCTCCCAAAGGGGGTTCCAACGTGCACACCCTTGTCC ATTCTTAAACCCCTGTGCACTTATTGTAGGCTTGGTGGCAGAGCTGACTTTGGTTGGTTCGAAAGCCTCGC CTATGTTTTAACACACGCTTCAGTCTATGAATGTCATTTTGCGGATAACGCATTAAATACAACTTTCAACA ACGGATCTCTTGGCTCTCGCATCGATGAAGAACGCAGCGAAATGCGATAAGTAATGTGAATTGCAGAATTC AGTGAATCATCGAATCTTTGAACGCACCTTGCGCTCCTTGGTATTCCGAGGAGCATGCCTGTTTGAGTGTC ATGGAATTCTCAACCTTTAACACTTTTGTGGCAAAGGCTTGGACTTGGAGGTCGTGTCGGCTTGCAAAGGT CGACTCCTCTGAAATGTATCAGCGCGAACCTTACGGATCGCTTCGGTGTGATAATTGTCTACGCCGTGGCG TTGAAGTAAAGCTGTGTTCGAGCTTCCAACCGTCCGCGAGGACAATTCTTTTTGACAATCTGACCTCAAAT CAG
\end{abstract}

12. Pholiota squarrosoides (Peck) Sacc.

\begin{abstract}
>PV540_BP106902_Pholiota_squarrosoides_ITS
CATTATTGAATGAACTTGGTAGATTGTAGCTGGCCATTTCTGTGGCATGTGCACGTCTATCATTTTTAATCT TTCCACCTGTGCACGTTTTGTAGATCATTGAATTACCTATCCAAGGTGACTTGGGGATGGGGATTGCTGTGT AGAAATACTTGGCTTTCCTTGGATTTTCAAGATCTATGTTTTTTCATATACACCATAAAAATGTTATAGAAA GTTATTATATTGGCACCAGTGGCCTATAAAAAGTATATACAACTTTCAGCAACGGATCTCTTGGTTCTCGCA TCGATGAAGAACGCAGCGAAATGCGATAAGTAATGTGAATTGCAGAATTCAGTGAATCATCGAATCTTTGAA CGCACCTTGCGCTCCTTGGTATTCCGAGGAGCATGCCTGTTTGAGTGTCATTAAATTATCATGCTTTTATCA GCTTTATTGTTGGGAAAGGCGTGGATGTGGGGGAAAATTTTTTTGCAGGTTTTTTAATGTAGATCTGCTCCC CTTAAATGTATTAGCTGGTTGCTTGTTCAGACTTGTTTATTAGTGTGATAATTATCTACGCTGTGGACTGTC TGTGCTTTAATGTAGCACCTGCTTATAAACAGTCCTTTGGGACAATCTATATGACAATTTGACCTCAAATCA G
\end{abstract}

13. Postia alni Niemelä \& Vampola

\section{>PV188_Postia_alni_ITS}

CATTATTGAATATTTGAAAGGGTTGTTTGCTGGTCCCTAGCGGGACATCGTGCACGCCCCGTTCAAAAATC CAACCTTyATACCCCTGTGCATCATTTGTAGGGTTGCGGCCGTCAGGCCTGCGCTCTATGTTTATCATAAA CTCTGTAGTATGTGTAGAATGACATCGCGTATAACGCATCTATAATACAACTTTCAGCAACGGATCTCTTG GCTCTCGCATCGATGAAGAACGCAGCGAAATGCGATAAGTAATGTGAATTGCAGAATTCAGTGAATCATCG 
AАTCTTTGAACGCACCTTGCGCTCCTTGGTATTCCGAGGAGCATGCCTGTTTGAGTGTCATGGAATCATCA АсTCTTATTTCTTTTTCGGAGATGAGAGCTTGGACTTGGAGGTCTTTGCTGGCTTTTTGAGCCGGCTCCTC TTGAATGCATTAGCTTGAACCTTTGCTGTATCGGCCTCGGTGTGATAATTGTCTACGCCGTGGCTGTGAGG CTTACTTTAACTGGGCTCAGCTTCCAACCGTCTGCTTGCGGACAACATCTCATTGACCtCTGACCTCAAAT CaG

\title{
14. Aff. Pleuroflammula
}

\section{$>$ PV983_aff_Pleuroflammula_ITS}

САTTATTTAÄACCTGATAGTTGTĞCTGGCCTTCTGTGCACGCTGTCATCTTTATATCTCCTGTGCACCTCCT GTAGATCTGTTCCGAGGAACTCGGGGGGATGTCGCCTCGGCTTTCGyCCAGGTCTATGTTTTTAACATACTC CGAATGTATwAGAATGTTGGCCGTGCCTTTATACAACTTTCAGCAACGGATCTCTTGGCTCTCGCATCGATG AAGAACGCAGCGAAATGCGATAAGTAATGTGAATTGCAGAATTCAGTGAATCATCGAATCTTTGAACGCACC TTGCGCTCCTTGGTATTCCGAGGAGCATGCCTGTTTGAGTGTCATTAAATTCTCAACTACCArAGTGGCTTG GATGTGGGGGGTTTGCAGGTTGAGGTCTGCTCCCTTGAAATGCATTAGCTGTGGTGCTGTCTATCAGTGTGA TATTATCTACGCTGTGGAyCGTTGGTTCTGCTTCTAATCGTCTGCAGACAAACTGACAATTTGACCT

\begin{abstract}
$>$ PV983_aff_Pleuroflammula_LSU
AACTAACAGGATTCCCCTAGTAAC̄TGCGAGTGAAGCGGGAAAAGCTCAAATTTAAAATCTGGCAGTCTTTGA TTGTCCGAGTTGTAATCTAGAGAAGTGTTACCCGTGCTGGACCGTGTACAAGTCTCCTGGAATGGAGCGTCA TAGAGGGTGAGAATCCCGTCTTTGACACGGACTACCAGGACTTTGTGGTGCGCTCTCAAAGAGTCGAGTTGT TTGGGAATGCAGCTCAAAATGGGTGGTAAATTCCATCTAAAGCTAAATATTGGCGAGAGACCGATAGCGAAC AAGTACCGTGAGGGAAAGATGAAAAGAACTTTGGAAAGAGAGTTAAACAGTACGTGAAATTGCTGAAAGGGA AACGCTTGAAGTCAGTCGCGTTGGTCGGAAATCAGCCTTGCTTTTGCTTGGTGTACTTTCTGGTTGACGGGT CAGCATCAATTTTGACCGGTGGATAAAGTCTAGAGGAATGTGGCATCTTCGGATGTGTTATAGCCTCTGGTC GCATACATCGGTTGGGATTGAGGAACTCAGCACGCCGCAAGGCCGGGTTTTTACCACGTTCGTGCTTAGGAT GCTGGCATAATGGCTTTAATCGACCCGTCTTGAAACACGGACCAAGGAGTCTAACATGCCTGCGAGTGTTTG GGTGGAAAACCCGAGCGCGTAATGAAAGTGAAAGTTGAGATCCCTGTCGTGGGGAGCATCGACGCCCGGACC AGACCTTTTGTGACGGATCCGCGGTAGAGCATGTATGTTGGGACCCGAAAGATGGTGAACTATGCCTGAATA GGGTGAAGCCAGAGGAAACTCTGGTGGAGGCTCGTAGCGATTCTGACGTGCAAATCGATCGTCAAATTTGGG TATAGGGGCGAAAGACTAATCGAACCATCTAGTAGCTGGTTCCTGCCGAAGTTTCCCTCAGGATAGCAGAAA CTCATATCAGATTTATGTGGTAAAGCGAATGATTAGAGGCCTTGGGGTTGAAACAACCTTAACCTATTCTCA AACTTTAAATATGTAAGAACGAGCCGTCTCTTGATTGGACCGCTCGGCGATTGAGAGTTTCTAGTGGGCCAT TTTTGGTAAGCAGAACTGGCGATGCGGGATGAACCGAACGCGAGGTTAAGGTGCCGGAATTTACGCTCATCA GACACCACAAAAGGTGTTAGTTCATCTAGACAGCAGGACGGTGGCCATGGAAGTCGGAATCCGCTAAGGAGT GTGTAACAACTCACCTGCCGAATGAACTAGCCCTGAAAATGGATGGCGCTTAAGCGTGATACCCATACCTCG CCGTCANCGTTGAAGTGACGCGCTGACGAGTAGGCAGGCGTGGAGGTCAGTGAAGAAGCCTGGCAGCGATGC $\mathrm{C}$
\end{abstract}


M6.2. A GenBank (http://www.ncbi.nlm.nih.gov/ genbank/) és Unite (http://unite.ut.ee/) adatbázisokból letöltött és a jelen munkában ismertetett filogenetikai vizsgálathoz felhasznált ITS-szekvenciák lelőhelyi adatai, valamint herbáriumi és génbanki azonosítói. Rövidítések: $\mathbf{H T}=$ holotípus; $\mathbf{N T}=$ neotípus; $\mathbf{E T}=$ epitípus.

\begin{tabular}{|c|c|c|c|}
\hline Fajnév & Lelőhely (ország) & Herb. szám & ITS-azonosító \\
\hline Bjerkandera adusta & Kína & DO125 & KP050680 \\
\hline Ceriporia pseudocystidiata & Kína & Li1704 & JX623944 \\
\hline Ceriporia viridans & Kína & Li1046 & KC182776 \\
\hline Ceriporiopsis niger $(\mathbf{H T})$ & Csehország & BRNM 709972 & EU546099 \\
\hline Climacodon roseomaculatus & Kína & Dai13277 & KP323409 \\
\hline Climacodon septentrionalis & ismeretlen & AFTOL-ID 767 & AY854082 \\
\hline Climacodon septentrionalis & USA & RLG-6890-Sp & KP135344 \\
\hline Climacodon septentrionalis & Észtország & TU118996 & UDB023705 \\
\hline Creolophus cirrhatus & Anglia & $\mathrm{K}(\mathrm{M}) 125827$ & EU784260 \\
\hline Crepidotus applanatus & Németország & WU 29809 & KF879613 \\
\hline Crepidotus applanatus & Ausztria & WU 29794 & KF879614 \\
\hline Crepidotus applanatus & Dél-Korea & KA13-0932 & KR673659 \\
\hline Crepidotus applanatus & USA & TENN61392 & FJ596805 \\
\hline Crepidotus applanatus & Kanada & BIOUG24046-F04 & KT695357 \\
\hline Crepidotus calolepis & Magyarország & WU 28902 & KF879617 \\
\hline Crepidotus cesatii & Olaszország & 16593 & JF907962 \\
\hline Crepidotus crocophyllus & Japán & TNS Kasuya B950 & KF680279 \\
\hline Crepidotus crocophyllus & USA & TENN61519 & FJ596825 \\
\hline Crepidotus epibryus & Kanada & UBC F19673 & HM240524 \\
\hline Crepidotus luteolus & Olaszország & 16834 & JF907963 \\
\hline Crepidotus malachioides & Ausztria & WU 32709 & KF879615 \\
\hline Crepidotus malachioides (ET) & Szlovákia & SLO 1250 & KF154019 \\
\hline Crepidotus malachius & Ausztria & WU 29795 & KF879618 \\
\hline Crepidotus mollis & Spanyolország & 6723 & JF907959 \\
\hline Crepidotus sphaerosporus & ismeretlen & 11253 & JF907960 \\
\hline Crepidotus subverrucisporus & Olaszország & 15720 & JF907961 \\
\hline Crepidotus tennesseensis $(\mathbf{H T})$ & USA & TENN:029144 & NR119720 \\
\hline Donkia sp. („Uncultured fungus” néven) & USA & L049816E03 & JX136577 \\
\hline Donkia sp. („Uncultured fungus” néven) & USA & L049816E11 & JX136327 \\
\hline Entocybe melleogrisea & Kanada & $4150 \mathrm{YL}$ & KC701386 \\
\hline Entocybe nitida $(\mathbf{H T})$ & Hollandia & Arnolds 02-760276 & KC710123 \\
\hline Entocybe vinacea & ismeretlen & 947 & KJ705165 \\
\hline Entocybe vinacea & ismeretlen & 706-HL0706 & KJ705166 \\
\hline Entocybe trachyospora & Kanada & den Bakker 1901 & KC710121 \\
\hline Entocybe turbidum & Olaszország & 16176 & JF908005 \\
\hline Entoloma allochroum $(\mathbf{H T})$ & Hollandia & L, 29-07-1973 & KC898372 \\
\hline Entoloma callichroum $(\mathbf{H T})$ & Svájc & ZT 71/58 & KC898350 \\
\hline Entoloma chytrophilum (HT) & Kanári-szigetek & L 855 & KC898434 \\
\hline Entoloma chytrophilum & Oroszország & LE262993 & KC898424 \\
\hline Entoloma chytrophilum & Lengyelország & W-R 08-08-2010 & KC 898425 \\
\hline Entoloma dichroum (NT) & Oroszország & LE227472 & KC 898440 \\
\hline Entoloma euchroum (NT) & Németország & KR-M-0032474 & KC898421 \\
\hline Entoloma euchroum & Netherlands & L 6502 & KC898415 \\
\hline Entoloma euchroum & Oroszország & LE254332 & KC898419 \\
\hline Entoloma euchroum & Spanyolország & JVG1020827-2 & KC898461 \\
\hline Entoloma lampropus (NT) & Svédország & UPS:BOT:F-176490 & KC898377 \\
\hline Entoloma lampropus & Németország & L 1509 & KC898382 \\
\hline Entoloma lampropus & Spanyolország & RM0855 & KC898458 \\
\hline
\end{tabular}




\begin{tabular}{|c|c|c|c|}
\hline Fajnév & Lelőhely (ország) & Herb. szám & ITS-azonosító \\
\hline Entoloma lepidissimum $(\mathbf{H T})$ & Csehország & PRM 755801 & KC898364 \\
\hline Entoloma percoelestinum $(\mathbf{H T})$ & Spanyolország & LE254390 & KF745927 \\
\hline Entoloma placidum $(\mathbf{E T})$ & Svédország & UPS:BOT:F-121714 & KC898394 \\
\hline Entoloma placidum & Spanyolország & JVG1060902-2 & КC898396 \\
\hline Entoloma placidum & Oroszország & LE254335 & КC898397 \\
\hline Entoloma pluteisimilis & Olaszország & Zugna 3671 & JX274501 \\
\hline Entoloma sclerotiogenum $(\mathbf{H T})$ & Spanyolország & LIP JVG 1091230 & JX274499 \\
\hline Entoloma sclerotiogenum & Spanyolország & JC-Zamora & JX274500 \\
\hline Entoloma sinuatum & Finnország & J. Vauras $8181 \mathrm{~F}$ & KC710116 \\
\hline Entoloma sublaevisporum $(\mathbf{H T})$ & Spanyolország & LIP, JVG1070823T & KC898436 \\
\hline Entoloma sublaevisporum & Ausztria & MEN 9858 & KC898437 \\
\hline Entoloma tjallingiorum $(\mathbf{H T})$ & Svédország & UPS:BOT:F-016378 & KC898412 \\
\hline Entoloma tjallingiorum var. tjallingiorum & Oroszország & LE254318 & KC898411 \\
\hline Entoloma tjallingiorum var. tjallingiorum & Spanyolország & SFC 081019-01 & KC898459 \\
\hline Entoloma alnetorum $(\mathbf{H T})$ & Svájc & G 00111402 & KC898400 \\
\hline Entoloma tjallingiorum var. alnetorum & Oroszország & LE227527 & KC898401 \\
\hline Entoloma tjallingiorum var. alnetorum & Oroszország & LE227507 & KC898404 \\
\hline Entoloma tjallingiorum var. laricinum $(\mathbf{H T})$ & Oroszország & LE254343 & KC898413 \\
\hline Entoloma zuccherellii & Spanyolország & JVG 1080120-1 & JX274498 \\
\hline Flavodon flavus & Kína & xsd08084 & FJ478126 \\
\hline Flavodon flavus & Mianmar & GSM-12 & JQ638521 \\
\hline Gloeoporus dichrous & Szlovákia & BRNM 709971 & EU546097 \\
\hline Gloeoporus dichrous & USA & DLL2009-167 & JQ673109 \\
\hline Gloeoporus pannocinctus & Csehország & BRNM 709972 & EU546099 \\
\hline Gymnopilus penetrans & Csehország & PRM901885 & AY925213 \\
\hline Hericium coralloides & Anglia & $\mathrm{K}(\mathrm{M}) 104978$ & EU784262 \\
\hline Hyphodermella corrugata & Spanyolország & MA-Fungi 11076 & FN600376 \\
\hline Hyphodermella corrugata & Portugália & MA-Fungi 26185 & FN600382 \\
\hline Hyphodermella rosae & Spanyolország & MA-Fungi 1556 & FN600385 \\
\hline Mycena galericulata & Olaszország & $457 \mathrm{~g}$ & JF908442 \\
\hline Mycoleptodonoides aitchisonii & Kína & HMJAU4527 & JF430078 \\
\hline Mycoleptodonoides sharmae $(\mathbf{H T})$ & India & KD-11-122 & JX855031 \\
\hline Phaeomyces dubiosus & Franciaország & PAM06110301 & KF830099 \\
\hline Phanerochaete chrysosporium & India & CAW-33 & HQ589222 \\
\hline Phanerochaete laevis & USA & DLL2011-284 & KJ140760 \\
\hline Phanerochaete laevis & USA & FP-101481 & AY219347 \\
\hline Phanerochaete sordida & Dél-Korea & КCTC 6757 & AF475149 \\
\hline Phanerochaete stereoides & India & VPCI $2073 / 12$ & KF291012 \\
\hline Phanerochaete velutina & USA & FP-102157 & AY219351 \\
\hline Phlebia acerina & USA & DLL2011-102 & KJ140616 \\
\hline Phlebia aurea & USA & DLL2011-100 & KJ140614 \\
\hline Phlebia aurea & USA & DLL2011-263 & KJ140747 \\
\hline Phlebia brevispora & Argentína & BAFC-633 & HM208154 \\
\hline Phlebia centrifuga & USA & RLG-7588 & L43380 \\
\hline Phlebia fuscoatra & Észtország & KHL13275 (GB) & JN649352 \\
\hline Phlebia fuscoatra & USA & DLL2011-259 & KJ140744 \\
\hline Phlebia fuscoatra & USA & FP-102173 & KP135364 \\
\hline Phlebia cf. fuscoatra & Peru & IQ123 & KJ831861 \\
\hline Phlebia livida subsp. tuberculata & Törökország & $11482(\mathrm{~GB})$ & HQ153421 \\
\hline Phlebia nothofagi & Új-Zéland & PDD 91610 & GQ411511 \\
\hline Phlebia nothofagi & Franciaország & KHL13750 & GU480000 \\
\hline Phlebia nothofagi & Spanyolország & AH31887 & GQ259416 \\
\hline Phlebia nothofagi (Hyphoderma sp. néven) & Kanada & UBC:F19735 & HQ604798 \\
\hline Phlebia nothofagi & USA & HHB-6906-Sp & KP135368 \\
\hline Phlebia nothofagi & USA & HHB-4273-Sp & KP135369 \\
\hline
\end{tabular}




\begin{tabular}{|c|c|c|c|}
\hline Fajnév & Lelőhely (ország) & Herb. szám & ITS-azonosító \\
\hline Phlebia nothofagi & USA & HHB-12067 & KP135370 \\
\hline Phlebia radiata & USA & JLL-15608-sp & AY219366 \\
\hline Phlebia radiata & Finnország? & ATCC 64658 & EF491867 \\
\hline Phlebia tremellosa & Lettország & $\mathrm{I} 236$ & GU062266 \\
\hline Phlebia uda & Japán & USDA Kropp-1 & AB084621 \\
\hline Phlebia uda & ismeretlen & FCUG 2452 & AF141614 \\
\hline Phlebia uda & Litvánia & olrim913 (SUAS) & AY787676 \\
\hline Pholiota adiposa & Észtország & TU106337 & UDB011677 \\
\hline Pholiota cerifera & Olaszország & MCVE12065 & JF908584 \\
\hline Pholiota gummosa & Olaszország & MCVE6555 & JF908580 \\
\hline Pholiota gummosa & Észtország & TU118641 & UDB018225 \\
\hline Pholiota jahnii & Olaszország & MCVE16840 & JF908590 \\
\hline Pholiota limonella & Kanada & UBCF23771 & KC581317 \\
\hline Pholiota lundbergii (P. squarrosa néven) & Olaszország & MCVE5257 & JF908579 \\
\hline Pholiota nameko & Kína & DD08081 & FJ810174 \\
\hline Pholiota nameko & Dél-Korea & ASI24036 & AY251304 \\
\hline Pholiota squarrosa & Németország & „Nov-09” & FR686575 \\
\hline Pholiota squarrosa & Észtország & TU106707 & UDB011866 \\
\hline Pholiota squarrosa & Észtország & TU106355 & UDB015813 \\
\hline Pholiota squarrosoides & USA & TENN61728 & FJ596877 \\
\hline Pholiota squarrosoides & USA & TENN61692 & FJ596859 \\
\hline Pholiota squarrosoides & Finnország & MCVE17140 & JF908591 \\
\hline Pholiota squarrosoides (P. jahnii néven) & Észtország & TU118785 & UDB019568 \\
\hline Postia alni & Finnország & $14211(\mathrm{H})$ & KC595931 \\
\hline Postia alni & Finnország & OMC617 & KC595932 \\
\hline Postia alni & Kína & Cui 10094 & KF699116 \\
\hline Postia alni & Kína & Dai 10854 & KF699117 \\
\hline Postia caesia & Finnország & $13610(\mathrm{H})$ & KC595935 \\
\hline Postia caesia & Egyesült Királyság & $\mathrm{K}(\mathrm{M}) 32506$ & AY599572 \\
\hline Postia caesia & Kína & Dai 11834 & KF699119 \\
\hline Postia caesia & Argentína & CIEFAP174 & JX090109 \\
\hline Postia caesia & Argentína & CIEFAP350 & JX090110 \\
\hline Postia caesia & Norvégia? & NFLI 2000-83/24 & JQ358816 \\
\hline Postia caesia & Anglia & FP-135373-Sp & KC585375 \\
\hline Postia caesia & USA & HHB-14891 & KC585376 \\
\hline Postia fragilis & ismeretlen & MJ106_04-2 & JF950575 \\
\hline Postia hibernica & Kína & Cui $8 \overline{2} 48$ & KF699126 \\
\hline Postia subcaesia & Dél-Korea & KA12-1375 & KR673585 \\
\hline Postia subcaesia & Új-Zéland & PDD:95774 & HQ533007 \\
\hline Postia subcaesia & USA & DLL2011-218 & KJ140707 \\
\hline Postia subcaesia & USA & DLL2010-106 & JQ673076 \\
\hline Postia subcaesia & Egyesült Királyság & $\mathrm{K}(\mathrm{M}) 41769$ & AY599577 \\
\hline Postia cf. subcaesia & Kína & $10637(\mathrm{H})$ & KC595944 \\
\hline
\end{tabular}




\section{KÖSZÖNETNYÍLVÁNÍTÁS}

Köszönettel tartozom témavezetőmnek, Prof. Dr. Rimóczi Imrének, aki elindított a tudományos pályámon, és akihez mindig bizalommal fordulhattam. Köszönöm a támogatást Dr. Höhn Máriának, aki tanszékvezetőként biztosította a mikológiai vizsgálataim eszközigényeinek hátterét. Hálámat szeretném továbbá kifejezeni a Növénytani Tanszék és Soroksári Botanikus Kert mindazon munkatársainak, akik segítették a munkámat, illetve hasznos tanácsaikkal hozzájárultak a dolgozatom elkészüléséhez.

A molekuláris vizsgálatok laborhátterének biztosításáért, valamint a molekuláris taxonómiai elemzések elméleti alapjainak elsajátításában való segítségükért szeretnék köszönetet mondani az ELTE Növényszervezettani Tanszék munkatársainak, Dima Bálintnak és Dr. Kovács M. Gábor tanszékvezetőnek.

A Juhdöglő-völgy Erdőrezervátum háttéradatainak rendelkezésemre bocsátásáért, valamint a holtfák kijelölésében és a korhadási fázisok megállapításában nyújtott segítségéért köszönettel tartazom Dr. Horváth Ferencnek, az MTA ÖBKI munkatársának.

Köszönöm a Magyar Természettudományi Múzeum főmúzeológusának, Dr. Barina Zoltánnak a problémás nómenklatúrai kérdésekben nyújtott önzetlen segítségét.

A házi védés során tett hasznos észrevételeikért, tanácsaikért és az építő jellegü kritikákért köszönettel tartozom opponenseimnek, Prof. Dr. Vetter Jánosnak és Dr. Pál-Fám Ferencnek.

Koszka Attilának köszönöm, hogy a Juhdöglö-völgy Erdőrezervátumban gyüjtött Aurantiporus alborubescens fungáriumi mintáját rendelkezésemre bocsátotta, valamint felhívta a figyelmemet a Donkia pulcherrima magterületen való előfordulására.

Köszönöm Dr. Szabó Annának baráti bíztató szavait és a dolgozatomhoz kapcsolódó, angol nyelven írt cikkeim során nyújtott segítségét.

Nem utolsó sorban köszönöm édesapámnak, Dr. Papp Ferencnek a tudományos munkához való példamutatását és azt, hogy sok éven át megteremtette, valamint biztosította a tanulmányaimhoz szükséges egzisztenciális hátteret. Köszönöm feleségemnek Pappné dr. Jászberényi Csillának a sok türelmet és támogatást. Hálával tartozom továbbá édesanyámnak, Horváth Éva Máriának és testvéremnek, Papp Dávidnak. 